1978

\title{
The Fort Sam Houston Project: An Archaeological and Historical Assessment
}

Andrea Gerstle

Thomas C. Kelly

Cristi Assad

Follow this and additional works at: https://scholarworks.sfasu.edu/ita

Part of the American Material Culture Commons, Archaeological Anthropology Commons, Environmental Studies Commons, Other American Studies Commons, Other Arts and Humanities Commons, Other History of Art, Architecture, and Archaeology Commons, and the United States History Commons

Tell us how this article helped you.

This Article is brought to you for free and open access by the Center for Regional Heritage Research at SFA ScholarWorks. It has been accepted for inclusion in Index of Texas Archaeology: Open Access Gray Literature from the Lone Star State by an authorized editor of SFA ScholarWorks. For more information, please contact cdsscholarworks@sfasu.edu. 


\section{The Fort Sam Houston Project: An Archaeological and Historical Assessment Creative Commons License \\ (c) $)(1)$ (9)}

This work is licensed under a Creative Commons Attribution-NonCommercial 4.0 International License 
THE FORT SAM HOUSTON PROJECT:

AN ARCHAEOLOGICAL AND HISTORICAL ASSESSMENT

\author{
Andrea Gerstle, Thomas C. Kelly \\ and Cristi Assad
}

\begin{abstract}
With contributions by:
Philip Dering, Anne A. Fox, Daniel E. Fox, Augustine Frkuska, Carol Graves, Joel D. Gunn, Jerry Henderson, Thomas R. Hester, James E. Ivey and Sara E. Kleine
\end{abstract}

Center for Archaeological Research The University of Texas at San Antonio Archaeological Survey Report, No. 40 
Submitted in fulfillment of the terms of Contract \#DACA 63-77-6-0081 between the Fort Worth District, U.S. Army Corps of Engineers and the Center for Archaeological Research, The University of Texas at San Antonio.

This report was edited by Carol Graves, Cristi Assad, James E. Ivey and Thomas R. Hester. Proofreading and editorial assistance were provided by Elizabeth Branch and Jane Smith. 
List of Figures. . . . . . . . . . . . . . . . . . i ii List of Tables...................... . . vi

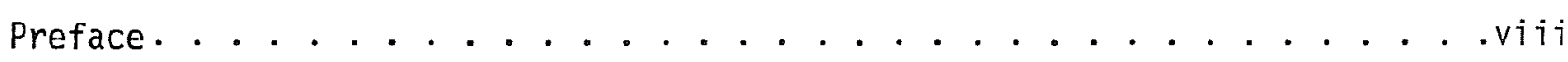
Acknowledgments . . . . . . . . . . . . . . . . . ix Introduction to the Project. . . . . . . . . . . . . . . . 1

PART I: A Study of Ethnic Groups in the Region. . . . . . . . . . 7 PART II: Historical Background: Political and Military Development. . . 17 PART III: The Camp Bullis Study

Section A. Prehistoric Archaeology at Camp Bul1 is

1. Goals of the Study................ 23

2. Environment .................. 25

3. Previous Archaeological Research. . . . . . . . . . 37

4. Research Methods. . . . . . . . . . . . 45

5. Observations on Chronology and Projectile Point Typology. . 63

6. Artifact Categories and Distributional Tabulations. . . . . 87

7. Descriptions of Sites and Scattered Artifact Finds. . . . 115

8. Site Types.................. 175

9. Settlement Patterns . . . . . . . . . . . . 195

10. Constant Volume Analysis. . . . . . . . . . . 215

11. Pollen Analysis of Soil Samples from $41 \mathrm{BX} 36,41 \mathrm{BX} 377$ and

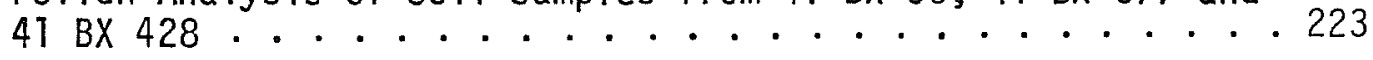

12. Faunal Analysis of Site $41 \mathrm{BX} 36$, with Data Presented for

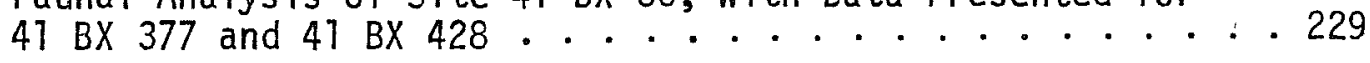

13. Radiocarbon Dating. . . . . . . . . . . . . . 253

Section B. Historical Archaeology at Camp Bullis

1. Introduction. . . . . . . . . . . . . 257 

Table of Contents:

Page

2. Site Descriptions. . . . . . . . . . . 259

3. Material Culture ............... 283

4. Conclusions. . . . . . . . . . . . . . 301

Section C. History of Camp Butlis . . . . . . . . . . . . 305 PART IV: The Fort Sam Houston Study

Section A. Archaeological Resources . . . . . . . . . . 309

Section B. History of Fort Sam Houston. . . . . . . . . . . . . 317

PART V: Studies at Fort Sam Houston Properties: U.S. Army

Reserve Centers and Canyon Lake Recreation Area

Section $A_{1}$ Archaeological Resources . . . . . . . . . . . 323

Section B. Historical Background. . . . . . . . . . . . . 329

PART VI: Recommendations

Section A. Camp Butlis. ................. 341

Section B. Fort Sam Houston and Fort Sam Houston Properties . . . . . 353

Section C. Some Final Thoughts on Protection of Cultural Resources. . . 357 PART VII: Bibliography

Section A. Ethnohistory .............. 361

Section B. History. . . . . . . . . . . . . . . 367

Section C. Archaeology . . . . . . . . . . . 377 



\section{LIST OF FIGURES}

Page

1. Locations of Fort Sam Houston and Camp Bullis, South

Central Texas. . . . . . . . . . . . . . . 2

2. Major Archaeological Sites, Northern Bexar County. . . . . . ...33

3. Illustration of a Bone Tool. . . . . . . . . . . . 37

4. Camp But7is, Texas: Survey Zones. . . . . . . . . . . . . 46

5. Computer Coded Field Survey Form . . . . . . . . . . . . . . 48

6. Field Survey Form. . . . . . . . . . . . . . 51

7. Computer Coded Excavation Level Form . . . . . . . . . . . . 53

8. Standard Unit Level Record . . . . . . . . . . . . . . . 54

9. Computer Coded Laboratory Form . . . . . . . . . . . . . . 56

10. Computer Coded Lithic Analysis Form. . . . . . . . . . . . . . 58

11. Cultural Type List . . . . . . . . . . . . . . . 59

12. Constant Volume Samples. . . . . . . . . . . . . 62

13. Lithic Artifacts from Camp Bullis: Dart Points. . . . . . . . . . 68

14. Lithic Artifacts from Camp Bullis: Dart Points. . . . . . . . . . 69

15. Lithic Artifacts from Camp Bullis: Dart Points. . . . . . . . . 70

16. Lithic Artifacts from Camp Bullis؛ Arrow Points . . . . . . . . 71

17. Lithic Artifacts from Camp Bullis: Dart and Arrow Points. . . . . . 72

18. Lithic Artifacts from Camp Bullis: Paleo-Indian Dart Points . . . . 75

19. Lithic Artifacts from Camp Bullis: Pre-Archaic Dart Points. . . . . 80

20. Lithic Artifacts from Camp Bullis: Unfinished Specimens

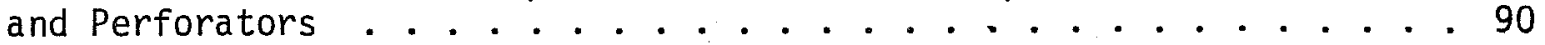

21. Lithic Artifacts from Camp Bullis: Quarry Blanks . . . . . . . 91

22. Lithic Artifacts from Camp Bullis: Quarry Blanks . . . . . . . 92

23. Lithic Artifacts from Camp Bullis ............. 93

24. Lithic Artifacts from Camp Bullis: Preforms . . . . . . . . . . 94 

Figure

25. Lithic Artifacts from Camp Bullis: Preform Fragments . . . . . . . 95

26. Lithic Artifacts from Camp Bullis: Triangular Preforms . . . . . . . 96

27. Lithic Artifacts from Camp Bullis. . . . . . . . . . . . . . 98

28. Lithic Artifacts from Camp Bullis: Concave Unifaces (Scrapers). . . . 99

29. Lithic Artifacts from Camp Bullis: Convex Unifaces (Scrapers) . . . . 100

30. Lithic Artifacts from Camp Butlis: Unifaces (Scrapers). . . . . . . 101

31. Cores from Camp Bul1 is Sites . . . . . . . . . . . . . 112

32. Lithic Artifacts from Camp Bullis. . . . . . . . . . . . . 113

33. Lithic Artifacts from Camp Bullis. . . . . . . . . . . . . . 114

34. Locations of Archaeological Sites at Camp Bu17is . . . . . . . . . 116

35. Site 41 BX 36, Camp Bullis ................. 119

36. Views of Prehistoric Sites, Camp Bul1is. . . . . . . . . . . 129

37. Site 41 BX 377, Camp Bul7is: West Profile............ 130

38. Site 41 BX 377, Camp Bul1is................. 131

39. Sites $41 \mathrm{BX} 378$ and $41 \mathrm{BX} 379$, Camp Bul1is ........... 133

40. Controlled Surface Collection Units at Site 41 BX 383,

Camp Bu17is. ................... . . . 140

41. Views of Prehistoric Sites, Camp Bullis. . . . . . . . . . . . 145

42. Site 41 BX 400, Camp Bu11is. ................. 148

43. Views of Prehistoric Sites, Camp Bu11is. . . . . . . . . . . 157

44. Site 41 BX 425, Camp But7is ................ . 159

45. Site 41 BX 425, Camp Bullis: East Profile ........... 160

46. Site 41 BX 428, Camp Bullis.................. 163

47. Site 41 CM 99, Camp But7is ................. 168

48. Site clusters. . . . . . . . . . . . . . . 178

49. Site Attributes: Locational and Artifact Assemblages. . . . . . . . 191

50. Model of Changes in Settlement Patterns on Camp Bu17is . . . . . 203 

51. Model of Settlement Pattern in North Central Texas. . . . . . . . 205

52. Model of Edwards Plateau Settlement Pattern . . . . . . . . . . . 207

53. South Texas Settlement Pattern (A). . . . . . . . . . . . . . 208

54. South Texas Settlement Pattern (B). . . . . . . . . . . . 209

55. Model of Changes in Settlement Patterns in Bexar County . . . . . . 211

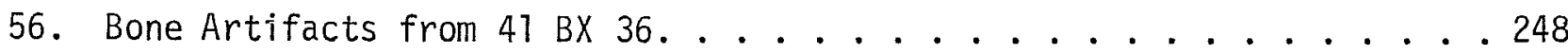

57. Map Showing Early Property Boundaries, Camp Bullis. . . . . . . . . 258

58. Site 41 CM 95, Washingtan-Mason House, Camp Bullis. . . . . . . . 260

59. Site 41 CM 97, E. Georg House, Camp Bul1is............. 262

60. Site 41 BX 397, H. Schmidt House, Camp Bullis . . . . . . . . . 263

61. Site 41 BX 398, A. Schmidt House, Camp Bullis . . . . . . . . . . 264

62. Site 41 BX 433, W. Schmidt House, Camp Bul1is ............ 265

63. Site 41 BX 420, Comanche Spring, Camp But7is. . . . . . . . . . 270

64. Comanche Spring (47 BX 420), Camp Bullis. . . . . . . . . . . . 272

65. Site 41 BX 432, Oppenheimer House, Camp Bullis. . . . . . . . . . 274

66. Historic Sites 41 BX 432 and 41 BX 434, Camp Bul1is . . . . . . . . 276

67. Site 41 BX 434, Doeppenschmidt House, Camp Bullis . . . . . . . . . 279

68. Historic Artifacts from Sites at Camp Bullis: Ceramic Artifacts. . . 284

69. Historic Artifacts from Sites at Camp Bullis: Ceramic Artifacts. . . 286

70. Historic Artifacts from Sites at Camp Bullis. . . . . . . . . . . 290

71. Historic Artifacts from Sites at Camp Bullis: Artifacts of Glass . . 292

72. Historic Artifacts from Sites at Camp Bullis: Artifacts of Metal . . 295

73. Locations of Archaeological Sites and Scattered Artifacts at Fort

Sam Houston ................................. 310

74. Views of Areas Surveyed, Fort Sam Houston Project . . . . . . . . . . 312

75. Locations of USAR Centers and the Fort Sam Houston Recreation Area. . . 324 



\section{LIST OF TABLES}

Page

1. Some Past and Present Flora of Bexar County. . . . . . . . 28

2. Some Past and Present Fauna of Bexar County. . . . . . . . . . 29

3. Projectile Point Types by Time and Site, Cibolo and Salado

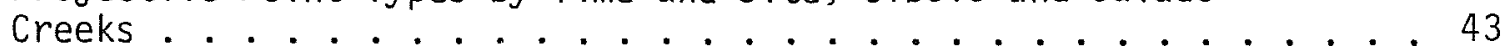

4. Camp Bullis Projectile Point Chronology. . . . . . . . . . . 65

5. Proposed Chronological Sequences ............. 66

6. Projectile Point Types and Dimensions. . . . . . . . . . 76

7. Measurements and Provenience of Angostura Specimens. . . . . . . 78

8. Tabulation of Analyzed Artifacts by Category and Distribution. . . . 104

9. Tabulation of all Analyzed Lithics . . . . . . . . . . 108

10. Artifact Provenience at $41 \mathrm{BX} 36 \ldots 120$

11. Artifact Provenience at 41 BX 377. . . . . . . . . . . 134

12. Artifact Provenience at 41 BX 379.............. . 138

13. Artifact Provenience at 41 BX 400............... . 149

14. Artifact Provenience at 41 BX 425................ 161

15. Artifact Provenience at 41 BX 428. . . . . . . . . . . . 164

16. Artifact Provenience at $41 \mathrm{CM} 99 \ldots 169$

17. Distribution of Scattered Artifacts. . . . . . . . . . . 171

18. Frequencies of Sites Located On and Off Transects. . . . . . . . 198

19. Frequencies of Scattered Artifact Types. . . . . . . . . . . 199

20. Contingency Table of Site Components by Type and Time Period . . . 201

21. Contingency Table of Site Components by North, South

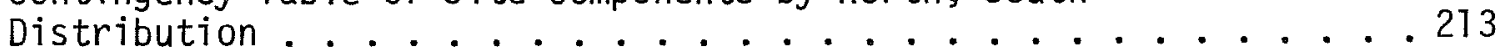

22. Heavy Fraction from Constant Volume Samples. . . . . . . . 216

23. Snails from Constant Volume Samples . . . . . . . . . 217

24. Results of Soils Analysis .................... 219 

25. Pollen Analysis From 41 BX 36, 41 BX 377 and 41 BX 428. ...... 225 26. Faunal Inventory. ................... . . 230 27. Distribution of Bone from $47 \mathrm{BX} 36 \ldots \ldots 232$

28. Biotic Communities Represented in Faunal Assemblage of 41 BX 36 . . 242

29. Age of Death of Animals Represented in Faunal Remains . . . . . . 246

30. Bone Tools and Miscellaneous Bone Modifications Noted Among

Faunal Remains. . . . . . . . . . . . . . . . 249

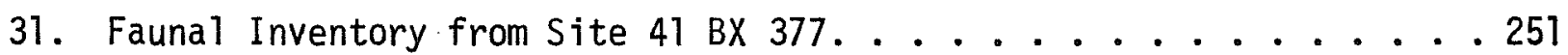

32. Faunal Inventory from Site 41 BX 428. . . . . . . . . . . 251

33. Radiocarbon Dates from Camp Bullis. . . . . . . . . 253

34. Historical Site Analysis. . . . . . . . . . . . . . 281

35. Quantitative Data: Artifacts Found at Historic Sites . . . . . 298

36: Fort Sam Houston Properties: USAR Centers and Canyon Lake Recreation Area .............. . . 325

37. Sites at Camp Bu.l7is at Which to Further Action is

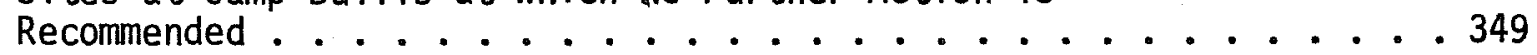





\section{PREFACE}

The archaeological and historical investigations reported here result from a contract between the Fort Worth District, U.S. Army Corps of Engineers, and the Center for Archaeological Research, The University of Texas at San Antonio (Contract \#DACA 63-77-6-0081).

During this project, I was privileged to serve as principal investigator, with Dr. Joel Gunn as comprincipal investigator. The archaeological field director, Thomas C. Kelly, his co-workers Andrea Gerstle and Cristi Assad, and the other members of the archaeological field and laboratory staff (see Acknowledgments) were faced with a challenging task in the assessment of cultural resources on properties controlled by Fort Sam Houston. Most challenging of all was the systematic sampling of cultural resources at the 28,000acre Camp Bullis military reservation. Before the project began, there was much discussion as to the kinds of survey procedures that might be successfully employed in the diverse and rugged terrain of Camp Bullis. I believe that the survey strategies that evolved from these discussions (see Research Methods, III.A.4) are highly useful ones, and may possibly have broad applicability in similar surveys along the eroded margin of the Edwards Plateau in southcentral and southwestern Texas. Another significant aspect of the survey and subsequent surface and subsurface site sampling was the use of specially designed computer-coded forms for data recording. These supplemented standard record-keeping procedures (III.A.4) and, during analysis, proved highly valuable in studying the variability of sites and assemblages within the Camp Bullis area. Additionally, the site information became part of a computer data bank that can be tapped in further problem-oriented research in the region.

Other strong elements of the project were ethnohistory, history and historic archaeology. These avenues of inquiry provided a framework within which to evaluate the cultural resources found during the project and, in the case of historic archaeology, yielded important new information on the 19th and early 20 th century human utilization of the Camp Bullis area. Anne Fox, Sara Kleine, James E. Ivey and Daniel E. Fox worked diligently in collaborative efforts in all of these areas of investigation.

There have been a number of criticisms leveled recently at public service archaeology, particularly in the areas of what some consider excessive cost and lack of long-range benefits to scientific research. I believe that in the Fort Sam Houston project such critical comments are negated by the data presented here. This report contains the information needed by the Corps of Engineers for future planning at Fort Sam Houston properties, it provides a weal.th of new data--both descriptive and interpretive--important to research into the history and prehistory of the region, and it represents the hard work and long hours (far exceeding the monetary value of the contract) of dedicated and concerned archaeologists and historians. All of these elements will serve to better insure the protection and interpretation of cultural resources in the study area.

Thomas R. Hester

Director

Center for Archaeological Research 



\section{ACKNOWLEDGMENTS}

Thomas C. Kelly

The Fort Sam Houston project was highly successful because of the close coordination, cooperation and plain hard work of a considerable number of people with multidisciplinary and complementary skills.

The initial planning phase was the product of Ms. Susan Hazen and Mr. Jack Swafford, Project Management Branch, Engineering Division, Army Corps of Engineers, Fort Worth District.

The detailed implementation plan was prepared by Dr. Thomas R. Hester, principal investigator and project administrator, Dr. Joel D. Gunn, Jack Eaton, Andrea Gerstle and Thomas C. Kelly.

The necessary military coordination with Fort Sam Houston, the Canyon Lake Recreational Facility, the 22 USAR Centers and Camp Bullis was provided by the Directorate of Facilities Engineering, Fort Sam Houston, in the persons of Lt. Col. Martin B. Carson, Director, Capt. Thomas R. Kruthers, Environmental Officer and Capt. William T. Melton, Operations Officer. Survey crews were consequently expected and courteously received at the Canyon Lake Recreational Facility, on Fort Sam Houston, and at each of the Reserve Centers.

The main thrust of the survey was at Camp Bullis, where only the closest coordination and positive attitude of Lt. Col. Paul E. Manna, Camp Bull is Commander, and the Operations Sergeant, SFC Richard K. Simmons, enabled the survey crew to accomplish its mission (a most refreshing change from the brusque and fruitless encounters with Fort Sam Houston and Camp Bull is authorities on these properties in past efforts to save important archaeological resources).

M. E. Brunes, the Conservation Officer at Camp Bullis, also was most helpful in locating a resource the survey had missed. He is presently making plans to preserve archaeological resources discovered by this survey.

Two consultants, Dr. C. M. Woodruff and Philip Dering, participated in and contributed their specialized knowledge to the Camp Bullis survey. Dr. Woodruff, Bureau of Economic Geology, The University of Texas at Austin, provided field appraisal of the geomorphology. Mr. Dering, Palynology Laboratory, Texas A \& M University, collected and analyzed soil samples from the tested sites at Camp Bullis.

Radiocarbon dating was provided by Dr. E. Mott Davis, Radiocarbon Laboratory, The University of Texas at Austin, and by Radiocarbon Ltd., Lampasas, Texas.

Specialized snail analysis was performed by John Clark, Jr., Texas State Historical Commission, Austin. Jerry Henderson of Texas Archeological Survey, The University of Texas at Austin, provided analysis of the faunal material. 

The historical survey was directed by Anne A. Fox, assisted by Sara E. Kleine, Daniel E. Fox, James E. Ivey and Vicki Holloway, who provided photographic coverage.

The following individuals were particularly helpful in expediting the historical research for this report:

Katherine McDowell and the Staff of the Research Library of the Daughters of the Republic of Texas,

The Deputy County Clerks in the Deed Record Department at the Bexar County Courthouse,

Mrs. Elizabeth S. Doss, Real Property Officer for the Facilities Engineer, Fort Sam Houston,

William M. Harris, Chief, Engineering Plans and Services Division, Fort Sam Houston, and

Capt. José N. Uranga, Jr., Environmental Law Specialist, Office of the Staff Judge Advocate General, Fort Sam Houston.

Special credit is due to the field survey crew, who, in addition to covering Fort Sam Houston, the Canyon Lake Recreational Facility and the 22 USAR Centers, spent long hours hiking the rugged terrain of Camp Bullis. The crew consisted. of Thomas C. Kelly, field director, Cristi Assad, Augustine Frkuska, Andrea Gerstle, Thomas E. Miller and Erwin Roemer (who was also in charge of survey photography).

The Camp Bullis archaeological resources proved to be more than the field crew expected, and the important sites more than could possibly be tested, given time and monetary constraints. The shortage of personnel was made up by the following volunteers from the Southern Texas Archaeological Association and archaeology students from The University of Texas at San Antonio: June Carter, David Cox, Mary Daamsgard, Bryan Forester, Joyce Pratt, Margaret Reasor, Tom Saunders, Elaine Saunders, Kay Simpson, Laura Simpson, Cliff Simpson, Terry Stevenson, Kate Vaught, Carol Walker, Margaret White and Max witkind. The following students from The University of Texas at San Antonio Summer Archaeological Field Course took a busman's holiday to work one weekend with the crew and other volunteers: Santiago Escobedo, Andy Hofling and Betty Guntharp.

Elizabeth Cantu Frkuska assisted Augustine Frkuska in mapping the Camp Bullis sites, recording excavation data, and analyzing and computerizing lithic data in the laboratory. Lynn Highley, Royce Mahula, Thomas Miller, Margarita Vázquez and Shirley Van der Veer assisted in limited testing at Camp Bullis.

Andrea Gerstle supervised preparation of the report, organizing and integrating the report for continuity and lucidity. She also carried the heaviest writing workload. Cristi Assad handled the processing and sorting of the constant volume samples, did partial analyses of bone samples and artifacts, and wrote several sections of the report.

Thomas C. Kelly, field director of the project, served as 1 iaison in matters of scheduling on Camp Bullis, and insured the timely completion of the field investigations. In addition, he was responsible for researching and writing several sections of the report. 

Shirley Van der Veer was an invaluable member of the write-up team, translating handwritten and largely illegible papers into typewritten copy. Along with Lynn Highley and Margarita Vázquez, she processed and catalogued the vast multitude of artifacts, site reports and computer forms that were constantly being submitted to the laboratory.

James E. Ivey provided advice and suggestions pertaining to the statistical analysis of site types, enabling clear and logical results to be obtained. He accomplished al1 computer programming, with Lynn Highley's assistance in keypunching. He was also in charge of the historical archaeological field work. 

INTRODUCTION TO THE PROJECT

Thomas C: Kelly

In March 1977, a contract was effected between the Center for Archaeological Research, The University of Texas at San Antonio (CAR-UTSA), and the Fort Worth District Army Corps of Engineers to conduct an archaeological and historical survey of Fort Sam Houston and its south-central Texas properties. This contract (DACA 63-77-6-0081) is part of an overal1 Environmental Impact Statement required by the National Environmental Policy Act of 1969, implementing Department of Defense Directive 6050.1 and Army Regulation AR 200-1.

The survey was designed to provide an inventory and evaluation of rapidiy disappearing archaeological and historical resources and to evaluate impacts and effects of planned activities on these resources. Where warranted, individual sites or districts were to be nominated to the National Register of Historic Places.

\section{SCOPE OF SURVEY}

Fort Sam Houston in San Antonio, Texas, with 3287 acres, the Canyon Lake Recreation Area with 110 acres, and 22 USAR Centers, totalling 99 acres, required $100 \%$ surveys (Fig. 1).

The Fort Sam Houston portion of the survey came many years too late with only two new archaeological sites recorded. It was also discovered that a site present in 1974 (41 BX 194) had been completely destroyed. No sites were recorded at the Canyon Lake Recreation Facility or at any of the USAR Centers.

The bulk of the survey activities took place at Camp Bullis just north of the San Antonio city limits. A $1.5 \%$ survey of the installation's 28,021 acres was the minimum requirement set forth by the Corps, with $100 \%$ examination required of areas planned for construction or impact. Limited testing was carried out where warranted.

The actual survey covered a little over $20 \%$ of Camp Bullis. An additional 10 days of testing at $41 \mathrm{BX} 36$, a large midden, was accomplished with the help of volunteer UTSA archaeological students and members of the Southern Texas Archaeological Association. The policy of the Center for Archaeological Research has always been to secure as much archaeological knowledge as possible from contract archaeology, and Camp Bullis, with its 72 recorded sites, presented the best (and possibly the last) opportunity to study a large and comparatively undisturbed archaeological area in Bexar County.

\section{PROBLEMS}

The nature of the Camp Bullis survey was bound to create some logistical problems. A small caretaker force at Camp Bullis provides facilities and scheduling for 150,000 to 250,000 people per year for military and medical training. A special problem was that one of the largest areas, Zone 9, is the impact area for 12 firing ranges spaced around a $180^{\circ}$ arc. Part 


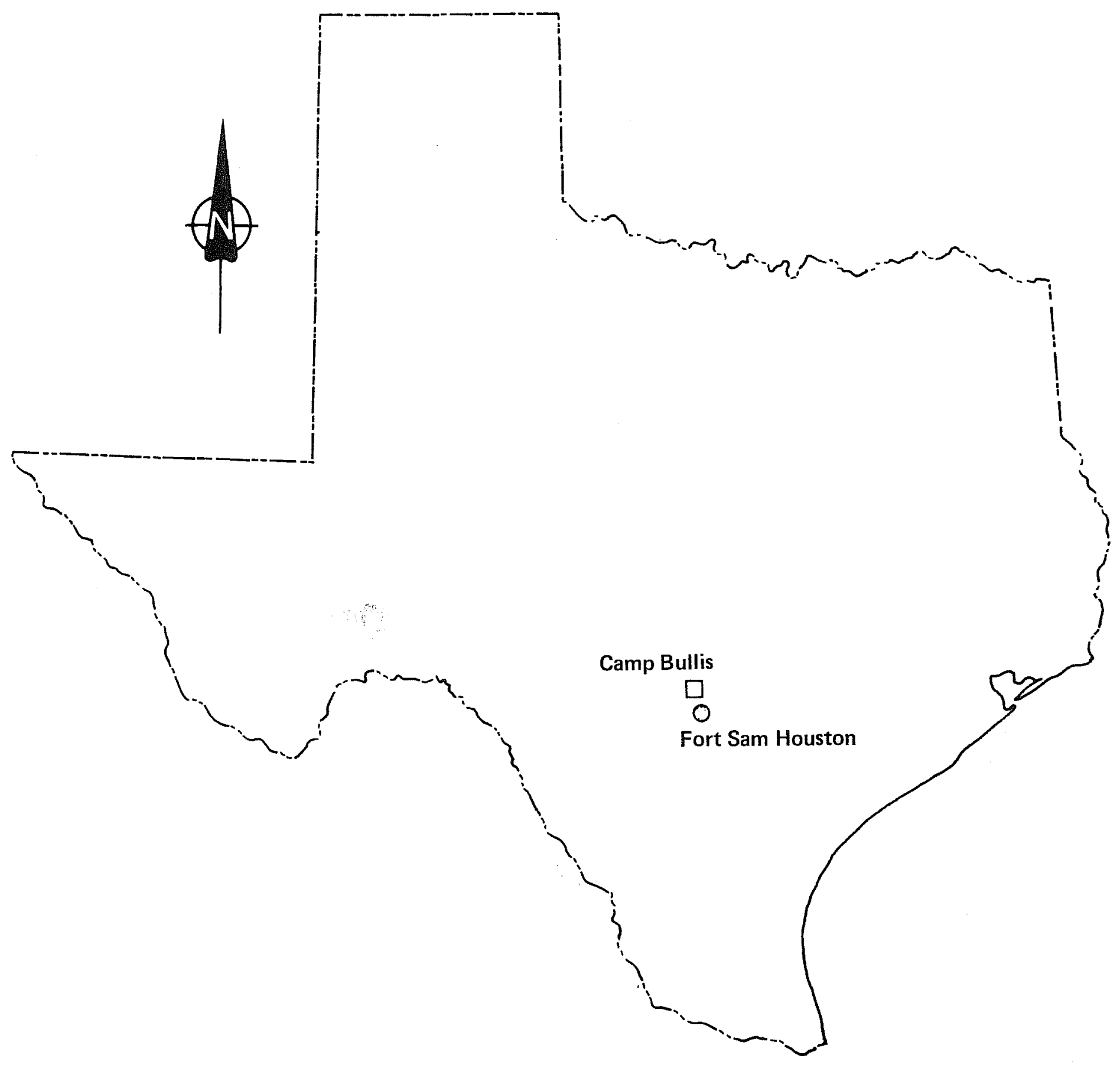

Figure 1. Locations of Fort Sam Houston and Camp Bullis, South Central Texas. 
of this area has unexploded grenades with sensitive fuses. The northern portion of Zone 9 also has an area where Southwest Research Center tests explosives. For this reason, Zone 9 was necessarily slighted.

Having to contend with both English and metric systems of measurement poses minor problems for archaeological reports. All of our maps had elevations expressed in feet above mean sea level. Similarly, the odometers on our vehicles were often used to measure longer distances in the field to establish site locations in reference to landmarks in the verbal descriptions on site survey forms. Road miles and elevations in feet were not converted to metric figures. Metric measurements were used for all excavations, controlled surface collection, intra-site measurements and map site locations.

\section{REPORT ORGANIZATION}

The report is presented in sections which are geographically defined, i.e., Camp Bullis, Fort Sam Houston, and the U.S. Army Reserve Centers and Canyon Lake Recreation Area. Within each of these sections, both the archaeology and the history are presented. This was done to facilitate the evaluation of each of these areas in terms of its history and prehistory.

The bibliographies (Part VII), however, are presented differently from the report contents. The Ethnohistory Bibitography (VII.A) references sources consulted for Part I. The History Bibliography (VII,B) pertains to sources from Part II; Part III, Section C; Part IV, Section B; and Part V, Section B. The Archaeology Bibliography (VII.C) is relevant to sources from Part III, Section $A$ and $B$; Part IV, Section A; and Part V, Section A. 



\section{PART I}

A STUDY OF ETHNIC GROUPS IN THE REGION

Daniel E. Fox 

I.

A STUDY OF ETHNIC GROUPS IN THE REGION

Daniel E. Fox

Southern and south-central Texas is and has been an interrelationship of physical and cultural elements. As a human region, it is built upon a heritage of many different cultural groups.

\section{THE ABORIGINES}

At the beginning of historic times, the area of what has become known as south Texas was inhabited by hunting and gathering peoples known as Tonkawas, Coahuiltecans, and Karankawas. During the 16th century, Tonkawa groups lived in the Edwards Plateau region, in parts of the coastal plain to the south, and in the Brazos River drainage to the east. Not much is known about the Tonkawa before they became organized into a tribal group during the 17th and 18th centuries. Although categorized as a Plains Indian culture, they were dependent upon many of the same natural resources and may have spoken dialects of the same linguistic stock as their neighbors to the south (Sjoberg 1953a; Hasskarl 1962; Jones 1969; Berlandier 1969).

Groups of Coahuiltecan-speaking Indians were in inland areas, with Karankawas along the coastal lowlands and 1ittoral (Ruecking 1955; Gatschet 1891). Culturally similar, both peoples led a seasonal hunting and gathering subsistence adapted to their semi-arid environment. Karankawa groups exploited the varied resources of offshore islands, mainland shores and prickly pear fields. Coahuiltecan bands also were dependent upon a variety of plant resources, particularly prickly pear, agave, pecans and mesquite, and animal life, including bison, deer, fish, birds and other small fauna of the Rio Grande Plain (Newcomb 1960:3-5; Campbe11 1975).

For the purposes of this overview, the Karankawas can be considered along with the Coahuiltecans as members of the Western Gulf culture area (Newcomb 1956). An ethnographic sketch of the Coahuiltecans will serve to give an impression of both peoples.

It should be noted at the outset that the term "Coahuiltecan," while in common use, is considered by many modern-day ethnohistorians to be an almost useless term. Many of the autonomous groups in southern Texas, south-central Texas, and northeastern Mexico were Coahuilteco-speakers; others spoke different languages. More importantly, these hunter and gatherer groups were largely autonomous and their lifeways were often considerably varied. The "Coahuiltecan" generalization has been discussed by Campbel1 (1975:1, 1977:2) and Nunley (1971). Only recently have detailed studies been done of specific Coahuilteco-speaking groups (cf. Campbel1 1975, 1977).

The material culture of these peoples was relatively simple, durable and transportable. Small huts were used for shelter. Bows and arrows, rabbit sticks, nets, baskets, mats and stone tools such as knives, scrapers and 
hammers were their basic implements (Hewcomb 1961:43-44). They often wore little clothing, although they adorned their bodies in various ways, including painting and tattooing, ear, nose, and lip piercing, and the use of jewelry fashioned from bone, stone, shell, and other materials (Schuetz 1969:78-80).

These populations existed much of the year in small family groups (the basic socio-economic unit), and assembled during the various plant harvest seasons into bands composed of patrilineally-related groups. Each band usually had a headman, and occasionally chiefs gained limited authority over a number of bands. Headmen and shamans, the only individuals who were set off from their fellows, often had several wives, perhaps as part of the prestige sphere of Coahuiltecan economy (llewcomb 1961:44-45).

Newcomb (1961:45) emphasizes the interdependence of this egalitarian society:

- personal gain or gain at the expense of the group was
unknown. All the people a person lived with and worked
with were his kin. Coahuiltecan society, then, ; . Was
distinguished by (1) fraternity - all were kin; (2) equality -
there were no full-time occupational specialists, much less
various social classes; and (3) freedom - the resources
of nature were free for the taking.

Relations between groups or bands were much less cooperative. Territorial in nature, Coahuilteco-speakers competed for natural resources, often to the point of intermittent feuding and small-scale warfare between neighboring bands (Schuetz 1969:81). Emissaries often mediated such clashes (Newcomb 1961:46-48), and it is possible that mitotes, ceremonial feasting and dancing, may have served to ameliorate conflict between groups.

Coahuiltecan supernaturalism probably was not a coherent mass of beliefs and practices. Specific magical and religious ways of dealing with the unknown may have differed between individuals as well as socio-economic groups. Shamans, usually the older members of either sex, combined magic, religion, and science into the treatment of the sick and ailing. Peyote and the laurel bean were drugs used in religious ceremonies or mitotes (Newcomb 1961:51-55; Schuetz 1969:87).

With the intrusion of European culture during the 16th century, Coahuiltecans faced new environmental pressures. The advent of new cultural elements such as horses and metal tools resulted in changes of subsistence, technology and social organization. European diseases spread rapidly, decimating much of the native population. Plains-adapted Tonkawa, Lipan Apache, and Comanche peoples pushed southward (Sjoberg 1953a, b; Tunnell and Newcomb 1969; Berlandier 1969; Fehrenbach 1974; Campbe11 1972:3). 
As Campel1 (1975:2) summarizes:

By tile end of the 17th century the Indians of southern

Texas were already beginning to face what most hunting and gathering peoples of the world have had to face: population decline, territorial displacement, segregation and ideological pressure, loss of ethnic identity, and absorption by invading populations.

In the end, the aborigines of south Texas became an important resource for exploitation by the northern expansion of the Spanish Colonial ermpire.

\section{SPANISH TEXAS}

During the late 17th century, Texas became the remote northeastern frontier of the Spanish Colonial empire in the Americas. The area of settlement encompassed the country between the Red and liueces Rivers, and by the mid-18th century the sparsely populated geographical framework of Spanish Texas became anchored upon the communities of San Antonio de Bexar, La Bahia (Goliad), and Nacogdoches. After more than 100 years of colonization, this structure was comprised of 3000-4000 people (Meinig 1969:28).

Missions, presidios and encomiendas were the traditional colonial institutions with which the Spanish frontier had been expanded. A7though the land-labor system of the encomienda was not as successful in Texas, a number of settlements (poblaciones) grew up near the missions and presidios (Leutenegger and Perry 1976:23). Canary Islanders were transported to San Antonio to establish a civil settlement, and families of Tlaxcaltecan Indians were brought from Mexico as settlers and teachers for the mission neophytes. Exemplifying the mixture of ethnic groups of Spanish Texas, races recorded in San Antonio included Indian, Negro, mulatto and Spaniard (Schuetz 1976:75-78).

The missions succeeded in Christianizing, and otherwise acculturating, a great many indigenous people into the socio-economic systems of the civil communities:

Where the Spanish found adaptable Indians, they always worked to incorporate them into the state as third- or fourth-class citizens to form a laboring class. And while the position of all except Spaniards born in Spain was always anomalous in the empire, and blood castes were rigidly defined, if not always enforced, after the Spanish departure the soon-to-be-dominant mestizo groups natural1y preferred never to dwell much on the notion of racial descent. It was impossible for all but a handful in New Spain to prove a racial purity that other European colonists took for granted. But class distinctions, always sharply drawn in Hispanic civilization, remained (Fehrenbach 1868:65). 


\section{MEXICAN TEXAS}

During the early 19th century the strategy of the Mexican regime was to colonize the broad area between San Antonio and Nacogdoches. In the early 1830s Texas was divided into three political units--the departments of Bexar, Nacogdoches and Brazoria--reflecting new patterns in cultural geography (Meinig 1969:32).

While the departments of Nacogdoches and Brazoria became more and more overrun by Anglo-American frontier culture, the Department of Bexar remained the Hispanic region, even though it was occupied along the coast by a few Anglo and Irish colonists. As Meinig (1969:32-33) depicts it,

Nearly two-thirds of the population was congregated in and around San Antonio, still the principal seat of Texas officials and the gateway between the Mexican nation and its distant frontier. The remainder were too few even to be spread thinly over the rest of the department, and they were loosely clustered around Goliad and Victoria, San Patricio and Refugio (an official inspection of 1834 found not a single ranch between San Antonio and Goliad). But even such tiny primitive centers were faithful if rather feeble exhibits of their common heritage. They represented a civic-centered ranching culture with all of the basic elements and character of the now longstabilized Mexican pattern: a cohesive, hierarchical structure of Spanish, Mestizo, and Indian-Catholic and formal, authoritarian and conservative; a typical society of officials, soldiers and priests, ranchers and foremen, vaqueros, carters, and peons.

Maintained through a hierarchy of underlings and bound together by folkways and mores which promoted centralized authority and implicit obedience as well as intolerance to outsiders and outside things, the Hispanic scheme of socio-economic organization was not compatible with the character of Ang10-American colonists (Lowrie 1967:71-72). Following the revolt against Mexico, most of the Hispano population moved out of Bexar to take refuge along the Rio Grande and beyond (Meinig 1969:46).

In 1860 there were about 12,000 Hispano people-in Texas, mostly in the south and southwest (Fehrenbach 1968:687). Along the southern edge of central Texas, especially along the Indianola-San Antonio road, Mexicans worked as carters, packers and drovers. Within this cultural border zone, the cotton plantation and the cattle enterprises of the hacienda, originally the two patriarchal landed institutions idealized by the contending cultures, were ruled by the Anglo. The Negro slave was necessary for one, the Mestizo vaquero for the other.

Further south, clusters of Mexican rancherias, with their jacal structures, brush-fenced yards, sheep and goats, were scattered about. Except for garrisons and a few Anglo merchants in Brownsville and Laredo, the Rio Grande Valley remained Hispano-American (Meinig 1969:55-56). 
ANGLO-AMERICANS

Decisive in Texas history was the encouragement of the immigration of Anglo-Americans under the Mexican empresario system of colonization. Beginning with Austin's colony which embraced much of the lower Brazos and Colorado river basins, other empresarios recruited Anglo-Americans, Mexicans, and Irish colonists for the settlement of adjoining lands. By the end of the Mexican period the population of Texas was at least 25,000 (Meinig 1969:31; Hogan 1969:3).

Seeking economic opportunity, many planters and frontiersmen emigrated to Texas from the Trans-Appalachian South (most commonly from Louisiana, Alabama, Arkansas, Tennessee and Missouri) as part of the great westward expansion of the United States (Fehrenbach 1968:142). Between 1835 and 1846, further immigration, coupled with natural increase, more than quadrupled the population of the Republic. In 1847 the first state census showed a total of about 142,000 people, including 39,000 Negros, approximately 300 of whom were free (Hogan 1969:9-10).

Although the Texas Republic laid claim to an area much greater than the Texas of Mexico, Anglo-American settlement did not extend beyond the Nueces River until after the war of 1846 (Meinig 1969:39-40). Distance from core areas of population and the threat of Indian depredations restricted the westward extension of the young empire (Hogan 1969:14-16).

The economic basis of Anglo-American settlement was agricultural:

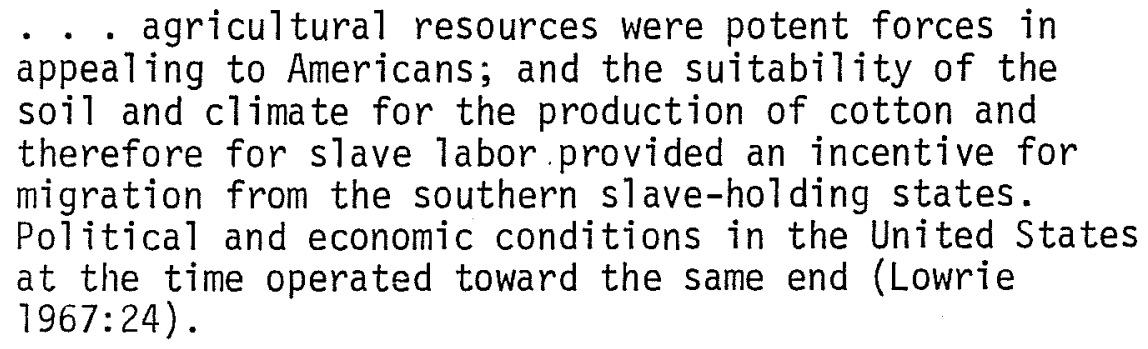

Thus the inflow of Anglo-American planters and yeomen filled the wellwatered, partially wooded bottom lands from the edge of the Hill Country to the coast.

Riverine in nature, Anglo-American settlement pattern was greatly influenced by the empresario system of land distribution. However, while some towns established during the Mexican period (e.g., Gonzales) were similar to planned Spanish Colonial towns, most Anglo-American communities grew up not by primary, formal, administrative creation but as secondary, speculative responses to commercial opportunity (Meinig 1969:36).

The emotional revivalism characteristic of the West during the first quarter of the 19th century appears to have been another expression of the highly individualistic Anglo-American society of Texas. "Religion rested upon the unrestrained freedom of the individual to accept or reject it" (Lowrie 1967:54). Actually, there is evidence to suggest that few ardently religious Anglo-Americans came to Mexican Texas (Lowrie 1967:58; 
Hogan 1969:191-194). In fact, the legal device of marriage by local bond removed one of the most important needs for clergymen (Hogan 1969:191). As late as 1845, what religion there was in Anglo-American Texas was predominantly Protestant, and most commonly Methodist (ibid.:194).

\section{EUROPEANS}

Throughout the 19th century, Texas received immigrants from a number of European countries. Prompted by economic and political pressures, Irish, Germans, French, Czechs, Poles, Norwegians and others brought new cultural variety to Anglo-American Texas. The immigration of Germans probably had greater input into the rural culture of central and southwestern Texas than any other European group (Flach 1974:158).

Although there were a few German settlers in Mexican Texas, it was not until later that a great volume of literature attracted large numbers of Germans to the Republic. In the period from 1844 to 1846 , the verein zum Schutze deutscher Einwander, a society of wealthy, titied Germans, brought 7,380 of their countrymen to the state. In 1844, 2,134 German-speakers, most of whom were Alsatians, were brought by empresario Henri Castro to settle in Castroville and the surrounding area. The United States Census of 1850 recorded 8,266 persons of German birth in Texas, and by 1860 the German element may weil have included more than 30,000 people. Following a temporary 7411 during the Civil War, German immigration resumed (Jordan 1975:40-54).

Unlike other Germans who came as secondary settlers to Anglo-American Texas, the Germans brought to the Hill Country by the Verein and by Castro were pioneers on the forefront of westward expansion. Nearly all of these colonists had come from parts of Germany where houses and related farm structures were clustered together in unplanned, irregular villages. New Braunfels, Fredericksburg and Castroville, the three most important settlements, represented attempts to establish planned, nucleated farm villages. The farm village plan, however, began to fail from the start as settlers moved out of the towns and onto their farms (Jordan 1975:157-160).

The settlement pattern became one of adjacent long, narrow strips of land, like headrights, extending back from stream channels. The increasing size of farms and the continual influx of colonists pushed the perimeter of settlement outward from the towns and into the fertile stream valleys scattered throughout the Hill Country. Leaving unoccupied interfluves between, this accelerated the dispersal of settlement (Jordan 1975:160).

The German agricultural system was based on a remarkable variety of crops and livestock. Marketed commercially were significant quantities of corn, wheat, garden vegetables, hay, cotton, cattle, hogs, sheep, eggs and dairy products (Jordan 1975:156).

The first German houses in the Hill Country usually were built of horizontally laid logs or of poles driven vertically into the ground. While this frontier architecture was Anglo-American in style, the Germans usually 
replaced their initial structures within five or ten years with small, sturdy stone buildings, employing some European construction techniques. Following the Civil War, many large stone houses were built. By about 1880 or 1890, German-Americans abandoned the use of stone construction and began building frame houses (Jordan 1975:165-167).

The stability of rural German settlement was based upon the stability of the family as the basic socio-economic unit. Even labor on German farms was a family affair (Jordan 1975:185).

- . the German-American people . . had one great central creed. It was woven into the very fabric of their being. All other characteristics stemmed from it. It motivated everything they did. This central theme was Family (Flach 1974:6).

The original German pioneer families often had eight and perhaps ten children; the next generation had five or six. Few of these relatives moved away. Marriage was for 1 ife, and divorce seldom occurred (Flach 1974:6, 51).

\section{AFRO-AMERICANS}

A pamphlet published by the Institute of Texan Cultures (1975) presents an ethnohistorical sketch of black people in Texas. A quick review reveals that this ethnic group has been represented throughout the entire period of Spanish and Anglo-American expansion into the area. Spanish explorers and colonists brought black Moorish slaves to Texas, and by 1791 Negro slaves and free blacks numbered $24 \%$ of the population.

In Spanish Texas, blacks who had been freed were accepted socially, but were forced to remain a part of the working class. Under Mexican law, a free black had the legal and political rights of citizenship. However, with the growth of the Anglo-American empire in Texas, slavery filled the labor requirements necessary for the growth and development of the plantation economy. The proportion of slaves increased from about $21 \%$ of the immigrant population in 1835 to about $27 \%$ of the total population in 1847 (Hogan 1969:21).

As slaves, Afro-Americans contributed to the growth of agriculture and the cattle industry. Following the Civil War, they found that they were no longer accepted in the political, economic and social structure of their former masters, and were i11-prepared to compete with other ethnic groups for job opportunities. Many migrated to the North; others remained in the service of their former masters, or worked as sharecroppers. Some grouped together, forming small communities such as Board House in Blanco County.

The early black church, more than a place of worship, was a place for social interaction. It served as a vehicle for motivating a new ethnic identity and for establishing black schools. Well-established by the end of the Civil War, the black church functioned to prepare its people to assume their freedom and to begin their gradual integration into 20th century 
American society. Throughout Texas history, black Americans, forced to abandon the heritage of their native Africa, have developed an indigenous culture of their own.

\section{AMERICAN TEXANS}

Following the Civil War, Texas became a part of a socio-economic system that removed state sovereignty over politics, money, and social organization. The cotton and cattle kingdoms were made tributary to the American industrialized society. In came the railroads, accompanied by two major groups of immigrants. One filled up vacant or unused lands and replaced the plantations with hordes of tenant farmers. The other settled the western counties. From 818,175 inhabitants in 1870 , the population of Texas grew to $2,235,527$ by 1890 (Fehrenbach 1968:603).

As Texans grew into the 20th century, they were drawn more and more tightly into the larger nation:

Increased internal organization, compulsion, and control were inevitable; the relatively tribal frontier society would coalesce into classes and then bureaucracies, with increasing social distinctions, whatever they were called . . Texas conducted a long, and losing, series of delaying actions and last-ditch campaigns. But as the planter economy was destroyed, so was the cattle kingdom, and finally the bedrock social institution, the family farm. As the better organized Texas society exterminated Indians and cowed Mexicans, Texas itself was made subject by greater organization and power (Fehrenbach 1968:703).

Today, one aspect of this complex socio-economic system, the U.S. Army, is supporting an investigation into the cultural heritage of the parts of south Texas it has come to occupy.

\section{ACKNOWLEDGMENT}

I wish to thank $D r$. Thomas R. Hester for calling to my attention several references on the aboriginal groups of southern and south-central Texas. 
PART I I

HISTORICAL BACKGROUND:

POLITICAL AND MILITARY DEVELOPMENT

Anne A. Fox 
II.

HISTORICAL BACKGROUND: POLITICAL AND MILITTARY DEVELOPMENT

Anne A. Fox

This brief overview of the history of central and south Texas is intended to provide a perspective for the sequence of events presented in the following sections. A Historical Bibliography is included (page 367) for those who wish to pursue any particular aspect in greater detail.

From the time of Columbus's discovery of the New World and Cortez's invasion of Mexico, the Spanish were concerned with ownership and control of the lands north of the Rio Grande. Beginning in 1519 with Alvarez de Pineda, a series of expeditions explored the coastal area of Texas, spurred on by rumors of French activity and settlement.

By the late 17th century, it had become apparent that the only way to assure control of the area was to acculturate the aboriginal inhabitants and start settlements of native Spaniards in the region. After a few unsuccessful attempts, a system of missions and presidios was constructed from the Rio Grande to the Louisiana boundary. By 1770 these establishments had evolved into a smal1 number of settlements spaced across the area, linked by tenuous roads. Travel, and indeed the existence of the settlements, was made hazardous by the constant raids of hostile Lipan Apache and Karankawa Indians from San Antonio to the south, and Comanche and other tribes from the north. As the towns began to prosper in the early 1800s, Anglo merchants and frontiersmen from the United States moved into the region, acquired land and became a part of the population.

The Mexican revolution, started by Fray Hidalgo in 1810, called worldwide attention to the region, and a number of filibustering expeditions were organized on the border with the United States, led by adventurous Americans and rebellious Spaniards. After the culmination of the revolution in Mexican independence from Spain, the Mexican government opened the doar to settlement from the United States and Europe by granting a series of empresario contracts to men who would promise to bring settlers to populate a given area of the province. Soon towns had sprung up throughout the eastern half of the state as new settlers acquired farmland along the major river valleys. At first the Indians accepted the new arrivals, but as they perceived the growing threat to their hunting territories, the raiding began and by the mid-19th century was prevalent everywhere on the frontier.

Meanwhile, the rise of General Santa Anna to dictatorial power in Mexico sparked rebellion among the new colonists. As discontent over his abuse of power grew into a determination to resist, a series of incidents led to a punitive expedition by a large force of Mexicans led by Santa Anna. Mexican forces captured San Antonio in the battle of the Alamo in 1836, and massacred a large part of the Texan army stationed at Goliad. Marching on toward the coast to overtake the rest of the rebels, Santa Anna was defeated by General Sam Houston at San Jacinto. 
With the defeat of the Mexican army, Texas declared itself a free republic and set up a government. Despite a number of later attempts by Mexico to recapture the state, the Republic endured and prospered for ten years. There was increasing sentiment, however, to join the United States, and statehood was finally acquired in 1845 .

By the time Texas was admitted to the Union, the United States was at war with Mexico and General Zachary Taylor's American Army of Occupation had landed on the Texas coast and marched to the Rio Grande. One of the points of contention between the two countries was the location of the southern boundary of Texas. Mexico had long considered the land between the Nueces River and the Rio Grande to be part of Mexico, while Texas and the United States claimed that area as part of Texas. American forces won decisive battles at the Rio Grande, Monterrey, and Vera Cruz, and finally captured Mexico City. The peace treaty which followed settled the southern boundary at the Rio Grande.

Between 1348 and the start of the Civil War in 1861, two lines of U.S. Army forts were built in south Texas, one along the Rio Grande, the other roughiy along the Nueces River. These posts were supplied from depots at San Antonio, Corpus Christi and Brazon Santiago. They served as a line of defense against Mexico, as a barricade against marauding Apache and Comanche Indians who regularly swept through south Texas to raid deep into Mexico, and as escorts for travelers through the country between the Nueces River and the Rio Grande, which was overrun with outlaws. Despite the vigilance of the U.S. Army and the Texas Rangers, Indian raids and banditry were commonplace throughout south Texas.

At the start of the Civil War, the state of Texas seceded and joined the Confederacy. This move was not popular in some parts of the state, particularly among the newly-arrived German settlers in the Hill Country and south Texas, most of whom wanted no part of the war. This caused serious problems in areas where the Germans were numerous, causing some to flee to Mexico and a few to return to Germany. When the majority of the able-bodied men left to fight for the South, farms were left undefended and the Indians soon took advantage of this opportunity. The frontier line of settlement retreated as families "forted up" behind palisade walls for mutual defense against the savage raiders, particularly in the area north of San Antonio.

In 1865 the end of the war brought an army of occupation, carpetbaggers and opportunists, who made life miserable for the returning Confederate soldiers and their families. In a desperate effort to recoup their losses, ranchers in south Texas began to collect large herds of the wild cattle which overran the state--a legacy from mission herds which ran wild after secularization. Hide and tallow factories were opened in coastal towns, and thousands of cattle were driven "up the trail" to railheads in Kansas and to Army posts in Texas and New Mexico.

The elimination of the buffalo brought an end to the Indian depredations on the frontier, as starving bands accepted reservation life or retreated into northern Mexico. At the same time, the discovery of oil and the blossoming 
of the industrial revolution brought new life to the state, as Texas emerged into the 20th century.

Sources consulted in the preparation of this historical background are:

Fehrenbach (1968), Flanagan (1974), Thompson (1974), Weddle and Thonhoff (1976), Wilkinson (1975) and Wood (1971). 

PART III

THE CAMP BULLIS STUDY

SECTION A

PREHISTORIC ARCHAEOLOGY

AT

CAMP BULLIS 
III. A. I

GOALS OF THE STUDY

Andrea Gerstle

\section{INTRODUCTION}

The purposes of this report are multiple. Basic requirements as specified by the Corps of Engineers contract include a minimum 15\% area coverage of Camp Bullis to determine the nature of the prehistoric cultural resources on that military reservation, a description and interpretation of each of the sites located, limited testing in selected sites, and recommendations for mitigation. With the exception of the 1atter, these form the basis for a scientific study which may deal with many of the multitude of problems yet to be resolved in the reconstruction and understanding of central Texas prehistory.

The location, nature and size of the area under consideration $(28,021$ acres) are advantageous for focusing on particular aspects of prehistory. The following chapter (III.A.2) provides a general discussion of this area of study. Settlement distribution and subsistence pattern studies are thus possible without the biases introduced by small area surveys. This, then, is the problem orientation of the project.

\section{RESEARCH DESIGN}

Analys is of the data recovered during the Camp Bull is survey proceeded on three different levels, each providing input and feedback to the others. The three levels of analysis are: (1) the artifact and artifact assemblages, (2) site types and functions, and (3) site distribution. These are considered from synchronic and diachronic perspectives and are related to characteristic and changing lifeways of the aboriginal populations, including tool-related behavior, subsistence economy and settlement systems.

These research goals are directed primarily to site data and inter-site comparisons. This is appropriate, as the major purpose of the project is to evaluate the cultural history resources over a large area. In addition, limited testing and controlled surface collections at several sites anable a closer look at intra-site variation, including horizontal distribution of artifacts and vertical stratigraphic occupational sequences.

It is hoped that this study will provide a sound basis for evaluating the archaeology of Camp Bullis, for purposes of planning as well as comparative archaeological research. 



\author{
III. A.2 \\ ENV IRONMENT \\ Cristi Assad
}

\title{
INTRODUCTION
}

The focus of this section is to summarize the environment of Camp Bullis with regard to its potential effect on human habitation, both historic and prehistoric. The geology, hydrology, vegetation and wildlife have been studied in detail and are reported in the Environmental Statement, Overall Mission, Fort Sam Houston, Texas (Freese and Nichols, Inc. 1977).

Camp Bullis is located on the southern edge of the Edwards Plateau, in north Bexar County between Comal County to the north and Loop 1604 (Charles W. Anderson Loop) to the south. Its eastern and western boundaries are Blanco Road and Interstate Highway 10, respectively. The total area of the reservation is 28,021 acres; it is drained by two major streams, the Salado Creek and Cibolo Creek, in addition to numerous ephemeral streams and springs.

\section{GEOLOGY}

The geology of Camp Bullis is an important factor when considering the archaeology of the area. It is located at the southern edge of the Edwards Plateau with the Coastal Plain Province to the south (Carr 1967). In between these geographic areas is the Balcones Fault Zone, the eastern and southern boundary of the Edwards Plateau (Blair 1950). It is in this fault zone that the differences between the Cretaceous, Lower Glen Rose Limestone Formation and the Edwards Limestone Formation are exposed at Camp Bullis.

The Edwards Formation is found only at the southern edge of Camp Bullis and is archaeologically significant in that it is a chert-bearing formation while the Glen Rose Formation is not (C. M. Woodruff, personal communication).* The source for chert in the Cibolo Creek area, where there is a concentration of aboriginal sites, is Edwards chert which has been carried downstream from other Edwards outcrops to the north (C. M. Woodruff, personal communication).

Approximately 12 million years ago, geological activity in the Balcones Fault Zone induced changes in erosional patterns resulting in the characteristic topography seen today. What is known as the "Hill Country" was uplifted relative to the present day coastal plain. The coastal plain currently receives the erosional sediments carried out of the higher Hill Country (C. M. Woodruff, personal communication). This fautting, and the subsequent exposure of the Glen Rose Formation, define the southern boundaries of the hydraulic unit

*Dr. Woodruff, a geomorphologist with the Bureau of Economic Geology, The University of Texas at Austin, was consulted for the present project at Camp Bullis during June 1977. 
known as the Edwards Underground Reservoir or Edwards Aquifer. It extends through five counties including Bexar County (Freese and Nichols, Inc. 1977), and is characterized by limestone caves and rockshelters in layers of differentially permeable limestone.

The Edwards Aquifer has had a direct impact on all of the peoples who have inhabited the Camp Bullis area. "Streams that cross the Balcones Fault Zone lose a large part of their water to the underground reservoir" (Anonymous n.d.:1). The release of this water from springs and seeps has had a significant influence on settlement of peoples, both aboriginal and historic.

The soils at Camp Bullis are of the Tarrant-Brackett series (Freese and Nich01s, Inc. 1977). They are alternating soft and hard calcareous deposits which appear as a "stepped" surface due to differential rates of erosion (C. M. Woodruff, personal communication; Taylor et al. 1966). Various alluvial soils from slope wash are also present and valley soils are naturally very fertile (Freese and Nichols, Inc. 1977).

\section{CLIMATE}

The climate in Bexar County is described as modified subtropical, i.e.s continental in the winter and marine in the summer. During the years 1931-1960 the average temperature for December, January and February was $53.7^{\circ} \mathrm{F}$ and, for June, July and August, $83.2^{\circ} \mathrm{F}$ (Taylor et al. 1966). Precipitation is fairly evenly distributed with an annual average of 27.84 inches per year. Heaviest rainfall is in May and September (Scurlock et al. 1976).

\section{FLORA AND FAUNA}

The environmental statement written by Freese and Nichols, Inc. (1977) for the Corps of Engineers goes into extensive description of the flora and fauna presently found in Bexar and Comal Counties, particularly with regard to Fort Sam Houston, Camp Bullis and the Fort Sam Houston Recreation Area at-Canyon Lake. The emphasis in this section will be on the fiora and fauna which may have been used and exploited by the native and later peoples.

\section{Flora}

The vegetation of the Edwards Plateau area is different from adjacent provinces. The most characteristic combination of plants is the "scrub forest" of juniper, various oaks and other less numerous associated plant species. A mesic forest of live oaks, elms, hackberries and pecans occupies the flood plains of streams (Blair 1950).

In the Tamaulipan province, the predominant vegetation is thorny brush. This thorny brush vegetation consists of mesquite, acacia, mimosa, white brush and prickly pear, among others, and extends from the Balcones Fault Zone south into Mexico (Blair 1950). 
Although the continued use of Camp Bullis since 1917 by the Army ". . . has had little direct impact (conscruction and road building) on the camp Bullis area - (it) has been responsible for considerable indirect impact on flora and fauna" (Freese and Nichols. Inc. 1977:28). Part of this indirect impact has been changes in the native vegetation caused by extensive grazing of cattle. Bogusch notes that mesquite and other "shrubby plants" have increasingly invaded the grasslands of southern Texas ". . "within the memory of Iiving men" (Bogusch 1952:85). It is not mesquite, however, which is invading the overgrazed lands of the Edwards Plateau-it is the juniper tree. This is due in part to the lack of extensive areas of deep soil, required by mesquite trees for their tap root system (C.M. Woodruff, personal communication). Juniper: thrives on the shallow solis characteristic of the Camp Bullis area. Zone 9, the artillery impact area on Camp Bullis, is the only area which has been relatively untouched, except for construction of firing ranges. Grazing has not been allowed for over 50 years in this part of the base and it may eventum ally become unique in Bexar county due to its unmodified condition (Freese and Nichols, Inc. 1977).

Table 1 lists the variety of major flora to be found at Camp Bullis and Fort Sam Houston. Symbols indicate which flora were encountered in the present project (as well as species apparently utilized) and those reported by other archaeological projects and ethnohistoric documents.

\section{Fauna}

The vertebrate fauna of the Balconian province is a mixture of Austroriparian, Tamaulipan, Chihuahuan and Kansan species and, when seen as a faunal assemblage, is completely different from that of any of the other biotic provinces (Blair 1950). Although Fort Sam Houston is in Blair's Tamaulipan biotic province, the fauna of that province consists of grassland species that range into the Texan and Kansan provinces and Neotropical species which have much in common with the Chihuahuan province (ibid.). The fauna of the study area concerned has more in common with the Balconian province which is only miles away.

Camp Bullis once again exhibits the potential of being a haven for fauna as it appears to be for native flora (Freese and Nichols, Inc. 1977). Table 2 lists a selection of fauna present or sighted in Bexar County and primarily at Camp Bullis. Some rare and endangered species are included; these were reported in Freese and Nichols, Inc. (1977). The fauna listed represents potentially valuable food and tool sources in the present project area, and is drawn from other excavation reports and ethnohistoric citations for the local aboriginal population.

Tables 1 and 2 were compiled from the following references: Anonymous 1970; Blair 1950; Bogusch 1952; Campbell 1975; Freese and Nichols, Inc. 1977: Hester 1970b, 1971, 1975b, 1976a; Hester and Kel1y 1976; Hudson et al. 1974; Jelks 1962; Jones et al. 1973; Kelly and Hester 1976; Krieger 1956; Lundelius 1967; Newcomb 1960; Schuetz 1969; Scurlock et al. 1976; Sjoberg 1953; and Suhm 1957. 
TABLE 1. SOME PAST AND PRESENT FLORA OF BEXAR COUNTY

Juniper (Juniperus ashei) $*$ Texas oak (Quercus texana) $\phi$ Live oak (Quercus virginiana) $\phi$ Pecan (Carya illinoinensis) $\phi$ Cedar elm (ulmus crassifolia)* Cottonwood (Populus deltoides)* Hackberry (Celtis reticulata) \# Mesquite (Prosopis spo) $\times \phi$ Texas persimmon (Diospyros texana)* Red buckeye (Aesculus pavia)* Mountain Taure1 (Sophora secundiflora) $\phi$ Texas red bud (Cercis texensis)* Whitebrush (Aloysia ligustrina)* Huisache (Acacia farmesiana)* Catclaw (Acacia sp.)*

Agarita (Berberis trifoliolata) $\phi$ Sumac (Rhus sp.)*

Poison ivy (Rhus toxicodendrum)*

Blackberry (Rubus trivialis)*

Mustang grape (Vitis mustangensis)*

Sunflower (Helianthus annuris)*

Wild verbena (Verbena bifinnatifida)*

Twisted-1eaf yucca (Yucca rubicoia)* Spanish dagger (Yucca treculeana) $\phi$ Arkansas yucca (Yucca arkansana)* Sotol (Dasylirion texensis) $\phi$ Prickly pear (Opuntia lindheimeri) $\phi$ Tasajillo (Opuntia leptocaulis)* Buffalo grass (Buchloe dactyloides)* Beargrass (Nolina texana)*

\# - On Carnp Bullis project sites

$\phi$ - Noted in ethnographic literature

$x$ - Recent invader

* - Noted in other archaeological reports 
TABLE 2. SOME PAST AND PRESENT FAUNA OF BEXAR COUNTY.

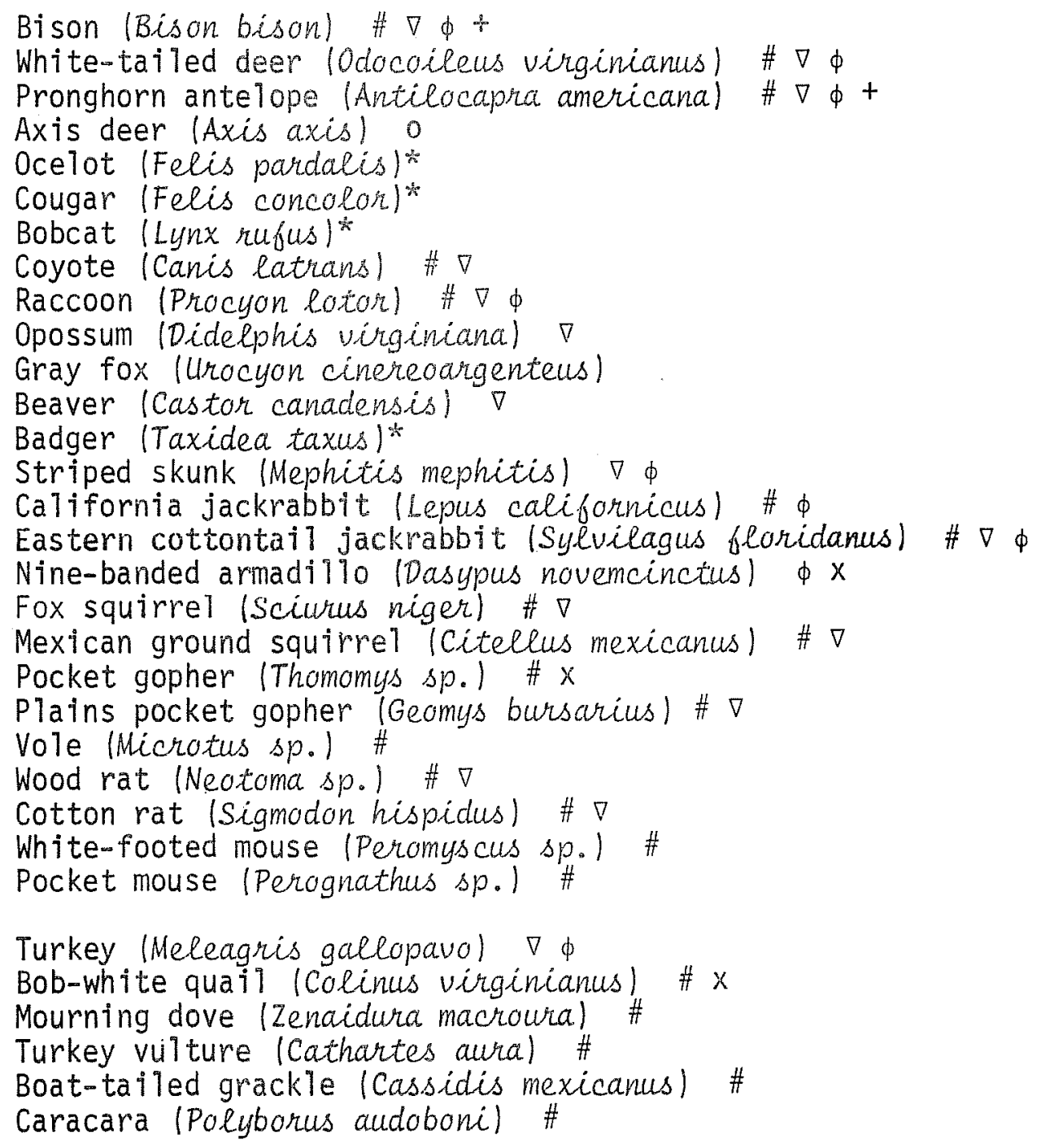

\# - Found at or near Carmp Builis project sites

$\nabla$ - Found at other archaeological sites in the region

+ - No longer in area

$\phi$ - Noted in ethnographic literature

o - Exotic species

$x$ - Invader species or recent introduction

* - Noted in other archaeological reports 


\author{
III. A.3 \\ PREVIOUS ARCHAEOLOGICAL RESEARCH \\ Thomas C. Kelly
}

\title{
INTRODUCTION
}

General summaries of archaeological research in Bexar County have been provided by Woolford (1935), Fawcett (1972) and Hester (1974b). Bibliographies of relevant literature have been published by Campbe11 (1960) and Hester (1975a). With the completion of the Fort Sam Houston Project, 434 archaeological and historical sites have been officially recorded in Bexar County. Only a few of these are scientifically excavated sites, and of the excavated sites only the St. Mary's Hal1 site (4.7 BX 229) has been adequately investigated.

The objective of this chapter is to summarize data on excavated sites in the Cibolo Creek (including Kendal1 County) and Salado Creek drainages in order to provide a basis for comparison with the Camp Bullis sites. Conclusions offered below must be accepted as tentative at this time because of the limited sampling that has taken place at most sites.

\section{CIBOLO CREEK}

The geologic information presented here was obtained from Barnes (1974) and from the project's consulting geologist, Dr. C. M. Woodruff.

Upper Cibolo Creek originates near the western edge of Kendall County 10 miles west of Boerne, in hills of Edwards Limestone. The hilltops are generally barren or thinly vegetated and are an excellent source of good quality chert, usually in large nodules. Patterson and Adams (1977) report heavily used lithic workshops and lithic resource procurement areas in this region. Downstream, four miles east of its source, the Upper Cibolo enters the Glen Rose Limestone Formation. Upper Cibolo Creek and Ranger Creek join to become Cibolo Creek west of IH10 at Boerne. The creek then enters the Recent low terrace deposit through which it continues to a point five miles northwest of Camp Bullis. Here it again enters the Glen Rose Formation.

Upper Cibolo and Ranger Creeks are spring-fed and fairly dependable sources of clear water, drying up only occasionally. However, Cibolo Creek, after entering the Gien Rose Formation near Camp Bullis, seeps into the Edwards Aquifer and is normally not flowing below Georgs Hole, two miles downstream from the western boundary of Camp Bullis. Water is impounded at Georgs Hole by a natural limestone dike and is clear and deep.

From Georgs Hole east across Camp Bullis, Cibolo Creek is normally dry except for the occasional deep stream bed holes gouged out from the combination of cavities (there are several sinkholes that enter into underground caverns) and flood transportation of huge boulders. Automobile tires have been washed into trees 20 feet above the stream bottom. 
Cibolo Creek enters the Quaternary low terrace deposits south of Bulverde five miles east of Camp Bullis' eastern boundary, meanders east for another eight miles, then changes direction to south. Four miles to the south it enters the Edwards Limestone Formation at the intersection of West Fork and Clear Fork Creeks with Cibolo Creek. The Edwards Limestone is an excellent chert source and here again, in combination with what in more mesic times was probably a dependable water source, are found important archaeological resources. A mile farther downstream, Cibolo Creek again turns east to Bracken where the Edwards Limestone is replaced by fluviatile deposits of Quaternary age. Cibolo Creek turns south beyond Bracken, and further south the geologic formation changes again to low terrace Quaternary deposits. These continue to the junction of Cibolo Creek with the San Antonio River four miles north of Karnes City, approximately 84 miles from Cibolo Creek's origin.

Upper Cibolo Creek Sites

The archaeology of Cibolo Creek will be described from its origin in western Kenda11 County downstream to its confluence with the San Antonio River. Fig. 2 is presented to clarify locational relationships.

A series of hilltop and creek terrace sites along Upper Cibolo Creek and tributary creeks have been described by Patterson and Adams (1977) on the Weaver Adams ranch in western Kenda 11 County. The Edwards Limestone Formation here is a rich source of chert, eroding from hilltops in large nodular form. Patterand Adams (ibid.) attribute two hilltop camp/lithic resource procurement areas to the Late Paleo-Indian period and date seven lower creek terrace sites from Pre-Archaic to the Middle Archaic. Their assignment of these sites to the respective periods is based mostly on differences in size and style in chert blades and debitage and secondly on a very few projectile point fragments. They also suggest that the movement from high lookout campsites to lower riverine camps indicates a change in hunting patterns from Pleistocene megafauna to deer and smaller game animals in the Archaic period. Judge (1973) and others have made similar observations for various parts of North America.

Approximately two miles downstream, Upper Cibolo Creek makes a $180^{\circ}$ horseshoe bend to the north around a comparatively flat flood plain atop sheer limestone banks. A survey was conducted behind proposed Floodwater Retarding Structure No. I for the USDA Soil Conservation Service (Bass and Hester 1975; Kelly and Hester 1976) from a point one mile upstream to the proposed structure site four miles downstream. A total of 26 archaeological sites were recorded. Two quarry-workshop areas were recognized, one at either end of the survey

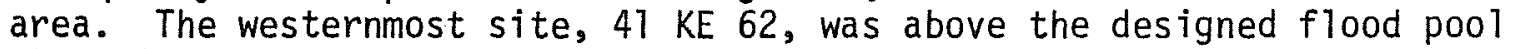
elevation of 1540 feet above mean sea level, and chert nodules eroding from the Edwards Formation were reduced here to quarry blanks and large, crude

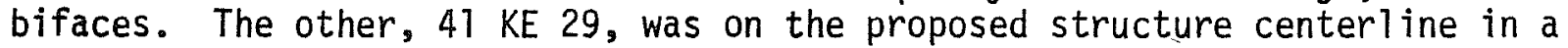
red clay soil atop a Glen Rose Limestone bluff on the north side of the creek. The eroding chert nodules were secondary deposits from the Edwards Formation upstream (C. M. Woodruff, personal communication). The entire process of projectile point manufacture was carried out at this site. Pedernales projectile points (Middle Archaic period markers) were found here. The fact that no Middle or Late Archaic period indicators were found anywhere in the productive 


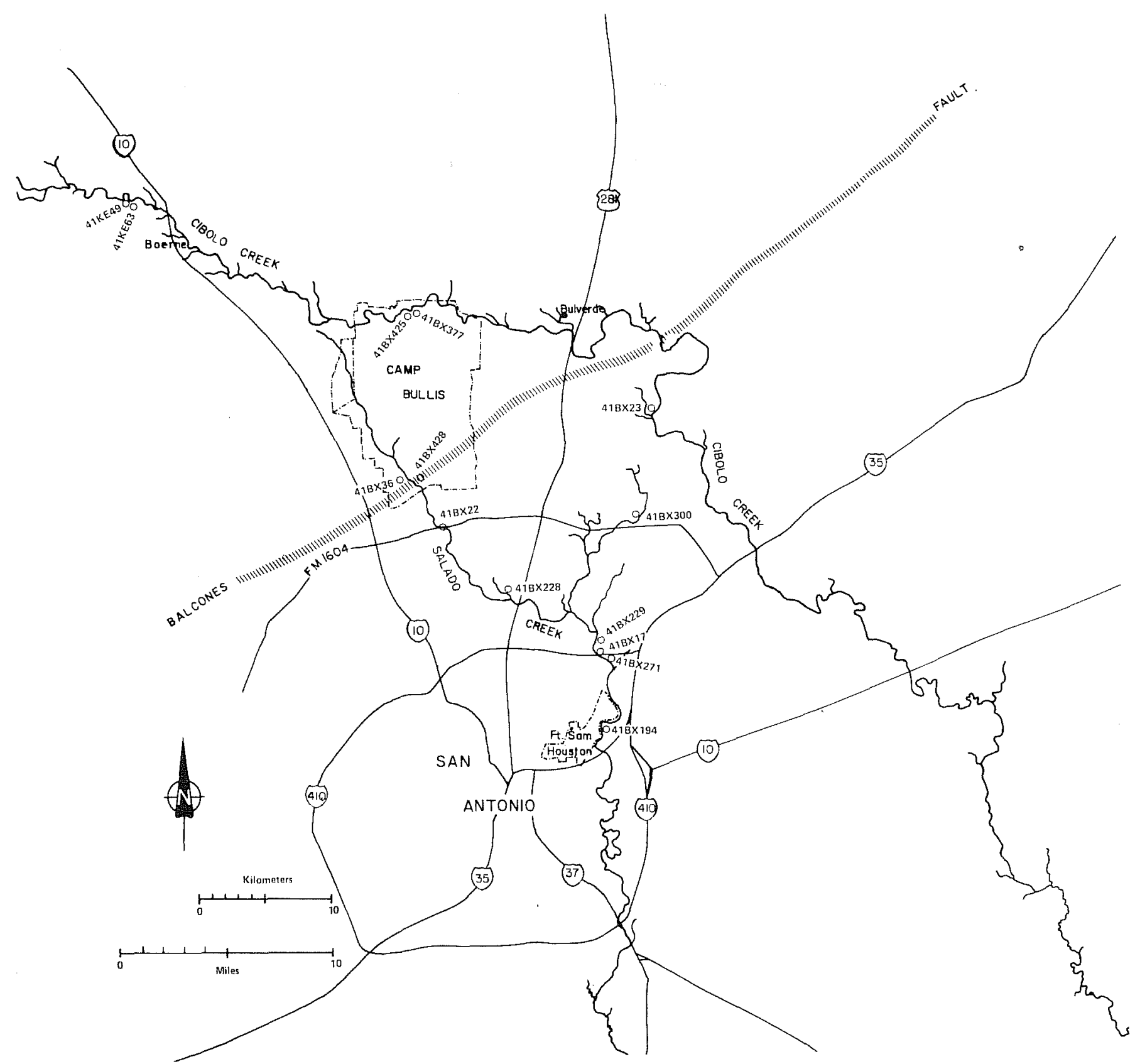

Figure 2. Major Archaeological Sites, Northern Bexar County. This map shows the location of major archaeological sites at which previous research had been done. Also shown are sites 41 BX 36, 41 BX 428, 41 BX 425 and 41 BX 377 at Camp Bul1is. The approximate 1ocation of the Balcones Fault is indicated. 
survey area below the design flood pool elevation is speculated to indicate xeric conditions in the Pre-Archaic and Early Archaic periods followed by more mesic conditions for the Middle and Late Archaic periods causing the later people to seek higher, drier campsites.

A similar relationship exists between $41 \mathrm{KE} 49$ in the oxbow and $41 \mathrm{KE} 63$, $120 \mathrm{~m}$ southeast and 20 feet higher on a ridge. A controlled surface collection and test excavation of $47 \mathrm{KE} 49$ yielded no diagnostic artifact that could be dated more recently than the Early Archaic. The large base camp was favored during the Pre-Archaic and Early Archaic periods and would probably have been used by later groups unless the habitat had substantially changed.

41 KE 63 was another major campsite subjected to limited testing. This site produced the only evidence of the Late Prehistoric period found anywhere in the survey area. Perdiz points and a few plain bone tempered pottery sherds (Leon Plain) were found in the top $10 \mathrm{~cm}$ of deposits. The two test pits also yielded Late Archaic point types, including Frio, Ensor, Castroville, Marcos and Montell. The landowner, however, had collected Angostura, Bell, Early Side Notched, Early Corner Notched, Early Triangular, Thavis, Nolan, Bulverde, Pedernales, Castroville, Montell, Marcos and Perdiz points, bone tempered plain pottery and bone awls, as these materials eroded out of the cliff face over many years.

Another probable Middle Archaic feature is an oval burned rock midden (4l KE 60) also located near the western edge of the survey area. This badly damaged midden $(13 \times 20 \mathrm{~m})$ rises $0.5 \mathrm{~m}$ above the surrounding terrace and has a depression two meters in diameter in the middle. It was impossible to tell whether this depression was a functional feature or whether it was a pothole. The midden contained no diagnostic artifacts or debitage and resembles Weir's (1976) Type 2 midden. The function of the burned rock middens of central Texas has not yet been resolved. Following is a partial list of discussions and theories: Kelley and Campbe11 (1942), Suhm (1959, 1960), Honea (1961), Kelly (1961), Johnson et al. (1962), Greer (1965, 1967), Sorrow, Shafer and Ross (1967) Hester (1970b, 1971, 1973) and Weir (1976).

Two small campsites were attributed to the Paleo-Indian period based on the recovery of Plainview dart points and associated lithic debitage. 41 KE 52 was on a high ridge above the southwest edge of the bend in the creek, and $41 \mathrm{KE} 61$ was in a cultivated field on the north side of the creek and at the west end of the area near readily available chert. A heavily patinated Early Side Notched point belonging to the Pre-Archaic period was also found on this site.

In general, Paleo-Indian sites were found at elevations above 1540 feet, as were quarry-workshop areas. Pre-Archaic and Early Archaic sites were the most numerous and were found all over the survey area below 1540 feet. Middle and Late Archaic period sites were very poorly represented as was the Late Prehistoric. The local settlement pattern appears to reflect two large base camps and a:number of satellite special purpose sites. The two base camps are only $120 \mathrm{~m}$ apart and were probably not occupied simultaneously. One is higher and more sheltered than the other and their occupation may have been determined by seasonality or changing climatic conditions. 


\section{Cibolo Creek Sites}

\section{BX 23: The classen Rockshelter}

Archaeologically, Cibolo Creek is unknown from its origin at Upper Cibolo Creek and Ranger Creek west of Boerne to Camp Bullis, and from Camp Bullis to the Classen Rockshelter 17 miles downstream. Fox and Fox (1967) report this rockshelter on the John L. Classen Ranch in northeastern Bexar County. It is located on a stream terrace under a limestone bluff above the junction of West Fork and Clear Fork Creeks with Cibolo Creek. There is a deep hole in the stream bed that may have held water during more mesic times but is now normally dry. Chert is plentiful in nodular form, eroding from the hilltops.

Limited testing at the site produced Middle Archaic, Late Archaic and transitional Late Archaic projectile points. Point types identified were (in the order of their frequency) Pedernales, Castroville, Montell and Dare. Photographs accompanying the manuscript also show projectile points that are probably of the Ensor and Frio types. An associated circular burned rock mound had no cultural material in it. This would seem to be another example of the same kind of midden as 41 KE 60 on Upper Cibolo Creek. 41 BX 23 was noted as being 20 feet above the stream bed and this may be another indicator of mesic conditions causing Middle Archaic and later people to seek higher campsites.

\section{SALADO CREEK AND NEARBY DRAINAGES}

Salado Creek originates at the northwest corner of Camp Bullis in the Glen Rose Limestone Formation. It runs south passing east of Camp Bullis Headquarters and west of the "Known Distance Ranges." One-half mile before it exits Camp Bullis it crosses the Balcones Fault and enters the Edwards Limestone. $41 \mathrm{BX} \mathrm{36}$, the only previously recorded site on Camp Bullis, is on the flood plain and first terrace west of Salado Creek (see Chapter III.A.7).

Salado Creek crosses FM 16041.5 miles south of Camp Bullis. Downstream 1.6 miles from FM 1604 the Edwards Limestone Formation is replaced by Quaternary low terrace deposits containing redeposited Edwards cherts from upstream. The creek turns east and crosses Blanco Road one mile north of Churchill High School and enters Walker Ranch.

Panther Springs Creek (which also originates on Camp Bullis) crosses the Walker Ranch from north to south intersecting Salado Creek, just west of West Avenue, the eastern boundary of Walker Ranch. Between the two creeks is a broad flood plain which has been cultivated in the past.

Salado Creek then turns east from its confluence with Panther Springs Creek for 4.5 miles to a confluence with Mud Creek. Salado Creek continues through the terrace deposits until it joins the San Antonio River four miles south of Loop 410 after a circuitous route of 28 miles, the last four miles cut through Quaternary fluviatile deposits. 
Sites on Salado Creek and Nearby Drainages

The archaeological sites witl be described in order proceeding from the origin of Salado Creek in the northwest corner of Camp Bullis to its confluence with the San Antonio River 28 miles southeast. See Fig. 2 for site locations.

\section{BX 36: Previous Investigations}

This large midden is the only site previousiy recorded on Camp Bullis. Despite massive damage for years by relic collectors and more recent destruction by heavy equipment in the construction of sewage settling basins, it is still a potentially valuable archaeological deposit (see III.A.7). The site is $100 \mathrm{~m}$ south of Salado Creek on the flood plain and extends up a colluvial slope and shelf. 01d aerial photographs indicated that the midden extended into the flood plain for another 25 to $35 \mathrm{~m}$ to the north before the settling basins were constructed. The author excavated a 10-foot square unit on the colluvial shelf in 1959 (material on file, CAR-UTSA).

The site was recorded by Thomas R. Hester in 1969 on information provided by Dale Patrick who reported uncontrolled digging in process. Captain Allen Leippe (USAF) donated a surface collection to UTSA in 1974 and reported the site as having been essentially destroyed by construction of the settling basins and by workmen who looted parts of the site during this period. Dr. Hester (personal communication) had only limited success in 1974 in staying the destruction, and the site was finally put off limits by a Department of the Interior Directive in 1976 according to the Camp Bullis Operations Officer. J. C. Townsend (1975) prepared a summary and recorded the artifacts known at that time. Her work has provided most of the bas is for this summary of previous activities at the site.

Bison and deer bones were found; one bone had been made into a highly polished and incised fragment of an aw1 (Fig. 3). Rabdotus and other snail shells were present in great quantities. Using a total of 39 documented projectile points, Townsend assigned the midden to time periods from Late Paleo-Indian through Late Prehistoric. Heaviest use of the site was thought to have been during the Middle and Late Archaic periods. There was a single specimen each of Angostura, Travis, Nolan and Bulverde to represent the Paleo-Indian and Early Archaic periods. Three specimens each of Montell and Marshall, two Frio, two Ensor-Frio, one Ensor and one Williams indicate the presence of Late and Transitional Archaic periods. Two Martindale points were present; one was described as patinated and would probably be placed in the Early Corner Notched classification of Pre-Archaic age in the present study. The Late Prehistoric was represented by four Edwards and four. Perdiz arrow points.

Bifaces, preforms, cores and flakes made up the balance of the collection studied by Townsend. No interpretations could be offered because the sample was neither collected nor excavated under controlled conditions.

\section{$41 B X$ 22: The Rogers Site}

The site has been destroyed by the construction of Fm $160 \mathrm{~m}^{\mathrm{H}}$ across Salado Creek, 1.5 miles south of Camp Bullis. The site was located on an alluvial terrace 


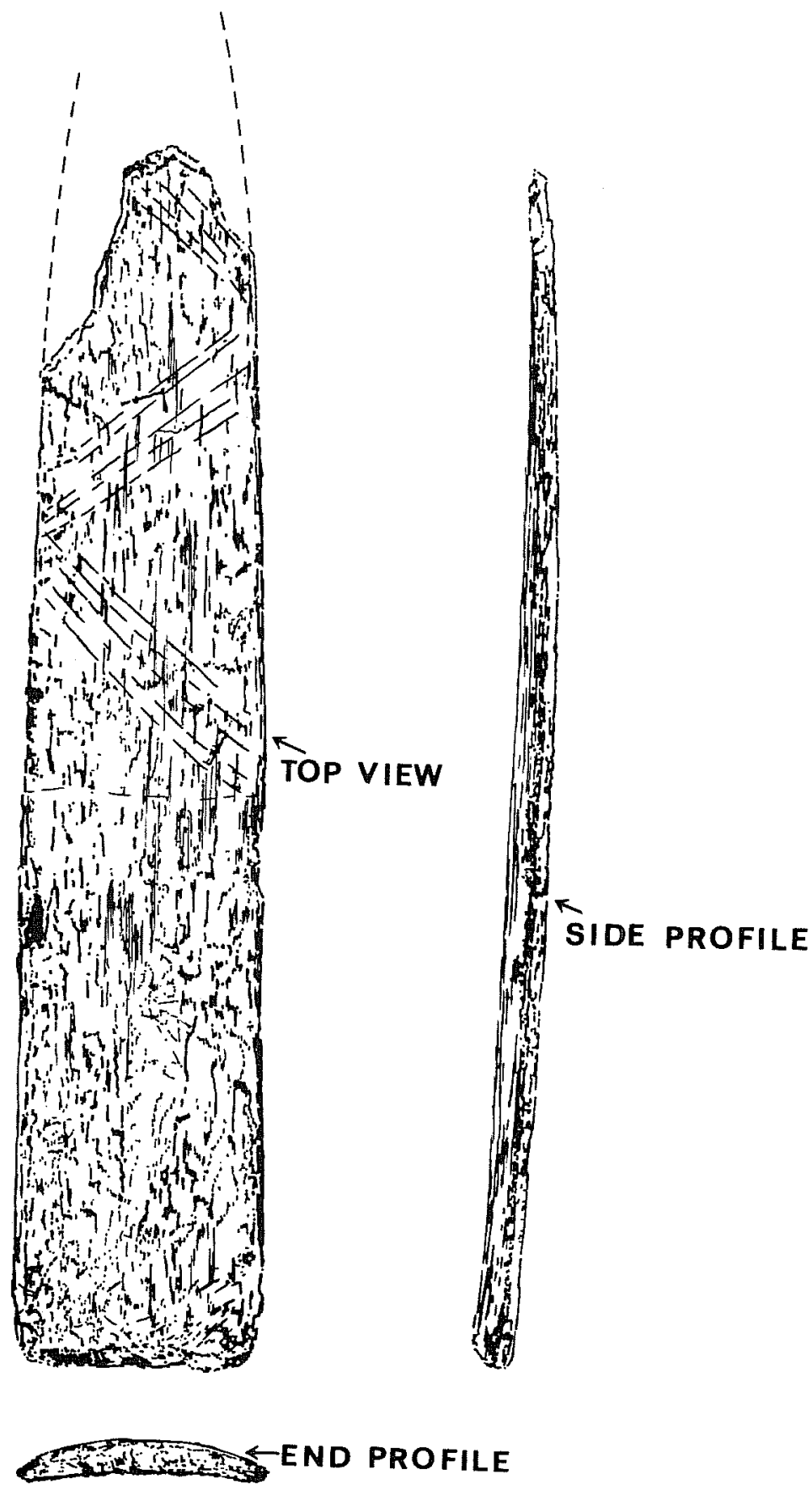

Figure 3. Illustration of a Bone Tool. This artifact illustration is taken from the report by Townsend (1975) on 41 BX 36 . 
adjacent to steep bluffs on the east bank. The locus is at the intersection of two tributary creeks with Salado Creek on the Rogers Ranch. Limited excavations were carried out by a group of young amateur archaeologists and were recorded by Daniel E. Fox (1965, manuscript on file at CAR-UTSA).

Pedernales, Castroville, Montell, Scallorn and Edwards projectile points were recovered, representing Middle and Late Archaic and the Late Prehistoric periods. It was noted that caves and rockshelters along the bluff were filled or partially filled with alluvium. It can be speculated that earlier occupations were buried below the levels of this campsite in the eight feet of alluvial deposit recorded in a natural vertical section. Only the upper 30 inches were tested.

\section{Floodwater Retarding Structure No. 3}

This flood control basin is located approximately $400 \mathrm{~m}$ upstrear from $41 \mathrm{BX} 22$ in some of the most rugged terrain in the Salado Creek drainage. Five sites were located on the stream terraces (Hester et al. 1974). Two were sma 11 short-term campsites, and two were quarry-workshop areas. The fifth site, 3-3, was on an alluvial terrace in a sharp bend of the creek just above the proposed structure site and is the closest upstream site to the Rogers site, lying about $800 \mathrm{~m}$ away. It is a mound-like, oval accumulation of burned limestone rock approximately $0.5 \mathrm{~m}$ above the surrounding terrace and approximately $10 \times 8 \mathrm{~m}$ in surface area. A shovel test during the 1974 survey yielded a few flakes of chert. More recent studies in this locality are reported by Valdez and McGraw (1977).

\section{BX 228 and The Walker Ranch}

Site $41 \mathrm{BX} 228$ is a very large site and may represent a series of repeated occupations, covering a large area on a broad flood plain on the east bank of Panther Springs Creek. It is 0.8 miles downstream from a large permanent spring-fed waterhole, and the flood plain on both sides of this waterhole was heavily utilized for aboriginal activities that are still visible despite farming in years past. A total of 36 archaeological sites were recorded on the Walker Ranch in the course of two other surveys (Hudson et al. 1974; Hester et al. 1974).

$41 \mathrm{BX} 228$ is believed to be one of the most important sites in the survey area and lies within a National Register District on the Walker Ranch. Hudson et al. (1974) placed a $1 \mathrm{~m}^{2}$ unit at the north end of the site, excavating to a dep:h of $20 \mathrm{~cm}$. They reported projectile points from Archaic and Late Prehistoric periods, bison bone and 1ithic debris. Kelly (197.4) excavated two $1.5 \mathrm{~m}^{2}$ to a depth of $60 \mathrm{~cm}$. A more recent project conducted by the Center for Archaeological Research in June-July 1977 added five $1 \mathrm{~m}^{2}$ test pits south of the previous excavations (Jaquier et al. 1978). The site was extensively mapped at that time.

The soil is charcoal-stained black humus of the Lewis Silty Clay series. It contained scattered burned rock (but without discernible stratigraphy) to a depth of 45 to $60 \mathrm{~cm}$. It is underlain by yellow gravelly clay followed by 
bedded limestone stream gravels to the level of the creek bottom (approximately $4.5 \mathrm{~cm}$ below the surface). A11 three testing phases have indicated traces of the Early Archaic period represented by a few Nolan points. The heaviest occupation was during the Middle Archaic represented by Pedernales points. The Late Archaic is also we11 represented by Castroville, Montell and Ensor points (in that order of frequency). The Late Prehistoric is only sparsely represented by Edwards, Scallorn and Perdiz points. Thousands of flakes, bifaces, unifaces, cores and other lithics were found. Shells of Rabdotus land snails were plentiful throughout the deposits, as were quantities of burned 1 imestone rocks. Cut and broken bone of deer, bison and other species has been subjected to analysis (Jaquier et al. 1978).

A large number of sites (36) were found in a comparatively small area (1ess than 200 acres) nearby. It is probable that there are more sites remaining undiscovered, as large portions of the area are covered with dense vegetation.

\section{BX 300: The Elm Waterhole Site*}

$41 \mathrm{BX} 300$ was discovered by an intensive survey behind Floodwater Retarding Structure $13 \mathrm{~A}$ on Elm Waterhole Creek, a tributary of Salado Creek (Kelly and Hester 1976, Kelly 1976a) and the perimeters were roughly determined by using a mechanical auger. The entire flood plain on which the site lay was in the process of being renoved for borrow fill for Floodwater Structure 13A, and the fact that the site still exists is a tribute to close cooperation between archaeologists, the contractor, the Soil Conservation Service and Elgin Steubing, the ranch owner. It is now an "island" surrounded by borrow pits. It has been nominated to the National Register of Historic Places.**

In 1976 the area was tested with $271 \mathrm{~m}^{2}$ test pits by the Center for Archaeological Research, assisted by volunteers from the Southern Texas Archaeological Association and archaeology students from UTSA (Kelly n.d.). These tests indicated at least two distinctive contiguous areas in the site. The southern portion is an oval burned rock midden covering an area approximately $100 \mathrm{~m}$ north-south and $55 \mathrm{~m}$ east-west. The matrix consists of nearly solid firecracked limestone, charcoal-stained clay soil, Rabdotus land snails (often in clusters of hundreds), projectile points, scrapers, cores, flakes and chert debitage. The burned rock deposit is without discernible stratigraphy and extends to a depth of one meter. Below are yellow river gravels and streamrolled cobbles continuing to an unknown depth. The bulk of the datable artifacts belong to the Early. Archaic period (Bulverde, Travis, Nolan projectile points). A few Pedernales points of Middle Archaic age, and Castroville, Marcos and Marshall of the Late Archaic period were recovered.

North of this burned rock midden the land rises gradually to its highest point at the south bank of an L-shaped waterhole. Tests here indicated intensive occupation. The shallow deposits yielded Late Archaic and Late Prehistoric

*The USGS Longhorn Quadrangle map 1ists the creek as Elm Waterhole Creek, but the Bexar County maps label it Long Creek.

**Mitigation of the site was accomplished by the Center for Archaeological Research in early 1978, with funding provided by Interagency Archeological Services. 
artifacts (Frio, Dare, Montell, Edwards and Perdiz projectile points in that order of frequency).

The removal of the borrow fill from the flood plain revealed several other areas of intensive aboriginal activities. Clear Fork and Guadalupe tools were found $100 \mathrm{~m}$ south of the site, and a small burned rock midden was exposed against a steep hillside $75 \mathrm{~m}$ west of $47 \mathrm{BX} 300$. This midden had two Pedernales dart points and considerable chert debitage on the surface.

$41 \mathrm{BX} 300$ was strategically located in relation to two major quarry-workshop areas. 41 BX 299 was to the east, just across the creek and above a high rocky bank; there was very little soil cover and much exposed Edwards Limestone. Chert is eroding out of the limestone, and the area was strewn with debitage, broken quarry blanks and crude bifaces. A much larger quarry-workshop, $41 \mathrm{BX}$ 301 , is located $250 \mathrm{~m}$ west-southwest. Chert nodules with diameters as large as $25 \mathrm{~cm}$ are found in this area eroding out of exposed limestone. Numerous individual knapping stations were found where quarry blanks were produced (Katz 1978).

\section{BX 229: The St. Mary's Hall Site}

Two miles downstream from the confluence of Elm Waterhole, Mud and Salado Creeks is the St. Mary's Hall site. It is located atop a steep bluff on the east bank of Salado Creek. It overlooks a wide valley with a gentle slope on the west side of the creek. It is one of the most important archaeological resources in south-central Texas.

The Paleo-Indian period is well represented in deep yellow caliche gravel deposits by Plainview, Golondrina and Angostura projectile points and their distinctive preforms. Unifacial scrapers, Clear Fork tools, cores and heavily patinated lithic debitage were associated. A single Folsom point was recovered from the site in the yellow gravels, but the evidence for a possible occupation during the Folsom period was not found.

The site was excavated by the Southern Texas Archaeological Association in 1974-1975, and was the site of the 1977 UTSA Archaeological Field Course under the direction of $\mathrm{Dr}$. Thomas R. Hester (1978). Above the Paleo-Indian deposits was found a "transitional gravels" unit of Pre-Archaic age. The upper deposits, an extensive midden with scattered burned rock, dated to Late Archaic and Late Prehistoric times. These midden deposits contained burned rock, charcoalstained soil, bone, snails, chipped stone artifacts and debitage. The Late Archaic is represented by Montell, Ensor, Frio and Ensor-Frio points. The Late Prehistoric period is best represented by Edwards points, al though a few Perdiz points and Leon Plain potsherds were found. A significant portion of the site was completely destroyed by the building of a house and swimming pool across the fence in the southern part of the site. The haass collection (Cantu et al. manuscript) was obtained as the site was destroyed. It contains Plainview, Golondrina, Meserve and unidentified Paleo-Indian points as well as numerous Archaic and Late Prehistoric points, cores, bifaces, unifaces, flakes and bone, and shell artifacts. 


\section{BX 17: The Granberg Site}

The Granberg site was located one mile down Salado Creek from 41 BX 229, in the right-of-way for the IH 410 Expressway. It became the scene of something approaching a public brawl in 1962 when the press headlined rich "Indian finds" exposed in a bulldozed water ma in trench in the highway construction area. There were at that time no laws protecting antiquities on state property in Texas, and literally hundreds of relic collectors overran barricades and fought over "choice" areas. It was only through the most strenuous efforts of Mardith Schuetz, Harvey Kohnitz, a group of spelunkers and others, that any information was salvaged (Schuetz 1966). A "public" area was set aside to placate the pothunters, and the salvage crew was able to sink several test pits with reasonably good control in the week before the contractor finally bulldozed the whole area.

The excavations revealed three stratigraphic units: an upper black humus clay soil; a lower burned rock midden with ashy soil; and a red gravel stratum at the bottom, approximately five feet below surface. Early and Middle Archaic points were predominant in both upper levels, with Pedernales, Castroville, Travis, Bulverde, Nolan and Pandora* points represented in the upper humus soil. Nolan, Travis, Pedernales and Pandora points were predominant in the burned rock midden stratum. Some Late Archaic points, Montell and Castroville, were found in both strata. The Ensor type point was found only in the upper humus stratum. The skeletal remains of eight individuals were found and attributed to the Late Archaic period. Grave goods included a shell gorget and a few crude bifaces.

\section{BX 271: The Granberg II Site}

The Granberg II site is on the east bank of Salado Creek south of the IH 410 Expressway on the first terrace above the flood plain. Several test pits were excavated with one extending to a depth of $360 \mathrm{~cm}$ (Hester and Kohnitz 1975); 11 strata were defined. The upper strata included a burned rock midden and a transitional stratum (zone III at 50 to $60 \mathrm{~cm}$ ) in which typical Middle and Late Archaic points (Pedernales and Montall) were found. The strata from 60 to $360 \mathrm{~cm}$ were alluvial sands and gravels, sometimes in a yellow/red clay matrix. Pre-Archaic dart points were predominant in these zones with Bell, Early Side Notched, Early Corner Notched, Early Triangular and Gower represented. These Pre-Archaic projectile points were found closely associated with a number of Clear Fork and Guadalupe tools (ibid.:22). Four Guadalupe tools were found in a "cache" in zone VIII, an occupation floor at $230 \mathrm{~cm}$. In the lowest stratum, zone XI, a chert core was found in large heavy stream gravel.

The Granberg II site has provided the clearest case so far for placement of the Guadalupe and unifacial Clear Fork tools in the Pre-Archaic period in central Texas (Hester 1976b).

*In light of present-day lithic knowledge, the Pendora type would probably be listed as dart point preforms. They are unfinished, broken, badly stepfractured and generally too heavy for projectile points. 


\section{DISCUSSION}

In this section, excavated sites along the Cibolo Creek and Salado Creek drainages have been examined to provide a basis of comparison and evaluation of the Camp Bullis survey and tested sites.

The period markers (diagnostic projectile points) are plotted by type and site (Table 3) with four partially excavated Camp Bullis sites added for ready comparison (41 BX 377 and 41 BX 425 on Cibolo Creek; 41 BX 428 and 41 BX 36 on Salado Creek). The sites are listed from left to right in order of the dominant time period, from most recent to oldest. Study of this chart indicates the greater numbers of point styles in the Late Archaic period (10 types), with Castroville found on seven sites, Ensor, Ensor-Frio and Montell found on six sites.

Pedernales points, the major period marker for the Middle Archaic, were found on eight sites, but a check of their total number showed surprisingly few in the area. By contrast, Weir $(1976: 113)$ indicates Pedernales points as being $33 \%$ of all points in the Middle Archaic sites considered in his study of the Central Texas Archaic.

The Early Archaic is best represented by the Nolan type, found at six sites. A11 of the Pre-Archaic points were found on only four sites, and the Late Paleo-Indian points were also found on four sites. There is a clustering of Late Prehistoric and Late Archaic points by site, and the same situation is seen for the Early Archaic and Pre-Archaic.

Major campsites (41 BX 36, $41 \mathrm{BX} 300,41 \mathrm{BX} 17$ and $41 \mathrm{KE} 49$ ) had the greater number of different point types, indicating preference over a long time period for the same camp facilities, probably based on dependable water, readily available limestone (for hearth construction), chert and food sources.

\section{SUMMARY}

A series of base camps and possible satellite auxiliary function sites occur in the drainages of Cibolo and Salado Creeks. The base camps were multipurpose with the entire gamut of aboriginal functions carried out within their spatial limits. Functions identified or hypothesized for satellite sites include: reduction of cobbles to preforms and quarry blanks, projectile point production, food preparation (possibly including special cooking areas for acorns and other plants) and small auxiliary hunting or foraging camps.

Paleo-Indian camps are found on high "overlooks" and ridges and were generally sma11 transient (hunting?) camps. The St. Mary's Hall site (41 BX 229) provides a notable exception as the only known Paleo-Indian base camp in the area. It, too, is on an overlook bluff above Salado Creek.

The Pre-Archaic sites are found at lower elevations closer to water sources and often in locales later used by Early Archaic peoples. However, within the Camp Bullis area, Pre-Archaic sites overlap topographically with Paleo-Indian sites. 
TABLE 3. PROJECTILE POINT TYPES BY TIME AND SITE, CIBOLO AND SALADO CREEKS

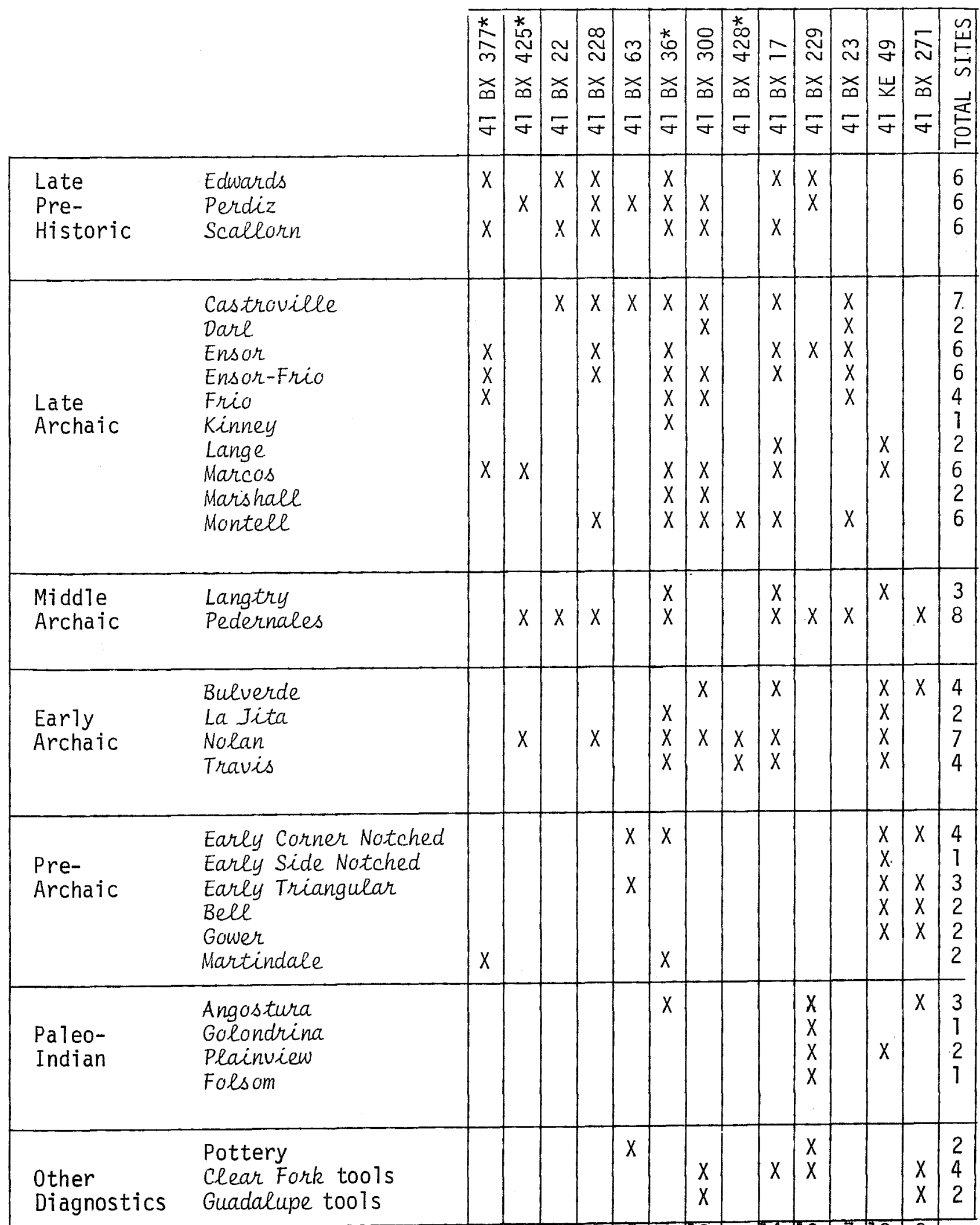

\begin{tabular}{|l|l|l|l|l|l|l|l|l|l|l|l|l|l|}
\hline TOTAL DIAGNOSTIC TYPES & 7 & 4 & 4 & 9 & 5 & 19 & 13 & 3 & 14 & 10 & 7 & 13 & 9 \\
\hline
\end{tabular}


The Middle Archaic is poorly represented throughout the area. There are several indications of a shift to higher elevations after the Early Archaic, possibly indicating a change from xeric to mesic conditions.

The primary change that we can recognize over a long time period was in projectile point styles. The trend was from early large barbless lanceolate to smaller barbed triangular points. These differences may be related to changes in size or type of game hunted.

The Toyah phase of the Late Prehistoric is represented at the same number of sites as the earlier Austin phase, but by less numerous points and only occasional potsherds. This may indicate a decline in population in the region or sampling bias. The latter is more likely, as numerous discrete campsites of the Austin phase are common along Cibolo Creek within the Camp Bullis survey area. 


\author{
III. A.4 \\ RESEARCH METHODS
}

Andrea Gerstle, Cristi Assad, Augustine Frkuska and Joel D. Gunn

\title{
SURVEY METHODS
}

Eleven zones were defined prior to the survey; these followed the outlines of existing "military zones" and were designed to avoid conflict between the military schedule and the archaeological survey activities (Fig. 4). For the purposes of the project, these are entirely arbitrary and did not affect the outcome of the sample. These zones were bounded by roads and were partially consistent with the five major drainage basins within the reservation. In the interests of obtaining a representative sample of the cultural resources and at the same time most efficiently using the time and personnel available, systematically-spaced transects across all of the zones except for one were surveyed. The one exception is the artillery impact zone, to which only limited access was possible. These transects were oriented either northsouth or east-west and placed approximately perpendicular to the drainage and roadway systems. Two purposes were thus served. By crossing the drainage system, the entire range of elevation and topographic variation was crossed with each transect. By walking perpendicular to the roadways, the logistical problems of crew transportation with one vehicle were minimized. The cardinal orientation of the transects allowed the surveyors to follow their compasses; thus only the ends of each transect on the roads were located and flagged prior to the survey. This was quickly accomplished in the vehicle.

The transects were $50 \mathrm{~m}$ wide, judged to be the maximum width that a two-member crew could intensively cover. In order to obtain the minimum sample size, the centers of each of the transects were spaced $300 \mathrm{~m}$ apart. Three transects, a total of $150 \mathrm{~m}$ in width, were surveyed for each $\mathrm{km}$ or $1000 \mathrm{~m}$ wide strip. Topographic maps showing the locations of the transects are on file at the Center.

The 15\% sample of Camp Bullis covered in this manner fulfills the minimum requirements set forth by the Corps of Engineers. This sampling scheme proved to be eminentiy suitable for covering a large area, maintaining a statistically valid sample and minimizing the problems associated with physically locating random quadrants or other sampling units in hilly, rugged and densely vegetated terrain which is largely inaccessible by vehicle (see Judge et al. 1975).

Three survey teams of two persons each were involved in the survey. Two of these teams were walking the transects while the third was surveying additional areas which were not covered by the transects, but which, based on topographic map study, were deemed likely to contain archaeological sites. The $15 \%$ representative sample was thus supplemented by additional intensive survey of these selected areas. However, the statistical analysis of data pertaining to site density, frequency of different site types and locational information was restricted in this report to the systematic transect sample. 


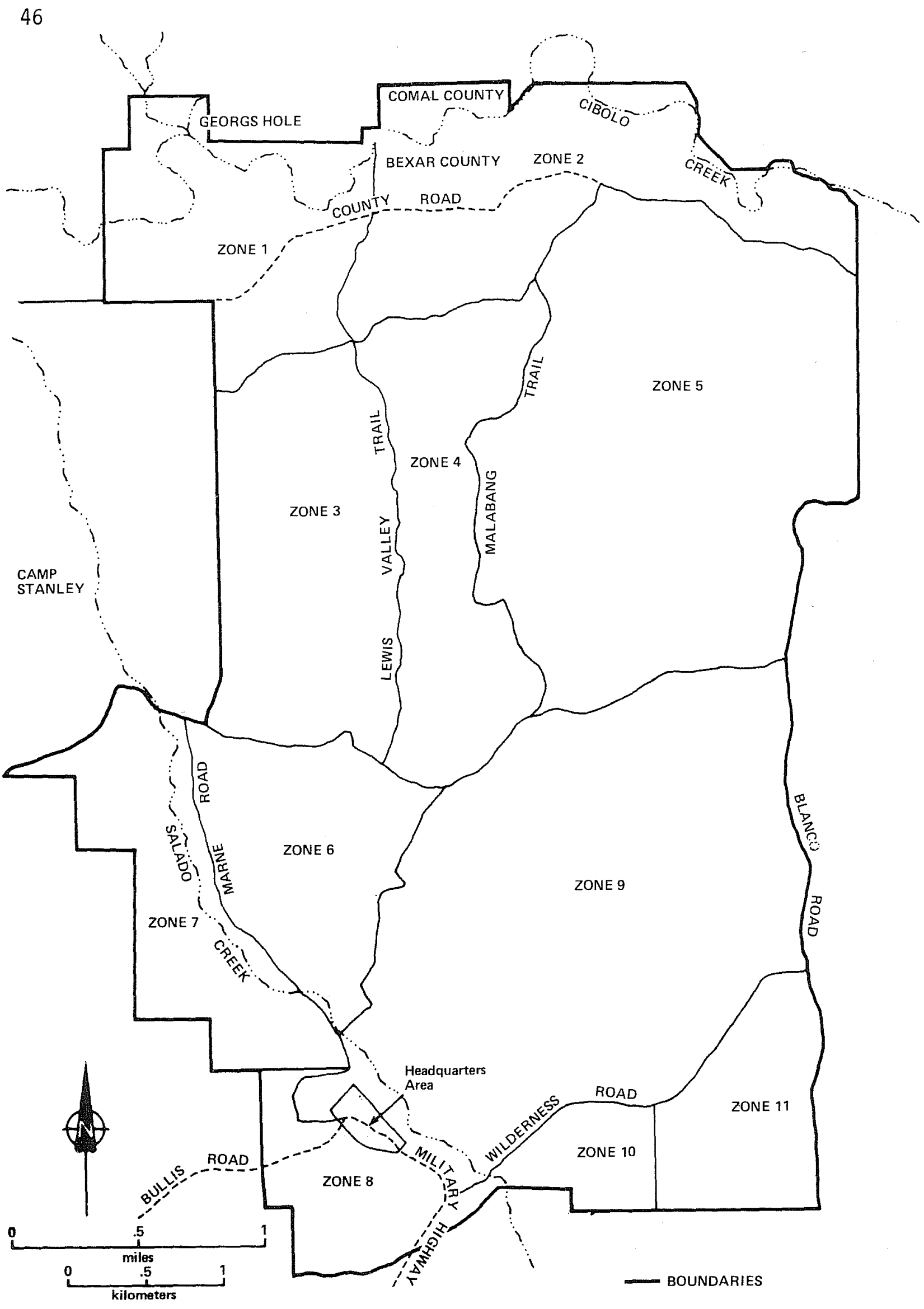

Figure 4. Camp Bullis, Texas: Survey Zones. The 11 zones utilized for survey activities are indicated. Also shown are major roads, streams and other landmarks at Camp Bullis. 


\section{SITE RECORDING}

Two different recording forms were used to record site survey data: a computer coded form and a written form. The purpose and nature of these are described below.

The computer coded form (Fig. 5), designed by Dr. Joel Gunn of The University of Texas at San Antonio, serves to quantify and make consistent certain types of data collected on each site. This allows inter-site comparisons by computer analysis to be carried out. The data recorded on this form is oriented toward inter-site rather than intra-site analysis. Hence, the emphasis is on locational and site contextual information rather than artifact-specific data. As a field form, this is entirely justifiable. Artifact analysis is more accurately carried out in the laboratory and provides a second data set of no less importance.

The second survey form (Fig. 6) is patterned on a project-specific site survey form used by the Center for Archaeological Research and supplements the coded form with specific observations which are unique to each site and cannot be coded in standardized format. This information is used in individual site evaluations and may explain anomalies presented by the computer analys is of the data on the coded form. This uncoded form allows the surveyors to record observations on artifact distribution, configuration of features such as hearths, preliminary evaluation of site function and initial recommendations for future work.

\section{COLLECTION METHOD}

In order to minimize artifact collection, yet gain a sufficient sample for laboratory analysis and maintain a fairly consistent procedure from one site to the next, a minimum standard for procedure was established. This included determination of site boundaries and dimensions in the cardinal directions, measuring and completely collecting a $3 \mathrm{~m}^{2}$ unit in the approximate center of the site and mapping the location of all artifacts collected outside the collection square.

Although it was not feasible in every case to collect a $3 \mathrm{~m}^{2}$ unit, any area that was $100 \%$ collected consisted of one or more $1 \mathrm{~m}^{2}$ units. This allowed some measure of artifact density to be calculated, a primary reason for standardizing the collection procedure. An indication of the variety of flake and tool types also resulted. The location of the collection area was plotted on a map along with those diagnostic tools found outside of the collection area. Lithic concentrations observed were also mapped and in some cases collected. Thus we have a record of artifact and feature locations within sites and a way of determining the nature of these based on the collections.

\section{EXCAVATION METHODS}

Grid Layout

All excavated units and surface collection squares were established on the basis of a grid superimposed on each site. An arbitrary datum labelled 
Zero $=$ Missing Data. Comments on Reverse Side. Fill in all blanks. Temporary Site Designation

Location

$1: 1-2$

$2: 3-4$

$3: 5-11$

4:12-18 - East Coordinate, UTM

5:19-25 - - - North Coordinate, UTM

6:26-30 - - - - Elevation (feet)

Components (Field Estimates)

$7: 31$

Predominant Occupation ( $1=\mathrm{Pa}$ leo,

- 2=Early Archaic, 3=Middle

Archaic, 4=Late Archaic

$8: 32$

$9: 33-35$

Site Location

$10: 36-37$

$11: 38-39$

$5=\mathrm{NeO}$-Amer. , $6=\mathrm{Historic)}$

$12: 40$

$13: 41-42$

$14: 43-44$

Secondary Occupation (see above)

_ _ _ Individual Find (see List I)

Date

$15: 45-46$

$16: 47-48$

$17: 49-50$

Site Dimensions

$18: 57-53$

$19: 54-56$

20:57-59

Density (Site-wide)

$21: 60$

$22: 61$

Physiographic Transect ( $1=$

Flood Plain, 2=Terrace, 3=Valley

Slope, 4=Upland Margin, 5=Upland, 6=Upland Feature)

Land Form within 1 mile (see above)

- Site Orientation ( $1=$ Upon, $2=N$. of

- Feature, 3=E. of Feature, $4=S$. of Feature, $5=W$. of Feature)

Vegetation on site (see List II)

- Water Source ( $1=0$ n Site, $2=<100 \mathrm{~m}$,

$-3=<1 \mathrm{~km}, 4=>1 \mathrm{~km})$ Wildlife in area (see List III)

- Lithic outcrops (see List IV)

- Soil type (see List V)

$23: 62$

$24: 63$

$25: 64-65$

$26: 66$

$27: 67$

$28: 68$

$29: 69-70$

$$
\begin{aligned}
& \text { Long orientation (degrees } E \text { of } N \text { ) } \\
& -- \text { Length }(m)
\end{aligned}
$$$$
\text { - Width (m) }
$$

Ceramic $(1=1-10,2=10-50,3=50-100)$

- Chipped Stone $(1=1-10,2=10-50,3=$

- 50-100, 4=>100)

Ground Stone (frequency, 9=>9)

- Burned Rock ( $1=$ scatter, $2=$ concentrated,

- 3=midden) \# of hearths

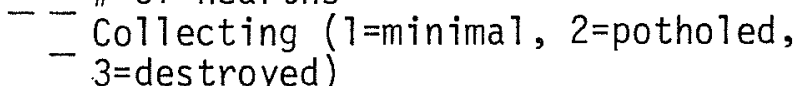

Economic activity (1=disturbed, 2=

- partially disturbed, 3=wholly disturbed)

_ Erosion (1=undisturbed, 2=partially

- eroded, 3=wholly eroded)

_ Surveyor

Figure 5. Computer Coded Field Survey Form. 
Point Types, List I

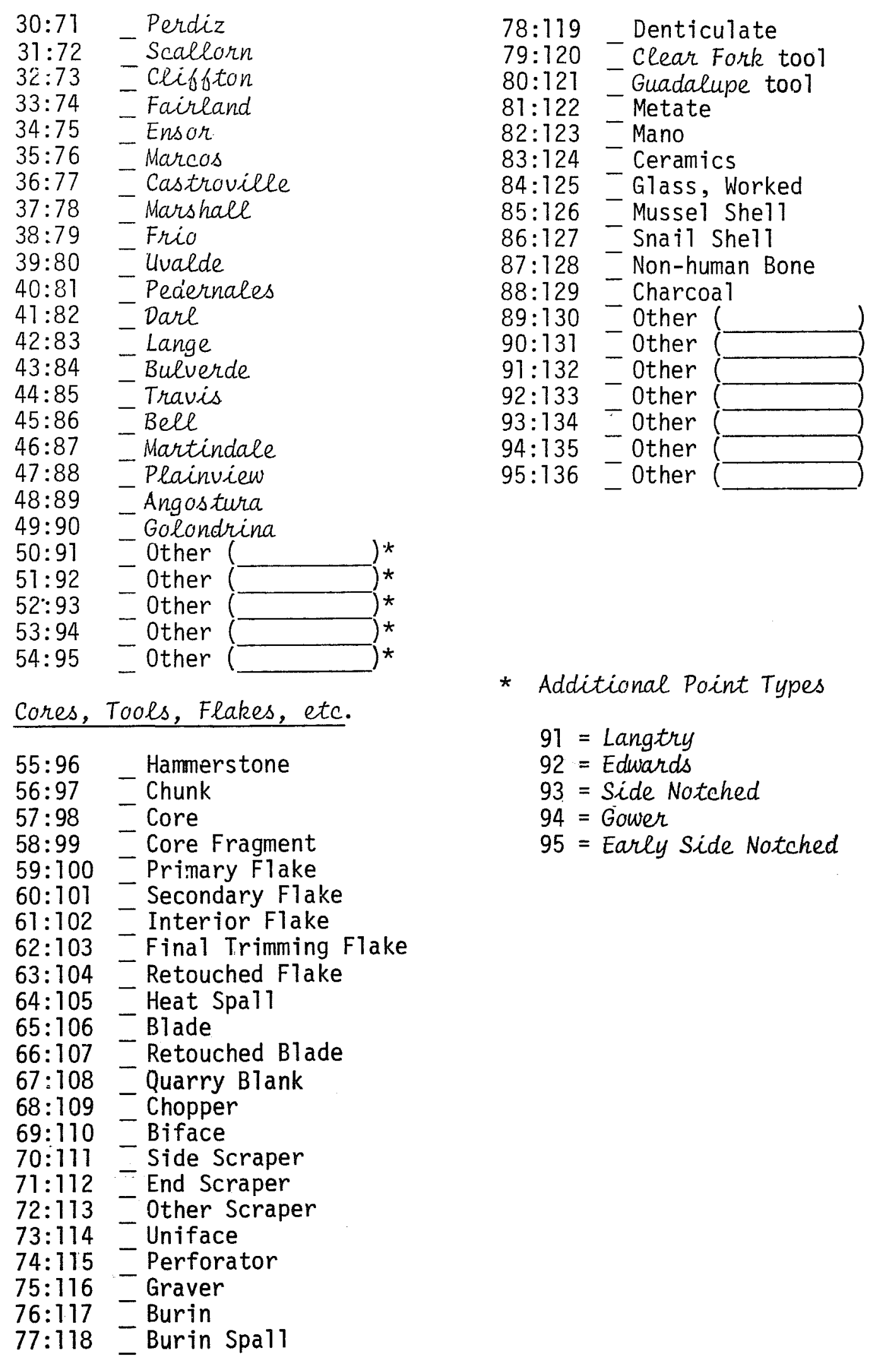

Figure 5. (continued) 
Vegetation, List II

1 - open, grassy fields with clumps of live oak, cedar

2 - above, plus prickly pear and/or yucca/sotol

3 - woods of live oak, hackberry, huisache, cedar, elm

4 - dense cedar, thorny brush, mesquite

5 - cultivated field

6 - cedar and grassland

7 - (2) and (3) combined

8 - (7) plus beargrass and grama

$9-$

Wildlife, List II

1 - deer, armadi110, turkey, snakes, rabbit, birds

2 - (1) plus fish (aquatic resources)

Lithic Outcrops - List IV

1 - river cobbles, very fine chert, translucent (Class I)

2 - river cobbles, medium fine chert (Class II)

3 - river cobbles, limey chert/cherty lime (Class III)

4 - slope or hilltop source, Class I, nodular

5 - slope or hilltop source, Class II, nodular

6 - slope or hilltop source, Class III, nodular

7 - slope or hilltop source, Class I, bedded

8 - slope or hilltop source, Class II, bedded

9 - slope or hilltop source, Class III, bedded

10 - sandstone

11 - other

Soils - List V

1 - predominant 1 imestone bedrock with very thin soil

2 - blackish loamy soil with some depth

3 - reddish clayey soil with some depth, possible chert grave1

4 - yellow caliche gravel; no real soil

Figure 5. (continued) 
Date

Zone

Map Name

Map Coordinates

Temporary Site Designation Site No.

LOCATIONAL DETAILS: Distinctive nearby features, including nature of nearest water source.

SITE CHARACTERISTICS: Associations of artifacts with features, distribution of artifact types through site, no. and type of artifact concentrations and content (describe each).

CONDITION OF SITE: Type and extent of disturbance plus notes on how site content and artifact distribution may have been affected.

PRELIMINARY FIELD EVALUATION: Ideas regarding site function, occupation, character of deposits, etc.

RECOMMENDATIONS:

ACTIVITIES OF RECORDER: What was done and how.

PHOTOGRAPHIC RECORDS (ro11, exposure \#'s)

B\&W:

Color:

Collection Bags

Recorder

Figure 6. Field Survey Form. 
East 1000, North 1000, was established on or to one side of the site. The grid was then measured from the datum and oriented in the cardinal directions. Stakes were placed at one meter intervals in the section of the site to be investigated. The southwest corner served as the datum for the individual $7 \mathrm{~m}^{2}(\mathrm{~s})$ in the grid. Their location relative to the site datum was recorded by adding or subtracting the distance north and east to the square from 1000 . The choice of the coordinate values E1000 and N1000 rather than East Zero and North Zero ensured that no negative coordinate values would be encountered. This greatly facilitated computer analys is.

\section{Excavation Units}

All excavation units were $1 \mathrm{~m}^{2}$. Excavation levels followed the contour of the present ground surface. Some small "shovel tests" were excavated at many of the sites in order to determine site boundaries and depth of cultural deposits. The soil from these tests was generally not screened.

On some sites ( $47 \mathrm{BX} 36$, for example), $2 \mathrm{~m}^{2}$ blocks were excavated. The purpose of these areas was to extract information from larger horizontal areas. The southwesternmost $1 \mathrm{~m}^{2}$ of these $2 \mathrm{~m}^{2}$ blocks served as an excavation "control" unit. These were excavated in $5 \mathrm{~cm}$ levels and screened through 1/8-inch mesh screens. The other three units in the block were excavated in $10 \mathrm{~cm}$ levels and screened through 1/4-inch mesh screens.

Constant volume soil samples were taken from the southwest corner of each unit (there were a few exceptions when the constant volume samples were taken from another corner due to the occurrence of a feature or abundant rocks). The size of the constant volume samples approximates $20 \times 20 \times 5 \mathrm{~cm}$ for a $5 \mathrm{~cm}$ level or $20 \times 20 \times 10 \mathrm{~cm}$ for a $10 \mathrm{~cm}$ level.

\section{Excavation Forms}

Two types of excavation level forms were used: a computer form developed by Dr. Joel Gunn, Center for Archaeological Research, for computer analys is of excavation units (Fig. 7), and a standard CAR Unit Level Record with a gridded continuation sheet for mapping (Fig. 8).

The computer form requests basic information about provenience, depth of level, strata, soil color (from Munsell Chart) and general quantitative information for charcoal, chipped stone (total count), snails and bone. The quantity and volume of all rock (burned and unburned, not including chert or ground stone) were also. recorded. The unit Level Record form allowed for more detailed descriptions and the individual recorder"s comments.

Photographs were taken of each level, feature and unit profile, and recorded on a photographic log sheet. 
Fil1 al1 blanks, Zero = Missing data

$$
\begin{aligned}
& \text { Card-Site \# } \\
& \text { meters centimeters } \\
& - \\
& - \\
& - \\
& -
\end{aligned}
$$

\section{Excavators}

Photo \#'s

Section $\#^{\top} s$

before excavation

color

$$
\begin{gathered}
\text { Hue } \\
-\quad Y=1, Y R=2, R=3) \\
-\cdots \text { VaTue and Chroma } \\
\text {-Constant Volume }
\end{gathered}
$$

$$
\begin{aligned}
& \ldots \text { Rocks } \\
& \ldots \ldots \ldots \text { Vol. Rocks }
\end{aligned}
$$

after excavation

$$
\begin{aligned}
& \text { Consolidation ( } 1=\text { soft, } 2=\text { hard) } \\
& \text { Grain Size (1=silt, 2=sand) } \\
& \text { Charcoal }(1=\text { flecks, } 2=\mathrm{Cl} 4) \\
& \text { Shell }(9=>9) \\
& \text { Chipped Stone } \\
& \text { - Bone }(9 \Rightarrow 9) \\
& \text { Extent of Excavation }(0=n o, T=N, 2=E, 3=S, 4=W) \\
& \text { Inspected } \\
& \text { Tagged } \\
& \text { Mapped } \\
& \text { - Day } \\
& \text { - Month } \\
& \text { - Year }
\end{aligned}
$$

Comments:

Figure 7. Computer Coded Excavation Level Form. 
Site

Project

Unit Leve] Date

Excavators: Screen size

Description of level/midden (color, composition, contents, etc.)

Materials recovered: (a) chipped stone

(b) animal bone

(c) shel1 (mussel, land snails)

(d) ceramics, metal, glass, etc.

Artifacts (briefly describe and draw; use reverse if necessary):

Features (use separate form for recording features) Disturbances

Photographs No. of bags Recorded by Field Director's Approval

Figure 8. Standard Unit Level Record. 


\section{LABORATORY PROCEDURE}

The laboratory work for this project proceeded concurrently with the field work. As artifacts were brought in, each bag was logged in and the contents washed. Before being catalogued, all lithics, bone, snails and any other items were sorted and counted. All of the artifacts collected were sorted into chipped stone and ground stone categories. The chipped stone was then divided into the following groups: cores, projectile points, scrapers, bifaces (quarry blanks, preforms and finished bifaces), retouched flakes and debitage. The latter group was further subdivided into primary, secondary, interior and "lipped" or biface thinning flakes. Finer subdivisions of tool type were based on the form of the specimens. Each category of artifact was labelled by site number or transect and provenience if from the survey, and by site number, unit and level if from the excavations. The type and quantity of each item was catalogued on standard Center for Archaeological Research Specimen Inventory Forms and a computer form (Fig. 9). The information on the computer form was then keypunched onto computer cards in preparation for numerical analysis.

Special analyses were performed on a selected sample of complete and fragmentary lithic artifacts, all identifiable animal bone and on a limited number of constant volume samples which were collected during excavation. Analysis of pollen, soil and snail samples was done in conjunction with the constant volume samples (see III.A.10 and III.A.11).

For the lithic analysis, a special computer form was developed (Fig. 10). The artifacts analyzed included points, bifaces, unifaces, cores and retouched flakes. Information on location, cultural type and time period, color, texture and measurements on length, width, thickness and weight were recorded only for complete specimens of other types. The cultural type list used with this form is presented as Fig. 11. Time did not permit analys is of tool use wear.

The faunal material was sorted into five categories: burned and unburned identifiable bone, burned and unburned unidentifiable bone and worked bone. The identifiable faunal material was sent to Jerry Henderson, Texas Archeological Survey, Balcones Research Center, The University of Texas at Austin, for analysis.

\section{Constant Volume Sample Analysis}

Twenty-four constant volume samples were processed for three of the sites excavated (41 BX 36, 41 BX 377 and 41 BX 428). The flotation procedure was as follows (see also Jaquier 1976):

1) A sample measuring $6.5 \times 11.5 \times 15.5 \mathrm{~cm}$ was selected for each $5 \mathrm{~cm}$ excavation level (two for each $10 \mathrm{~cm}$ level). This was mixed with water in a bucket by gentle agitation. 
1-4 - - - Sequence Number

Point Types

$\begin{aligned} 5 & \text { - Angostura } \\ 6 & \text { - Golondrina } \\ 7 & \text { - Plainview } \\ 8 & \text { - Meserve } \\ 9 & \text { - Early Corner Notched } \\ 10 & \text { - Bell } \\ 11 & \text { - Uvalde } \\ 12 & \text { - Martindale } \\ 13 & \text { - Gower } \\ 14 & \text { - Tortugas } \\ 15 & \text { - Nolan } \\ 16 & \text { - Travis } \\ 17 & \text { - Wells } \\ 18 & \text { - Bulverde } \\ 19 & \text { - Langtry } \\ 20 & \text { - Pedernales } \\ 21 & \text { - Marshale } \\ 22 & \text { - Castroville } \\ 23 & \text { - Lange } \\ 24 & \text { - Montell } \\ 25 & \text { - Marcos } \\ 26 & \text { - Williams } \\ 27 & \text { - Darl } \\ 28 & \text { - Fairland } \\ 29 & \text { - Ensor } \\ 30 & \text { - Frio } \\ 31 & \text { - Kinney } \\ 32 & \text { - Unidentified/Unfinished Dart Point } \\ 33 & \text { - Edwards } \\ 34 & \text { - Perdiz } \\ 35 & \text { - Scallorn } \\ 36 & \text { - Unidentified/Unfinished Arrow Point } \\ 37 & \text { - Edgewood } \\ 38 & \text { - Other } \\ & \text { - }\end{aligned}$

Tools, Cores, Flakes, Miscellaneous

$\begin{array}{ll}39 & \text { - Distal Fragments } \\ 40 & \text { - Medial Fragments } \\ 47 & \text { - Miscellaneous Bifacial Fragments } \\ 42 & \text { - Biface } \\ 43 & \text { - Uniface } \\ 44 & \text { - Preform } \\ 45 & \text { - Quarry Blank } \\ 46 & \text { - Chopper } \\ 47 & \text { - Side Scraper }\end{array}$

Figure 9. Computer Coded Laboratory Form. 


\begin{tabular}{|c|c|}
\hline $\begin{array}{l}48 \\
49 \\
50 \\
51 \\
52 \\
53 \\
54 \\
55 \\
56 \\
57 \\
58 \\
59 \\
60 \\
61 \\
62 \\
63 \\
64-65 \\
66-67 \\
68-70 \\
71-72 \\
73 \\
74 \\
75 \\
76-77 \\
78 \\
79 \\
80\end{array}$ & $\begin{array}{l}\text { - End Scraper } \\
\text { - Double Side Scraper } \\
\text { - Double End Scraper } \\
\text { - Ovate Scraper } \\
\text { - Circular Scraper } \\
\text { - Concave Scraper } \\
\text { - End/Side Scraper } \\
\text { - Perforator } \\
\text { - Graver } \\
\text { - Burin } \\
\text { - Burin Spa11 } \\
\text { - Clear Fork Tool } \\
\text { - Guadalupe Too1 } \\
\text { - Hammers tone } \\
\text { - Core } \\
\text { - Core Fragment } \\
\text { - Primary Flakes } \\
\text { - - Secondary Flakes } \\
\text { - - Interior Flakes } \\
\text { - Lipped Flakes } \\
\text { - Retouched Flake } \\
\text { - Blade } \\
\text { - Retouched Blade } \\
\text { - Chunks } \\
\text { - Heat Spal1 } \\
\text { - Metate } \\
\text { - Mano }\end{array}$ \\
\hline $\begin{array}{l}8 \\
9-11 \\
12-14 \\
15-16 \\
17-18 \\
19\end{array}$ & $\begin{array}{c}\text { - - - Sequence Number } \\
\text { - Ceramics } \\
\text { - Glass } \\
\text { - Glass, worked } \\
\text { - Mussel Shel1s } \\
\text { - - - Snail She } 115 \\
\text { - - - Non-human Bones } \\
\text { - - Burned Bone } \\
\text { - - Metal Items } \\
\text { - Charcoal Sample }\end{array}$ \\
\hline
\end{tabular}

Figure 9. (continued) 
- $\overline{\text { Zone }}$ - No. (6-7)

Sequence No. $(1-5)$

- Survey Unit/Transect No. (8-9)

- - - - Site No. $(10-16)$

- - - - East UTM (17-23)

- North UTM (24-30)

- Survey=1, Excavated $=2$ (31)

- - - East (unit) $(32-37)$

North (unit) $(38-43)$

- Depth (44-46)

- Cultural Type (see 1ist) (47-49)

- Opaqueness ( $1=$ translucent, $2=$ edge translucent, $3=$ opaque) (50)

- Color ( $1=$ neutral, 2=red, $3=$ brown, 4=ye $17 \mathrm{ow}, 5=$ green, $6=$ blue, $7=$ purple

- Grain (1=very fine, $2=$ fine, $3=$ medium, 4 =coarse, $5=$ very coarse) (52)

- Fired ( $1=$ none, $2=$ crazed, $3=$ pot 7 idded, $4=$ fire reddened) (53)

- - Length $(\mathrm{mm})(54-56)$

- Width $(\mathrm{mm})(57-59)$

- Thickness (mm) (60-62)

Weight (grams) (63-68)

- Cortex- $\overline{0}=$ none, $\quad \bar{c}=<50 \%, 2=>50 \%)$ (69)

- Time period (70)

- Flake size (1=>80mm, 2=40-80m, 3=20-40m, 4=10-20m, $5=0-10 \mathrm{~mm})$ (71)

Figure 10. Computer Coded Lithic Analysis Form. 
Point Types

$\begin{array}{ll}1 \text { - Abasolo } & 41 \text { - Pandale } \\ 2 \text { - Almagre } & 42 \text { - Pandora } \\ 3 \text { - Angostura } & 43 \text { - Pedernales } \\ 4 \text { - Bell } & 44 \text { - Plainview } \\ 5 \text { - Bulverde } & 45 \text { - Refugio } \\ 6 \text { - Carrizo } & 46 \text { - San Patrice } \\ 7 \text { - Carrollton } & 47 \text { - Scottsblifo } \\ 8 \text { - Castroville } & 48 \text { - Shumla } \\ 9 \text { - Catan } & 49 \text { - Tortugas } \\ 10 \text { - Clovis } & 50 \text { - Travis } \\ 11 \text { - Dare } & 51 \text { - Trinity } \\ 12 \text { - Desmuke } & 52 \text { - Uvalde } \\ 13 \text { - Edgewood } & 53 \text { - Wells } \\ 14 \text { - Elam } & 54 \text { - Wileiams } \\ 15 \text { - Ellis } & 55 \text { - Yarbrough } \\ 16 \text { - Ensor } & 56 \text { - Early Corner Notched } \\ 17 \text { - Ensor-Frio } & 57 \text { - Alba } \\ 18 \text { - Fairland } & 58 \text { - Bassett } \\ 19 \text { - Folsom } & 59 \text { - Bonham } \\ 20 \text { - Frio } & 60 \text { - Clifbton } \\ 21 \text { - Gary } & 61 \text { - Cuney } \\ 22 \text { - Golondrina } & 62 \text { - Edwards } \\ 23 \text { - Gower } & 63 \text { - Fresno } \\ 24 \text { - Kent } & 64 \text { - Harrell } \\ 25 \text { - Kinney } & 65 \text { - Hayes } \\ 26 \text { - La Jita } & 66 \text { - Livermore } \\ 27 \text { - Lange } & 67 \text { - Maud } \\ 28 \text { - Langtry } & 68 \text { - Perdiz } \\ 29 \text { - Lerma } & 69 \text { - Scallorn } \\ 30 \text { - Marcos } & 70 \text { - Starr } \\ 31 \text { - Marshall } & 71 \text { - Talco } \\ 32 \text { - Martindale } & 72 \text { - Toyah } \\ 33 \text { - Matamoros } & 73 \text { - Turney } \\ 34 \text { - Meserve } & 74 \text { - Young } \\ 35 \text { - Montell } & 75 \text { - Val Verde } \\ 36 \text { - Morhiss } & 76 \text { - Granbury } \\ 37 \text { - Morrill } & 77 \text { - Early Side Notched } \\ 38 \text { - Nolan } & 78 \text { - Unfinished } \\ 39 \text { - Paisano } & 79 \text { - Unfinown } \\ 40 \text { - Palmillas } & 80 \text { - Unknown } \\ & \end{array}$

Bifaces

86 - Complete

87 - Distal-Proximal fragment

88 - Medial fragment

89 - Beaked (complete)

90 - Beaked fragment

Figure 11. Cultural Type List. 
Unifaces

100 - Convex Unilaterally trimmed

101 - Concave Unilaterally trimmed

102 - Bilaterally trimmed (both sides convex)

103 - Bilaterally trimmed (both sides concave)

104 - Bilaterally trimmed (convex and concave)

105 - Unilaterally and End trimmed

106 - Bilaterally and End trimmed

107 - End trimmed

108 - Circular trimmed

109 - Miscellaneous or irreguiar

110 - Beaked

Blades

120 - Blade

121 - Flake-Blade

122 - Notched Blade

123 - Notched Flake-Blade

124 - Double Notched Blade

125 - Double Notched Flake-Blade

126 - Blade Fragment

127 - Flake-Blade Fragment
Ground or Battered Stone

170 - Battered Stone

171 - Metate (complete)

172 - Metate fragment

173 - Mano (complete)

174 - Mano fragment

Bone

$$
\begin{aligned}
& 180 \text { - Incised } \\
& 181 \text { - Retouched } \\
& 182 \text { - Aw1 }
\end{aligned}
$$

Shel1

$$
\begin{gathered}
195- \\
196- \\
197- \\
\text { Misce11aneous } \\
210 \text { - Worked Glass }
\end{gathered}
$$

Cores
130 - Unidirectional
131 - Bidirectional
132 - Multiplatform
133 - Bifacial
134 - Blade
135 - Flake-Blade

Burins

$145-$

146 -

147 -

Clear Fork/Guadalupe Tools

156 - Clear Fork

157 - Guadalupe

Flake Tools

160 - Convex Retouched Flake

161 - Concave Retouched Flake

162 - Straight Retouched Flake

Figure 11. (continued) 
2) A nylon stocking was used as a strainer to skim the light fraction (floating material) and a 1/16-inch mesh screen was used to collect the heavy fraction (the material remaining in the bottom of the bucket).

3) After drying, both the light and the heavy fraction were sorted for lithics, bone, seeds, snails and other foreign items, e.g., glass fragments.

The information resulting from this analysis, also coded on computer forms (Fig. 12), may be used as a "control" for comparing the levels of a given excavation unit.

The constant volume samples also provided the material for a pollen analysis by Philip Dering, Department of Anthropology, Texas A \& M University, College Station, Texas; and a soil analysis by the Agricultural Extension Service, Texas A \& M University. The smaller snail species were identified by John Clark, Texas Historical Commission, Austin, Texas, enabling evalu= ation of their significance in terms of past environments (see III.A.10 and III.A.11).

\section{MAPPING TECHNIQUES}

The mapping phase of site recording was correlated with the testing phase of the project. The sites were mapped using the following equipment: the Englishmade Crowley Automatic Leve1, a stadia rod, a 30-meter tape and a Brunton compass. These were chosen because of mobility of the instruments and rapid operation time.

A temporary bench mark was chosen on the site where the Crowley level was set up. The fixed position of the level established a horizontal plane over the temporary bench mark. A distance was measured out from this point and the degrees from north were sighted back to the level with the Brunton compass. The elevation of the point was read when the horizontal piece on the stadia rod was moved vertically until it reached the horizontal plane. This allowed the stadia person to read the elevation at any point in a $360^{\circ}$ radius around the bench mark. The points were tied onto a base map by triangulation. Whenever vegetation was too dense for direct observation, a traverse was used with the Brunton compass and a 30-meter tape.

A11 sketches and notes were made in the field and drafted in the laboratory. The maps provide topographic information, intra-site artifact relationships, water-site correlations and, at times, inter-site relationships between nearby sites. 
Light Fraction
5-6 $\quad--$ Seeds
7-8 -- Snails
9-10 -- Anima1 Bone
11-12 -- Charcoal
13-14 -- Other

Heavy Fraction

15

16

17

$18-20$

21

$22-23$

24

25

26-27 -- Historic Items (glass, metal, etc.)

28-29

30-31

$32-33$

34- 35

$36-38$

$39-40$

41

$42-43$

44-45

$46-47$

48-49

50

$51-53$

54

55-57

58

$59-60$

$61-62$

63-64

65-66

$$
\begin{aligned}
& \text { - Chert Artifacts } \\
& \text { - Primary Flakes } \\
& \text { - Secondary Flakes } \\
& \text {-- Interior Flakes } \\
& \text { - Retouched Flakes } \\
& \text { - Chunks } \\
& \text { - Heat Spa1ls } \\
& \text { - Other }
\end{aligned}
$$

-.- Burned Seeds/Frags

-- Seeds/Frags

-- Identifiable Bone

-- Identifiable Bone - Burned

--- Unidentifiable Bone

-- Unidentifiable Bone - Burned

- Other Bone

- Rabdotus sp.

- Polygyra sp.

- Helicina arbiculata tropica

-- Snai1 \#1 polygyridae juv.

- Snai1 \#2A Pupoides modicus (Gould)

-.- Snail \#3 Rabdotus sp. juv.

- Snail \#4 Succenia grosvenois (Lea)

--- Burned Snail Fragments

- Mussel Shell Fragments

-- Charcoal Fragments

- Other

-- Snail \#2B Vertigo ascarina (Sterki)

-- Snail Fragments (per 5 dram vial)
Soil

1-4 -..- Sequence Number

5-6 $\quad--\mathrm{pH}$

7 - Nitrate $1 \mathrm{~b} / \mathrm{A}$

8-10 -.- Phosphorus

11-14 -... Potassium. 15-17 -..- Organic Matter

SNAIL FRAGMENT MEASUREMENTS

$1=2$ full 5 dram vial or more

$2=1$ full 5 dram vial or more

$3=3 / 4$ full 5 dram vial or more

$4=1 / 2$ full 5 dram vial or more

$5=1 / 4$ full 5 dram vial or more

$6=$ less than $1 / 4$ ful1 5 dram vial 


\section{A.5 \\ OBSERVATIONS ON CHRONOLOGY AND PROJECTILE POINT TYPOLOGY}

Thomas C. Kelly and Andrea Gerstle

\section{CHRONOLOGICAL BACKGROUND}

Camp Bullis, located in south central Texas, is situated in the center of a region of rather intensive recent archaeological research. In spite of this, the cultural chronology of the area has not yet been clearly defined and, in fact, has been outlined in only the broadest of terms which have as yet only general temporal boundaries.

In their review of central Texas prehistory, Suhm et al. (1954) divided the regional cultural framework into the Paleo-American (Paleo-Indian), Archaic, Neo-American (Late Prehistoric) and Historic stages. The stages were thought of not only as changes in projectile point sequences, but were also thought to mark a series of changes in economic development, population and site characteristics (Suhm et al. 1954:22). The Paleo-American (Paleo-Indian) stage was represented by distinctive projectile points, particularly Angostura, Plainview and Clovis; age estimates were not provided, although the occurrence of Folsom points possibly associated with fossil bison at Kincaid Rockshelter (ibid.: 101-102) indicated a late Pleistocene date for at least part of this stage. The central Texas Archaic was labeled as the "Edwards Plateau Aspect"; no smaller components (i.e., foci) were defined, al though the writers did review earlier concepts of the Archaic as published by J. E. Pearce, E. B. Sayles, Cyrus Ray and J. Charles Kelley (cf. Suhm et al. 1954:106). The time span for the Edwards Plateau Aspect was guessed to be from ca. 4000 or 5000 B.C. to A.D. 1000. The Neo-American (Late Prehistoric) stage was also not subdivided, with these late cultural manifestations lumped under the "Central Texas Aspect," ranging in age from ca. A.D. 500-800 to A.D. 1500. The Historic stage proposed by Suhm et al. (1954:117) includes Spanish mission sites and identified historic Indian villages.

A later review of central Texas chronology was published by Suhm (1960). Certain changes were offered in the chronological framework. The earliest occupations (Paleo-Indian) were described as beginning in late Pleistocene times and lasting until about 4000-5000 B.C. Following the Paleo-Indian period was the Edwards Plateau Aspect (Archaic), lasting until approximately A.D. 500-1000. The subsequent. Central Texas Aspect was divided into two foci: Austin and Toyah (see also Jelks 1962). This period ends with the arrival of Europeans in the Historic era.

Further chronological research at Canyon Reservoir in Comal County, south central Texas, led Johnson et al. (1962) to propose a further refinement of the regional culture history, based largely on changes in projectile point styles. This sequence generally follows that of Suhm (1960), with Paleo-Indian, Archaic and Neo-American stages. Within the Archaic stage, Johnson et al. (1962; Fig. 45) defined four periods: Early, Middle, Late and Transitional. The Neo-American stage was divided into two parts: the Austin Focus and the Toyah 
Focus. Absolute dating for the temporal units within this chronological framework was not available.

In addition to cultural sequences based on the above terminology, several authors have proposed new methods of dividing and identifying periods in central Texas prehistory. One such sequence comes from the Stillhouse Hollow Reservoir basin to the north of Austin (cf. Sorrow et al. 1967; Fig. 72). Their chronological framework consists of ten "local phases." Phases I and II are the equivalent of the Paleo-Indian period and are guess-dated at 17000 B.C. or older to 6000 B.C." "Local phases" III and IV represented cultural materials later termed the "Pre-Archaic" by Sollberger and Hester (1972); Sorrow et al. (1967) estimate the time span for these three phases at 6000-3500 B.C. "Local phase" $V$ is the equivalent of the Early Archaic of Johnson et al. (1962), and has temporal boundaries of 3500-2000 B.C. "Local phase" VI equates with the Middle Archaic (2000-1000 B.C.), VII with the Late Archaic (1000 B.C. - A.D. 1), and VIII with the Transitional Archaic (A.D. 1-500). Finally, "local phase" IX is typical of the Austin Focus (A.D. 500-1200), and $X$ is characteristic of the Toyah Focus (A.D. 1200-1500).

In a quantitative comparison of projectile point types from central Texas and southwest Texas, Johnson (1967) has defined five periods in the aboriginal occupational sequence. Johnson's Period I is equivalent to the Paleo-Indian period, Period II is the same as the Pre-Archaic, Periods III and IV comprise the Archaic, and Period V can be equated with the Late Prehistoric. This chronology has not gained wide acceptance, as it is not based entirely on central Texas materials. Its goal was not to determine differences within the central Texas assemblages, but to point out the distinctions between assemblages from central and southwest Texas.

More recently, Weir (1976) has redefined the Central Texas Archaic in terms of five consecutive phases, each designed to correspond to different characteristic tool assemblages resulting from cultural adaptive responses. This innovative study has generated much discussion, and may or may not prove to be a more accurate representation of the culture history of the area. The five phases are described by Weir according to their lithic assemblage components and inferred subsistence/economic patterns. The proposed sequence and phase characteristics have yet to be tested with independent data.

Drawing on all of this previous research, we have used the following chronological framework in the analysis of data from Camp Bullis sites: Paleo-Indian; Pre-Archaic; Early, Middle and Late Archaic; Transitional Archaic; and Late Prehistoric (divided into the Austin and Toyah phases). In Table 4, we have indicated the diagnostic time markers for each of these periods and have listed applicable radiocarbon dates from central and southwestern Texas. In addition, our chronological sequence is compared with those described above in Table 5.

\section{PROJECTILE POINTS}

Most of the dart and arrow point types collected during the field work at Camp Bullis have been extensively defined and exhaustively discussed in the regional literature. Thus, we have not prepared detailed artifact descriptions for 
TABLE 4. CAMP BULLIS PROJECTILE POINT CHRONOLOGY

\begin{tabular}{|c|c|c|c|c|c|}
\hline Time & Period & Phase & Point Type & Applicable C-14 Dates & $\begin{array}{l}\text { Source Sjte } \\
\text { for } \mathrm{C}-14^{f}\end{array}$ \\
\hline 1600 & \multirow{3}{*}{ Late Prehistoric } & $\begin{array}{l}\text { (Toyah } \\
\text { Phase) }\end{array}$ & Perdiz & $1561,1291,1276$ & Kyle \\
\hline 1200 & & $\begin{array}{l}\text { (Austin } \\
\text { Phase) }\end{array}$ & Scallorn & $971,801,557$ & Kyle \\
\hline 900 & & & Edwards & $1040,990,960$ & La Jita \\
\hline 600 & (Transitional) & & Dare & 650,470 & Loeve-Fox \\
\hline & \multirow{3}{*}{ Late Archaic } & & $\begin{array}{l}\text { Edgewood } \\
\text { Ensor } \\
\text { Frio }\end{array}$ & $\begin{array}{l}650,380,280 \\
260,40 \mathrm{BC}, 20 \mathrm{BC}\end{array}$ & Loeve-Fox \\
\hline$A D$ & & & & $460,490,360$ & $\begin{array}{l}\text { La Jita } \\
\text { Arenosa* }\end{array}$ \\
\hline$\overline{B C}$ & & & $\begin{array}{l}\text { Marcos } \\
\text { Castroville } \\
\text { Marshall }\end{array}$ & $360,560,830,860$ & Bonfire* \\
\hline & \multirow[t]{2}{*}{ Middle Archaic } & & Langtry & 1620 & \multirow{2}{*}{$\begin{array}{l}\text { Oblate } \\
\text { Arenosa* }\end{array}$} \\
\hline \multirow{2}{*}{2000} & & & Pedernales & $1100,1360,1620,2130$ & \\
\hline & Early Archaic & & $\begin{array}{l}\text { Bulverde } \\
\text { Travis } \\
\text { Nolan } \\
\text { La Jita }\end{array}$ & $\begin{array}{l}2150,2480,2840 \\
2500,2630,2990\end{array}$ & Arenosa* \\
\hline 5500 & \multirow{2}{*}{\multicolumn{2}{|c|}{ Pre-Archaic }} & $\begin{array}{l}\text { Gower } \\
\text { Martindale } \\
\text { Early Corner Notched }\end{array}$ & $\begin{array}{l}3400,3600,4100 \\
4160,5290,6330 \\
6590,6810\end{array}$ & $\begin{array}{l}\text { Eagle Cave* } \\
\text { Hinds Cave* }\end{array}$ \\
\hline & & & Early Side Notched & 6830 & Devil's Mouth* \\
\hline 7000 & \multicolumn{2}{|l|}{ Paleo-Indian } & $\begin{array}{l}\text { Angostura } \\
\text { Plainview }\end{array}$ & 5400 & Levi Rockshelter \\
\hline
\end{tabular}

*These are sites in the Trans-Pecos area. There are no central Texas dates available. $\neq \mathrm{f}-14$ dates are included as general chronological indicators for a given time period. 
TABLE 5. PROPOSED CHRONOLOGICAL SEQUENCES

\begin{tabular}{|c|c|c|c|c|c|c|c|}
\hline $\begin{array}{l}\text { Time } \\
\mathrm{AD} / \mathrm{BC} \\
\end{array}$ & $\begin{array}{c}\text { Suhm et al。 } \\
1954\end{array}$ & $\begin{array}{l}\text { Suhm } \\
1960 \\
\end{array}$ & $\begin{array}{c}\text { Johnson et al. } \\
1962\end{array}$ & $\begin{array}{c}\text { Sorrow et al. } \\
1967\end{array}$ & $\begin{array}{c}\text { Johnson } \\
\quad 1967 \\
\end{array}$ & $\begin{array}{l}\text { Weir } \\
1976 \\
\end{array}$ & $\begin{array}{l}\text { Camp } \\
\text { Bullis }\end{array}$ \\
\hline \multicolumn{8}{|l|}{1500} \\
\hline 1200 & $\begin{array}{l}\text { Central } \\
\text { Texas } \\
\text { Aspect }\end{array}$ & $\begin{array}{l}\text { Central } \\
\text { Texas } \\
\text { Aspect }\end{array}$ & Neo-American & & Period V & $\begin{array}{l}\text { Late } \\
\text { Prehistoric }\end{array}$ & $\begin{array}{l}\text { Late } \\
\text { Prehistoric }\end{array}$ \\
\hline \multirow[t]{2}{*}{900} & & (Austin) & (Austin) & Phase IX & & & (Austin) \\
\hline & & & & & & Twin Sisters & \\
\hline 500 & & & $\begin{array}{l}\text { Transitional } \\
\text { Archaic }\end{array}$ & Phase VIII & Period IV & & $\begin{array}{l}\text { Transitional } \\
\text { Archaic }\end{array}$ \\
\hline \multicolumn{8}{|l|}{ A.D. } \\
\hline \multirow[t]{2}{*}{1000} & $\begin{array}{l}\text { Edwards } \\
\text { Plateau }\end{array}$ & $\begin{array}{l}\text { Edwards } \\
\text { Plateau }\end{array}$ & $\begin{array}{l}\text { Late } \\
\text { Archaic }\end{array}$ & Phase VII & & San Marcos & $\begin{array}{l}\text { Late } \\
\text { Archaic }\end{array}$ \\
\hline & Aspect & Aspect & Middle Archaic & Phase VI & Period III & Round Rock & Middle Archaic \\
\hline \multicolumn{8}{|l|}{2000} \\
\hline & & & Early Archaic & Phase V & & Clear Fork & Early Archaic \\
\hline \multirow[t]{2}{*}{3500} & & & & & Period II & & \\
\hline & & & & $\begin{array}{l}\text { Phase III \& } \\
\text { Phase IV }\end{array}$ & & San Geronimo & Pre-Archa ic \\
\hline \multicolumn{8}{|l|}{5500} \\
\hline & $\begin{array}{l}\text { Paleo- } \\
\text { American }\end{array}$ & $\begin{array}{l}\text { Paleo- } \\
\text { American }\end{array}$ & $\begin{array}{l}\text { Paleo- } \\
\text { Indian }\end{array}$ & $\begin{array}{l}\text { Phase I \& } \\
\text { Phase II }\end{array}$ & Period I & $\begin{array}{l}\text { Paleo- } \\
\text { Indian }\end{array}$ & $\begin{array}{l}\text { Paleo- } \\
\text { Indian }\end{array}$ \\
\hline
\end{tabular}


these types. Tables 6 and 7 contain descriptive and distributional data (see 2150 III.A.6), and representative examples of these types are found in Figs. 1317. These previously defined types (cf. Suhm, Krieger and Jelks 1954; Suhm and Jelks 1962; Johnson et al. 1962; Sorrow et al. 1967; Hester 1971) include: Nolan, Travis, Bulverde, Wells, Tortugas, Pedernales, Langtry, Marshall, Marcos, Kinney, Castroville, Montell, Ensor, Edgewood, Ensor-Frio, Frio, Darl, Uvalde, Scallorn, Perdiz and Fresno. In addition, there were several unclassifiable specimens that. could not be placed in meaningful groups; these are illustrated in Fig. 17.

We have chosen to devote our descriptive efforts to several tentative or poorlyknown types (e.g., La Jita, Edwards) and to points representing the Paleo-Indian and Pre-Archaic period. There is a lack of description for Paleo-Indian specimens in the regional literature, and the typological problems that exist in the present definitions of the types of points representing the Pre-Archaic period dictate that they, too, received detailed attention.

\section{Paleo-Indian Projectile Points}

Plainview (2 specimens; Fig. 18,k)

One specimen is a basal fragment $25 \mathrm{~mm}$ long, $20 \mathrm{~mm}$ wide and $6 \mathrm{~mm}$ thick. It has horizontal flaking scars, as well as ground edges and base; basal concavity is $4 \mathrm{~mm}$ deep. The base has been thinned with a large flake removed from either side and is almost fluted. This latter attribute is the only variation from the type site Plainview points described by Knudson (1973). The Center for Archaeological Research Computerized Classification Program (Kelly 1976b) places it securely within the Plainview category. The specimen has a heavy white patina and is made of fine quality chert.

This Plainview point, found at site 41 BX 391, is derived from an upland meadow overlooking the Muesebach Creek drainage. Erosional wash over centuries has exposed scattered points (Bulverde and Ensor-Frio), preforms, cores, bifaces of several types, scrapers and scattered flakes over a considerable area. A few of the flakes were found with the same degree of patination as the plainview point.

A second small basal fragment was recovered from the surface of $41 \mathrm{BX} 408$, a camp site located on a stream terrace. Other artifacts from the site include a Pedernales fragment, an end scraper and preforms.

Meserve (1 specimen; Fig. 18,j)

The specimen is $79 \mathrm{~mm}$ long, $21 \mathrm{~mm}$ wide at the base, $8 \mathrm{~mm}$ thick and has a s7ight basal concavity. The blade has been reworked at some time later than its original manufacture, as a lesser patina is evident on the blade than on the base. The more recent flaking was on one face only, producing beveled edges. Beginning approximately $10 \mathrm{~cm}$ below the tip, both blade edges have been nibbled and polished by heavy wear for $31 \mathrm{~mm}$. Some form of boring action is indicated. It has been suggested that Meserve points may have been reworked Plainview 


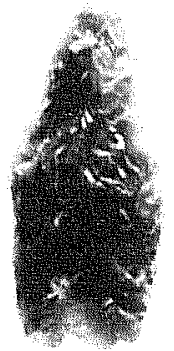

a

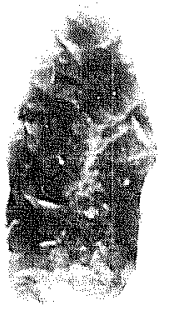

b
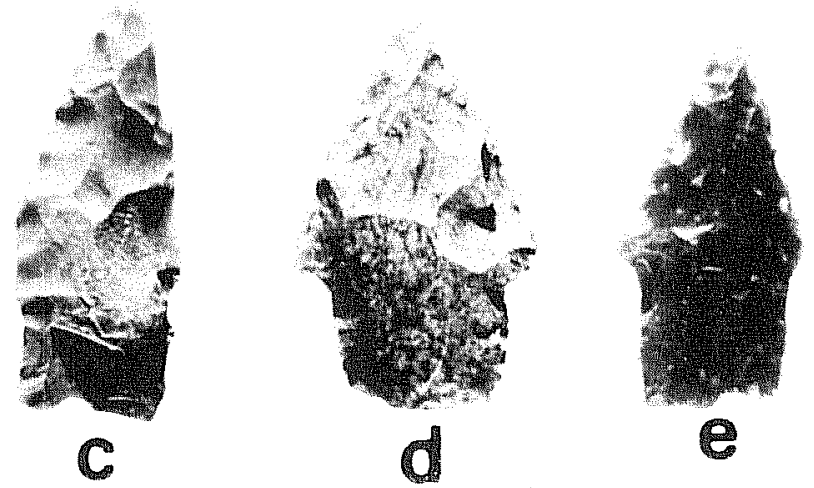

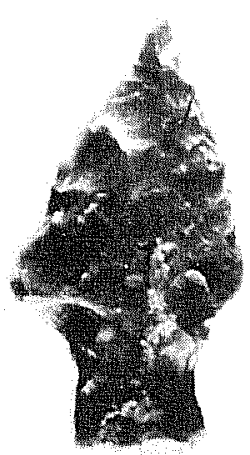

f
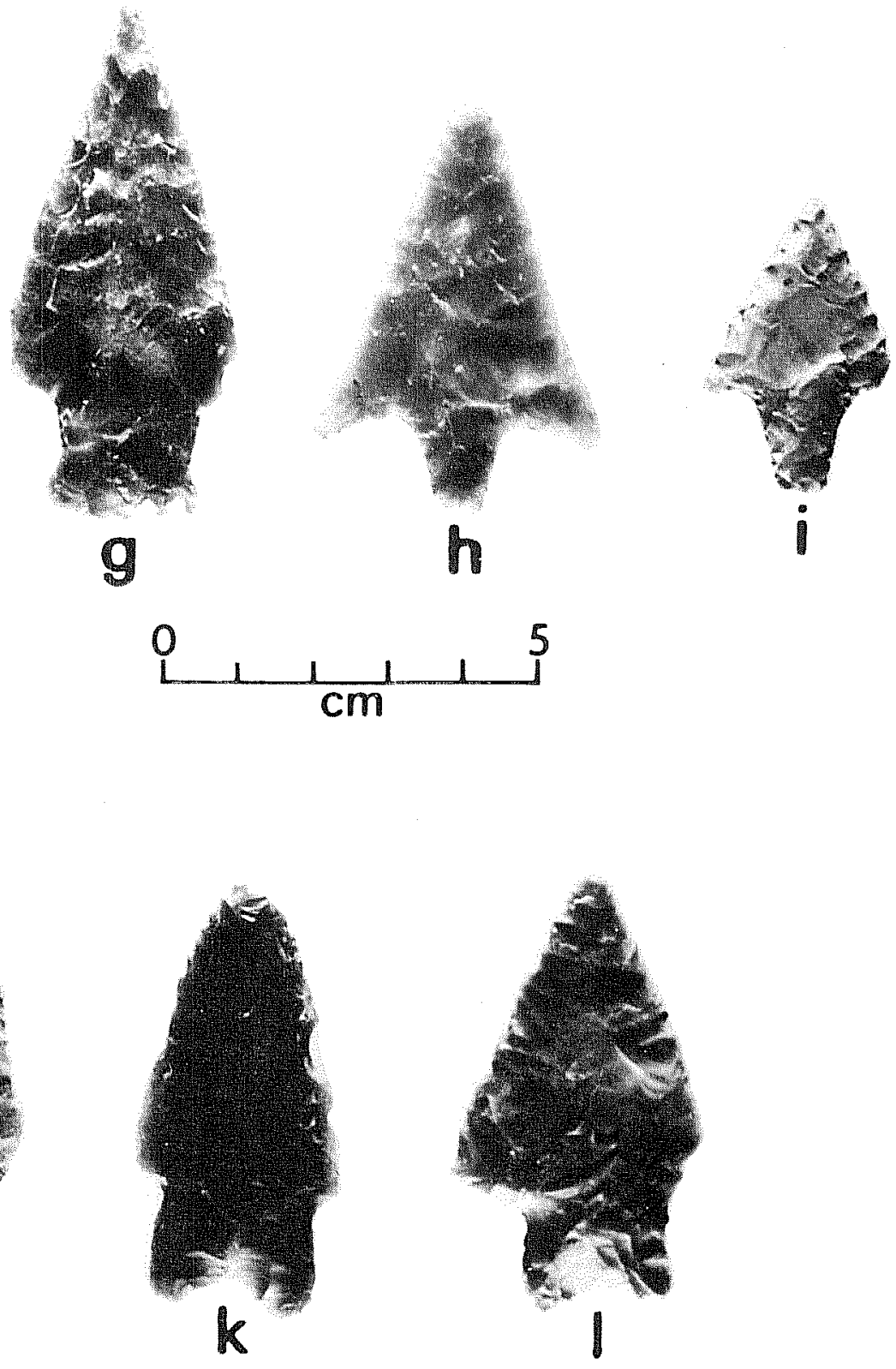

Figure 13. Lithic Artifacts from Camp Bullis: Dart Points. a,b, Travis ( $a, 41 \mathrm{BX}$ 36; b, Zone 1); c-e, Bulverde (c, 41 BX 400; d, 41 BX 388; e, 41 BX 403); f,g, Nolan (41 BX 36); $h, i$, Langtry ( $h, 41 \mathrm{BX} 36 ; i, 41 \mathrm{CM} 100) ; j-1$, Pedernales (41 BX 36). 

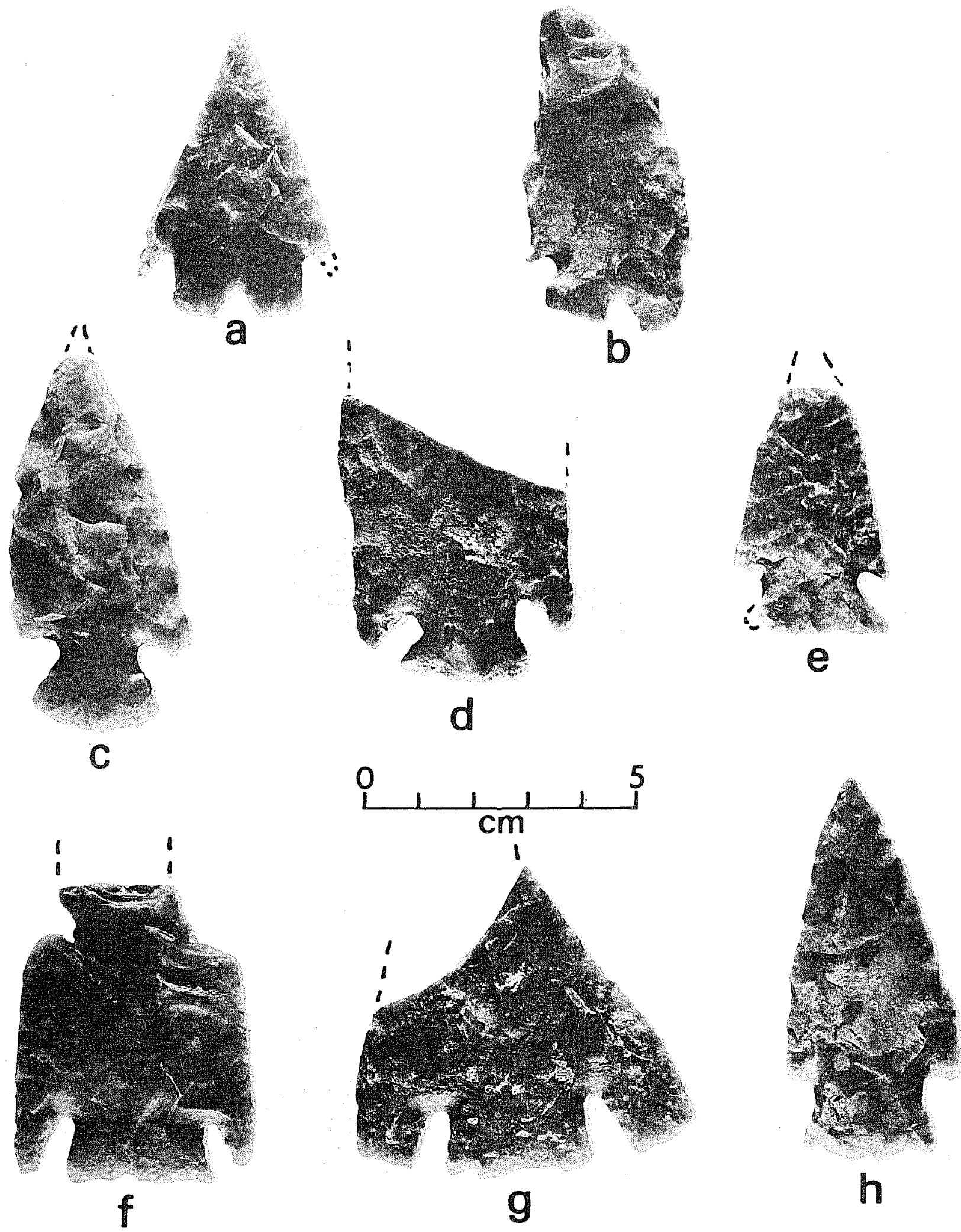

Figure 14. Lithic Artifacts from Camp Bullis: Dart Points. a,b, Montell (41 BX 36); c-e, Marcos (c,d, 41 BX 36; e, 41 BX 425); f-h, Castroville (41 BX 36). 


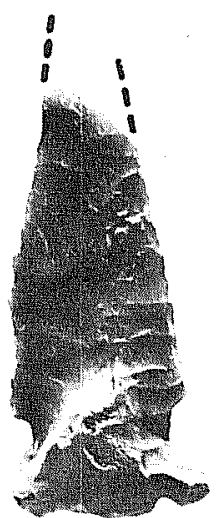

a
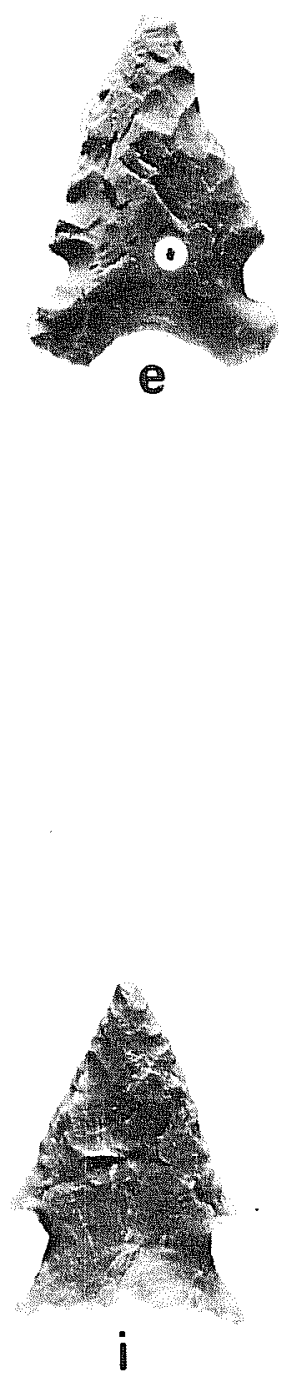

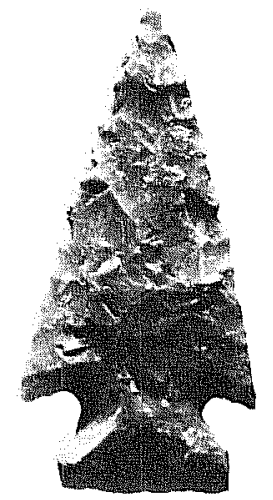

b

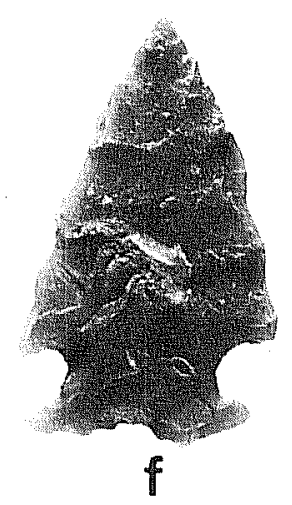

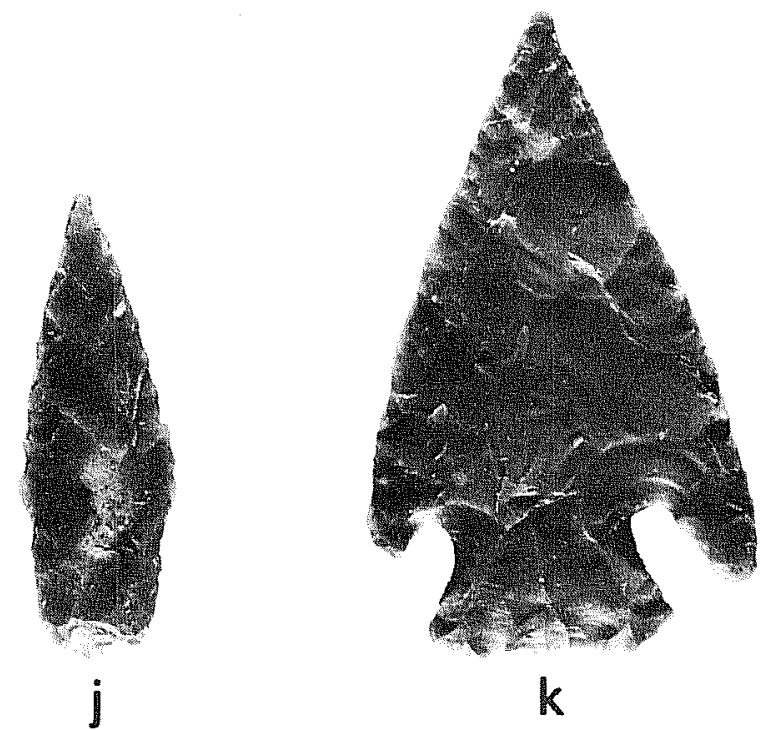

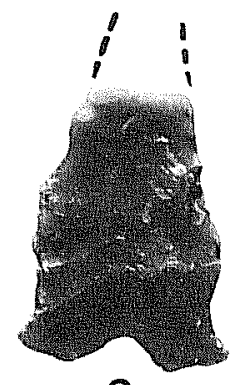

C
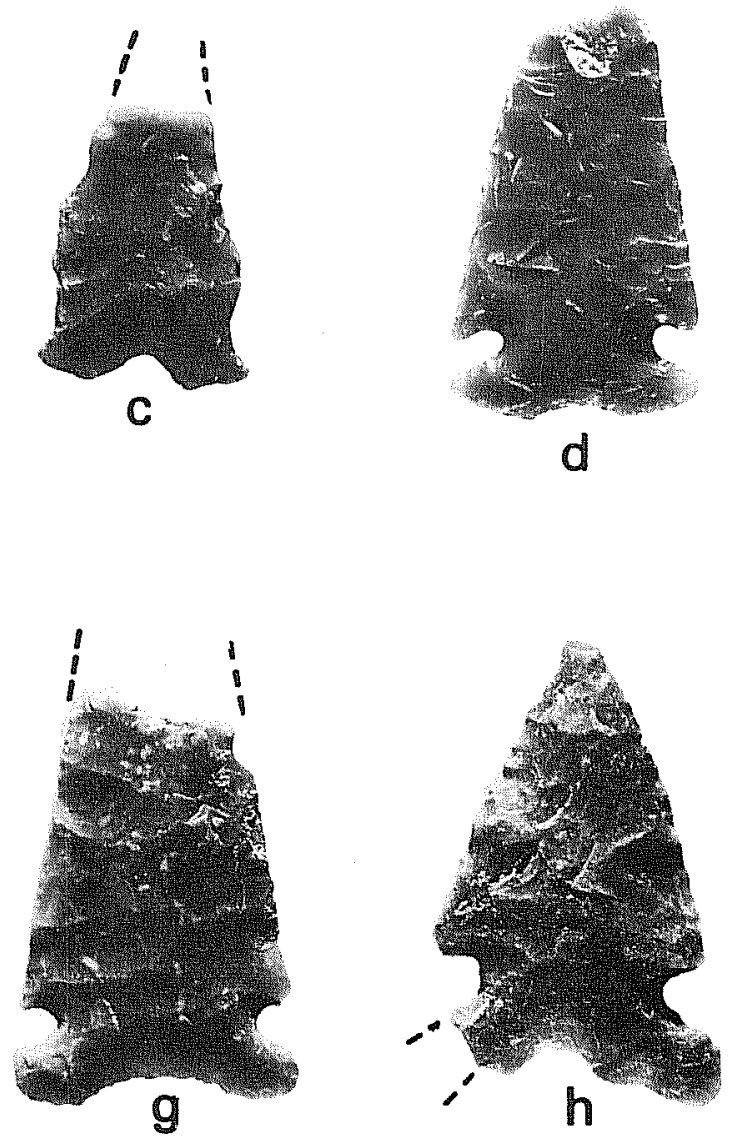
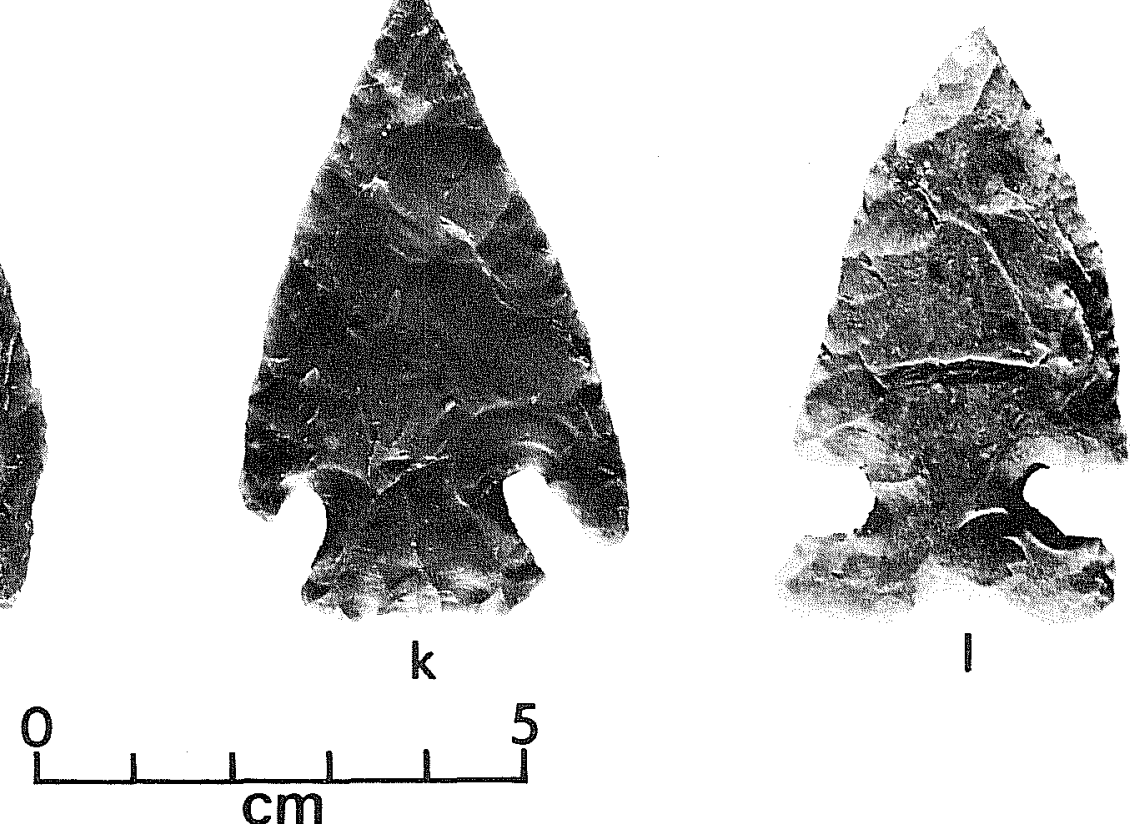

Figure 15. Lithic Artifacts from Camp Bullis: Dart Points. a-b, Ensor ( $a, 41 \mathrm{BX}$ 36; b, 41 BX 377); c-d, Frio (41 BX 36); e- $h$, Ensor-Frio (e,g,h, 41 BX 377; f, 41 BX 36); $i$, Edgewood (41 CM 99); $j$, wells (41 BX 428); $k$, Marshall (41 BX 36); 1 , Big Sandy-like (4l CM 96). 

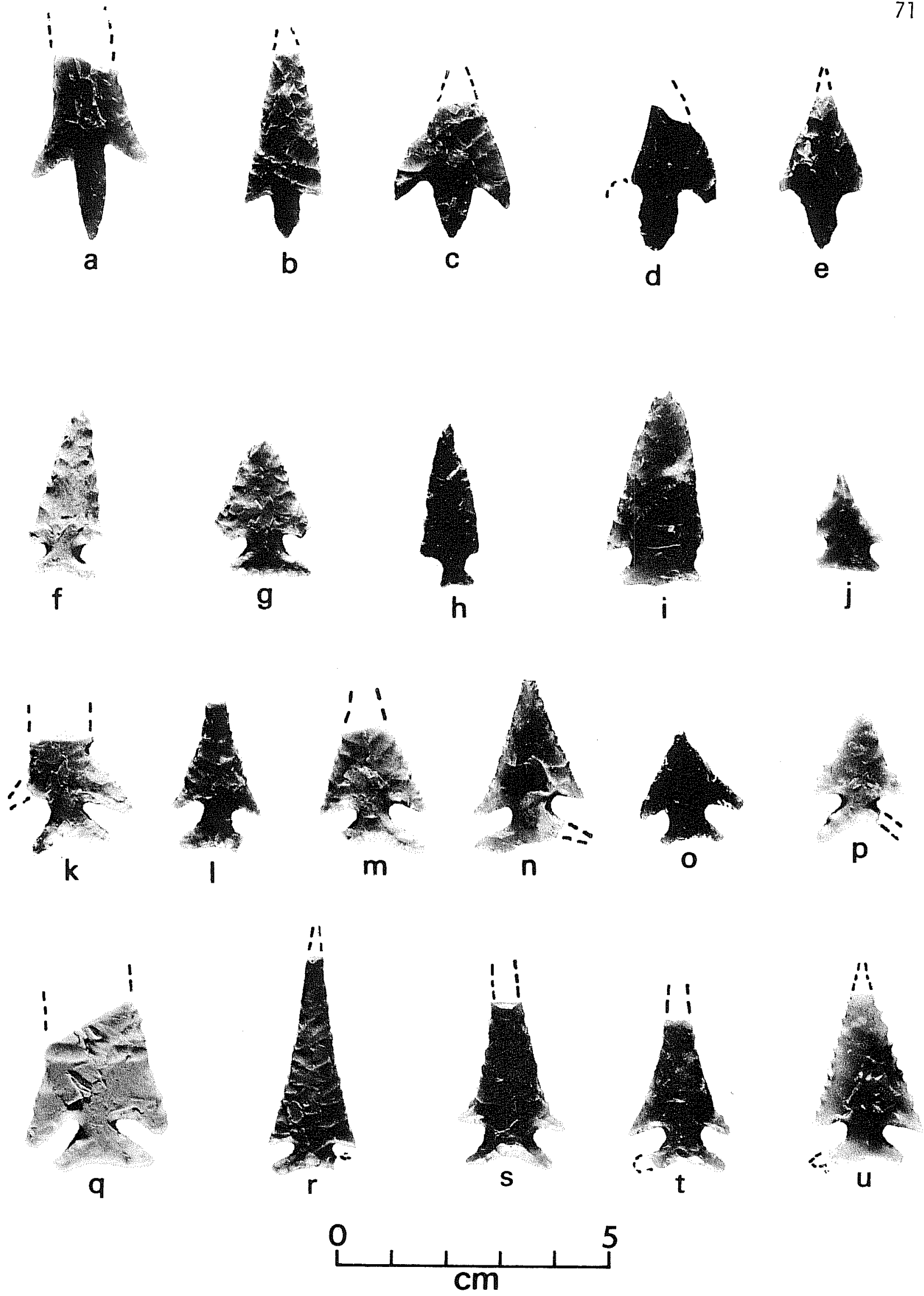

Figure 16. Lithic Artifacts from Camp Bullis: Arrow Points. a-e, Perdiz (a, 41 BX 425; b-e, 41 BX 36); f-j, Scallorn ( $f, 41$ BX 400; g, 41 BX 379; $h, j$, $41 \mathrm{CM} 99 ; i, 41 \mathrm{BX} 36$ ); $k-u$, Edwards ( $k, n, 0, q, t, u, 41 \mathrm{BX} 36 ; 1, m, 41 \mathrm{BX} 377$; $p, 41$ BX 383; r, 41 BX 379; s, 41 BX 385. 
Figure 17. Lithic Artifacts from Camp Bullis: Dart and Arrow Points. a-e, unclassified dart and arrow points (a, 41 BX 426; b, 41 BX 383; c, 41 BX 377; d, 41 BX 387; e, 41 BX 36); f, Tortugas (41 BX 402); g, Kinney (41 BX 36); h, Dare 41 BX 409); i, Fresno (41 BX 36); j-m, Gower ( $j, 41$ BX 403; k, 41 BX 409; 1, 41 BX 402; m, 41 BX 376); n-p, La Jita (al1 from $41 \mathrm{BX} 36)$. 

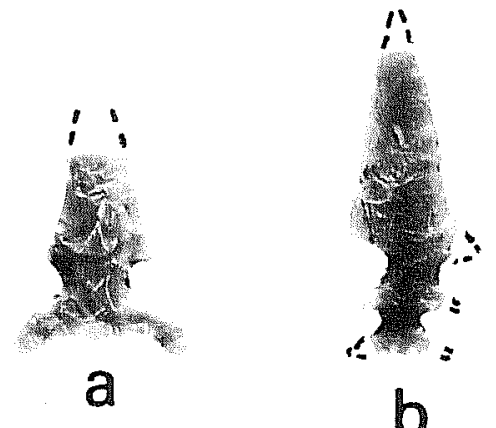

b

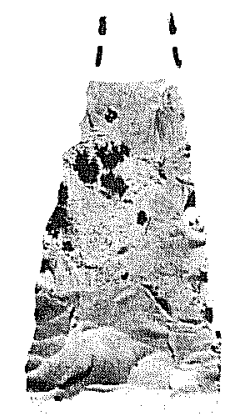

f

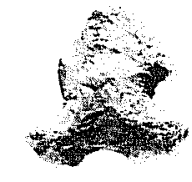

C
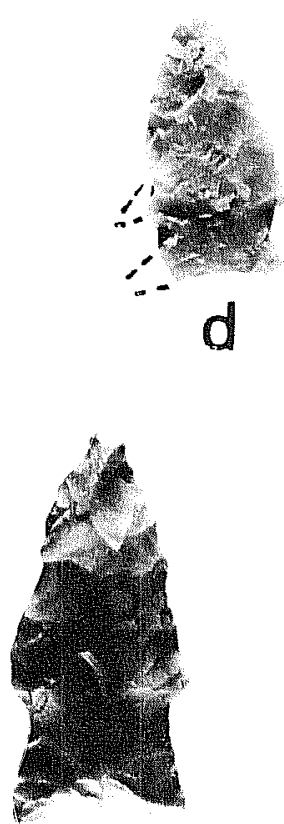

h

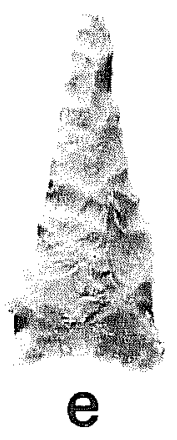

73

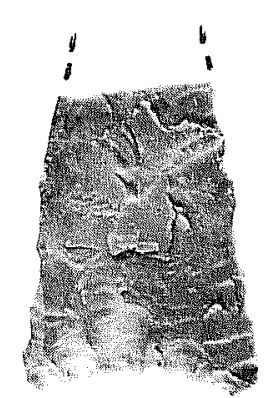

g
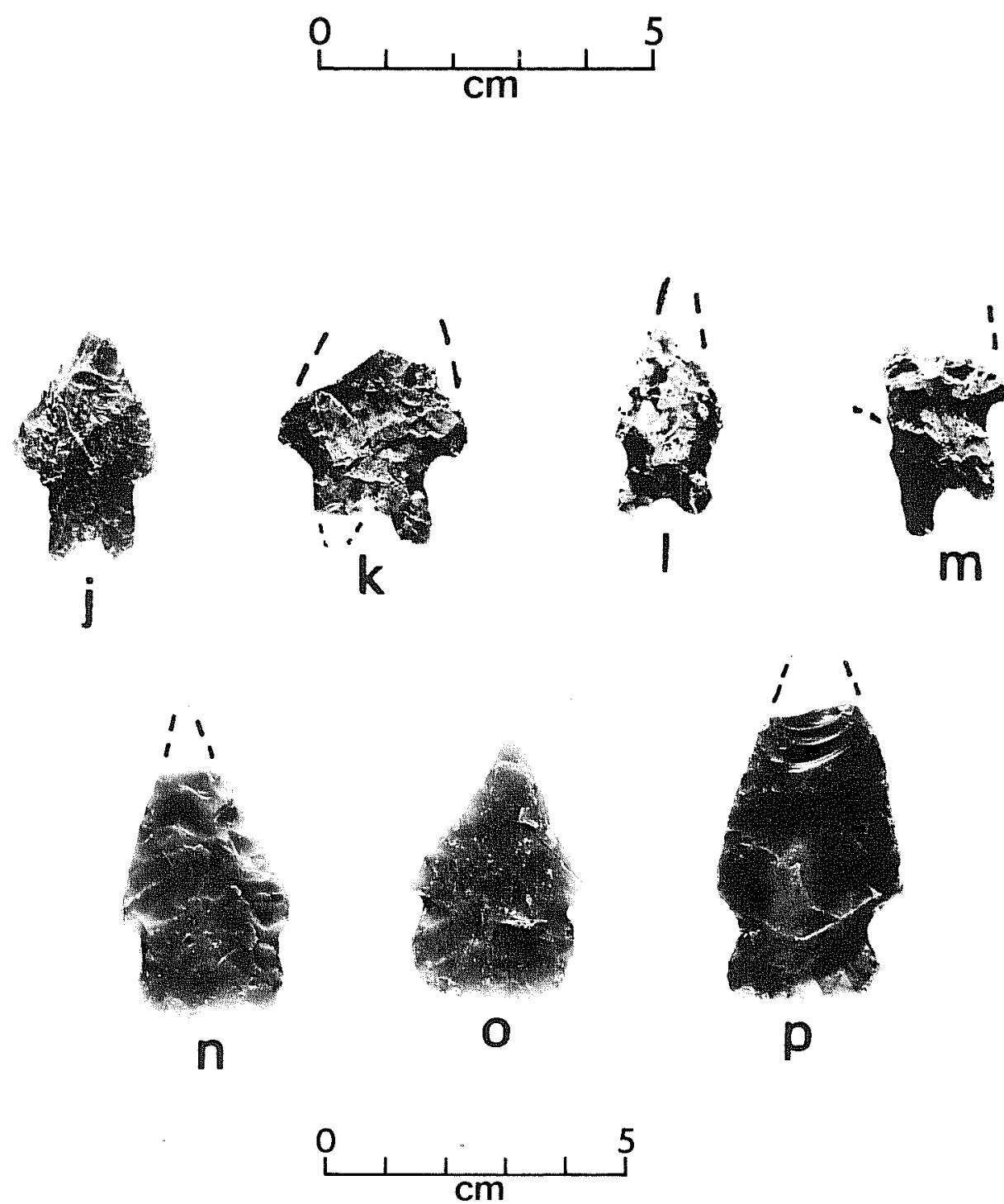


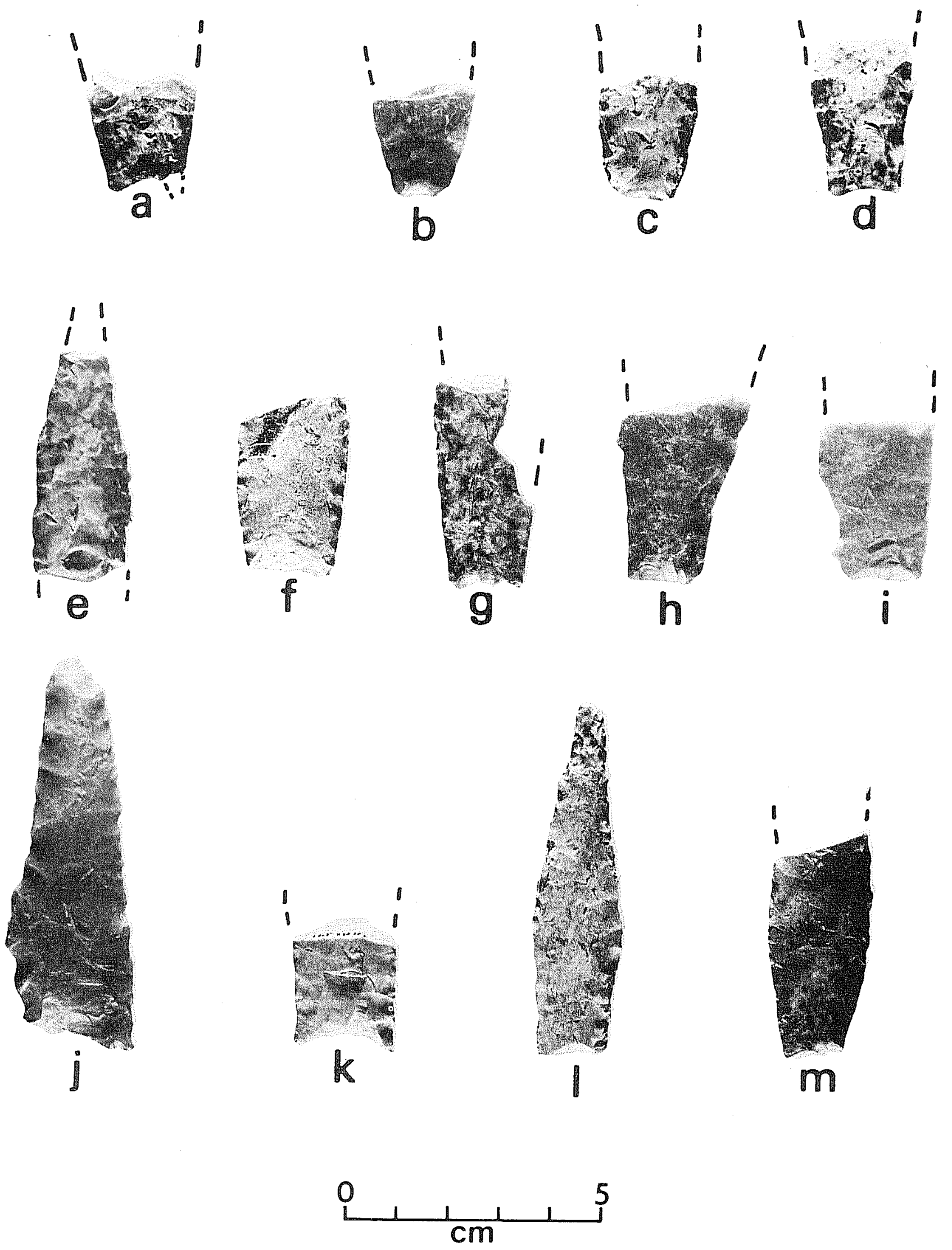

Figure 18. Lithic Artifacts from Camp Bullis: Paleo-Indian Dart Points. a-i,1,m, Angostura (a, 41 BX 381; b, Zone 4; c, Zone 8; d,g,h, 41 BX 424; e, 41 BX 403; $f, m, 41 \mathrm{BX} 376 ; i, 41 \mathrm{BX} 373 ; 1,41 \mathrm{BX} 36$ ); j, Meserve (41 BX 36); $k$, Plainview (41 BX 391). 


\section{Point Type}

Late Prehistoric

Edwards
Fresno
Perdiz
Scallorn

\section{Late Archaic}

Castroville

Dare

Edgewood

Ensor

Ensor-Frio

Frio

Kinney

Marcos

Marshale

Montell

Tortugas

lualde

wells

Middle Archaic

Langtry

Pedernales

Early Archaic

Bulverde

La Jita

Nolan

Travis

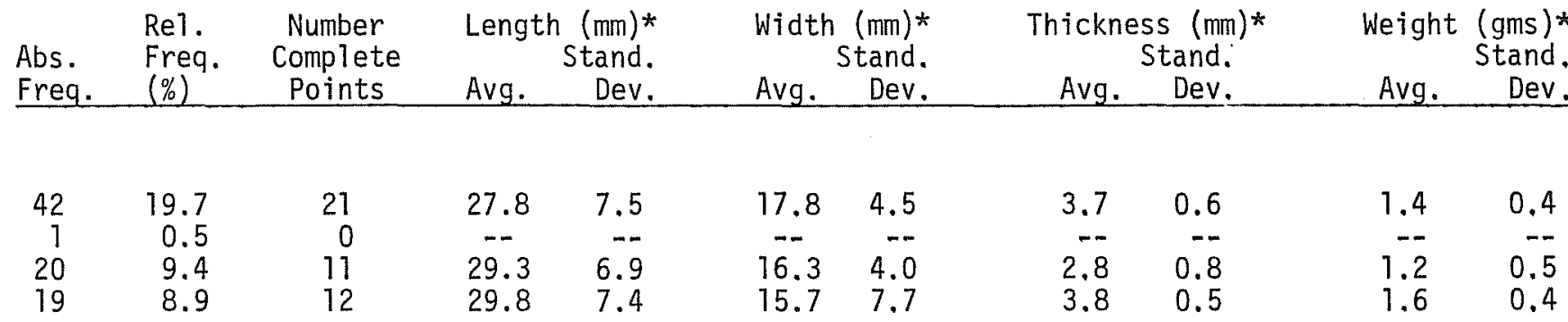

$\begin{array}{rr}6 & 2.8 \\ 1 & 0.5 \\ 2 & 0.9 \\ 8 & 3.7 \\ 11 & 5.2 \\ 9 & 4.2 \\ 1 & 0.5 \\ 6 & 2.8 \\ 2 & 0.9 \\ 7 & 3.3 \\ 1 & 0.5 \\ 1 & 0.5 \\ 1 & 0.5\end{array}$

$$
\begin{aligned}
& 2 \\
& 1 \\
& 1 \\
& 5 \\
& 9 \\
& 5 \\
& 0 \\
& 2 \\
& 1 \\
& 5 \\
& 1 \\
& 1 \\
& 1
\end{aligned}
$$

$\begin{array}{rrrr}67.5 & 5.0 & 36.5 & 5.0 \\ 49.0 & -- & 22.0 & -- \\ 28.0 & -- & 23.0 & -- \\ 43.8 & 3.9 & 24.8 & 6.7 \\ 41.2 & 7.1 & 26.2 & 2.8 \\ 40.0 & 12.0 & 23.6 & 4.5 \\ -- & -- & -- & -- \\ 60.5 & 14.9 & 32.0 & 1.4 \\ 65.0 & -- & 40.0 & -\overline{-} \\ 51.2 & 17.6 & 32.6 & 9.7 \\ 57.0 & -- & 24.0 & -- \\ 45.0 & -- & 27.0 & - \\ 49.0 & -- & 6.0 & --\end{array}$

$\begin{array}{rr}6.5 & 0.7 \\ 8.0 & -- \\ 5.0 & -- \\ 5.8 & 0.8 \\ 6.0 & 1.2 \\ 5.0 & 0.7 \\ --. & -- \\ 7.5 & 2.7 \\ 8.0 & -- \\ 6.0 & 1.2 \\ 8.0 & -- \\ 5.0 & -- \\ 7.0 & --\end{array}$

$15.1 \quad 2.8$

$\begin{array}{ll}9.9 \\ 2.3 & --\end{array}$

$\begin{array}{ll}5.6 & 2.1\end{array}$

$\begin{array}{ll}5.2 & 2.3 \\ 4.7 & 2.4\end{array}$

$14 . \overline{9} \quad \overline{7 . \overline{5}}$

$14.7 \quad 12 . \overline{3}$

$8.3 \quad-$.

$6.7 \quad--$

\begin{tabular}{|c|c|c|c|c|c|c|c|c|c|c|}
\hline $\begin{array}{r}2 \\
15\end{array}$ & $\begin{array}{l}0.9 \\
7.0\end{array}$ & $\begin{array}{l}7 \\
7\end{array}$ & $\begin{array}{l}40.0 \\
50.4\end{array}$ & $\overline{7.6}$ & $\begin{array}{l}26.0 \\
29.9\end{array}$ & $6 . \overline{3}$ & $\begin{array}{l}5.0 \\
6.7\end{array}$ & 0. & 3.6 & $\overline{1 . \overline{9}}$ \\
\hline
\end{tabular}

$\begin{array}{ll}5 & 2.3 \\ 4 & 1.9 \\ 9 & 4.2 \\ 7 & 3.3\end{array}$

$\begin{array}{ll}45.0 & -- \\ 48.0 & -- \\ 52.8 & 5.5 \\ 45.7 & 8.8\end{array}$

$\begin{array}{rr}29.0 & -- \\ 29.0 & - \\ 25.2 & 3.8 \\ 20.7 & 3.5\end{array}$

$\begin{array}{ll}7.0 & -- \\ 7.0 & 0.0 \\ 6.4 & 2.0 \\ 8.2 & 7.8\end{array}$

$\begin{array}{rr}8.8 & -- \\ 10.5 & - \\ 9.3 & 2.0 \\ 6.9 & 1.9\end{array}$


TABLE 6. (continued)

\begin{tabular}{|c|c|c|c|c|c|c|c|c|c|c|c|}
\hline Point Type & $\begin{array}{l}\text { Abs. } \\
\text { Freq. }\end{array}$ & $\begin{array}{l}\text { Re1. } \\
\text { Freq. } \\
(\%)\end{array}$ & $\begin{array}{c}\text { Number } \\
\text { Complete } \\
\text { Points }\end{array}$ & $\begin{array}{l}\text { Lengtl } \\
\text { Avg. }\end{array}$ & $\begin{array}{l}(\mathrm{mm}) * \\
\text { tand. } \\
\text { Dev. }\end{array}$ & $\begin{array}{l}\text { Width } \\
\text { Avg. }\end{array}$ & $\begin{array}{l}\text { (mm)* } \\
\text { tand. } \\
\text { Dev. }\end{array}$ & $\begin{array}{r}\text { Thickne } \\
\text { Avg. }\end{array}$ & $\begin{array}{l}(\mathrm{mm}) * \\
\text { and. } \\
\text { Dev. }\end{array}$ & $\begin{array}{c}\text { Weight } \\
\text { Avg. }\end{array}$ & $\begin{array}{l}\text { (gms)* } \\
\text { Stand, } \\
\text { Dev. }\end{array}$ \\
\hline \multicolumn{12}{|l|}{ Pre-Archaic } \\
\hline $\begin{array}{l}\text { Early Corner Notched } \\
\text { Early Side Notched }\end{array}$ & 5 & 2.3 & 2 & 70.0 & & 32.0 & 5.7 & 7.0 & 0.0 & 6.5 & 9.1 \\
\hline $\begin{array}{l}\text { Early Side Notched } \\
\text { Gower }\end{array}$ & 5 & 2.3 & 3 & 35,7 & 4.0 & 22.3 & $3 . \overline{8}$ & $6 . \overline{3}$ & $0 . \overline{6}$ & 4,8 & $\overline{1,7}$ \\
\hline Martindale & 7 & 3.3 & 4 & 58.0 & 12.8 & 32.0 & 3.5 & 7.3 & 1.1 & 10.7 & 3.2 \\
\hline \multicolumn{12}{|l|}{ Late Paleo-Indian } \\
\hline Angostura & 11 & 5.2 & 1 & 71.0 & -- & 18.0 & -- & 7.0 & -- & 9.0 & - \\
\hline Meserve & 1 & 0.5 & 1 & 79.0 & - & 26.0 & -- & 8.0 & -- & 16.3 & -- \\
\hline Plainview & 2 & 0.9 & 0 & -- & -- & -- & -- & -- & -- & - & -- \\
\hline \multicolumn{12}{|l|}{ Unknown } \\
\hline Big Sandy-like & $\frac{1}{213}$ & 0.5 & $\frac{1}{111}$ & 61.0 & -- & 35.0 & - & 7.0 & -- & 16.3 & - \\
\hline
\end{tabular}

*Measurements taken on complete points only 
TABLE 7. MEASUREMENTS AND PROVENIENCE OF ANGOSTURA SPECIMENS

\begin{tabular}{|c|c|c|c|c|c|}
\hline $\begin{array}{l}\text { Length* } \\
(\mathrm{mm})\end{array}$ & $\begin{array}{c}\text { Maximum } \\
\text { Width (mm) }\end{array}$ & $\begin{array}{l}\text { Maximum } \\
\text { Thickness (mm) }\end{array}$ & $\begin{array}{l}\text { Weight** } \\
\text { (gms) }\end{array}$ & $\begin{array}{c}\text { Basal Width } \\
(\mathrm{mm})\end{array}$ & Provenience \\
\hline 71 & 18 & 7 & 9.0 & 13 & $\begin{array}{l}41 \text { BX } 36 \\
\text { (Unit } 6, \\
\text { Level 4) }\end{array}$ \\
\hline (32) & 22 & 6 & - & 16 & 41 BX 373 \\
\hline (23) & 21 & 6 & - & 12 & Bullis $\mathrm{Hill}$ \\
\hline (42) & 20 & 7 & - & 12 & 41 BX 376 \\
\hline (36) & 22 & 8 & - & 17 & $41 \mathrm{BX} 376$ \\
\hline$(45)$ & 20 & 7 & - & 10 & 41 BX 403 \\
\hline (22) & 21 & 6 & - & 14 & $41 \quad B X \quad 381$ \\
\hline (42) & 20 & n.a. & - & 14 & 41 BX 424 \\
\hline (37) & 26 & 8 & - & 14 & 41 BX 424 \\
\hline (31) & 19 & 7 & - & 15 & 41 BX 424 \\
\hline (23) & 21 & 6 & - & 12 & $\begin{array}{l}\text { Lewis Creek } \\
\text { Zone } 4\end{array}$ \\
\hline
\end{tabular}

*Incomplete measurements enclosed in parentheses.

**Complete specimens only. 
specimens (Suhm and Jelks 1962). The base of this point is not Plainview, but is more similar to the Golondrina type.

Angostura (11 specimens; Fig. 18, $a-i, 1$ and $m$ )

Measurements and provenience for the Angostura specimens are presented in Table 7. Only one specimen is complete; the remainder are basal fragments. Flaking on the majority of the points is oblique collateral, with basal and stem grinding present on most specimens. The body and tip of the complete specimen have been reworked; wear pattern analysis indicates it was used as a punch and boring tool. Its thick base was probably hafted in a hollow bone or wooden foreshaft.

The bases of all but one specimen are slightly concave, with short flake scars present on both faces. Two of the points were broken in manufacture and are lacking basal grinding.

Many of the specimens are heavily patinated; about half appear to have been heat treated. The material from which one specimen is made is identical to Alibates dolomite samples from the Texas panhandle, varying in color from cream to mottled red to orange-red.

The complete specimen from 41 BX 36 was closely associated with a patinated Early Corner Notched point. Nolan points were recovered two and three levels above, but a Marshall point was found two levels below in the same unit. The specimen from 41 BX 403 was associated with Travis, Bulverde, Pedernales and Gower points, al1 surface finds. Three Angostura points, fragments of other unidentified projectile points and scattered debitage were recovered from 41 BX 424, a "pure" Late Paleo-Indian site. At 41 BX 376, two Angostura specimens were associated with Early Side Notched, Early Corner Notched and Gower projectile points and a Guadalupe tool.

\section{Pre-Archaic Projectile Points}

The Pre-Archaic dart points represent a series that is more difficult to describe because various authors include three morphologically different forms: a "Martindale-1ike" point (Fig. 19), the Gower type (Fig. 17) and a form that is morphologically similar to the lualde type.

Martindale (7 specimens; Fig. 19,f-1)

The bodies are triangular with straight to slightly convex edges. Prominent barbs were formed by deep corner notches, with a stem to base angle of $45^{\circ}$ to $60^{\circ}$. The basal concavity is formed by chipping two convex curves that meet in the center of the base, producing a swallowtail appearance. Six of the seven Camp Bullis specimens are patinated, varying from light to heavy. All are finely made points with one (Fig. 19,i) being exceptionally well made. The specimen was found in the third level of Unit 7 at 41 BX 36, associated with a Nolan type point. It is the only unpatinated Martindale point, being of dark 


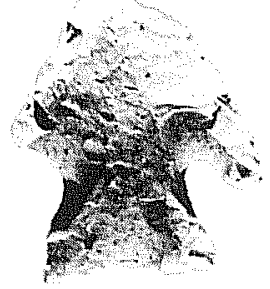

a

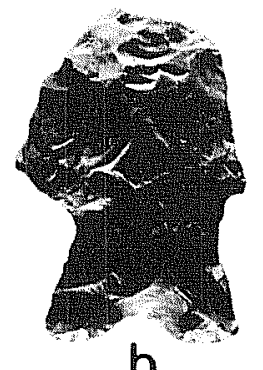

b
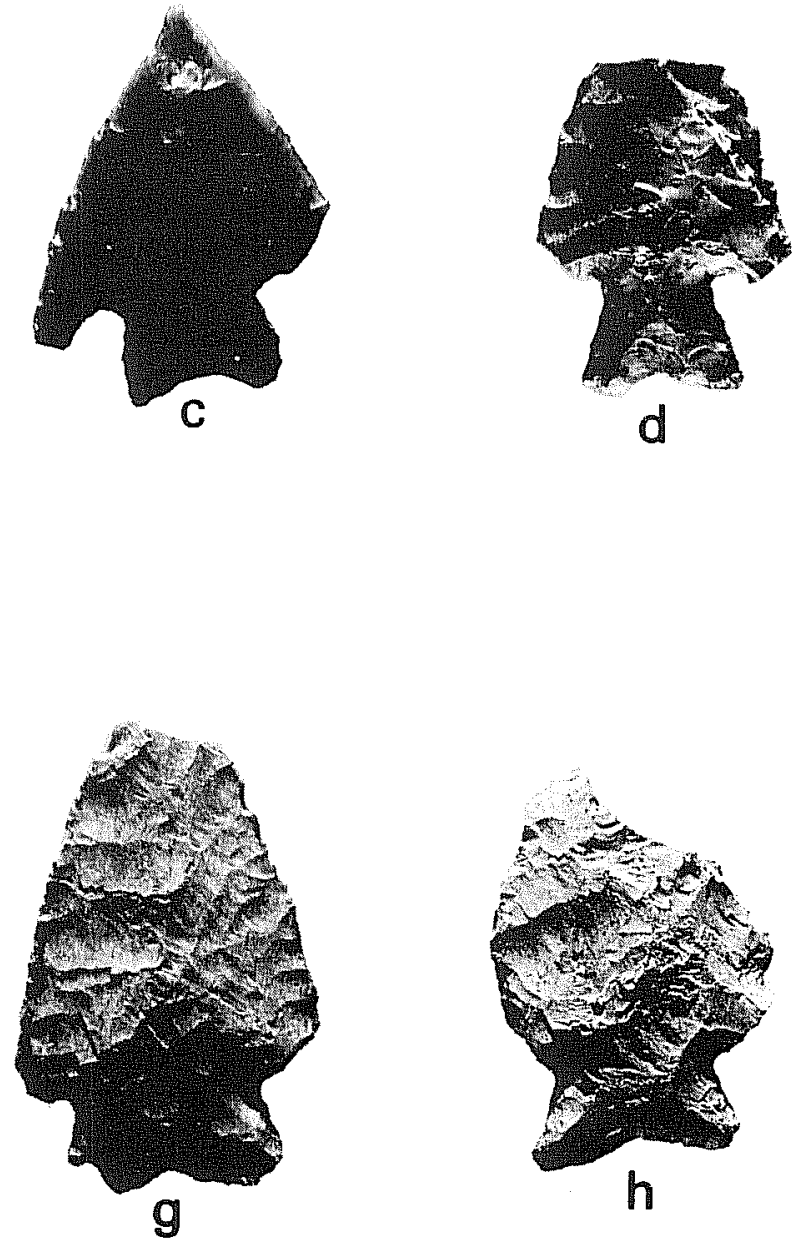
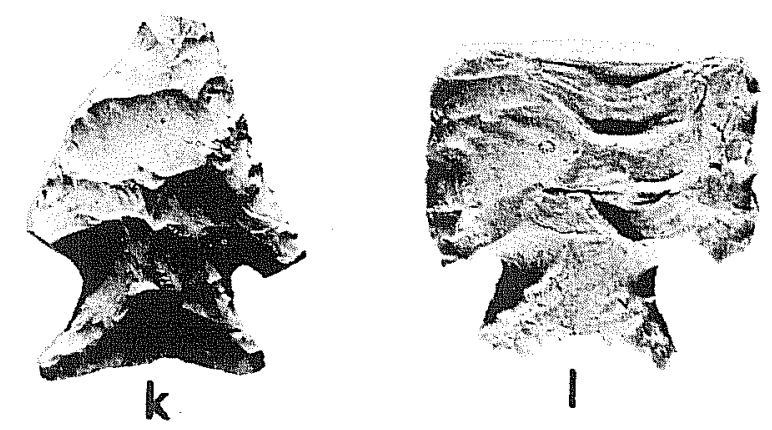
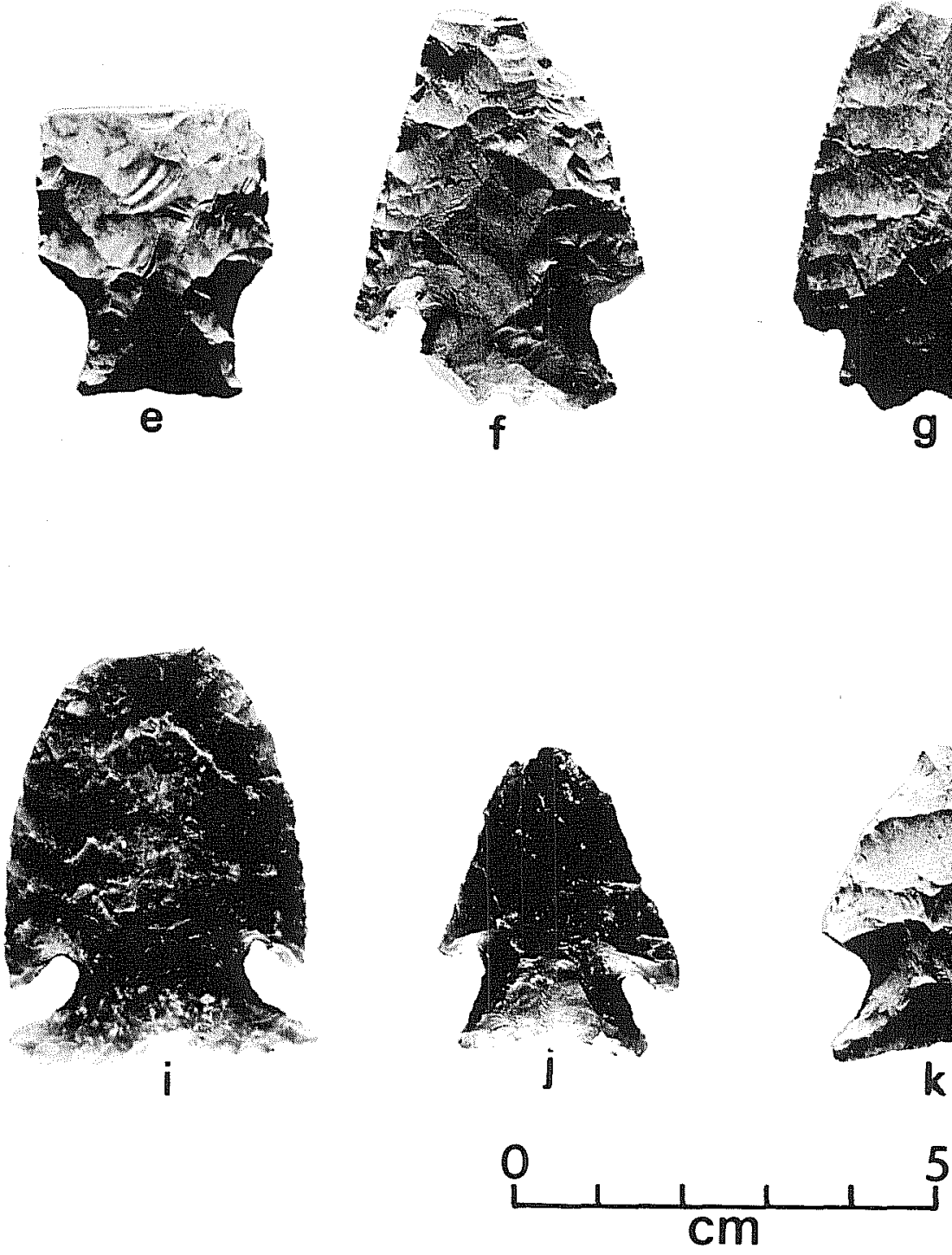

Figure 19. Lithic Artifacts from Camp Bullis: Pre-Archaic Dart Points. a-d, Early Corner Notched (a, 41 BX 371; b,d, 41 BX 376; c, 41 BX 36); e, Early Side Notched 41 BX 376); f-1, Martindale (f, 41 BX 375; g, Zone 5; h, 41 BX 371; $i, 41$ BX 377; $j, k, 41$ BX 36; 1, 41 BX 407). 
honey-colored translucent chert (source not found on Camp Bullis). Two Middle Archaic Pedernales points were found in the level below it, an unfortunate circumstance in this much disturbed site. Stratigraphy is equally mixed on the second point from 41 BX 36 , which was from Unit 1, Level 4, associated with Nolan and Castroville points. Another castroville point was found two levels below it. The fact that none of the other points in what is believed to be an undisturbed unit were patinated might indicate that Martindale points (as defined by Suhm and Jelks 1962) were manufactured in the Archaic period.

Gower ( 5 specimens; Fig. $17, j-m$ )

A11 have short triangular bodies with nearly straight edges. The stem is straight to slightly expanding; the base is indented deeply by removal of a large flake unifacially in three cases. Two have alternately beveled blades, one does not, and enough remains of a fourth to determine that at least one edge was beveled. Two specimens have sinuous edges. All five points have a heavy white patina which at Camp Bullis consistently is associated with PaleoIndian and Pre-Archaic artifact types. Four points have basally ground stems and bases. None of the tips are sharply pointed nor is pressure flaking anywhere evident.

Gower points were all surface finds at Camp Bullis and came from four different sites. Three of these sites were camp sites (41 BX 376, 41 BX 402, 41 BX 403) approximately one $\mathrm{km}$ from water sources. The associated artifacts at $47 \mathrm{BX} 376$ were two Angostura, one Early Side Notched and two Early Corner Notched points. Associated artifacts at 41 BX 402 were Tortugas, Ensor-Frio and Frio points, with only the Gower points patinated. Associated artifacts at 41 BX 403 were one Travis, three Bulverde and one Angostura point. The Angostura and Gouer are the only deeply patinated points. The fourth site, 41 BX 409, was a multipurpose camping site/lithic resource procurement area and the associated artifacts were one unpatinated Dare dart point and a heavily patinated Guadalupe tool.

The most distinguishing characteristic of the Gower type at Camp Bullis is the poor quality of workmanship and the method of creating the basal concavity. This is consistent with points reported from the Youngsport site (Shafer 1963) where five Gower and nine Gower variants were found in Stratum 8 in a yellow clay matrix, we11 separated from Early Archaic points, Morrill and wells in Stratum 6, and Bulverde, Travis and Nolan in Stratum 4. Shafer (1963:64-65) repeatedly uses the adjectives "poorly made," "crudely made" and "poor workmanship" to describe Gower points. Beveled blades are not mentioned, but two Gower Variant A have edges described as sinuous.

Crawford (1965), in describing the Granite Beach surface specimens (associated on the surface with Paleo-Indian point types Angostura, Plainview, Golondrina and points closely resembling Uvalde), also comments on the crude workmanship, except for occasional long oblique flake scars across the blade. Twelve specimens had beveled blades and four had indications of smoothing on stem edges. Sollberger and Hester (1972) report heavily patinated Gower-like points in an early surface context at the Strohacker site. A few had smoothed stem edges. They were associated on the surface with Angostura, Plainview and 
Golondrina Paleo-Indian types and other corner notched Pre-Archaic points similar in form to Martindale and Uvalde.

Pre-Archaic points such as Bell and Martindale, etc., are generally of the same fine quality of workmanship as PaleomIndian points they replace and Early Archaic points they precede. One must then ask: why is the Gower point so poorly made? Sollberger (1971) has mentioned the efficiency of beveled-edged knives, and this observation caused the writer to do a microscopic wear pattern study of the three relatively complete Camp Bullis Gower specimens. All revealed heavy crushing of the edges and several gouged-out flake scars parallel to the longitudinal axis of the body. The tip of one specimen has striations parallel to the longitudinal axis of the point. Heavy cutting wear is indicated, as would occur from cutting wood or bone. The sample is too small for general conclusions, but all Gower points should be reexamined for similar wear patterns to see if Gower "points" might not have been utilized as knives.

\section{Early Corner Notched (5 specimens; Fig. 19,a-d)}

These are small triangular points, with the body straight to slightly convex, and with corner notches at steep angles $\left(60^{\circ}-70^{\circ}\right)$. The stem is slightly expanding, the base is concave and the workmanship is good. This point is morphologically very similar to Uualde (Suhm and Jelks 1962). Weir (1976:52) illustrates very similar points classified as Uualde but attributed to the San Geronimo phase corresponding to our Pre-Archaic. Hester (1971:73) has similar points classified as Early Corner Notched Variety I, but also includes recurved base points similar to Martindale. The Camp Bul is Early Corner Notched specimens have prominent barbs, slightly narrower bases and simple basal concavities--a11 of which differentiate them from Martindale. Two of the specimens are heavily patinated, a characteristic of Camp Bullis Pre-Archaic points, while two others are of medium to light patination.

\#1. (Fig. 19,a). The point is a heavily patinated specimen, associated with a Martindale point, lithic debitage and cores at $41 \mathrm{BX} 371$ on an upland terrace overlooking Cibolo Creek at the west end of Camp Bullis.

\#2. (Fig. 19,C). This point is only slightly patinated. It was found in a badly disturbed unit at 41 BX 36 (Unit 12, level 2), overlying an Ensor-Frio Late Archaic point in Level 4.

\#3. (Fig. 19,b). This specimen is highly patinated, has a slender stem and the basal notch is a simple curve which distinguishes it from Martindale. It is from an upland site (41 BX 376) one $\mathrm{km}$ south of Cibolo Creek. It was associated (on the surface) with Angostura, Early Side Notched and Gower points and a Guadalupe tool. All artifacts are highly patinated.

\#4. (Not illustrated). The point fragment is damaged and the base is so fragmented as to make it difficult to separate from the Martindale form. It is patinated and vitreous, suggesting thermal alteration. It was found at 41 BX 36 (Unit 6, Leve1 4) and was associated with an 
Angostura point. However, a Marshall point was found two levels below, again indicative of subsurface disturbance at this site.

\#5. (Fig. 19, d). This basal fragment of an Early Corner Notched point was the second specimen of this type recovered from the surface at site $41 \mathrm{BX} 376$.

\section{Early Side Notched (1 specimen; Fig. 19,e)}

The specimen is a basal fragment, $33 \mathrm{~mm}$ long, $27 \mathrm{~mm}$ wide and $7 \mathrm{~mm}$ thick, with large side notches resulting in weak shoulders and an expanding base. The basal edge is slightly concave and both stem edges are lightly ground. The base is thinned with a series of small flake scars. Several wide parallel flake scars are apparent on one face. The point is morphologically similar to expanding stem points from Devil's Mouth Site (Sorrow 1968:Fig. 17, K-Q) dated to 6830 B.C. It might be classified as Lange were it not for the patina and its surface association with a series of early points.

The specimen is a surface find at $41 \mathrm{BX} 376$, an upland margin site one $\mathrm{km}$ south of Cibolo Creek. It was associated with two Angostura, two Gower and two Early Corner Notched points, a Guadalupe tool, scattered burned 1 imestone, cores, quarry blanks, broken bifaces and chert debitage. A11 1ithic material was covered by heavy white patina.

Other Distinctive Projectile Point Forms

La Jita (4 specimens; Fig. 17,n-p)

The specimens are triangular, three with lateral edges straight to slightly convex and one wide specimen with markedly convex edges. A11 are weakly sidenotched, three with alternate bevels. Notching forms weak shoulders with rudimentary barbs on two specimens. Three stems expand slightly and one is straight. The bases are slightly concave on one specimen and slightly convex on three. Workmanship is only fair. Secondary flaking is minimal on edges; bases are thinned on both sides by two or more broad flake scars. They appear identical to Hester's (1971) tentative La Jita type.

Three specimens were from $41 \mathrm{BX} 36$, Units 14 and 15, which contained the only concentration of Early Archaic points found in the site: Bulverde and Nolan. The fourth was from $41 \mathrm{BX} 428$, the smal1 burned rock midden one mile north of $41 \mathrm{BX} 36$ on Davis Creek. It was found in the fourth level $(40 \mathrm{~cm})$. The only other points found in this midden were wells and Castroville.

La Jita points at the type site were mixed in distribution and are thought to be Middle Archaic (Hester 1971), al though some occurred in Early Archaic contexts. At $41 \mathrm{KE} 49$ (Ke11y and Hester 1976), six La Jita points were found associated with Early Side Notched, Early Corner Notched, Early Triangular, Travis, Bulverde and Nolan points. 
The Middle Archaic was not represented at $41 \mathrm{KE} \mathrm{49}$, so it would seem that the La Jita point type is either Pre-Archaic or Early Archaic. Based on patination, the $41 \mathrm{KE} 49$ points would fall into the Early Archaic period, as the Pre-Archaic points there had a heavy white patina, while Early Archaic points had none. None of the Camp Bullis specimens are patinated. Thus, the best estimate at present would suggest the placement of La Jita points in the Early Archaic period. Now that La Jita points have been found in three excavated sites, it is recommended that Hester's (1971) "tentative" rubric be dropped and the type accepted as an Archaic point type. Its exact time placement is not yet certain.

\section{Big Sandy-1ike (1 specimen; Fig. 15,1)}

This point is radically different from any other point found in the Camp Bullis survey. It is $61 \mathrm{~mm}$ long, $35 \mathrm{~mm}$ wide, $7 \mathrm{~mm}$ thick and weighs $16.3 \mathrm{gm}$. The body is triangular with convex, finely pressure-flaked serrated edges. It has carefully flaked wide side notches and an incurvate base. The buff patina obscures the chert so it could not be determined whether it was local.

The point is morphologically close to the Big Sandy Side Natched from the type site in Henry County, Tennessee (Kneberg 1956:25). Lewis and Lewis (1961:37) present a detailed discussion of the type and its temporal placement in the Archaic at ca. 3000-4000 B.C. As far as the author can determine, no similar specimens have been reported from the central and south central region.

The specimen was found in a flood plain site north of Cibolo Creek (41 CM 96), associated with a light lithic scatter and a few burned limestone rocks.

Edwards (42 specimens; Fig. 16,k-u)

This type is a Late Prehistoric arrow point with triangular blade and straight, concave, or convex edges often finely serrated. Barbs are prominent and pointed, formed by corner notches at approximately a $45^{\circ}$ angle to the longitudinal axis. The base is deeply concave forming two long pointed barbs usually flaring and often wider than the blade. The average measurements of 21 complete points were $27.8 \mathrm{~mm}$ length, $17.8 \mathrm{~mm}$ width, $2.7 \mathrm{~mm}$ thickness and $1.4 \mathrm{gm}$ weight. The quality of flaking is very fine.

Sollberger (1967) reported the point type in Kerr County rockshelters and in one burned rock midden. He notes the resemblance in form of these points to Frio and Martindale dart points.

At Camp Bullis, Edwards points are found in the upper levels of terrace sites, and in surface sites overlooking Cibolo Creek. They are closely associated with Scallorn points, which they resemble slightly. However, the Scallorn are simple triangular points, corner notched and generally with straight bases. The Edwards point constituted $19.7 \%$ of the Camp Bullis projectile point sample (Table 6). Perdiz and Scallorn were next in frequency with $9.4 \%$ and $8.9 \%$ respectively. 
These distinctive points have been reported over the southern and western portion of central Texas (Sollberger 1967; Hester 1971; Graves and Highley 1978). Their known distribution includes Atascosa, Bexar, Coma1, Hayes, Kenda11, Kerr, Medina and Uvalde Counties. 



\author{
II I. A.6 \\ ARTIFACT CATEGORIES AND DISTRIBUTIONAL TABULATIONS \\ James E. Ivey, Thomas R. Hester and Carol Graves
}

\title{
INTRODUCTION
}

In this chapter, we present a review of the artifact categories used in the analysis of materials collected at Camp Bullis. In addition, we have presented distributional and cross tabulation data for artifacts from the principal sites found there.

There is a certain degree of terminological inconsistency in artifact categories found in III.A.6 through III.A.9. We apologize to the reader for these somewhat irritating inconsistencies, but as we shall explain below, they stem from an effort to approach the goals of these four chapters from different analytical levels.

Lithic data were tabulated on four separate computer coded forms utilized in different phases of the project. These forms, designed by Joel Gunn, Andrea Gerstle and Elizabeth Frkuska, have attempted to codify established projectile point types, and the basic categories of other lithic and non-lithic tools. As anyone who has worked in central Texas will realize, attempts to categorize non-projectile point lithics in a standard fashion have not previously been successful, and we fear that we must report that we have done little better. For example, in Fig. 11 (Cultural Type List), the designers attempted to implement some standardization, by utilizing terms (particularly among the unifaces) proposed by Weir (1976) in his synthesis of the central Texas Archaic. Yet on other forms (see Figs. 5, 9, 10) the designers had to revert to more commonly used (and commonly confused) functional terminology in order to address the specific goals of certain chapters. If the Fort Sam Houston Project were to be done over, it is highly likely that different and potentially more consistent approaches would be taken in the design of these forms. However, project personnel had to work under the constraints of funding which allowed for a rather brief period for the preparation of research design, implementation of field work and submission of a full draft report (approximately 7 months). After submission of the full draft, the principal project archaeologists had to move on to other tasks and did not have the opportunity, which most archaeologists 7 ike to have, for continued analysis, re-design and re-interpretation. This is one of the major problems confronting public service archaeology in the United States, and, if the pattern continues, it is one we will have to become better equipped (both intellectually and methodologically) to handle. The design of the coding forms for this project was an effort on our part to speed the analytical process, but the vast amount of data obtained during field work required much more time for processing, keypunching, production and review of print-outs, etc., than we had anticipated.

As noted above, lithic analysis was done at several levels, with specific aims in mind. Thus, for the contents of this chapter, the Computer Coded Lithic Analysis Form (Fig. 10) anc the Cultural Type List (Fig. 11) were utilized. These focus 
on diagnostic artifacts and a series of general, morphologically-based 1ithic categories, which, it was felt, would facilitate the preparation of basic distributional data.

In III.A.7, documented sites and scattered artifacts are described. These descriptions contain lithic terminology based on the use of the Computer Coded Field Survey Form (Fig. 5). This particular coding format allowed the field workers to rapidly enter Tithic (and other) data, once they had agreed on the appropriate categories during conferences in the field.

In III.A.8 and III.A.9, dealing with site types and settlement patterns, yet another level of lithic analysis was needed in order to carry out these more far-reaching studies of site relationships at Camp Bullis. For such studies, it was necessary to have a rather wide latitude in making functional interpretations for lithic categories. This facilitated, in terms of the studies (and, we hope, in terms of their utility), broad real comparisons, using literature in which these functional terms are quite commonly employed. Therefore, the Computer Coded Laboratory Form (Fig. 9) was used. This form was completed by the project analysts once artifact processing had been completed in the laboratory.

\section{ARTIFACT CATEGORIES}

The descriptions of our artifact categories are based on the coding format shown in Fig. 11; however, we have made an effort to correlate, when necessary, entries or items on that form with other coding forms used during the project (see the discussion above).

For the purposes of this assessment report, and given the short period allotted to analysis, we have avoided detailed artifact descriptions and have not included lengthy morphological descriptions or series of metric attributes. Because both the cultural diagnostics and the other artifactual materials are quite typical of the central Texas region (see below), we feel that the reader will have abundant published sources to which to refer if additional descriptive information is desired on a particular category. We have also attempted in this report to illustrate as many of the collected specimens as possible. Data for the analyzed artifacts is presented in Table 8. Non-diagnostic artifacts (i.e., bifaces, unifaces and cores) were analyzed from the excavated sites only and they are included in Table 8.

\section{Projectile Points}

In III.A.5, diagnostic projectile point types and forms were reviewed. of the 77 potential types or forms 1 isted in $\mathrm{Fig}$. 11, al1 but 10 are extensively described in the original definitions by Suhm et al. (1954) and Suhm and Jelks (1962). And, of these 77 potential categories, the specimens collected from Camp Bullis correspond to only 23. Illustrations of most can be found in Figs. 13-19. 
There are, however, 10 types or forms found on the 1ist (Fig. 11) which were not originally defined by Suhm et al. (1954). Of these, four were not found on the survey; these are Bell (Sorrow et al. 1967), Carrizo (House and Hester 1967), Golondrina (Johnson 1967; Hester 1977:175ff) and Val Verde (Schuetz 1956).

Five of the six other types or forms that did occur (Gower, La Jita, Early Corner Notched, Early Side Notched, Edwards) have been described in some detail by Kelly in III.A.5. One form, called Ensor-Frio (item 17, Fig. 11), was not discussed. As the term implies, these are projectile points which resemble both the Ensor and Frio types. Identical specimens recovered from Oblate Rockshelter were described as Ensor, Variety $B$ and Variety $C$; those from the Wunderlich site were described as Ensor, Variety 2 (Johnson et al. 1962). We do not conceive of this form as some sort of projectile point "hybrid." However, the specimens typically have the side-notching and size typical of Ensor, but in the center of the basal edge of the stem, a narrow, $V$-shaped notch was placed, causing the specimens to bear some resemblance to Frio. Whether these are typologically significant, or simply represent the vagaries of projectile point manufacture, we cannot say. Excavations in central and south central Texas in recent years have not clarified this typological quandary, although they have confirmed that the specimens are found in the Transitional Archaic.

Several projectile points were also sorted into Unfinished and Unknown categories. Specimens classified as unfinished (item 79, Fig. 11) have certain attributes that indicate they were never completed or utilized (see Fig. 20). These attributes include very thick proximal or distal portions with multiple hinge fractures, reflecting the inability of the stoneworker to successfully thin the specimen; these hinge fractures sometimes led to breakage. 0ther attributes which were considered are lack of basal thinning (i.e., the specimen has a thick base which did not appear suitable, at least to the archaeologist, for hafting) and partially formed stems (e.g., only one notch was completed). The unknown category (item 80, Fig. 11) constitutes finished projectile points which could not be classified according to presently defined types or forms; there were only a few of these faund during the survey.

\section{Bifaces}

We recognize, of course, that most projectile points are bifaces, but here we are referring to non-projectile point artifacts, and to fragments of bifaces that might represent either category (see items 87, 88, Fig. 11). Of the five potential biface categories in Fig. 11 , only two have been tabulated in this chapter. Complete bifaces ( $i$ tem 86) include non-projectile point forms; in general, these are discarded specimens representing "fossilized" stages in the lithic reduction process. These are generally quarry beanks (large, crude bifaces usually with cortex remnants on one or both faces, representing initial phases of biface reduction; Figs. 2l-23,a,b) and preforms (percussion, and sometimes pressure, flaked bifaces further reduced in size and mass and apparently intended for manufacture into projectile points; Figs. 24-26,a-n). other bifaces were simply lumped together, as the analysts were uncertain as to whether they represented preforms, knives (a function we were unwilling to assign without microwear confirmation), or even aberrant forms of projectile points. 


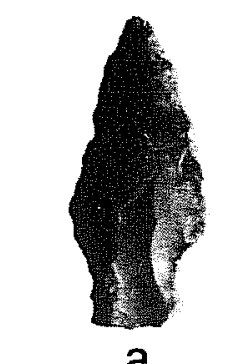

a

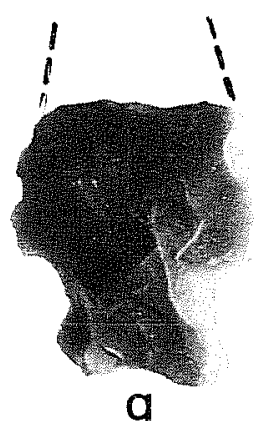

g
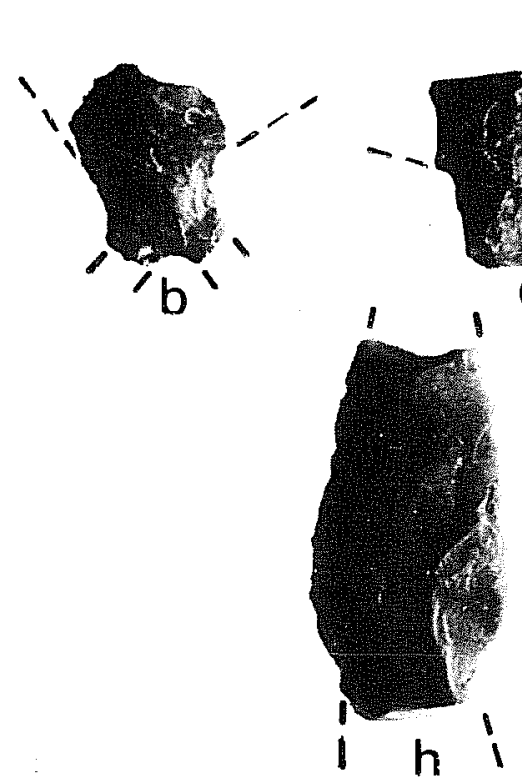
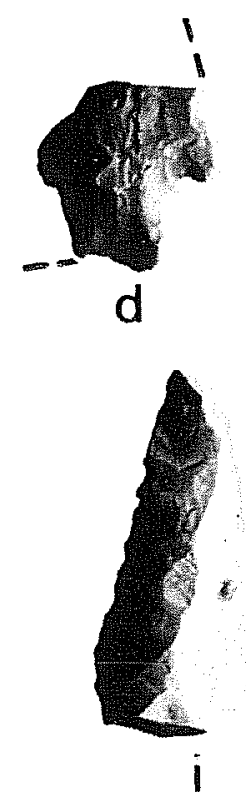
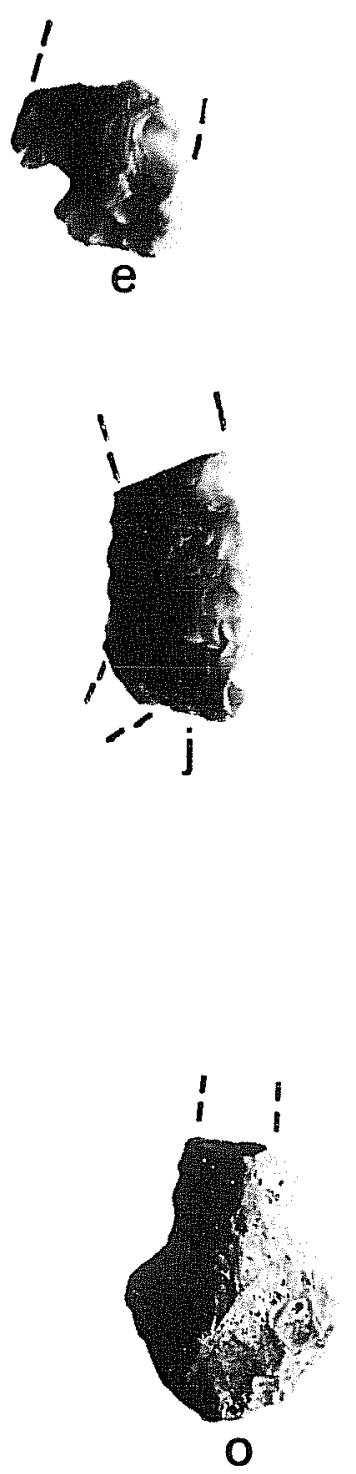
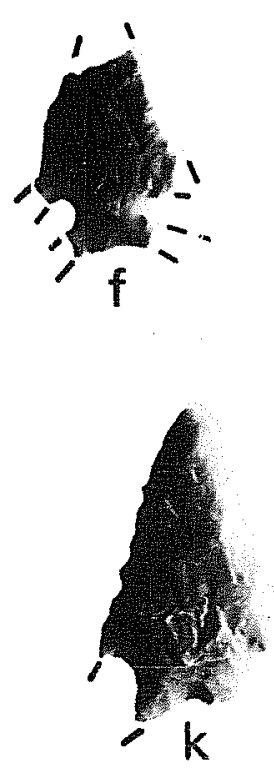
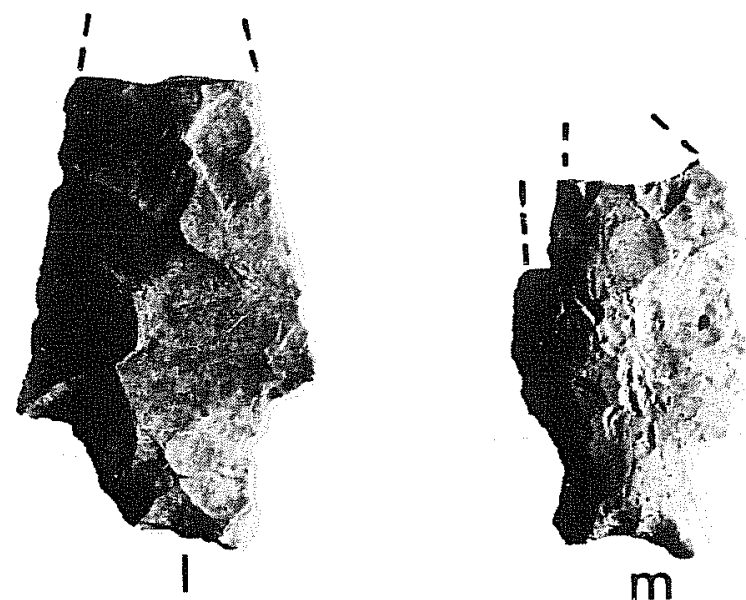

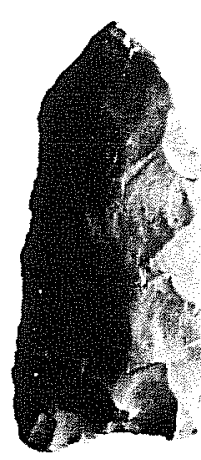

n
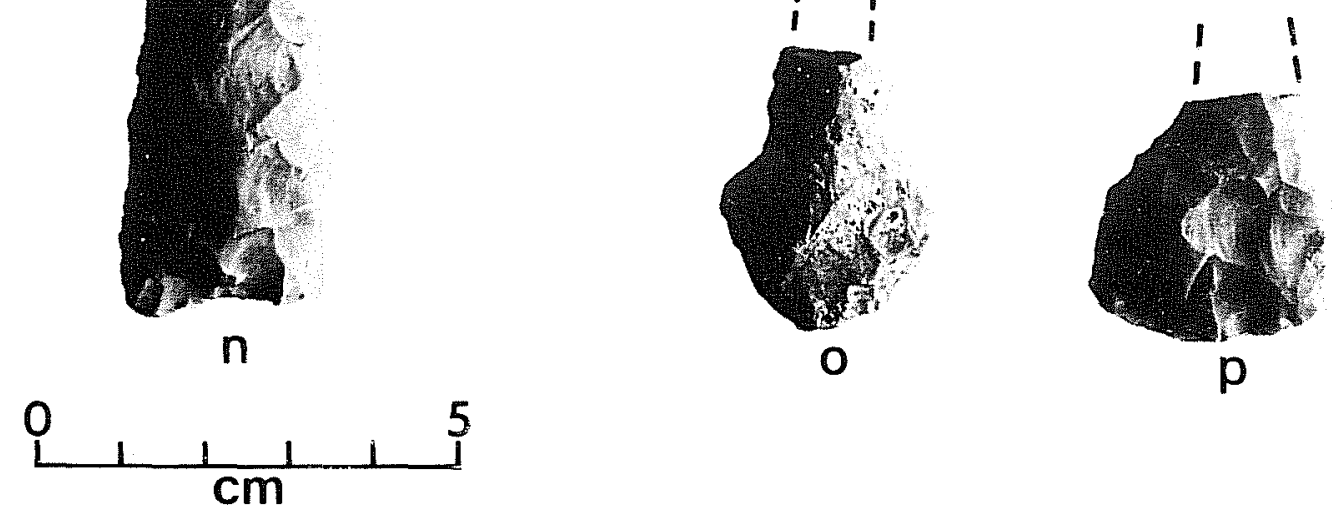

Figure 20. Lithic Artifacts from Camp Bullis: Unfinished Specimens and Perborators. a-n, unfinished artifacts (mostly unfinished dart points); $a, 41 \mathrm{CM} \mathrm{70,b,m,41} \mathrm{BX} \mathrm{393;} \mathrm{c,g,} 41$ BX 399; d, 41 BX 378; e, 41 BX 382; $f, 41$ BX 380; $h, 41$ BX 421; i, 41 BX 382; j, 41 BX 390; k, 41 CM 99; 1, 41 BX 431. o-p, perforators (beaked bifaces); $i, 41$ BX 424; $p, 41$ CM 99. 


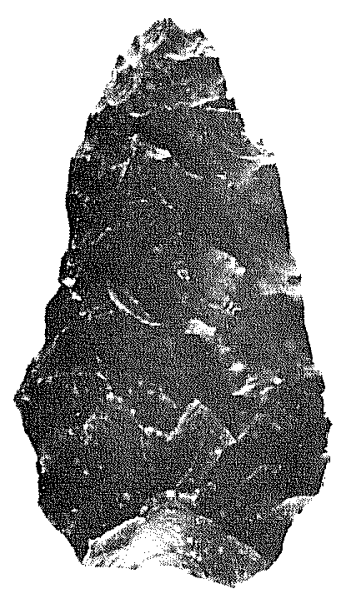

a
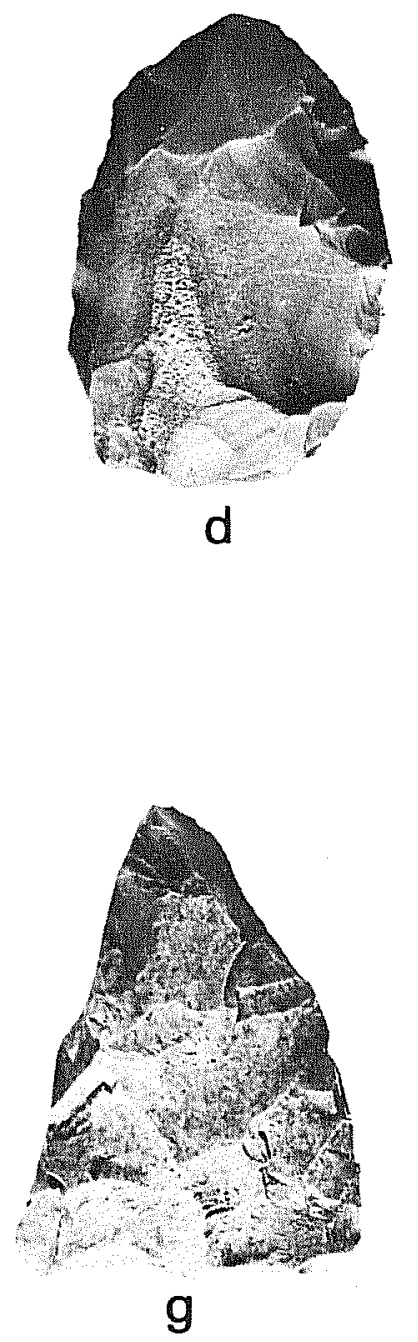

g
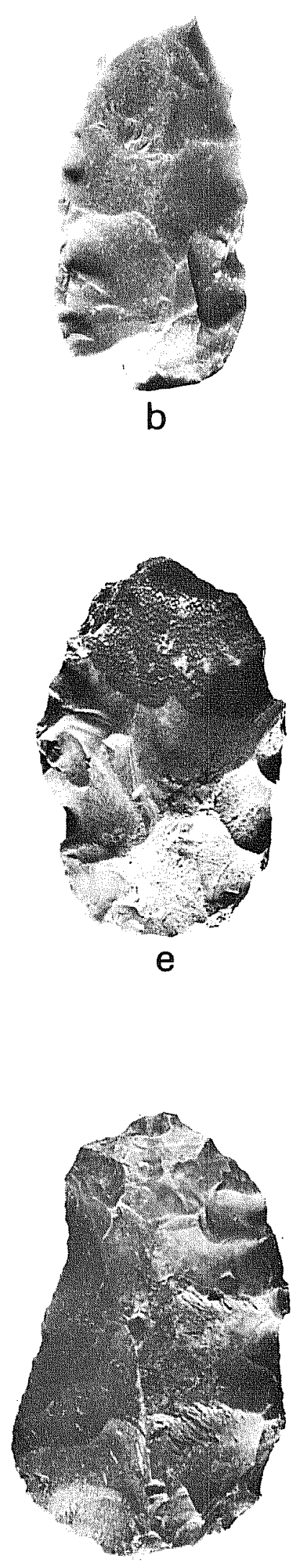

h

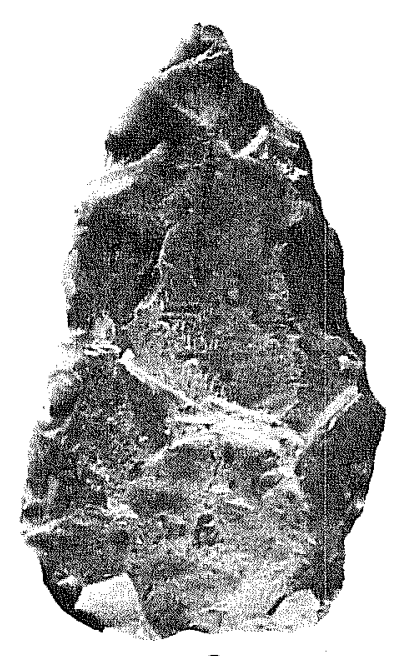

C

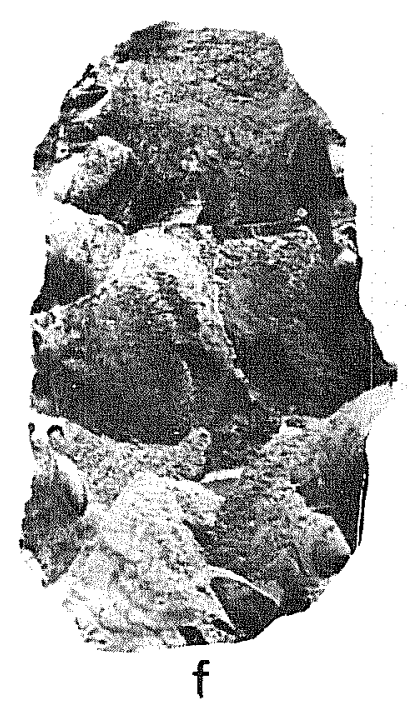



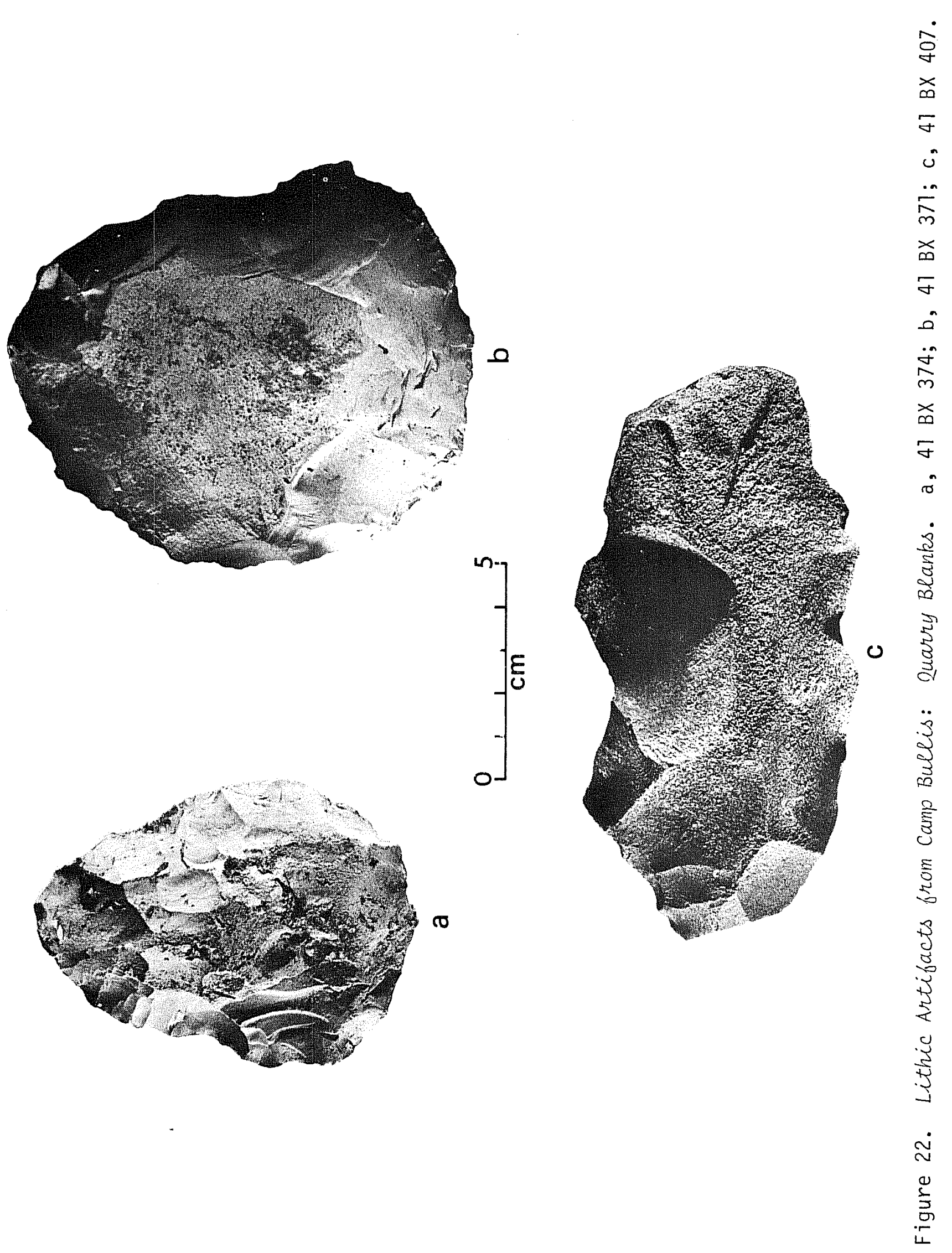

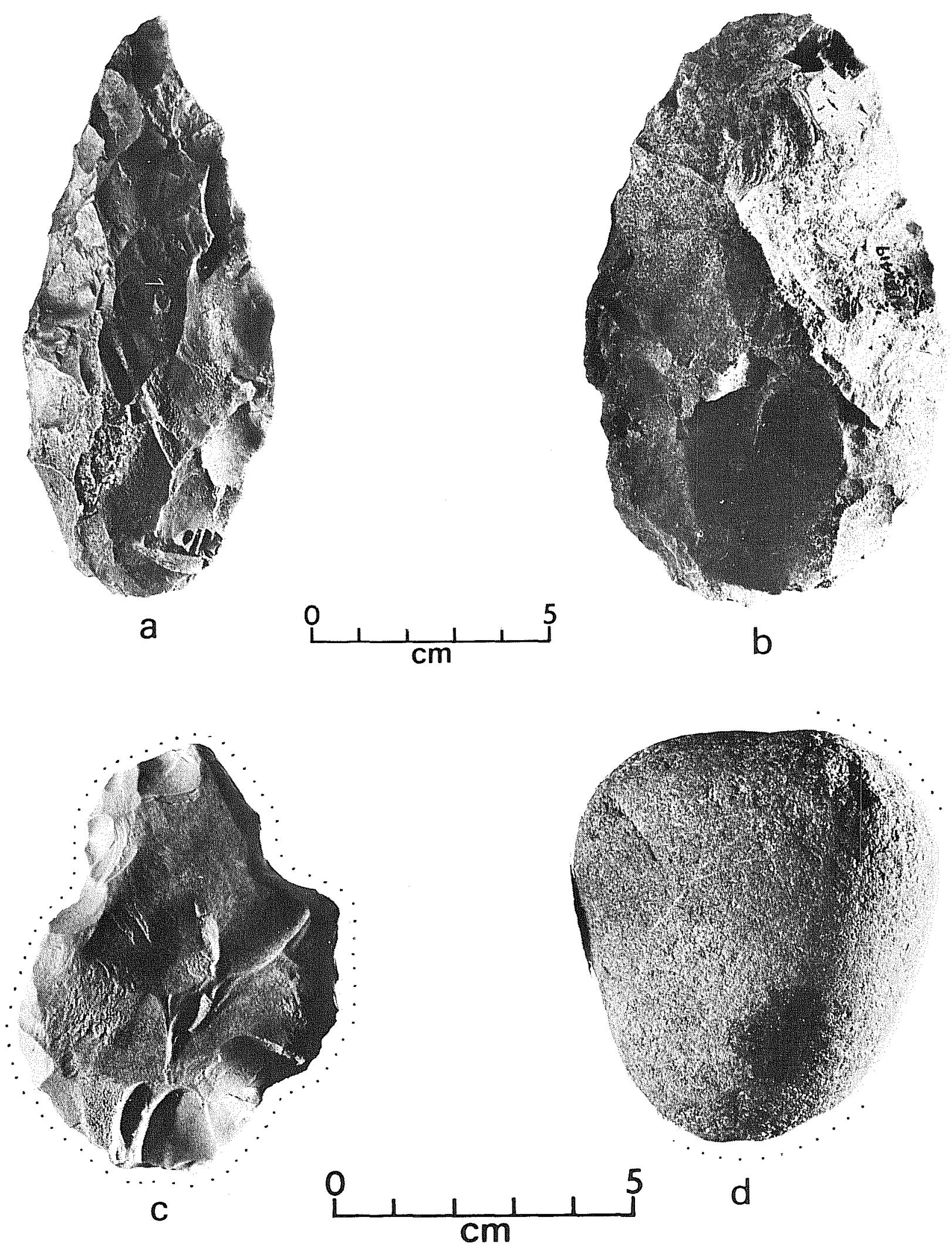

Figure 23. Lithic Artifacts from Camp Bullis. a-b, quarry blanks (a, 41 BX 410; $b, 41$ BX 419); c, d, hammerstones (c, 41 CM 102; d, 41 BX 431). Dots indicate battered edges. 


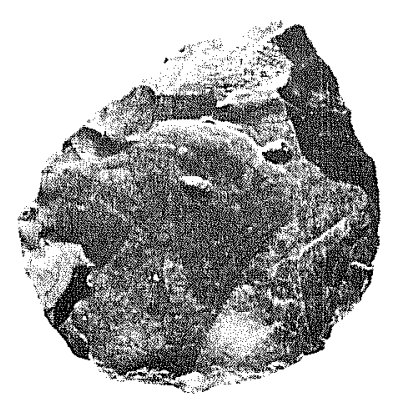

a

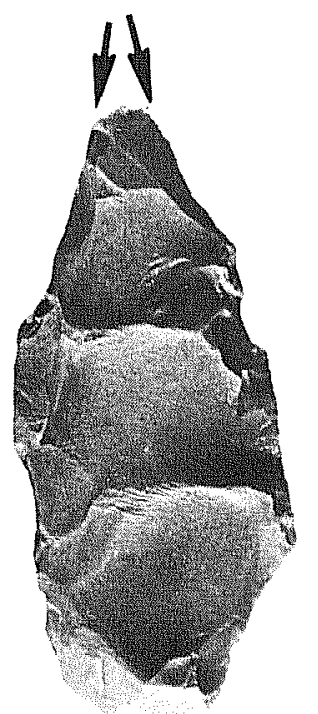

e

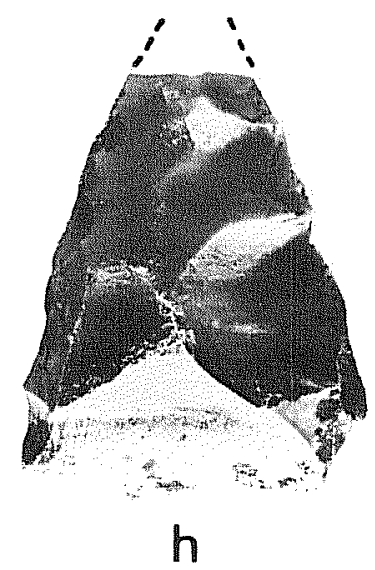

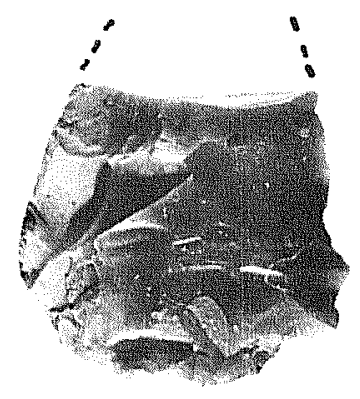

b

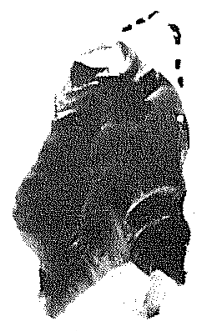

C
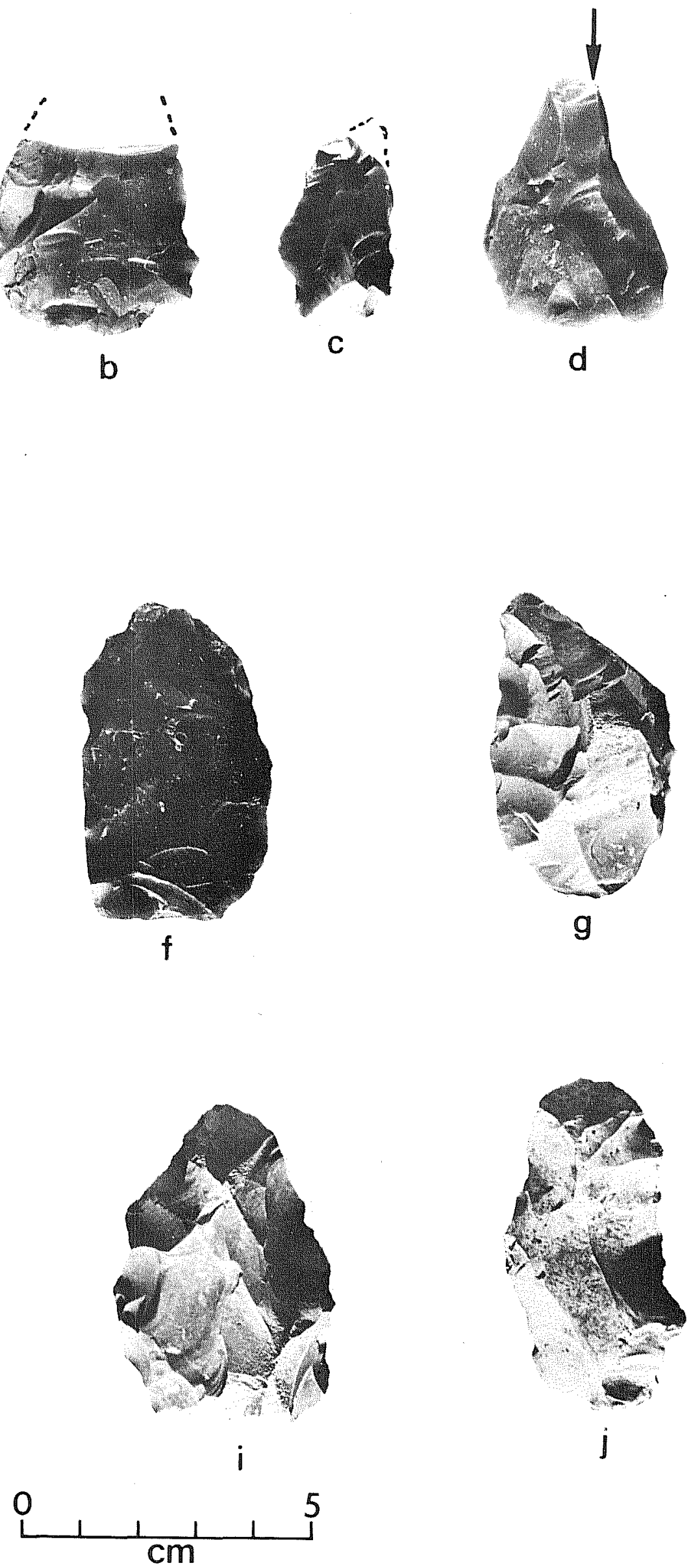

Figure 24. Lithic Artifacts from Camp Bullis: Preforms. a, $i, 41 \mathrm{BX} 377$; $b, 41$ BX 423; c, 41 BX 378; d, 41 BX 379; e, 41 BX 375; f, 41 BX 409; g, 41 BX $374 ; h, 41$ BX 426; $j, 41$ BX 424. Arrows denote burin-like facets. 


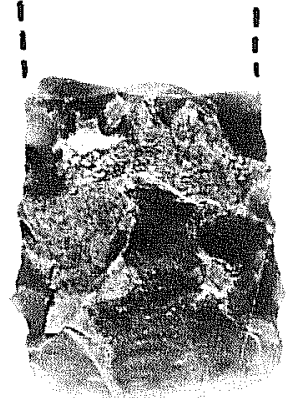

a

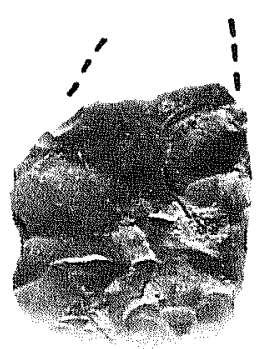

b

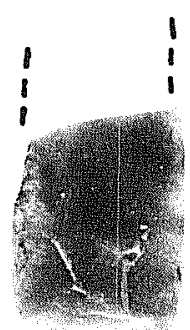

C

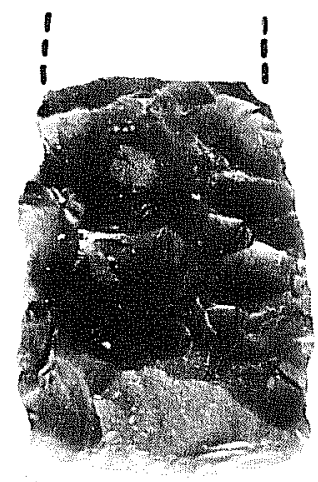

d

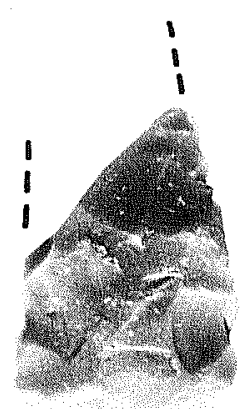

e

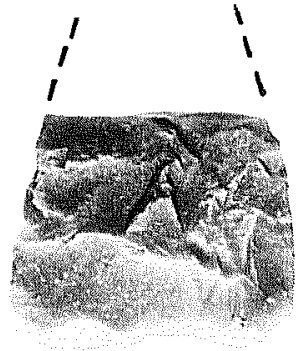

f

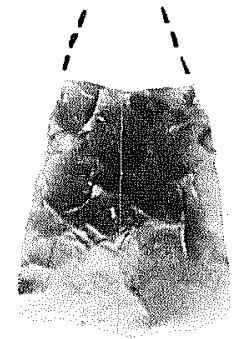

g

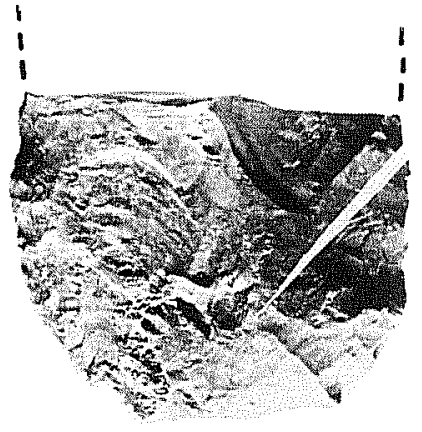

$\mathrm{n}$

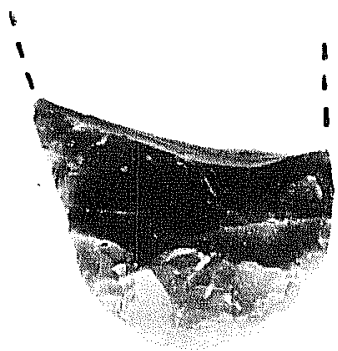

i
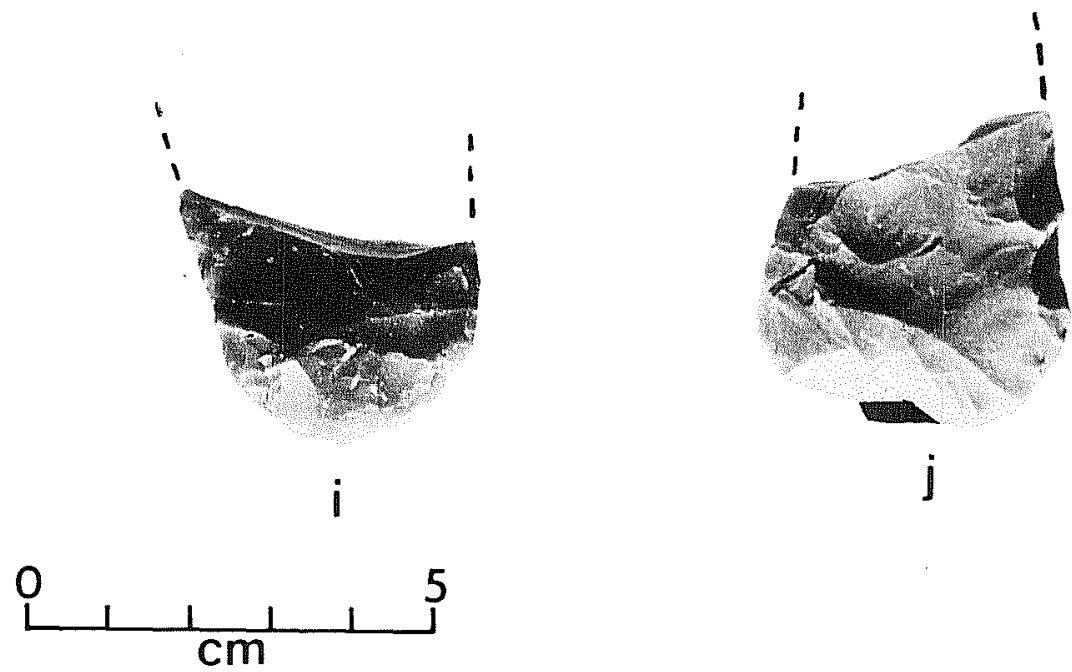

Figure 25. Lithic Artifacts from Camp Bullis: Preform Fragments. a,e, 41 BX 431; b, 41 CM 99; c, 41 BX 374; d, 41 BX 409; f,i, 41 BX 396S; g, 41 BX 400; $h, 41$ BX 390; $j, 41$ BX 377. 

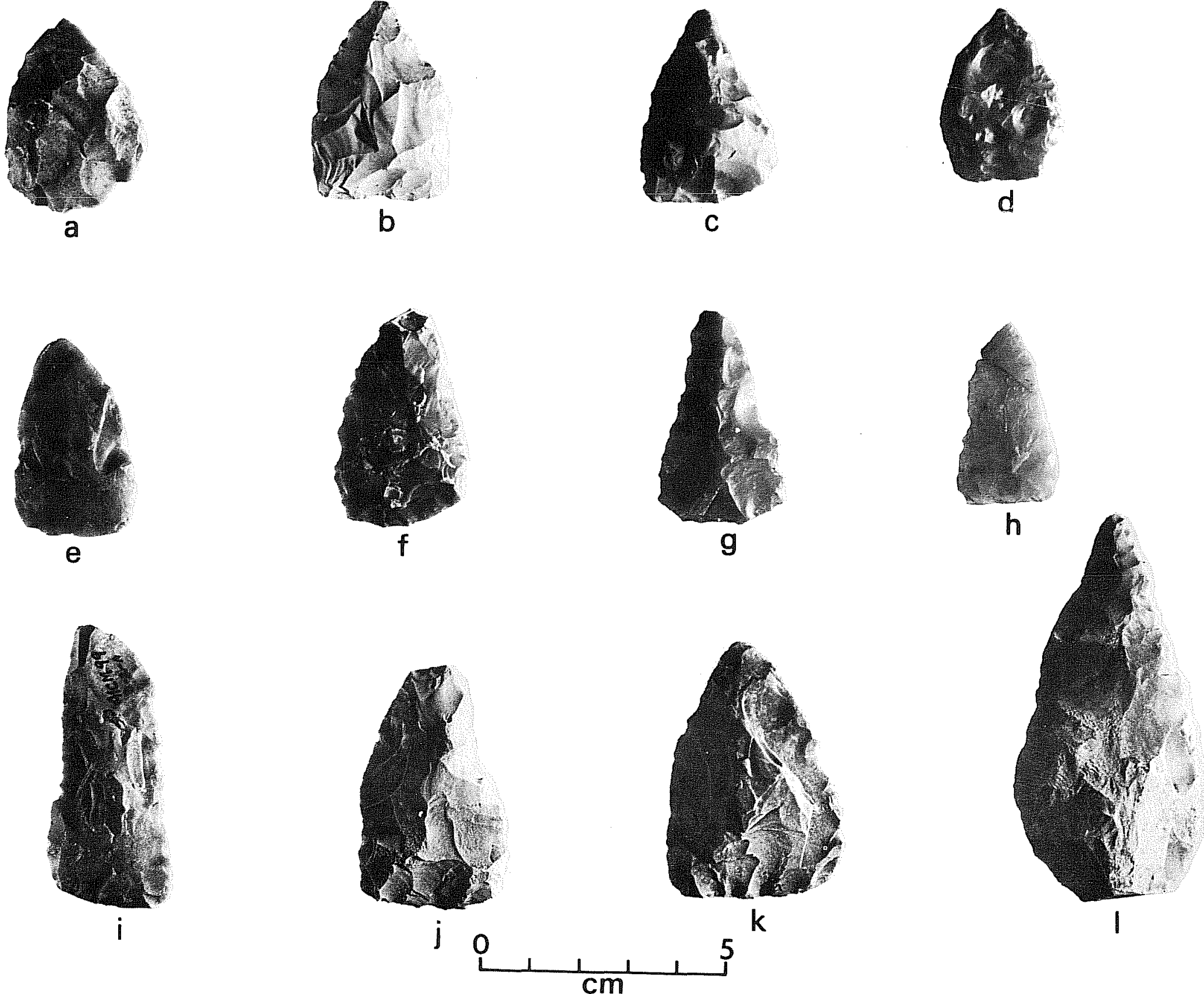

Figure 26. Lithic Artifacts from Camp Bullis: Triangular Preforms. $a, 41 \mathrm{BX} 381 ; \mathrm{b}, 41 \mathrm{BX} 402 ; \mathrm{c}, j, 41 \mathrm{BX}$ $431 ; d, 41$ BX 396; e,f,i, 41 CM 99; g, 41 BX 396; h, 41 BX 379; k, 41 BX 377; 1,41 BX 428. 
Beaked bifaces (items 89, 90; Fig. 11) have protrusions which may have functioned as awls, perforators, or gravers (Fig. 20,0,p; Fig. 27,a-e). Because of uncertainty as to exact function, this descriptive term is employed. None of the distinctive perforators with long, carefully chipped bits, often found in central Texas (cf. Weir 1976:Figs. 16,19), were recovered during the survey activities.

$\underline{\text { Unifaces }}$

Most unifacial implements are usually thought of as scrapers, although microwear analysis of unifacially trimmed specimens has sometimes indicated their use in other functions, e.g., as cutting or slicing tools (cf. Hester and Shafer 1975). Eleven potential groups were entered for coding. The terminology (Fig. 11) generally follows that of Weir (1976). Of the uniface groups, eight were recognized and are entered in Table 8 (items 100, 101, 104, 105, 106, 107, 109, 110, Fig. 11; also Figs. 28-30). These are uniface forms which would often be referred to, at the functional level, as "side scrapers" (items 100104; see Fig. 9, items 47, 49), "end/side scrapers" (items 105, 106; see item 54 in Fig. 9) and "gravers" (item 110; item 56 in Fig. 9; see also Weir 1976: Figs. 23,24). Item 109, "miscellaneous or irregular" unifaces, represents occasional specimens with steeply trimmed edges but which are not distinctively patterned; items 57-53 in Fig. 9 can be included within this category. Again, we should point out that our use of both descriptive and functional terms in III.A.6-9 reflects the aims of those particular chapters.

\section{$\underline{\text { Blades }}$}

Blades are specialized types of flakes, usually resulting from an intentional lithic process designed to produce long, parallel-edged flakes. In central Texas, there is evidence of blade industries especially in Late Prehistoric times (see Green and Hester 1973), but blade-like flakes ("flake-blades") are often produced as incidental byproducts in lithic industries based on flake production. Thus, in items 120-127 in Fig. 11, eight potential categories were set forth. Of these, only two are tabulated in this chapter, Glake-blades and notched flake-blades. Both categories consist of what we believe to be blade-like flakes produced in flake industries.

\section{Cores}

Fig. 11 lists six potential kinds of cores, including those used for flake production and evidericing particular kinds of platforms (items 130-133) or cores used either for blade (item 134) or flake-blade (item 135) production. This latter category is a difficult one for the lithic analyst and is essentially a grouping of those cores which show the removal of blades or blade-like flakes, but which cannot be assigned with any certainty to either a blade- or flake-oriented technology.

In Table 8, four kinds of cores are 1isted: bidirectional cores, multiplatform cores (see Shafer 1969), bifacial cores (see Hester 1975c), and flake-blade 


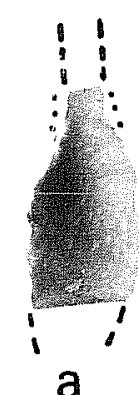

a

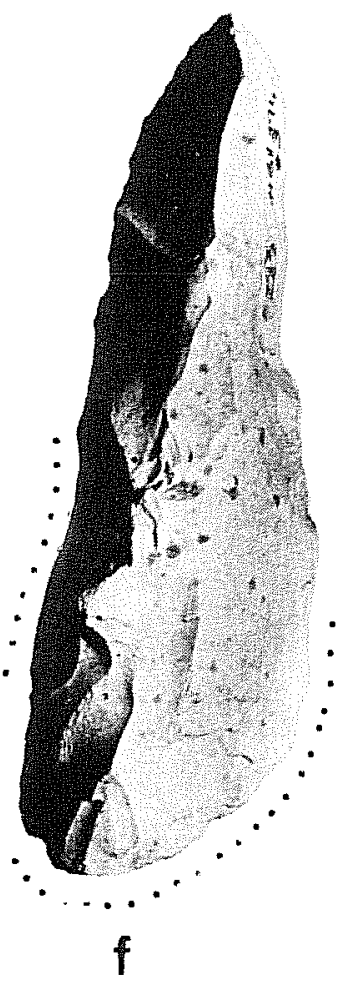

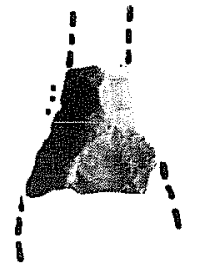

b

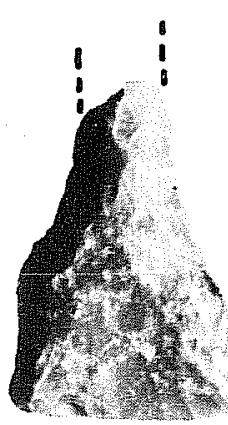

C

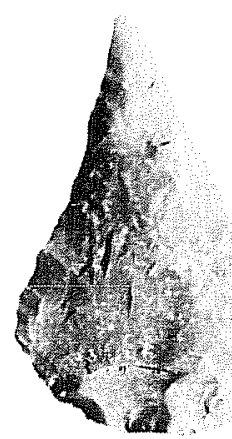

d
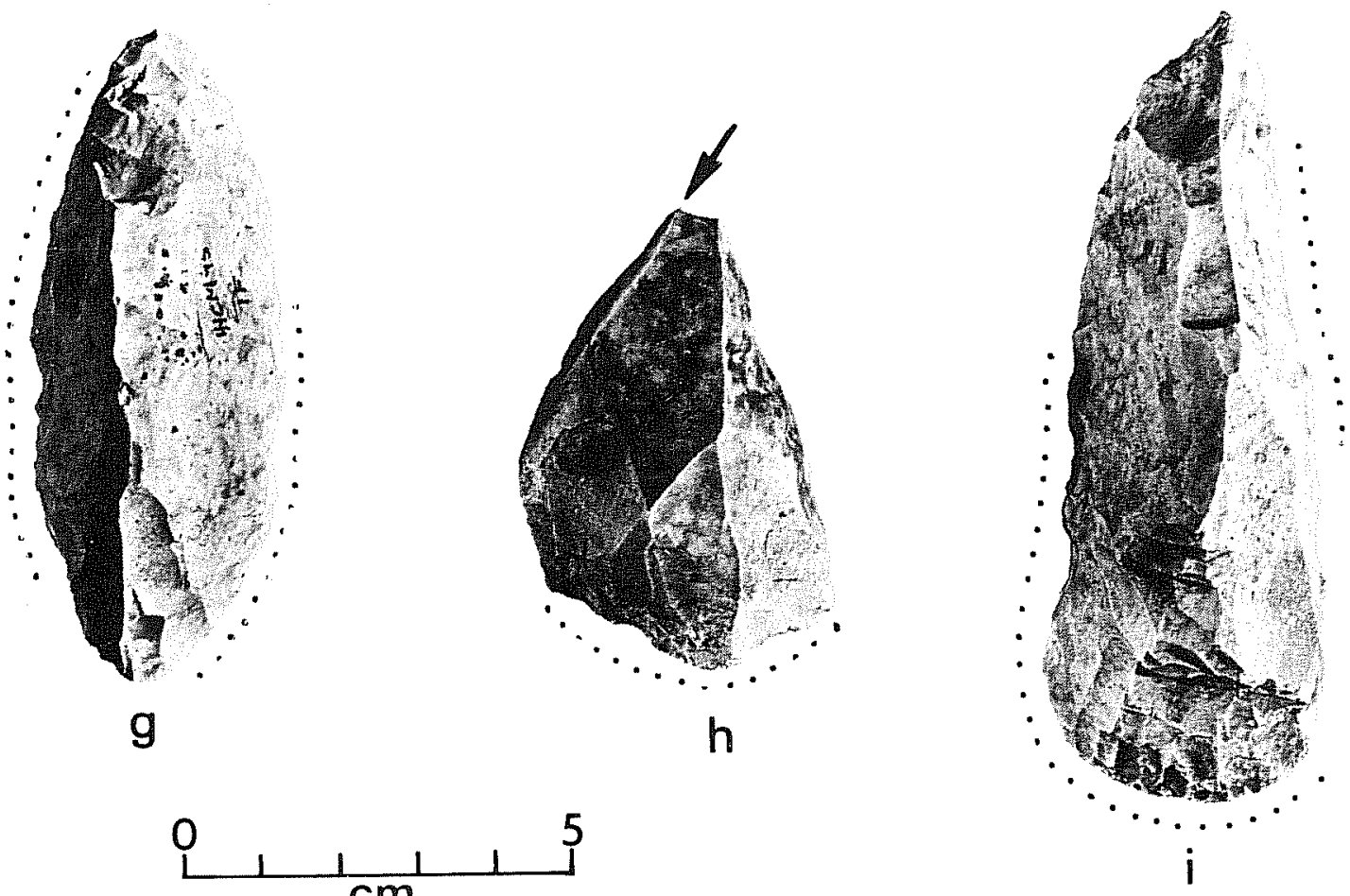

Figure 27. Lithic Artifacts from Camp Bullis, a-d, perforators (beaked bifaces; a, $c, 41 \mathrm{CM} 99 ; \mathrm{b}, 41 \mathrm{CM} 94$; $d, 41 \mathrm{BX} 377$ ); e, graver (beaked uniface), $41 \mathrm{CM} 94 ; \mathrm{f}-\mathrm{i}$, Guadalupe tools (f, $41 \mathrm{BX} 376 ; \mathrm{g}, 41 \mathrm{CM} 95 ; \mathrm{h}, 41 \mathrm{BX}$ 424; i, 41 BX 409. The Guadalupe tools are shown with the bit down. Dots indicate utilized or worn edges. 

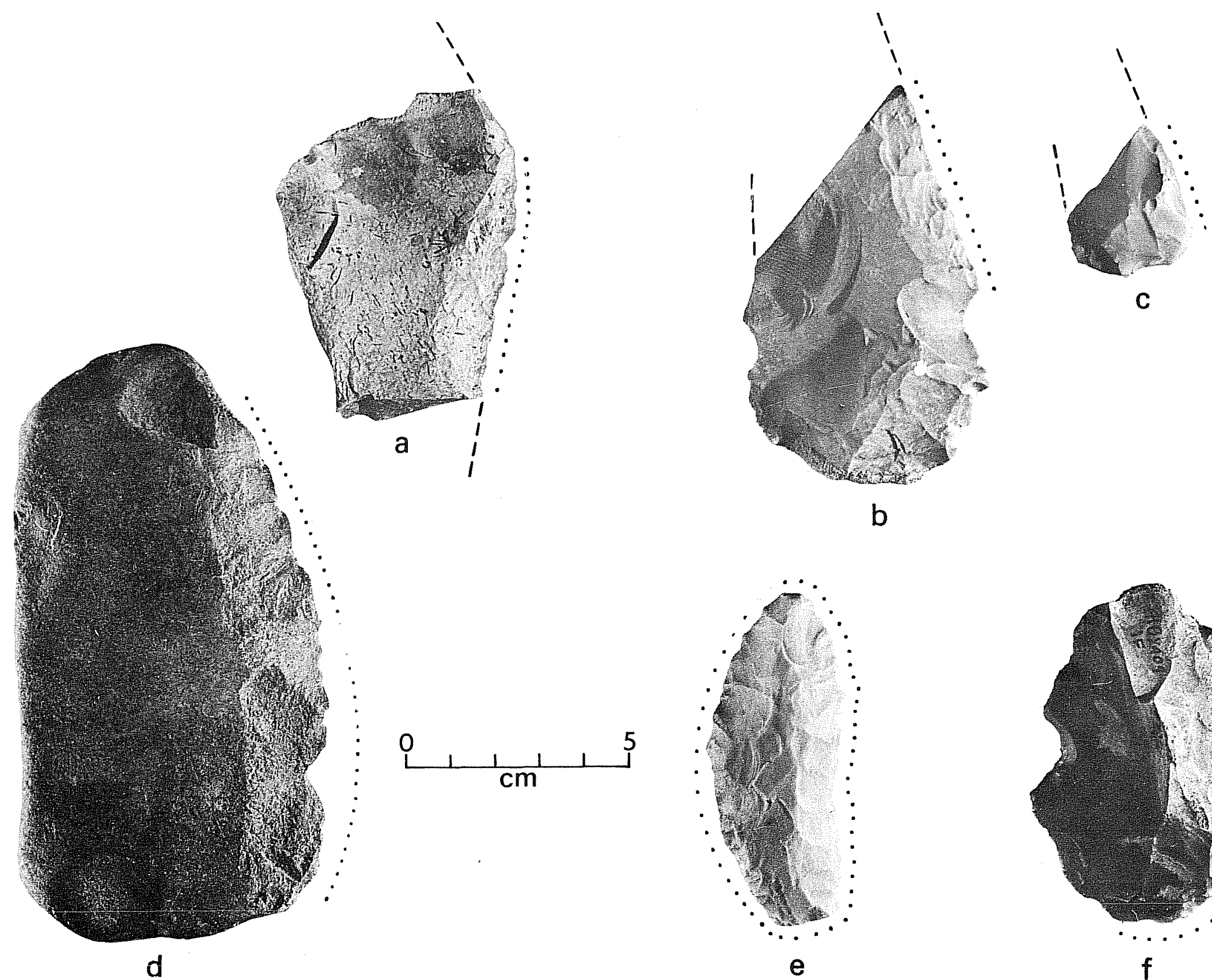

d
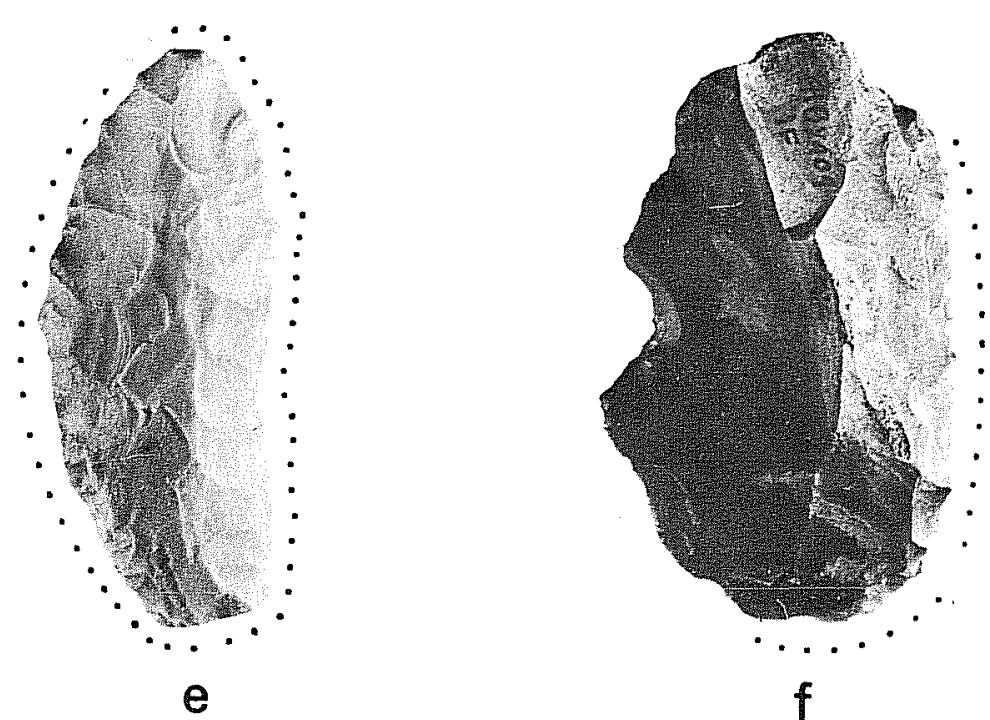

Figure 30. Lithic Artifacts from Camp Bullis: Unifaces (Scrapers). a, 41 BX 393; b, 41 BX 377; C, 41 BX 400; d, 41 BX 377; e, 41 BX 400; f, 41 BX 409. Dots indicate utilized or worn edges. 
cores, just discussed above. The cores recovered from the sites listed in Table 8 and those found at other sites not tabulated here, all reflect a flake production technology during all cultural periods at Camp Bullis (Figs. 31; $32, a, b)$. Flakes were manufactured for conversion into unifaces and bifaces and were also used for casual cutting and scraping tasks (see items 160-162 in Fig. 11). Of course, many flakes ended up as byproducts, or debitage.

\section{Other Tools}

In the chipped stone analysis, three additional categories can be found listed in Fig. 11. Burins (none of which were recognized at Camp Bullis), Clear Fork and Guadalupe Tools, and Flake Tools. Only the Guadalupe tool form and the flake tool forms were found at Camp Bullis. The Guadalupe tool (or "adze" or "gouge" as it is sometimes called) is a distinctive bifacial artifact, trianguloid in cross-section, with an oblique "bit" or presumed working edge (Fig. $27, f-i)$. The function of these tools remains unknown, but their chronological affiliations seem to lie with the Pre-Archaic (Hester and Kohnitz 1975). Flake tools used for casual tasks were of three kinds: those with convex retouch on one or more edges, those with concave retouch on one or more edges, and specimens on which retouch formed essentially straight lateral edges.

\section{Other Artifact Categories}

In Fig. 11, there are entries for Ground or Battered Stone artifacts, Bone artifacts, Shell artifacts and Miscellaneous specimens (e.g., worked glass from potential historic Indian components). Ground stone specimens were the only category to be recognized at Camp Bullis, and, in this case, only mano fragments (item 174) or pecked stone were represented (Fig. 32,C and Fig. 33). There was a bone artifact found in earlier non-scientific collecting activities at site 41 BX 36 (see Fig. 3), and a few bone tools or "modified bone" were found during the excavation of $41 \mathrm{BX} 36$ (see III.A.12).

\section{ARTIFACT DISTRIBUTIONS}

of the 63 prehistoric sites documented during the Camp Bullis survey, 33 were felt to have significant collections suitable for distributional analys is and cross tabulations. These include sites at which major testing or controlled surface collecting activities took place, while the remainder are sites for which chronological attribution could be established through the occurrence of diagnostic projectile points.

There were 368 artifacts analyzed from these 33 sites (41 BX $396 \mathrm{~N}$ and $396 \mathrm{~S}$ are combined), and their distributions are plotted in Table 8 . The four different categories of data for each site and artifact are arranged as follows: 
$41 \mathrm{BX} 36$

(Artifact category) Castroville

4 There are 4 Castroville points at site $41 \mathrm{BX} 36$.

$66.7 \quad 66.7$ percent of al1 Castroville points analyzed are at 41 BX 36.

2.72 .7 percent of al1 artifacts at 41 BX 36 are Castroville points.

$1.1 \quad 1.1$ percent of al1 artifacts analyzed are Castroville points at $41 \mathrm{BX} 36$.

Table 9 has been prepared to compare the relative percentages of dart and arrow points at these sites, and to compare these with the total chipped stone assemblage (mano fragment category is excluded. The data is arranged as in Table 8. 
TABLE 8. TABULATION OF ANALYZED ARTIFACTS BY CATEGORY AND DISTRIBUTION

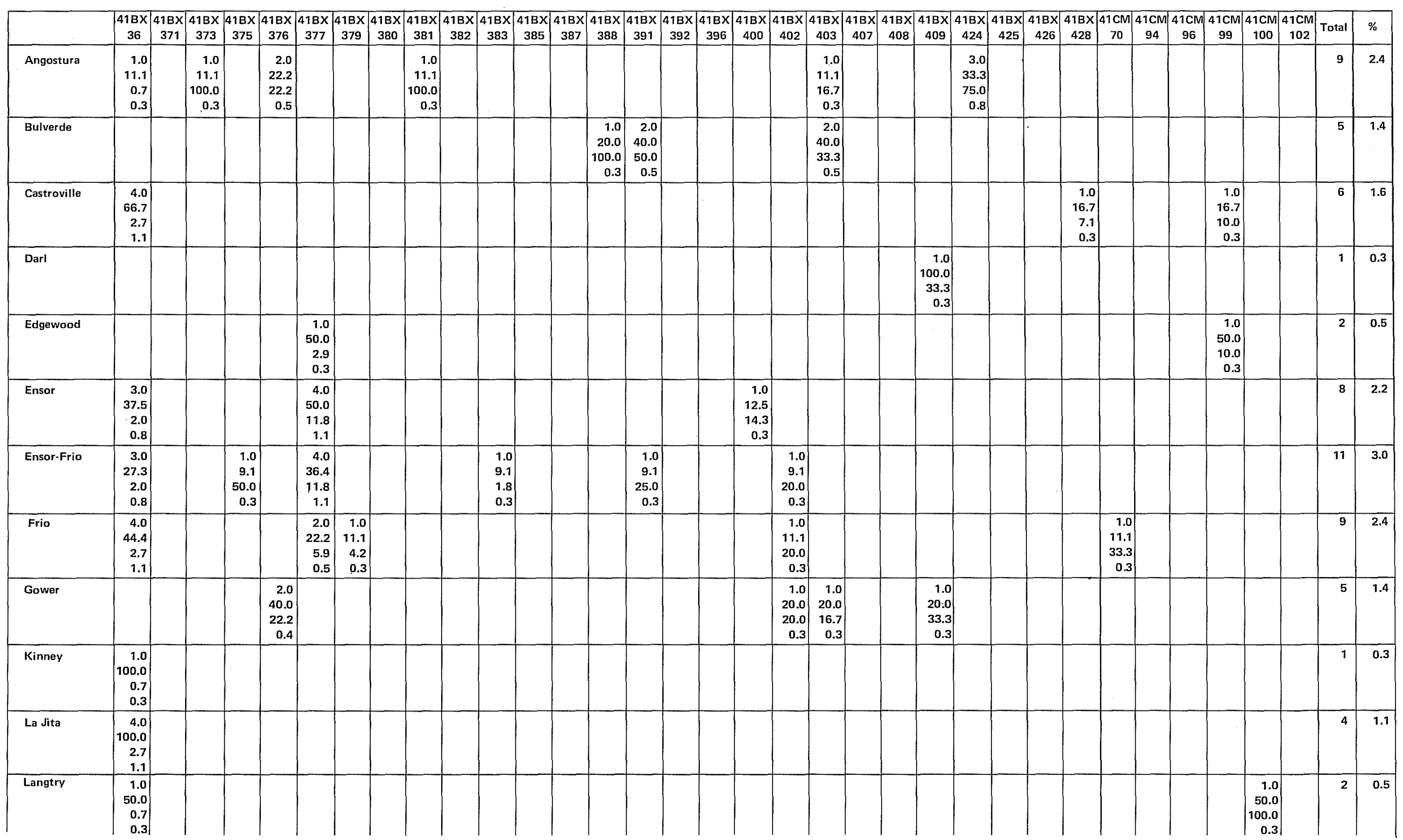




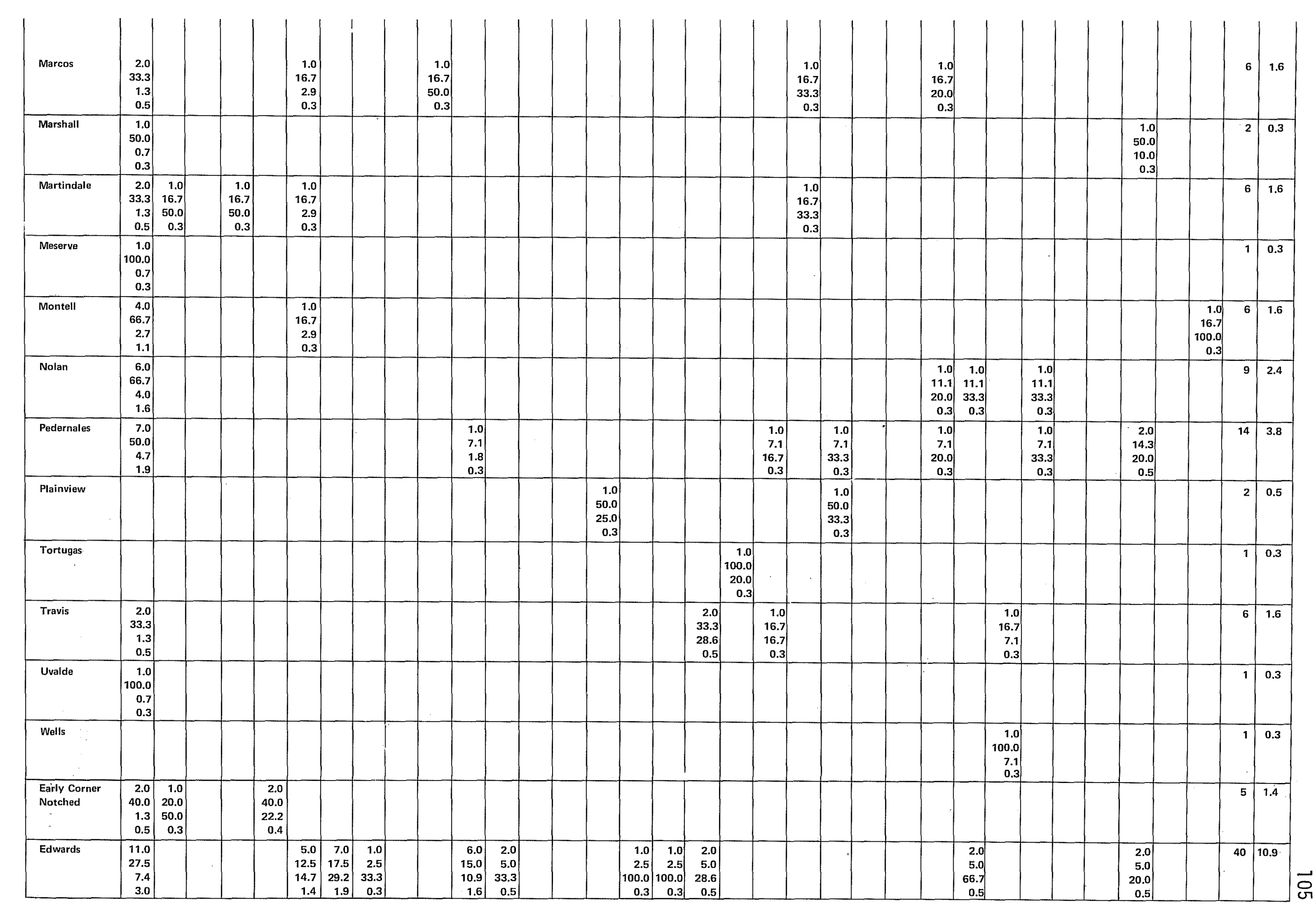


Table 8. (Continued)

\begin{tabular}{|c|c|c|c|c|c|c|c|c|c|c|c|c|c|c|c|c|c|c|c|c|c|c|c|c|c|c|c|c|c|c|c|c|c|c|c|}
\hline & $\begin{array}{c}41 \mathrm{BX} \\
36\end{array}$ & $\begin{array}{l}41 \mathrm{BX} \\
371\end{array}$ & \begin{tabular}{|c|}
$11 \mathrm{BX}$ \\
373 \\
\end{tabular} & \begin{tabular}{|c|}
$41 \mathrm{BX}$ \\
375 \\
\end{tabular} & \begin{tabular}{|r|}
$41 \mathrm{BX}$ \\
376
\end{tabular} & \begin{tabular}{|r|}
$41 \mathrm{BX}$ \\
377
\end{tabular} & \begin{tabular}{|r|r|}
$41 B X$ \\
379
\end{tabular} & \begin{tabular}{|r|}
$41 B X$ \\
380 \\
\end{tabular} & $\begin{array}{r}41 \mathrm{BX} \\
381\end{array}$ & $\begin{array}{r}41 \mathrm{BX} \\
382\end{array}$ & $\begin{array}{r}41 \mathrm{BX} \\
383\end{array}$ & $\begin{array}{c}41 \mathrm{BX} \\
385\end{array}$ & \begin{tabular}{|r|}
$41 \mathrm{BX}$ \\
387
\end{tabular} & \begin{tabular}{|r|}
$41 \mathrm{BX}$ \\
388
\end{tabular} & \begin{tabular}{|c|}
$41 \mathrm{BX}$ \\
391
\end{tabular} & $\begin{array}{r}41 \mathrm{BX} \\
392\end{array}$ & \begin{tabular}{|r|}
$418 x$ \\
396
\end{tabular} & $\begin{array}{r}41 \mathrm{BX} \\
400 \\
\end{array}$ & \begin{tabular}{r|}
$41 \mathrm{BX}$ \\
402
\end{tabular} & $\begin{array}{c}41 \mathrm{BX} \\
403\end{array}$ & $\begin{array}{r}418 x \\
407\end{array}$ & $\begin{array}{r}41 \mathrm{BX} \\
408\end{array}$ & \begin{tabular}{|c|}
$418 X$ \\
409
\end{tabular} & $\begin{array}{r}41 \mathrm{BX} \\
424\end{array}$ & $\begin{array}{r}41 \mathrm{BX} \\
425\end{array}$ & $\left|\begin{array}{r}41 \mathrm{BX} \\
426\end{array}\right|$ & $\begin{array}{r}41 \mathrm{BX} \\
428\end{array}$ & $\left|\begin{array}{c}41 \mathrm{~cm} \\
70\end{array}\right|$ & $\begin{array}{c}41 \mathrm{CM} \\
94\end{array}$ & $\begin{array}{c}41 \mathrm{~cm} \\
96\end{array}$ & $\begin{array}{c}41 \mathrm{CM} \\
99\end{array}$ & $\begin{array}{c}41 \mathrm{CM} \\
100\end{array}$ & $\begin{array}{r}41 \mathrm{CM} \\
102\end{array}$ & Total & $\%$ \\
\hline Fresno & $\begin{array}{r}1.0 \\
100.0 \\
0.7 \\
0.3 \\
\end{array}$ & & & & & & & & & & & & & & & & & & & & & & & & & & & & & & & & & 1 & 0.3 \\
\hline Perdiz & \begin{tabular}{|r|}
15.0 \\
75.0 \\
10.1 \\
4.1 \\
\end{tabular} & & & & & & & & & & \begin{tabular}{r|}
2.0 \\
10.0 \\
3.6 \\
0.5 \\
\end{tabular} & & & & & & & & & & & & & & \begin{tabular}{r|}
2.0 \\
10.0 \\
40.0 \\
0.5
\end{tabular} & & & & & & $\begin{array}{r}1.0 \\
5.0 \\
10.0 \\
0.3\end{array}$ & & & 20 & 5.4 \\
\hline Scallorn & \begin{tabular}{|r|}
5.0 \\
26.3 \\
3.4 \\
1.4 \\
\end{tabular} & & & & & \begin{tabular}{r|}
3.0 \\
15.8 \\
8.8 \\
0.8 \\
\end{tabular} & \begin{tabular}{|r|}
2.0 \\
10.5 \\
8.3 \\
0.5 \\
\end{tabular} & \begin{tabular}{|r|}
1.0 \\
5.3 \\
33.3 \\
0.3 \\
\end{tabular} & & & & \begin{tabular}{|r|}
4.0 \\
21.1 \\
66.7 \\
1.1 \\
\end{tabular} & & & & & & $\begin{array}{r}1.0 \\
5.3 \\
14.3 \\
0.3 \\
\end{array}$ & & & & & & & & & & & \begin{tabular}{|r|}
1.0 \\
5.3 \\
33.3 \\
0.3 \\
\end{tabular} & & \begin{tabular}{r|}
2.0 \\
10.5 \\
20.0 \\
0.5 \\
\end{tabular} & & & 19 & 5.2 \\
\hline $\begin{array}{l}\text { Early Side } \\
\text { Notched }\end{array}$ & & & & & $\begin{array}{r}1.0 \\
100.0 \\
11.1 \\
0.3\end{array}$ & & & & & & & & & 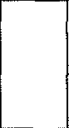 & & & & & & & & . & & . & & & & & & & & & & 1 & 0.3 \\
\hline Unfinished & \begin{tabular}{|r|}
3.0 \\
20.0 \\
2.0 \\
0.8 \\
\end{tabular} & & & & & \begin{tabular}{l|}
1.0 \\
6.7 \\
2.9 \\
0.3 \\
\end{tabular} & \begin{tabular}{|r|}
3.0 \\
20.0 \\
12.5 \\
0.8 \\
\end{tabular} & & & & $\begin{array}{r}3.0 \\
20.0 \\
5.5 \\
0.8 \\
\end{array}$ & & \begin{tabular}{|r|}
1.0 \\
6.7 \\
100.0 \\
0.3 \\
\end{tabular} & & & & & \begin{tabular}{r|}
1.0 \\
6.7 \\
14.3 \\
0.3 \\
\end{tabular} & \begin{tabular}{|r|}
1.0 \\
6.7 \\
20.0 \\
0.3 \\
\end{tabular} & & & \begin{tabular}{|r|}
1.0 \\
6.7 \\
33.3 \\
0.3 \\
\end{tabular} & & & & & & & \begin{tabular}{|r|}
1.0 \\
6.7 \\
33.3 \\
0.3 \\
\end{tabular} & & & & & 15 & 4.1 \\
\hline Unknown & \begin{tabular}{|r|}
4.0 \\
28.6 \\
2.7 \\
1.1 \\
\end{tabular} & & & & \begin{tabular}{|r|}
1.0 \\
7.1 \\
11.1 \\
0.3 \\
\end{tabular} & \begin{tabular}{|r|}
2.0 \\
14.3 \\
5.9 \\
0.5 \\
\end{tabular} & \begin{tabular}{l|}
1.0 \\
7.1 \\
4.2 \\
0.3 \\
\end{tabular} & \begin{tabular}{|r|}
1.0 \\
7.1 \\
33.3 \\
0.3 \\
\end{tabular} & & $\begin{array}{r}1.0 \\
7.1 \\
50.0 \\
0.3 \\
\end{array}$ & & & & & & & & & & & \begin{tabular}{|r|}
1.0 \\
7.1 \\
33.3 \\
0.3 \\
\end{tabular} & & & $\begin{array}{r}1.0 \\
7.1 \\
25.0 \\
0.3 \\
\end{array}$ & & & & & $\begin{array}{r}1.0 \\
7.1 \\
33.3 \\
0.3 \\
\end{array}$ & \begin{tabular}{|r|}
1.0 \\
7.1 \\
100.0 \\
0.3 \\
\end{tabular} & & & & 14 & 3.8 \\
\hline Complete Biface & \begin{tabular}{|r|}
22.0 \\
52.4 \\
14.8 \\
6.0 \\
\end{tabular} & & & & & \begin{tabular}{r|r}
5.0 \\
11.9 \\
14.7 \\
1.4 \\
\end{tabular} & \begin{tabular}{|r|}
5.0 \\
11.9 \\
20.8 \\
1.4 \\
\end{tabular} & & & & \begin{tabular}{r|}
8.0 \\
19.0 \\
14.5 \\
2.2 \\
\end{tabular} & & & & & & & & & & & & & & & & \begin{tabular}{r|}
2.0 \\
4.8 \\
14.3 \\
0.5 \\
\end{tabular} & & & & & & & 42 & 11.4 \\
\hline Beaked Biface & \begin{tabular}{|r|}
1.0 \\
25.0 \\
0.7 \\
0.3 \\
\end{tabular} & & & & & \begin{tabular}{r|}
1.0 \\
25.0 \\
2.9 \\
0.3 \\
\end{tabular} & & & & & $\begin{array}{r}2.0 \\
50.0 \\
3.6 \\
0.5 \\
\end{array}$ & & & & & & & & & & & & & & & & & & & & & & & 4 & 1.1 \\
\hline $\begin{array}{l}\text { Convex } \\
\text { Unilaterally } \\
\text { Trimmed } \\
\text { Uniface } \\
\end{array}$ & & & & & & $\begin{array}{r}1.0 \\
33.3 \\
2.9 \\
0.3 \\
\end{array}$ & & & & & $\begin{array}{r}2.0 \\
66.7 \\
3.6 \\
0.5 \\
\end{array}$ & & & & & & & & & & & & & & & & & & & & & & & 3 & 0.8 \\
\hline $\begin{array}{l}\text { Concave } \\
\text { Unilaterally } \\
\text { Trimmed } \\
\text { Uniface }\end{array}$ & & & & & & & & & & & $\begin{array}{r}1.0 \\
100.0 \\
1.8 \\
0.3\end{array}$ & & & & & & & & & & & & & & & & & & & & & & & 1 & 0.3 \\
\hline $\begin{array}{l}\text { Bilaterally } \\
\text { Trimmed } \\
\text { Uniface }\end{array}$ & \begin{tabular}{|r|}
1.0 \\
50.0 \\
0.7 \\
0.3 \\
\end{tabular} & & & & & & & & & & \begin{tabular}{r|}
1.0 \\
50.0 \\
1.8 \\
0.3 \\
\end{tabular} & & & & & & & & & & & & & & & & & & & & & & & 2 & 0.5 \\
\hline $\begin{array}{l}\text { Unilaterally and } \\
\text { End Trimmed } \\
\text { Uniface }\end{array}$ & \begin{tabular}{r|}
3.0 \\
60.0 \\
2.0 \\
0.8 \\
\end{tabular} & & & & & & & & & & \begin{tabular}{r|}
1.0 \\
20.0 \\
1.8 \\
0.3 \\
\end{tabular} & & & & & & & & & & & & & & & & $\begin{array}{r}1.0 \\
20.0 \\
7.1 \\
0.3 \\
\end{array}$ & & & & & & & 5 & 1.4 \\
\hline $\begin{array}{l}\text { Bilaterally and } \\
\text { End Trimmed } \\
\text { Uniface }\end{array}$ & $\begin{array}{r}1.0 \\
33.3 \\
0.7 \\
0.3\end{array}$ & & & & & & & & & & $\begin{array}{r}1.0 \\
33.3 \\
1.8 \\
0.3\end{array}$ & & & & & & & & & & & & & & & & \begin{tabular}{r|r|}
1.0 \\
33.3 \\
7.1 \\
00.3
\end{tabular} & & & & & & & 3 & 0.8 \\
\hline
\end{tabular}




\begin{tabular}{|c|c|c|c|c|c|c|c|c|c|c|c|c|c|c|c|c|c|c|c|c|c|c|c|c|c|c|c|c|c|c|c|c|c|c|c|}
\hline $\begin{array}{l}\text { End Trimmed } \\
\text { Uniface }\end{array}$ & & & & & & \begin{tabular}{|r|}
1.0 \\
20.0 \\
2.9 \\
0.3 \\
\end{tabular} & & & & & $\begin{array}{r}2.0 \\
40.0 \\
3.6 \\
0.5 \\
\end{array}$ & & & & & & & & & & & & & & & & $\begin{array}{r}2.0 \\
40.0 \\
14.3 \\
0.5\end{array}$ & & & & & & & 5 & 1.4 \\
\hline $\begin{array}{l}\text { Miscellaneous } \\
\text { Uniface }\end{array}$ & \begin{tabular}{|r|}
6.0 \\
85.7 \\
4.0 \\
1.6 \\
\end{tabular} & & & & & & & & & & $\begin{array}{r}1.0 \\
14.3 \\
1.8 \\
0.3 \\
\end{array}$ & & & & & & & & & & & & & & & & & & & 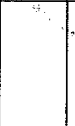 & 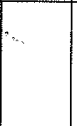 & & & 7 & 1.9 \\
\hline $\begin{array}{l}\text { Beaked } \\
\text { Uniface }\end{array}$ & \begin{tabular}{|r|}
2.0 \\
66.7 \\
1.3 \\
0.5 \\
\end{tabular} & & & & & & & & & & $\begin{array}{r}1.0 \\
33.3 \\
1.8 \\
0.3 \\
\end{array}$ & & & & & & & & & & & & & & & & & & & & & & & 3 & 0.8 \\
\hline Flake-Blade & $\begin{array}{r}1.0 \\
50.0 \\
0.7 \\
0.3 \\
\end{array}$ & & & & & & & & & & $\begin{array}{r}1.0 \\
50.0 \\
1.8 \\
0.3 \\
\end{array}$ & & & & & & & & & & & & & & & & 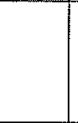 & & & & & & & 2 & 0.5 \\
\hline $\begin{array}{l}\text { Notched } \\
\text { Flake-Blade }\end{array}$ & $\begin{array}{r}1.0 \\
100.0 \\
0.7 \\
0.3\end{array}$ & & & & & & & & & & & & & & & & & & & & & & & & & & & & & & & & & 1 & 0.3 \\
\hline $\begin{array}{l}\text { Bidirectional } \\
\text { Core }\end{array}$ & \begin{tabular}{|r}
1.0 \\
100.0 \\
0.7 \\
0.3 \\
\end{tabular} & & & & & & & & & & & & & & & & & & & & & & & & & & & & & & & & & 1 & 0.3 \\
\hline $\begin{array}{l}\text { Multiplatform } \\
\text { Core }\end{array}$ & $\begin{array}{r}6.0 \\
54.5 \\
4.0 \\
1.6 \\
\end{array}$ & & & & & $\begin{array}{l}1.0 \\
9.1 \\
4.2 \\
0.3 \\
\end{array}$ & $\begin{array}{l}1.0 \\
9.1 \\
4.2 \\
0.3 \\
\end{array}$ & & & & $\begin{array}{r}3.0 \\
27.3 \\
5.5 \\
0.8 \\
\end{array}$ & & & & & & & & & & & & & & & & & & & & & & & 11 & 3.0 \\
\hline $\begin{array}{l}\text { Bifacial } \\
\text { Core }\end{array}$ & $\begin{array}{r}3.0 \\
60.0 \\
2.0 \\
0.8 \\
\end{array}$ & & & & & & $\begin{array}{r}1.0 \\
20.0 \\
4.2 \\
0.3 \\
\end{array}$ & & & & $\begin{array}{r}1.0 \\
20.0 \\
1.8 \\
0.3 \\
\end{array}$ & & & & & & & & & & & & & & & & & & & & & & & 5 & 1.4 \\
\hline $\begin{array}{l}\text { Flake-Blade } \\
\text { Core }\end{array}$ & & & & & & & & & & & $\begin{array}{r}2.0 \\
100.0 \\
3.6 \\
0.5 \\
\end{array}$ & & & & & & & & & & & & & & & & & & & & & & & 2 & 0.5 \\
\hline $\begin{array}{l}\text { Guadalupe } \\
\text { Tool }\end{array}$ & & & & & $\begin{array}{r}1.0 \\
50.0 \\
11.1 \\
0.3 \\
\end{array}$ & & & & & & & & & & & & & & & & & & $\begin{array}{r}1.0 \\
50.0 \\
33.3 \\
0.3 \\
\end{array}$ & & & & & & & & & & & 2 & 0.5 \\
\hline $\begin{array}{l}\text { Convex } \\
\text { Retouched } \\
\text { Flake }\end{array}$ & $\begin{array}{l}1.0 \\
4.8 \\
0.7 \\
0.3 \\
\end{array}$ & & & & & & $\begin{array}{r}3.0 \\
14.3 \\
12.5 \\
0.8 \\
\end{array}$ & & & & $\begin{array}{r}13.0 \\
61.9 \\
23.6 \\
3.5 \\
\end{array}$ & & & & & & & & & & & & & & & & $\begin{array}{r}4.0 \\
19.0 \\
28.6 \\
1.1 \\
\end{array}$ & & & & & & & 21 & 5.7 \\
\hline $\begin{array}{l}\text { Concave } \\
\text { Retouched } \\
\text { Flake }\end{array}$ & $\begin{array}{r}5.0 \\
83.3 \\
3.4 \\
1.4 \\
\end{array}$ & & & & & & & & & & \begin{tabular}{|r|}
1.0 \\
16.7 \\
1.8 \\
0.3 \\
\end{tabular} & & & & & & & & & & & & & & & & & & & & & & & 6 & 1.6 \\
\hline $\begin{array}{l}\text { Straight } \\
\text { Retouched } \\
\text { Flake }\end{array}$ & $\begin{array}{r}2.0 \\
50.0 \\
1.3 \\
0.5 \\
\end{array}$ & & & & & & & & & & \begin{tabular}{|r|}
1.0 \\
25.0 \\
1.8 \\
0.3 \\
\end{tabular} & & & & & & & & & & & & & & & & $\begin{array}{r}1.0 \\
25.0 \\
7.1 \\
0.3 \\
\end{array}$ & & & & & & & 4 & 1.1 \\
\hline $\begin{array}{l}\text { Mano } \\
\text { Fragment }\end{array}$ & $\begin{array}{r}5.0 \\
100.0 \\
3.4 \\
1.4\end{array}$ & & & & & & & & & & & & & & & & & & & & & & & & & & & & & & & & & 5 & 1.4 \\
\hline Total & 149.0 & 2.0 & 1.0 & 2.0 & 9.0 & 34.0 & 24.0 & 3.0 & 1.0 & 2.0 & 55.0 & 6.0 & 1.0 & 1.0 & 4.0 & 1.0 & 1.0 & 7.0 & 5.0 & 6.0 & 3.0 & 3.0 & 3.0 & 4.0 & 5.0 & 3.0 & 14.0 & 3.0 & 3.0 & 1.0 & 10.0 & 1.0 & 1.0 & 368 & \\
\hline Percentage & 40.5 & 0.5 & 0.3 & 0.5 & 2.4 & 9.2 & 6.5 & 0.8 & 0.3 & 0.5 & 14.9 & 1.6 & 0.3 & 0.3 & 1.1 & 0.3 & 0.3 & 1.9 & 1.4 & 1.6 & 0.8 & 0.8 & 0.8 & 1.1 & 1.4 & 0.8 & 3.8 & 0.8 & 0.8 & 0.3 & 2.7 & 0.3 & 0.3 & & 100.0 \\
\hline
\end{tabular}


TABLE 9. TABULATION OF ALL ANALYZED LITHICS

Site

41 BX 36

Dart Points

$$
\begin{array}{r}
49 \\
39.5 \\
34.0 \\
13.5 \\
2 \\
1.6 \\
100.0 \\
0.6
\end{array}
$$

$41 \mathrm{BX} 371$

41 BX 373

$$
\begin{array}{r}
1 \\
0.8 \\
100.0 \\
0.3
\end{array}
$$

41 BX 375

$$
\begin{array}{r}
2 \\
1.6 \\
100.0 \\
0.6
\end{array}
$$

41 BX 376

$$
\begin{array}{r}
7 \\
5.6 \\
77.8 \\
1.9
\end{array}
$$

41 BX 377

$$
\begin{array}{r}
14 \\
11.3 \\
41.2 \\
3.9
\end{array}
$$

41 BX 379

$$
\begin{array}{r}
1 \\
0.8 \\
4.2 \\
0.3
\end{array}
$$

$41 \mathrm{BX} 380$

$$
\begin{array}{r}
2 \\
2.5 \\
66.7 \\
0.6
\end{array}
$$

22.2

8.8
TOTAL

144

39.6

43.8

17.4

PERCENTAGE

39.6

2

0.6

1

0.3

2

0.6

2
1.3

9

2.5

22.2

0.6

$\begin{array}{rr}8 & 12 \\ 10.0 & 7.5 \\ 23.5 & 35.3 \\ 2.2 & 3.3\end{array}$

34.

9.4

35.3

14

8.8

58.3

3.9

41 BX 381

$$
\begin{array}{r}
1 \\
0.8 \\
100.0 \\
0.3
\end{array}
$$

$$
\begin{array}{r}
1 \\
0.6 \\
33.3 \\
0.3
\end{array}
$$

24

$$
6.6
$$

3

0.8

1

0.3

$41 \mathrm{BX} 382$

$$
\begin{array}{r}
1 \\
0.8 \\
50.0
\end{array}
$$$$
\begin{array}{r}
1 \\
0.6
\end{array}
$$

2

0.6 
TABLE 9. (continued)

Site

41 BX 383

$$
\begin{array}{r}
2 \\
1.6 \\
3.6 \\
0.6
\end{array}
$$

41 BX 385

41 BX 387

41 BX 388

$$
\begin{array}{r}
1 \\
0.8 \\
100.0 \\
0.3
\end{array}
$$

41 BX 391

$$
\begin{array}{r}
4 \\
3.2 \\
100.0 \\
1.1
\end{array}
$$

41 BX 392

$$
\begin{array}{r}
6 \\
7.5 \\
100.0 \\
1.7
\end{array}
$$

$$
\text { Arrow Points }
$$$$
\begin{array}{r}
8 \\
10.0 \\
14.5 \\
2.2
\end{array}
$$

45

28.3

81.8

12.4
TOTAL

55

15.0

6

1.7

1
0.6
100.0
0.3

1

0.3

PERCENTAGE 
TABLE 9. (continued)

Site

$41 \mathrm{BX} 407$

$$
\begin{array}{r}
2 \\
1.6 \\
66.7 \\
0.6
\end{array}
$$

$41 \mathrm{BX} 408$

$$
\begin{array}{r}
2 \\
1.6 \\
66.7 \\
0.6
\end{array}
$$

$41 \mathrm{BX} 409$

$$
\begin{array}{r}
2 \\
1.6 \\
66.7 \\
0.6
\end{array}
$$

41 BX 424

$$
\begin{array}{r}
3 \\
2.4 \\
75.0 \\
0.8
\end{array}
$$

41 BX 425

$\begin{array}{rr}3 & 2 \\ 2.4 & 2.5 \\ 60.0 & 40.0 \\ 0.8 & 0.6\end{array}$

41 BX 426

$\begin{array}{rr}1 & 2 \\ 0.8 & 2.5 \\ 33.3 & 66.7 \\ 0.3 & 0.6\end{array}$

47 BX 428

$$
\begin{array}{r}
3 \\
2.4 \\
21.4 \\
0.8
\end{array}
$$

47 CM 70

$$
\begin{array}{r}
3 \\
2.4 \\
100.0 \\
0.8
\end{array}
$$

66.7

0.6
TOTAL PERCENTAGE

0.8

33.3

0.3

1
0.6
33.3
0.3

1
0.6
33.3
0.3

1
0.6
25.0
0.3

4

1.1

3

0.8

3

0.8

5

1.4

3

0.8

$\begin{array}{rlr}11 & 14 & 3.8 \\ 6.9 & & \\ 78.6 & & \\ 3.0 & & \end{array}$

3

0.8

$$
\begin{array}{r}
1 \\
1.3 \\
33.3 \\
0.3
\end{array}
$$

2
1.3
66.7
0.6

$$
\begin{array}{r}
1 \\
0.6 \\
100.0 \\
0.3
\end{array}
$$


TABLE 9. (continued)

Site

41 CM 99 Dart Points Arrow Points Other Lithics TOTAL

PERCENTAGE

$\begin{array}{rr}5 & 5 \\ 4.0 & 6.3 \\ 50.0 & 50.0 \\ 1.4 & 1.4\end{array}$

41 CM 100

$$
\begin{array}{r}
1 \\
0.8 \\
100.0 \\
0.3
\end{array}
$$

41 CM 102

$$
\begin{array}{r}
1 \\
0.8 \\
100.0 \\
0.3
\end{array}
$$

TOTAL

124

34.2
6.3

1.4
2.7

1

0.3

1

0.3

159

363

43.8
100.0 

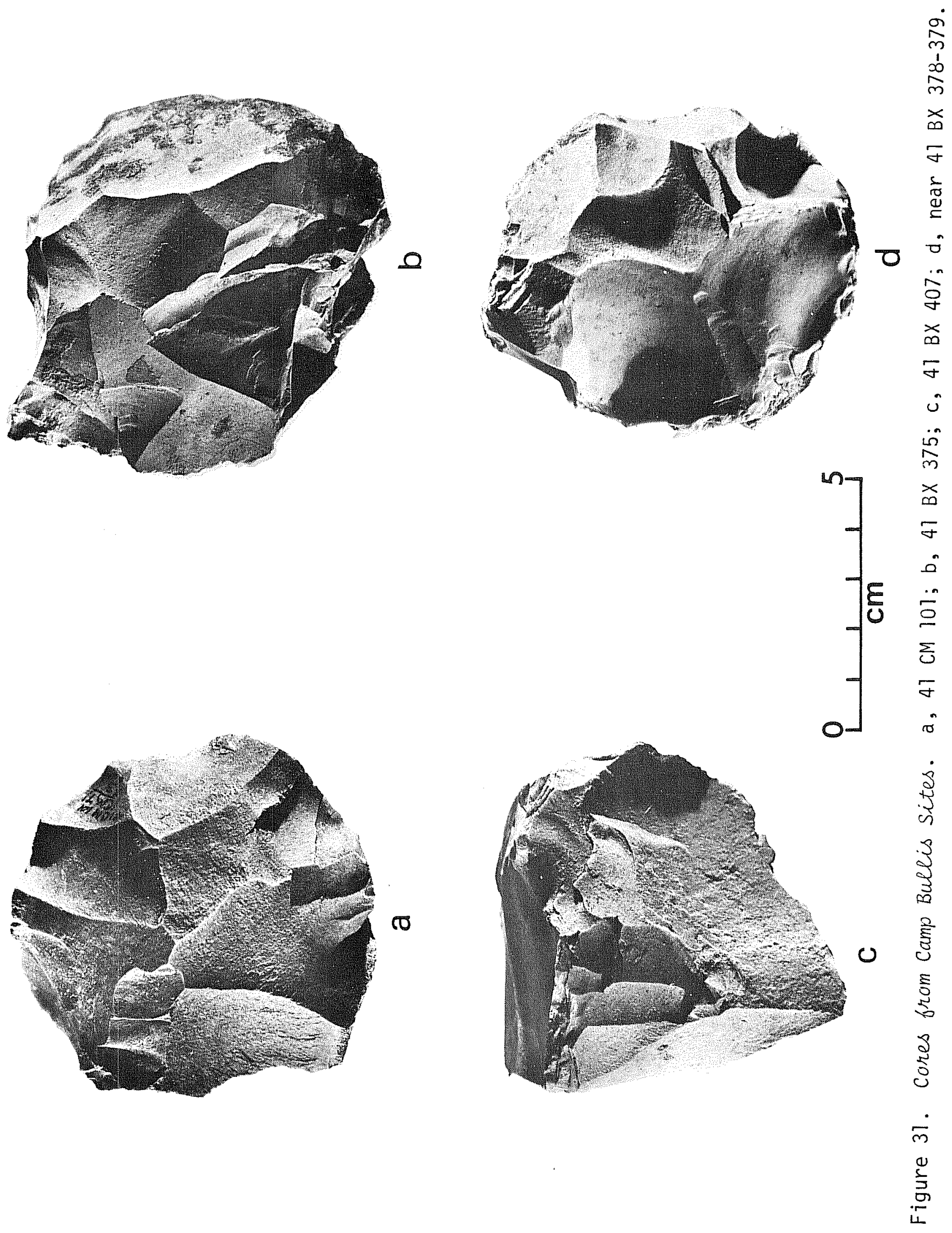

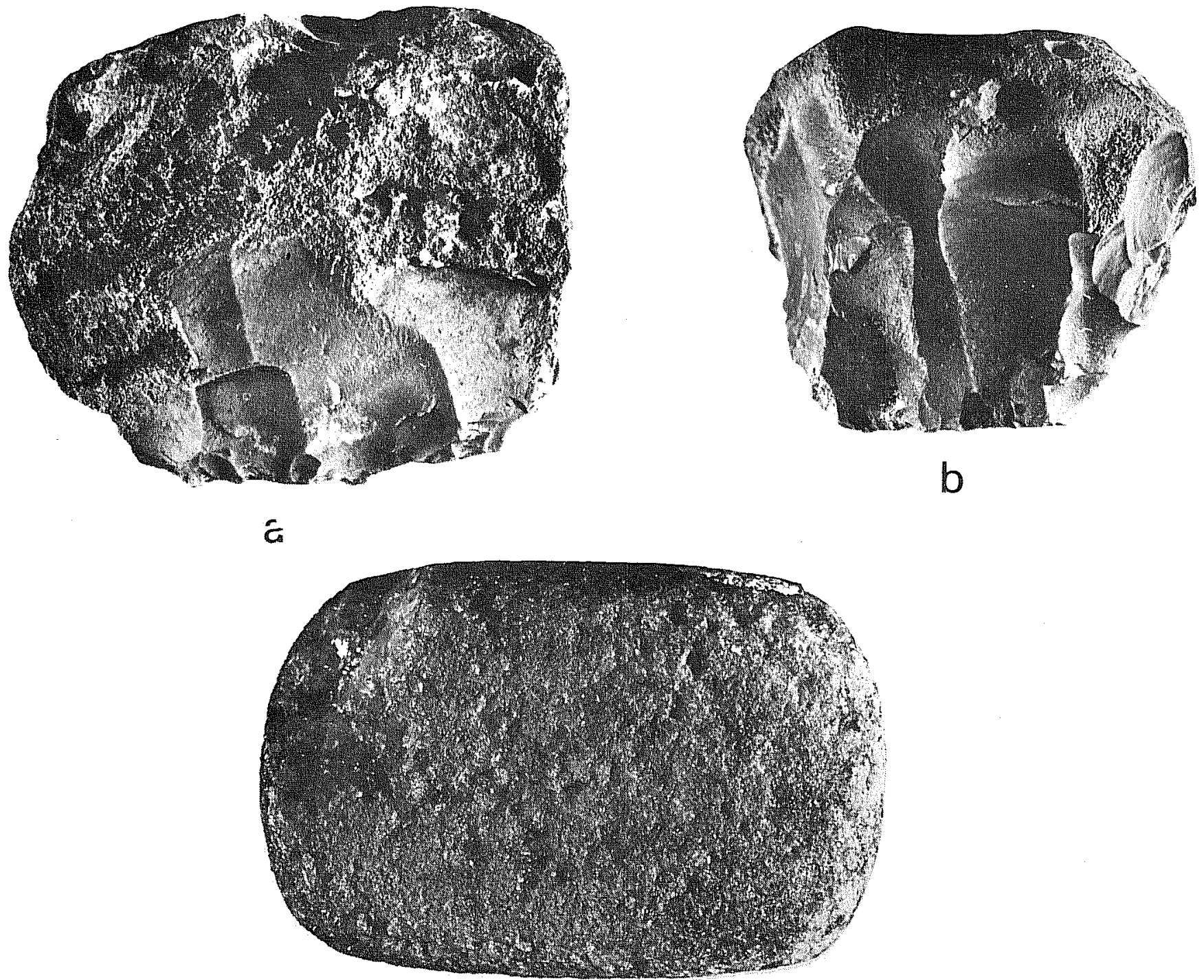

C

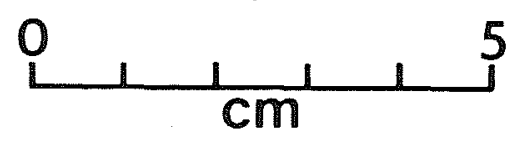

Figure 32. Lithic Artifacts from Camp Bullis. $a, b$, cores ( $a, 41 \mathrm{BX} 379 ; b, 41 \mathrm{BX}$ $374)$; c, ground stone artifact (41 BX 402). 


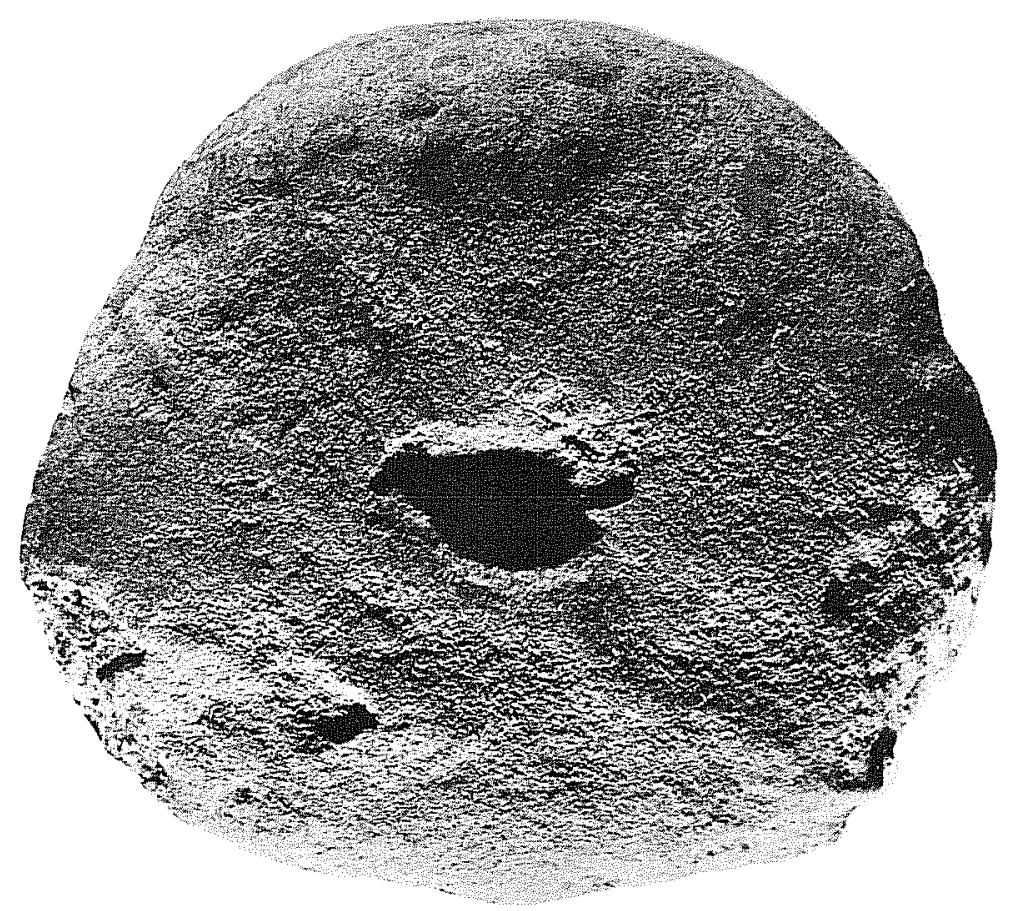

a

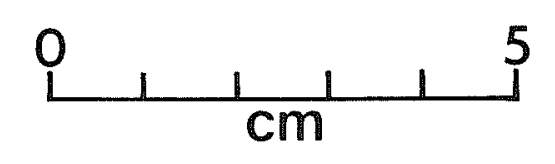

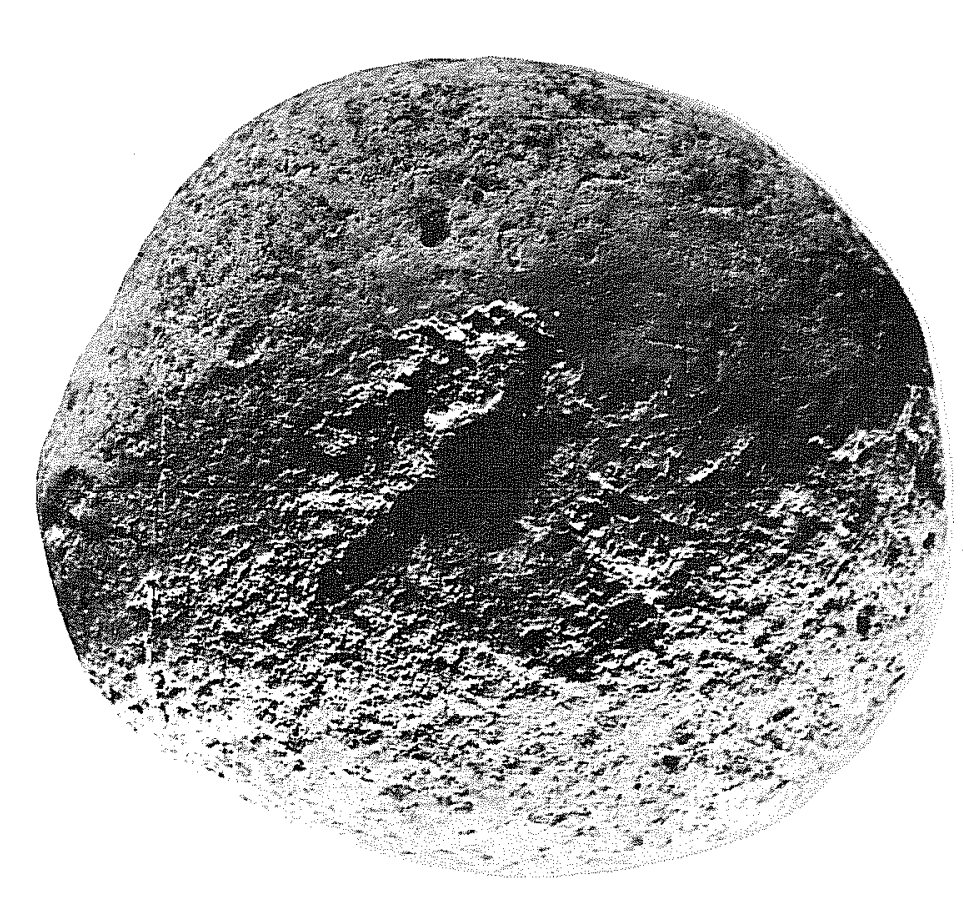

b

Figure 33. Lithic Artifacts from Camp Bullis. a,b, pecked stone artifacts; both are from site 41 BX 377 . 


\section{A.7 \\ DESCRIPTIONS OF SITES AND SCATTERED ARTIFACT FINDS \\ Andrea Gerstle}

The following site descriptions are taken from both the computer coded and written field forms (III.A.4). In the interests of brevity, pertinent information is presented in a standardized format. Frequency data are not given due to the varied collection areas and techniques. However, the collection areas are mentioned, and potentially permit comparisons. Site locations are presented in Fig. 34 .

\section{SITE DESCRIPTIONS}

\section{$41 B \times 36$}

Location: Site is located on a terrace at the edge of the Salado Creek flood plain, currently flowing only seasonally. It extends onto the colluvial slope and shelf, ca. $100 \mathrm{~m}$ southeast of the creek.

Elevation: 1050'

Environment: Vegetation on and around the undisturbed areas of the site includes live oak, hackberry, huisache, juniper, persimmon and moderately heavy grass cover. The flood plain soils are a deep dark loam.

Description: The site consists of a disturbed and partially destroyed burned rock accumulation with high densities of chipped stone and bone. Remaining portion of the site measures approximately $60 \times 40 \mathrm{~m}$ and is adjacent to the natural terrace slope. The maximum depth of the site is currently $110 \mathrm{~cm}$; some overburden or cultural fill may have been removed during construction activities.

Investigation: Although no surface collections were conducted due to disturbances, a total of $231 \mathrm{~m}^{2}$ units was excavated (Fig. 35). These consisted in several cases of blocks of four units, in which the southwesternmost unit served as a control unit (see III.A.4). Table 10 presents the artifact types and frequencies per level in each unjt.

The deposits appear to be badly mixed in some units as shown by the presence of historic material to a maximum depth of $50 \mathrm{~cm}$ below the ground surface. This is also revealed in the lack of chronological (projectile point) stratigraphy or natural stratigraphy. 


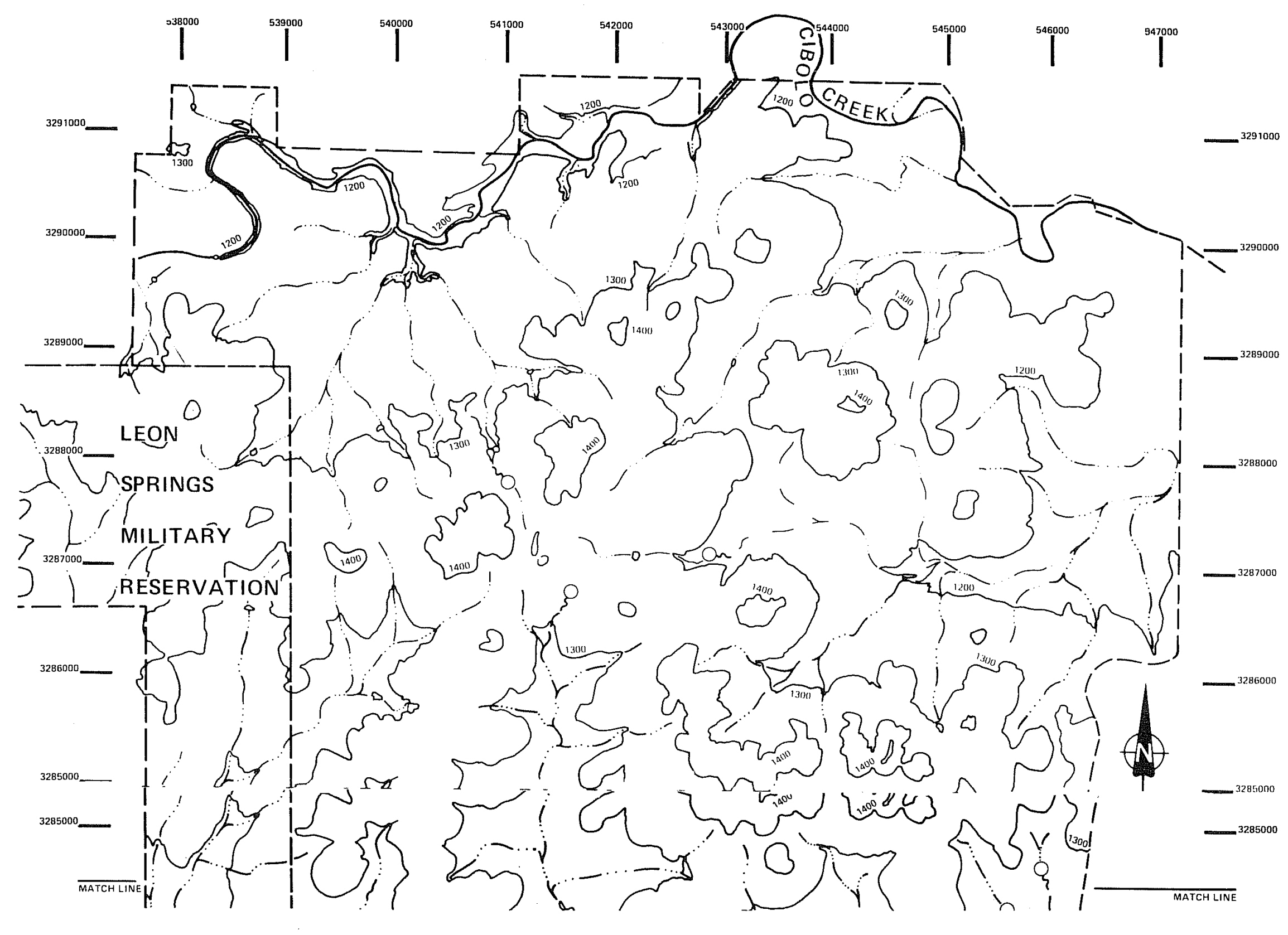




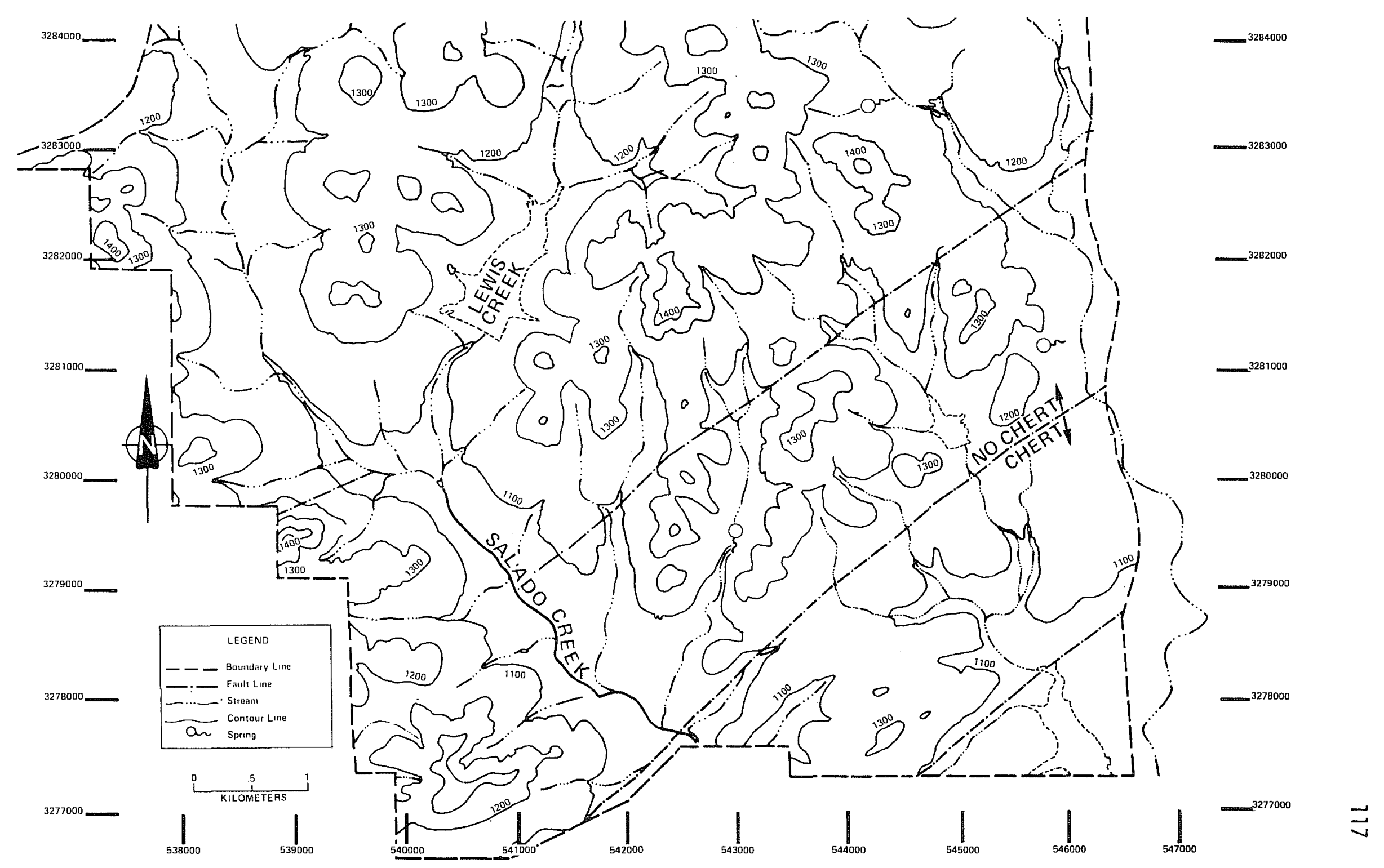

Figure 34. The Camp Bullis Survey Area. In order to protect the sites at Camp Bullis, their locations are not plotted on this version of the map. Qualified researchers may obtain site locations from the Center. Adapted from the USGS Camp Bu17is 7.5' topographic map. Note match line. 



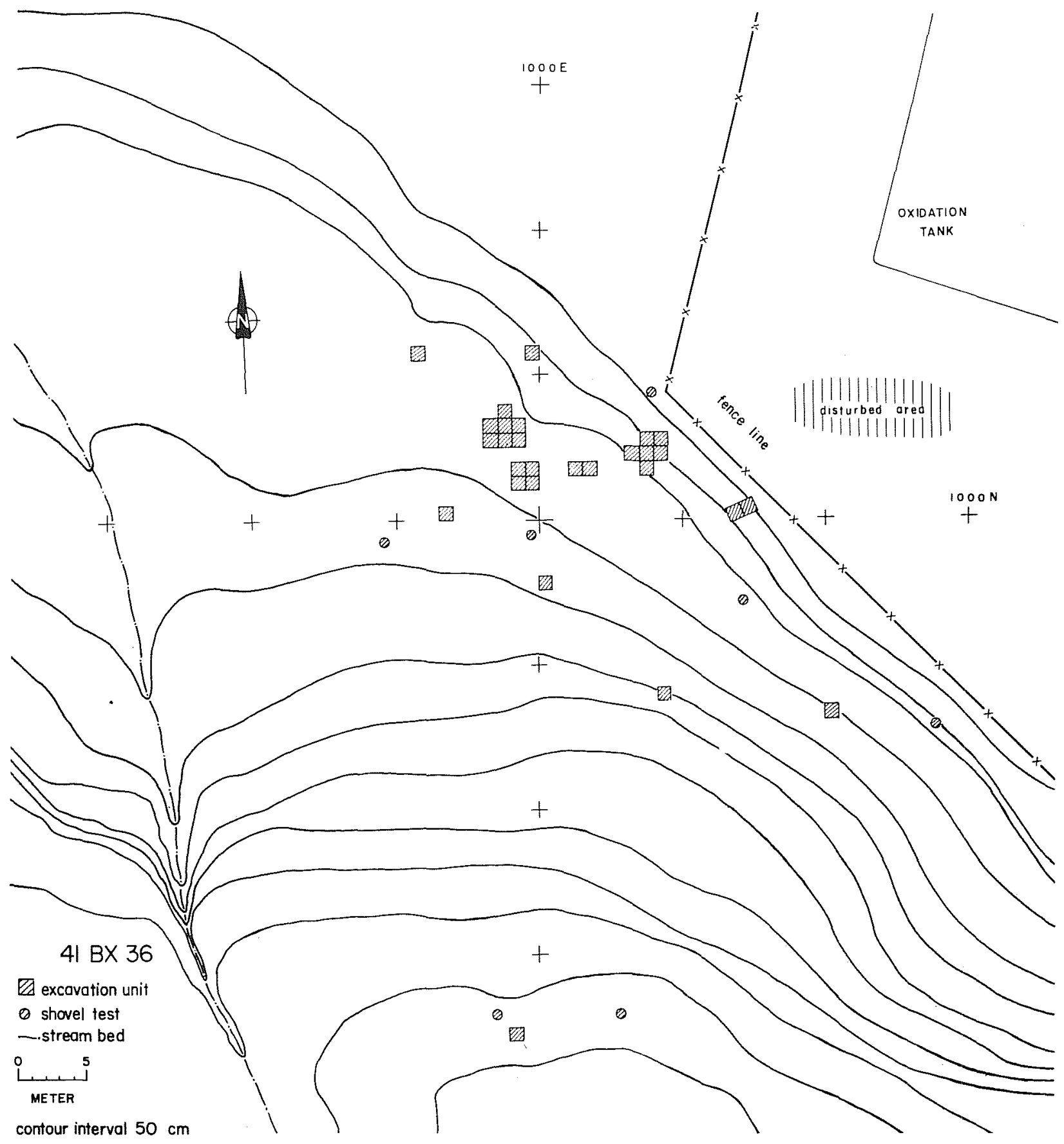

Figure 35. Site 41 BX 36, Camp Bullis. Plan of the 1977 excavations. 
TABLE 10. ARTIFACT PROVENIENCE AT 41 BX 36

\begin{tabular}{|c|c|c|c|c|c|c|c|c|}
\hline Unit & $\begin{array}{l}\text { Depth } \\
\text { below } \\
\text { Datum }\end{array}$ & $\begin{array}{r}\text { Leve1 } \\
(\mathrm{cm})\end{array}$ & $\begin{array}{l}\text { Screen } \\
\text { Size }\end{array}$ & $\begin{array}{c}\text { Historic } \\
\text { Material } \\
\text { (*=Presence) }\end{array}$ & $1^{\circ}$ & $\begin{array}{c}\text { Flakes } \\
\underline{2}^{\circ}\end{array}$ & Int. & $\underline{\text { other Lithics }}^{\neq}$ \\
\hline $\begin{array}{l}\text { T.P.1 } \\
\text { (E1000, } \\
\text { N995) }\end{array}$ & $3 \mathrm{~cm}$ & $\begin{array}{r}0-10 \\
10-20 \\
20-30\end{array}$ & $\begin{array}{l}1 / 4^{\prime \prime} \\
1 / 8^{\prime \prime}\end{array}$ & * & $\begin{array}{r}5 \\
19 \\
0\end{array}$ & $\begin{array}{r}18 \\
19 \\
8\end{array}$ & $\begin{array}{r}170 \\
247 \\
31\end{array}$ & $\begin{array}{l}\text { Biface, Chunk } \\
\text { Biface, Chunk } \\
\text { Biface, Retouched flake, Pedernales }\end{array}$ \\
\hline $\begin{array}{l}\text { T.P.2 } \\
(\text { E1008, } \\
\text { N987) }\end{array}$ & $\begin{array}{c}146 \mathrm{~cm} \\
\text { above }\end{array}$ & $\begin{array}{r}0-10 \\
10-20 \\
20-30 \\
30-40\end{array}$ & $\begin{array}{l}1 / 4 " \\
11 \\
1 "\end{array}$ & * & $\begin{array}{l}4 \\
4 \\
2 \\
3\end{array}$ & $\begin{array}{r}17 \\
20 \\
2 \\
0\end{array}$ & $\begin{array}{r}78 \\
107 \\
20 \\
4\end{array}$ & $\begin{array}{l}\text { Retouched flake, Chunk, Scallorn } \\
\text { Preform }(3) \text {, Quarry blank }(2) \text {, Side scraper (2), } \\
\text { Core, Retouched flake }(2) \text {, Chunk } \\
\text { Chunk } \\
\text { Chunk }\end{array}$ \\
\hline $\begin{array}{l}\text { T.P.3 } \\
\text { (E998, } \\
\text { N1000) }\end{array}$ & $23 \mathrm{~cm}$ & $\begin{array}{r}0-10 \\
10-20 \\
20-30 \\
30-45 \\
45-55 \\
55-65 \\
65-75\end{array}$ & $\begin{array}{l}\text { " } \\
\text { " } \\
\text { " } \\
\text { " } \\
\text { " }\end{array}$ & * & $\begin{array}{l}6 \\
5 \\
6 \\
4 \\
1 \\
0 \\
0\end{array}$ & $\begin{array}{r}27 \\
23 \\
13 \\
5 \\
3 \\
2 \\
0\end{array}$ & $\begin{array}{r}162 \\
202 \\
104 \\
54 \\
10 \\
4 \\
0\end{array}$ & $\begin{array}{l}\text { Chunk, Perdiz (2) } \\
\text { Biface, Chunk, Pedernales } \\
\text { Chopper, Biface } \\
\text { Core, Biface, Chunk } \\
\text { Retouched flake } \\
- \\
-\end{array}$ \\
\hline $\begin{array}{c}1 \\
\text { (E997) } \\
\text { N1007) }\end{array}$ & $80 \mathrm{~cm}$ & $\begin{array}{r}0-10 \\
10-20 \\
20-30 \\
30-40 \\
40-50 \\
50-60 \\
60-70 \\
70-80 \\
80-90 \\
90-100 \\
100-110\end{array}$ & $\begin{array}{l}\text { " } \\
\text { " } \\
\text { " } \\
\text { " } \\
\text { " } \\
\text { " } \\
\text { " } \\
\text { " }\end{array}$ & * & $\begin{array}{r}27 \\
32 \\
37 \\
0 \\
0 \\
0 \\
0 \\
3 \\
0 \\
0 \\
1\end{array}$ & $\begin{array}{r}58 \\
63 \\
41 \\
10 \\
6 \\
2 \\
4 \\
2 \\
1 \\
3 \\
0\end{array}$ & $\begin{array}{r}384 \\
441 \\
365 \\
163 \\
122 \\
134 \\
112 \\
80 \\
32 \\
28 \\
15\end{array}$ & $\begin{array}{l}\text { End/side scraper, Edwards } \\
\text { Biface, Core, Scallorn } \\
\text { Biface, Retouched flake, Perdiz } \\
\text { Castroville, Martindale, Nolan } \\
\text { Biface (2), Core } \\
\text { Core, Castroville } \\
\text { Biface } \\
\text { - } \\
\text { Biface } \\
\text { - }\end{array}$ \\
\hline
\end{tabular}


TABLE 10. (continued)

\begin{tabular}{|c|c|c|c|c|c|c|c|c|}
\hline Unit & $\begin{array}{l}\text { Depth } \\
\text { below } \\
\text { Datum }\end{array}$ & $\begin{array}{r}\text { Level } \\
(\mathrm{cm}) \\
\end{array}$ & $\begin{array}{l}\text { Screen } \\
\text { Size }\end{array}$ & $\begin{array}{c}\text { Historic } \\
\text { Material } \\
(*=\text { Presence) } \\
\end{array}$ & $1^{\circ}$ & $\begin{array}{c}\text { Flakes } \\
\underline{2}^{\circ}\end{array}$ & Int. & Other Lithics ${ }^{\ddagger}$ \\
\hline $\begin{array}{l}2 \\
(E 998 \\
\text { N1006) }\end{array}$ & $83 \mathrm{~cm}$ & $\begin{array}{r}0-10 \\
10-20 \\
20-30 \\
30-40 \\
40-50 \\
50-60\end{array}$ & $\begin{array}{l}1 / 4 " \\
11 \\
11 \\
11 \\
11\end{array}$ & * & $\begin{array}{r}7 \\
15 \\
7 \\
7 \\
2 \\
1\end{array}$ & $\begin{array}{r}46 \\
36 \\
29 \\
13 \\
14 \\
2\end{array}$ & $\begin{array}{r}277 \\
324 \\
337 \\
226 \\
148 \\
90\end{array}$ & $\begin{array}{l}\text { Biface (3), Edwards } \\
\text { Unknown point } \\
\text { End/side scraper, Scallorn } \\
\text { Retouched flake, Montell } \\
\text { Retouched flake } \\
\text { Pedernales }\end{array}$ \\
\hline \multirow[t]{2}{*}{$\begin{array}{l}3 \\
(E 998 \\
N 1-05)\end{array}$} & \multirow[t]{2}{*}{$85 \mathrm{~cm}$} & $\begin{array}{l}0-5 \\
5-10\end{array}$ & $1 / 8^{\prime \prime}$ & * & $\begin{array}{l}2 \\
3\end{array}$ & $\begin{array}{l}8 \\
3\end{array}$ & $\begin{array}{r}70 \\
202\end{array}$ & $\begin{array}{l}\text { Ground stone, Side scraper, Retouched } \\
\text { flake, Chunk } \\
\text { Uniface, Retouched flake, Ground stone, } \\
\text { Chunk }\end{array}$ \\
\hline & & $\begin{array}{l}10-20 \\
20-30 \\
30-40\end{array}$ & $\begin{array}{c}1 / 4^{\prime \prime} \\
11\end{array}$ & * & $\begin{array}{l}1 \\
1 \\
0\end{array}$ & $\begin{array}{r}10 \\
11 \\
7\end{array}$ & $\begin{array}{r}264 \\
140 \\
97\end{array}$ & $\begin{array}{l}\text { Biface, Retouched flake, Chunk, Perdiz } \\
\text { Biface, Retouched flake, Chunk, Edwards, Uualde } \\
\text { Biface, Chunk, Marcos }\end{array}$ \\
\hline $\begin{array}{l}4 \\
(E 996 \\
N 1006)\end{array}$ & $67 \mathrm{~cm}$ & $\begin{array}{c}0-5 \\
5-10 \\
10-15 \\
15-20 \\
20-25 \\
25-30 \\
30-35 \\
35-40 \\
40-45 \\
45-50 \\
50-55 \\
55-60\end{array}$ & $\begin{array}{l}1 / 8 " \\
11 \\
11 \\
11 \\
11 \\
1 \\
11 \\
11 \\
11 \\
11 \\
11 \\
11\end{array}$ & * & $\begin{array}{l}0 \\
0 \\
0 \\
1 \\
0 \\
4 \\
0 \\
1 \\
0 \\
0 \\
1 \\
2\end{array}$ & $\begin{array}{r}15 \\
13 \\
30 \\
22 \\
6 \\
13 \\
7 \\
3 \\
4 \\
2 \\
4 \\
5\end{array}$ & $\begin{array}{r}26 \\
149 \\
280 \\
236 \\
79 \\
148 \\
35 \\
38 \\
24 \\
10 \\
28 \\
30\end{array}$ & $\begin{array}{l}\text { - } \\
\text { Retouched flake, Perdiz, Ensor-Frio } \\
\text { Retouched flake, Core } \\
\text { - } \\
\text { Retouched flake (2), Frio, Ensor-Frio } \\
\text { Frio } \\
\text { - } \\
\text { Retouched flake } \\
\text { - } \\
\text { - }\end{array}$ \\
\hline $\begin{array}{l}5 \\
\left(\begin{array}{l}E 997 \\
\text { N1005) }\end{array}\right.\end{array}$ & $69 \mathrm{~cm}$ & $\begin{array}{r}0-10 \\
10-20 \\
20-30 \\
30-40 \\
40-50 \\
50-60\end{array}$ & $\begin{array}{l}1 / 4 " \\
11 \\
" 1 \\
" 1 \\
" 1\end{array}$ & * & $\begin{array}{r}12 \\
11 \\
5 \\
4 \\
0 \\
2\end{array}$ & $\begin{array}{r}38 \\
36 \\
18 \\
9 \\
6 \\
0\end{array}$ & $\begin{array}{r}208 \\
338 \\
177 \\
69 \\
64 \\
12\end{array}$ & $\begin{array}{l}\text { Core, Perforator, Perdiz (2) } \\
\text { Perdiz ( } 2) \text {, Retouched flake } \\
\text { Dart point fragment } \\
\text { - } \\
\text { Montell } \\
\text { - }\end{array}$ \\
\hline
\end{tabular}


TABLE 10. (continued)

\begin{tabular}{|c|c|c|c|c|c|c|c|c|}
\hline Unit & $\begin{array}{l}\text { Depth } \\
\text { below } \\
\text { Datum } \\
\end{array}$ & $\begin{array}{r}\text { Leve] } \\
(\mathrm{cm}) \\
\end{array}$ & $\begin{array}{l}\text { Screen } \\
\text { Size }\end{array}$ & $\begin{array}{c}\text { Historic } \\
\text { Material } \\
(*=\text { Presence) }\end{array}$ & $1^{\circ}$ & $\begin{array}{c}\text { Flakes } \\
2^{\circ}\end{array}$ & Int. & $\underline{\text { Other Lithics }}^{\ddagger}$ \\
\hline $\begin{array}{c}6 \\
\text { (E996) } \\
\text { N1006) }\end{array}$ & $71 \mathrm{~cm}$ & $\begin{array}{r}0-10 \\
10-20 \\
20-30 \\
30-40 \\
40-50 \\
50-60\end{array}$ & $\begin{array}{l}1 / 4 " \\
11 \\
11 \\
1 "\end{array}$ & * & $\begin{array}{r}8 \\
11 \\
8 \\
2 \\
1 \\
2\end{array}$ & $\begin{array}{r}21 \\
40 \\
22 \\
12 \\
10 \\
8\end{array}$ & $\begin{array}{r}186 \\
259 \\
278 \\
102 \\
122 \\
55\end{array}$ & $\begin{array}{l}\text { Castroville, Nolan } \\
\text { Retouched flake, Nolan } \\
\text { Side scraper } \\
\text { Angostura, Early Corner Notched } \\
\text { Marshall }\end{array}$ \\
\hline $\begin{array}{c}7 \\
(\text { E997, } \\
\text { N1006) }\end{array}$ & $75 \mathrm{~cm}$ & $\begin{array}{r}0-10 \\
10-20 \\
20-30 \\
30-40 \\
40-50 \\
50-60\end{array}$ & $\begin{array}{l}\text { " } \\
" 1 \\
" 1 \\
" 1\end{array}$ & * & $\begin{array}{r}8 \\
10 \\
14 \\
8 \\
6 \\
0\end{array}$ & $\begin{array}{r}38 \\
37 \\
20 \\
13 \\
12 \\
5\end{array}$ & $\begin{array}{r}268 \\
325 \\
463 \\
133 \\
111 \\
24\end{array}$ & $\begin{array}{l}\text { Core } \\
\text { Biface (2), Retouched flake, Montell } \\
\text { Core, Retouched flake, Nolan, Martindale } \\
\text { Pedernales (2) } \\
\text { Biface } \\
\text { - }\end{array}$ \\
\hline \multirow[t]{2}{*}{$\begin{array}{c}8 \\
(E 1002, \\
\text { N1003) }\end{array}$} & \multirow[t]{2}{*}{$73 \mathrm{~cm}$} & $\begin{array}{l}0-5 \\
5-10\end{array}$ & $1 / 8^{11}$ & * & $\begin{array}{r}10 \\
6\end{array}$ & $\begin{array}{l}23 \\
35\end{array}$ & $\begin{array}{l}258 \\
469\end{array}$ & \multirow{2}{*}{$\begin{array}{l}\text { Biface, Retouched flake, Chunk } \\
\text { Biface, Retouched flake, Chunk, Fresnc } \\
\text { Unknown dart point } \\
\text { Biface, Retouched flake, Chunk } \\
\text { Core, Chunk, Retouched flake, Biface } \\
\text { Biface, Retouched flake, Chunk }\end{array}$} \\
\hline & & $\begin{array}{l}10-15 \\
15-20 \\
20-25\end{array}$ & $\begin{array}{l}" 1 \\
" 1\end{array}$ & * & $\begin{array}{l}15 \\
16 \\
10\end{array}$ & $\begin{array}{l}16 \\
32 \\
28\end{array}$ & $\begin{array}{l}335 \\
508 \\
276\end{array}$ & \\
\hline $\begin{array}{c}9 \\
(\text { E1003, } \\
\text { N1003) }\end{array}$ & $73 \mathrm{~cm}$ & $\begin{array}{r}0-10 \\
10-20 \\
20-30 \\
30-40 \\
40-50 \\
50-60 \\
60-70 \\
70-80 \\
80-90\end{array}$ & $\begin{array}{l}1 / 4 " \\
11 \\
11 \\
11 \\
11 \\
11 \\
11 \\
\text { " }\end{array}$ & $\begin{array}{l}* \\
* \\
* \\
*\end{array}$ & $\begin{array}{r}11 \\
21 \\
7 \\
2 \\
2 \\
0 \\
0 \\
7 \\
1\end{array}$ & $\begin{array}{r}58 \\
76 \\
30 \\
13 \\
12 \\
27 \\
1 \\
0 \\
4\end{array}$ & $\begin{array}{r}739 \\
744 \\
382 \\
193 \\
122 \\
0 \\
17 \\
0 \\
11\end{array}$ & $\begin{array}{l}\text { Ground stone, Retouched flake, Ensor, Perdiz } \\
\text { Biface (2), Edwards (2) } \\
\text { Core }(2), \text { Travis } \\
\text { End/side scraper } \\
\text { Biface } \\
- \\
-\end{array}$ \\
\hline $\begin{array}{l}10 \\
\text { (E998, } \\
\text { N1003) }\end{array}$ & $62 \mathrm{~cm}$ & $\begin{array}{r}0-10 \\
10-20\end{array}$ & $1 / 8^{11}$ & & $\begin{array}{l}1 \\
2\end{array}$ & $\begin{array}{r}6 \\
39\end{array}$ & $\begin{array}{l}111 \\
276\end{array}$ & $\begin{array}{l}\text { Biface, Retouched flake, Chunk, Perdiz, Marcos } \\
\text { Biface, Retouched flake, Chunk, Edwards }\end{array}$ \\
\hline
\end{tabular}


TABLE 10. (continued)

\begin{tabular}{|c|c|c|c|c|c|c|c|c|}
\hline$\underline{\text { Unit }}$ & $\begin{array}{l}\text { Depth } \\
\text { below } \\
\text { Datum }\end{array}$ & $\begin{array}{r}\text { Leve1 } \\
(\mathrm{cm}) \\
\end{array}$ & $\begin{array}{l}\text { Screen } \\
\text { Size }\end{array}$ & $\begin{array}{c}\text { Historic } \\
\text { Material } \\
\left({ }^{*}=\text { Presence) }\right. \\
\end{array}$ & $1^{\circ}$ & $\begin{array}{c}\text { Flakes } \\
\underline{2}^{\circ}\end{array}$ & Int. & $\underline{\text { Other Lithics }}^{\ddagger}$ \\
\hline $\begin{array}{l}11 \\
(\text { E999, } \\
\text { N1003) }\end{array}$ & $64 \mathrm{~cm}$ & $\begin{array}{r}0-10 \\
10-20\end{array}$ & $1 / 4^{\prime \prime}$ & * & $\begin{array}{l}9 \\
0\end{array}$ & $\begin{array}{l}37 \\
38\end{array}$ & $\begin{array}{l}286 \\
195\end{array}$ & $\begin{array}{l}\text { Biface, Chunk, Edwards } \\
\text { Biface, Preform, Chunk, Retouched flake }\end{array}$ \\
\hline $\begin{array}{l}12 \\
(\text { E998, } \\
\text { N1002) }\end{array}$ & $57 \mathrm{~cm}$ & $\begin{array}{r}0-5 \\
5-10 \\
10-15 \\
15-20\end{array}$ & $\begin{array}{l}1 / 8 " \\
11 \\
11 \\
1 "\end{array}$ & * & $\begin{array}{l}2 \\
0 \\
1 \\
0\end{array}$ & $\begin{array}{r}13 \\
23 \\
9 \\
13\end{array}$ & $\begin{array}{r}0 \\
82 \\
99 \\
52\end{array}$ & $\begin{array}{l}\text { Biface, Guadalupe too 1, Perdiz } \\
\text { Biface, Chopper, Chunk, Early Corner Notched } \\
\text { Core, Chunk } \\
\text { Biface, Chunk, Ensor-Frio }\end{array}$ \\
\hline $\begin{array}{l}13 \\
(\text { E999, } \\
\text { N1002) }\end{array}$ & $59 \mathrm{~cm}$ & $\begin{array}{r}0-10 \\
10-20\end{array}$ & $1 / 4^{11}$ & * & $\begin{array}{l}1 \\
9\end{array}$ & $\begin{array}{l}13 \\
27\end{array}$ & $\begin{array}{l}166 \\
199\end{array}$ & $\begin{array}{l}\text { Biface, Retouched flake, Chunk } \\
\text { Biface, Chopper, Core, Retouched flake, } \\
\text { Chunk, Perdiz, Langtry }\end{array}$ \\
\hline $\begin{array}{l}14 \\
(\text { E1007 } \\
\text { N1004) }\end{array}$ & $83 \mathrm{~cm}$ & $\begin{array}{r}0-15 \\
15-25 \\
25-35 \\
35-45 \\
45-55\end{array}$ & $\begin{array}{l}" 1 \\
" 1 \\
" 1 \\
" 1\end{array}$ & & $\begin{array}{r}17 \\
4 \\
7 \\
0 \\
1\end{array}$ & $\begin{array}{r}42 \\
10 \\
4 \\
0 \\
2\end{array}$ & $\begin{array}{r}512 \\
84 \\
62 \\
13 \\
58\end{array}$ & $\begin{array}{l}\text { Biface, Retouched flake, Chunk } \\
\text { Chunk } \\
\text { Biface, La Jita } \\
\text { Core } \\
\text { Core, Retouched flake }\end{array}$ \\
\hline \multirow{2}{*}{$\begin{array}{l}15 \\
(\text { E1007) } \\
\text { N1003) }\end{array}$} & \multirow[t]{2}{*}{$62 \mathrm{~cm}$} & $0-10$ & $"$ & & 14 & 5 & 368 & \multirow{2}{*}{$\begin{array}{l}\text { Biface, Retouched flake, Chunk, La Jita, } \\
\text { Pedernales (2), Frio } \\
\text { Chunk, Kinney }\end{array}$} \\
\hline & & $\begin{array}{l}10-20 \\
20-30 \\
30-40\end{array}$ & $\begin{array}{l}" 1 \\
" 1 \\
" 1\end{array}$ & * & $\begin{array}{l}8 \\
5 \\
4\end{array}$ & $\begin{array}{r}15 \\
12 \\
8\end{array}$ & $\begin{array}{r}179 \\
74 \\
63\end{array}$ & \\
\hline \multirow{2}{*}{$\begin{array}{l}16 \\
(\text { E998, } \\
\text { N964) }\end{array}$} & \multirow[t]{2}{*}{$\begin{array}{l}460 \mathrm{~cm} \\
\text { above }\end{array}$} & $0-10$ & $"$ & \multirow[t]{2}{*}{ * } & 5 & 14 & 101 & \multirow{2}{*}{$\begin{array}{l}\text { End/side scraper, Retouched flake, Chunk, } \\
\text { Edwards }\end{array}$} \\
\hline & & $\begin{array}{l}10-20 \\
20-30\end{array}$ & " & & $\begin{array}{l}4 \\
0\end{array}$ & $\begin{array}{l}9 \\
0\end{array}$ & $\begin{array}{r}105 \\
2\end{array}$ & \\
\hline $\begin{array}{l}17 \\
(\text { E1008, } \\
\text { N1004) }\end{array}$ & $150 \mathrm{~cm}$ & $\begin{array}{r}0-10 \\
10-20 \\
20-30\end{array}$ & " & * & $\begin{array}{l}2 \\
0 \\
6\end{array}$ & $\begin{array}{r}0 \\
11 \\
15\end{array}$ & $\begin{array}{r}27 \\
55 \\
116\end{array}$ & $\begin{array}{l}\text { End/side scraper, Castroville } \\
\text { Edwards, Ensor, Nolan } \\
\text { Biface, Chunk }\end{array}$ \\
\hline
\end{tabular}


TABLE 10. (continued)

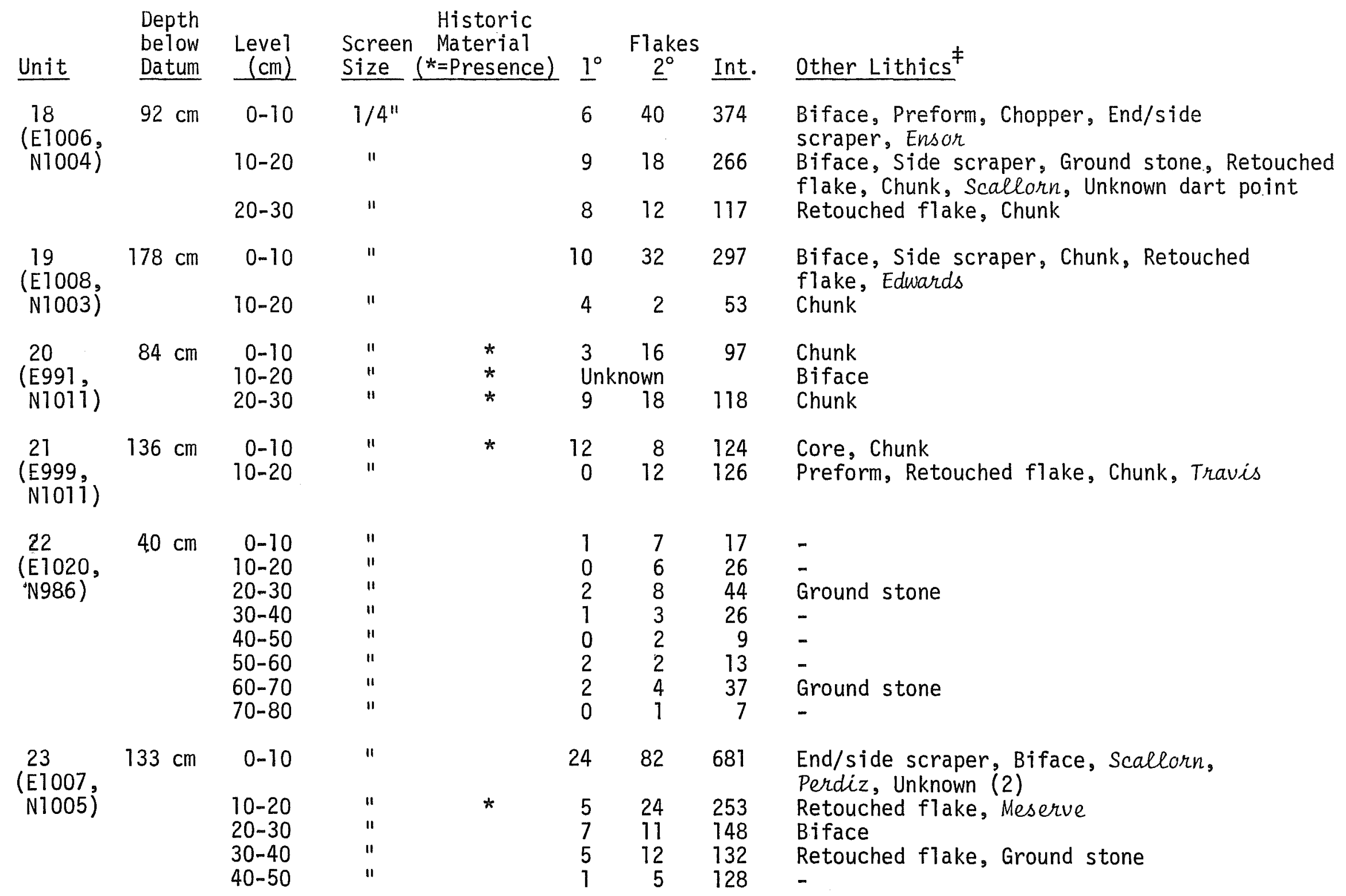

${ }^{\ddagger}$ One specimen unless otherwise indicated.

$1^{\circ}$, primary flake; $2^{\circ}$, secondary flake; Int., interior flake. 
Early observations (before modification) indicate that the site was originally very large (see III.A.3). The remaining segment, although yielding large quantities of artifactual material, must be only the very edge of the site. Several burials were reputedly uncovered during the process of destruction; however, none of the materials are available and they were not documented.

Although little can be said regarding the manner in which the site was constructed, it is suggested that this is a segment of a large base camp area. Long-term and intensive use is indicated by the projectile point types present and by high frequencies of chipped stone, burned rock and bone (see III.A.12).

Occupation Period: Late Paleo-Indian through Late Prehistoric.

\section{$41 B \times 37.1$}

Location: Upland margin site; less than one $\mathrm{km}$ to nearest water source, a permanent waterhole in Cibolo creek.

\section{Elevation: $1300^{\prime}$}

Environment: Vegetation is predominantly grasses with clumps of juniper and live oak. Soil cover is very thin with areas of bedrock outcrops.

Description: Low density lithic scatter consisting of points, unifaces, biface fragments and flakes. Some scattered burned rock is present. The site has no depth. Dimensions of the site are approximately $75 \times 50 \mathrm{~m}$.

Investigation: A11 visible diagnostic artifacts and worked chert were collected.

Occupation Period: Pre-Archaic.

\section{$41 B \times 372$}

Location: Flood plain site; nearest permanent water (Cibolo Creek) is less than $100 \mathrm{~m}$ distant.

Elevation: $1300^{\prime}$

Environment: The soil is a dark loam of indeterminate depth. Vegetation is primarily clumps of juniper and live oak interspersed with grassy areas.

Description: The site consists of scattered burned rock and chipped stone. Artifacts include a point, cores, biface fragments, scrapers and flakes. The site area is over $100 \times 100 \mathrm{~m}$. The site depth is indeterminate.

Investigation: The site was recorded but no collection was made.

Occupation Period: Unknown. 


\section{$41 B \times 373$}

Location: Terrace site with small river cobbles of medium fine chert; nearest permanent water, Cibolo Creek, is less than $100 \mathrm{~m}$ away.

Elevation: $1210^{\prime}$

Environment: Vegetation consists of live oak, hackberry, juniper and elm woods. The soil is reddish and clayey, containing some chert gravels. The soil depth is undetermined.

Description: The site is marked by a moderate density lithic scatter containing a point, bifaces, cores and flakes. The site depth is unknown; its area is ca. $40 \times 30 \mathrm{~m}$.

Investigation: The site was mapped according to standard procedure.

Occupation Period: Late Paleo-Indian.

\section{$41 B \times 374$}

Location: Flood plain site; nearest water source less than one $\mathrm{km}$ distant (Cibolo Creek). No chert in immediate area.

Elevation: $1270^{\prime}$

Environment: Vegetation is composed of juniper and live oak brakes interspersed among grassy fields. The soil is dark and laomy with some depth. The site is located in a plowed field.

Description: The site consists of a lithic scatter including bifaces, preforms, biface fragments, a chopper and flakes. The site depth is unknown; dimensions are approximately $45 \times 30 \mathrm{~m}$.

Investigation: A surface collection of worked chert was made. The locations of the artifacts were mapped.

Occupation Period: Unknown.

\section{BX 375}

Location: Flood plain site; permanent water source less than one km away (Cibolo Creek). The site is on a bluff overlooking Cibolo Creek and approximately $50 \mathrm{~m}$ from an intermittent stream. Medium fine chert available in small river cobbles.

Elevation: 1190'

Environment: Vegetation includes sparse grasses with dense juniper clumps. The soil ranges from black clay-loam to reddish clay with chert gravels. The depth is indeterminate but probably fairly shallow. 
Description: The site is a lithic scatter with points, bifaces, unifaces, blanks, cores and flakes present. The site area is ca. $100 \times 50 \mathrm{~m}$; the site depth is undetermined.

Investigation: $A 3 \mathrm{~m}^{2}$ unit was completely collected, and other diagnostic artifacts were collected and mapped.

Occupation Period: Pre-Archaic, Late Archaic.

\section{$41 B \times 376$}

Location: Upland margin site; ca. $150 \mathrm{~m}$ to nearest seasonal water source (a ravine) and one $\mathrm{km}$ from Cibolo Creek, a permanent water supply.

Elevation: $1250^{\prime}$

Environment: Vegetation consists of grassy fields with clumps of juniper and live oak. The soil is very thin with bedrock outcrops. Moderately fine chert is available $800 \mathrm{~m}$ northwest at $41 \mathrm{BX} 375$.

Description: The site is a lithic scatter covering a large $(320 \times 250 \mathrm{~m})$ area. Artifacts consist of points, bifaces, cores, a Guadalupe tool and flakes. Burned rock is scattered over the site.

Investigation: The site area was sketched and diagnostic artifacts were collected.

Occupation Period: Late Paleo-Indian, Pre-Archaic.

$41 B \times 377$

Location: The site is buried in a colluvial terrace within $30 \mathrm{~m}$ of Cibolo Creek, which has a deep waterhole at this point. No chert in immediate area. Photograph on cover.

Elevation: $1200^{\prime}$

Environment: The present day vegetation includes juniper and live oak mixed with hackberry and persimmon. Disturbed areas have a heavy grass cover. The terrace soil iș a deep reddish sandy silt, alluvially deposited.

Description: The site is buried in the terrace, indicating that Cibolo Creek was much higher during the time of occupation. Probably the area was an outside edge of a meander of Cibolo Creek and received flood-carried material (C. M. Woodruff, personal communication).

The prehistoric occupation is represented by a series of partially superimposed hearths within a $30 \times 30 \mathrm{~m}$ area. Associated with these hearths are numerous chipped stone artifacts and land snail shells, often occurring in pockets. It is likely, given the nature of the probable soil deposition processes and the hearth stratigraphy, that the site was repeatediy occupied during non-flood seasons or years. 
The low bone frequency may be due to poor preservation conditions (see III.A.12) or an original lack of bone. Only a few mussel shell fragments were recovered.

Table 11 presents data on the volume of burned rock present per leve1. The higher concentrations indicated hearths, often constructed with slab limestone and forming a discrete horizontal layer (Fig, 36,a). These hearths often contained pockets of unburned Rabdotus sp. land snail shells. Several contained charcoal and ash-stained soil. Artifact proveniences are presented in Table 11.

No clear chronological separation between Late Archaic and Late Prehistoric components was discernible.

Investigation: A roadcut through the site enabled initial recognition of severaT hearths (Fig. 37). A large number of artifacts had washed into the roadcut; a selective collection was made of these, but the locations were not mapped. Subsequently, eight $1 \mathrm{~m}^{2}$ units were excavated, most of them in $5 \mathrm{~cm}$ levels and using 1/8-inch mesh screen. These are arranged in Fig. 38 according to surface topography.

Occupation Period: Pre-Archaic, Late Archaic, Late Prehistoric.

\section{BX 378}

Location: Terrace site with no chert in immediate area. A seasonal water supply is available within $100 \mathrm{~m}$, as well as Cibolo Creek, which has permanent waterholes (Fig. 39).

Elevation: $1190^{\prime}$

Environment: Vegetation is primarily juniper and thorny brush, with light grass cover. The soil is very thin with bedrock visible.

Description: The site is a lithic concentration in a small area ( $5 \times 5 \mathrm{~m})$. A point, scrapers and flakes were present. The site has no depth.

Investigation: Diagnostic artifacts were collected.

Occupation Period: Unknown.

41 BX 379

Location: Terrace site located on a bluff above a waterhole in Cibolo Creek, within $100 \mathrm{~m}$.

Elevation: 1190'

Environment: Vegetation is composed of dense juniper and thorny brush, with sparse grasses. The soil is a dark clayey loam, never more than $5 \mathrm{~cm}$ deep. 

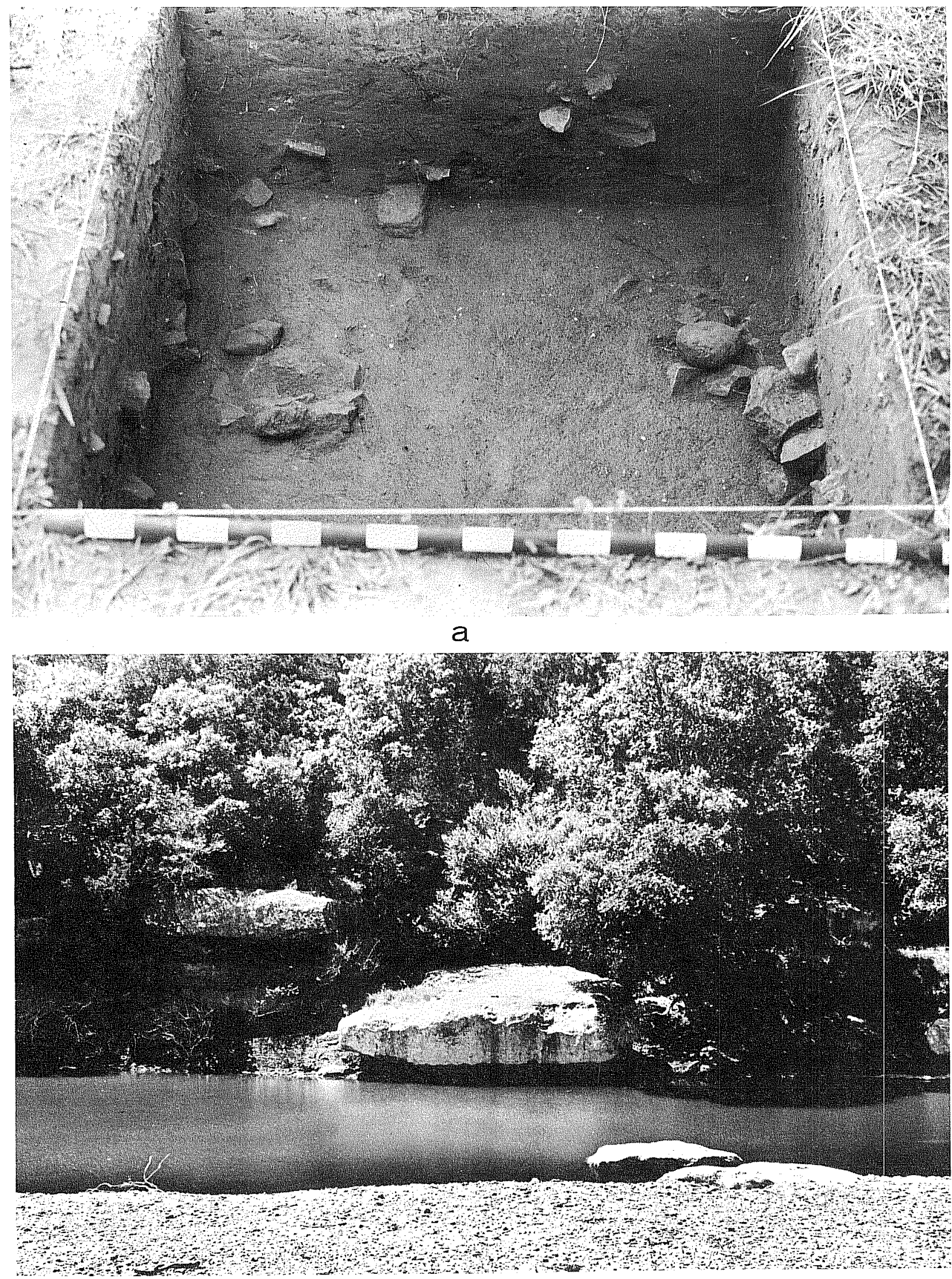

b

Figure 36. Views of Prehistoric Sites, Camp Bullis. a, hearths at site 4.1 BX 377; b, Cibolo Creek below site 41 BX 383. 
$41 \mathrm{BX} 377$

WEST PROFILE OF ROADCUT

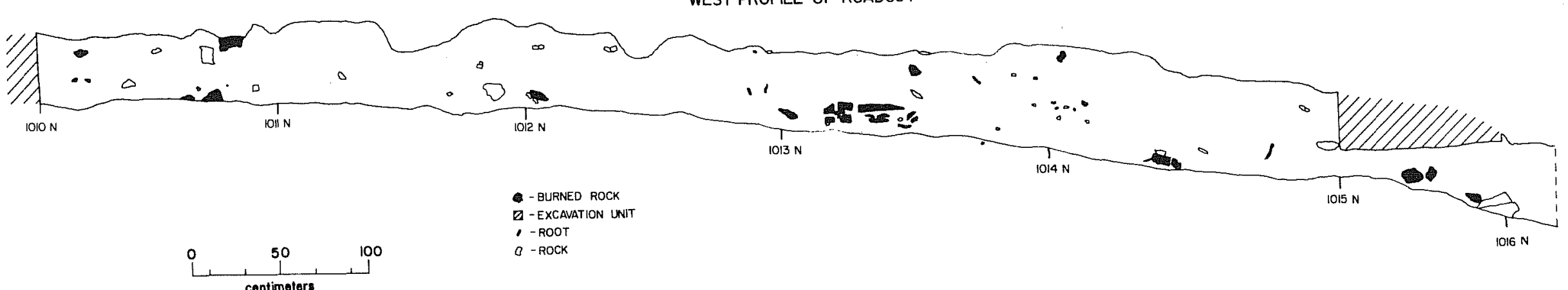

centimoters

Figure 37. Site $41 \mathrm{BX} 377$, Camp Bullis: West Profile. The west profile along the roadcut at site $41 \mathrm{BX} 377$ is shown. See Fig. 38 for location of this profile within the site. 


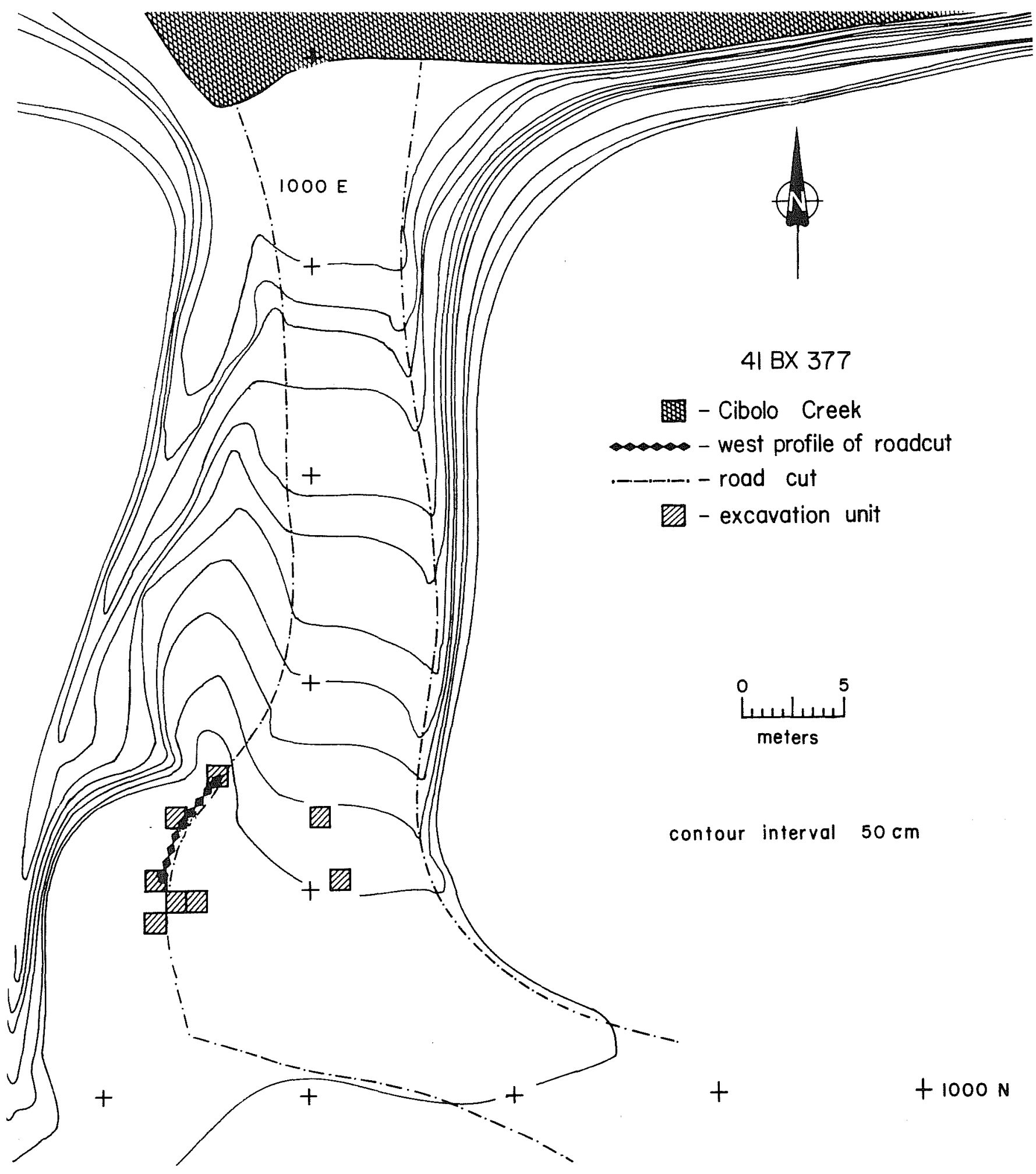

Figure 38. Site 41 BX 377, Camp Bullis. 

CIBOLO CREEK

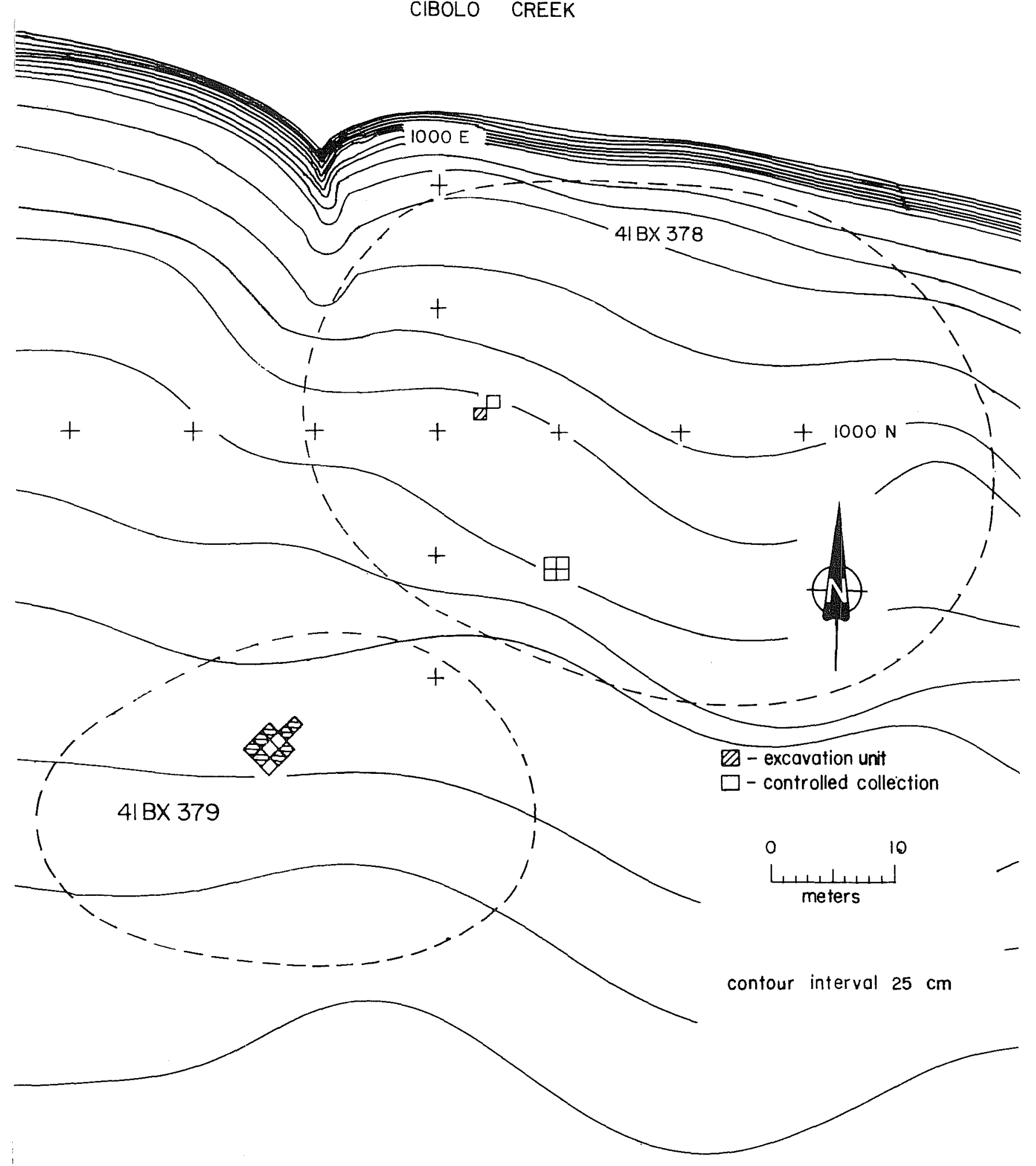

Figure 39. Sites 41 BX 378 and 41 BX 379, Camp Bullis. 
TABLE 11. ARTIFACT PROVENIENCE AT 41 BX 377

\begin{tabular}{|c|c|c|c|c|c|c|c|c|}
\hline Unit & $\begin{array}{l}\text { Depth } \\
\text { below } \\
\text { Datum }\end{array}$ & $\begin{array}{r}\text { Level } \\
(\mathrm{cm}) \\
\end{array}$ & $\begin{array}{l}\text { Screen } \\
\text { Size } \\
\end{array}$ & $\begin{array}{l}\text { Vol. of } \\
\text { Burned } \\
\text { Rock* } \\
\end{array}$ & $1^{\circ}$ & $\begin{array}{c}\text { Flakes } \\
\underline{2}^{\circ}\end{array}$ & Int. & $\underline{\text { Other Lithics }}^{\ddagger}$ \\
\hline $\begin{array}{c}1 \\
(E 1000 \\
N 1013)\end{array}$ & $125 \mathrm{~cm}$ & $\begin{array}{l}0-5 \\
5-10\end{array}$ & $1 / 8^{\prime \prime}$ & $\begin{array}{l}618 \\
412\end{array}$ & $\begin{array}{l}0 \\
0\end{array}$ & $\begin{array}{r}11 \\
0\end{array}$ & $\begin{array}{l}50 \\
17\end{array}$ & $\begin{array}{l}\text { Unknown arrow point } \\
\text { - }\end{array}$ \\
\hline $\begin{array}{l}2 \\
(E 1001 \\
\text { N1010) }\end{array}$ & $95 \mathrm{~cm}$ & $\begin{array}{l}0-5 \\
5-10 \\
10-15\end{array}$ & $\begin{array}{l}\text { " } \\
\text { "1 }\end{array}$ & $\begin{array}{r}4738 \\
2678 \\
678\end{array}$ & $\begin{array}{l}7 \\
3 \\
1\end{array}$ & $\begin{array}{r}22 \\
27 \\
3\end{array}$ & $\begin{array}{r}179 \\
112 \\
15\end{array}$ & $\begin{array}{l}\text { Point fragment, Edwards (2) } \\
\text { Edwards, Edgewood } \\
\text { - }\end{array}$ \\
\hline $\begin{array}{l}3 \\
(E 992, \\
\text { N1008) }\end{array}$ & $0 \mathrm{~cm}$ & $\begin{array}{c}0-5 \\
5-10 \\
10-15 \\
15-20 \\
20-25 \\
25-30 \\
30-35 \\
35-40 \\
40-45 \\
45-50 \\
50-55 \\
55-60 \\
60-65\end{array}$ & $\begin{array}{l}1 " \\
" 1 \\
1 " \\
1 " \\
1 " \\
11 \\
1 " \\
1 " \\
1 " \\
1 " \\
1 " \\
\text { " }\end{array}$ & $\begin{array}{l}4738 \\
1648 \\
6180 \\
7210 \\
1648 \\
1442 \\
2266 \\
4326 \\
3090 \\
1648 \\
1648 \\
1442 \\
6180\end{array}$ & $\begin{array}{l}0 \\
0 \\
6 \\
3 \\
3 \\
1 \\
3 \\
5 \\
1 \\
4 \\
0 \\
1 \\
0\end{array}$ & $\begin{array}{r}14 \\
36 \\
23 \\
15 \\
11 \\
8 \\
20 \\
4 \\
5 \\
4 \\
6 \\
3 \\
2\end{array}$ & $\begin{array}{r}38 \\
150 \\
103 \\
87 \\
26 \\
59 \\
68 \\
41 \\
20 \\
16 \\
15 \\
57 \\
27\end{array}$ & $\begin{array}{l}\text { - } \\
\text { Boint fragment (3), Biface fragment, Scallorn } \\
\text { - } \\
\text { - } \\
\text { - Core fragment (2) } \\
\text { Preform fragment } \\
\text { Core } \\
\text { Quarry blank fragment } \\
\text { Preform fragment } \\
\text { Ensor-Frio } \\
\text { Frio }\end{array}$ \\
\hline $\begin{array}{l}4 \\
(E 994, \\
\text { N7009) }\end{array}$ & $13 \mathrm{~cm}$ & $\begin{array}{c}0-5 \\
5-10 \\
10-15 \\
15-20 \\
20-25 \\
25-30 \\
30-35 \\
35-40 \\
40-45 \\
45-50 \\
50-60 \\
60-70\end{array}$ & $\begin{array}{l}11 \\
11 \\
11 \\
11 \\
11 \\
11 \\
11 \\
11 \\
1 / 4 " \\
11\end{array}$ & $\begin{array}{r}1442 \\
4120 \\
6180 \\
6180 \\
1030 \\
1030 \\
618 \\
1030 \\
412 \\
618 \\
618 \\
412\end{array}$ & $\begin{array}{l}6 \\
3 \\
1 \\
1 \\
6 \\
2 \\
2 \\
2 \\
1 \\
0 \\
0 \\
0\end{array}$ & $\begin{array}{r}5 \\
11 \\
4 \\
10 \\
13 \\
12 \\
4 \\
8 \\
4 \\
1 \\
1 \\
0\end{array}$ & $\begin{array}{r}43 \\
48 \\
32 \\
63 \\
101 \\
81 \\
36 \\
31 \\
20 \\
2 \\
6 \\
1\end{array}$ & $\begin{array}{l}\text { - } \\
\text { Ground stone } \\
\text { Point fragment, Side scraper } \\
\text { Thinned biface fragment } \\
\text { - } \\
- \\
- \\
- \\
- \\
-\end{array}$ \\
\hline
\end{tabular}


TABLE 11. (continued)

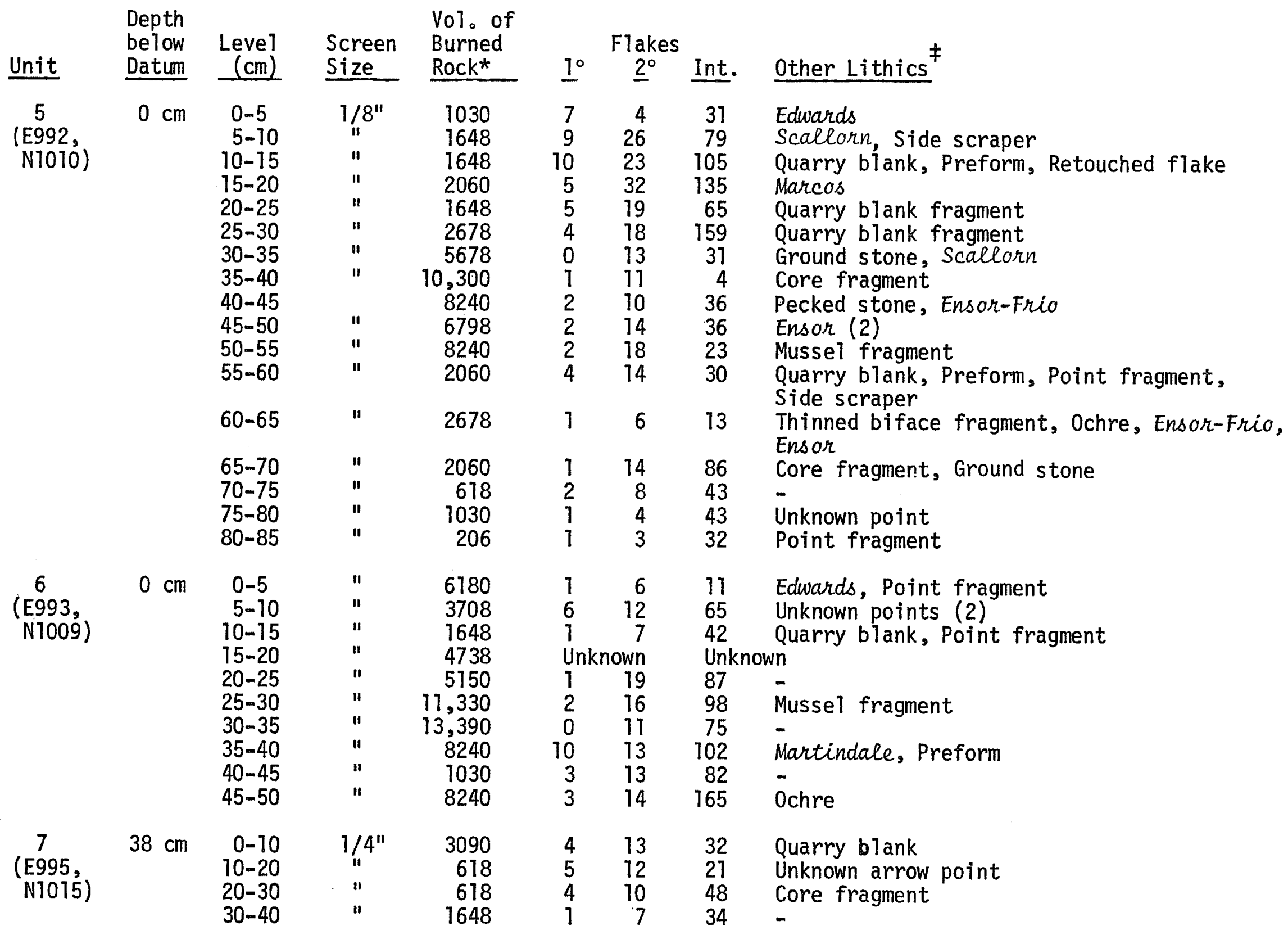


TABLE 11. (continued)

\begin{tabular}{|c|c|c|c|c|c|c|c|c|}
\hline Unit & $\begin{array}{l}\text { Depth } \\
\text { below } \\
\text { Datum }\end{array}$ & $\begin{array}{r}\text { Leve } \\
(\mathrm{cm}) \\
\end{array}$ & $\begin{array}{l}\text { Screen } \\
\text { Size }\end{array}$ & $\begin{array}{l}\text { Vol. of } \\
\text { Burned } \\
\text { Rock* } \\
\end{array}$ & $1^{\circ}$ & $\begin{array}{c}\text { Flakes } \\
\underline{2}^{\circ}\end{array}$ & Int. & Other Lithics $^{\neq}$ \\
\hline$\stackrel{7}{\left(\operatorname{con}^{\prime} t_{0}\right)}$ & & $\begin{array}{l}40-50 \\
50-60 \\
60-70 \\
70-80\end{array}$ & $\begin{array}{l}1 / 4 " \\
1 " \\
11\end{array}$ & $\begin{array}{r}1648 \\
2678 \\
24,720 \\
1648\end{array}$ & $\begin{array}{l}1 \\
0 \\
1 \\
1\end{array}$ & $\begin{array}{r}10 \\
2 \\
3 \\
2\end{array}$ & $\begin{array}{r}31 \\
16 \\
18 \\
8\end{array}$ & $\begin{array}{l}- \\
-\end{array}$ \\
\hline $\begin{array}{c}8 \\
\text { (E994 } \\
\text { N1013) }\end{array}$ & $13 \mathrm{~cm}$ & $\begin{array}{r}0-10 \\
10-20 \\
20-30 \\
30-40 \\
40-60 \\
60-70 \\
70-80 \\
80-90 \\
90-100 \\
100-120\end{array}$ & $\begin{array}{l}", \\
" 1 \\
" 1 \\
" 1 \\
" 1 \\
" 1 \\
\text { " }\end{array}$ & $\begin{array}{r}4532 \\
4738 \\
4120 \\
25,750 \\
15,450 \\
? \\
? \\
4120 \\
1030 \\
0.0\end{array}$ & $\begin{array}{l}3 \\
2 \\
3 \\
2 \\
2 \\
0 \\
3 \\
1 \\
0 \\
0\end{array}$ & $\begin{array}{r}16 \\
4 \\
6 \\
18 \\
5 \\
2 \\
12 \\
1 \\
0 \\
0\end{array}$ & $\begin{array}{r}62 \\
56 \\
41 \\
28 \\
36 \\
18 \\
25 \\
5 \\
0 \\
0\end{array}$ & $\begin{array}{l}\text { Point fragment, Mussel fragment } \\
\text { Point fragment, Ground stone } \\
\text { Ground stone }(2) \text {, Core scraper, Ensor } \\
\text { Point fragment } \\
\text { Preform, Ground stone, Unknown point } \\
\text { - Montell } \\
\text { - } \\
\text { - }\end{array}$ \\
\hline
\end{tabular}

* Cubic centimeters.

Fone specimen unless otherwise indicated.

$1^{\circ}$, primary flake; $2^{\circ}$, secondary flake; int., interior flake. 
Description: The site is a concentration of chipped stone covering an area approximately $1 \times 4 \mathrm{~m}$. Artifacts include points, worked chert and flakes.

Investigation: The initial investigation consisted of complete collection of three $1 \mathrm{~m}^{2}$ units. Subsequent excavations were carried out in eight $1 \mathrm{~m}^{2}$ units (Fig. 39, Table 12). No hearths or other features were observed.

Occupation Period: Late Archaic, Late Prehistoric.

\section{BX 380}

Location: Terrace site; permanent water source within $.25 \mathrm{~km}$ (Cibolo Creek). No chert in vicinity.

Elevation: $1220^{\prime}$

Environment: The soil is a dark clay-loam with some depth. Vegetation includes sparse grasses and dense juniper and live oak forest.

Description: The site measures approximately $30 \times 30 \mathrm{~m}$. Chipped stone artifacts include points and flakes with a few bifaces and rare core fragments. Cultural deposits are shallow.

Investigation: Diagnostic artifacts were collected and a $2 \mathrm{~m}^{2}$ unit was completely collected.

Occupation Period: Late Prehistoric.

\section{$41 B \times 381$}

Location: Terrace site; water available within one km (Cibolo Creek). No chert available.

Elevation: $1200^{\prime}$

Environment: Vegetation consists of dense juniper and sparse grasses. The soil is very thin; bedrock is predominant on the surface.

Description: The site is a low density lithic scatter covering an area approximate 1 y $150 \times 20 \mathrm{~m}$. Artifacts include points, cores, uniface and biface fragments and fiakes.

Investigation: In addition to collecting the points, a $3 \mathrm{~m}^{2}$ unit was completely collected.

Occupation Period: Late Paleo-Indian. 


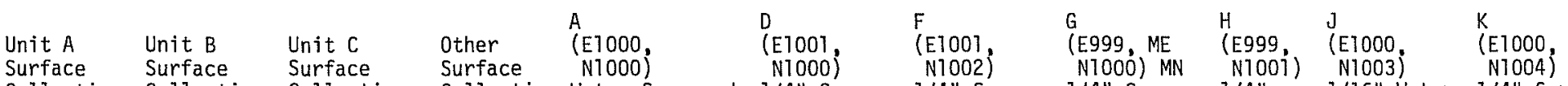
Collection Collection Collection Collection water Screened 1/4" Screen 1/4" Screen 1/4" Screen 1/4" $1 / 16^{\prime \prime}$ Water 1/4" Screen

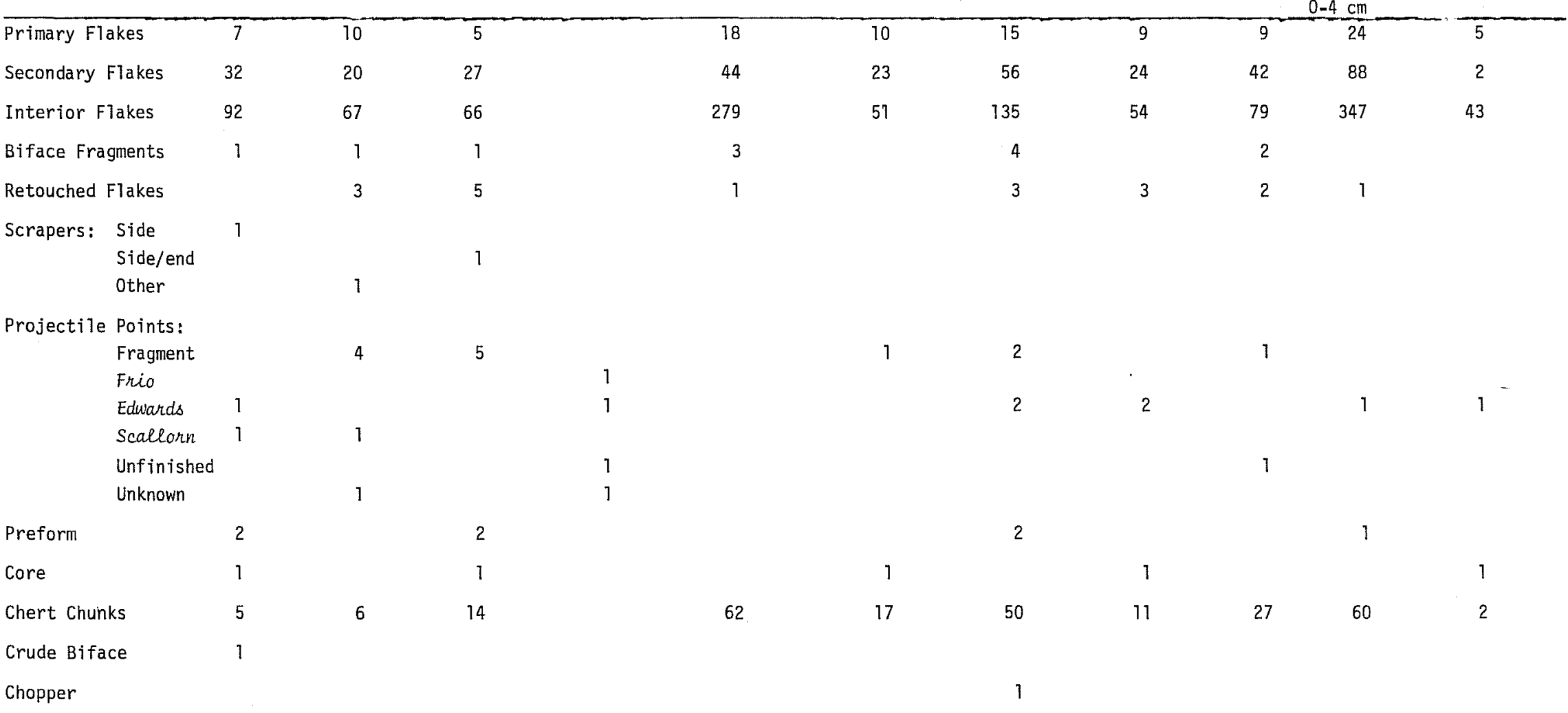


41 BX 382

Location: Upland margin site; a seasonal water supply is available within $.25 \mathrm{~km}$; the Cibolo Creek is ca. $0.3 \mathrm{~km}$ distant.

Elevation: $1240^{\prime}$

Environment: Vegetation is primarily grassy fields with clumps of live oak and juniper. The soil is very thin, with bedrock predominant.

Description: The site is a lithic scatter encompassing an area ca. $85 \times 75 \mathrm{~m}$. Artifacts include points, bifaces, unifaces, core fragments and flakes.

Investigation: A11 diagnostic artifacts were collected, and a $3 \mathrm{~m}^{2}$ unit was completely collected. This was placed in a high density section near the center of the site.

Occupation Period: Late Archaic.

\section{$41 B \times 383$}

Location: Flood plain site, ca. $50 \mathrm{~m}$ south of a water hole in Cibolo Creek (Fig. 36, b). No chert source in area.

\section{Elevation: $1160^{\prime}$}

Environment: Vegetation consists of dense but patchy juniper growth, with moderate grass cover. The soil is dark brown clay, approximately 20 to $30 \mathrm{~cm}$ deep, with some chert gravel. This is an erosional surface (strath plain).

Description: The site is a large lithic scatter with minimum dimensions of $200 \mathrm{~m} \times 50 \mathrm{~m}$. Chipped stone occurs in severa 1 concentrations connected by lower densities of material. Scattered burned rock is visible on the surface.

Investigation: Complete surface collection of $105 \mathrm{~m}^{2}$ units forming a T-shape was accomplished in hopes of defining activity areas and/or separating different occupations (see Fig. 40). This was not successful, probably because of the partial erosion in the collection area, located between dense juniper stands.

Three units were excavated to determine the depth of cultural deposition. Unit 1 (E991, N1003) was excavated in a single level to a depth of $15 \mathrm{~cm}$. A hearth was located, consisting of a concentration of fire-reddened and fractured limestone. A charcoal sample was recovered, as well as three pieces of chipped stone.

Unit 2 (E998, N1005), excavated to a depth of $35 \mathrm{~cm}$, yielded a fair number of artifacts but no features. Only the upper $10 \mathrm{~cm}$ were screened. In spite of this, over a dozen flakes and a biface were recovered from the $30-35 \mathrm{~cm}$ level alone. 


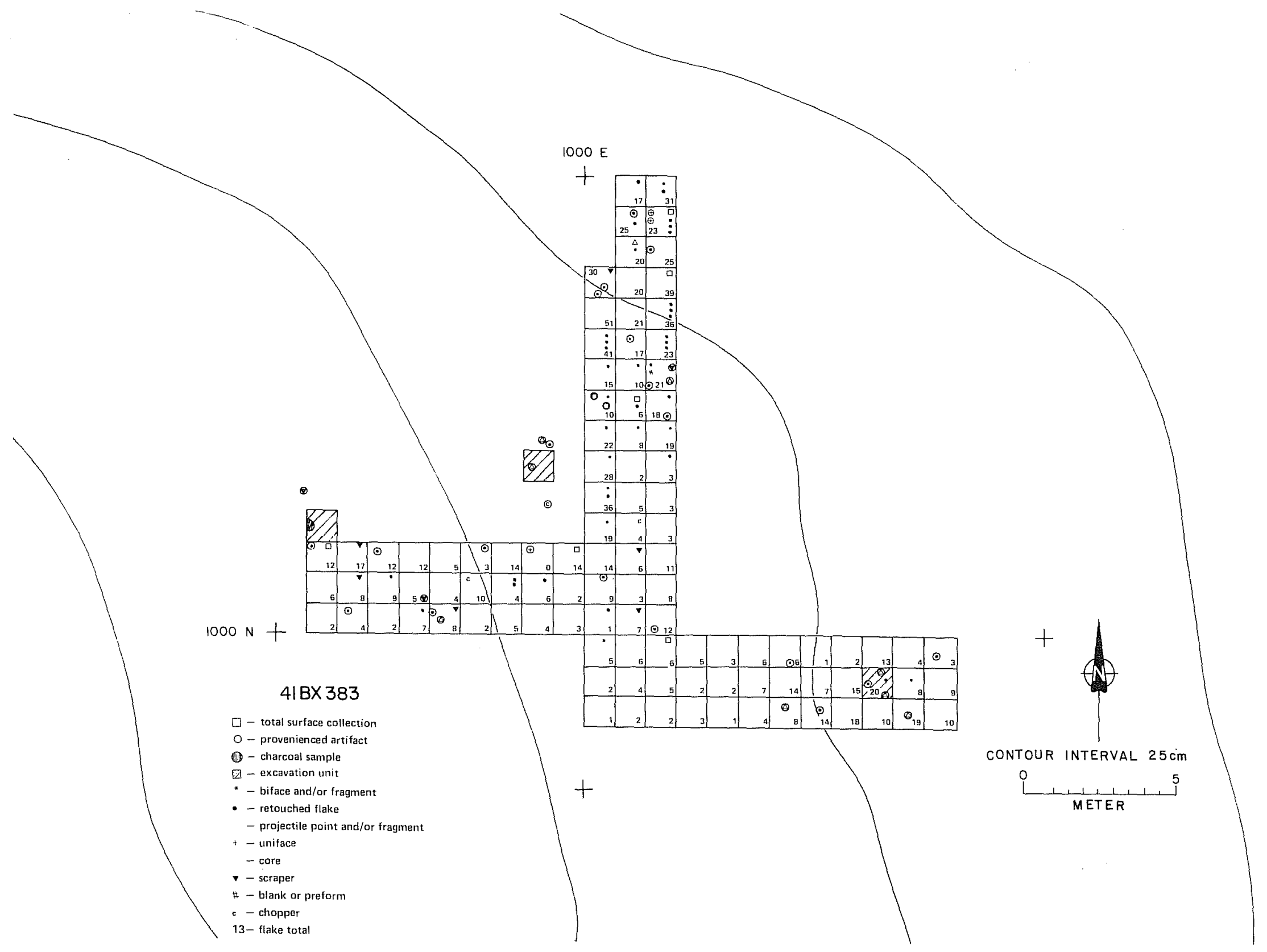

Figure 40. Controlled Surface Collection units at Site 41 BX 383, Camp Bullis. 
Unit 3 (E1009, N998) was excavated in two levels to a depth of $10 \mathrm{~cm}$ and screened with $1 / 4$-inch mesh screen. The upper level yielded one biface fragment, one retouched flake and 35 flakes. The second level contained five flakes.

It appears that the greatest depth of the cultural material is to the north and west of the collection area. However, the hearth located to the west indicates the possibility of a living area to the west. It must be kept in mind that the collection area represents only a small portion of the site and that more extensive excavations over a larger area may reveal patterns that surface disturbance has destroyed.

0ccupation Period: Intensive Late Prehistoric, with a minor Middle and Late Archaic manifestation on the east end of the site.

\section{$41 B \times 384$}

Location: Flood plain site with large river cobbles of medium fine chert; water available within one km (Cibolo Creek).

Elevation: $1240^{\prime}$

Environment: Vegetation consists of open grassy fields with clumps of juniper and live oak. The soil is dark and loamy, of undetermined depth. Large chert gravels are present in the soil.

Description: The site is contained within an area measuring ca. $100 \times 60 \mathrm{~m}$. Artifacts include quarry blanks, preforms, core and core fragments and flakes.

Investigation: Six $1 \mathrm{~m}^{2}$ units were completely collected, in addition to other diagnostic artifacts.

Occupation Period: Unknown, but the size of cores and debitage indicates Archaic or earlier production of large quarry blanks and preforms.

\section{BX 385}

Location: Terrace site; permanent water is available within $100 \mathrm{~m}$ (Cibolo Creek). No chert in immediate area.

Elevation: $1190^{\prime}$

Environment: Only very shallow soil is present; the site is mostly on bedrock. Vegetation is mixed juniper and grasslands.

Description: The site contains scattered burned rock and chipped stone. Artifacts include points, bifaces, cores and flakes. The site area is ca. $5 \times 2 \mathrm{~m}$; the site has no depth. 
Investigation: All diagnostic artifacts were collected as well as a series of five $1 \mathrm{~m}^{2}$ units.

Occupation Period: Late Prehistoric (Austin phase component).

\section{BX 386}

Location: Terrace site; seasonal water available within $50 \mathrm{~m}$ and a permanent water supply (Cibolo Creek) within $200 \mathrm{~m}$. Medium fine chert cobbles in area.

Elevation: $1210^{\prime}$

Environment: The soil is very thin, overlying bedrock. Vegetation is open grassy fields with dense live oak and juniper clumps.

Description: The site is a lithic scatter measuring approximately $50 \times 50 \mathrm{~m}$. Artifacts include an unidentifiable arrow point fragment, bifaces, cores and flakes. The point and tools are concentrated toward one edge of the site.

Investigation: In addition to collecting the diagnostic artifacts, an area measuring $3 \times 2 \mathrm{~m}$ was completely collected near the site center.

0ccupation Period: Late Prehistoric.

\section{BX 387}

Location: Terrace site; Cibolo Creek affords a permanent water supply within $100 \mathrm{~m}$. No chert resources.

Elevation: $1210^{\prime}$

Environment: Vegetation is the typical terrace covered by juniper and live oak clumps. The soil is a reddish clay with chert nodules present. The soil depth is undetermined.

Description: The site is a lithic scatter covering an area ca. $30 \times 6 \mathrm{~m}$. Artifacts include point fragments, bifaces, unifaces, cores and flakes.

Investigation: A $3 \mathrm{~m}^{2}$ unit was completely collected and all diagnostic artifacts were collected and mapped.

Occupation Period: Late Prehistoric.

\section{BX 388}

Location: Terrace site; water available within $100 \mathrm{~m}$ from two intermittent streams and from the Cibolo Creek, ca, one km distant. 


\section{Elevation: $1270^{\prime}$}

Environment: The soil is of the reddish clay type with chert gravels present. Vegetation consists of open grassy fields with clumps of juniper and live oak.

Description: This site is a smal1 $(15 \times 6 \mathrm{~m})$ 1ithic scatter containing a point, biface fragments, a scraper and flakes. No chert resources.

Investigation: $\mathrm{A} 3 \mathrm{~m}^{2}$ unit was completely collected.

Occupation Period: Early Archaic.

\section{BX 390}

Location: Upland margin site; nearest water source more than one km distant. No chert resources.

\section{Elevation: $1250^{\prime}$}

Environment: The area is predominantly limestone bedrock with very thin soil cover. Vegetation consists of woods of live oak, hackberry, huisache, juniper and $\mathrm{elm}$.

Description: The site is a moderate density small lithic scatter with scattered burned rock on the surface. It measures approximately $12 \times 17 \mathrm{~m}$, and contains an unidentifiable dart point, biface and core fragments, a preform and flakes.

Investigation: Diagnostic artifacts were collected and mapped. In addition, a $3 \mathrm{~m}^{2}$ area was completely collected.

Occupation Period: Archaic.

\section{$41 B \times 391$}

Location: Terrace site; seasonal water source is available within $100 \mathrm{~m}$ (Muesebach Creek).

\section{Elevation: $1175^{\prime}$}

Environment: Dark loamy soil of some depth and dense juniper and thorny brush vegetation characterize the area of the site.

Description: The site consists of a large lithic scatter with dimensions of approximately $140 \times 90 \mathrm{~m}$. Artifacts include points, cores and core fragments, biface fragments, scrapers, preforms and flakes. Depth of deposits is indeterminate.

Investigation: Artifacts were collected and mapped. A $2 \mathrm{~m}^{2}$ area was also completely collected.

Occupation Period: Late Paleo-Indian, Early Archaic. 


\section{$41 B \times 392$}

Location: Upland margin site; nearest seasonal water supply ca. $200 \mathrm{~m}$ away, and a permanent source (Cibolo Creek) within one $\mathrm{km}$.

Elevation: $1305^{\prime}$

Environment: Bedrock surface with on ly very thin soil cover underlies the site. Vegetation is characterized by grassy fields with juniper and live oak brakes.

Description: The site is a sma 11 lithic concentration about $5 \times 2 \mathrm{~m}$ in measurement. Artifacts include a point, unifaces, quarry blanks, biface fragments and flakes.

Investigation: In addition to collecting diagnostic artifacts and special tools, an area measuring $1.5 \times 2.5 \mathrm{~m}$ was completely collected.

Occupation Period: Late Prehistoric.

\section{BX 393}

Location: Upland margin site; water source within $100 \mathrm{~m}$.

Elevation: $1320^{\prime}$

Environment: The soil is thin with bedrock predominant. Vegetation consists of grassy fields with juniper and live oak clumps.

Description: The site contains only chipped stone in an area approximately $50 \times 50 \mathrm{~m}$. Artifacts include points, biface fragments, scrapers, cores and flakes.

Investigation: $\mathrm{A} 3 \mathrm{~m}^{2}$ area was completely collected as well as additional artifacts (Fig. 41,a).

Occupation Period: Unknown.

41 BX 395

Location: Upland margin site located along a seasonal stream. The Salado Creek, currently only seasonal, is within one $\mathrm{km}$. Bedded 1 ime chert resources.

Elevation: $1140^{\prime}$

Environment: Bedrock with very thin soil cover is characteristic. Vegetation includes grassy fields with juniper and live oak brakes.

Description: The site is a lithic scatter with dimensions of ca. $40 \times 20 \mathrm{~m}$. Chert nodules, cores, preforms and flakes are present. 


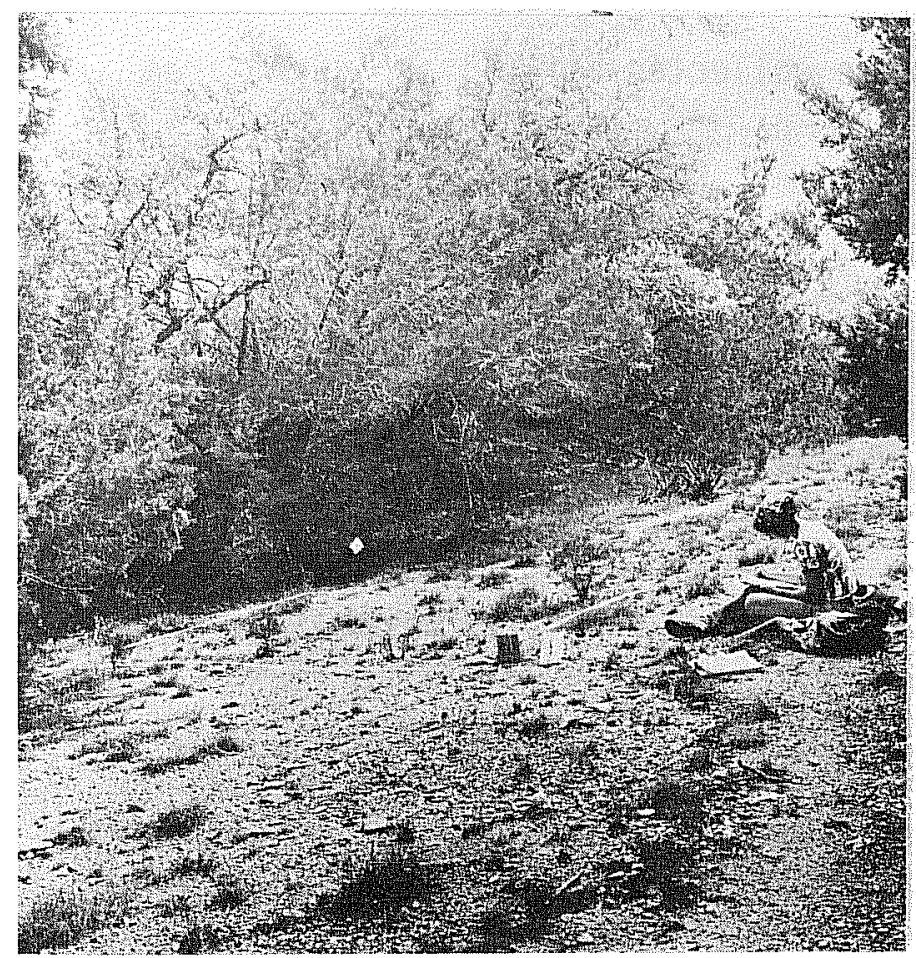

a

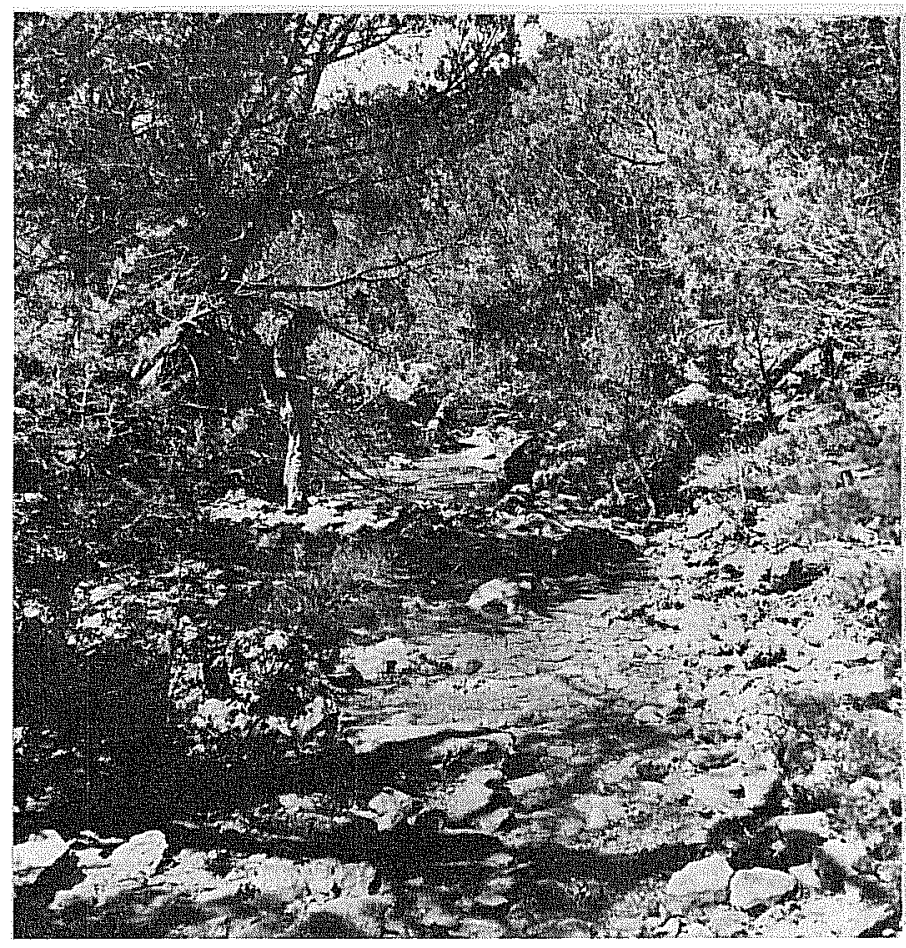

C

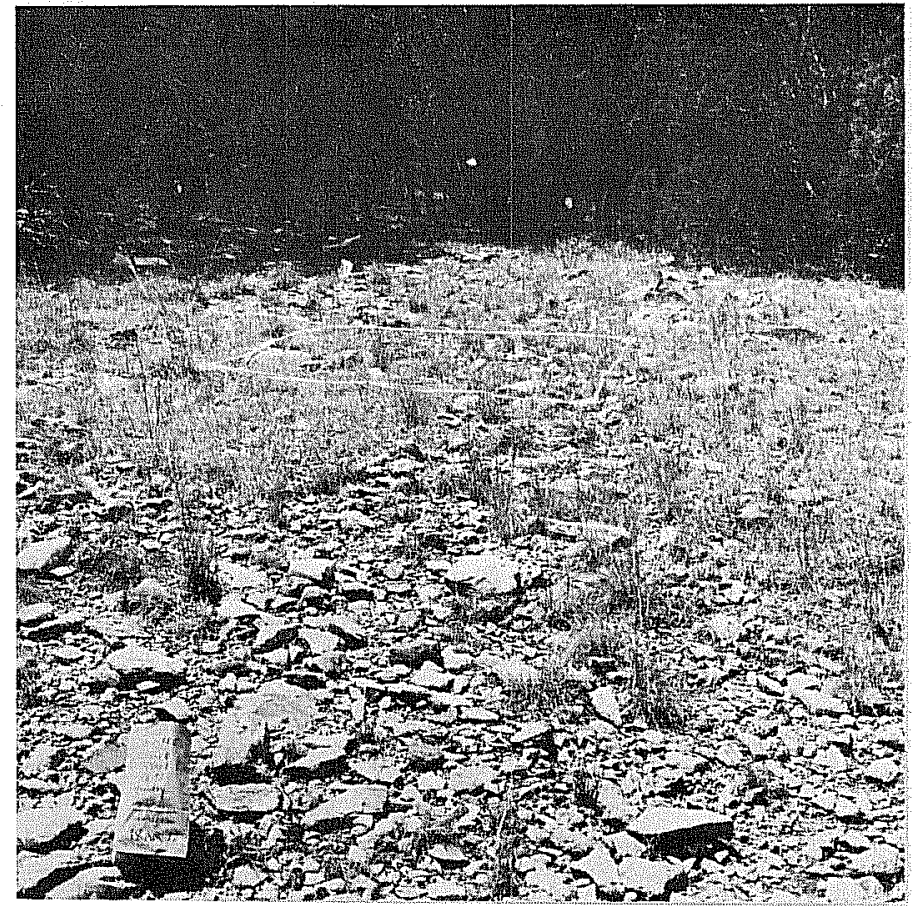

b

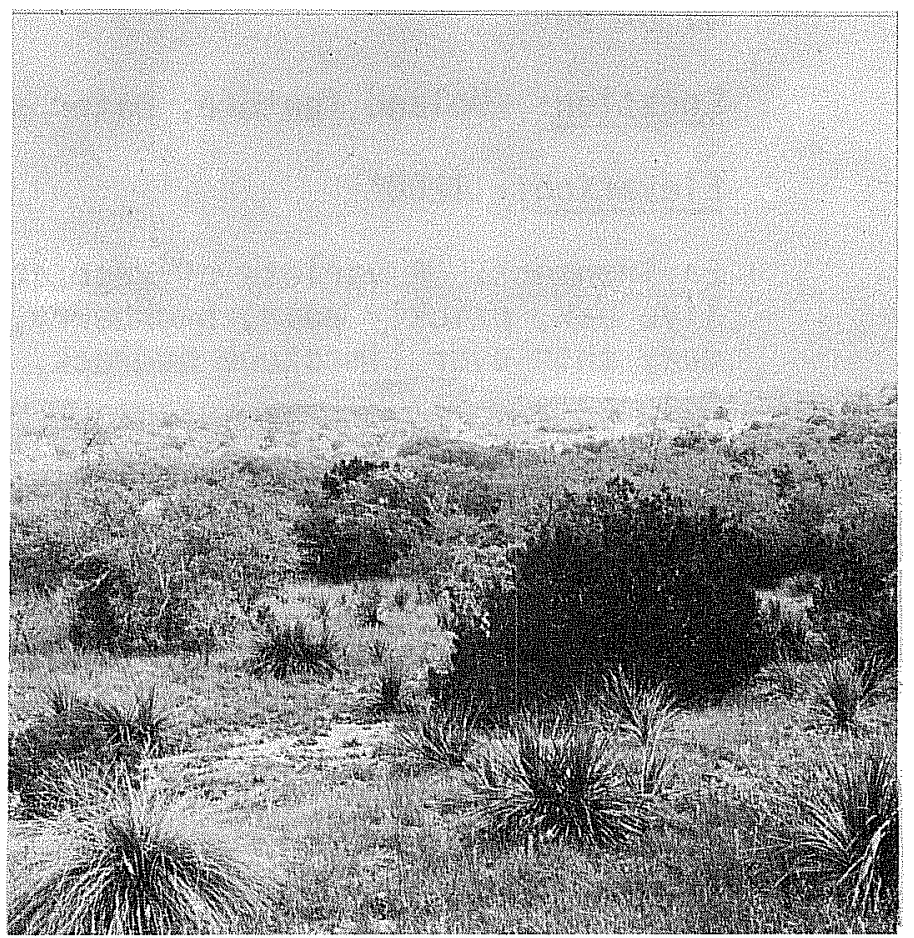

d

Figure 41. Views of Prehistoric Sites, Camp Bullis. a, 41 BX 393, view of controlled collection unit; b, 41 BX 395, view of controlled collection unit; c, 41 BX 408, view looking south along Lewis Creek; d, view of area near 41 BX 437. 
Investigation: Worked chert artifacts were collected as well as a $2 \mathrm{~m}^{2}$ area (Fig. 47,b).

Occupation Period: Unknown.

\section{$41 B \times 396$}

Location: The site is located on a terrace above a presently seasonal drainage within $100 \mathrm{~m}$ of the site. No chert resources.

Elevation: $1140^{\prime}$

Environment: Juniper and live oak brakes are interspersed with grassy areas and prickly pear patches. The soil is a dark loam of considerable depth.

Description: The site is divided into two parts. The northern part has scattered burned rock and chipped stone including points, scrapers, biface fragments, flakes and a possible mano fragment. The southern portion has only chipped stone artifacts including biface fragments, preforms, cores and flakes.

Investigation: Artifacts were collected and mapped from both parts of the site. In the south part, a $50 \mathrm{~cm}$ square test pit was excavated to a depth of five $\mathrm{cm}$. The cultural deposits were no deeper than four $\mathrm{cm}$, where the dark loam became reddish clay. In addition a $3 \mathrm{~m}^{2}$ area was completely surface collected.

Occupation Period: Late Prehistoric.

41 BX 399

Location: Upland feature; water source, Salado Creek, within one km. Elevation: $1200^{\prime}$

Environment: A variety of vegetation is present, including grasses, juniper, live oak, prickly pear, hackberry, huisache and beargrass. The soil cover is very thin over limestone bedrock, containing abundant chert.

Description: The site is a very low density lithic scatter covering an area approximately $500 \times 500 \mathrm{~m}$. Artifacts include unidentifiable dart point fragments, bifaces, scrapers, cores and flakes. Bedded chert provides a lithic resources procurement area.

Investigation: Selected worked chert artifacts were collected in addition to a $2 \mathrm{~m}^{2}$ area on the south slope of Bush Hill.

Occupation Period: Archaic.

\section{$41 B \times 400$}

Location: Terrace site, $100 \mathrm{~m}$ south of the south fork of Muesebach Creek, an ephemeral stream. 


\section{Elevation: $1260^{\prime}$}

Environment: Vegetation consists of juniper and live oak clumps and fields of moderately heavy grass cover. The soil is a rocky dark brown clay.

Description: The site is a lithic scatter measuring approximately $10 \times 10 \mathrm{~m}$. Artifacts include points, bifaces, scrapers and flakes.

Investigation: Initial investigation involved complete surface collection of a $3 \mathrm{~m}^{2}$ area and excavation of a $1 \mathrm{~m}^{2}$ unit to a depth of five $\mathrm{cm}$. Further activities include horizontal excavations consisting of a block of four $1 \mathrm{~m}^{2}$ units and a second block of five $1 \mathrm{~m}^{2}$ units (Fig. 42, Table 13). No hearths or other features were observed. The density of land snails was very high and almost exclusively Rabdotus sp. Their significance is unknown.

Occupation Period: Early Archaic, Late Archaic, Late Prehistoric.

\section{BX 402}

Location: Upland margin site; water is available seasonally from Salado Creek, within one $\mathrm{km}$.

Elevation: $1205^{\prime}$

Environment: Vegetation includes woods of live oak, hackberry, huisache, juniper and elm. Red clay soil with chert gravel is present.

Description: The site covers an area approximately $40 \times 30 \mathrm{~m}$ and has a high density of chipped stone, one mano and scattered burned rock. Chipped stone artifacts include points, bifaces, scrapers, cores and flakes.

Investigation: A11 worked chert was collected and mapped. A $3 \mathrm{~m}^{2}$ area was completely collected.

Occupation Period: Pre-Archaic, Late Archaic.

\section{BX 403}

Location: Valley slope site; seasonal drainage near the site. The Salado Creek is within one $\mathrm{km}$.

Elevation: $1140^{\prime}$

Environment: Very thin soil overlying bedrock supports a vegetation cover consisting of grassy fields with clumps of live oak and juniper.

Description: The site is a chipped stone scatter with dimensions of ca. $60 \mathrm{x}$ $40 \mathrm{~m}$. Artifacts include points, bifaces, a perforator and flakes. Scattered burned rock is present.

Investigation: Worked chert was collected and mapped. 
148

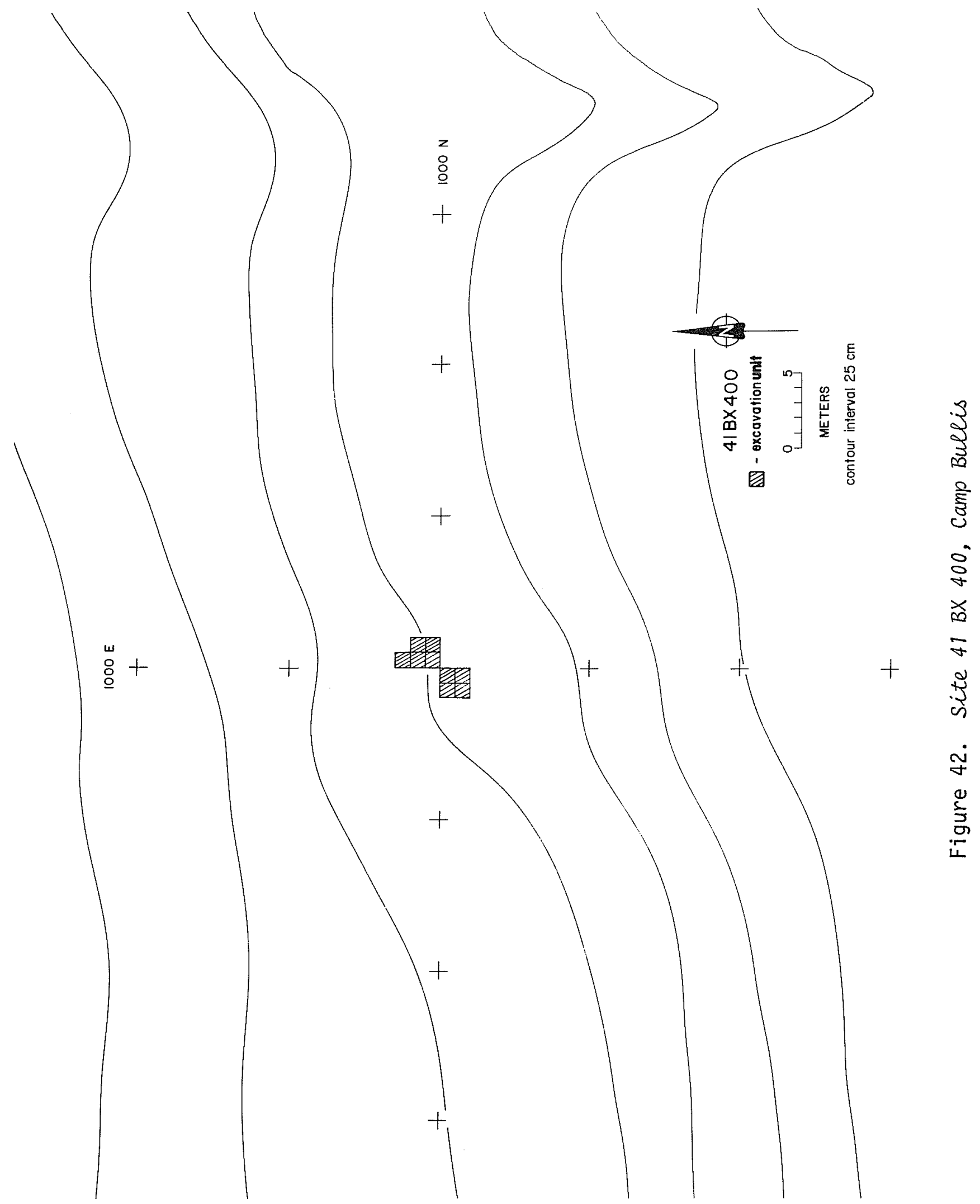


TABLE 13. ARTIFACT PROVENIENCE AT 41 BX 400

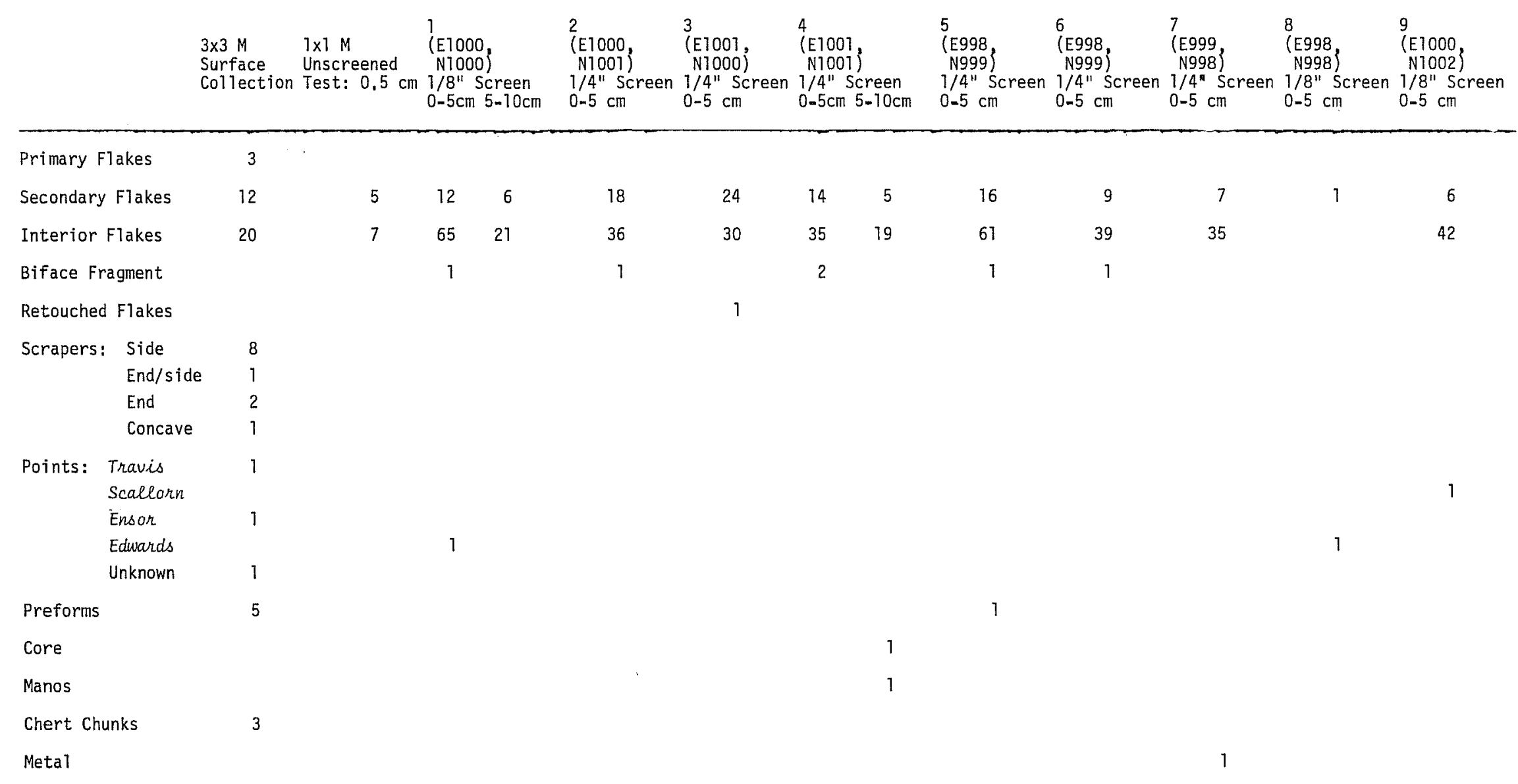


Occupation Period: Late Paleo-Indian, Pre-Archaic, Early Archaic, Middle Archaic.

$41 B \times 404$

Location: Upland site between two seasonal tributaries of Salado Creek, Salado Creek is within one $\mathrm{km}$ of the site.

\section{Elevation: $1140^{\prime}$}

Environment: Grassy fields and clumps of juniper and live oak are supported by very thin soil cover overlying bedrock.

Description: The site is a lithic scatter with dimensions of approximately $600 \times 100 \mathrm{~m}$. Artifacts include bifaces, choppers, quarry blanks, cores and flakes. A concentration of quarry blanks and flakes were noted. Chert nodules are eroding from Edwards Limestone.

Investigation: $A 2 \mathrm{~m}^{2}$ area in the approximate site center was completely collected as well as a $1 \mathrm{~m}^{2}$ area from the subconcentration.

0ccupation Period: Unknown.

$41 B \times 405$

Location: Upland margin site; seasonal tributary of Salado Creek ca. $30 \mathrm{~m}$ from the site.

Elevation: $1100^{\prime}$

Environment: Vegetation is composed of grassy fields with clumps of live oak and juniper. Prickly pear and yucca/sotol are also present. The soil is reddish clay with chert gravels.

Description: The site is a smal1 lithic scatter covering an area ca. $25 \times 20 \mathrm{~m}$. Artifacts include cores, core fragments and flakes. No tools were observed.

Investigation: No collection was made.

Occupation Period: Unknown.

41 BX 406

Location: Valley slope site; seasonal water supply available within one $\mathrm{km}$. Elevation: $1070^{\prime}$

Environment: Vegetation consists of grassy fields with juniper and live oak clumps. Bedrock is predominant with very thin soil cover. 
Description: The site is a moderate density lithic scatter covering an area ca. $200 \times 350 \mathrm{~m}$. Cores, core fragments and flakes are common. One bifacial scraper and retouched fiakes were also found.

Investigation: No collection was made.

Occupation Period: Unknown.

$41 B \times 407$

Location: Upland margin site; seasonal water supply approximately $400 \mathrm{~m}$ away.

Elevation: $1190^{\prime}$

Environment: Vegetation includes grasses and juniper and live oak stands plus prickly pear and yucca/sotol. Soil cover is very thin.

Description: The site is a moderate density lithic concentration covering an area approximately $50 \times 25 \mathrm{~m}$. Points, bifaces? quarry blanks, gravers, cores and flakes are present.

Investigation: A $3 \mathrm{~m}^{2}$ area was completely collected.

Occupation Period: Pre-Archaic, Late Archaic.

\section{$41 B \times 408$}

Location: Terrace site; water source (Lewis Creek) whin $100 \mathrm{~m}$ (Fig. 41,c). No chert resources.

Elevation: $1210^{\prime}$

Environment: Ground cover consists of juniper and grasses. Reddish clay soil is present.

Description: The site is a moderate density lithic scatter with dimensions of ca. $20 \times 15 \mathrm{~m}$. Points, bifaces, preforms, scrapers and flakes are present.

Investigation: A $3 \mathrm{~m}^{2}$ area was completely collected.

Occupation Period: Late Paleo-Indian, Middle Archaic.

$41 B \times 409$

Location: Terrace site; water available within one $\mathrm{km}$. Elevation: $1070^{\prime}$ 
Environment: Vegetation consists of juniper and grassland. Bedrock is predominant with very thin soil cover.

Description: The site is sma $11(30 \times 18 \mathrm{~m})$ and contains scattered chipped stone and burned rock. Points, bifaces, preforms, quarry blanks, scrapers, cores and core fragments, a Guadalupe tool and flakes are present.

Investigation: A $3 \mathrm{~m}^{2}$ area was completely collected in addition to other tools and diagnostics.

0ccupation Period: Pre-Archaic, Late Archaic.

41 BX 410

Location: Terrace site; Panther Springs Creek ca. $220 \mathrm{~m}$ distant.

Elevation: 1060'

Environment: Juniper and grassland vegetation is supported by dark clay-loam soil of indeterminate depth.

Description: The site is a lithic concentration measuring ca. $30 \times 15 \mathrm{~m}$. Artifacts include bifaces, unifaces, preforms, quarry blanks, core fragments and flakes.

Investigation: Worked chert was collected and mapped as well as a $5 \mathrm{~m}^{2}$ area. Occupation Period: Unknown.

41 BX 411

Location: Terrace site; seasona 1 water supply from Parither Springs Creek and a tributary stream, ca. 350 to $500 \mathrm{~m}$ distant.

Elevation: 1040'

Environment: The soil is very thin; bedrock outcrops are common. Vegetation is primarity juniper and grassland.

Description: The site is a lithic concentration covering an area of approximately $80 \times 80 \mathrm{~m}$. Artifacts include bifaces, quarry blanks, core and core fragments and flakes.

Investigation: A $1 \mathrm{~m}^{2}$ area was completely collected.

Occupation Period: Unknown. 
41 BX 412

Location: Terrace site; approximately $270 \mathrm{~m}$ from Panther Springs Creek, a seasona 7 water supply.

Elevation: $1060^{\prime}$

Environment: The area is predominantly bedrock, with a very thin and patchy soil cover. Vegetation consists of juniper and grassland.

Description: The site is a lithic scatter covering an area approximately $35 \times 20 \mathrm{~m}$. Artifacts include bifaces, quarry blanks, scrapers, core fragments and flakes.

Investigation: $\mathrm{A} 3 \mathrm{~m}^{2}$ area was completely collected in addition to other worked chert and diagnostic artifacts.

Occupation Period: Unknown.

$41 B \times 412$

Location: Terrace site; water available within one $\mathrm{km}$.

Elevation: $1070^{\prime}$

Environment: Clumps of juniper and live oak interspersed with grassy fields are the characteristic vegetation. The soil is a dark loam of indeterminate depth.

Description: The site is a lithic concentration within an area of ca. $30 \mathrm{x}$ $15 \mathrm{~m}$. Artifacts include bifaces, scrapers and flakes.

Investigation: Worked chert artifacts were collected and mapped. A $3 \mathrm{~m}^{2}$ area was completely collected.

Occupation Period: Unknown.

\section{BX 414}

Location: Upland margin site; seasonal water supply within $100 \mathrm{~m}$ and the Salado Creek approximately one km away.

Elevation: $1150^{\prime}$

Environment: Vegetation consists of grassy fields with clumps of juniper and live oak. Thin soil overlies limestone bedrock.

Description: The site is a lithic scatter covering an area approximately $200 \times 100 \mathrm{~m}$. Artifacts include cores, core fragments and flakes. 
Investigation: Two adjacent $1 \mathrm{~m}^{2}$ areas were completely collected. Occupation Period: Unknown.

41 BX 415

Location: Terrace site, approximately $500 \mathrm{~m}$ from Panther Springs Creek. Elevation: $1150^{\circ}$

Environment: Vegetation consists of open grassy fields with juniper and live oak clumps. The soil is dark and loamy.

Description: The site is a lithic scatter spread out over an area approximateTy $400 \times 300 \mathrm{~m}$. Artifacts include quarry blanks and flakes.

Investigation: $\mathrm{A} 3 \mathrm{~m}^{2}$ area was completely collected.

Occupation Period: Unknown.

$41 B \times 416$

Location: Terrace site; seasonal water supply within one $\mathrm{km}$.

Elevation: $1130^{\prime}$

Environment: Juniper and live oak brakes are supported by reddish clay soil of indeterminate depth.

Description: The site is a lithic concentration scattered over a $20 \times 15 \mathrm{~m}$ area. Artifacts include flakes and chert chunks.

Investigation: $\mathrm{A} 2 \mathrm{~m}^{2}$ area was completely collected.

Occupation Period: Unknown.

$41 B \times 417$

Location: Terrace site; nearest water source (seasonal) less than one $\mathrm{km}$ distant.

Elevation: $1100^{\prime}$

Environment: Vegetation consists of grassy fields with live oak and juniper clumps. Bedrock is predominant with very thin soil cover.

Description: The site is a lithic concentration with flakes and core fragments present. The site area is approximately $20 \times 10 \mathrm{~m}$. 
Investigation: No collection was made.

Occupation Period: Unknown.

\section{BX 418}

Location: Terrace site; seasonal water source within $100 \mathrm{~m}$.

Elevation: 1100'

Environment: Dark loamy soil with a vegetation cover of grassy fields and juniper and live oak brakes.

Description: The site covers an area approximately $40 \times 40 \mathrm{~m}$ and contains chipped stone artifacts, including cores and flakes.

Investigation: Two adjacent $1 \mathrm{~m}^{2}$ areas were completely collected.

Occupation Period: Unknown.

41 BX 419

Location: Upland margin lithic resources procurement site; seasonal tributary of Salado Creek ca. $200 \mathrm{~m}$ distant.

Elevation: 1140'

Environment: Vegetation includes grassy fields with juniper and live oak clumps. Bedrock is predominant with a very thin soil cover.

Description: The site is a lithic concentration covering an area ca. $60 \times 50 \mathrm{~m}$. Chipped stone includes bifaces, preforms, scrapers, cores and flakes.

Investigation: Worked chert artifacts were collected and mapped and a $2 \mathrm{~m}^{2}$ area was completely collected.

Occupation Period: Unknown.

\section{$41 B \times 421$}

Location: Upland site; seasonal water supply available 300 to $400 \mathrm{~m}$ distant and the Salado Creek approximately $1.25 \mathrm{~km}$ away.

Elevation: $1150^{\prime}$

Environment: Vegetation is composed of grassland with juniper and live oak brakes. The soil is very thin, overlying bedrock. 
Description: The site is a lithic concentration with an area of approximately $50 \times 40 \mathrm{~m}$. Artifacts include cores, core fragments, flakes, scrapers and bifaces.

Investigation: A $2 \mathrm{~m}^{2}$ area was completely collected and other artịfacts were collected and mapped.

Occupation Period: Unknown.

$41 B \times 423$

Location: Upland site; water available more than one $\mathrm{km}$ distant.

Elevation: $1200^{\prime}$

Environment: Vegetation includes live oak, huisache, juniper, prickly pear and yucca/sotol. Bedrock predominates, with very thin soil cover.

Description: The site consists of chipped stone scattered over an area ca. 40 $\times 20 \mathrm{~m}$. Artifacts include bifaces, cores and flakes.

Investigation: A $3 \times 2 \mathrm{~m}$ area was completely collected along with other artifacts.

Occupation Period: Unknown.

41 BX 424

Location: Valley slope site; seasonal drainage near the site and Panther Springs Creek ca. $300 \mathrm{~m}$ distant.

Elevation: $1275^{\prime}$

Environment: Vegetation consists of live oak, huisache, juniper, prickly pear and yucca/sotol. The soil. is very thin with bedrock outcrops.

Description: The site is a lithic scatter covering an area $40 \times 40 \mathrm{~m}$. Artifacts include points and flakes.

Investigation: In addition to a collection of diagnostic artifacts, a $2 \mathrm{~m}^{2}$ area was completely collected.

Occupation Period: Late Paleo-Indian.

$41 B \times 425$

Location: Terrace site located within $100 \mathrm{~m}$ of Cibolo Creek. A water hole provides a permanent supply currentiy. The creek was probably much higher at the time of site occupation (Fig. $43, a$ ). 


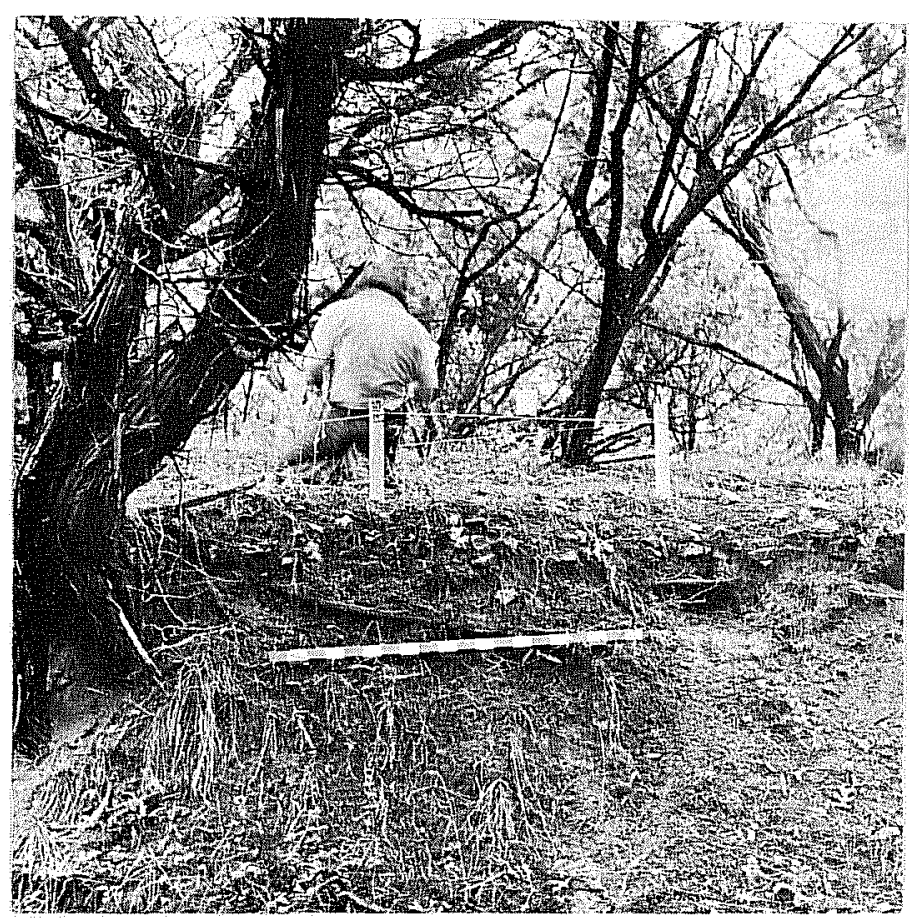

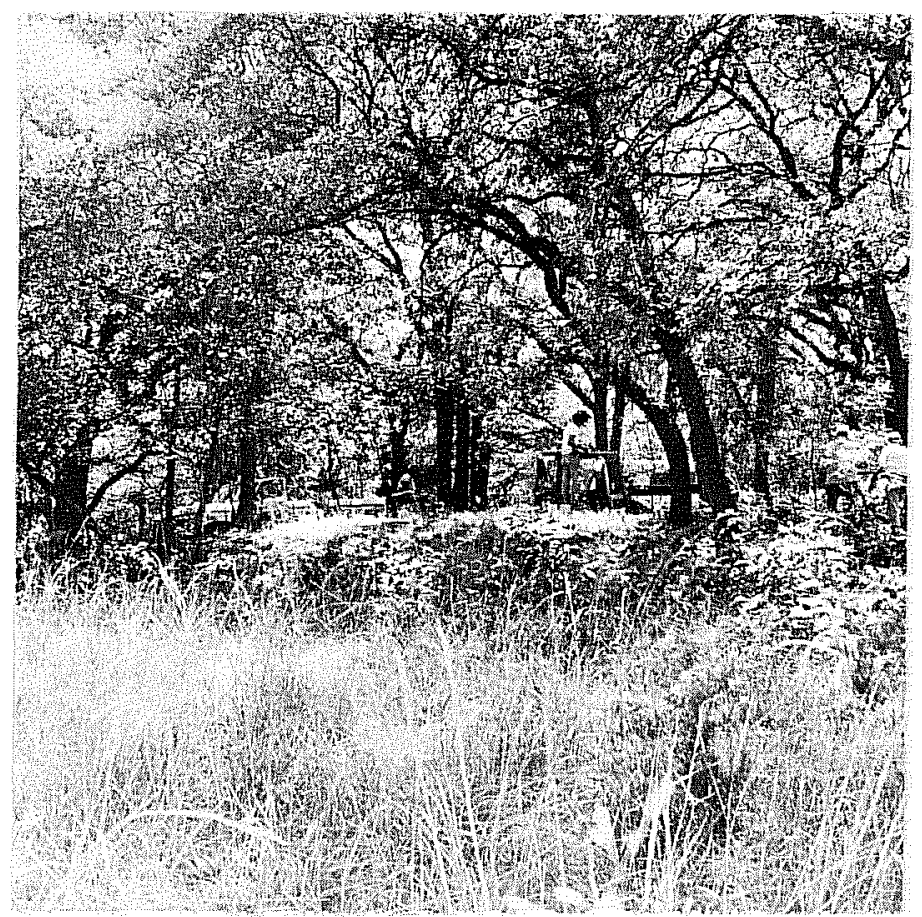

b

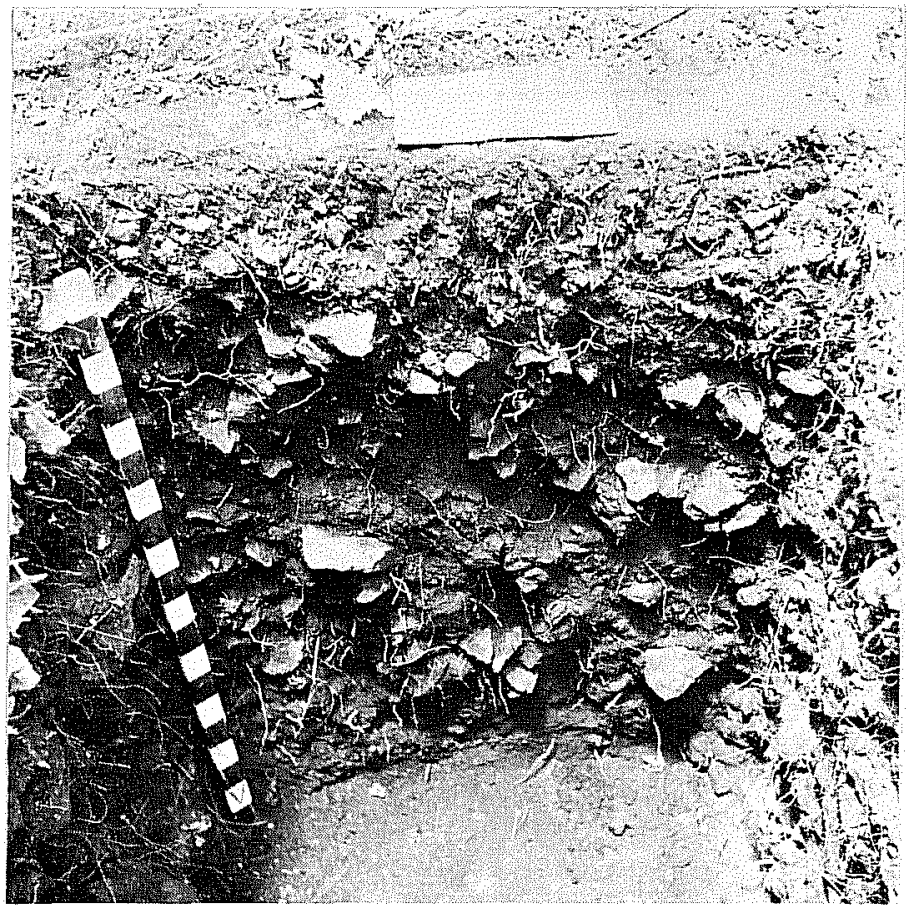

C

Figure 43. Views of Prehistoric Sites, Camp Bullis. a, $41 \mathrm{BX} 425$, meter stick 1 ies at a profile cleared along roadcut through site; b, $41 \mathrm{BX} 428$, general view looking south; C, 41 BX 428, profile of east wall of Unit 2 at $110 \mathrm{~cm}$. 


\section{Elevation: $1180^{\prime}$}

Environment: The site is covered and surrounded by dense juniper growth and sparse grass cover. The soil is very thick, alluvially deposited reddish sandy silt.

Description: The site is recognizable in a jeep road cut throuqh the terrace which has exposed the layer of burned rock making up the site. No artifacts are visible on the surface.

Investigation: Initial investigation consisted of a shovel test in the northcentral part of the site, taken to a depth of $35 \mathrm{~cm}$ and unscreened. A flake, a Pedernales point and a broken mano were recovered, and some charcoal was noted.

Further testing involved the excavation of six $1 \mathrm{~m}^{2}$ units placed in a row across the northwestern portion of the site (Fig. 44). The jeep road profile was cleaned and mapped (Fig. 45).

The excavations indicated that the burned rock layer was formed on a hill sloping to the east. The thickness of the burned rock varies from 20 to $30 \mathrm{~cm}$. It is $10 \mathrm{~cm}$ deep in the western portion of the excavations, increasing to 80 $\mathrm{cm}$ deep in the eastern end. A hearth-7ike feature was uncovered in the western half, consisting of a concentration of smaller burned rock fragments in a pile. No definite outline or structure could be identified.

Table 14 presents the provenience of artifacts recovered as well as the volume of burned rock in each level.

Occupation Period: Early Archaic through Late Prehistoric.

$41 B \times 426$

Location: Terrace site; water source (seasonal) within one $\mathrm{km}$.

Elevation: $1210^{\prime}$

Environment: Reddish clay soil is present with a vegetation cover of woods of live oak, hackberry, huisache, juniper and elm,

Description: The site is a lithic concentration approximately $20 \times 20 \mathrm{~m}$. Artifacts include points, biface fragments, preforms, core fragments and flakes.

Investigation: Worked chert artifacts were collected as well as an area measuring $3 \times 1 \mathrm{~m}$.

Occupation Period: Early Archaic, Late Prehistoric. 


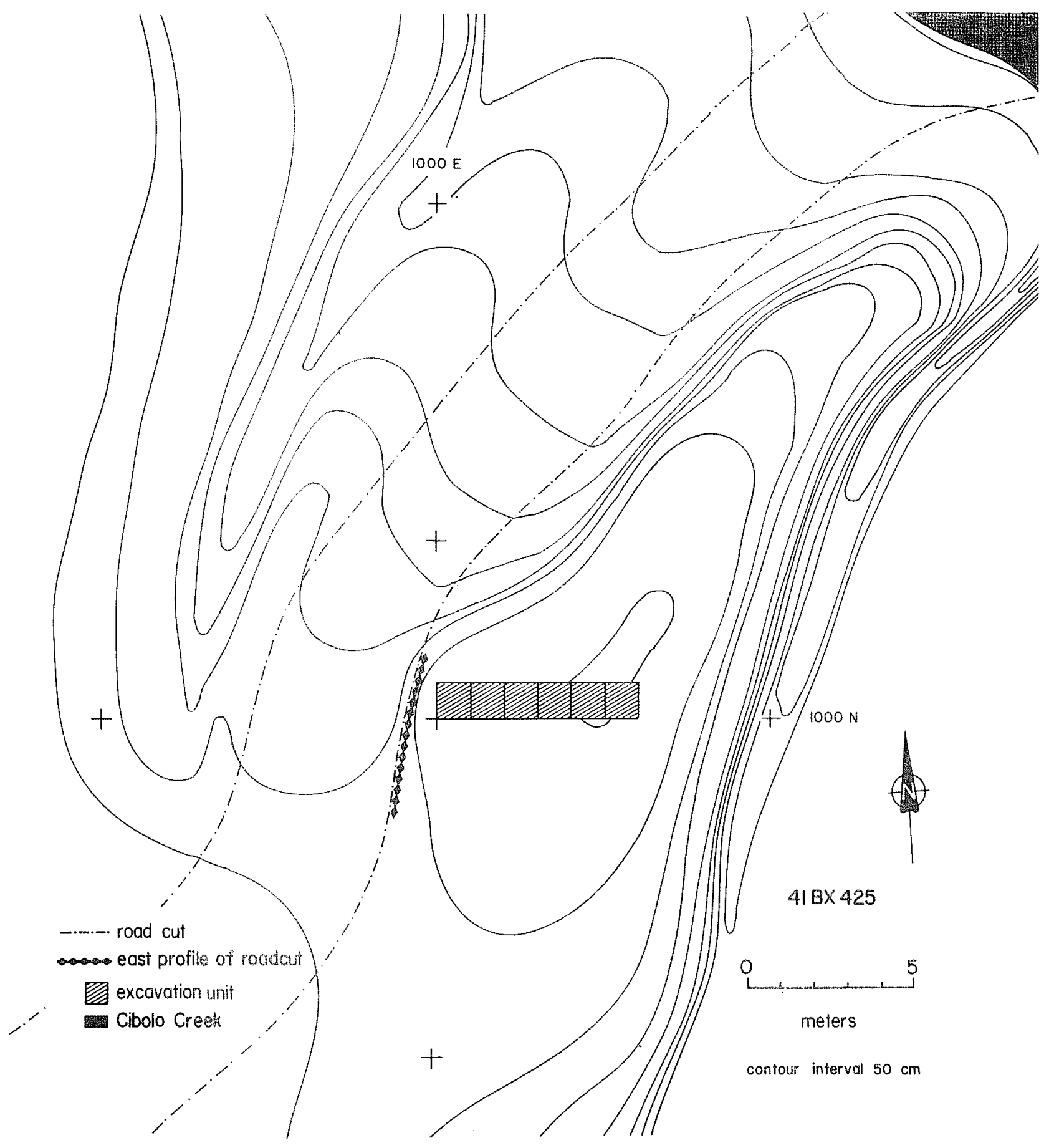

Figure 44. Site 41 BX 425, Camp Bullis. 
$41 \mathrm{BX} 425$

\section{EAST PROFILE OF ROADCUT}

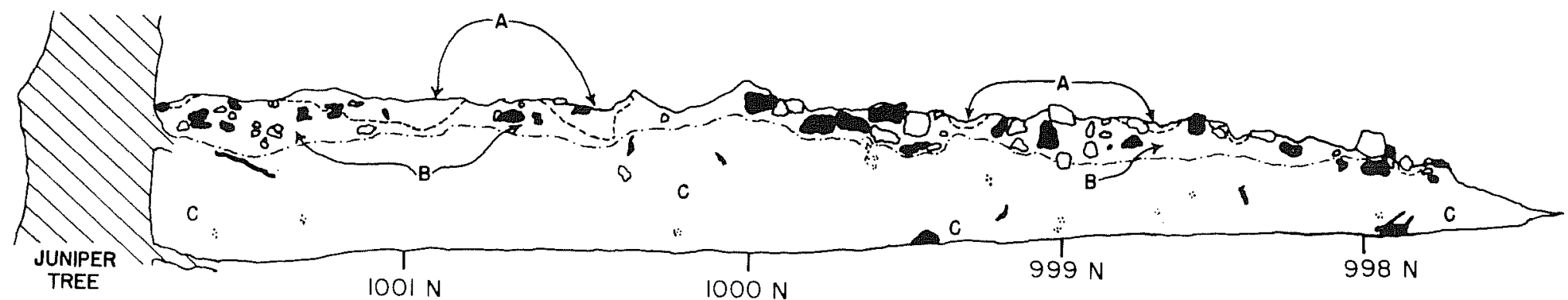

$$
\begin{aligned}
& \text { MUNSELL COLOR } \\
& \text { A - } 5 \text { YR } 2.5 / 2 \\
& \text { B } 7.5 Y R 5 / 4 \\
& C-10 Y R 4 / 6 \\
& \text { - BURNED ROCK } \\
& \text { - SCATTERED ROCK } \\
& : \text { - SNAIL SHELL } \\
& \text { - ROOT }
\end{aligned}
$$

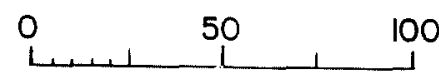

GENTIMETERS

Figure 45. Site 41 BX 425, Camp Bullis: East Profile. The east profile along the road cut at site 41 BX 425 is shown. See Fig. 44 for location of this profile within the site. 
TABLE 14. ARTIFACT PROVENIENCE AT 41 BX 425

\begin{tabular}{|c|c|c|c|c|c|c|c|c|}
\hline Unit & $\begin{array}{l}\text { Depth } \\
\text { below } \\
\text { Datum } \\
\end{array}$ & $\begin{array}{r}\text { Level } \\
(\mathrm{cm}) \\
\end{array}$ & $\begin{array}{l}\text { Screen } \\
\text { Size }\end{array}$ & $\begin{array}{l}\text { Vol. of } \\
\text { Burned } \\
\text { Rock* } \\
\end{array}$ & $1^{\circ}$ & $\begin{array}{c}\text { Flakes } \\
\underline{2}^{\circ}\end{array}$ & Int. & Other Lithics ${ }^{\ddagger}$ \\
\hline $\begin{array}{c}A \\
(E 1000, \\
N 1000)\end{array}$ & $41 \mathrm{~cm}$ & $\begin{array}{l}0-5 \\
5-10 \\
10-15\end{array}$ & $\begin{array}{l}1 / 4^{\prime \prime} \\
1 / 8^{\prime \prime} \\
?\end{array}$ & $\begin{array}{c}4120 \\
8858 \\
?\end{array}$ & $\begin{array}{l}5 \\
0 \\
0\end{array}$ & $\begin{array}{l}7 \\
0 \\
2\end{array}$ & $\begin{array}{l}40 \\
15 \\
10\end{array}$ & $\begin{array}{l}- \\
-\end{array}$ \\
\hline $\begin{array}{c}\text { B } \\
(E 1001, \\
\text { N1000) }\end{array}$ & $33 \mathrm{~cm}$ & $\begin{array}{r}0-10 \\
10-20 \\
20-25 \\
25-30 \\
30-35 \\
35-40 \\
40-45\end{array}$ & $\begin{array}{l}1 / 4^{\prime \prime} \\
1 / 8 " \\
11 \\
11 \\
11\end{array}$ & $\begin{array}{r}1030 \\
2678 \\
8858 \\
8240 \\
10,300 \\
6798 \\
4120\end{array}$ & $\begin{array}{l}1 \\
2 \\
0 \\
2 \\
0 \\
0 \\
0\end{array}$ & $\begin{array}{l}5 \\
3 \\
1 \\
0 \\
0 \\
0 \\
1\end{array}$ & $\begin{array}{r}21 \\
14 \\
8 \\
9 \\
5 \\
7 \\
0\end{array}$ & $\begin{array}{l}- \\
- \\
- \\
- \\
\text { Quarry blank } \\
\text { Mussel fragment } \\
-\end{array}$ \\
\hline $\begin{array}{c}\text { C } \\
(\text { El002, } \\
\text { N1000) }\end{array}$ & $24 \mathrm{~cm}$ & $\begin{array}{r}0-10 \\
10-20 \\
20-30\end{array}$ & $\begin{array}{l}1 / 4 " \\
11\end{array}$ & $\begin{array}{l}15,450 \\
20,600 \\
20,600\end{array}$ & $\begin{array}{l}0 \\
1 \\
0\end{array}$ & $\begin{array}{l}7 \\
2 \\
3\end{array}$ & $\begin{array}{r}11 \\
21 \\
7\end{array}$ & $\begin{array}{l}\text { Nolan } \\
\text { - } \\
\text { Quarry blank }\end{array}$ \\
\hline $\begin{array}{l}\text { D } \\
(E 1003, \\
\text { N1000) }\end{array}$ & $11 \mathrm{~cm}$ & $\begin{array}{r}0-10 \\
10-20 \\
20-30 \\
30-40 \\
40-50\end{array}$ & $\begin{array}{l}\text { " } \\
\text { "1 } \\
1 " \\
11\end{array}$ & $\begin{array}{r}206 \\
5768 \\
7210 \\
22,660 \\
6180\end{array}$ & $\begin{array}{l}0 \\
1 \\
0 \\
0 \\
0\end{array}$ & $\begin{array}{r}1 \\
5 \\
17 \\
10 \\
1\end{array}$ & $\begin{array}{r}1 \\
52 \\
103 \\
39 \\
39\end{array}$ & $\begin{array}{l}\text { - } \\
\text { Thound stone } \\
\text { Thinned biface, Marcos } \\
\text { Thinned biface } \\
\text { - }\end{array}$ \\
\hline $\begin{array}{c}E \\
(E 1004, \\
N 1000)\end{array}$ & $4 \mathrm{~cm}$ & $\begin{array}{r}0-10 \\
10-20 \\
20-30 \\
30-40 \\
40-50 \\
50-60 \\
60-70 \\
70-80 \\
80-90\end{array}$ & $\begin{array}{l}\text { " } \\
" 1 \\
11 \\
" 1 \\
11 \\
11 \\
11\end{array}$ & $\begin{array}{r}? \\
1030 \\
618 \\
1648 \\
2060 \\
16,480 \\
16,480 \\
3090 \\
2060\end{array}$ & $\begin{array}{l}0 \\
7 \\
3 \\
0 \\
0 \\
2 \\
0 \\
0 \\
0\end{array}$ & $\begin{array}{r}1 \\
15 \\
13 \\
3 \\
6 \\
6 \\
0 \\
0 \\
0\end{array}$ & $\begin{array}{r}5 \\
69 \\
73 \\
21 \\
34 \\
23 \\
13 \\
12 \\
12\end{array}$ & $\begin{array}{l}\text { - } \\
\text { Perdiz (2), Unknown point } \\
\text { - } \\
\text { Quarry blank } \\
\text { - } \\
\text { - } \\
\text { - }\end{array}$ \\
\hline $\begin{array}{c}F \\
(E 1005, \\
\text { N1000) }\end{array}$ & $0 \mathrm{~cm}$ & $\begin{array}{r}0-10 \\
10-20\end{array}$ & " & $\begin{array}{l}? \\
?\end{array}$ & $\begin{array}{l}0 \\
3\end{array}$ & $\begin{array}{r}0 \\
16\end{array}$ & $\begin{array}{r}0 \\
57\end{array}$ & Biface core \\
\hline
\end{tabular}

* Cubic centimeters.

$1^{\circ}$, primary flake; $2^{\circ}$, secondary flake; Int., interior flake.

${ }^{\ddagger}$ One specimen unless otherwise indicated. 
Location: Terrace site; spring located $50 \mathrm{~m}$ south of the site (presently seasonat flow).

Elevation: $1105^{\prime}$

Environment: Dense vegetation surrounds the site, including Tive oak, hackberry, huisache, pecan, elm and juniper. Sotol is present in the neighboring hills (Fig。 43,b). The soil is dark and deep ciaymoam.

Description: The site is a burned rock accumulation th th a sight depression in the center. The diameter of the mound is ca. $15 \mathrm{~m}$ its elevation above the ground surface is approximately $1.5 \mathrm{~m}$. Few artifacts were located on or around the accumulation.

Investigation: Initial. investigation involved survey, mapping and excavation of a $1 \mathrm{~m}^{2}$ area near the eastern edge of the mound. A Caschoville projectile point was found on the surface.

Subsequent testing included a series of eight shove tests around the site to determine its boundaries, and the excavation of four $1 \mathrm{~m}^{2}$ units, two in the burned rock accumulation and two to the north of it $(F+4,46)$. A profile of Unit 2 is illustrated in Fig. 43,c.

To the north of this mound, a hearth was uncovered at 10 on below the ground surface. This cluster of burned rock was associated wh thigher frequency of chipped stone than above or around it.

The two test units to the nonth of the burned rock accurtulation yielded altogether a larger quancliby of flakes and tools than the flll from the mound. Very likely, this was the living area, with the burned rock pile possibly representing food processing activities or a refuse heap (Fig. 46).

Table 15 provides artisct and provenience data as well as the volume of burned rock.

Occupation Period: Ranly Archiac. Late Archaic.

$41 B \times 429$

Location: Terrace stap? nearest water source more than one km distant.

Elevation: $1125^{\circ}$

Environment: Reddish clay soll is present, with a ground cover consisting of grassy fields and jumiper and live oak clumps. 


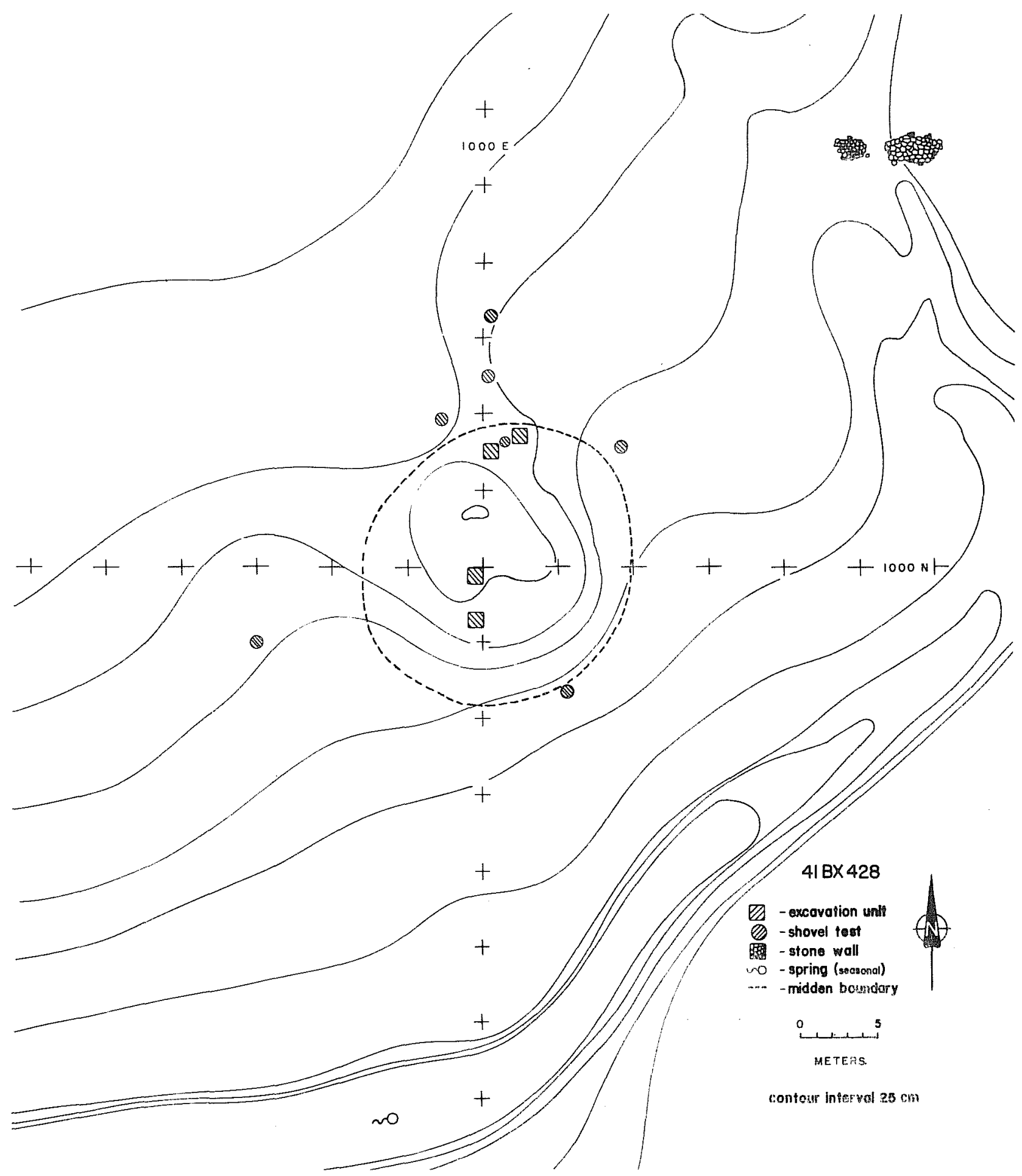

Figure 46. Site 41 BX 428, Camp Bullis. 
TABLE 15. ARTIFACT PROVENIENCE AT 41 BX 428*

\begin{tabular}{|c|c|c|c|c|c|c|c|}
\hline Unit & $\begin{array}{l}\text { Depth } \\
\text { below } \\
\text { Datum }\end{array}$ & Level $(\mathrm{cm})$ & $\begin{array}{l}\text { Volume of } \\
\text { Burned Rock** }\end{array}$ & $1^{\circ}$ & $\begin{array}{c}\text { Flakes } \\
\underline{2}^{\circ}\end{array}$ & Int. & $\underline{\text { Other Lithics }}^{\ddagger}$ \\
\hline $\begin{array}{l}1 \\
(\text { E999 } \\
\text { N996) }\end{array}$ & $17 \mathrm{~cm}$ & $\begin{array}{r}0-10 \\
10-20 \\
20-30 \\
30-40\end{array}$ & $\begin{array}{l}82,400 \\
51,500 \\
72,100 \\
79,310\end{array}$ & $\begin{array}{l}0 \\
0 \\
0 \\
0\end{array}$ & $\begin{array}{l}1 \\
0 \\
1 \\
0\end{array}$ & $\begin{array}{l}1 \\
0 \\
1 \\
1\end{array}$ & $\begin{array}{l}\text { Retouched flake } \\
\text { Biface fragment } \\
\text { Ground stone } \\
\text { - }\end{array}$ \\
\hline \multirow[t]{2}{*}{$\begin{array}{l}2 \\
\text { (E999, } \\
\text { N999) }\end{array}$} & \multirow[t]{2}{*}{$0 \mathrm{~cm}$} & $\begin{array}{r}0-10 \\
10-20\end{array}$ & $\begin{array}{r}2060 \\
22,660\end{array}$ & 1 & $\begin{array}{l}0 \\
4\end{array}$ & $\begin{array}{l}13 \\
41\end{array}$ & \multirow[t]{2}{*}{$\begin{array}{l}\text { Point fragment, Biface fragment, Retouched } \\
\text { flake, Chunk }\end{array}$} \\
\hline & & $\begin{array}{r}20-30 \\
30-40 \\
40-50 \\
50-60 \\
60-70 \\
70-80 \\
80-90 \\
90-100 \\
100-110\end{array}$ & $\begin{array}{r}46,350 \\
82,400 \\
106,090 \\
41,200 \\
61,800 \\
80,340 \\
39,140 \\
20,600 \\
28,840\end{array}$ & $\begin{array}{l}0 \\
0 \\
0 \\
0 \\
1 \\
0 \\
0 \\
0 \\
0\end{array}$ & $\begin{array}{l}1 \\
4 \\
0 \\
1 \\
2 \\
0 \\
0 \\
0 \\
0\end{array}$ & $\begin{array}{r}10 \\
5 \\
7 \\
8 \\
9 \\
7 \\
13 \\
4 \\
3\end{array}$ & \\
\hline \multirow{3}{*}{$\begin{array}{l}3 \\
\text { (E1000, } \\
\text { N1007) }\end{array}$} & $19 \mathrm{~cm}$ & $0-10$ & 618 & 2 & 8 & 144 & \multirow{3}{*}{$\begin{array}{l}\text { Wells, Retouched flake, Biface preform, } \\
\text { Biface fragment } \\
\text { Retouched flake, Biface fragment, Chunk (2) } \\
\text { Core (2), Biface fragment, Nolan } \\
\text { Retouched flake } \\
\text { Retouched flake, Point fragment, Biface } \\
\text { fragment } \\
\text { Core fragment, Retouched flake }\end{array}$} \\
\hline & 1 & $\begin{array}{l}10-20 \\
20-30 \\
30-40 \\
40-50(1 / 2)\end{array}$ & $\begin{array}{l}3090 \\
7210 \\
1648 \\
4120\end{array}$ & $\begin{array}{l}1 \\
2 \\
0 \\
1\end{array}$ & $\begin{array}{r}8 \\
10 \\
5 \\
5\end{array}$ & $\begin{array}{l}81 \\
99 \\
20 \\
64\end{array}$ & \\
\hline & feature & e $40-50$ & 12,978 & 3 & 16 & 55 & \\
\hline $\begin{array}{l}4 \\
(E 1002 \\
\text { N1008) }\end{array}$ & $37 \mathrm{~cm}$ & $\begin{array}{r}0-10 \\
10-20 \\
20-30 \\
30-40\end{array}$ & $\begin{array}{r}618 \\
1648 \\
15,450 \\
15,450\end{array}$ & $\begin{array}{r}4 \\
0 \\
2 \\
15\end{array}$ & $\begin{array}{r}7 \\
11 \\
6 \\
67\end{array}$ & $\begin{array}{r}24 \\
23 \\
33 \\
193\end{array}$ & $\begin{array}{l}\text { - } \\
\text { Thound stone } \\
\text { Prinned biface, Retouched flake (4) } \\
\text { Biface fragment (2) }\end{array}$ \\
\hline
\end{tabular}

*1/4" screen used on a11 units.

**Cubic centimeters.

F One specimen unless otherwise indicated.

$1^{\circ}$, primary flake; $2^{\circ}$, secondary flake; Int., interior flake. 
Description: The site is a lithic scatter containing bifaces, preforms, choppers, core fragments and flakes. The area is approximately $500 \times 40 \mathrm{~m}$. Several areas of higher density lithics were observed.

Investigation: General surface collections were made and a $50 \mathrm{~cm}$ square area was completely collected within a subconcentration.

Occupation Period: Unknown.

41 BX 430

Location: Terrace site; water available within one $\mathrm{km}$.

Elevation: $1180^{\prime}$

Environment: Dark loamy soil is present, with vegetation consisting of woods of live oak, hackberry, huisache, juniper and elm.

Description: The site is a burned rock midden ca. $25 \mathrm{~m}$ in diameter. Very few Tithic artifacts were observed; these included a scraper.

Investigation: A shovel test (unscreened) was placed in the center of the mound to a depth of $30 \mathrm{~cm}$. No chert was recovered.

Occupation Period: Unknown.

41 BX 431

Location: A terrace site; small spring located just north and west of the site (presently seasonal) forming a stream tributary of Panther Springs Creek. Permanent water source within one $\mathrm{km}$ (Fig. 41,d).

\section{Elevation: $1135^{\prime}$}

Environment: Vegetation includes grassy fields and juniper and 1ive oak brakes. The soil cover is very thin.

Description: Chipped stone and burned rock are scattered over an area approximately $75 \times 75 \mathrm{~m}$.

Investigation: At the time of initial recording, a biased "grab" sample of artifacts was collected but not mapped. A single test pit was excavated in the western portion of the site to a depth of $10 \mathrm{~cm}$, in two levels. The first level yielded a biface fragment, a retouched flake and 42 debitage flakes (all but six are interior flakes). The second level yielded 45 flakes, of which 37 are interior flakes.

Occupation Period: Unknown. 


\section{$41 \mathrm{CM} 70$}

Location: Flood plain site with river cobble chert nearby; permanent water source (Cibolo Creek) less than $100 \mathrm{~m}$ distant.

\section{Elevation: $1235^{\prime}$}

Environment: Dark loamy soil with chert gravels is present, with a vegetation cover of live oak, hackberry, huisache, juniper and elm woods.

Description: The site contains scattered lithic artifacts and burned rock. Artifacts include points and flakes.

Investigation: Diagnostic artifacts were collected and mapped. A $3 \mathrm{~m}^{2}$ area was completely collected and a $50 \mathrm{~cm}^{2}$ unit was excavated to $10 \mathrm{~cm}$ depth, where bedrock was encountered.

Occupation Period: Early Archaic, Middle Archaic, Late Archaic.

\section{$41 \mathrm{CM} 94$}

Location: Terrace site; permanent water supply (Cibolo Creek) within one km. Elevation: $1210^{\prime}$

Environment: Dark loamy soil is present, covered by woods of live oak, juniper, huisache, hackberry and elm.

Description: The site is a lithic concentration confined to an area ca. $20 \mathrm{x}$ $20 \mathrm{~m}$. Artifacts include points, biface fragments, unifaces, scrapers and flakes.

Investigation: Diagnostic artifacts were collected and mapped and an area measuring $5 \times 3 \mathrm{~m}$ was completely collected.

Occupation Period: Archaic, Late Prehistoric.

$41 \mathrm{CM} 96$

Location: Flood plain site; permanent water supply (Cibolo Creek) within $100 \mathrm{~m}$. Elevation: $1205^{\prime}$

Environment: Reddish clay soil with chert gravels is characteristic. Vegetation includes grassland and juniper.

Description: The site is a 1ithic concentration covering an area approximately $20 \times 20 \mathrm{~m}$. Scattered burned rock, bifaces and flakes are present. A single point was found (Big Sandy-1ike).

Investigation: Only the point was collected.

Occupation Period: Unknown. 
Location: Terrace site approximately $300 \mathrm{~m}$ from Cibolo Creek, a permanent water supply.

Elevation: $1220^{\prime}$

Environment: Ground cover consists of grassy fields and clumps of live oak and juniper. Prickly pear and yucca/sotol are also present. Reddish clay soil is of moderate depth.

Description: Scattered burned rock and a high density of chipped stone are confined to an area ca. $60 \times 40 \mathrm{~m}$. Artifacts include bifaces, unifaces, quarry blanks, cores and flakes.

Investigation: No collection was made.

Occupation Period: Unknown.

\section{$41 \mathrm{CM} 99$}

Location: Terrace site; nearest water supply within one $\mathrm{km}$ of Cibolo Creek. A smalT side drainage (seasonal) is near the site.

Elevation: $1220^{\prime}$

Environment: Grassland and juniper growth are supported by reddish clay soil.

Description: The site contains scattered burned rock and chipped stone artifacts within an area approximately $50 \times 35 \mathrm{~m}$. Two concentrations are apparent: a wel1-defined Late Prehistoric area within a scattered Archaic occupation.

Investigation: Initial investigation included the complete collection of a $5 \mathrm{~m}^{2}$ area in the Late Prehistoric concentration. A $15 \mathrm{~cm}^{2}$ area was also shovel tested, although unscreened. This shovel test was located two $m$ northeast of the collection area. Flakes were present in the upper $15 \mathrm{~cm}$ of the test; the excavations went down to $30 \mathrm{~cm}$ depth.

Subsequent testing was performed in the Late Prehistoric artifact concentration. This consisted of three $1 \mathrm{~m}^{2}$ units, one of which was partially superimposed over another (Fig. 47). A hearth was excavated in the $.5 \mathrm{~m}^{2}$ area of overlap which extended into the diagonally adjacent square. The hearth consisted of a pile of burned rocks without any apparent structural pattern.

Table 16 presents the artifacts recovered from each level.

Occupation Period: Middle Archaic, Late Archaic, Late Prehistoric. 


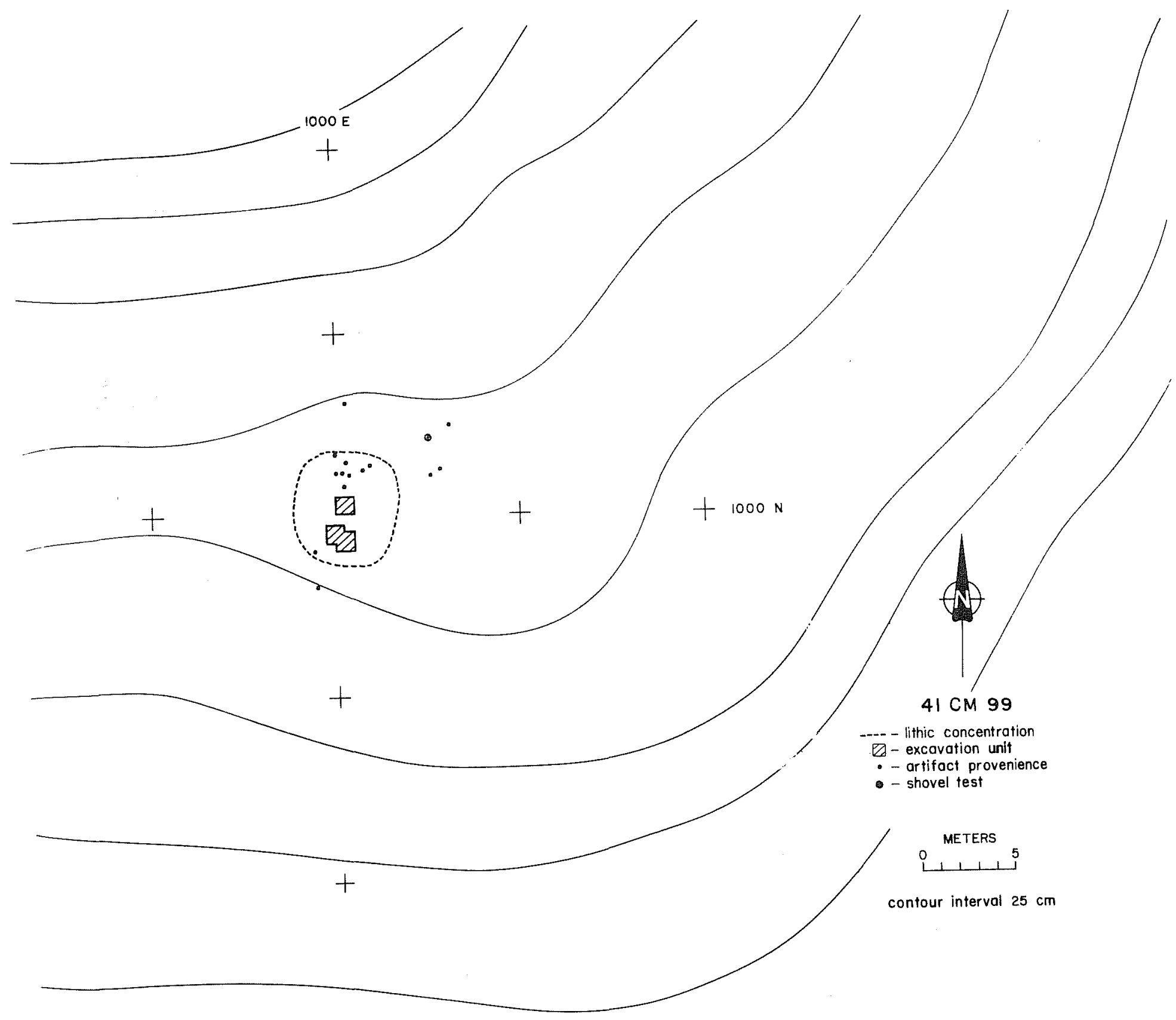

Figure 47. Site 41 CM 99, Camp Bullis 
TABLE 16. ARTIFACT PROVENIENCE AT 41 CM 99

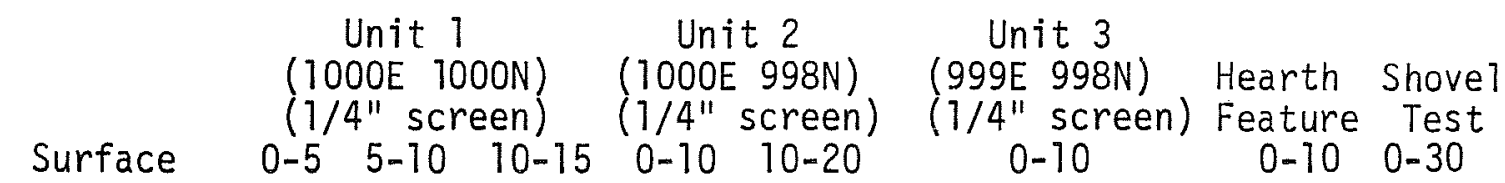

$\mathrm{cm}$

$\mathrm{cm}$

$\mathrm{cm}$

$\mathrm{cm}$

$\mathrm{cm}$

$\mathrm{cm}$

Primary

flakes

$\begin{array}{llll}3 & 11 & 4 & 8\end{array}$

6

5

20

Secondary

flakes

50

50

57

26

61

42

59

162

Interior

flakes

$132 \quad 137$

144

96

147

48

Biface

fragments

2

Quarry blank

(whole \& frag.)

4

Preform

(whole \& frag.) 5

Core and frag. 2

Retouched flake I

Points

fragment

$$
4
$$

Scallorn

2

Edwards

3

Perdiz

Marshall

Pedernales

castroville

Ensor-Frio

Side scraper

Chopper

Perforator

Chunks

10

Ground stone

$\begin{array}{lll}1 & 2 & 1\end{array}$ 
$41 \mathrm{CM} 1.00$

Location: Terrace site; water supply (seasonal) within $100 \mathrm{~m}$.

Elevation: $1200^{\prime}$

Environment: Vegetation consists of grassy fields with juniper and live oak clumps and prickly pear and yucca/sotol patches. Very thin soil cover overlying bedrock is present.

Description: The site is a lithic scatter covering an area approximately $65 \times 20 \mathrm{~m}$. Artifacts include points, biface fragments, scrapers, cores and flakes.

Investigation: A general collection was made and four shovel tests were excavated.

Occupation Period: Middle Archaic.

41 CM 101

Location: Flood plain site; permanent water supply (Cibolo Creek) within one $\mathrm{km}$.

Elevation: $1195^{\prime}$

Environment: Reddish clay soil is present with a cover of grassy fields, juniper and live oak clumps, prickly pear and yucca/sotol.

Description: The site is a lithic concentration containing cores, bifaces, preforms and flakes. Site area is ca. $30 \times 15 \mathrm{~m}$.

Investigation: Chert artifacts were collected and mapped.

Occupation Period: Unknown.

$41 \mathrm{CM} 102$

Location: Flood plain site within one $\mathrm{km}$ of Cibolo Creek, a permanent water supply.

Elevation: $1150^{\prime}$

Environment: Vegetation includes grassy areas and clumps of juniper and Tive oak. Reddish clay soil is present.

Description: The site is a lithic concentration covering an area approximately $25 \times 25 \mathrm{~m}$. Artifacts include points, scrapers, bifaces and flakes.

Investigation: Artifacts were collected and mapped.

Occupation Period: Late Archaic 
TABLE 17. (continued)

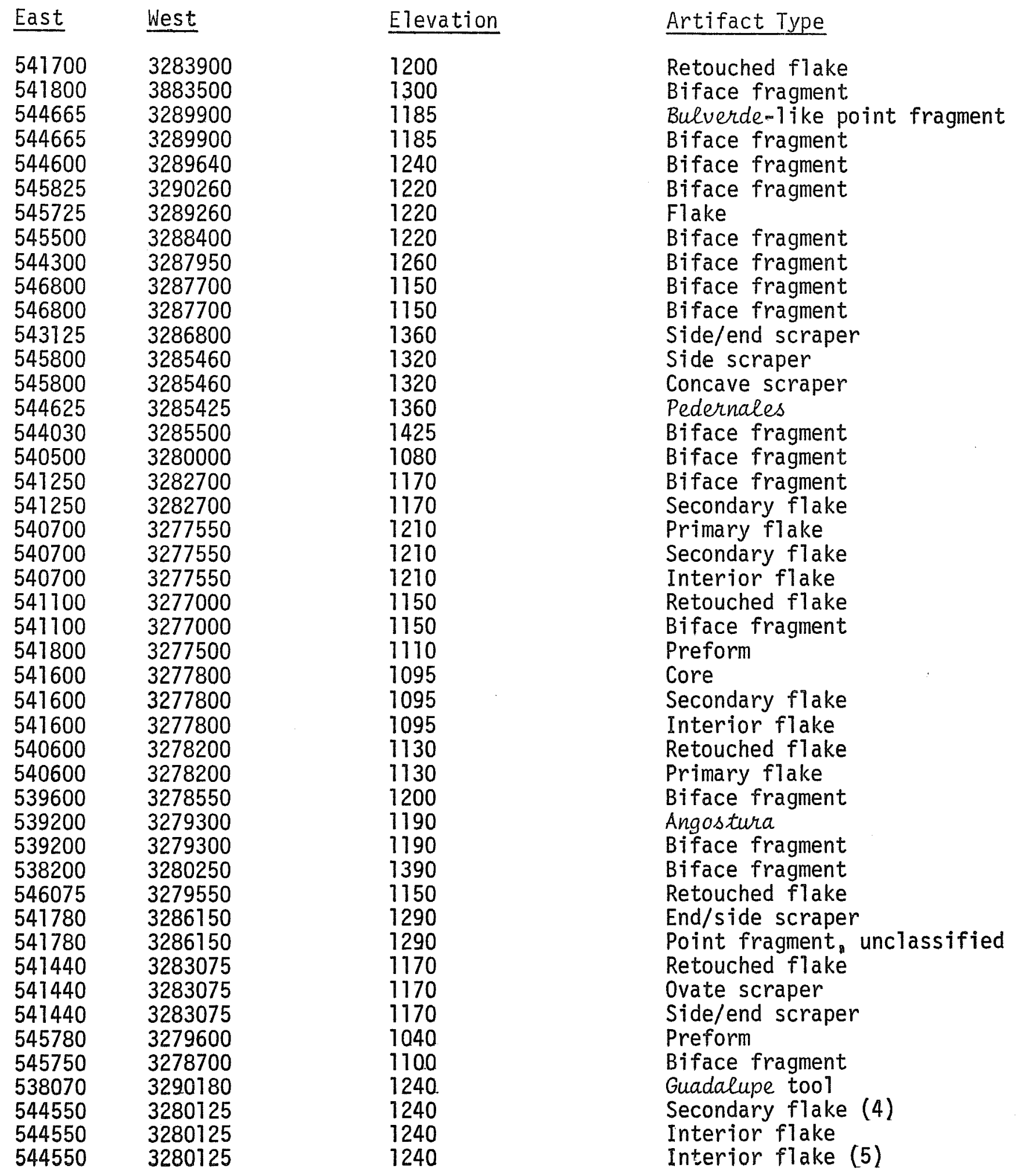


Scattered Artifacts

The scattered artifacts are presented here in tabular form with their UTM coordinates and elevation. The distribution of scattered artifacts is discussed in III.A.9.

TABLE 17. DISTRIBUTION OF SCATTERED ARTIFACTS

UTM Coordinates

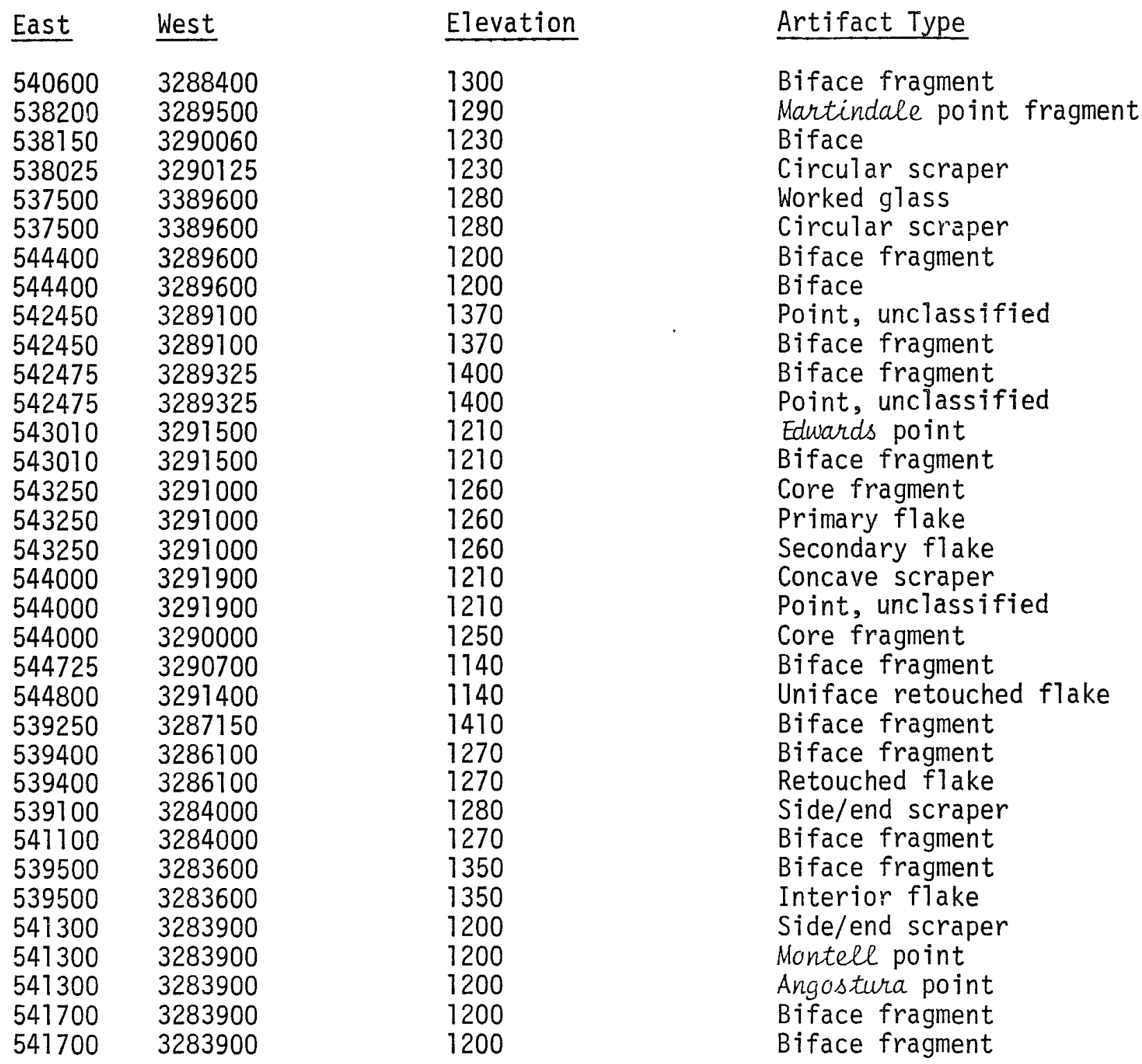


TABLE 17, (continued)

$\begin{array}{llll}\text { East } & \text { West } & \text { Elevation } & \text { Artifact Type } \\ 544950 & 3282700 & 1215 & \text { Biface } \\ 544700 & 3283500 & 1210 & \text { Biface } \\ 546300 & 3281550 & 1130 & \text { Preform } \\ 543450 & 3281800 & 1250 & \text { Preform } \\ 545800 & 3281500 & 1230 & \text { Biface } \\ 545800 & 3281500 & 1230 & \text { Interior flake } \\ 545800 & 3281500 & 1230 & \text { Edwards } \\ 542425 & 3291060 & 1190 & \text { Travis } \\ 542425 & 3291060 & 1190 & \text { Point, unclassified arrow } \\ 542425 & 3291060 & 1190 & \text { Preform } \\ 542350 & 3281400 & 1370 & \text { Biface fragment }\end{array}$





\section{A.8}

\section{SITE TYPES}

Andrea Gerstle and James E. Ivey

The analysis of site types (functions) and settlement patterns does not consist of separate, unrelated procedures; it is logically necessary to consider the two aspects in conjunction with each other, and the process of identifying one of these aspects requires consideration of the other. The function of the site is the totality of activities carried out at the site (as seen in the artifact assemblage); this is in part related to the environmental setting, available resources, and the exploitative orientation of the inhabitants. The combination of site types, their location and their distribution, is the settlement pattern. The analytical process involves observing the complete configuration in order to identify site functions and settlement patterns. The division of the two into separate chapters is purely an organizational advantage.

\section{CLUSTER ANALYSIS}

The sites were classified into groups using the BMDP (Biomedical Computer Programs) program 2M: Cluster analys is on cases (Dixon 1975:323-337). For the purposes of this project, the sites are considered cases and the locational attributes of each site comprise the variables. The mathematical procedure used by the cluster analysis is briefly explained.

The program begins by taking the original data for each site and standardizing it. The values of each variable used in the analysis are added together, and the average or mean value of each variable is found. The values of each variable are then subtracted from this mean, and this difference is divided by the standard deviation of that variable from the mean value. In mathematical notation, the mean is computed as follows:

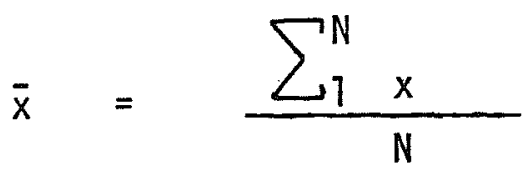

where: $\bar{x}=$ the mean of the variable,

$\mathrm{N}=$ the number of cases,

$x=$ the value of the variable, and

$\sum \begin{aligned} & N=\text { the sum of the values of } \\ & 1\end{aligned}$ 
The standard deviation is:

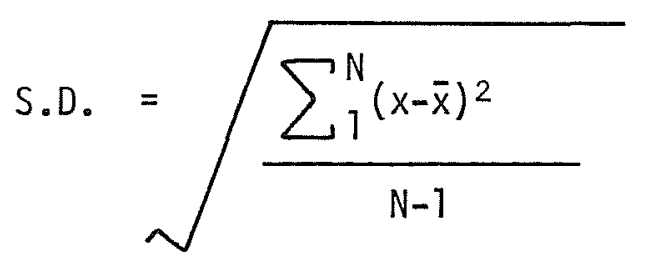

or the square root of the sum of the squares of the differences between the variable describing each case and the mean value of that variable for all cases used in the analysis. This is a single numerical value for each variable.

The standardized value of each variable, then, is expressed as:

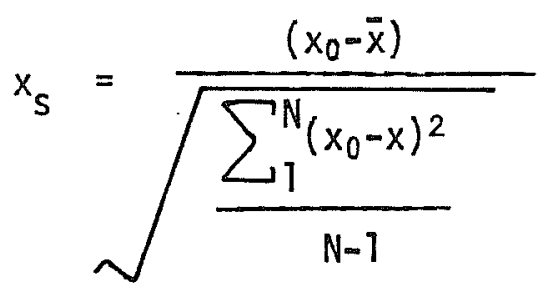

$$
\text { where: } \begin{aligned}
x_{s} & =\begin{array}{l}
\text { standardized value of the } \\
\text { variable, and }
\end{array} \\
x_{0} & =\text { original value of the variable. }
\end{aligned}
$$

Once each case has been standardized, the "distance" from each case to all other cases used in the analys is is computed. This is a quite complicated procedure, and there are four possible methods permitted by the BMDP program. The one employed here uses the square root of the sums of the squares of the differences between the cases.

Since in this analysis we are using seven measurements, each case is described by a unique point in a seven-dimensional space, the seven dimensions being the seven variables. Each point in this space, representing one site, can be connected to any other point by a straight line. This line has a specific length, determined by the distances between the two points in the seven dimensions. To find this length in a space of two dimensions (horizontal and vertical, for example), one finds the horizontal and vertical differences between their positions. These differences would be squared, added together, and the square root of that sum found. This is the familiar method of finding the hypotenuse of a triangle. If a third dimension is added, the procedure would be the same with the difference in the third dimension included, and so on.

Once the distances between cases are found, the cases are grouped, or "amalgamated," according to closeness; those two cases which are most similar or closest are amalgamated into a cluster. This cluster is then described by the mean values of the variables describing each of the two cases within it. As 
far as the program is concerned, the two individual cases cease to exist, and a single case, the cluster, replaces them. The amalgamation step is then repeated. After a series of these steps, there are usually several clusters, each formed of two or more cases, and a number of individual cases, still too different from each other to have been placed into any cluster.

When, in the later stages of the amalgamation process, individual cases are added to already formed clusters, the values describing the cluster change by smaller and smaller amounts depending on the number of cases already in the cluster. The averaging procedure is "weighted" so that the cases a lready in the cluster have more influence on the description than does the less similar newcomer. The logical extreme of this clustering process is the formation of a single large cluster including a11 cases input into the program.

The smallest clusters, those consisting of pairs of very similar cases, are of little use to us in this analysis; the final cluster, consisting of everything in the analysis, is also of little use. It is necessary to compare the encoded values describing each site cluster, and select that stage of clustering which most meaningfully amalgamates our sites into easily comprehended and described groups.

This analytical tool has revealed intersite relationships which it is unlikely we would have been able to see otherwise and has many potential uses.

\section{CLUSTERS}

First, all of the locational attributes from each of the 24 sites located on the transects were input in the clustering program. The cluster analysis grouped the sites on the basis of topographic setting, distance to water and type of surrounding resources (1ithic outcrops, soi $1^{*}$ ), mean diameter of site, the amount of chipped stone on the site and the absence or configuration of burned rock on the surface. Eight clusters resulted containing two or more sites, two sites were sufficiently unique so that they did not group with any others, and two sites formed an extended group too loose to be considered a cluster (Fig. 48). These clusters are assumed to be unbiased, i.e., representative of the major variation in all sites on Camp Bullis, as they are based on the statistically valid $15 \%$ survey samples. These "true" clusters are the baseline for determining site types and settlement patterns.

The second step was to conduct an identical cluster analysis using all of the sites located, including those found on the $15 \%$ transect sample as well as others, a total of 63 sites. The purpose of this is twofold: (1) to see if any major differences are present in the unsystematically located sites, i.e., if "intuitive" site location techniques result in a biased representation of site types, and (2) to include the non-transect-located sites in clusters along with transect-located sites, thus maintaining the "objectivity" of mathematical (statistical) analysis.

\footnotetext{
* Note that the values assigned to lithic outcrops and soils have little relationship to each set of characteristics assigned a value; that is, soils coded as 3 do not have any specific increase in some characteristics over soils coded 2 , but are simply different. This had little effect on the clusters, but such systems of coding should be avoided when using cluster analys is on future projects.
} 
WATER-PROXIMATE SITES

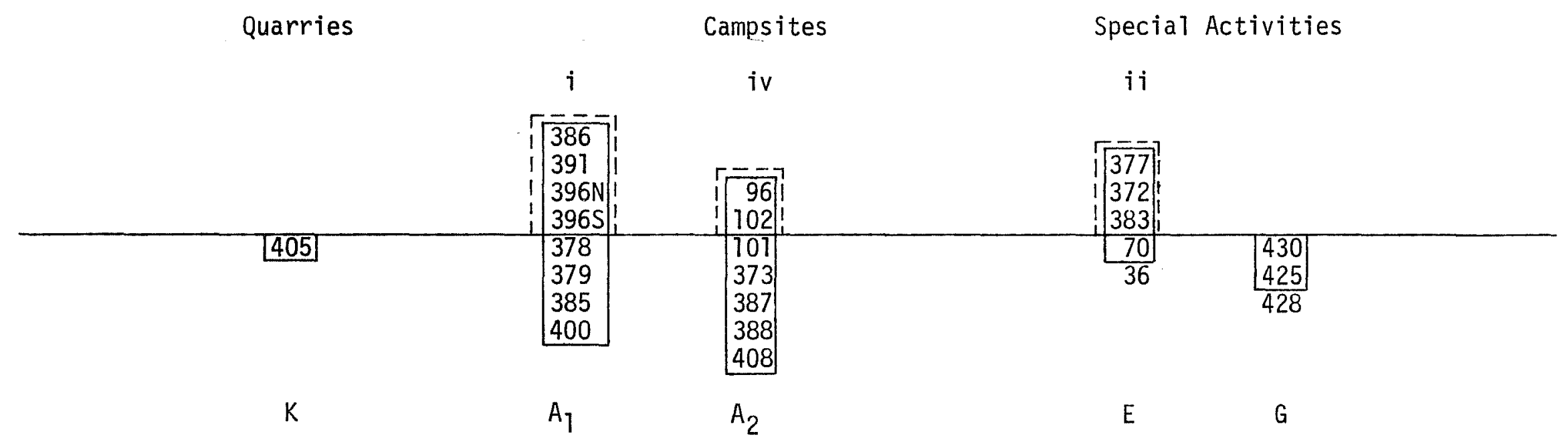

WATER-DISTANT SITES

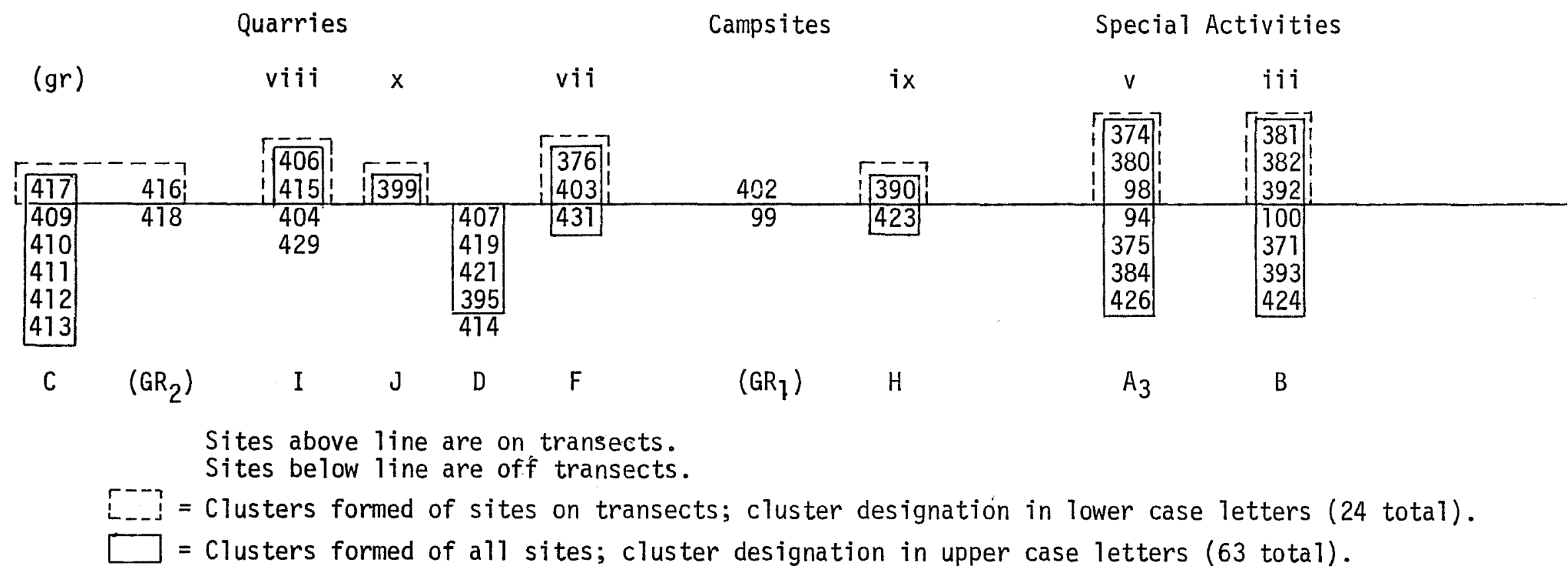

Figure 48. Site clusters 
The cluster analysis of all sites yielded a total of 13 clusters, of which 11 have two or more sites, and two consist of a single site (Fig. 48). Five sites are associated with, but not included in, these clusters. They are not unique but are not "similar enough" to the sites in the clusters to warrant their inclusion. Four other sites form two extended groups, one of these unassociated with any single cluster.

Examination of Fig. 48 shows us the similarities and differences between the clusters produced by the two analyses. More clusters are defined by using a larger sample of sites. This is to be expected; more sites result in more variation in the attribute combinations. This is seen in the sites which are associated with, but not included in, clusters. It is also logical that certain attribute combinations would occur more often, resulting in more and more well-defined clusters of sites.

Comparison of the clusters of sites produced by the two analyses are also instructive with regard to identifying the biases introduced by unsystematic survey. In the Camp Bullis survey, it is apparent that the Clusters $i i$, $i j i$, vii, viii, $i x$ and $x$, defined from the representative sample of 24 sites, are substantiated by clusters E, B, F, I, $H$ and $J$ from the combined 63-site sample. Clusters $D, G$ and $K$ are found only in the combined sample. Clusters $i$, iv and $\checkmark$ correspond to subdivisions of cluster $A$ : $A_{1}=i, A_{2}=i v, A_{3}=v$. Cluster $A$ of the all-sites analysis was formed from three subclusters, all of very similar characteristics. This cluster was formed at the threshold of similarity selected to be the level at which the detailed examination of the cluster would be carried out. Since A included 22 sites, or about $32 \%$ of the total number of sites, it was decided to use the three subclusters $A_{7}, A_{2}$ and $A_{3}$ for the analysis, because they were representative of three clusters from the ontransect analysis, and a more detailed picture of site typology would result. Cluster $C$ of the all-sites analysis is similar to the two-site grouping of the on-transect sites.

The clusters are presented graphically in Fig. 48 . In this figure, sites which are members of a cluster are enclosed in a rectangle. Sites associated with a given cluster, but not part of $i t$, are listed outside the appropriate rectangle. In the on-transect clusters the two-site unassociated grouping is indicated by the symbol $(\mathrm{gr})$; in the all-sites clusters the groupings are marked by the symbols $\left(G R_{1}\right)$ and $\left(G R_{2}\right)$.

Close examination of the attributes of the sites forming each cluster provides the means of identifying site functions and settlement patterns.

\section{CLUSTER INTERPRETATION}

The clusters illustrated in Fig. 48 are defined on the basis of locational information plus amount of chipped stone and configuration of burned rock. When combined with artifact types, including tools and manufacturing debris, the result is a composite picture of site functions and settlement patterns.

The configuration of locational attributes is most readily divided into groupings of clusters by the "distance-to-water" attribute. Clusters were sorted 
according to whether they were "water-proximate" (less than $100 \mathrm{~m}$ from a permanent or intermittent water supply) or "water-distant" (more than $100 \mathrm{~m}$ from a permanent or intermittent water supply). The other attributes, and the tool assemblages, were then taken into account for a more specific description of each site type represented by a cluster.

The tool assemblages are evaluated according to the presence or absence of the different artifact types. Chipping debris consists of cores, core fragments, chunks, quarry blanks, preforms, and primary, secondary and interior flakes. The presence of cores, core fragments, chunks, quarry blanks, and primary and secondary flakes is taken to indicate initial core reduction activities. The presence of quarry blanks, preforms and interior flakes would result from secondary reduction and final tool manufacturing activities, especially in conjunction with finished tools.

The presence of finished tools is taken to mean that they were used as well. Although probably not all tool use occurred on the site itself, the variety occurring is assumed to be representative of the activities which took place in and around the site. Projectile points are hunting implements; scrapers, thinned bifaces (knives), perforators, choppers and retouched flakes were probably used for plant food collecting and plant and animal processing. Ground stone manos were used for plant processing (including seeds). The two specimens of pitted stones were possibly "nutting stones." Guadalupe and clear Fork tools are assumed to be special purpose scraping tools (cf. Hester, Gilbow and Albee 1973). Hammerstones are likely knapping implements.

In many cases, the artifacts classed as knapping debris, especially cores, blanks and preforms, were probably utilized as tools as well as being tool "sources." No use wear analysis was performed on the artifacts, hence possible multiple functions are not recognized. For those artifacts believed to be tools, the functions are inferred from the form and manufacture of the specimen. This approach is fraught with dangerous assumptions. Foremost among these is the assumption that tools of similar function will have similar morphology. For this reason, the tool types used here are not specific as to the exact morphology of the part of the tool that presumably was utilized.

The clusters are arranged here in two major groups (Fig. 48): "water-distant" (far from water) and "water-proximate" (close to water) sites. Within these two, the major functions of the sites are designated: quarry sites, campsites and special activity sites. The individual clusters are indicated within the major functional classes. These are described in the text according to their specific characteristics: the environmental features and artifact assemblages.

Small Water-distant Quarry Sites (Cluster C/gr and GR2)(Fig. 49)

Including sites 41 BX 409, 41 BX 410, 41 BX 411, 41 BX 412, 41 BX 413, 41 BX 417 and associated sites $41 \mathrm{BX} 416,41 \mathrm{BX} 418$.

\section{Locational Attributes}

All sites in this cluster are located in a small group in the extreme southeast corner of Camp Bullis, on a high terrace of Panther Springs Creek. Soil 
varies from very shallow to moderately deep red clay or dark clayey loam. Chert sources are near all of the sites. The mean diameter of the sites varies from $15.0 \mathrm{~m}$ to $80.0 \mathrm{~m}$. The frequency of chipped stone is generally high, from 50 to more than 100, except for two sites with an estimated 10 to 50 pieces. Burned rock is present at only one of the sites.

\section{Artifact Assemblage}

The artifacts on these sites consist primarily of knapping debris but are variable between sites. All of the sites contain secondary flakes, and all but one contain chunks. A11 but two have primary flakes, and al1 but one have interior flakes. Five of these also have core fragments. All but two have quarry blanks. Five sites have cores and three have preforms.

Evidence of tool use is scanty on these sites. Scrapers are present on three sites, one of which also has a chopper. Four sites have retouched flakes and two have bifaces. One of these sites also has a Guadalupe tool.

The small size of the sites, the quarry/knapping nature of the artifact assemblages, and the lack of burned rock, a11 indicate very short-term occupation of the sites for the purpose of quarrying and initially reducing the local chert for later use elsewhere. Site $41 \mathrm{BX} 409$, which is the only site in this cluster having identifiable points and a Guadalupe tool, is considered a quarry/campsite rather than strictly a quarry.

Water-distant Quarry Sites (Cluster D)(Fig. 49)

Including sites $41 \mathrm{BX} 395,41 \mathrm{BX} 407,41 \mathrm{BX} 419,41 \mathrm{BX} 421$, with related site $41 \mathrm{BX} 414$.

\section{Locational Attributes}

The sites comprising this cluster form a small group in the extreme south central part of Camp Bullis, with the exception of 41 BX 395, located in the southwestern corner of the camp. They are upland or upland margin sites, with the closest water supply usually less than one $\mathrm{km}$ away. A11 are on very shallow soil or bedrock, and all are on or near an upland (water-distant) chert source. The mean diameter of these sites ranges from a minimum of $30.0 \mathrm{~m}$ to a maximum of $150.0 \mathrm{~m}$. Estimated chipped stone frequency is greater than 100 . None contains burned rock.

\section{Artifact Assemblage}

The artifact assemblages in these sites are very much alike, supporting the notion that sites of similar function will be similarly located.

Tool manufacturing debris is predominant. All of the sites contain cores and core fragments. All of the sites have primary, secondary and interior flakes. Three sites have quarry blanks present; two have preforms. 
The variety of tools occurring at sites in this cluster is limited and inconsistent. Four sites have scrapers; of these, three have retouched flakes, and one of those has a projectile point and a perforator graver. This site is 41 BX 407, which is apparently a quarry/camp similar to 41 BX 409.

It is apparent, then, that these upland (water-distant) sites are primarily quarry and initial core reduction sites, with only minor and varied tool-using activities occurring. The general lack of burned rock, either scattered or in a hearth configuration, indicates that, for the most part, these were not habitation sites. This is confirmed by the lack of extensive tool use.

The supplementary activities indicated by the tools evidently involved either projectile points (hunting) or scraping tools (processing).

Large Water-distant Quarry Sites (Cluster I/viii)(Fig. 49)

Including 41 BX 406, 41 BX 415 and related sites 41 BX 404, 41 BX 429.

\section{Locational Attributes}

This group of sites is rather variable according to location. The sites are scattered throughout the southern portion of Camp Bullis and are terrace, valley slope and upland sites with water available at more than $100 \mathrm{~m}$. All of the sites are located near or on lithic outcrops and are very extensive. Mean diameter ranges from $270 \mathrm{~m}$ to $350 \mathrm{~m}$. Soil is generally very thin (two sites) or moderately deep red clay or dark clay/loam (two sites). Frequency of chipped stone is always greater than 100, and no burned rock is present.

\section{Artifact Assemblage}

The artifacts comprising these sites are almost exclusively core reduction debris. All sites have cores, chunks, primary and secondary flakes. Three sites have core fragments, interior flakes and quarry blanks, and two sites have preforms. The areal extent of these sites, the chipping debris within them, and their location near or on chert sources argues strongly for their primary function as quarrying and initial core reduction sites.

The lack of many and varied tools corroborates this. No sites contain projectile points, perforators or gravers. Two sites have scrapers, one site has only a thinned biface, one site has a chopper, and three sites have retouched flakes. The meager finished tool assemblage suggests that only occasional minor food procurement occurred on these sites. They may be characterized, then, as large upland quarry sites with essentially no other activity taking place.

Water-distant Quarry Area (Cluster J/X)(Fig. 49)

Including site $41 \mathrm{BX} 399$. 


\section{Locational Attributes}

This enormous site covers the tops and northeast sides of two large adjacent hills, Laurin Hill and Bush Hill, which contain extensive chert outcrops, but very shallow soil deposits. Water is available within one $\mathrm{km}$. The exact boundaries of the site are indeterminate. No burned rock was observed on the site, which contained well over 100 pieces of chipped stone.

\section{Artifact Assemblage}

The vast majority of artifacts in this site consists of cores, core fragments, chunks, quarry blanks and large primary, secondary and interior flakes. It is apparent that the area served as a chert quarry, with some crude initial core reduction occurring as wel1. The density of the artifacts varies with the amount of surface chert, but no discrete concentrations are present.

Finished tools are present, but scarce. Three unidentifiable dart points were found on the eastern extension of Bush Hill, and some scrapers and thinned bifaces were recovered from the north end of Laurin Hill. These artifacts indicated very limited hunting and plant collecting activities.

The site is perhaps best described as an upland quarry area, with probable continued exploitation through time.

Large Water-distant Campsites (Cluster F/vii) (Fig. 49)

Including sites $41 \mathrm{BX} 376,41 \mathrm{BX} 403$ and $41 \mathrm{BX} 431$.

\section{Locational Attributes}

The three sites in this cluster include terrace, valley slope and upland margin. Water is over $100 \mathrm{~m}$ away. The soil is very shallow, and no chert sources are nearby. Mean site diameter ranges from $52.5 \mathrm{~m}$ to $162.5 \mathrm{~m}$, and the chipped stone frequency in all cases is above 100. Scattered burned rock occurs on all of the sites as well.

\section{Artifact Assemblage}

Evidence of initial and secondary core reduction is weak on all sites. The predominant manufacturing debris consists of cores, quarry blanks and preforms. One site has primary flakes, a second has secondary flakes, and the third has interior flakes. It appears that little lithic processing was carried out at these sites.

In addition to the knapping function of the site, a variety of tools are also present. All of the sites have projectile points, and two have retouched flakes, two have thinned bifaces (knives), two have scrapers, one has a perforator, and one has a chopper. One site also has a Guadalupe tool--a very distinctive tool form with a presumably specialized function. 
Smal1 Water-distant Campsites (Cluster H/ix) (Fig. 49)

Including sites $41 \mathrm{BX} 390$ and $41 \mathrm{BX} 423$.

\section{Locational Attributes}

Both sites contained in Cluster $\mathrm{H}$ are upland sites with water available within one $\mathrm{km}$ or more. The soil is very thin, but no chert source is located near the sites. The mean diameters of the sites are 30.0 and $6.5 \mathrm{~m}$. Both contain approximately 10 to 100 pieces of chipped stone, and one site has scattered burned rock.

\section{Artifact Assemblage}

The chipped stone assemblages in these two sites are very similar. Manufacturing debris at both sites consists of cores and chunks, as well as secondary and primary flakes. The other has quarry blanks. This combination suggests that secondary core reduction and tool manufacturing were carried out at these sites.

The tools present at $41 \mathrm{BX} 390$ include projectile points, scrapers, thinned bifaces (knives) and retouched flakes. Site 41 BX 423 contained only thinned bifaces and retouched flakes. These varied tool types indicate numerous foodprocurement and processing activities. This, plus the secondary core reduction activity and the presence of burned rock, indicates use of the sites as temporary upland knapping and camping locales. The presence of burned rock indicates at least temporary occupation of one of these sites.

Water-distant Knapping Campsites (Group GR]) (Fig. 49)

Including sites $41 \mathrm{CM} 99$ and $41 \mathrm{BX} 402$.

\section{Locational Attributes}

These two sites form a group not closely associated enough to form a cluster, but still more like each other than any of the clusters. One is a terrace site, while the other is on the upland margin. Both are more than $100 \mathrm{~m}$ from water; in fact, one is more than one km from a water source. Neither is located near a chert source; both have reddish clay soils of some depth. Mean diameters are quite similar: $35.0 \mathrm{~m}$ and $42.5 \mathrm{~m}$. Chipped stone counts exceed 100 at both sites, and both have scattered burned rock.

\section{Artifact Assemblage}

Both sites show strong evidence of initial and secondary core reduction activities, having cores, core fragments, chunks, secondary flakes and interior flakes. Both have quarry blanks, one has preforms, and the other has primary flakes. It is evident, then, that much, if not all, of the core reduction and tool manufacturing sequence occurred at these sites. 
Tools at both sites include projectile points and retouched flakes. One site also has scrapers and thinned bifaces. The other has a perforator/graver.

These two sites are probably best described as short-term knapping campsites.

Water-distant Special Activity Sites (Cluster A3/v) (Fig. 49)

Including $41 \mathrm{BX} 374,41 \mathrm{BX} 375,41 \mathrm{BX} 380,41 \mathrm{BX} 384,41 \mathrm{BX} 426,41 \mathrm{CM} 94$ and $41 \mathrm{CM} 98$.

\section{Locational Attributes}

The sites composing this cluster are flood plain and terrace sites. Distance to water is consistently less than one $\mathrm{km}$. Soil is either moderately deep dark loam or moderately deep reddish clay. Chert cobble deposits are present near two of these sites. The mean diameter ranges from $20 \mathrm{~m}$ to $80 \mathrm{~m}$. The majority of the sites (five) have a mean diameter of $20 \mathrm{~m}$ to $50 \mathrm{~m}$. A71 have a moderate to large amount of chipped stone on the surface, from 50 to over 100 pieces. One site has burned rock visible on the surface.

\section{Artifact Assemblage}

The artifacts contained in these sites emphasize tool manufacturing activities.

Manufacturing debris on all sites includes cores, quarry blanks, and secondary and interior flakes. All except one site have core fragments and all but one have primary flakes. A11 but two have preforms. Four sites have "chunks." The implication of this type of manufacturing assemblage is that primary and secondary core, quarry blank and preform reduction was being carried out. It is likely that raw cores, chert and quarry blanks were brought into the site, and the consistent presence of quarry blanks, preforms, and primary, secondary and interior flakes are the products of the reduction processes.

The tool types found on sites in this cluster include projectile points (three sites), scrapers (four sites), thinned bifaces (four sites), choppers (one site) and retouched flakes (three sites). No pattern of association of the different tool types is evident, indicating that no specific resource, but rather a variety of resources, was being collected or processed.

The lack of burned rock in these sites is an indication of their likely short occupation span. These sites are primarily tool manufacturing locations, with some food collecting activities.

Sites 41 BX 375 and 41 BX 384 were located on chert sources and have artifact assemblages characteristic of quarrying sites. They were probably used primarily as quarry sites. 
Water-distant Special Activity Sites (Cluster B/iii) (Fig. 49)

Including $41 \mathrm{BX} 371,41 \mathrm{BX} 381,41 \mathrm{BX} 382,41 \mathrm{BX} 392,41 \mathrm{BX} 393,41 \mathrm{BX} 424$ and $41 \mathrm{CM} 100$.

\section{Locational Attributes}

Two sites in this cluster are on terraces, one on a valley slope, and the rest on upland margin sites; all have a water source generally available within one $\mathrm{km}$ (in one case, the distance is less than $100 \mathrm{~m}$ ). No chert source is available near these sites, and the soil is generally thin. The sites range from 3.5 to $85 \mathrm{~m}$ in mean diameter. The sites are characterized by a fairly low frequency of chipped stone, an estimated 10 to 100 pieces. Scattered burned rock is present on one site.

\section{Artifact Ass emblage}

A11 of the sites contain some manufacturing debris, including secondary and interior flakes (a11 sites), cores (four sites), chunks (three sites), core fragments (four sites) and primary flakes (two sites). Four sites have quarry blanks and three have preforms present. This combination of artifacts indicates that secondary core reduction and tool manufacturing activities were carried out.

All seven sites have projectile points, five have scrapers, five have thinned bifaces, two have choppers, and two have retouched flakes. Of the seven sites, two (41 BX 371, $41 \mathrm{BX} 393$ ) have al1 these tools. Of these two, $41 \mathrm{BX} 371$ is the only site with burned rock in the cluster and probably was occupied somewhat longer than the others.

In general, these sites likely functioned as secondary reduction sites and specialized resource procurement sites. The lack of burned rock and low chipped stone density again imply very short-term occupation of the site.

Water-proximate Quarry Sites (Cluster K) (Fig. 49)

Including 41 BX 405.

Locational Attributes

Site 41 BX 405 is located on the upland margin but is within $100 \mathrm{~m}$ of a water source. A chert outcrop is present on the site, and the soil is red clay with some depth. The mean site diameter is $22.5 \mathrm{~m}$. The chipped stone count is quite low for a quarry site, from 10 to 50 pieces. No burned rock was found on the site. 
Artifact Assemblage

Lithic debris found at the site consisted of cores, core fragments, chunks, and primary, secondary and interior flakes. No finished tools were found. Other than its relative proximity to a water source, this site is much like the sites in cluster $C$, small water-distant quarries.

Water-proximate Campsites (Cluster $A_{7} / i$ ) (Fig. 49)

Including sites $41 \mathrm{BX} 378,41 \mathrm{BX} 379,41 \mathrm{BX} 385,41 \mathrm{BX} 386,41 \mathrm{BX} 391,41 \mathrm{BX}$ $396 \mathrm{~N}, 41 \mathrm{BX} 396 \mathrm{~S}$ and $41 \mathrm{BX} 400$.

\section{Locational Attributes}

The sites in this cluster are less variable than those in the previous clusters with regard to locational attributes. These sites are situated on terraces. Distance to water is less than $100 \mathrm{~m}$. The soil type is either very shallow soil or deep, dark soil.

Average site diameter varies from a minimum $1.0 \mathrm{~m}$ to a maximum of $115 \mathrm{~m}$. (The second largest site is $50 \mathrm{~m}$ in diameter.) The amount of chipped stone is consistently greater than 50 pieces, and scattered burned rock appears on two of the eight sites.

\section{Artifact Assemblage}

Most of the eight sites contained cores (seven sites), primary flakes (seven sites), secondary flakes (eight sites) and interior flakes (eight sites). Seven sites had preforms. Four sites had core fragments, four had chunks, and only two had quarry blanks. These numbers indicate an emphasis on secondary reduction and tool manufacture.

Projectile points were recovered from all sites, and scrapers from six sites. Thinned bifaces (knives) and retouched flakes were located on six of the eight sites.

The presence of a wide range of tools and similar tool types on every site may indicate similar resource extractive activities. Those presumably included hunting and plant collecting/processing. They were likely temporary campsites at which a variety of activities took place. Site $41 \mathrm{BX} 386$, located on a chert cobble source, was probably a quarry-camp.

Water-proximate Campsites (Cluster $A_{2} /$ iv) (Fig. 49)

Including $41 \mathrm{BX} 373,41 \mathrm{BX} 387,41 \mathrm{BX} 388,41 \mathrm{BX} 408,41 \mathrm{CM} 96,41 \mathrm{CM} 101$ and 41 CM 102. 


\section{Locational Attributes}

These sites are found on flood plains or terraces with water generally available within $100 \mathrm{~m}$. Chert is present as a raw material source at only one site. The soil is a moderately deep reddish clay. Mean site diameter varies from 10.5 to $35.0 \mathrm{~m}$, and the chipped stone frequency is moderate, ranging from 10 to 100 specimens. Hearths are present at two sites.

\section{Artifact Assemblage.}

The general pattern of artifacts present at the sites of this cluster shows somewhat less emphas is on manufacturing debris than in cluster A. All sites have interior flakes, and five of the seven sites have primary and secondary flakes. Four sites have preforms. Three sites have cores, two have chunks, two have quarry blanks and one has core fragments.

The tool assemblages present on these sites include projectile points (six sites), scrapers (five sites) and thinned bifaces (a11 sites). Two sites contain retouched flakes. These varied tool types reflect a diversity of activities.

The sites in this cluster are similar in function to the previously described lowland (water-proximate) campsites (Cluster $A_{1}$ ). Site 41 BX 373 was located on a chert cobble source and was probably primarily a quarry-camp.

Water-proximate Special Activity Sites (Cluster G) (Fig. 49)

Including sites $41 \mathrm{BX} 425$ and $41 \mathrm{BX} 430$ and related site $41 \mathrm{BX} 428$.

\section{Locational Attributes}

Sites which are grouped into Cluster $G$ are all located on low terraces with deep dark clay/loam soil. The distance to a water source ranges from on the site to one $\mathrm{km}$. No chert sources are found in the vicinity of these sites. Chipped stone frequency on the surfaces of these sites is very low, from one to 10 pieces or none at a11. They are recognizable by the extensive quantity of burned rock in a small area, often called burned rock middens. The mean diameter of these middens varies from $7.5 \mathrm{~m}$ to $25 \mathrm{~m}$.

\section{Artifact Assemblage}

Although the frequency of chipped stone is very low, a large variety of artifact types was recovered from test excavations at two of the sites. Observations on the assemblages are necessarily limited to the two tested sites.

Manufacturing debris consists of cores, core fragments, chunks, quarry blanks, preforms, and primary, secondary and interior flakes. Evidently a wide range of activities took place at or near the midden. The fragmentary nature of most of the artifacts in the burned rock accumulations suggests that these may be disposal areas. 
Tools recovered from the two sites include projectile points, scrapers and thinned bifaces. One site also contained retouched flakes. Ground stone fragments were recovered from both sites. The majority of these tools are fragmentary; however, those from $41 \mathrm{BX} 425$ were mixed in with the burned rock, while those from $41 \mathrm{BX} .428$ were recovered primarily from test pits placed adjacent to the burned rock concentration.

The function of these sites is unclear, but it is evident that a variety of knapping and tool-using activities occurred. The burned rock concentrations suggest long-term or repeated occupation, yet the low total artifact frequency does not substantiate this. The possible function of burned rock accumulations such as these is discussed elsewhere (see III.A.9).

Water-proximate Special Activity Sites (Cluster E/ii) (Fig. 49) Including sites $41 \mathrm{BX} 372,41 \mathrm{BX} 377,41 \mathrm{BX} 383,41 \mathrm{CM} 70$ and associated site $47 \mathrm{BX} 36$.

\section{Locational Attributes}

All the sites in this cluster are located on flood plains or low terraces. All are within $100 \mathrm{~m}$ of a water source, and all but one have no on-site chert sources. Soils are moderately deep black loam or reddish clay. The mean diameter ranges from $30 \mathrm{~m}$ to $130 \mathrm{~m}$, with three of the five sites having mean diameters larger than $100 \mathrm{~m}$.

\section{Artifact Assemblage}

A1l sites had primary, secondary and interior flakes. Most had cores, core fragments, quarry blanks and preforms. Three of the five had chunks.

All sites had projectile points and thinned bifaces. Most had scrapers and retouched flakes. Three sites had perforator/gravers and two had choppers.

Both the size and depth of the burned rock accumulation, and the nature and quantity of chipped stone and bone tools and debris, indicate long-term intensive use of the sites as habitation areas. The major differences between these and other campsites, however, cause them to be placed in the category of lowland special activity sites. Most were probably used as long-term occupation sites, as well as knapping sites.

\section{SUMMARY}

A total of 13 clusters of similar sites were defined on the basis of locational attributes and artifact assemblages. These form six larger types of sites, based on their general location and primary activities: upland or lowland, and quarry, camp, or special activity. Each major grouping contained one or more 
site clusters with a greater or lesser range of specific functions. These functions relate to the site locations, artifact assemblages and site features. Briefly, they include four types of upland (water-distant) quarry sites: small, moderate, large and extensive; upland camps with extensive tool manufacture; upland hunting camps; and upland special activity sites of two types: general food procurement including hunting and plant collecting along with moderate knapping activity, and specialized food procurement (either hunting or plant collecting) with minor knapping activity. Water-proximate site types include one quarry site, campsites, general food procurement sites with minor knapping activity and two types of burned rock accumulations, small and extensive.

Certain general patterns are visible in these divisions. For example, excluding cluster $K$, consisting of site 41 BX 405 (which is virtually the same type of site as those of cluster $C$ ), there are no clusters of water-proximate quarry sites. All sites which could have qualified as such a type were clustered with campsites. At the same time, all sites which are strictly quarry sites are in the southern half of the survey area.

Burned rock accumulation clusters are all near water. The only other clusters with a consistent burned rock attribute are $F, H$ and $\mathrm{GR}_{1}$, the water-distant campsites.

In general, the impression is that sites associated with a nearby, dependable water supply tend to have been used for a wider range of activities or for longer time spans than water-distant sites. 


\begin{tabular}{|c|c|c|c|c|c|c|c|c|c|c|c|c|c|c|c|c|c|c|c|c|c|}
\hline ఫ్ & 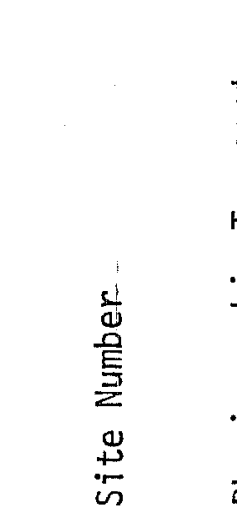 & 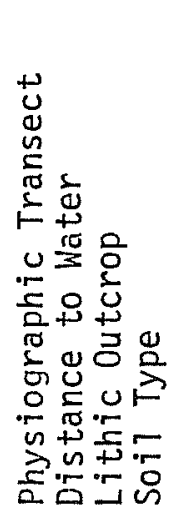 & 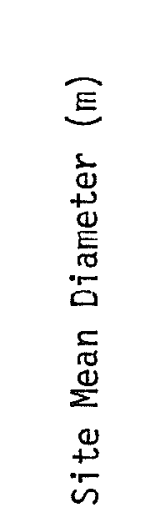 & 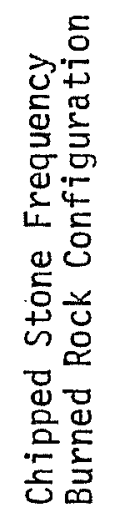 & 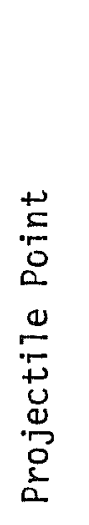 & 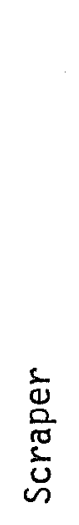 & 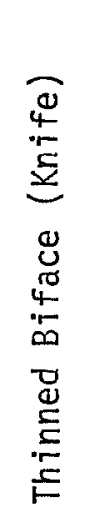 & $\begin{array}{l}0 \\
0 \\
0 \\
0 \\
0 \\
0 \\
0 \\
0 \\
0 \\
0 \\
0 \\
0 \\
0 \\
0 \\
0\end{array}$ & $\begin{array}{l}\frac{1}{\Phi} \\
\frac{0}{0} \\
\frac{0}{0}\end{array}$ & 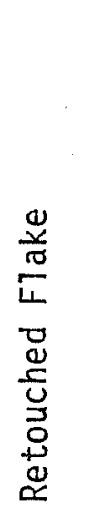 & 峁 & 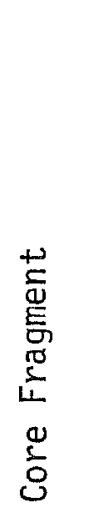 & $\begin{array}{l}\text { 兰 } \\
\text { 吾 }\end{array}$ & 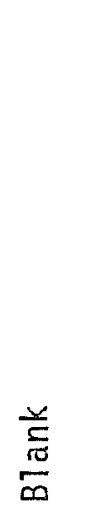 & $\begin{array}{l} \\
E \\
0 \\
0 \\
4 \\
0 \\
0 \\
0 \\
0\end{array}$ & 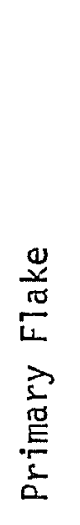 & 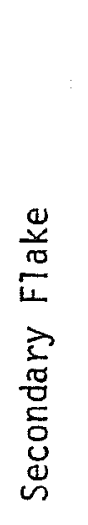 & 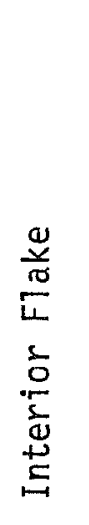 & 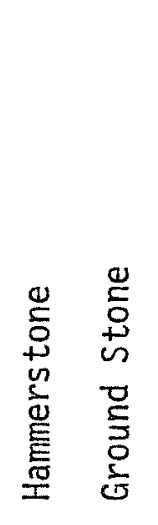 & 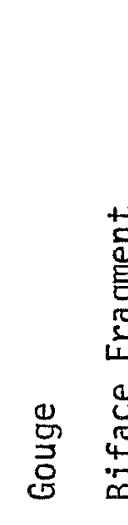 & 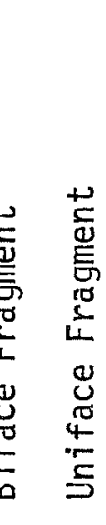 \\
\hline$C$ & $\begin{array}{lll}41 & \text { BX } & 409 * \\
41 & \text { BX } & 417 \\
41 & \text { BX } & 417 \\
47 & \text { BX } & 412 \\
41 & \text { BX } & 413 \\
47 & \text { BX } & 410\end{array}$ & $\begin{array}{rrrr}* 2 & 3 & 5 & 1 \\
2 & 3 & 5 & 1 \\
2 & 3 & 5 & 1 \\
2 & 3 & 5 & 1 \\
2 & 3 & 4 & 2 \\
2 & 3 & 5 & 2 \\
& & & \end{array}$ & $\begin{array}{l}24.0 \\
15.0 \\
80.0 \\
27.5 \\
22.5 \\
22.5\end{array}$ & $\begin{array}{ll}4 & 1 \\
4 & 0 \\
4 & 0 \\
2 & 0 \\
2 & 0 \\
3 & 0 \\
- & -\end{array}$ & $x$ & $\begin{array}{l}x \\
x\end{array}$ & $\begin{array}{l}x \\
x\end{array}$ & & $x$ & $\begin{array}{l}x \\
x \\
x \\
-\end{array}$ & $\begin{array}{l}x \\
X \\
X\end{array}$ & $\begin{array}{l}X \\
X \\
X\end{array}$ & $\begin{array}{l}x \\
y \\
x \\
x \\
X \\
\end{array}$ & $\begin{array}{l}x \\
x \\
x \\
x \\
x \\
\end{array}$ & $x$ & $\begin{array}{l}x \\
x \\
x \\
x \\
x \\
x\end{array}$ & $\begin{array}{l}X \\
X \\
X \\
X \\
X \\
X \\
\end{array}$ & $\begin{array}{l}X \\
X \\
X \\
X \\
X \\
X\end{array}$ & & $x$ & \\
\hline 22 & $\begin{array}{l}41 \text { BX } 418 \\
47 \text { BX } 416 \\
\end{array}$ & $\begin{array}{llll}2 & 2 & 6 & 2 \\
2 & 3 & 6 & 3 \\
\end{array}$ & $\begin{array}{l}40.0 \\
17.5 \\
\end{array}$ & $\begin{array}{l}40 \\
40 \\
\end{array}$ & & & & & & & $\begin{array}{l}x \\
x \\
\end{array}$ & $x$ & $\begin{array}{l}x \\
x \\
\end{array}$ & $x$ & $x$ & $x$ & $\begin{array}{l}x \\
x\end{array}$ & $\begin{array}{l}x \\
x\end{array}$ & & & \\
\hline I & $\begin{array}{lll}41 & \text { BX } & 429 \\
41 & \text { BX } & 406 \\
47 & \text { BX } & 415 \\
41 & \text { BX } & 404\end{array}$ & $\begin{array}{llll}2 & 4 & 5 & 3 \\
3 & 3 & 5 & 1 \\
2 & 3 & 6 & 2 \\
5 & 3 & 6 & 1\end{array}$ & $\begin{array}{l}270.0 \\
275.0 \\
350.0 \\
350.0\end{array}$ & $\begin{array}{ll}4 & 0 \\
4 & 0 \\
4 & 0 \\
4 & 0\end{array}$ & & $\begin{array}{l}x \\
x\end{array}$ & $x$ & & $x$ & $\begin{array}{l}x \\
x \\
x\end{array}$ & $\begin{array}{l}x \\
x \\
x \\
x\end{array}$ & $\begin{array}{l}x \\
x \\
x\end{array}$ & $\begin{array}{l}x \\
x \\
x\end{array}$ & $\begin{array}{l}x \\
x \\
x\end{array}$ & $x$ & $\begin{array}{l}x \\
x \\
x \\
x\end{array}$ & $\begin{array}{l}X \\
X \\
X \\
X\end{array}$ & $\begin{array}{l}x \\
X \\
X \\
X\end{array}$ & & & $x$ \\
\hline J & $41 B \times 399$ & 6381 & $500.0+$ & 40 & $x$ & $x$ & $x$ & & & $x$ & $x$ & $x$ & $x$ & $x$ & & $x$ & $x$ & $x$ & & & \\
\hline D & $\begin{array}{lll}41 & \text { BX } & 414 \\
41 & \text { BX } & 407 \\
41 & \text { BX } & 419 \\
41 & \text { BX } & 421 \\
41 & \text { BX } & 395 \\
\end{array}$ & $\begin{array}{llll}4 & 2 & 6 & 1 \\
4 & 3 & 5 & 1 \\
4 & 3 & 6 & 1 \\
5 & 3 & 6 & 1 \\
4 & 3 & 9 & 1 \\
\end{array}$ & $\begin{array}{r}150.0 \\
37.5 \\
55.0 \\
45.0 \\
30.0 \\
\end{array}$ & $\begin{array}{ll}4 & 0 \\
4 & 0 \\
4 & 0 \\
4 & 0 \\
4 & 0 \\
\end{array}$ & $x$ & $\begin{array}{l}x \\
x \\
x\end{array}$ & $x$ & $x$ & & $\begin{array}{l}x \\
x \\
x\end{array}$ & $\begin{array}{l}X \\
X \\
X \\
X \\
X \\
\end{array}$ & $\begin{array}{l}x \\
\hat{x} \\
x \\
x \\
x\end{array}$ & $\begin{array}{l}x \\
x \\
x\end{array}$ & $\begin{array}{l}x \\
x \\
x\end{array}$ & $\begin{array}{l}x \\
x\end{array}$ & $\begin{array}{l}x \\
x \\
x \\
x \\
x \\
x\end{array}$ & $\begin{array}{l}X \\
X \\
X \\
X \\
X \\
\end{array}$ & $\begin{array}{l}X \\
X \\
X \\
X \\
X \\
\end{array}$ & & & \\
\hline$F$ & $\begin{array}{lll}41 & \text { BX } & 403 \\
41 & \text { BX } & 431 \\
41 & \text { BX } & 376 \\
\end{array}$ & $\begin{array}{llll}3 & 3 & 0 & 1 \\
2 & 3 & 0 & 1 \\
4 & 3 & 0 & 1 \\
\end{array}$ & $\begin{array}{r}52.5 \\
75.0 \\
162.5 \\
\end{array}$ & $\begin{array}{ll}4 & 1 \\
4 & 7 \\
4 & 1 \\
\end{array}$ & $\begin{array}{l}X \\
X \\
X \\
\end{array}$ & $\begin{array}{l}x \\
x\end{array}$ & $\begin{array}{l}x \\
x \\
\end{array}$ & $x$ & $x$ & $\begin{array}{l}x \\
x\end{array}$ & $\begin{array}{l}X \\
X \\
\end{array}$ & $x$ & & $\begin{array}{l}x \\
x \\
x \\
\end{array}$ & $\begin{array}{l}x \\
x\end{array}$ & $\begin{array}{l}x \\
x \\
\end{array}$ & $x$ & $\begin{array}{l}x \\
x \\
\end{array}$ & $x$ & $x$ & \\
\hline GRT & $\begin{array}{rrr}41 & \mathrm{CM} & 99 \\
41 & \mathrm{BX} & 402 \\
\end{array}$ & $\begin{array}{llll}2 & 4 & 0 & 3 \\
4 & 3 & 0 & 3 \\
\end{array}$ & $\begin{array}{l}42.5 \\
35.0 \\
\end{array}$ & $\begin{array}{l}41 \\
41 \\
\end{array}$ & $\begin{array}{l}x \\
x \\
\end{array}$ & $x$ & $x$ & $x$ & & $\begin{array}{l}x \\
x \\
\end{array}$ & $\begin{array}{l}x \\
x \\
\end{array}$ & $\begin{array}{l}x \\
x\end{array}$ & $\begin{array}{l}x \\
x\end{array}$ & $\begin{array}{l}x \\
x \\
\end{array}$ & $x$ & $x$ & $\begin{array}{l}x \\
x \\
\end{array}$ & $\begin{array}{l}x \\
x \\
\end{array}$ & & $x$ & $x$ \\
\hline H & $\begin{array}{lll}41 & \text { BX } & 423 \\
41 & \text { BX } & 390\end{array}$ & $\begin{array}{llll}5 & 4 & 0 & 1 \\
4 & 4 & 0 & 1\end{array}$ & $\begin{array}{r}30.0 \\
6.5\end{array}$ & $\begin{array}{ll}2 & 0 \\
3 & 1\end{array}$ & $x$ & $x$ & $\begin{array}{l}x \\
x\end{array}$ & & & $\hat{x}$ & $\begin{array}{l}x \\
x\end{array}$ & & $\begin{array}{l}x \\
x\end{array}$ & $x$ & $x$ & $\gamma$ & $\begin{array}{l}x \\
x\end{array}$ & $\begin{array}{l}x \\
x\end{array}$ & & & \\
\hline
\end{tabular}

Figure 49. Site Attributes: Locational and Artifact Assemblages. 


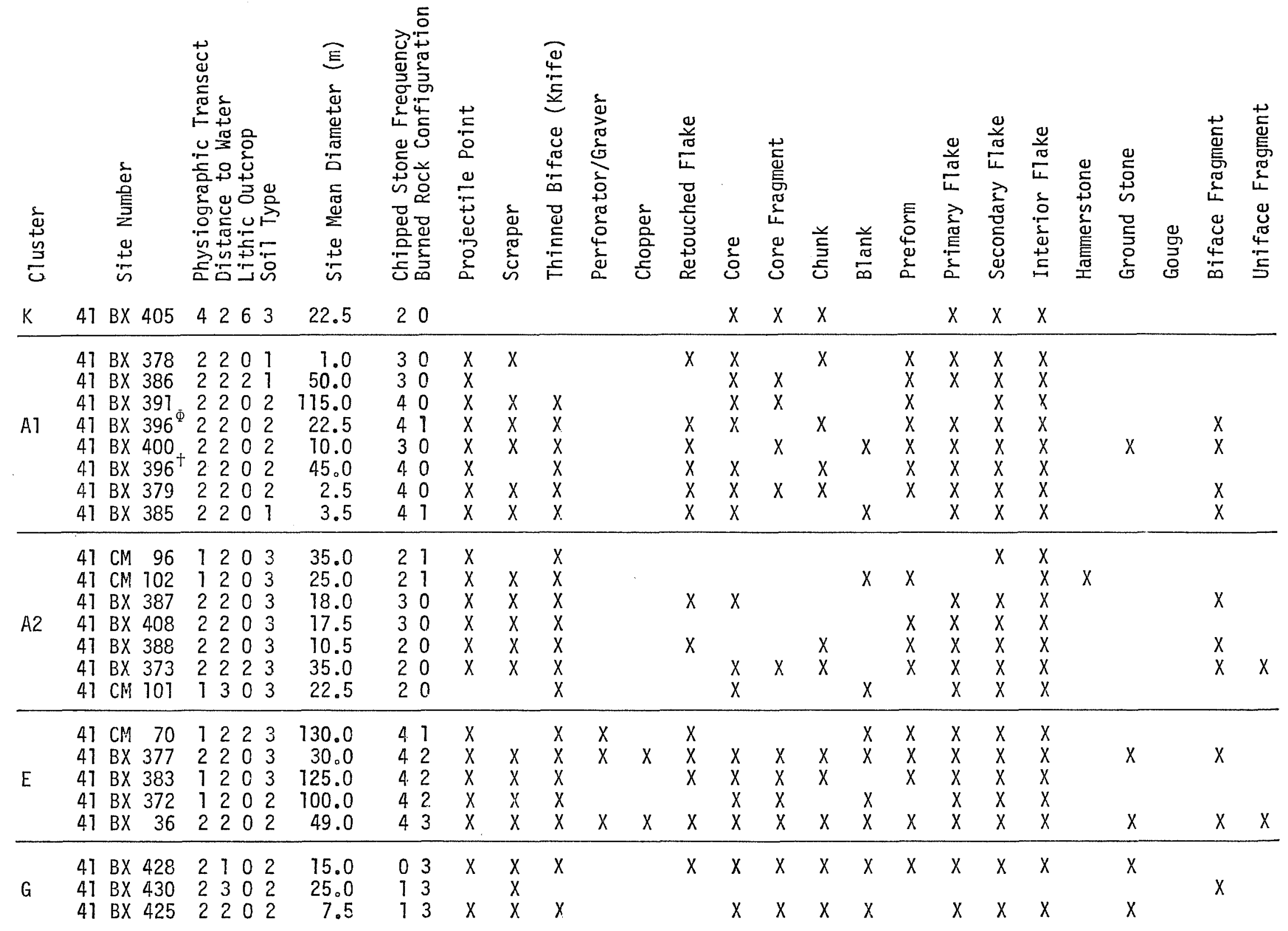




\begin{tabular}{|c|c|c|c|c|c|c|c|c|c|c|c|c|c|c|c|c|c|c|c|c|c|c|c|}
\hline 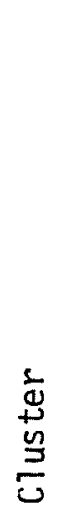 & 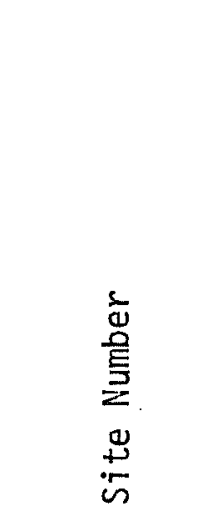 & 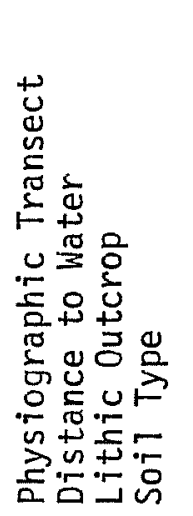 & 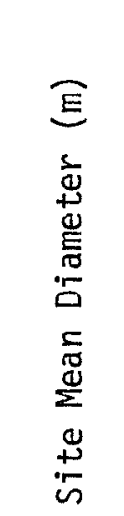 & 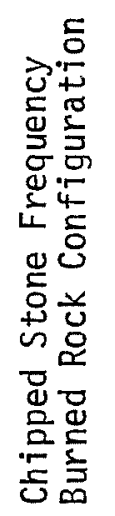 & 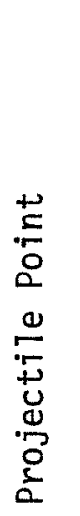 & $\begin{array}{l}\frac{1}{d} \\
\frac{0}{\pi} \\
\frac{0}{0} \\
\sim\end{array}$ & 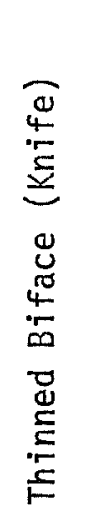 & 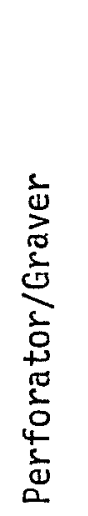 & 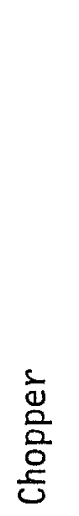 & 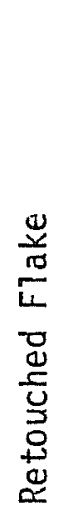 & 巳ัँ & 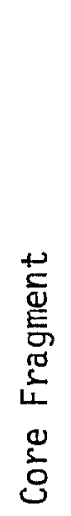 & 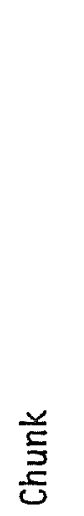 & $\begin{array}{l}\frac{\text { L }}{\frac{\pi}{m}} \\
\end{array}$ & 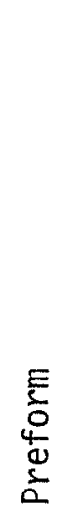 & 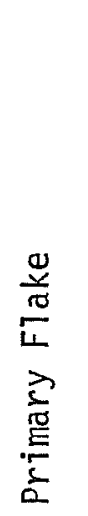 & 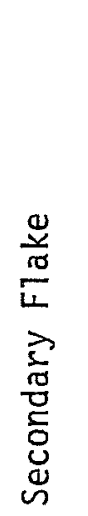 & 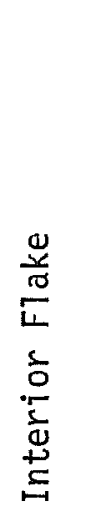 & 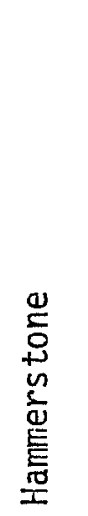 & 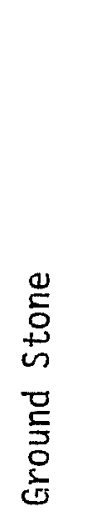 & 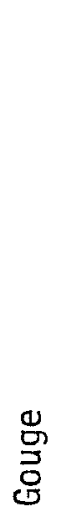 & 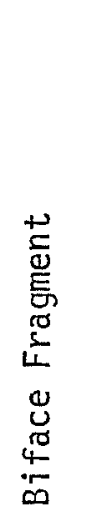 & $\vec{c}$ \\
\hline 3 & $\begin{array}{llr}41 & C M & 98 \\
41 & B X & 426 \\
41 & B X & 384 \\
41 & B X & 375 \\
41 & B X & 374 \\
41 & B X & 380 \\
41 & C M & 94 \\
\end{array}$ & $\begin{array}{llll}2 & 3 & 0 & 3 \\
2 & 3 & 0 & 3 \\
1 & 3 & 2 & 2 \\
1 & 3 & 2 & 3 \\
1 & 3 & 0 & 2 \\
2 & 3 & 0 & 2 \\
2 & 3 & 0 & 2 \\
\end{array}$ & $\begin{array}{l}50.0 \\
20.0 \\
80.0 \\
75.0 \\
37.5 \\
20.0 \\
20.0\end{array}$ & $\begin{array}{ll}4 & 1 \\
4 & 0 \\
4 & 0 \\
4 & 0 \\
3 & 0 \\
3 & 0 \\
3 & 0 \\
\end{array}$ & $\begin{array}{l}x \\
x \\
x\end{array}$ & $\begin{array}{l}X \\
X \\
X \\
X \\
\end{array}$ & $\begin{array}{l}x \\
X\end{array}$ & & $x$ & $\begin{array}{l}x \\
x \\
x\end{array}$ & $\begin{array}{l}x \\
x \\
x \\
x \\
x \\
x \\
x \\
\end{array}$ & $\begin{array}{l}x \\
x \\
x \\
x \\
x \\
x \\
x\end{array}$ & $\begin{array}{l}x \\
x \\
x \\
x\end{array}$ & $\begin{array}{l}x \\
X \\
X \\
X \\
X \\
x \\
x\end{array}$ & $\begin{array}{l}x \\
x \\
x \\
x \\
x \\
\end{array}$ & $\begin{array}{l}x \\
x \\
x \\
x \\
x \\
x\end{array}$ & $\begin{array}{l}x \\
X \\
x \\
x \\
x \\
X \\
x\end{array}$ & $\begin{array}{l}x \\
x \\
x \\
x \\
x \\
x \\
x \\
\end{array}$ & & & $x$ & $\begin{array}{l}x \\
x\end{array}$ & \\
\hline & $\begin{array}{lll}41 & C M & 100 \\
41 & B X & 381 \\
41 & B X & 424 \\
41 & B X & 392 \\
41 & B X & 382 \\
41 & B X & 371 \\
41 & \text { BX } & 393\end{array}$ & $\begin{array}{llll}2 & 3 & 0 & 1 \\
2 & 3 & 0 & 1 \\
3 & 3 & 0 & 1 \\
4 & 3 & 0 & 1 \\
4 & 3 & 0 & 1 \\
4 & 3 & 0 & 1 \\
4 & 2 & 0 & 1\end{array}$ & $\begin{array}{l}42.5 \\
85.0 \\
40.0 \\
3.5 \\
77.5 \\
62.5 \\
50.0\end{array}$ & $\begin{array}{ll}2 & 0 \\
2 & 0 \\
2 & 0 \\
2 & 0 \\
3 & 0 \\
3 & 1 \\
3 & 0\end{array}$ & $\begin{array}{l}x \\
x \\
x \\
x \\
x \\
x \\
x\end{array}$ & $\begin{array}{l}x \\
x\end{array}$ & $\begin{array}{l}x \\
x \\
x\end{array}$ & & $\begin{array}{l}x \\
x\end{array}$ & $\begin{array}{l}X \\
X \\
X\end{array}$ & $\begin{array}{l}x \\
x\end{array}$ & $\begin{array}{l}x \\
X \\
x\end{array}$ & $\begin{array}{l}x \\
x \\
x\end{array}$ & $\begin{array}{l}X \\
X \\
X\end{array}$ & $\begin{array}{l}x \\
x \\
x \\
x\end{array}$ & $\begin{array}{l}x \\
x\end{array}$ & $\begin{array}{l}x \\
x \\
x \\
x \\
x \\
x \\
x\end{array}$ & $\begin{array}{l}x \\
x \\
x \\
x \\
x \\
x \\
x\end{array}$ & & & $x$ & $\begin{array}{l}X \\
X \\
X \\
X\end{array}$ & $x$ \\
\hline
\end{tabular}

*The code presented here is from the Computer Coded Field Survey Form (see Fig. 5 for expianation). It is presented as a visual aid in gauging the similarity of sites in the cluster. These attributes were used in the cluster analysis.

$\Phi 41 \mathrm{BX} 396 \mathrm{~N}$

$\dagger_{41}$ BX 3965 



\title{
III. A.9
}

\section{SETTLEMENT PATTERNS}

\author{
Andrea Gerstle
}

The spatial configuration of the site types presents some indication of the relationships between the different sites. A glance at the map shows that distribution of sites is not uniform over the survey area. This is not only the result of the off-transect survey focus being along Cibolo Creek, but is also evident in the $15 \%$ systematic transect sample (see Fig. 34 ). Most of the sites are located along Cibolo Creek, with a second concentration in the south and southeast sections of Camp Bullis, i.e., the area south of the Balcones Fault Zone where chert resources are available. The extensive area between these two site concentrations contains only a few sites.

The explanation for this distribution lies partly in the function of the site and partly in the resources available or absent. For the purposes of discussion, Camp Bullis is divided into three archaeological sections: (1) the southern quarter, (2) the middle half and (3) the northern quarter (measured along the north-south dimension of the reservation). The divisions are approximate areas, not actual boundaries.

\section{SOUTH SECTION}

The southern section contains a concentration of sites, most of which are located in the eastern portion. The majority (19 out of 28) of these are quarry sites. Since chert outcrops are abundant here, it is logical that the primary purpose of the sites is directed toward the exploitation of that resource.

Six sites ( 41 BX 396N, 41 BX 396S, 41 BX 402, 41 BX 403, 41 BX 423 and 41 BX 431) appear to have functioned as campsites. Four of the six have scatters of burned rock; all show evidence that lithic reduction activities were carried out on the site.

The occurrence of three of the eight burned rock accumulations in this section is somewhat problematical. Two of the sites (41 BX 428 and 41 BX 430) are without extensive chipped stone present. The third (41 BX 36) is large and with abundant artifactual remains. It is probable that these three sites functioned as habitations. The location of these three sites near permanent or intermittent water sources and distant from chert sources (in direct contrast to the quarry sites) supports this possibility. It may well be that the small campsites in this area are satellite camps to the sites with burned rock accumulations. Sma11 groups may have made forays for a short time for the purpose of collecting chert to bring back to the main camp. The chert was tested and reduced to the quarry blank stage before returning to the home base.

The sites in this southern area fall naturally, by type and physical location, into five groups:

(1) Sites $41 \mathrm{BX} 36,41 \mathrm{BX} 428$ and $41 \mathrm{BX} 430$ are stream valley sites with burned rock accumulations. 
(2) Sites $41 \mathrm{BX} 396 \mathrm{~N}, 41 \mathrm{BX} 396 \mathrm{~S}, 41 \mathrm{BX} 402,41 \mathrm{BX} 403,41 \mathrm{BX} 423$ and $41 \mathrm{BX} 431$ are campsites, most with burned rock scatter, and in general are well up out of the major stream valleys.

(3) South of the chert line (Fig. 34), where chert is available at the surface, quarry sites of clusters I and J (see III.A.8) are large lithic procurement areas scattered through the area.

(4) Quarry sites of cluster C/gr form a group of five small sites close together on low hills in the Panther Springs Creek valley with a sixth member at a little distance to the north, and the two sites $41 \mathrm{BX} 416$ and $41 \mathrm{BX} 418$ (Grouping $\mathrm{GR}_{2}$, associated with cluster $\mathrm{C} / \mathrm{gr}$ ) immediately north of that. Of this group of eight sites, one (41 BX 409) is an anomalous site with a scatter of burned rock and a wide range of tool types found on site, the kind of site being called a quarry-camp here. Quarry site $41 \mathrm{BX}$ 405 is much like the sites in cluster C/gr and GR2, but is located within $100 \mathrm{~m}$ of a water source; thus, it formed the single member of cluster $\mathrm{K}$.

(5) Quarry sites of cluster $D$ form a group of four moderate-sized quarry sites on the upper ridges and crests of Scott Hill and its neighbors to the immediate west. A fifth member of cluster $D$ is $41 \mathrm{BX} 395$, about 1-1/2 miles away to the west across the Salado Creek valley. Of the close group, one site (41 BX 407) has an artifact collection quite similar to that seen at $41 \mathrm{BX} 409$, but no burned rock is reported. $41 \mathrm{BX} 407$ can be tentatively considered as a quarry-camp. Sites 41 BX 409 in Group 4 above and 41 BX 407 in this group are the only quarry sites in their respective clusters to which dates can be assigned. Both are dated to the Pre-Archaic and Late Archaic.

The configuration of site types and locations in the southern portion of Camp Bullis is a good application of Central Place Theory. Several major centers (the burned rock accumulation sites) are surrounded by minor centers (the short-term campsites). Both of these are in turn surrounded by resourceproducing locations. The resource, in this case primarily chert, is funnelled either into the major centers directly or by way of the minor centers. The symmetry of the hexagonal Central Place Model is slightly distorted in this example due to the non-uniform distribution of the chert (it is restricted to the south) and the limits of the available transportion services (on foot).

The location of the main camps to the north of the chert source has interesting implications with regard to population movement. It is possible that the peoples exploiting the chert sources came from the north just for that purpose. However, this suggestion must remain tentative until surveys outside of the Camp Bullis boundary have determined the presence and types of sites occurring to the south.

Another possibility is the presence of abundant and varied plant resources to the north. The heaviest present-day concentration of sotol is to the north of $41 \mathrm{BX} 428$ and $41 \mathrm{BX} 430$. These burned rock accumulations may have been sotolprocessing operations with concurrent camping activities. If this is true, 
then $41 \mathrm{BX} 36$, a larger burned rock accumulation with abundant tools and bone, may have been a base camp of a higher level. The sotol-processing sites 41 BX 428 and 41 BX 430 would have been satellites of 41 BX 36 while serving as centers to the satellite quarry sites.

\section{CENTRAL SECTION}

The central section of Camp Bullis, half of the area of the reservation, contains a total of six sites, or $9.5 \%$ of the total number of sites recorded. This astonishingly low proportion may be due to several factors. First, one must consider the survey techniques employed, and second, the nature of the sites and the environment of the area.

One of the primary reasons why so few sites were located is because only minimal off-transect searching was conducted (in contrast to the northern section, where liberal time was spent in additional survey). The entire area was covered by the $15 \%$ systematic transect sample, but only parts of the western Muesebach Creek drainage were surveyed intensively. It may be assumed that these sites actually represent 15\% of the tota 7 number and variability of sites in this area.

The second factor to be considered is the nature of the sites and the environment. Of the six sites in this section, three are campsites and three are special activity sites. The campsites are located in the stream valleys, while the special activity sites are well up into the hills. This situation suggests that the area was used only occasionally and for special purposes.

The relative scarcity of campsites and their satellites in this area may result from several factors. Although small springs and streams are scattered throughout the region, they are all unreliable water sources. Related to this water scarcity is the limited number and non-uniform distribution of plant species (at least currently, and probably in the past; C. M. Woodruff, personal communication). It may be that sufficient and varied food resources were not available, making the area less desirable for intensive prehistoric habitation.

Another possible cause for the scanty occupation may be related to the social organization of the prehistoric peoples. Ethnohistoric records document the existence of a band-level society with territorial limits (see Part I). In all likelihood, the arrangement also extended into prehistoric times. The central section of Camp Bullis may represent a territorial boundary zone which was exploited less intensively than either the southern section or the northern section, each of which would belong to different band territories. Unfortunately, this hypothesis cannot be tested at present, as the contemporaneity of whole site groupings, especially in the southern section, is as yet indeterminate.

NORTH SECTION

When considering the distribution of sites in the northern section, survey techniques must be taken into account once again. Although the entire area was covered with the $15 \%$ systematic transect sample, this section was also 
the focus of much additional intensive survey. A total of 29 prehistoric sites was recorded for the northern section. Of these, $13(45 \%)$ were located on the transects comprising the $15 \%$ sample. Based on these figures, at 1 east $30 \%$ of the sites in this area were located (in the judgment of the survey crews, probably more nearly 75\%). Table 18 presents the frequencies of sites located by transect survey and off-transect survey for each major site type in this section. Examination of this table indicates the direction of bias introduced by non-systematic survey techniques. Sites far from water tend to be slighted while water-proximate sites are emphasized.

The distribution of campsites, which in the central and southern sections forms the central focus of a series of special activity sites, is rather scattered in the northern section. In the transect sample, two water-distant campsites were located (from west to east: 41 BX 376 and 41 BX 390).

TABLE 18. FREQUENCIES OF SITES LOCATED ON AND OFF TRANSECTS

Site Type

Water-distant Quarry Sites

Water-distant Campsites

Water-distant Special Activity sites

Water-proximate Quarry sites

Water-proximate Campsites

Watermproximate Special Activity sites
On-Transect Off-Transect

0

2

5

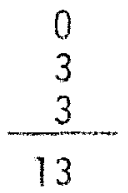

0

1

6

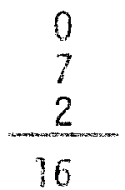

Three water-proximate camps were also located on transects (41 BX 386, 41 CM 102 and $41 \mathrm{CM}$ 96). These are all situated within $100 \mathrm{~m}$ of Cibolo Creek, and one was on a chert source (remnant chert gravels on erosional surfaces, or strath plains; C. M. Woodruff, personal communication). This strategic locam tion enables combining chert quarrying and tool manufacturing activities at the same place and time as other necessary living activities.

The fairly uniform distribution of campsites along Cibolo Creek suggests that it was a major deciding factor in the choice of campsite locations. It is a relatively reliable water source (deep water holes provide a year-round supply) and is definitely attractive because of its varied food and chert resources.

Five water-distant special activity sites were also located on the transects. They are all food procurement and secondary knapping areas. One (41 BX 381) is located in the uplands; the others (41 CM 98, $41 \mathrm{BX} 380,41 \mathrm{BX} 374$ and $41 \mathrm{BX}$ $382)$ are in the flood plain of the Cibolo, or on its terraces. Three waterproximate special activity sites, situated on flood plains or low terraces, were located on the transects. They are all large burned rock accumulations, including sites $41 \mathrm{BX} 372,41 \mathrm{BX} 377$ and $41 \mathrm{BX} 383$. 
A review of the types and distribution of systematically (transect) located sites from the north section indicates a different pattern of associations than in the south and central sections of Camp Bullis. The major difference lies in the lack of specific quarrying activity sites on the Cibolo Creek. However, many of the campsites served as quarry and resource procurement sites as well as camps, thus combining activities which in other areas occurred in separate locales. The environment along Cibolo Creek apparently was favorable enough to allow this consolidation of tasks in a single area.

The high site density along Cibolo Creek suggests that the area may have supported a relatively large population, but without better chronological definitions as to the times of site use, this prospect must remain speculative. The permanent water supply, varied food resources and availability of chert apparently were major criteria for defining a favorable occupation area.

\section{SCATTERED ARTIFACTS}

A total of 57 artifact scatters yielding 105 specimens was documented on Camp Bullils. These are divided into 10 types: projectile points, thinned bifaces and biface fragments, scrapers, cores and core fragments, flakes, retouched flakes, preforms, Guadalupe tool, chunks and worked glass. Table 19 presents the frequencies for each. It is apparent that thinned bifaces and fragments are the most common, followed by flakes, points and scrapers, and retouched flakes. It is very likely that many of the thinned biface fragments are actually projectile point fragments. Their shape is usually that of finely flaked distal tips or midsections with contracting, straight lateral sides. Most of these artifacts probably result from hunting activities. The high frequency of scattered scrapers and retouched flakes suggests plant collection away from campsites.

\section{TABLE 19. FREQUENCIES OF SCATTERED ARTIFACT TYPES}

$\begin{array}{lr}\text { Projectile points } & 14 \\ \text { Bifaces and fragments } & 34 \\ \text { Scrapers } & 12 \\ \text { Retouched flakes } & 8 \\ \text { Guadalupe tool } & 1 \\ \text { Cores and fragments } & 3 \\ \text { Preforms } & 5 \\ \text { Flakes } & 25 \\ \text { Worked glass } & 1 \\ \text { Chunks } & \\ & \text { Total } \\ \end{array}$

In comparing the distribution of the scattered artifacts with known sites, we see some interesting patterns. For example, a series of bifaces, retouched flakes and scrapers surround $41 \mathrm{BX} 408$, in the upper reaches of Lewis Creek. 
Of the 12 artifacts, only three, and possibly five, are near the main watercourse. An additional three are along a small tributary which joins Lewis Creek near the site. Four artifacts were found in the upland (water-distant) margin, three of which are bifaces or biface fragments, as well as a retouched flake. Of the artifacts occurring along the drainages (water-proximate), two are bifaces, three are scrapers, two are retouched flakes and one is an unretouched flake. This distribution suggests that bifaces (possibly projectile point fragments) are used mostly in the uplands (water-distant) and scrapers and retouched flakes are predominant in the lowlands (water-proximate).

The same pattern is also true for the north section of Camp Bullis. Points and biface fragments are scattered throughout the uplands south of Cibolo Creek up to a distance of approximately three $\mathrm{km}$. Scrapers and retouched flakes are much less common, but are for the most part within one $\mathrm{km}$ of Cibolo Creek, and generally much closer.

On the basis of these characteristics, it is suggested that biface fragments and projectile points, distributed throughout the uplands as well as the lowlands, are evidence of wide-ranging hunting activities. The scrapers and retouched flakes, on the other hand, are found most frequently in lowland (water-proximate) areas bordering streams, suggesting that their primary function was the gathering of lowland plant resources.

In the south section of Camp Bullis, containing predominantly quarry sites, projectile points, bifaces, scrapers and retouched flakes are less frequent and generally not associated with particular sites. The lack of major water sources or altitudinal differences precludes a correlation with resource or topographic zones. However, the majority of scattered preforms, cores and flakes occur in this area, indicating additional minor quarrying and core reduction activities. This would be expected, given the nature of the sites and the presence of chert.

\section{CHANGE THROUGH TIME}

Change in site types and settlement patterns through time is rather difficult to assess, as almost half of the prehistoric sites (29, or $46 \%$ ) contained no chronologically diagnostic artifacts (i.e., identifiable projectile points). This decreased sample of dated sites includes both systematically (transect) located sites and off-transect sites. Any trends suggested by the data must remain tentative for the present.

Table 20 presents a tabulation of site components of a given time period, sorted according to site function and distance from water. A component is an occupation of a site in a particular period as shown. The percentage column refers to the proportion of water-distant and water-proximate sites of a particular type in each time period. A review of the totals by time period (the column on the far right) shows that the heaviest occupation was during the Late Archaic and Late Prehistoric, with slightly less than half the total number of sites in these two most recent periods. Although the bias introduced by the limited sample of dated sites cannot be accounted for, these figures would tentatively suggest a higher population density during the Late Archaic and Late Prehistoric periods. Most of this late population was 
TABLE 20. CONTINGENCY TABLE OF SITE COMPONENTS BY TYPE AND TIME PERIOD

Water-distant Water-proximate Water-distant Water-proximate Quarry Site Quarry Site
Water-distant Water-proximate Special Activity Sites Activity Sites
Frequency Total

\begin{tabular}{|c|c|c|c|c|c|c|c|}
\hline $\begin{array}{l}\text { Late-Paleo } \\
\text { Indian }\end{array}$ & & $1(100)$ & $2(50)$ & $2(50)$ & $2(67)$ & $1(33)$ & 8 \\
\hline Pre-Archaic & $3(100)$ & & $3(100)$ & & $7(50)$ & $T(50)$ & 8 \\
\hline Early Archaic & & $1(100)$ & $3(75)$ & $1(25)$ & $1(25)$ & $3(75)$ & 9 \\
\hline $\begin{array}{l}\text { Middle } \\
\text { Archaic }\end{array}$ & & $1(100)$ & $2(67)$ & $1(33)$ & $1(25)$ & $3(75)$ & 8 \\
\hline Late Archaic & $3(75)$ & $1(25)$ & $2(33)$ & $4(67)$ & $1(16)$ & $5(84)$ & 16 \\
\hline $\begin{array}{l}\text { Late Pre- } \\
\text { historic }\end{array}$ & & $1(100)$ & $1(14)$ & $6(86)$ & $4(50)$ & $4(50)$ & 16 \\
\hline $\begin{array}{l}\text { Frequency } \\
\text { Total }\end{array}$ & 6 & 5 & 13 & 14 & 10 & 17 & 65 \\
\hline
\end{tabular}

Frequencies and the percentage of components of the sites are recorded.

First number $=$ Frequency $\quad$ Second number $(\nu=$ Percentage 
concentrated along cibolo creek. Whether this is a function of the distribution of projectile points or actual population concentration is currently unknown.

The fact that most of the sites in the south section of Camp Bullis are quarry sites and have no finished, datable points makes it difficult to estimate when the sites were used and whether the utilization was varied in extent and intensity through time. Only 41 BX 407 and 41 BX 409, the two quarry-camps associated with clusters $D$ and $C / g r$ respectively, and $41 \mathrm{BX} 399$, with general Archaic lithic material, have datable points. These suggest dates of PreArchaic and Late Archaic utilization for both sites. The presence of these dated sites in the two groups could be taken to imply that the groups themselves were used only during those periods, but this is only a very tentative suggestion. It has yet to be proven that similarity of characteristics and physical association of sites indicate similarity of date, and such an assumption is necessary before the dating of sites without identifiable points can be possible. The figures presented in Table 20 make use only of the sites with dated components.

Examination of each of the site types and the frequency of dated occupations in each yield information suggestive of changing trends in land use through time. The differential utilization through time of different types of sites and areas is perhaps best seen in a comparison of the percentages in Table 20. Five sites located along the Cibolo Creek valley, which are located on chert cobble sources and show artifact assemblages appropriate to those of a quarry, were counted as quarry sites rather than as camps or special activity sites for the purposes of this table. These were $41 \mathrm{BX} 386,41 \mathrm{BX} 373,41 \mathrm{CM} 70$, $41 \mathrm{BX} 375$ and 41 BX 384.

In the Pre-Archaic and Late Archaic, quarry sites are largely water-distant, but in the remaining periods they are entirely water-proximate (see Table 20 ). Campsites are 50\% water-proximate in the Late Paleo-Indian period but are entirely water-distant in the Pre-Archaic. Thereafter, the trend toward water-proximate campsites gradually increases, with $86 \%$ of such sites being water-proximate in the Late Prehistoric. Special activity sites also evidence an increase in water-proximate location through time, from $33 \%$ in the Late Paleo-Indian period to $84 \%$ in the Late Archaic; however, the trend is slightly reversed in the subsequent Late Prehistoric period, where special activity sites are divided equally between water-distant and water-proximate locations.

The great majority of quarry sites are undated, but are water-distant and would push the distribution curve for quarries well into the "water-distant" region for any period they were in use. In other words, the curves are probably reasonably representative for campsites, special activity sites and water-proximate quarries, but not trustworthy as an indicator for the usage of most water-distant quarry sites.

The preceding statements, of course, are not to be taken as conclusive. The small sample of sites per period and the potential bias introduced by nonsystematic site locating techniques are not considered here. Hence, the changes in settlement patterns delineated are only tentative indications and must be further substantiated by simitar studies in the area. 
Another important bias which is unaccounted for here is the high frequency of multiple occupations. All of the site types were party defined on the basis of the ton 1 assemblages. If two or more occupations are indicated by projectile point types, then the remainder of the chipped stone must have been divided between the groups. In other words, what may have functioned as a hunting camp during one occupation might have been a secondary core reduction locale during another occupation. The combined assemblage would fall into the knapping campsite type category, but obviously this was not the function of the site during either occupation. Although detailed studies of chert-working technology and non-projectile point tool types may allow for the division of the entire artifact assemblage into its separate components, this was not attempted with the Camp Bullis data.

The following model (Fig. 50) for chlange through time is proposed as an aid for comparing Camp Bullis settlement patterns with those of other areas.

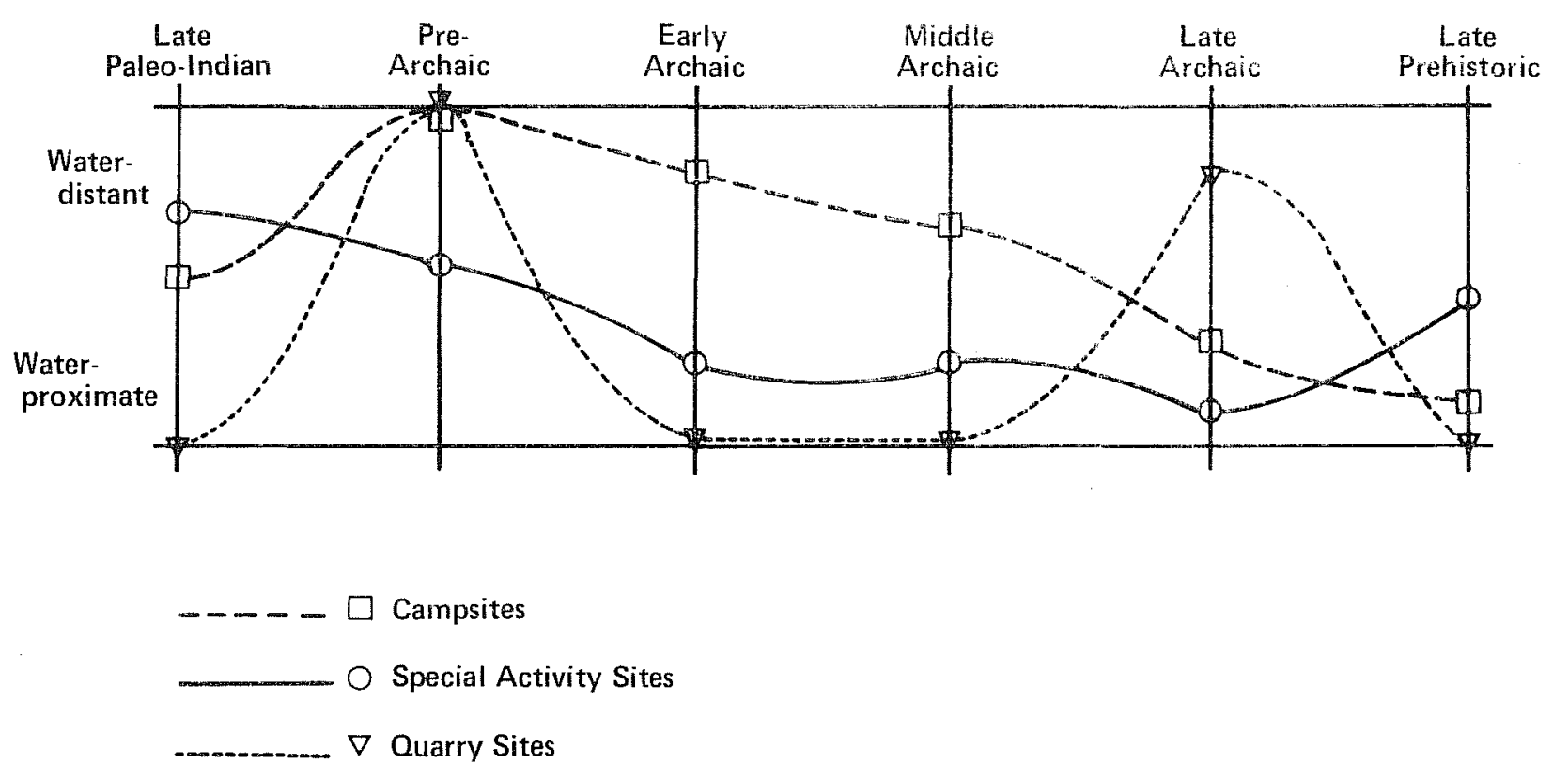

Figure 50. Model of Changes in Settlement Patterns on Camp Bullis. Campsites exhibit a gradual trend toward water-proximate locations from the Pre-Archaic to the Late Prehistoric. Special activity sites are generally water-proximate in the Archaic, with varied locations in the other periods. Quarry sites are largely water-distant in the Pre-Archaic and Late Archaic, but are entirely water-proximate in the remaining periods. 


\section{COMPARATIVE MODELS}

The pattern delineated for the Camp Bullis data is compared here to settlement patterns of prehistoric hunter-gatherer groups in several different areas in Texas. Such comparisons may indicate the presence or absence of relationships with neighboring areas. These relationships may be due to cultural affinities in the sense of "genetically" related groups, i.e., actual contact and exchange of cultural traditions, or may be the result of similar cultureecological adaptations to similar environments, while separation between groups is maintained.

The method of comparison to be used here is that of model testing. The settlement patterns characteristic of other areas are presented as models against which the Camp Bullis data can be tested for similarities and differences. Each model consists of three data subsets: (1) site types, (2) site locations and (3) change through time. When these are not available from a certain project or area, the subsistence interpretations presented are used in lieu of specific details. The reader should keep in mind that "water-proximate" is roughly locationally equivalent to river valley floors, flood plains and low terraces, while "water-distant" is equivalent to valley rims, bluffs and uplands.

Central and North Central Texas

Archaeological investigations in central and north central Texas consist largely of small area and reservoir surveys (cf. Hester 1975a). As mentioned previously, these emphasize the flood basin areas rather than yielding even coverage of all topographic features. In spite of this, two models are presented, the first based primarily on data derived from Skinner (1971), the second from Briggs (1971a), Kelly and Hester (1975a,b), Kelly and Hester (1976) and Patterson and Adams (1977).

\section{Model I}

At Cordova Bend Reservoir, Skinner has identified three types of sites. There are base camps, hunting and gathering camps and chipping stations, essentially the same as Hester's (1970a, 1976b) site types at Chaparrosa Ranch and Shafer and Baxter's (1975) multiple function, limited function and resource procurement sites, with some slight overlap of the latter two types. Skinner's (1971: 158) base camps are considered long term, repeated occupations of large size and depth. The hunting and gathering camps are presumably seasonal, rather limited activity sites occupied by smaller groups (ibid.:158, 259). The chipping station definition is self-explanatory.

The distribution of these types of sites is decidedly not uniform. Base camps are located on the alluvial terraces of the major watercourses. Seasonal hunting and gathering camps are along the tributary stream banks, and chipping stations are present on the high limestone bluffs (Fig. 51). The types of sites are correlated highly with the various micro-environments (ibid.:160). 


\section{MODEL I}

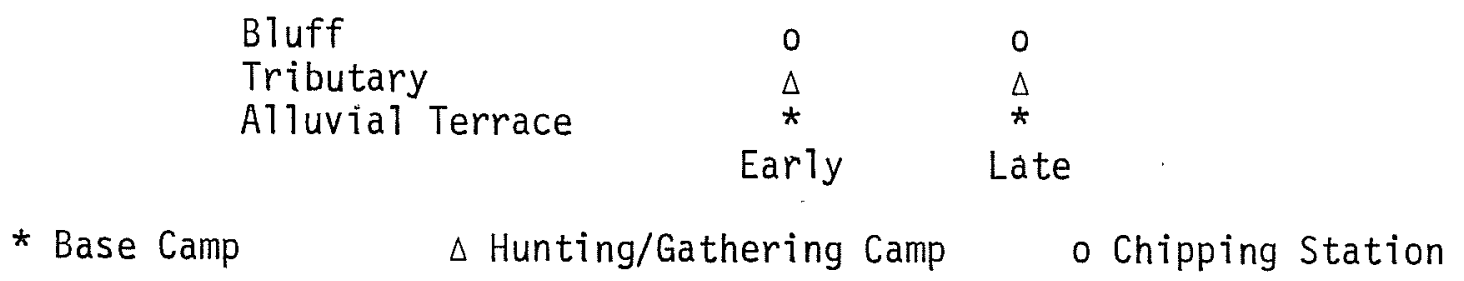

Figure 51. Model of Settlement Pattern in North Central Texas.

Skinner hypothesizes about the social organization of the prehistoric reservoir inhabitants. The proposed "central-based wanderer" model is characterized by ". . two different size living sites, the larger one being the central base which was inhabited by many families and the smaller ones having been occupied by nuclear or extended families on a seasonal or activity specific basis. All these sites would be within an area recognized as their own by the peoples" (ibid.:285).

Skinner (1971:259) observes no change in settlement patterns through time. It is apparently similar during the entire time span covered by the Archaic and Late Prehistoric periods.

\section{Model II}

Briggs (1971a) found a basically similar pattern of settlement present in the Ingram Reservoir area. The main period of occupation was during the Archaic. He has identified two major site types: camps and quarry sites. The camps are subdivided into two groups: those with burned rock middens and open campsites without burned rock middens. The majority of sites were camps with burned rock middens. These and the open campsites are almost without exception located on the first terrace above the river or near other flowing or intermittent water sources. Briggs surmises that ". . . the main emphasis in utilization of streams may have been as a water source, with additional emphasis placed on the hunting of game in the higher reaches of the hills and terraces" (ibid.:30). Briggs' open campsites are comparable to skinner's hunting and gathering camps, and Briggs' burned rock midden sites can be equated with Skinner's base camps.

The same sort of pattern is duplicated in other survey areas. On Walker Ranch in northern Bexar County, all but nine of 43 sites located are on the lower terraces adjoining the main creek. Of the nine other sites, one is a campsite located on a bluff, and one is a specialized quarry site. The others ". . . show little evidence of occupation ..." (Hudson et al. 1974:15).

Investigations at Lake Whitney, Texas, show the same distribution of site type and a similar continuity through time (Skinner and Gallagher 1974). In this area, rockshelters show seasonal habitation beginning in the Late Prehistoric, although excavations at other rockshelters in central Texas have yielded Archaic occupation levels (cf. Johnson, Suhm and Tunnel1 1962; Fawcett 1972). 
Patterson and Adams (1977:7.9), in a survey of a ranch in Kendain County, explored the relationship between types of quarry sites and change through time. They have identified two types of quarry sites: (1) campsite-quarry sites with a full lithic tool kit and (2) quarry-workshop sites which are limited to core reduction and tool manufacture. Type 1 sites, the campsite-quarry sites, are Paleo-Indian and Pre-Archaic in age and are located on hilltop chert sources. The quarry-workshop sites of Type 2 are Early to Middle Archaic in age (ibid.: 12) and located on lower terraces overlooking creeks (Patterson and Adams 1977:9; cf. Hester, Bass and Kelly 1975; Kelly and Hester 1975a,b).

The distinction between these two quarry site types corresponds with change through time; ". . . there could be a change in site locations.. . from the early llookout sites to later Archaic period sites with a lower riverine adaptation" (Patterson and Adams 1977:12). Surveys by Patterson (ibid.:12-14) in Bandera, Medina and Real Counties suggest that this shift in site locations ". . is not an isolated phenomenon, but rather may be a generalized pattern for the hill country of South-Central Texas." This survey has produced indications of settlement changes through time, namely that of sites moving closer to major waterways as time progresses.

The phenomenon of burned rock middens is restricted to the Edwards Plateau and Trans-Pecos regions (kelley and Campbel1 1942; Suhm 1960:68). They generally appear during the Middle Archaic and continue to be constructed in the Late Archaic. By the Late Prehistoric period, although occupation is often on or near the burned rock midden, they were not added to. Although form varies (cf. Weir 1976; Greer 1967), they are often interpreted as a special type of base camp feature ". . not purposefully constructed" (Kelley and Campbell 1942:322). They are possibly the remains of broken-up hearths which are consistently cleared and dumped on a convenient pile (Hester 1970b, 1971:125), or they may be a series of superimposed hearths (Kelley and Campbei1 1942; Suhm 1959, 1960:68) accumulated through time. The burned rock midden sites are typically located on low terraces fronting a good water source, or near a permanent or now intermittent spring or stream (Hester 1970b, 1971; Johnson, Suhm and Tunne11 1962:10; Fawcett 1972).

Open campsites without burned rock middens are also numerous during the Archaic, but their distribution seems to have a slightly broader range, extending farther up tributaries and often associated with less reliable water sources.

The Late Prehistoric campsites are often located directly on or adjacent to Archaic burned rock middens. This indicates a similar site location pattern, but the occupations themselves are invariably without the burned rock accumulations characteristic of the earlier Archaic occupations.

Model II, based on the research summarized above, consists of the following attributes (Fig. 52). Paleo-Indian sites are usually campsite-quarry sites located on upland chert sources. Archaic site types are of three major types: base camps, of which two types are noted, one with burned rock middens, one without; hunting and gathering camps; and quarry workshops or chipping stations. Both base camp types are located mainly on major river or stream terraces, as are chipping stations. Hunting and gathering camps are located along tributaries of the larger water courses. Late Prehistoric sites also consist of base camps, hunting and gathering camps, and chipping stations with a similar 
distribution. However, no burned rock middens are formed during this period. Rockshelters are occupied throughout the Archaic and Late Prehistoric, with perhaps a greater emphasis on the Late Prehistoric (Shafer 1971:2).

A depopulation from the Archaic to the Late Prehistoric is tentatively suggested for Bexar County by Fawcett (1972:33) and for the Austin area and much of central Texas in general by Shafer $(1971: 5)$. Fawcett also notes a possible change in the location of hunting and gathering camps from high bluffs overlooking major streams in the Archaic to locations at the junction of tributaries with major creeks in the Transitional Archaic, but moving back up to blufftops during the Late Prehistoric.

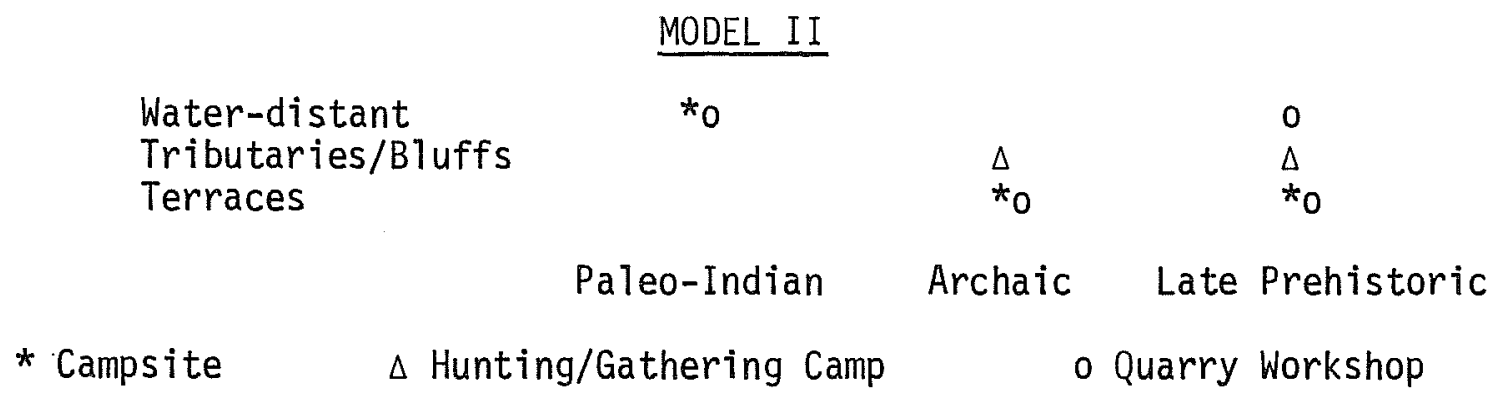

Figure 52. Model of Edwards Plateau Settlement Pattern.

South Texas

Studies in south and south central Texas, i.e., on the coastal plain south and southeast of the Balcones Escarpment, have yielded substantial data on settlement patterns. Foremost among these studies are surveys carried out on Chaparrosa Ranch (Hester 1970a, 1976b), the Lignite Project. in Atascosa and McMullen Counties (Shafer and Baxter 1975), Palmetto Bend Reservoir (Mallouf, Fox and Briggs 1973), Cuero I Reservoir (Fox et al. 1974), and Cibolo Reservoir (Hsu and Ralph 1968), in addition to other smaller scale surveys. These surveys have revealed a considerable amount of variability in settlement patterns, and as a result, a single model is insufficient. Two models are presented here. Model III is based on Hester's work at Chaparrosa Ranch. Model IV is derived from Shafer and Baxter's report on the Lignite Project. Both of these models are based on surveys which covered the entire range of topographic variability, from stream bottom to hilltop, rather than selected topographic areas such as reservoir basins. The reservoir survey data, however, provides supplementary details, especially on site types and changes through time.

\section{Model III}

Hester's settlement pattern model for south Texas is presented in brief form below (Fig. 53). Three basic site types are identified: base camps, temporary hunting/foraging camps and lithic workshops. Base camps are extensive linear accumulations of artifactual material, often with some depth, 
paralleling the stream channels. They are situated on the flood plain, low terraces or natural levees. Short-term hunting and foraging sites are shallow, small sites with scattered debitage and hearth stones, located in the uplands, on high gravel terraces and on the flood plain margins. Chipping stations, or lithic workshops, are located in the uplands near gravel outcrops (Hester 1970a:12-13; Hester 1976b:85).

MODEL III

$\begin{array}{lcc}\begin{array}{l}\text { Water-distant } \\ \text { Gravel Terraces }\end{array} & \Delta & \Delta \\ \text { Low Terrace/Flood Plain } & * 0 \Delta & \Delta 0 \\ & & * \\ * \text { Base Camp } & \Delta \text { Hunting/Gathering Camp } & \text { Late }\end{array}$

Figure 53. South Texas Settlement Pattern (A).

Hester (1970a:13) refers to the short-term hunting and gathering camps and lithic workshops as "subsidiary sites," implying that they are satellites to the base camps where the majority of the population lived and most of the everyday campsite tasks were accomplished.

A distinct change in settlement locations through time is noted on Chaparrosa Ranch.
"Paleo-Indian and Pre-Archaic sites are found on high terraces rimming the stream valley; later sites, particularly Late Archaic and Late Prehistoric, are found near the present channels . . . often positioned in ecotone situations" (Hester 1976b:95).

The three types of sites are apparently present during the entire culturalhistorical sequence.

Model IV

The second model proposed for south Texas is based on the Lignite Project survey in Atascosa and McMullen Counties (Shafer and Baxter 1975), somewhat closer to Camp Bullis than the Chaparrosa Ranch area.

In a manner similar to Hester's, several site types have been identified, based on the type and number of activities indicated by the material remains. These are called Multiple Function Sites, Limited Function Sites and Resource Procurement sites. The definitions of the sites are as follows (ibid.:72).

Multiple Function Sites are represented by a wide range of activities (Hester's base camps). Limited Function Sites are considered short-term or seasonal; ". . although a wide range of activities were actually conducted there, the 
occupations were not extensive enough that most activities were represented by lithic refuse" (Shafer and Baxter 1975:72). Resource Procurement Sites are represented by only one or very few specific activities. Often these are lithic procurement sites, or chipping stations.

The distribution of these site types between the physiographic areas is apparently more uniform than on Chaparrosa Ranch (Fig. 54). Multiple Function Sites occur in every location from the stream bottoms to the upland (waterdistant) margins and upland ridges between drainages. Limited Function and Resource Procurement Sites are similarly distributed as shown by an insignificant Chi-square value $\left(X^{2}=5.66, \mathrm{df}-6\right)$ calculated on the cross-tabulation of site types with physiographic locations (upland, upland margin and stream valley) (ibid.:74; Table 4:8).

Shafer and Baxter (1975) propose several possible reasons why the site types do not correlate with physiographic zones. These include the lack of natural and biotic resource diversity, the common utilization by all bands of the resources (ibid.:15), and the fact that "There is ample water in the upland drainages during wetter seasons ... (and) that the Archaic populations would venture into the uplands and establish encampments during wetter seasons or years" (Shafer and Baxter 1975:74). Due to the seasonality of upland water availability, however, "the better watered areas... over time . . would see the most intensive utilization" (ibid.:75).

A chronology of sites located in the Lignite Project study area was impossible to establish, due to the scarcity of projectile points (Shafer and Baxter 1975: 70). It is likely that the majority of the sites are Archaic in age, and therefore the model presented is considered typical of that period. Change in settlement patterns through time is impossible to assess using data from this survey.

\section{MODEL IV}

Water-distant Water-distant Margin Stream Bottom

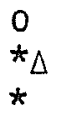

Archaic

* Multiple Function Site (base camp) o Resource Procurement Site (primarily lithic)

$\Delta$ Limited Function Site

Figure 54. South Texas Settlement Pattern (B).

\section{Other South Texas Surveys}

The data from other surveys in south Texas conforms in part with one or the other of the two models presented above. The data is of limited utility in formulating models of entire settlement systems because it is restricted to the flood basins of proposed reservoirs. In addition, the types of sites are 
not so clearly defined or described; hence, comparability with the areas under consideration is limited. However, some interesting data on site locations and change through time is presented.

The Cuero I Reservoir survey (Fox et al. 1974) presents some information on changing settlement locations through time. Paleo-Indian, Early and Middle Archaic tool forms are not found on the modern flood plains or colluvial gravel deposits, but are present on the older fossil flood plain and upland sandstone terraces. It is suggested for the Early and Middle Archaic that, a) though the river is the focus of settlement, the subsistence base included the upland terraces and prairie outside the river basin. Late Archaic and Late Prehistoric occupations are concentrated in the modern flood plain, with Late Prehistoric covering a slightly wider range of locations. This indicates a reliance on riverine resources. These changes in settlement and subsistence may be associated with climatic changes, from xeric during the Early and Middle Archaic, to mesic during the Late Archaic, although this has not been conclusively demonstrated (ibid.:205,213-215).

It appears that the upland orientation of Early and Middle Archaic settlement at Cuero I may correspond with the upland Archaic occupation in the Lignite Project area. It is possible, however, that settlement in the Lignite Project area was as dynamic as in the Cuero I Reservoir area. It seems that settlement trends through time are similar for both Chaparrosa Ranch and other areas in south Texas, i.e., the later populations moved closer to the major water sources.

Fawcett's (1972:23-24) summary of Bexar County archaeology is based on two settlement pattern mode1s, one for the Edwards Plateau region, and one for the southern portion of the county, corresponding to the Rio Grande Plain. The latter model, based primarily on Hester's (1970a, 1971) work, is examined here.

Fawcett defines three site types, primarily on the basis of site size and artifact content. These are base camps, hunting and gathering camps, and chipping stations.

The base camps are large, thick alluvial sites situated on major watercourses. Hunting and gathering camps are located on valley rims and in the uplands. Chipping stations are present on the gravel terraces on the rims of large valleys. This model, similar to Model III presented above, is examined for change through time.

Most of the Paleo-Indian materials are mixed with later Archaic occupations. This may tentatively indicate a similar settlement pattern as in the later Archaic; however, no isolated Paleo-Indian components are known. The distribution of point types at the time of the review (1972) appeared to be nonrandom; Angostura points are predominant in the northern part of the county, and Plainview and other types appear mostly in the southern part. This remains to be conclusively demonstrated.

During the Archaic period, base camps are large, thick terrace sites with evidence of plant and mussel collecting as major food sources. Archaic hunting camps are unknown from south Bexar County, and the only Archaic chipping 
station known is on the upper edge of the Cibolo creek valiey on a natural chert gravel concentration. Except for the lack of known gathering camps, Archaic settlement conforms with the general model. The Archaic pattern is continuous with the Transitional Archaic. However, there is evidence of a rapid depopulation combined with a possibie northward migration (Fawcett 1972:33).

The Late Prehistoric period in south Bexar County is characterized by a scar. city of sites. All of the ones as yet located are base camps where Late Prehistoric and Archaic materials are mixed. The sites are located on alluvial terraces.

The distribution of Late Prehistoric point types is apparently significant. Edwards points are commonly found in the northern zone; Scaleon and Pordiz points are concentrated along the eastermost edge of the Edwards plateau (ibid.:35).

It appears, on the basis of the limited amount of data avaliable from south Bexar County, that settlement patterns did not change through time. However, there seems to be a decrease in population density fron the Archaic to the Late Prehistoric, corresponding with a northward movenent. This settiement pattern and population decrease is also observed in the results of a survey of the Cibolo Reservoir, Wilson County (Hsu and Ralph 1968:52-53).

Some of the surveys mentioned above indicate a change from upland to stream bottom site locations through time. Similarly, evidence of depopulation is present in some areas. These are combined in a mode? of change through time (Fig. 55).

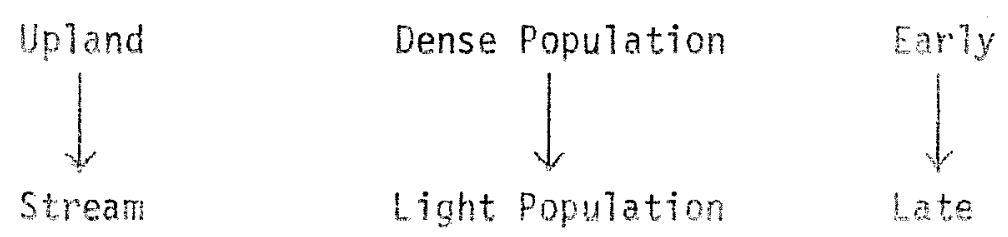

Figure 55. Model of Changes in Settlement Pattesh in Bexat County.

\section{COMPARATIVE ANALYSIS}

The settlement patterns suggested by the Camp Bullis data (Fig. 50) and the models presented for neighboring areas in Texas may be compared for similari... ties and differences. A review of the trends through time is instructive.

One striking similarity is seen in the changing locations of base camps. It is apparent in all the models that either base camps were moved into the low lands (water-proximate) as time progressed or, as in north centra? Texas, the main camping locations were always the lowlands. This is 5 en in Camp Bullis where the Late Prehistoric campsites are predominantly in the 7owlands. Within the Archaic period, however, campsites gradually migrated from upland 
(water-distant) to lowland (water-proximate) locations. There is some difference, however, in the lowland (water-proximate) 1ocation of 50\% of the campsites on Camp Bullis with Late Paleo-Indian components. This appears to contradict Models II and III for the surrounding areas, where Late PaleoIndian campsites were water-distant; however, this contrast may not be real, but rather an artifact of the possible misidentification of site functions for these components on Camp Bullis (see discussion, page 203).

The variations within the Archaic period (including Early, Middle and Late Archaic) settlement patterns in Camp Bullis are only roughly comparable with the less specific models presented for other regions. Again, the variation may be due to differing views on site-functional classifications, but given the long time span covered by the Archaic period, some differences are to be expected.

Comparison of Camp Bullis with other regional models in terms of quarry sites is complicated by the large number of undated, upland (water-distant) quarry sites located in the Bullis survey (see page 202). Quarry sites generally occupied upland (water-distant) locations in the four regional models, al though Model II notes lowland (water-proximate) quarries in the Archaic and Late Prehistoric.

It is interesting to note the similarities between Fawcett's model south of Bexar County and the counts of site components from Camp Bullis. In Table 20, these counts are presented showing the actual number of site components of each type in each location, according to their distance from water. Table 21 is a count with the division according to whether the sites are in the north portion of Camp Bullis, largely Cibolo Creek and its associated terraces and valley rims, or in the south portion, the lower hills and small stream valleys of the edge of the Edwards Plateau. Both tables show a distinct trend of increase through time, but the north/south histograms reveal that this increase is largely in the north. The south shows little change through time. It is tempting to suppose that Fawcett's apparent northward movement is being reflected here, with his population moving into such areas as the Cibolo Valley.

Obviously, it is very difficult to compare the changing Camp Bullis settlement pattern to those of other areas. This is primarily due to the lack of specific and suitable data from these other regions; either the studies did not focus on settlement patterns, or the dating possibilities were restricted by the lack of chronologically diagnostic tool types. This latter factor is probably the major one, caused either by different adaption of the prehistoric inhabitants or, more likely, by the selective collecting of projectile points by modern inhabitants. The Camp Bullis military reservation has long been accessible only to military personnel, which probably accounts for the large number and variety of projectile points recovered during the survey of Camp Bullis, thus enabling more detailed, if still tentative, trends in settlement patterns through time to be identified. The model presented remains to be tested with and compared to other detailed studies of this type. 
TABLE 21. CONTINGENCY TABLE OF SITE COMPONENTS BY NORTH, SOUTH DISTRIBUTION

Quarry Sites

North

Late Paleo-Indian

Pre-Archaic

Early Archaic

Middle Archaic

Late Archaic

Late Prehistoric

Total
Campsites

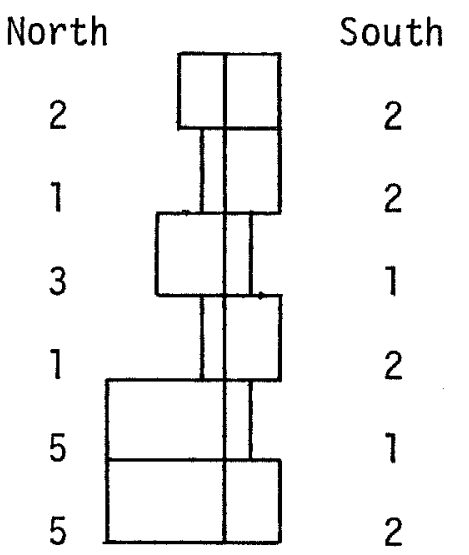

17

10
Special Activity Sites

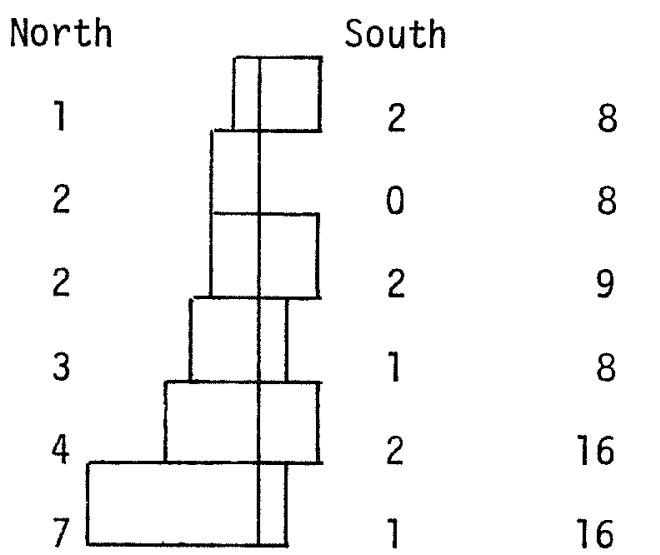

19

Total

8

65

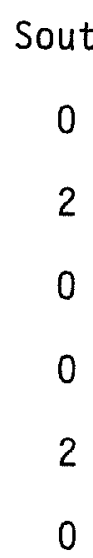

4 



\author{
III. A.10 \\ CONSTANT VOLUME ANALYSIS \\ Cristi Assad
}

\title{
INTRODUCTION
}

Three sites were chosen for analysis of constant volume samples (hereafter referred to as CVS). The sites 41 BX 36, 41 BX 377 and $41 \mathrm{BX} 428$ were chosen for a variety of reasons: (1) each was in a different area of the base, (2) each was excavated to a depth of $80 \mathrm{~cm}$ or more, and (3) this depth provided ample vertical sample for a variety of studies including soil analysis, microfaunal analysis, pollen analys is and micro-snail analysis.

\section{FLOTATION ANALYSIS}

The CVS provide information which the normal excavation procedures do not allow. Flotation analysis, consisting of a light and heavy fraction (see III.A.4), provides control data which is normally unobserved during excavation (Tables 22 and 23; see discussion of laboratory procedures on pages 55 and 61).

The heavy fraction was sorted for six samples from two units $(1,23)$ from $41 \mathrm{BX} 36$; nine samples from Unit 5 of $41 \mathrm{BX} 377$; and nine samples from the two units $(2,4)$ from $41 \mathrm{BX} 428$. The material obtained from this sorting includes: a variety of lithics, seeds (burned and unburned), numerous snails (many very small), faunal material (burned and unburned) and a few miscellaneous items. Separate soil and pollen analyses were also carried out on soil from these samples.

Site $41 \mathrm{BX} 36$ is a major mulit-occupation site. Two units were samples from this site: Unit 1 (E997, N1007), excavated to $110 \mathrm{~cm}$ where limestone bedrock was encountered; and Unit 23 (ET-07, N1005), excavated to $50 \mathrm{~cm}$ where limestone bedrock was encountered. Both were excavated in $10 \mathrm{~cm}$ levels; a sample was processed for every alternate level. Site 41 BX 36 produced numerous lithics, bone, snails and a variety of other material.

Site $41 \mathrm{BX} 377$ is a Late Prehistoric/Pre- and Late Archaic site located in alluvial deposits along Cibolo Creek. One excavation unit, Unit 5 (E992, N1010). was sampled. This unit was excavated in $5 \mathrm{~cm}$ levels and was sampled at every $10 \mathrm{~cm}$. Unit 5 was excavated to $85 \mathrm{~cm}$ and bedrock was never reached. The site produced a moderate amount of lithics, many snails and very little faunal material.

Site 41 BX 428 is a possible special activity and occupation site. Two units were sampled from this site, one in the burned rock accumulation (Unit 2) and one in the adjacent occupation area (Unit 4). Unit 2 (E999, N999) was excavated to a depth of $110 \mathrm{~cm}$ and bedrock was never reached. The soil from Unit 2 was very black but consisted primarily of burned limestone. The CVS yielded very little in the way of cultural material. Unit 4 (E1002, N1008), 
TABLE 22. HEAVY FRACTION FROM CONSTANT VOLUME SAMPLES*

\begin{tabular}{|c|c|c|c|c|c|c|c|c|c|c|c|}
\hline Site & Unit & $\begin{array}{l}\text { Level } \\
(\mathrm{cm}) \\
\end{array}$ & $\begin{array}{l}\text { Artifacts } \\
\text { or Re- } \\
\text { touched } \\
\text { Flakes } \\
\end{array}$ & Flakes $†$ & $\begin{array}{l}\text { Misc. } \\
\text { Chert } \\
\text { Debris } \\
\end{array}$ & Seeds & $\begin{array}{l}\text { Seeds } \\
\text { (Burned) } \\
\end{array}$ & $\begin{array}{l}\text { Identi- } \\
\text { fiable } \\
\text { Bone } \\
\end{array}$ & $\begin{array}{l}\text { Identi- } \\
\text { fiable } \\
\text { Bone } \\
\text { (Burned) } \\
\end{array}$ & $\begin{array}{l}\text { Uniden- } \\
\text { tifiable } \\
\text { Bone } \\
\end{array}$ & $\begin{array}{l}\text { Uniden- } \\
\text { tifiable } \\
\text { Bone } \\
\text { (Burned) }\end{array}$ \\
\hline \multirow[t]{2}{*}{$41 \mathrm{BX} 36$} & $\begin{array}{l}1 \\
1 \\
1 \\
1\end{array}$ & $\begin{array}{l}30-40 \\
50-60 \\
70-80 \\
90-100\end{array}$ & & $\begin{array}{r}76 \\
138 \\
44 \\
30\end{array}$ & $\begin{array}{l}7 \\
6 \\
2 \\
2\end{array}$ & $\begin{array}{l}10 \\
15 \\
11 \\
13\end{array}$ & 1 & $\begin{array}{l}3 \\
1\end{array}$ & & $\begin{array}{r}32 \\
21 \\
12 \\
9\end{array}$ & $\begin{array}{r}21 \\
7 \\
11 \\
3\end{array}$ \\
\hline & $\begin{array}{l}23 \\
23\end{array}$ & $\begin{array}{l}10-20 \\
30-40\end{array}$ & $\begin{array}{l}1 \\
2\end{array}$ & $\begin{array}{l}328 \\
205\end{array}$ & $\begin{array}{r}11 \\
6\end{array}$ & $\begin{array}{l}17 \\
31\end{array}$ & $\begin{array}{l}13 \\
21\end{array}$ & $\begin{array}{r}14 \\
9\end{array}$ & 1 & $\begin{array}{l}136 \\
172\end{array}$ & $\begin{array}{l}74 \\
34\end{array}$ \\
\hline $41 \quad B \times 377$ & $\begin{array}{l}5 \\
5 \\
5 \\
5 \\
5 \\
5 \\
5 \\
5 \\
5\end{array}$ & $\begin{array}{c}0-5 \\
10-15 \\
20-25 \\
30-35 \\
40-45 \\
50-55 \\
60-65 \\
70-75 \\
80-85\end{array}$ & & $\begin{array}{r}12 \\
30 \\
22 \\
20 \\
13 \\
17 \\
8 \\
4 \\
7\end{array}$ & $\begin{array}{l}2 \\
1\end{array}$ & $\begin{array}{r}10 \\
2 \\
1 \\
2 \\
\end{array}$ & $\begin{array}{l}3 \\
1\end{array}$ & & & $\begin{array}{l}1 \\
3 \\
2 \\
7 \\
4 \\
2\end{array}$ & $\begin{array}{l}1 \\
3 \\
1\end{array}$ \\
\hline \multirow[t]{3}{*}{41 BX 428} & $\begin{array}{l}2 \\
2 \\
2 \\
2\end{array}$ & $\begin{array}{c}0-10 \\
20-30 \\
40-50 \\
\star \star\end{array}$ & & $\begin{array}{l}13 \\
32 \\
10\end{array}$ & $\begin{array}{l}3 \\
3\end{array}$ & $\begin{array}{c}16 \\
1\end{array}$ & 7 & & & $\begin{array}{l}1 \\
1\end{array}$ & $\begin{array}{l}2 \\
2\end{array}$ \\
\hline & $\begin{array}{l}2 \\
2 \\
2\end{array}$ & $\begin{array}{c}70-80 \\
90-100 \\
100-110\end{array}$ & & $\begin{array}{l}9 \\
5 \\
6\end{array}$ & 1 & $\begin{array}{l}3 \\
3 \\
9\end{array}$ & $\begin{array}{l}1 \\
4\end{array}$ & & & $\begin{array}{l}1 \\
4\end{array}$ & \\
\hline & $\begin{array}{l}4 \\
4 \\
4\end{array}$ & $\begin{array}{r}0-10 \\
20-30 \\
30-40\end{array}$ & & $\begin{array}{r}31 \\
57 \\
141\end{array}$ & $\begin{array}{l}1 \\
5\end{array}$ & $\begin{array}{l}2 \\
1\end{array}$ & & & & $\begin{array}{l}2 \\
7\end{array}$ & $\begin{array}{r}1 \\
8 \\
13\end{array}$ \\
\hline
\end{tabular}

\footnotetext{
* - The information for the snails is in Table 23, and the soils analysis results are in Table 24. ** - The CVS between 50 and $70 \mathrm{~cm}$ were not available for processing.

+ - Includes primary, secondary and interior. The majority of flakes were interior.
} 
TABLE 23. SNAILS FROM CONSTANT VOLUME SAMPLES

\begin{tabular}{|c|c|c|c|c|c|c|c|c|c|}
\hline Site & Unit & $\begin{array}{l}\text { Leve1 } \\
(\mathrm{cm})\end{array}$ & $\begin{array}{c}\text { Rabdotus } \\
\text { sp.* }\end{array}$ & $\begin{array}{l}\text { Polygy- } \\
\text { ridae*t }\end{array}$ & $\begin{array}{l}\text { Helicina } \\
\text { orbiculata } \\
\text { trapica* }\end{array}$ & $\begin{array}{l}\text { Pupoides } \\
\text { modicus }\end{array}$ & $\begin{array}{l}\text { Succinea } \\
\text { grosue- } \\
\text { nori }\end{array}$ & $\begin{array}{l}\text { Vertigo } \\
\text { oscar- } \\
\text { iana }\end{array}$ & $\begin{array}{l}\text { Burned } \\
\text { Snail } \\
\text { Fragments }\end{array}$ \\
\hline 41 BX 36 & $\begin{array}{l}1 \\
1 \\
1 \\
1\end{array}$ & $\begin{array}{l}30-40 \\
50-60 \\
70-80 \\
90-100\end{array}$ & $\begin{array}{r}142 \\
72 \\
79 \\
71\end{array}$ & $\begin{array}{l}21 \\
21 \\
20 \\
26\end{array}$ & $\begin{array}{l}59 \\
54 \\
32 \\
14\end{array}$ & & $\begin{array}{l}1 \\
3 \\
7\end{array}$ & 1 & $\begin{array}{l}82 \\
21 \\
61 \\
27\end{array}$ \\
\hline & $\begin{array}{l}23 \\
23\end{array}$ & $\begin{array}{l}10-20 \\
30-40\end{array}$ & $\begin{array}{l}228 \\
142\end{array}$ & $\begin{array}{l}33 \\
45\end{array}$ & $\begin{array}{r}56 \\
101\end{array}$ & & & $\begin{array}{l}3 \\
2\end{array}$ & $\begin{array}{l}277 \\
299\end{array}$ \\
\hline Total & & & 734 & 166 & 316 & & 11 & 6 & 742 \\
\hline $41 \mathrm{BX} 377$ & $\begin{array}{l}5 \\
5 \\
5 \\
5 \\
5 \\
5 \\
5 \\
5 \\
5\end{array}$ & $\begin{array}{c}0-5 \\
10-75 \\
20-25 \\
30-35 \\
40-45 \\
50-55 \\
60-65 \\
70-75 \\
80-85\end{array}$ & $\begin{array}{r}6 \\
2 \\
18 \\
26 \\
22 \\
2 \\
4\end{array}$ & $\begin{array}{l}1 \\
4 \\
1 \\
3 \\
\\
6 \\
1 \\
3 \\
2\end{array}$ & $\begin{array}{r}2 \\
19 \\
2 \\
2 \\
1 \\
2 \\
3 \\
1\end{array}$ & $\begin{array}{l}1 \\
2 \\
1 \\
2\end{array}$ & & & $\begin{array}{r}2 \\
9 \\
2 \\
28 \\
27 \\
11 \\
12 \\
2\end{array}$ \\
\hline Total & & & 56 & 21 & 32 & 6 & & & 63 \\
\hline $41 B \times 428$ & $\begin{array}{l}2 \\
2 \\
2 \\
2 \\
2 \\
2\end{array}$ & $\begin{array}{c}0-10 \\
20-30 \\
40-50 \\
70-80 \\
90-100 \\
100-710\end{array}$ & $\begin{array}{l}14 \\
64 \\
43 \\
25 \\
33 \\
41\end{array}$ & $\begin{array}{r}10 \\
9 \\
9 \\
7 \\
12 \\
16\end{array}$ & $\begin{array}{r}19 \\
10 \\
15 \\
10 \\
1 \\
6\end{array}$ & $\begin{array}{l}3 \\
1\end{array}$ & 2 & & $\begin{array}{r}46 \\
35 \\
13 \\
4 \\
1 \\
4\end{array}$ \\
\hline & $\begin{array}{l}4 \\
4 \\
4\end{array}$ & $\begin{array}{r}0-10 \\
20-30 \\
30-40\end{array}$ & $\begin{array}{r}10 \\
53 \\
116\end{array}$ & $\begin{array}{l}7 \\
2 \\
9\end{array}$ & $\begin{array}{r}10 \\
6 \\
16\end{array}$ & & & & $\begin{array}{r}35 \\
212\end{array}$ \\
\hline Total & & & 399 & 81 & 93 & 4 & 2 & & 318 \\
\hline
\end{tabular}


however, with dark brown humic soil, produced many snails and lithics. It was only excavated to $40 \mathrm{~cm}$ and did not completely penetrate the cultural deposits.

Time did not allow for the sorting of the light fraction which would have required a microscope. Nor was there time for a horizontal sample to complement the present vertical sampling.

\section{SOIL ANALYSIS}

Twenty-four soil samples were tested in conjunction with the constant volume samples. The Agricultural Extension Service of Texas A \& M University, College Station, processed the soil. The tests gave readings for $\mathrm{pH}$, calcium, magnesium, nitrates, phosphorus, potassium and organic matter. Table 24 lists the provenience of the samples and the test results. In dealing with these various chemical elements, some general statements can be made before applying them in an archaeological context:

1. Soil reaction, or $\mathrm{pH}$ values, are usually high (alkaline) when the sediments involved develop in calcareous environments (Shackley 1975). A high acid pH in soils causes decomposition of bone and plant material (Shackley 1975).

2. Both calcium and magnesium are supplied from lime or lime-related sources (in this case the limestone bedrock) (Buckman and Brady 1969).

3. Nitrates are derived mainly from plant matter and are added to soil by decomposition of proteins (Cornwal1 1958). Nitrogen, organic phosphorus and potassium are supplied to soil from fecal material or organic matter (Buckman and Brady 1969). Both organic matter and nitrogen are easily lost through oxidation and leaching (ibid.).

4. Organic phosphorus, as stated above, is produced in soils by decomposition of bone and fecal material (Buckman and Brady 1969, Shackley 1975). A pH value of 5.6 or less (more acidic) will allow for the leaching-out of phosphates.

5. Potassium is usually added to soils the same way as phosphorus and nitrates. However, potassium, in contrast to phosphorus, is usually plentiful except in sandy soils (Buckman and Brady 1969).

6. Organic matter is deposited by dead and decomposing organisms and is directly related to many of the above chemicals.

Each of the three sites tested will be discussed separately with regard to its soil composition. The results of the soil analysis of these sites are inconclusive; comparative horizontal data would probably prove very informative. 
TABLE 24. RESULTS OF SOILS ANALYSIS*

\begin{tabular}{|c|c|c|c|c|c|c|c|}
\hline Site & Unit & Level ** & $\mathrm{pH}$ & Nitrate & Phosphorust & Potassiumt & $\begin{array}{l}\text { Organic } \\
\text { Matter }(\%)\end{array}$ \\
\hline $41 B \times 36$ & $\begin{array}{l}1 \\
1 \\
1 \\
1\end{array}$ & $\begin{array}{l}30-40 \\
50-60 \\
70-80 \\
90-100\end{array}$ & $\begin{array}{l}8.1 \\
8.2 \\
8.6 \\
8.3\end{array}$ & $\begin{array}{r}4 \\
1 \\
<1 \\
1\end{array}$ & $\begin{array}{r}>640 \\
553 \\
475 \\
194\end{array}$ & $\begin{array}{l}>1200 \\
>1200 \\
>1200 \\
>1200\end{array}$ & $\begin{array}{r}1.3 \\
1.1 \\
.6 \\
.4\end{array}$ \\
\hline $41 \mathrm{BX} 36$ & $\begin{array}{l}23 \\
23\end{array}$ & $\begin{array}{l}10-20 \\
30-40\end{array}$ & $\begin{array}{l}8.4 \\
8.2\end{array}$ & 1 & $\begin{array}{l}>640 \\
>640\end{array}$ & $\begin{array}{l}>1200 \\
>1200\end{array}$ & $\begin{array}{l}2.8 \\
1.6\end{array}$ \\
\hline 41 BX 377 & $\begin{array}{l}5 \\
5 \\
5 \\
5 \\
5 \\
5 \\
5 \\
5+\dagger \\
5\end{array}$ & $\begin{array}{c}0-5 \\
10-15 \\
20-25 \\
30-35 \\
40-45 \\
50-55 \\
60-65 \\
70-75 \\
80-85\end{array}$ & $\begin{array}{l}8.2 \\
8.2 \\
8.5 \\
8.3 \\
8.6 \\
8.4 \\
8.6 \\
8.2 \\
8.6\end{array}$ & $\begin{array}{r}4 \\
1 \\
1 \\
10 \\
4 \\
4 \\
2 \\
2 \\
2 \\
2\end{array}$ & $\begin{array}{r}34 \\
16 \\
22 \\
27 \\
22 \\
16 \\
18 \\
13 \\
5\end{array}$ & $\begin{array}{l}750 \\
460 \\
410 \\
390 \\
440 \\
480 \\
440 \\
570 \\
550\end{array}$ & $\begin{array}{l}3.3 \\
1.5 \\
.8 \\
.4 \\
.4 \\
.4 \\
.3 \\
.3 \\
.3\end{array}$ \\
\hline 41 BX 428 & $\begin{array}{l}2 \\
2 \\
2 \\
2 \\
2 \\
2\end{array}$ & $\begin{array}{c}0-10 \\
20-30 \\
40-50 \\
70-80 \\
90-100 \\
100-110\end{array}$ & $\begin{array}{l}7.8 \\
8.2 \\
8.0 \\
8.1 \\
8.2 \\
8.3\end{array}$ & $\begin{array}{r}12 \\
4 \\
5 \\
1 \\
1 \\
4\end{array}$ & $\begin{array}{r}553 \\
103 \\
78 \\
13 \\
132 \\
132\end{array}$ & $\begin{array}{r}>1200 \\
>1200 \\
730 \\
620 \\
460 \\
410\end{array}$ & $\begin{array}{l}4.2 \\
4.2 \\
4.0 \\
3.7 \\
2.8 \\
2.0\end{array}$ \\
\hline & $\begin{array}{l}4 \\
4 \\
4\end{array}$ & $\begin{array}{r}0-10 \\
20-30 \\
30-40\end{array}$ & $\begin{array}{l}8.1 \\
8.1 \\
8.2\end{array}$ & $\begin{array}{r}10 \\
8 \\
4\end{array}$ & $\begin{array}{r}201 \\
42 \\
38\end{array}$ & $\begin{array}{r}>1200 \\
>1200 \\
1140\end{array}$ & $\begin{array}{r}>4.2 \\
2.4 \\
1.7\end{array}$ \\
\hline
\end{tabular}

* - Calcium and magnesium readings are omitted; al1 were above maximum instrument sensitivity.

** - Number of $\mathrm{cm}$ below ground surface.

+ - Pounds per acre.

t+ - Possible error in this level. 


\section{THE SITES}

Both the calcium and magnesium values were well over the scale of the instruments they were tested on for all three sites. Their source is the limestone bedrock of the Camp Bullis area. The nitrate level fluctuates for all the sites tested and, due to its easy leaching qualities, has been disregarded.

The data for 41 BX 36 are presented briefly. The pH level increases in alkalinity from top to bottom (Unit $1,40 \mathrm{~cm}$ to $100 \mathrm{~cm}$, and Unit $23,10 \mathrm{~cm}$ to $40 \mathrm{~cm}$ ) as the levels get nearer to the limestone bedrock. The organic matter decreases correspondingly from the upper levels to the lower levels. The potassium readings for this site are all above the instrument levels and cannot be used. The phosphorus readings are extremely high (over the instrument scales) in the upper levels of both units (Unit 23, 10-20 cm and 30-40 cm, and Unit 1, 30-40 cm). In Unit 1 the phosphorus values drop steadily along with the bone count (see Table 24) but are still high. These phosphorus readings may be partially the result of former human occupation, although the specific organic phosphates which would indicate this are not recognized. Cornwal1 (1958:196) states that ". . . the presence of a concentration of phosphate at any level in an archaeological (site) may be taken to represent a surface occupied by man or animal." Specialized phosphate testing would likely prove profitable.

The results for 41 BX 377 can only be considered negative evidence (Philip Dering, personal communication).* The site was formed during the deposition of alluvial silt. Repeated inundations through time result in alternate leaching and deposition of organic materials. The $\mathrm{pH}$ and the organic matter readings are similar at $41 \mathrm{BX} 377$ and $41 \mathrm{BX} 36$, but there are no other similarities. The phosphorus readings are very low, indicating probable leaching caused by the flooding of Cibolo Creek.

The two excavation units on 41 BX 428 represent two different activity areas. Unit 4 is in a living area with numerous lithics and burned rock, while Unit 2 is in a burned rock accumulation, a possible special food processing area. Unit 4 was only excavated to a depth of $40 \mathrm{~cm}$ and was not culturally sterile at that level. The information for Unit 4 is incomplete and, for this reason, provides an incomplete comparison with Unit 2, excavated to a depth of $110 \mathrm{~cm}$.

The $\mathrm{pH}$ readings increase in alkalinity as the levels get closer to the 1 imestone bedrock, while the organic matter decreases with greater depth. The phosphate readings are low and erratic when compared to those for $41 \mathrm{BX} 36$. There may be some cultural cause for the correlation between the potassium levels and the phosphorus levels, but at this point, no data has been found in the published archaeological literature to allow any conclusions.

*Mr. Philip Dering is with the Department of Anthropology, Texas A\&M University, College Station, and consulted for the present project on many occasions in June and August, 1977. 
SNAIL ANALYSIS

A total of 1921 snails were analyzed for the present project. These were obtained from the constant volume samples, thus providing comparable information.

Seven different genera of snails were identified, six to the species level, from CVS. Table 23 lists the provenience and quantities of these snails. $\mathrm{Mr}$. John Clark, Jr., Archeologist, Texas Historical Commission, Austin, identified many of the smaller snails and provided useful information. The types of snails recovered from excavations are listed below, along with habitat information.

Rabdotus (Bulimulus) ch. dealbatus. Inhabits semi-arid to arid areas in grassy fields with low brush (Clark 1969).

Polygyra c6. texasiana. Open fields and woodlands; a hardy species (Allen and Cheatum 1961).

Helicina orbiculata tropica. Drought-resistant; inhabits open fields and more often woodlands; has arboreal habits (ibid.).

Pupoides modicus (Gould). A hardy species which inhabits wooded as well as arid areas (Allen and Cheatum 1961).

Succinea grosvenori. Inhabits moist wooded areas with woodland floor cover (Clark 1969).

Vertigo oscariana (Sterki). Found in moist areas under stones and ground debris (Allen and Cheatum 1961).

Mesodon sp. Occurs in heavily wooded areas (ibid.).

Three types of snails, Rabdotus sp., the family Polygyridae and Helicina orbiculata tropica, were found at each of the three sites. Succinea grosvenori and Vertigo ascariana were found in small quantities at $41 \mathrm{BX} 36$. Pupoides modicus was the only other snail found at 41 BX 377 and only in the lower Tevels $(55-85 \mathrm{~cm})$. Both Pupoides modicus and Succinea grosvenori were found in the upper levels of Unit 2 at 41 BX 428 but only in very limited quantities. The snails in the samples are all usually found in an upland habitat, and no major environmental conclusions can be drawn from the data.

Many archaeologists have used snails for dating and attempting to determine changes in environmental conditions. References have also been made to the use of snails as a food item. Clark (1969) briefly mentions previous works involving the analysis and interpretation of the use of snails in archaeological contexts.

No conclusive statements can be made at this writing about the snails found in the constant volume samples. Future statistical analysis may prove fruitful in correlating relative quantities of snails to other culture data. 

III. A.11

POLLEN ANALYSIS OF SOIL SAMPLES FROM 41 BX 36, 41 BX 377 AND 41 BX 428

Philip Dering

\section{INTRODUCTION}

Pollen analysis was performed on soil from the CVS subjected to flotation and chemical analysis (see III.A.10). Central Texas is notorious for having a poor environment for pollen preservation. This prompted the use of a new process for pollen recovery. Unfortunately, pollen was still not recovered in frequencies large enough to allow inferences about the prehistoric ecology of the area. This report will examine the pollen extraction method and possible factors which may have contributed to the destruction of pollen.

\section{METHODS}

Removal of pollen from soil involves basic steps: (1) separation of the pollen from the soil matrix and (2) concentration of the fossil pollen. Because the soil matrix at the sites in the Camp Bullis area had a relatively high clay content, an extraction method utilizing the Nitex nylon screen was employed. Nylon screens with $15-20 \mu$ mesh which allows clay to pass but stops pollen grains were used instead of the chemical methods of clay removal. In this manner chemical damage to the pollen was minimized. After treatment with $10 \% \mathrm{HCl}$ to remove carbonates, the zinc chloride-density separation method was used to remove silicates. The laboratory techniques for removing fossil pollen from Camp Bullis sediments are outlined below.

1. A $25 \mathrm{ml}$ portion of the sample was screened through a $250 \mu$ screen to remove larger particles.*

2. The sample was poured into a small sieve fitted with a $20 \mu$ mesh Nitex screen until the sieve was one-half full. Then the sieve was filled to near the brim with trisodium phosphate $\left(\mathrm{Na}_{3} \mathrm{PO}_{4}\right)$. The bottom of the sieve was tapped rapidly with the tips of the fingers until all the liquid portion of the sample passed through the screen.

Note: Step 2 was repeated until the filtrate was clear, which meant that most of the clay had been removed.

3. The residue on the screen was washed into a beaker with distilled water and the beaker was filled with water and stirred. Heavy

*Five milliliter portions were originally used, but the poor pollen preservation in the samples forced us to use larger samples. 
sand sediments were removed by quickly decanting the beaker, discarding the heavy sediments which remained on the bottom. The decanting process was repeated until most of the heavy sediments were removed.

4. The mixture remaining in the beaker was concentrated into a $90 \mathrm{ml}$ centritube by pouring it into the centritube, and spinning the tube at $2000 \mathrm{rpm}$ for 10 seconds to pull the pollen to the bottom. The liquid fraction was decanted, leaving the residue in the bottom. This process was repeated until the beaker was emptied, and all the pollen-containing sediments were concentrated into the tube.

5. The tube was filled with $10 \% \mathrm{HCl}$ and vibrated on a Vortex mixer to remove carbonates. The $10 \% \mathrm{HCl}$ was added until all bubbling stopped, indicating that no carbonates remained.

6. The tubes were centrifuged at $2000 \mathrm{rpm}$ for 10 seconds and decanted, leaving the residue at the bottom.

7. Each tube was filled one-half full with 1.90 zinc chloride $\left(\mathrm{ZnCl}_{2}\right)$ and centrifuged at 2000 rpm for 30 minutes.

8. The centritubes were then removed and examined for a thin black line at the top of the solution. The liquid portion of the sample was poured into a beaker, taking care to leave the unwanted sediment in the bottom of the centritube. The bottom sediment was examined for pollen loss and then discarded.

9. The $\mathrm{ZnCl}_{2}$ solution was then diluted $5 \mathrm{X}$ with distilled filtered water. The resulting solution was centrifuged as in step \#4.

10. Once the solution was concentrated into a centritube it was washed with distilled water twice, centrifuging in between washings as in step \#4.

11. The remaining residue was examined for pollen content.

\section{RESULTS}

Pollen from the Camp Bullis sites was not found in sufficient numbers to justify counting the slides. The few pollen grains observed were highly degraded and often difficult to identify as result of pollen distribution. Five pollen grain types appeared repeatedly in the samples: Pinus sp., Gramineae, high spine Compositae, Juniperus sp., and Quercus sp. The results are given in Table 25 . 
TABLE 25 . POLLEN ANALYSIS FROM 41 BX 36, 41 BX 377 AND 41 BX 428

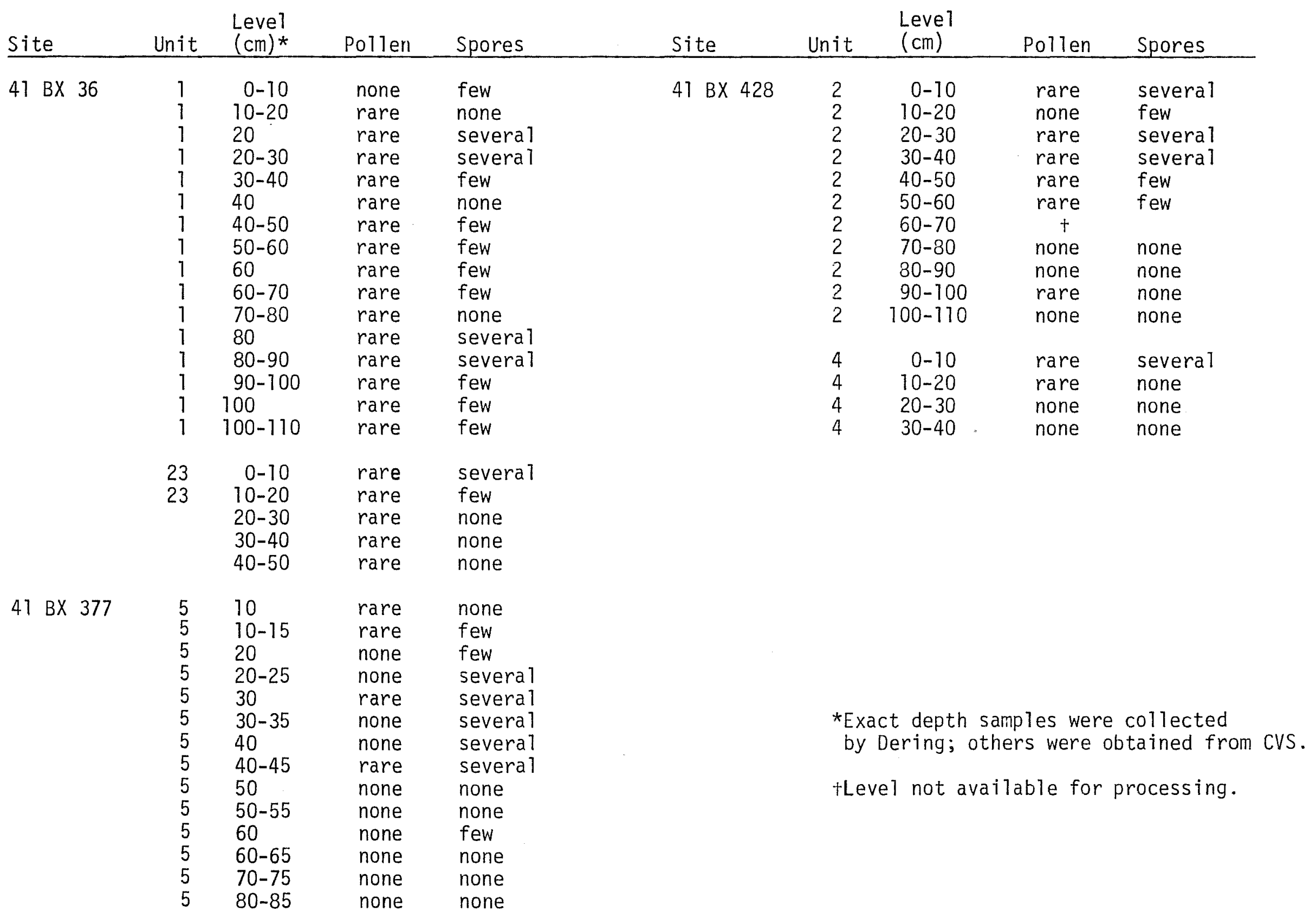


Despite the improved extracting ability of Nitex, we were unable to recover pollen in adequate numbers to justify more palynological research of fossil pollen in the soils of the area, at least until another new means of processing and quantifying low concentrations of pollen in the soil is developed.

\section{DISCUSSION}

Pollen preservation was the primary obstacle encountered in this project. The amount of pollen preserved in soils often depends upon many factors in addition to how much pollen the regional vegetation produces. Studies of depositional environments have revealed that the susceptibility of pollen grain destruction varies greatly from pollen type to pollen type (Sangster and Dale 1961, 1964). In general, alkaline environments, leaf moulds and riverine clays are considered to be the most destructive environments of deposition (Havinga 1971).

Within the environment of deposition, at least three major processes acting alone or in combination can lead to the eventual destruction of some or all of the pollen found in soils. These are: (1) physical or mechanical processes, (2) chemical processes and (3) biological processes.

Mechanical destruction of pollen grains can begin any time after the pollen is released into the air. Since many airborne pollen types have thin walls and lack excessive ornamentation, they are among the most susceptible to mechanical destruction. Destruction of pollen grains may result from airborne collisions with any other objects during transport, and from abrading action while on the surface of soils or during the post-depositional period.

The chemistry of the depositional environment can also determine the probability of preservation. The oxidation-reduction potential (Eh) affects the rate of pollen attrition. Sediments with a low Eh indicate a reducing environment which is favorable for pollen preservation (Tshudy 1969).

The $\mathrm{pH}$ of soils has been shown to be a factor in pollen preservation (Dimbelby 1957). Dimbelby noted that fossil pollen was best preserved in soils with a low $\mathrm{pH}$, and that pollen probably could not be recovered in soils with a $\mathrm{pH}$ higher than 6.5. Since Dimbelby's study, Martin (1963) and Bryant (1969) have been able to recover pollen from deposits with a $\mathrm{pH}$ as high as 8.9 in the arid southwestern states. However, in those cases where the $\mathrm{pH}$ was higher than 6.5, the condition of recovered pollen was extremely poor. Analysis of soil samples from Camp Bullis conducted by the Texas Agricultural Extension Service Soil Test Laboratory indicated that all except one sample were very alkaline, with $\mathrm{pH}$ readings higher than 8.0 .

Certain biological agents such as fungi and bacteria play a role in the degradation of pollen grains. Species of fungi in the Phycomycetes were investigated by Goldstein (1960) and were found to prey upon certain pollen types. Elsik (1971) recorded the destruction of pollen grains by bacteria. He found that bacteria in the Actinomycetes degrade pollen walls of both 
fresh and fossil pollen. As the results columns in Table 25 indicate, fungal spores were observed in several samples from Camp Bullis. Although these spores were not identified, the high fungal spore count suggests the possibility that biological degradation was one of the destruction agents in the Camp Bullis area.

\section{CONCLUSIONS}

Any combination of the above mentioned factors could have caused the destruction of pollen at the Camp Bullis sites. The most likely causes are fungal activity and a high soil pH. Because of the high attrition rate of pollen in the soils of Camp Bullis, no further testing for pollen presence is recommended until new methods for the extraction and quantification of potien from low-yield soils are devised. 



\author{
III. A. 12 \\ FAUNAL ANALYSIS OF SITE 41 BX 36, \\ WITH DATA PRESENTED FOR 41 BX 377 AND 41 BX 428
}

Jerry Henderson

\title{
INTRODUCTION
}

Analysis of the faunal materials from sites 41 BX 36, 41 BX 377 and 41 BX 428 was undertaken in an attempt to assess the role of the vertebrate fauna in the subsistence strategies of the aboriginal occupants of the sites. The small amounts of bone recovered from sites 41 BX 377 and 41 BX 428 prevented any detailed cultural inferences. The recovery from $41 \mathrm{BX} 36$ was conducive to a study of prehistoric faunal exploitation including detection of the subsistence base and the major sources of meat protein, a survey of the habitats represented by each species in order to determine aboriginal exploitation patterns, determination of butchering practices, explanations of other signs of cultural modifications such as burning and secondary usage, and determination of the season(s) of occupation at the site.

\section{METHODOLOGY}

The vertebrate collections housed at the Texas Archeological Research Lab and The University of Texas Vertebrate Paleontology Lab at Balcones Research Center, Austin, Texas, were used to identify the specimens. Species identifications were recorded for each level of each excavation unit, and any additional observations such as age at death of the animal, burning, butchering marks or secondary usage were also noted. Spatial distribution of the faunal remains was determined from this procedure. In addition, minimum numbers of individuals within each species were calculated for the entire site, according to procedures recommended by Chaplin (1971) which involve, briefly, the counting of specific elements with consideration given to symmetry of the element (right versus left) and maturity of the animal at death. This methodology produced statistical data from which cultural inferences were drawn.

\section{$41 \mathrm{BX} 36$}

\section{Statistical Data}

Four classes of fauna (amphibians, reptiles, birds and mammals) were identified from $41 \mathrm{BX} 36$. Table 26 lists the identified species along with the total number of individuals represented by this count.

Species identifications were virtually impossible on the reptile and amphibian remains due to the lack of species-diagnostic elements and the fragmentary nature of the remains. In the case of the snake remains, only isolated vertebrae were present which are difficult, if not impossible, to identify even at the genus level. The turtles were represented only by pieces of carapace 
Species

AMPHIBIANS

Frog (Rana sp.)

REPTILES

Unidentifiable turtle

Unidentifiable snake

Fence lizard (cf. Sceloporus sp.)

BIRDS

Bob-white quail (Colinus virginianus)

Mourning dove (Zenaidura macroura)

Boat-tailed grackle (Cassidix mexicanus)

Turkey vulture (Cathartes aura)

Caracara (Polyborus audoboni)

\section{MAMMALS}

Pronghorn ante lope (Antilocapra americana)

White-tailed deer (Odocoileus virginianus)

Bison (Bison bison)

Cow (Bos sp.)

* Javelina (Pecari tejacu)

Domestic pig (Sus scrofa)

Coyote/Dog (Canis sp.)

Raccoon (Procyon lotor)

Eastern cottontail rabbit (Sylvilagus floridanus)

Jackrabbit (Lepus californicus)

Plains pocket gopher (Geomys bursarius)

*Pocket gopher (Thomomus spo)

Fox squirre] (Sciurus niger)

Mexican ground squirre1 (Citellus mexicanus)

Cotton rat (Sigmodon hispidus)

Woodrat (Neotoma sp.)

White-footed mouse (Peromyscus sp.)

Pocket mouse (Perognathus spo)

Vole (Microtus sp.)

*Invader species
Number of Minimum Number Fragments of Individuals

?

?

3

3

$\begin{array}{ll}4 & 1 \\ 1 & 1 \\ 1 & 1 \\ 1 & 1\end{array}$


which were too fragmentary for further identification. The one amphibian element (a frog tibio-fibula) and the lizard remains (three mandible fragments) are similar among many different species and thus could not be identified specifically. However, the lizard remains were tentatively identified, based on similarities to species in the comparative collections and presentday geographic ranges of these species.

It is extremely difficult to distinguish antelope from deer remains unless skull parts (especially teeth) or metapodials are present; hence, the only definite antelope identifications were based on these diagnostic elements. It is therefore probable that other non-diagnostic skeletal parts identified as deer were actually antelope. The non-diagnostic elements were identified as deer because the location of the site is well within the goegraphic range of white-tailed deer while somewhat outside the known range of antelope (cf. Hester and Hill 1975; Hester 1975b).

A similar problem exists with distinguishing coyote from dog. Since none of these remains have distinctive characters, they were simply called canis sp.

It is also difficult to distinguish Bison from Bos species except with certain diagnostic elements. Since none of these remains were species-diagnostic, it was considered here that they represented Bos when recovered from a historically disturbed deposit and Bison when recovered from an undisturbed deposit. The bovid remains referred to as Bos were probably Bison even though they were associated with historic debris. They were also associated with many aboriginal artifacts and lithic debris. The distinction in no way attempts to identify the elements at the species level but rather assumes the possibility that such species were present.

A similar situation arose over javelina versus domestic pig remains. However, since the earliest known javelina remains date to the early 1700 s in northeastern Mexico (Guerrero missions), they are assumed to be a recent introduction (T. R. Hester, personal communication).

Most of the small rodents were not identified at the species level because of the similarity of like elements among species; therefore, these were identified at the genus level only. However, in cases where positive identification of specific diagnostic traits was possible, identifications were taken to the species level.

Table 27 presents the spatial distribution of all identified and unidentifiable fragments within the site. Horizontally, highest bone concentrations occurred in Excavation Units 1 and 2, and 4 through 7 in the central northwestern portion of the site. Smaller concentrations occurred in the central northeastern portion of the site in Excavation Units 18 and 23, and at the southeastern edge of the site in Excavation Unit 22. This pattern of horizontal distribution remained consistent vertically. No attempt was made to separate the fauna into vertical levels or zones of occupation because of the highly disturbed nature of the deposits and the recovery techniques (i.e., some units were excavated in $5-\mathrm{cm}$ increments, some in $10-\mathrm{cm}$ increments and, rarely, in 15-cm increments). 
Unit Level Unidentifiable

$\frac{\mathrm{cm})}{\mathrm{cm}}$ Unburned Burned

TP 1

$0-10$
$10-20$

33

47

20-30

TP 2

$0-10$

$10-20$

14

52

20-30

$30-40$

40-bedrock

TP

$\begin{array}{rr}0-10 & 15 \\ 10-20 & 122\end{array}$

20-30

$30-45$

$45-55$

55-65

Unknown

1

$0-10$
$10-20$

143

213
12

2

Modified

-

$-$

$-$

$-$

-

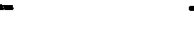

4
-

\section{-}

\section{-}

-

$-$

$-$

1

2
Identifiable

\begin{tabular}{|c|c|c|}
\hline & & \\
\hline Number & Species & ETement \\
\hline - & - & - \\
\hline 2 & Bovid & Left lunate, tooth \\
\hline 1 & Bob-white quail & Right femur \\
\hline 3 & Cotton rat & Mandible, 2 upper incisor \\
\hline 1 & Plains pocket gopher & Lower incisor \\
\hline- & - & - \\
\hline 3 & White-tailed deer & Humerus, 2 antler tips* \\
\hline 1 & White-tailed deer & Right mandible \\
\hline 1 & Pocket gopher & Tibia \\
\hline 1 & Bob-white quail & Left humerus \\
\hline 1 & Boat-tailed grackle & Left coracoid \\
\hline - & - & - \\
\hline- & - & - \\
\hline - & - & - \\
\hline 1 & Pronghorn antelope & Tooth \\
\hline 1 & White-tailed deer & Humerus* \\
\hline 1 & Bison & Carpa 1* \\
\hline- & - & - \\
\hline - & - & - \\
\hline 1 & White-tailed deer & Left pelvis \\
\hline- & - & - \\
\hline 1 & White-tailed deer & Tooth \\
\hline 2 & White-tailed deer & Right metapodial, vertebr \\
\hline $\begin{array}{l}1 \\
5\end{array}$ & $\begin{array}{l}\text { Cotton rat } \\
\text { Turtle }\end{array}$ & $\begin{array}{l}\text { Left mandible } \\
\text { Five carapace fragments }\end{array}$ \\
\hline 8 & White-tailed deer & Upper left P3, 2 right \\
\hline & & $\begin{array}{l}\text { 2nd phalanges, lumbar } \\
\text { vertebra, naviculo-cuboid }\end{array}$ \\
\hline & & $\begin{array}{l}\text { lower left } P 3 \text {, left lst } \\
\text { phalanx. right magnum }\end{array}$ \\
\hline 1 & Pronghorn antelope & Right metacarpal \\
\hline 4 & Cottontail rabbit & $\begin{array}{l}\text { Right humerus, calcaneus, } \\
\text { right radius, metatarsal }\end{array}$ \\
\hline
\end{tabular}


TABLE 27. (continued)

\begin{tabular}{|c|c|c|c|c|c|c|c|}
\hline \multirow[t]{2}{*}{ Unit } & \multirow{2}{*}{$\frac{\text { Level }}{(\mathrm{cm})}$} & \multicolumn{2}{|c|}{ Unidentifiable } & \multirow[t]{2}{*}{ Modified } & \multicolumn{2}{|r|}{ Identifiable } & \multirow[b]{2}{*}{ Element } \\
\hline & & Unburned & Burned & & Number & Species & \\
\hline \multirow{15}{*}{$\begin{array}{l}1 \\
\text { (cont.) }\end{array}$} & $10-20$ & & & & 1 & Cotton rat & Right mandible \\
\hline & & & & & 1 & Woodrat & Right mandible \\
\hline & & & & & $i$ & White-footed mouse & Right mandible \\
\hline & & & & & $i$ & Plains pocket gopher & Right femur \\
\hline & & & & & 5 & Turtle & Five carapace fragments \\
\hline & $20-30$ & 68 & 7 & - & 1 & Turtle & Carapace fragment \\
\hline & & & & & 2 & White-tailed deer & Two metapodials \\
\hline & $30-40$ & 20 & 1 & - & 1 & Eastern fox squirrel & $\begin{array}{l}\text { Metapodial } \\
\text { Lower right molar* }\end{array}$ \\
\hline & $40-50$ & 11 & 1 & _ & - & - & Lower rignt molar* \\
\hline & $50-60$ & - & - & - & - & - & 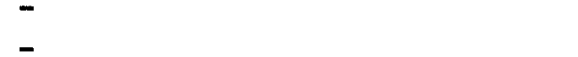 \\
\hline & $60-70$ & 4 & - & - & _ & - & - \\
\hline & $70-80$ & 7 & 2 & - & _ & - & - \\
\hline & $80-90$ & 2 & - & _ & - & _- & - \\
\hline & $90-100$ & - & 2 & - & - & _ & - \\
\hline & $100-110$ & - & $\overrightarrow{1}$ & - & - & - & - \\
\hline \multirow[t]{10}{*}{2} & $0-10$ & - & _ & - & 3 & White-tailed deer & left radius* riaht meta- \\
\hline & & & & & & whrce-catrea uetr & tarsal, right tibia \\
\hline & & & & & 1 & Bovid & Right cuneiform \\
\hline & & & & & $i$ & Canine & Tooth \\
\hline & $10-20$ & - & 61 & - & 5 & White-tailed deer & Lower right $\mathrm{P} 4$, rib, \\
\hline & & & & & & & $\begin{array}{l}\text { right scaphoid } \\
\text { right }\end{array}$ \\
\hline & $20-30$ & 28 & 4 & - & - & - & - \\
\hline & $30-40$ & 17 & 2 & - & - & - & - \\
\hline & $40-50$ & 7 & - & - & - & - & - \\
\hline & $50-60$ & 24 & 2 & - & 2 & White-tailed deer & $\begin{array}{l}\text { Left metatarsal, right } \\
\text { lunate }\end{array}$ \\
\hline \multirow[t]{6}{*}{3} & $0-5$ & 14 & - & - & 2 & White-tailed deer & Tooth, femur* \\
\hline & $5-10$ & 65 & 8 & - & 1 & White-tailed deer & Right lunate \\
\hline & $10-20$ & 45 & 7 & - & $i$ & White-tailed deer & Lower first or second molar \\
\hline & $20-30$ & 18 & - & - & - & - & - \\
\hline & $30-40$ & 6 & - & - & - & - & - \\
\hline & Clean-up & - & - & - & 1 & White-tailed deer & Right second phalanx \\
\hline
\end{tabular}


TABLE 27. (continued)

\begin{tabular}{|c|c|c|c|c|c|c|c|}
\hline \multirow[t]{2}{*}{ Unit } & \multirow{2}{*}{$\frac{\text { Level }}{(\mathrm{cm})}$} & \multicolumn{2}{|c|}{ Unidentifiable } & \multirow[t]{2}{*}{ Modified } & \multicolumn{3}{|c|}{ Identifiable } \\
\hline & & Unburned & Burned & & Tiumber & Species & Element \\
\hline \multirow[t]{15}{*}{4} & $0-5$ & 3 & 2 & 1 & - & - & - \\
\hline & $5-10$ & 37 & 5 & - & 2 & White-tailed deer & Left radius, skul1 fragment \\
\hline & $10-15$ & 133 & 25 & 1 & 5 & White-tailed deer & $\begin{array}{l}\text { Right radius, rib, right } \\
\text { patella, left first phalanx* } \\
\text { antler tip* }\end{array}$ \\
\hline & & & & & 3 & Cottontail rabbit & $\begin{array}{l}\text { Left maxilla, left scapula, } \\
\text { first phalanx* }\end{array}$ \\
\hline & $15-20$ & 72 & 32 & - & 4 & White-tailed deer & $\begin{array}{l}\text { Third phalanx, first phalanx } \\
\text { left astragulus, left } \\
\text { calcaneus }\end{array}$ \\
\hline & & & & & 1 & Bison & Second phalanx \\
\hline & $20-25$ & - & 3 & - & 1 & Cottontail rabbit & Left mandible \\
\hline & & & & & 1 & Turkey vulture & Left tibiotarsus \\
\hline & $25-30$ & 29 & 5 & - & 2 & White-tailed deer & First phalanx*, vertebra \\
\hline & $30-35$ & 1 & 1 & - & - & - & - \\
\hline & $35-40$ & 2 & - & - & - & - & - \\
\hline & $40-45$ & 8 & 1 & - & - & - & - \\
\hline & $45-50$ & 1 & - & - & - & - & - \\
\hline & $50-55$ & 3 & 1 & - & - & - & - \\
\hline & $55-60$ & - & - & - & - & - & - \\
\hline \multirow[t]{8}{*}{5} & $0-10$ & 127 & 35 & 1 & 3 & White-tailed deer & $\begin{array}{l}\text { Antler tip*, left second } \\
\text { phalanx, left lunate }\end{array}$ \\
\hline & & & & & 1 & Bovid & Carpal \\
\hline & & & & & 1 & Cotton rat & Right femur \\
\hline & $10-20$ & 138 & 60 & 1 & 6 & $\begin{array}{l}\text { White-tailed deer } \\
\text { Whited }\end{array}$ & $\begin{array}{l}\text { Pelvis } \\
\text { Left } 1 \text { st phalanx, } 2 \text { right }\end{array}$ \\
\hline & & & & & & & $\begin{array}{l}\text { naviculo-cuboids, left } \\
\text { radius, lower left } 1 \text { st or } \\
\text { 2nd molar, upper 1st or 2nd } \\
\text { molar }\end{array}$ \\
\hline & & & & & 4 & Bison & $\begin{array}{l}\text { Right tibia, } 2 \text { left astra- } \\
\text { guli, upper left P3, right } \\
\text { femur }\end{array}$ \\
\hline & & & & & 1 & Woodrat & Right femur \\
\hline & & & & & 3 & Cottontail rabbit & $\begin{array}{l}\text { Metacarpal, calcaneus*, } \\
\text { left radius }\end{array}$ \\
\hline
\end{tabular}


TABLE 27. (continued)

\begin{tabular}{|c|c|c|c|c|c|c|c|}
\hline Unit & Level & Unidentif & able & Modified & & Identifia & \\
\hline & $(\mathrm{cm})$ & Unburned & Burned & & Number & Species & ETement \\
\hline $\begin{array}{l}5 \\
\text { (cont.) }\end{array}$ & $10-20$ & & & & 1 & Snake & Vertebra \\
\hline & $20-30$ & 21 & 9 & - & $\begin{array}{l}3 \\
-\end{array}$ & Iurtie & $\begin{array}{l}\text { Inree carapace tragments } \\
\text { - }\end{array}$ \\
\hline & $30-40$ & 11 & 1 & - & 1 & White-tailed deer & First phalanx \\
\hline & $40-50$ & 2 & - & - & - & - & - \\
\hline & $50-60$ & 3 & - & - & - & - & - \\
\hline 6 & $0-10$ & 78 & - & - & 3 & White-tailed deer & $\begin{array}{l}\text { Lower right } M 2 \text {, upper } M 1 \\
\text { or } M 2 \text {, upper right } P 4\end{array}$ \\
\hline & & & & & $\begin{array}{l}1 \\
2\end{array}$ & $\begin{array}{l}\text { Bison } \\
\text { Coyote/dog }\end{array}$ & $\begin{array}{l}\text { Upper left P2 } \\
\text { Naviculo-cuboid, upper } \\
\text { right P4 }\end{array}$ \\
\hline & & & & & $\begin{array}{l}1 \\
2\end{array}$ & $\begin{array}{l}\text { Cottontail rabbit } \\
\text { Turtle }\end{array}$ & $\begin{array}{l}\text { Left mandible } \\
\text { Two carapace fragments }\end{array}$ \\
\hline & $10-20$ & 127 & 41 & - & 4 & White-tailed deer & $\begin{array}{l}\text { Right first phalanx*, } \\
\text { cuneiform, right radius, } \\
\text { right first phalanx }\end{array}$ \\
\hline & & & & & $\begin{array}{l}2 \\
2\end{array}$ & $\begin{array}{l}\text { Bison } \\
\text { Cottontail rabbit }\end{array}$ & $\begin{array}{l}\text { First and third phalanx } \\
\text { Right mandible and pelvis }\end{array}$ \\
\hline & $20-30$ & 46 & 18 & - & - & - & - \\
\hline & $30-40$ & 16 & - & - & 1 & White-tailed deer & Antler* \\
\hline & $40-50$ & 14 & - & - & - & - & - \\
\hline & $50-60$ & 14 & 1 & - & 2 & White-tailed deer & $\begin{array}{l}\text { Metapodial, lateral first } \\
\text { phalanx ("dew claw") }\end{array}$ \\
\hline & & & & & 1 & Bison & Left lunate \\
\hline 7 & $0-10$ & 64 & 32 & - & $\begin{array}{l}1 \\
4\end{array}$ & $\begin{array}{l}\text { White-tailed deer } \\
\text { Bovid }\end{array}$ & $\begin{array}{l}\text { Left calcaneus } \\
\text { Upper M1 or M2, 2nd phalanx } \\
\text { (Art.H), upper right M3, } \\
\text { lower left incisor (Art.A) }\end{array}$ \\
\hline & & & & & 1 & Domestic pig & Left second phalanx \\
\hline & & & & & 1 & Mourning dove & $\begin{array}{l}\text { Left calcaneus } \\
\text { Left humerus }\end{array}$ \\
\hline & $10-20$ & 136 & 39 & - & 4 & White-tailed deer & $\begin{array}{l}\text { Left mandible, left second } \\
\text { phalanx, } 2 \text { right humeri }\end{array}$ \\
\hline & & & & & 3 & Cottontail rabbit & $\begin{array}{l}\text { Left and right maxilla, } \\
\text { right femur }\end{array}$ \\
\hline
\end{tabular}


TABLE 27. (continued)

\begin{tabular}{|c|c|c|c|c|c|c|c|}
\hline Unit & Level & Unidentif & ble & Modified & & Identifia & $\widetilde{\omega}$ \\
\hline & $(\mathrm{cm})$ & Unburned & Burned & & Number & Species & Element \\
\hline 7 & $10-20$ & & & & 1 & Cotton rat & Left femur \\
\hline (cont.) & & & & & 1 & Turtle & Carapace* \\
\hline & $20-30$ & 54 & 30 & - & 2 & White-tailed deer & $\begin{array}{l}\text { Right naviculo-cuboid, } \\
\text { left petrosal }\end{array}$ \\
\hline & & & & & 1 & Turtle & Carapace fragment \\
\hline & $30-40$ & 25 & 4 & - & 1 & White-tailed deer & Left scapula \\
\hline & $40-50$ & 29 & 4 & - & 1 & White-tailed deer & Rib \\
\hline & $50-60$ & 6 & - & - & 1 & White-tailed deer & Right ulna \\
\hline 8 & $0-10$ & 26 & 14 & - & - & - & - \\
\hline & $10-15$ & 51 & 19 & - & 3 & White-tailed deer & Right mandible, 2 phalanges \\
\hline & $15-20$ & 55 & 8 & - & 1 & $\begin{array}{l}\text { White-tailed deer } \\
\text { Cottontail rabbit }\end{array}$ & $\begin{array}{l}\text { Left first phalanx } \\
\text { Right femur }\end{array}$ \\
\hline & & & & & 1 & Snake & Vertebra \\
\hline & $20-25$ & 109 & 6 & - & 1 & Turtle & Larapace fragment* \\
\hline & $25-30$ & 42 & 13 & - & - & - & - \\
\hline 9 & $0-10$ & 90 & 26 & - & 1 & $\begin{array}{l}\text { White-tailed deer } \\
\text { Cottontail rabbit }\end{array}$ & $\begin{array}{l}\text { Right metacarpal } \\
\text { Maxilla }\end{array}$ \\
\hline & $10-20$ & 94 & 24 & - & 6 & White-tailed deer & Left humerus, upper left \\
\hline & & & & & & & $\begin{array}{l}\text { astragulus, metapodial, } \\
\text { right naviculo-cuboid }\end{array}$ \\
\hline & $20-30$ & 08 & 25 & - & $\begin{array}{l}2 \\
?\end{array}$ & Cottontail rabbit & Left and right mandible \\
\hline & $20-30$ & 98 & $\angle 0$ & - & 1 & Cottontail rabbit & $\begin{array}{l}\text { Humerus, tooth } \\
\text { Left calcaneus }\end{array}$ \\
\hline & $30-40$ & 31 & 11 & - & 1 & Pronghorn antelope & Metatarsal \\
\hline & $10-50$ & 12 & & & $\begin{array}{l}1 \\
2\end{array}$ & Javelina/pig & Third phalanx \\
\hline & $40-50$ & 12 & 7 & - & $\begin{array}{l}2 \\
1\end{array}$ & $\begin{array}{l}\text { White-tailed deer } \\
\text { Turtle }\end{array}$ & $\begin{array}{l}\text { Metapodial, right humerus } \\
\text { Carapace fragment }\end{array}$ \\
\hline & $50-60$ & 5 & - & - & - & - & - \\
\hline & $60-70$ & 4 & - & - & - & - & - \\
\hline & $70-80$ & - & - & - & - & - & - \\
\hline & $80-90$ & - & - & - & - & - & - \\
\hline
\end{tabular}


TABLE 27. (continued)

\begin{tabular}{|c|c|c|c|c|c|c|c|}
\hline \multirow[t]{2}{*}{ Unit } & \multirow{2}{*}{$\frac{\text { Level }}{(\mathrm{cm})}$} & \multicolumn{2}{|c|}{ Unidentifiable } & \multirow[t]{2}{*}{ Modified } & \multicolumn{3}{|c|}{ Identifiable } \\
\hline & & Unburned & Burned & & Number & Species & Element \\
\hline \multirow[t]{4}{*}{10} & \multirow{4}{*}{$\begin{array}{r}0-10 \\
10-20\end{array}$} & \multirow{4}{*}{$\begin{array}{r}20 \\
100\end{array}$} & \multirow{4}{*}{$\begin{array}{r}4 \\
10\end{array}$} & \multirow{4}{*}{ - } & - & - & \multirow{4}{*}{$\begin{array}{l}\text { - } \\
\text { phalanx, } 2 \text { right humeri } \\
\text { Left and right maxilla, } \\
\text { right femur } \\
\text { Left femur } \\
\text { Carapace fragment* }\end{array}$} \\
\hline & & & & & 4 & White-tailed deer & \\
\hline & & & & & 3 & Cottontail rabbit & \\
\hline & & & & & $\begin{array}{l}1 \\
1\end{array}$ & $\begin{array}{l}\text { Cotton rat } \\
\text { Turtle }\end{array}$ & \\
\hline \multirow[t]{4}{*}{11} & $0-10$ & 62 & 9 & - & $\begin{array}{l}2 \\
1\end{array}$ & $\begin{array}{l}\text { White-tailed deer } \\
\text { Cottontail rabbit }\end{array}$ & \multirow{4}{*}{$\begin{array}{l}\text { Left calcaneus, vertebra } \\
\text { Right humerus } \\
\text { Right calcaneus, lower } \\
\text { left M1 or M2 } \\
\text { Left naviculo-cuboid } \\
\text { Left tarsometatarsus }\end{array}$} \\
\hline & $10-20$ & 12 & - & - & 2 & White-tailed deer & \\
\hline & & & & & 1 & Bison & \\
\hline & & & & & 1 & Bob-white quail & \\
\hline \multirow[t]{5}{*}{12} & $0-5$ & 15 & 2 & - & 1 & Bovid & \multirow{5}{*}{$\begin{array}{l}\text { Upper right } \mathrm{P4} \\
\text { Femur } \\
\text { Left mandible, left femur, } \\
\text { left tibia, left humerus } \\
\text { Upper M1 or M2 } \\
\text { Right tibio-fibula }\end{array}$} \\
\hline & $5-10$ & 72 & 3 & - & $\begin{array}{l}1 \\
4\end{array}$ & $\begin{array}{l}\text { Woodrat } \\
\text { Plains pocket gopher }\end{array}$ & \\
\hline & & & & & & & \\
\hline & $10-15$ & 30 & 5 & - & 1 & White-tailed deer & \\
\hline & $15-20$ & - & - & - & 1 & Frog & \\
\hline \multirow[t]{3}{*}{13} & $0-10$ & - & - & - & - & - & \multirow{3}{*}{$\begin{array}{l}\text { Right calcaneus, left meta- } \\
\text { carpal, right radius* } \\
\text { Carapace fragment* }\end{array}$} \\
\hline & $10-20$ & - & - & - & 3 & White-tailed deer & \\
\hline & & & & & 1 & Turtle & \\
\hline \multirow[t]{5}{*}{14} & $0-15$ & 49 & 11 & - & 1 & Bison & Tooth* \\
\hline & $15-25$ & 11 & 1 & - & - & - & - \\
\hline & $25-35$ & 22 & 1 & - & - & - & - \\
\hline & $35-45$ & - & - & - & - & - & - \\
\hline & $45-55$ & 5 & 1 & - & - & - & - \\
\hline \multirow[t]{4}{*}{15} & $0-10$ & 54 & 21 & - & 1 & Plains pocket gopher & Left humerus \\
\hline & $10-20$ & 20 & 5 & - & $\begin{array}{l}1 \\
1\end{array}$ & $\begin{array}{l}\text { Jackrabbit } \\
\text { Snake }\end{array}$ & $\begin{array}{l}\text { First phalanx } \\
\text { Vertebra }\end{array}$ \\
\hline & $20-30$ & 6 & - & - & - & - & - \\
\hline & $30-40$ & 5 & 1 & - & - & - & - \\
\hline
\end{tabular}


TAELE 27. (continued)

\begin{tabular}{|c|c|c|c|c|c|c|c|}
\hline \multirow[t]{2}{*}{ Unit } & \multirow{2}{*}{$\frac{\text { Level }}{(\mathrm{cm})}$} & \multicolumn{2}{|c|}{ Unidentifiable } & \multirow[t]{2}{*}{ Modified } & \multicolumn{3}{|c|}{ Identifiable } \\
\hline & & Unburned & Burned & & Number & Species & Element \\
\hline \multirow[t]{3}{*}{16} & $0-10$ & 1 & - & - & - & - & - \\
\hline & $10-20$ & - & - & - & 1 & Bison & Tooth \\
\hline & $20-30$ & - & - & - & - & - & - \\
\hline \multirow[t]{3}{*}{17} & $0-10$ & 34 & 6 & - & 1 & White-tailed deer & Lower left M3 \\
\hline & $10-20$ & 5 & 3 & - & - & - & - \\
\hline & $20-30$ & 18 & 3 & - & 2 & White-tailed deer & Tooth, left astragulus \\
\hline \multirow[t]{6}{*}{18} & $0-10$ & 46 & - & 1 & 3 & White-tailed deer & $\begin{array}{l}\text { Rib, left radius, right } \\
\text { third phalanx* }\end{array}$ \\
\hline & & & & & 1 & Coyote/dog & Left ulna \\
\hline & & & & & 1 & Cottontail rabbit & Left scapula* \\
\hline & & & & & 1 & Caracara & Left humerus \\
\hline & $10-20$ & 26 & 9 & - & 1 & White-tailed deer & Left scapula \\
\hline & $20-30$ & 19 & 5 & 1 & $\frac{1}{2}$ & $\begin{array}{l}\text { Raccoon } \\
\text { White-tailed deer }\end{array}$ & $\begin{array}{l}\text { Right mandible } \\
\text { Left astragulus, right ulna }\end{array}$ \\
\hline \multirow[t]{2}{*}{19} & $0-10$ & 34 & 17 & - & - & - & - \\
\hline & $10-20$ & 8 & 2 & - & - & - & - \\
\hline \multirow[t]{3}{*}{20} & $0-10$ & 4 & - & - & - & - & - \\
\hline & $10-20$ & - & - & - & - & - & - \\
\hline & $20-30$ & 44 & 4 & - & - & - & - \\
\hline \multirow[t]{2}{*}{21} & $0-10$ & 5 & 1 & - & - & - & - \\
\hline & $10-20$ & 12 & 1 & - & - & - & - \\
\hline \multirow[t]{8}{*}{22} & $0-10$ & 11 & 6 & - & 1 & Woodrat & Left tibia \\
\hline & $10-20$ & 27 & 6 & - & 1 & Woodrat & Left maxilla \\
\hline & & & & & 2 & Cotton rat & Two right femurs \\
\hline & $20-30$ & 53 & 11 & - & 1 & White-tailed deer & Phatanx \\
\hline & & & & & 1 & Cotton rat & Left femur \\
\hline & & & & & 1 & Bob-white quail & Left coracoid \\
\hline & & & & & 1 & Mourning dove & Left coracoid \\
\hline & & & & & $\begin{array}{l}1 \\
1\end{array}$ & $\begin{array}{l}\text { Turtle } \\
\text { Snake }\end{array}$ & $\begin{array}{l}\text { Carapace fragment } \\
\text { Vertebra }\end{array}$ \\
\hline
\end{tabular}


TABLE 27. (continued)

\begin{tabular}{|c|c|c|c|c|c|c|c|}
\hline \multirow{2}{*}{ Unit } & \multirow{2}{*}{$\frac{\text { Level }}{(\mathrm{cm})}$} & \multicolumn{2}{|c|}{ Unidentifiable } & \multirow{2}{*}{ Modified } & \multicolumn{3}{|c|}{ Identifiable } \\
\hline & & Unburned & Burned & & Number & Species & Element \\
\hline \multirow{5}{*}{$\begin{array}{l}22 \\
(\text { cont. })\end{array}$} & $30-40$ & 11 & 6 & - & 1 & White-tailed deer & Right first phalanx \\
\hline & $40-50$ & 8 & 1 & - & - & & \\
\hline & $50-60$ & - & 4 & - & - & & \\
\hline & $60-70$ & 9 & 1 & - & 1 & Cottontail rabbit & Right mandible \\
\hline & $70-80$ & & - & - & - & - & - \\
\hline \multirow[t]{12}{*}{23} & $0-10$ & 72 & - & 1 & 2 & White-tailed deer & \multirow{12}{*}{$\begin{array}{l}\text { First phalanx, lateral } \\
\text { first phalanx ("dew claw") } \\
\text { Left tibia, right tibia* } \\
\text { Left metacarpal } \\
\text { Right mandiblet } \\
\text { Tootht } \\
\text { Vertebrat } \\
\text { Vertebraet } \\
\text { - } \\
\text { Two right mandiblest } \\
\text { Molart } \\
\text { Calcaneust } \\
\text { Molart } \\
\text { Pelvis, upper left incisort } \\
\text { Vertebraet } \\
\text { - }\end{array}$} \\
\hline & & & & & 2 & Cottontail rabbit & \\
\hline & $10-20$ & 37 & 6 & - & 1 & White-tailed deer & \\
\hline & & & & & 1 & $\begin{array}{l}\text { Fence lizard } \\
\text { Vole }\end{array}$ & \\
\hline & & & & & 1 & Reptile & \\
\hline & & & & & 2 & Snake & \\
\hline & $20-30$ & 15 & 4 & - & - & - & \\
\hline & $30-40$ & 8 & 2 & - & 2 & $\begin{array}{l}\text { Fence lizard } \\
\text { Cotton rat }\end{array}$ & \\
\hline & & & & & 1 & Pocket mouse & \\
\hline & & & & & $\begin{array}{l}1 \\
2\end{array}$ & Vole & \\
\hline & & & & & 2 & Snake & \\
\hline & $40-50$ & 21 & 4 & - & - & - & \\
\hline \multirow[t]{2}{*}{ Pit G } & $0-10$ & 20 & 9 & - & 3 & White-tailed deer & \multirow{2}{*}{$\begin{array}{l}\text { Right metatarsal, right } \\
\text { metacarpal, lower left P2 } \\
\text { Carapace fragment* }\end{array}$} \\
\hline & & & & & 1 & Turtle & \\
\hline
\end{tabular}

*Burned.

tFrom constant volume samples (only Units 1 and 23 were processed). 



\section{Biotic Communities Represented}

To understand more fully the aboriginal exploitation patterns occurring at site $41 \mathrm{BX} 36$, it was first necessary to establish the biotic community preferred by each species recovered from the site. Information on habitat, abundance, seasonality, behavior and any other factors directly relating to that species' relationship with the human component was compiled, so that inferences could be drawn regarding human exploitation patterns and subsistence activities. Following is a brief summary for each species. Omitted were those animals which could not be identified to the species level when a simple genus classification was too arbitrary to disclose specific habitat requirements (Table 28 ).

\section{Reconstruction of Aboriginal Exploitation Strategies}

From Table 28, it would appear that the aboriginal inhabitants of 41 BX 36 exploited at least two major biotic zones--an open grassland/prairie zone and a mixed scrub forest zone. The species recovered from the site representing a grassland prairie and mixed grassland situation include pronghorn antelope, bison, jackrabbit and Mexican ground squirrel. Those representing a mixed forest situation include the boat-tailed grackle, white-tailed deer, raccoon and fox squirrel. The remaining species can be found in either biotic zone-or perhaps more likely, in an ecotonal situation where there is an overlapping of both vegetation types.

The conspicuous absence in the archaeological assemblage of aquatic and riverine species such as fish, river fowl, beaver, mink and raccoon (only one was noted) indicates that these species either were not available to the prehistoric hunters or were not exploited by them. Since the species recovered represent a wide range of size and kind of animal, it is natural to assume that the aborigines would also have taken aquatic and riverine species had they been available. It is possible that Salado Creek, if it has only a seasonal flow, would not have supported aquatic and riverine species of fauna. However, the extensive flood plain suggests a permanent flow. Hester (1975b:109) suggests that ". . overgrazing and the resultant watershed destruction ...." was the cause of the loss of formerly available surface water, which was confirmed by historic accounts to have been present even as late as the 20th century.

The three species of antelope, bison and white-tailed deer probably represent the main sources of meat protein for the aboriginal diet in terms of the amount of edible meat furnished by each, relative to the other smaller animals recovered from the site. Therefore, it can be hypothesized that the aboriginal hunters were deliberately and actively hunting these larger game species, and taking the smaller animals when encountered as supplements to the diet.

An alternate hypothesis involves the distinct division of labor, according to age and sex, practiced by many prehistoric groups; hunting parties consisted of adult males, and the women and children remained at the site. It can be inferred that the adult males hunted the larger game species, while the women and children caught the smaller animals during the course of their daily 
Habitat

Pronghorn antelope

White-tailed deer

Bison

Javelina

Coyote/dog

Raccoon near water vegetation [3] areas [2]

\section{Behavior}

Plains and mixed grasslands, not necessarily

Highest population densities in ecotonal areas with largest variety of

Tall and short grass plains and mixed grasslands. Extended prehistorically into central Texas [5]

Tropical and subtropical environments; primarily rooting animals

Desert scrub through grassland and timbered

Wide variety but especially river and lake margins, brushland, forested ridges, etc. six $\mathrm{km}$ [1] one per sq $\mathrm{km}$

\section{Meat Yield}

Diurnal browsing in small bands. Home range: three to

Seasonal range of single deer ca. one mile. Acorns as winter food, stream-bottom grasses as spring food, woody glades and meadows provide summer food [4]

Emigrated in summer. $[6,7,8]$ Concentrated herds during summer mating season (July to September), otherwise smaller groups. Birthing in Apri1. Animal healthiest in fall and winter [9]

Travel in bands from a few to several hundred individuals

Varying diet, depending on type available. Home range is several km; density ca.

In winter and spring, timbered river bottoms favored; in summer and fall, dispersal into uplands. Arboreal dens ca. $120 \mathrm{~m}$ from water. [4] Average home range: $2.6 \mathrm{~km}$; average density: 15 per sq $\mathrm{km}$ [3]
Average weight: $68 \mathrm{~kg}$. Edible meat: $36 \mathrm{~kg}$ [2]

Average weight: $68 \mathrm{~kg}$. Edible meat: $36.32 \mathrm{~kg}$ [4]

Edible meat: $160 \mathrm{~kg}$ [3]

Average weight: $18.16 \mathrm{~kg}$. Edible meat: $4.54 \mathrm{~kg}$

Average weight: $9.08 \mathrm{~kg}$. Edible meat: $3.86 \mathrm{~kg}[3]$ 
TABLE 28. (continued)

Habitat

Eastern cottontail rabbit

Jackrabbit

Plains pocket gopher

Pocket gopher

Eastern fox squirre]

Mexican ground squirrel

Cotton rat

Woodrat
Forest border habitat with brushy cover ideal, but highly adaptable [4]

Hot, dry desert scrubland and brushy habitats. Prefers sparse vegetation [2]

Prefers sandy soils at least $10 \mathrm{~cm}$ deep

Prefers moist and easily worked soil, al though some found in rocky areas

Upland mixed hardwood and pine forests and open bottomlands. Rarely in dense climax forest

Grassland, brush, mesquite, cactus vegetation preferred, with sandy or gravelly soil

Tal1-grass prairies not subject to flooding [2]

In desert, plains and rocky areas
Average home range: 0.54 ha, but expands during breeding season [4]

Maximum density: 154 per sq $\mathrm{km}$. Diet includes herbs and grasses [2]

Mostly remains underground, with a diet of roots and stems. Overland range limited, but underground range large. Average density: 332 per sq km

Gopher species usually spatially separate, although with similar habitats. Home range ca. 1700 sq ft; solitary and territorial. Recent invader of Edwards Plateau [10]

Diet of nuts, plants, insects, larvae, fruits. Home range of a few hundred meters. Average density: 124 per sq km [3]

Subsurface dens with burrows with maximum home range of $30 \mathrm{~m}$. Some hibernate in winter [1]

Diet of grasses, sedges, herbs. Population correlates positively with rainfall. Average density: 20 per ha [2]

Nocturnal habits. Dens of sticks and rubbish [1]
Average weight: 2.59

$\mathrm{kg}$. Edible meat:

0.98

Average weight: 0.45

$\mathrm{kg}$. Edible meat: $0.17 \mathrm{~kg}$

Average weight: 2.27 $\mathrm{kg}$. Edible meat:

$0.68 \mathrm{~kg}$

Average weight: 0.15 $\mathrm{kg}$. Edible meat:

$0.06 \mathrm{~kg}$

Average weight: 0.23 $\mathrm{kg}$. Edible meat: $0.10 \mathrm{~kg}$

Average weight: 0.03 $\mathrm{kg}$. Edible meat: negligible 
TABLE 28. (continued)

Habitat

White-footed mouse

Pocket mouse

Vole

Bob-white quail

Mourning dove

Boat-tailed grackle

Turkey vulture

Caracara

Fence lizard

References:
Woodland and bottomland habitat

Prefers friable or sandy soil with moderately dense vegetation

Prefers good grass cover, occasionally rocky and wooded areas [1]

Brushy habitats preferred [11]

Open fields preferred

Temperate regions

Prairie region of south

Texas

Varies from steaming tropical forest to sparse timberline growth [13]
Burt and Grossenheider 1964 Davis 1974

Charles Winkler, large game biologist, Texas Parks and Wildi ife Department: personal communication
Behavior

Seed and nut diet. Dens in hollow trees above ground.

Average range: $50 \mathrm{~m}$

Lives in burrows; active all year. Herb diet [2]

cratching birds with seed, fruit and insect diet.

May be an introduced

species [12]

Slow-moving ground feeders. Diet of seed and grain

Lives in flocks all year. Bulky nests of mud and grasses

Carrion eaters

Carrion eaters

Ground dwellers, often climbing rocks and stumps to bask in the sun [13]

$\begin{array}{ll}{[4]} & \text { Smith } 1975 \\ {[5]} & \text { Dillehay 1974 } \\ {[6]} & \text { Roe 1951 } \\ {[7]} & \text { Haines 1970 } \\ {[8]} & \text { Levy 1961 }\end{array}$

\section{Meat Yield}

Average weight: 0.03 $\mathrm{kg}$. Edible meat: negligible

Average weight: 0.03 $\mathrm{kg}$. Edible meat: negligible [2]

Edible meat: negligible [1]

Probably not a food source

Probably not a food source

[9] Garretson 1934

[10] Lundelius 1967

[11] Peterson 1947

[12] Hester 1975b

[13] Stebbins 1966 
activities. This hypothesis is somewhat supported by the presence of many small rodents at the site whose habitats correspond with edible wild plant sources (particularly the woodrat which nests in cactus and yucca plants). If this division of labor were practiced at $41 \mathrm{BX} 36$, the resulting faunal assemblage would be expected to reveal exactly what has been recovered--a combination of large game animals plus a variety of small animals and reptiles.

A survey of the age at death of the individual remains was undertaken in an attempt to ascertain whether the aboriginal hunters were practicing a "cropping" technique or had an age preference among the animal populations avai1able to the site. Extent of epiphyseal fusion, amount of dental attrition and presence of antlers were used as criteria to estimate the maturity at death of the individual. Only crude age categories were established since many other variables such as sex, diet, geographic range and climate also affect maturity characteristics within species. Table 29 is a breakdown of all elements showing age characteristics.

A total of 30 white-tailed deer elements, four bison elements, one cotton rat element and one plains pocket gopher element displayed such ageindicators. The sample is too small in both the rodent cases (only one per species) to indicate any kind of patterning. Although the sample of bison elements (only four) is too small to be conclusive, it is interesting to note that all these elements represent adults.

Of the 30 white-tailed deer elements, the age categories were established in the following manner. The "Juvenile" category was based on lack of epiphyseal fusion of the long bones, little or no wear on permanent teeth and presence of deciduous teeth. This category would comprise individuals up to 1-1/2 years of age (Davis 1974). The "Young Adu1t" category was based on partial or incomplete fusion of epiphyses, mild dental attrition and presence of "yearling" or "spike" antlers. This category consists of individuals from 1-1/2 to 3 years old (Winkler, personal communication). The "Adult" category was based on complete epiphyseal union, moderate dental attrition and presence of fully developed antlers. Individuals in this category would have been three years or older at time of death (Winkler, personal communication). The "Very 01d Adult" category was based only on extreme dental attrition since epiphyseal union is complete at, and antler development can not be age-diagnostic beyond, three years of age. Individuals in this category would have been five years or older at time of death.

A11 age categories were present among the white-tailed deer remains. Juveniles and young adults represent nine of the total of 30 specimens (or $30 \%$ ), while adults represent 21 of 30 specimens $(70 \%)$. This configuration is about what would be expected to occur in the 1 ive white-tailed deer populations; that is, there would normally be about one fawn or yearling for every two adults. From this data it can be inferred that the aboriginal hunters did not practice any form of "cropping" among the deer populations or did not have a preference as to the age of the animal taken. However, it must be remembered that the specimens used to arrive at these conclusions represent individual elements rather than individual animals and thus do not indicate a true ratio of juveniles to adults but merely a range of elements 
TÁALE 29. AGE OF DEATH OF ANIMALS REPRESENTED IN FAUNAL REMAINS

\begin{tabular}{|c|c|c|c|c|c|}
\hline Species & Element & Juvenile & $\begin{array}{l}\text { Young } \\
\text { Adult }\end{array}$ & Adult & $\begin{array}{l}\text { Very } \\
\text { old } \\
\text { Adult }\end{array}$ \\
\hline \multirow[t]{7}{*}{ White-tailed deer } & Metapodials & 1 & 1 & 5 & \\
\hline & Phalanges & 2 & & 1 & \\
\hline & Teeth & 1 & 4 & 6 & 1 \\
\hline & Radius & & & 1 & \\
\hline & Humeri & & & 2 & \\
\hline & Antlers & & & 5 & \\
\hline & & 4 & 5 & 20 & 1 \\
\hline Bison & Teeth & & & 3 & 1 \\
\hline Cotton rat & Femur & 1 & & & \\
\hline $\begin{array}{l}\text { Plains pocket } \\
\text { gopher }\end{array}$ & Femur & & & 1 & \\
\hline
\end{tabular}


present. Nonetheless, it is obvious that a11 age categories were present, although the sample used may not be representative of the true situation.

Tools, Butchering Marks, Burning and 0ther Modifications

Only one distinctive bone tool was found at 41 BX 36. A white-tailed deer ulna flaking tool came from Unit 18 (Fig. 56,b) and is similar to ulna flaking tools from other archaeological sites (Jelks 1962, Hester 1971 and Suhm 1957). There are two unidentifiable burned and modified pieces. One is a rib section which is notched on one side (Fig. 56,a), and the other is a sma 17 fragment which is very highly polished on the outer surface.

Two bovid shaft fragments exhibit modification. One was possibly broken up for marrow extraction and discarded. It has a cut mark and has been burned at one end. The other appears to have been utilized or worked as chert would be. Both outer sides of the fragment have flake scars (Fig. 56,c).

Cut marks interpreted as butchering marks were observed on four white-tailed deer elements: an antler tip, a rib, a right humerus (distal end) and a left radius (distal end). The marks on the antler tip, which was also extensively burned and somewhat smoother, could possibly be the result of tool manufacture, since these parts were often used as flaking tools. Butchering at the locations of the marks on the two long bones would serve to sever the forelimbs. The cut marks on the rib occurred parallel to the long axis of the bone and could have resulted from severing and eating the meat as well as from butchering the carcass. Table 30 gives the provenience of the culturally modified bone.

The range of elements representing the large game species indicates that the entire carcass was returned to the site for butchering. In the case of whitetailed deer, most parts of the skeleton were present, although 88 of the 118 identified pieces were foot or skul1 parts. With bison, 20 of the 22 identielements were foot or skull parts; the remaining two elements (a humerus and a tibia) represent a forelimb and a hindlimb. This frequency of foot and skull parts is puzzling in that these elements represent the least desirable parts of the carcass as far as edible meat is concerned.

There are several possibilities to account for this preponderance. One possibility is that the site contained a butchering area in which the non-edible parts were discarded and the edible parts taken elsewhere for consumption. This theory is perhaps the least likely because of the presence, though scarce, of a few edible parts of the larger species as well as a number and variety of smaller animals. Another possibility is that the entire carcass was utilized at the site, but the long bones were further modified into tools or fractured beyond recognition for marrow extraction, and the more fragile bones of the torso (i.e., scapulae, vertebrae and ribs) were not recovered in quantity due to poor preservation.

The most likely explanation, based on the evidence at hand, for the high frequency of foot and sku11 parts is that they represent an intra-site locale (especially the area sampled by Units 1 through 7 ) utilized by the aboriginal occupants as a refuse area in which the least preferred parts were discarded. 

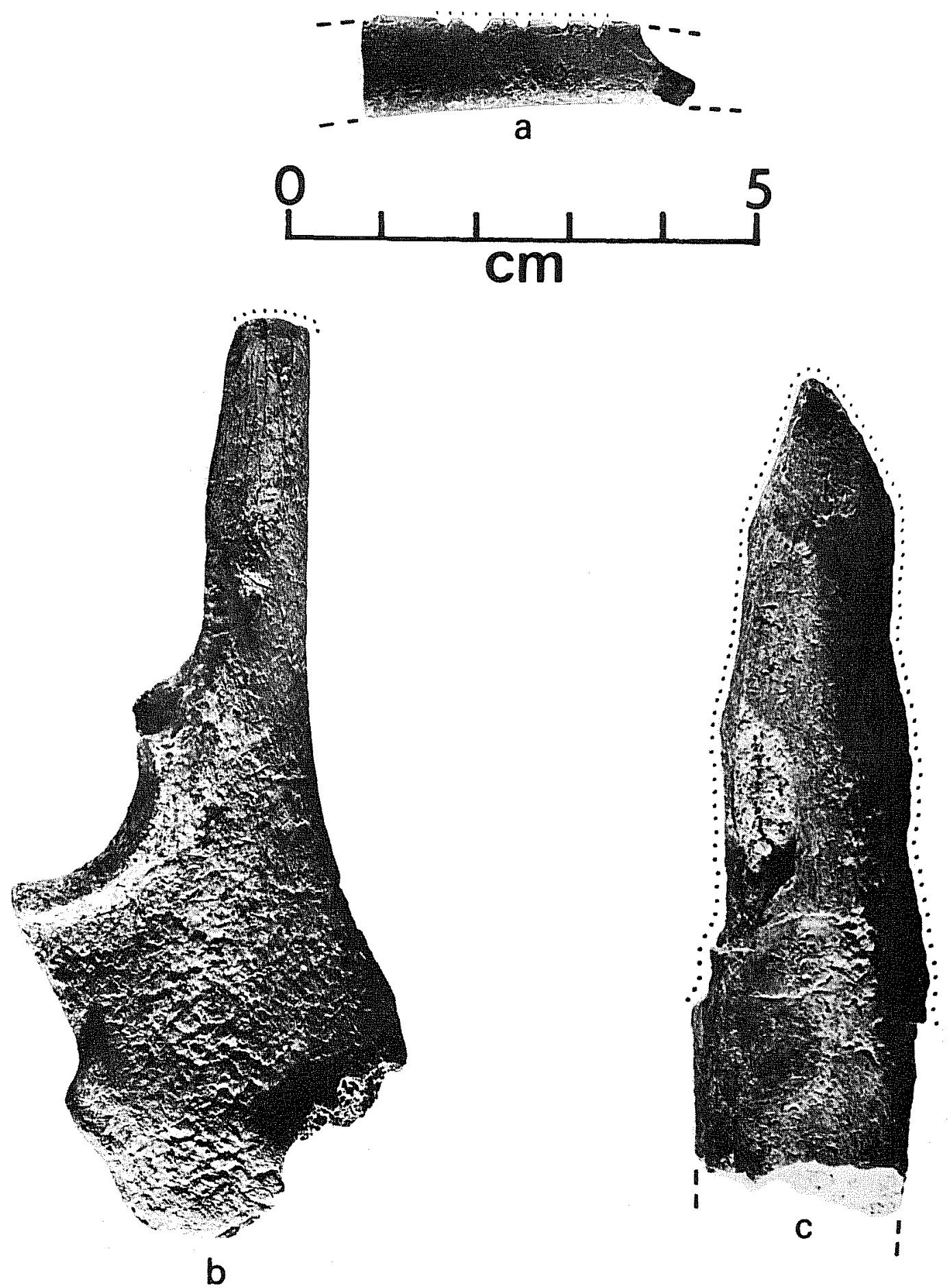

Figure 56. Bone Artifacts from 41 BX 36. a, burned and notched animal rib fragment; b, deer ulna flaking tool; $c$, probably worked and utilized fragment (dots indicate extent of modified edges). 
TABLE 30. BONE TOOLS AND MISCELLANEOUS BONE MODIFICATIONS NOTED AMONG FAUNAL REMAINS

Excavation

Unit

$1 \quad 0-10 \quad$ Bovid

Leve1 Element

Modification

Function

Utilized or worked

Unknown

bone fragment. Flake

scars on both sides

(Fig. 56, C).

$1 \quad$ 10-20 White-tailed deer

first phalanx

Possible hole drilled

through long axis at

proximal end

1

10-20 Bovid shaft

Burned on one end and

cut marks present

4

0-5 Unknown

Sma 11 fragment which

is very burned and

highly polished on

the outer surface

4

5

5

18

13

23
10-15 White-tailed deer right radius

$0-10$

White-tailed deer antler tip

10-20 White-tailed deer

left radius

0-10 White-tailed deer

left radius

20-30 White-tailed deer

left ulna

0-10 Unidentifiable

rib section
Non-natural sawtoothed
fracture line at proximal end

Burned and smoothed

Proximal end fractured

longitudinally

Very smooth and

straight but through

longitudinal axis at

distal end

Heavy use wear at shortened distal end (Fig. 56,b).

Burned and notched on one side (Fig, 56,a).
Possible marrow extraction

Unknown

Unknown

Unknown

Possible

flaker or awl

Possible marrow extraction or tool fragment

Possibly the result of tool manufacture or a tool fragment

Flaking tool

Unknown 
Support for this interpretation is the presence of different species of carrion eaters within the refuse area, the variety of small animals not considered here to have been the main or preferred meat source and of little value as secondary utilization (i.e., for tools, etc.), and the disposal of at least two individual bison in the same place in the same manner (one left astragulus recovered from Unit $5,13 \mathrm{~cm}$ deep). A definitive statement regarding the temporal aspect of the refuse area cannot be made due to the highly disturbed nature of the cultural deposits. (A factor contributing to the disturbances could have been the carrion eaters themselves scavenging among the waste.) Sampling error could, of course, account for this skewed distribution of skeletal parts. Unexcavated portions of the site might yield a somewhat different faunal assemblage, the analysis of which might serve to support or dismiss the above hypotheses.

Table 27 lists the identified elements exhibiting burning. Burning in general increases the preservation qualities of bone by dehydrating and chemically altering its composition. Therefore, it can be assumed that burning might have caused the differential preservation of the recovered faura. It was felt that the burned elements other than white-tailed deer occurred in frequencies too low to be conclusive. Regarding white-tailed deer, all the recovered antler fragments were burned; the post-cranial elements revealed no apparent pattern as to which parts of the body were burned or to the relationship of burned to unburned bone in general. The recovery of the antler tips may have been due to the fact that the burning enhanced their preservation since these elements, in their natural state, deteriorate rapidly once deposited in the ground.

Since the species are potential food sources, it can be assumed that the burning was primarily a result of cooking. However, especially in the instances of antlers and foot parts, other reasons for burning should be considered. It is possible that the burning was a result of general site maintenance (i.e., the burning of trash for hygienic reasons), tool manufacture (i.e., the preparation of the bone for modification into a tool), convenient disposal (i.e., the tossing of a bone back into a campfire rather than a remote trash area), and grass fires and other natural causes.

Seasonality of the Site

Seasonality of the site can only be indirectly inferred from the faunal remains. There were no migratory birds or winter hibernators identified. The antlered/ antlerless condition of adult male deer skulls can be used to indicate seasonality; however, the only antler fragments recovered were four tips and one medial section, so that their shed/intact condition could not be ascertained. A general statement regarding the availability of bison herds during certain periods of the year can be made. Haines (1970) and Levy (1961) state that, although bison did not migrate regularly with any pattern, they generally vacated the southern extremes of their range in the summertime because of the heat. Hornaday (1887) says that during a three-month period (July through September) there were large portions of the range where bison could not be 
located because of their propensity to aggregate toward the center of their range during mating season. From these data, it can be inferred that bison herds were probably absent during the summer months in Texas. Therefore, their presence at 41 BX 36 indicates an other-than-summer occupation.

This interpretation is supported by additional, though negative, observations involving the absence of riverine and aquatic species which might have been exploited had they been available in other seasons. Their absence suggests that the local water supply may have been seasonal, probably drying up during the hot summer months. Based on these data, it can be speculated, but not concluded, that the site was not occupied during the summer months.

\section{BX 377}

Table 31 is a list of the identified fauna from Site 41 BX 377. The sample is obvious ly too small to generate cultural inferences.

TABLE 31. FAUNAL INVENTORY FROM SITE 41 BX 377

\begin{tabular}{|c|c|c|}
\hline $\begin{array}{c}\text { Excavation } \\
\text { Unit }\end{array}$ & $\begin{array}{l}\text { Leve1 } \\
(\mathrm{cm})\end{array}$ & Species \\
\hline 3 & $10-15$ & White-tailed deer \\
\hline 3 & $15-20$ & White-tailed deer \\
\hline $\begin{array}{l}\text { Surface (from } \\
\text { road cut) }\end{array}$ & & Mule deer* \\
\hline
\end{tabular}

Element

Right mandible, 2 teeth

Left calcaneus (adult)

Right humerus (aduTt)

\section{$41 B X 428$}

Table 32 is a list of the identified fauna from Site 41 BX 428 . The sample is obviously too small to generate cultural inferences.

TABLE 32. FAUNAL INVENTORY FROM SITE 41 BX 428

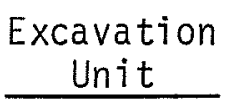

2

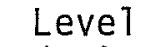

$(\mathrm{cm})$

$0-10$
Species

White-tailed deer
Element

Third phatanx (looks very recent) 
SUMMARY

Faunal data from 41 BX 36 were analyzed to determine the basic subsistence strategies operating within the prehistoric confines of the site. It was concluded that the major sources of meat protein were antelope, white-tailed deer and bison, with many smaller animals supplementing the diet. The fact that these three major species represent two distinct biotic zones indicates that the aboriginal hunters were exploiting at least two different environments: a mixed scrub forest zone and a grassland prairie zone. Al1 stages of maturity of the individual at the time of death were evident from the white-tailed deer remains. The small sample of bison remains showing age characteristics was from mature adults. The range of elements present suggested that the entire carcass was returned to the site for butchering, but actual butchering marks were observed on only a very few bones. There was a very high frequency of foot and skull parts relative to other parts of the body among the white-tailed deer and bison remains. Several hypotheses were given for this configuration, as well as for the occurrence of burned bone within the collection. Other cultural modifications to the bones were described. The season(s) of occupation at the site were speculated to be other than summer, based on the presence of bison and the absence of riverine and aquatic species.

The conclusions generated from the faunal data perhaps best serve as indicators of prehistoric man's adaptations to the local environment and his relationship with his food sources. It is hoped that these data will lead to a fuller understanding and a more comprehensive interpretation of the site. 


\title{
III. A.13
}

\section{RADIOCARBON DATING}

\author{
Thomas C. Kelly
}

Only three charcoal samples suitable for radiocarbon dating were recovered during excavations at Camp Bullis. In addition, a bone sample recovered from the same unit and level as one of the charcoal samples was radiocarbon dated for the purpose of comparison. The following dates were obtained from Radiocarbon Limited (RL designation), Lampasas, Texas, and from the Radiocarbon Laboratory $(T x)$, The University of Texas at Austin.

TABLE 33. RADIOCARBON DATES FROM CAMP BULLIS

\begin{tabular}{|c|c|c|c|c|}
\hline Laboratory No. & Sample Location & B.P. Date & AD/BC Date & MASCA Calibrati \\
\hline $\mathrm{RL}-816$ & $\begin{array}{l}41 \mathrm{BX} 36 \text {, Unit } 1 \\
(20-30 \mathrm{~cm})\end{array}$ & $900 \pm 100$ & A.D. 1050 & A.D. 1090 \\
\hline RL-817 & $\begin{array}{l}41 \mathrm{BX} 36 \text {, Unit } 5 \\
(10-20 \mathrm{~cm})\end{array}$ & $420 \pm 720$ & A.D. 1530 & A.D. 1440 \\
\hline$T x-2815$ & $\begin{array}{l}41 \text { BX } 36 \text {, Unit } 5 \\
(10-20 \mathrm{~cm}) \text { bone }\end{array}$ & $300 \pm 120$ & A.D. 1650 & A.D. $1610-1520$ \\
\hline$T x-2771$ & $\begin{array}{l}41 \mathrm{BX} 377 \text {, Unit } 3 \\
(10-15 \mathrm{~cm})\end{array}$ & $890 \pm 70$ & A.D. 1060 & A.D. 1100 \\
\hline
\end{tabular}

*Ralph et al. 1973

RL-816 was obtained from a level containing a Perdiz arrow point, with Edwards points found in the level immediately below. The author submitted the sample to obtain information on temporal interface between Edwards points and the Toyah phase. The Edwards arrow point type was associated with dates of A.D. 930, 960 and 1040 at the La Jita site in Uvalde County (Hester 1971:114-115).

RL-817 was closely associated with Perdiz arrow points and considerable bovid bone; this seems to be a valid date for the Perdiz variety as defined for the Toyah phase of the Late Prehistoric period.

Tx-2815, the burned bone sample, was from the same unit and level as charcoal sample RL-817. The two dates are reasonably close.

TX-2771 is from $41 \mathrm{BX} 377$, a colluvial terrace site on Cibolo Creek, and was closely associated with Edwards points. The date correlates closely with RL-816 and seems to be valid for the Edwards type (cf. Hester 1971). 
254

Comments

The strongly alkaline soils of Camp Bullies are often non-conducive to the preservation of charcoal samples adequate for radiocarbon dating. Numerous hearths which would seem to be obvious charcoal sources were excavated, yet only the above samples were suitable for dating. The disappearance of charcoal in open sites in this area appears to be a function of the time the material is exposed to leaching by the soil. Dates from other open sites in the central Texas area suggest that radiocarbon dates earlier than 1500 B.C. may be difficult to obtain. The oldest dates obtained from several area sites are La Vita, A.D. 100 (Hester 1971); 41 KE 49, A.D. 830 (Kelly and Hester 1976); the Crumley site, 1500 B.C. (Kelly 1961); Oblate Rockshelter (a shallow shelter with an open occupation area), 1600 B.C. (Johnson et al. 1962); Loeve-Fox, 40 B.C.; and John James Park, A.D. 750 (Katz 1977).

The radiocarbon dates obtained from Camp Bullies are valuable for their corroboratimon of the age of the Edwards and Perdiz arrow point types. 
PART III

THE CAMP BULLIS STUDY

SECTION B

HISTORICAL ARCHAEOLOGY

AT

CAMP BULLIS 

III. B. 1

INTRODUCTION

James E. Ivey

In addition to the extensive prehistoric cultural remains found in the Camp Bullis area, there are a number of sites dating from the period of the European occupation of this region. This section will describe and discuss the more notable of these sites (Fig. 57).

The sites mentioned here were found during the survey of Camp Bul1 is or were previously known from maps and specifically located as part of this study. In either case, a site description was filled out, a site number assigned and a set of photographs and a representative surface collection made. A measured sketch was then made of the more important structural remains. The artifacts collected were studied in the Center for Archaeological Research laboratory and their approximate dates of manufacture were estimated. Considering the collection from each site, a period of occupation was derived for that site. In some cases the nature of the artifacts permitted us to make some inferences about the sort of activities carried out at the site.

It must be recalled that only a very preliminary investigation has been made of these sites; the intent was to collect enough information to permit a reasonable estimation of the importance of each site as a cultural resource. A "representative" surface collection, one which collects a few examples of most of the varieties of artifacts found on-site, is not a controlled sampling, and the inferences about a site, based on such a collection, may be far from accurate. In most cases, however, such a "representative" collection has been found to give a fair approximation of the time period and major activities of a site, if only in the most general frame. Such a generalized first step should never be forced to say more than the quality of its evidence can permit.

The first tracts of 1 and which eventually became Camp Bullis were purchased by the government in December 1906, and consisted of two large ranches totalling over 16,000 acres. These were the Conrad Schasse tract of 4,877 acres and the Oppenheimer tract of 11,840 acres (Fig. 57).

Other, much smaller tracts were added in 1907 and 1917, and Camp Bullis achieved its present outline in a final series of purchases in 1941 . The majority of the historical sites found within the Camp Bullis reservation were in the tract added in this last series. A few, however, are located in the original tracts. 


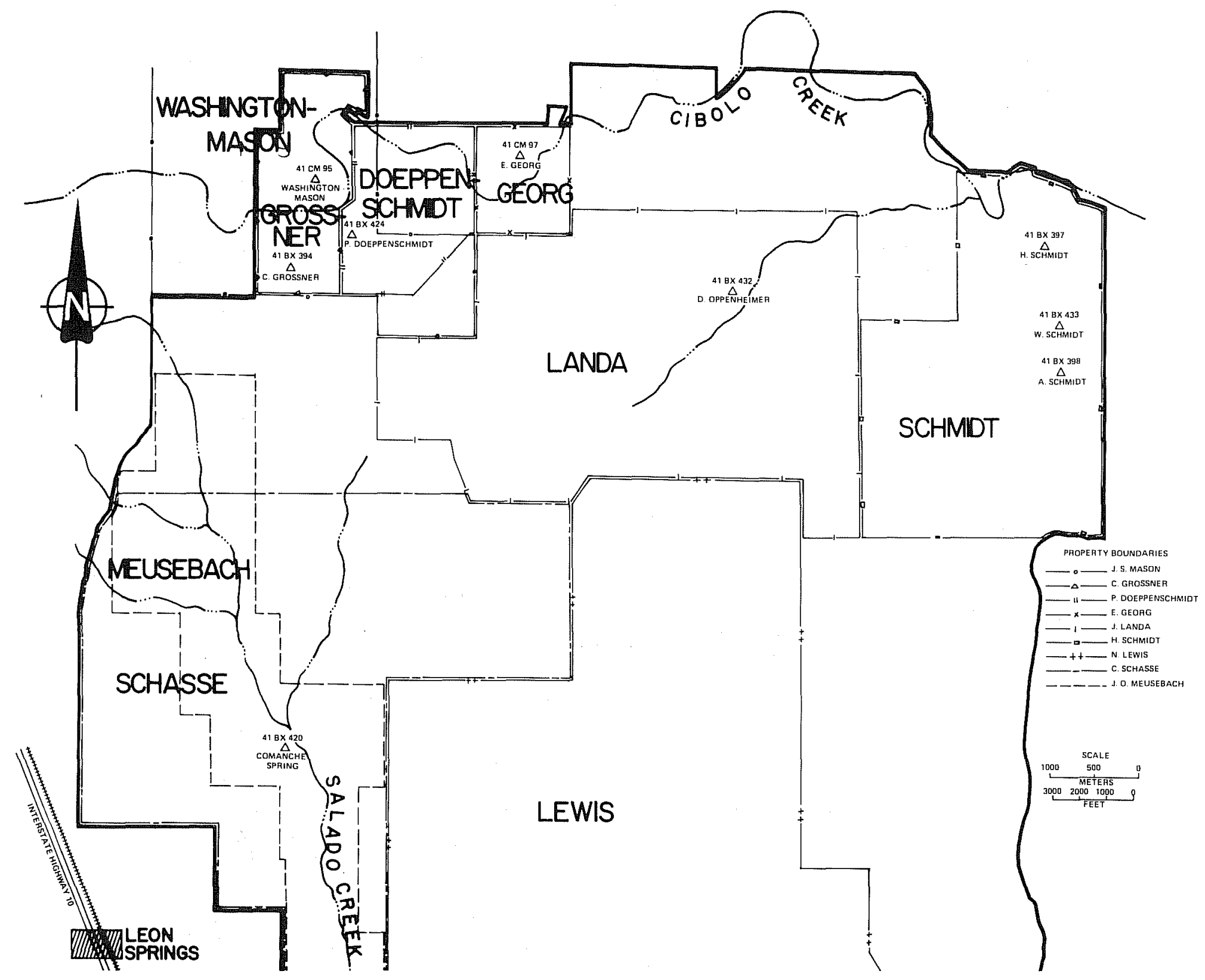

Figure 57. Map Showing Early Property Boundaries, Camp Bullis. The Landa and Lewis tracts were later combined to form the Oppenheimer property (see text). 


\author{
III. B.2 \\ SITE DESCRIPTIONS \\ James E. Ivey and Sara E. Kleine
}

In this section we will present a discussion of each site based on an assessment of the nature of the site, its artifacts and available historical records. In the following section we will consider the artifacts in more detail.

\title{
41 CM 95 (the "Washington-Mason house")
}

This site consists of the structural remains of a house about $10 \times 13 \mathrm{~m}$, with two apparent masonry chimney bases near the front (eastern) side of the structure (see Fig. 58). An area in the central part of the house appears to have been paved with flagstones. There is a flagstone walkway along the back edge of the house, extending in a northerly direction, which was probably associated with a back door or doors. The "front yard" of the house is a rectangular area along the eastern side of the remains, bordered by fieldstone placed edge-up in the ground. In some areas a further decorative edging of limestone chunks eroded into sponge-like masses is found along the inside face of the fieldstone edging. In the center of the eastern face of this rectangular area is a narrow avenue formed by a continuation of this edging.

Some alignment of brush along the south side of the structural traces indicates the presence of a fence line in the past, perhaps associated with the structure. To the south and slightly west is a large cistern, an estimated 3-4 $\mathrm{m}$ in diameter and 5-6 m deep, uncollapsed, and with perhaps $0.5 \mathrm{~m}$ of fill covering the interior floor. No indications of other structures have been found at the site.

The artifact collection implies an occupation period from about 1850 to earlier than 1940. In fact, a final date for occupation could predate 1900. The lack of any recognizable traces of other structures on the site implies that they were probably built of wood, if they were present.

The artifact collection is too limited to permit any activity descriptions other than that of general household operations. It should be noted, however, that the house is unique in several respects. Its artifacts are quite different from those of the other sites, this being the only place where glazed brick, Victorian majolica and blue flown ware are found. The cut square nail count is quite high, also; the total here is higher than the sum of all cut nails collected at other sites.

A component of the Comanche Spring site, $41 \mathrm{BX} 420$, is also dated by its artifacts to a mid-19th century origin, but its diagnostic 19th century earthenware is unlike the Washington house collection; it consists of blue shell-edged ware and banded slipware (mocha). The implication is that two quite different groups occupied the two sites in the 1850s--but whether the differences stem from the cultural backgrounds of the inhabitants, the purpose of the sites, or 


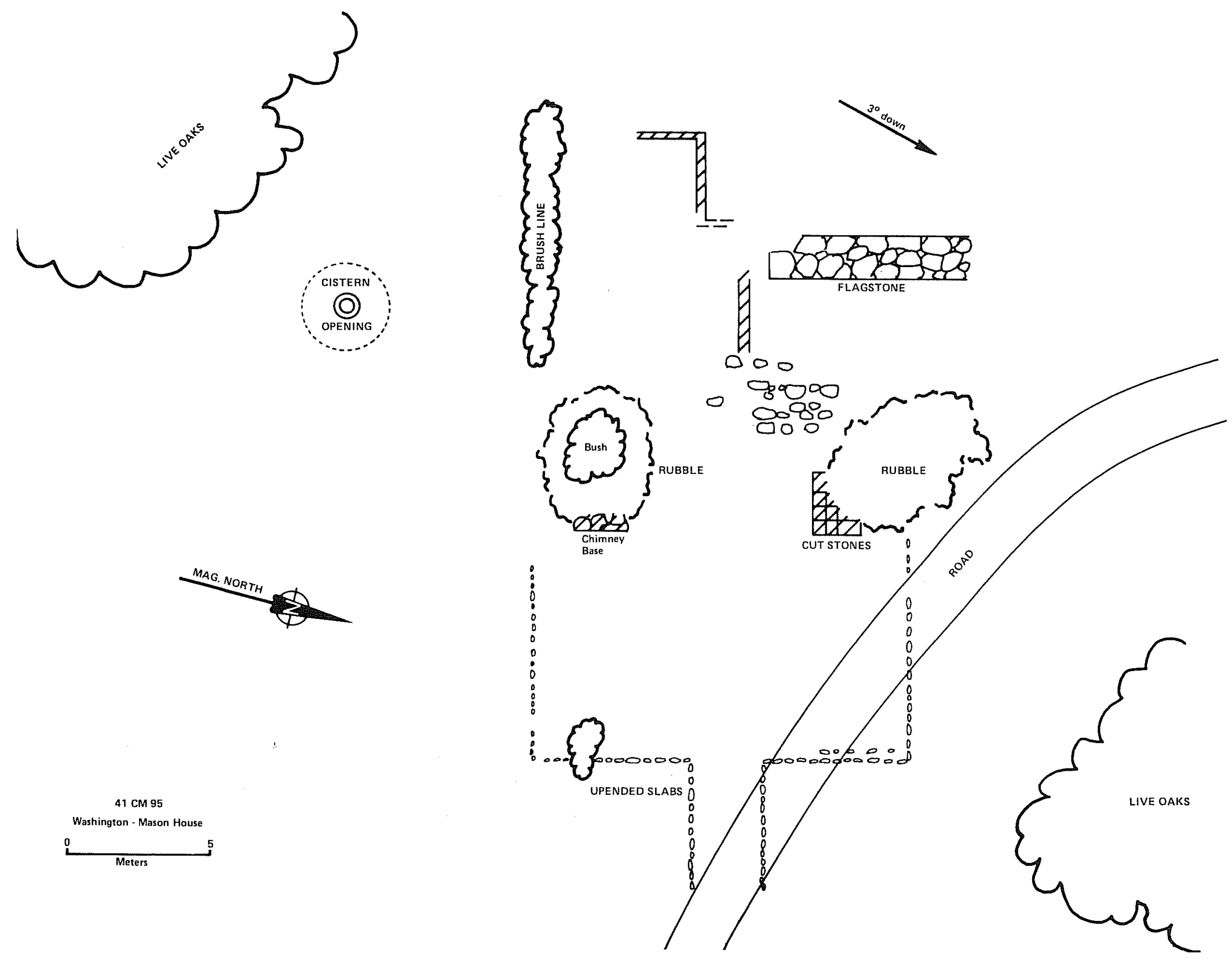

Figure 58. Site $41 \mathrm{CM} 95$, Washington-Mason House, Camp Bullis. 
even simply the financial status of the occupants, cannot be told from such limited information.

Bexar County Courthouse Deed Records show that this land was first granted to Enoch Jones in 1844 as part of survey \#172, the M. de la Luz Guerra League (BCCDR U2:132)。 Jones transferred it to his daughter, 01 ive Ann Washington, in 1860 (BCCDR S1:389). She and her husband, Lieutenant T. A. Washington, the acting Assistant Adjutant General of Texas (Chabot 1937:320), sold it to General John S. Mason in 1867 (BCCDR U2:132). Mason owned the iand for over 25 years before he began selling tracts of it in the 1890s. Mason lived here only briefly in the $1860 \mathrm{~s}$ while he was stationed in the area; the rest of the time he leased the land to J.W.Eckles (BCCDR 138:774), who probably was the occupant of the Washington-Mason house.

\section{CM 97 (the "E. Georg house")}

The major structure is a building foundation of $5 \times 7 \mathrm{~m}$, of roughly squared limestone blocks of irregular size (see Fig。59). The structure was apparently divided into two rooms, with a connecting doorway and another opening eastward out of the southernmost room. The size of the structure implies that it was not a dwelling, but rather a small outbuilding similar to those seen at 41 BX 397, 41 BX 398 and 41 BX 433 (Figs。60,61,62)。

To the south of this stone structure, traces of yard edging are visible, connecting this area with the large rectangular "garden" area to the east. South of this and down-slope from the structure there is one line of rough fieldstone wall which was apparently a retaining wall. To the east of the garden area are found the base-posts of what appears to have been a sorghum or sugar cane press, and immediately east of it is a rectangular outdoor oven, $1.35 \times 3.5 \mathrm{~m}$ with the remains of a chimney structure at the eastern end, which is quite similar to molasses cookers still in use in various parts of Texas (Clark 1976:251)。

A number of fragments of structures are visible immediately north of the major stone structure and scattered over a large area to the west. Many of these consist of alignments of individual stones set in the earth, or alignments of posts with sawed or ax-cut notches. These probably represent the remains of farm and ranch utility structures, animal and poultry coops and stalls, etc. Some, however, are undoubtedly traces of a larger house structure. The 1947 map of Leon Springs Military Reservation shows the presence of four structures at this site (U.S.A. 1947)。

The major characteristic of this site is the several large mounds of metal, wood and cut stone, each about $5 \mathrm{~m}$ across and perhaps $7-1.5 \mathrm{~m}$ high. These appear to be mounds of rubble piled by a bulldozer, and probably are the remains of a house and perhaps several other structures.

This site was probably a large ranching and farming complex, consisting of a house or houses and the necessary utility structures needed to maintain such an operation. From the extent of the structural traces, it is reasonable to assume that this was the central habitation and farm/ranch headquarters of a fairly large property. 

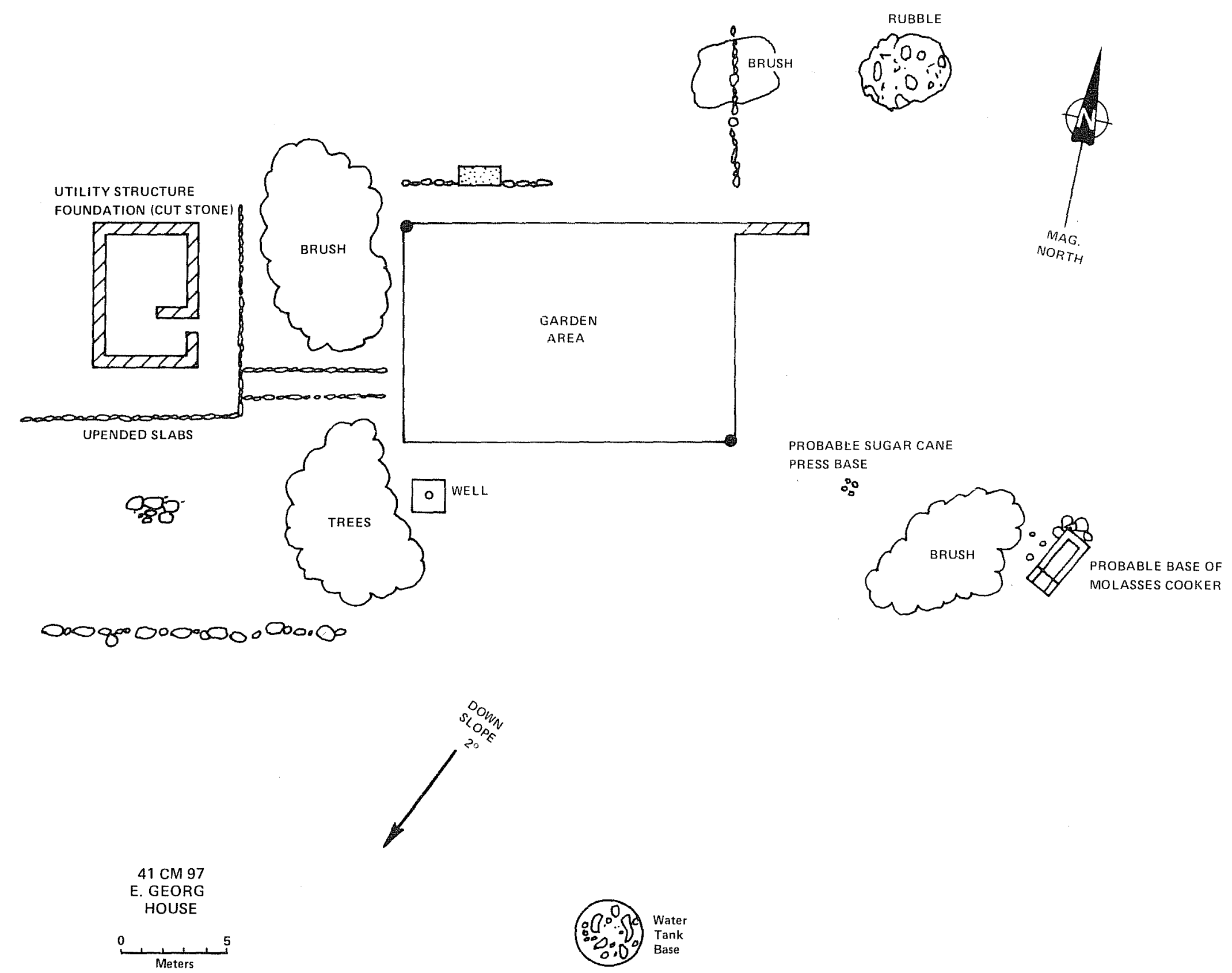

Figure 59. Site $41 \mathrm{CM} 97$, E. Georg House, Camp Bullis. 


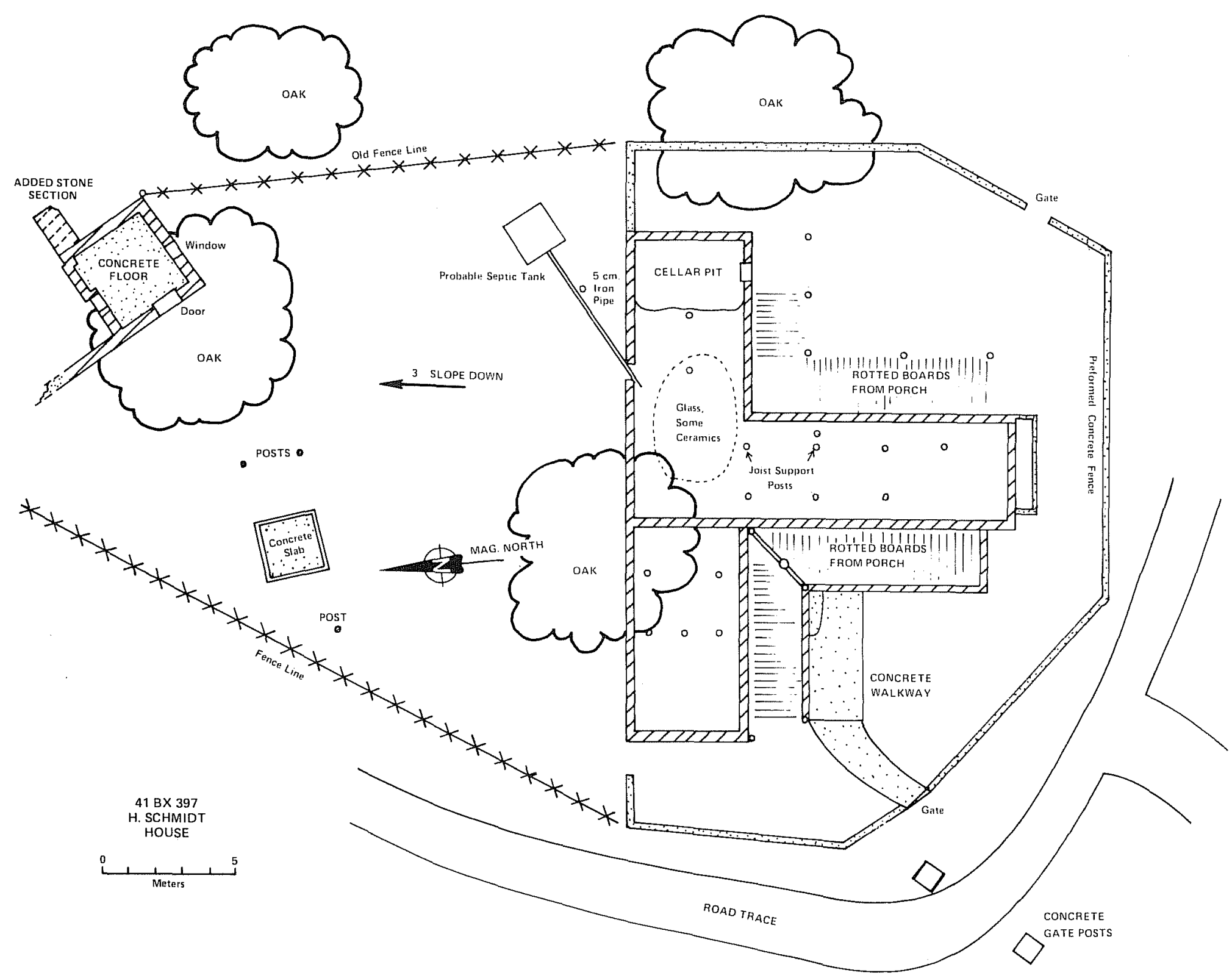

Figure 60. Site 41 BX 397, H. Schmidt House, Camp Bullis. 


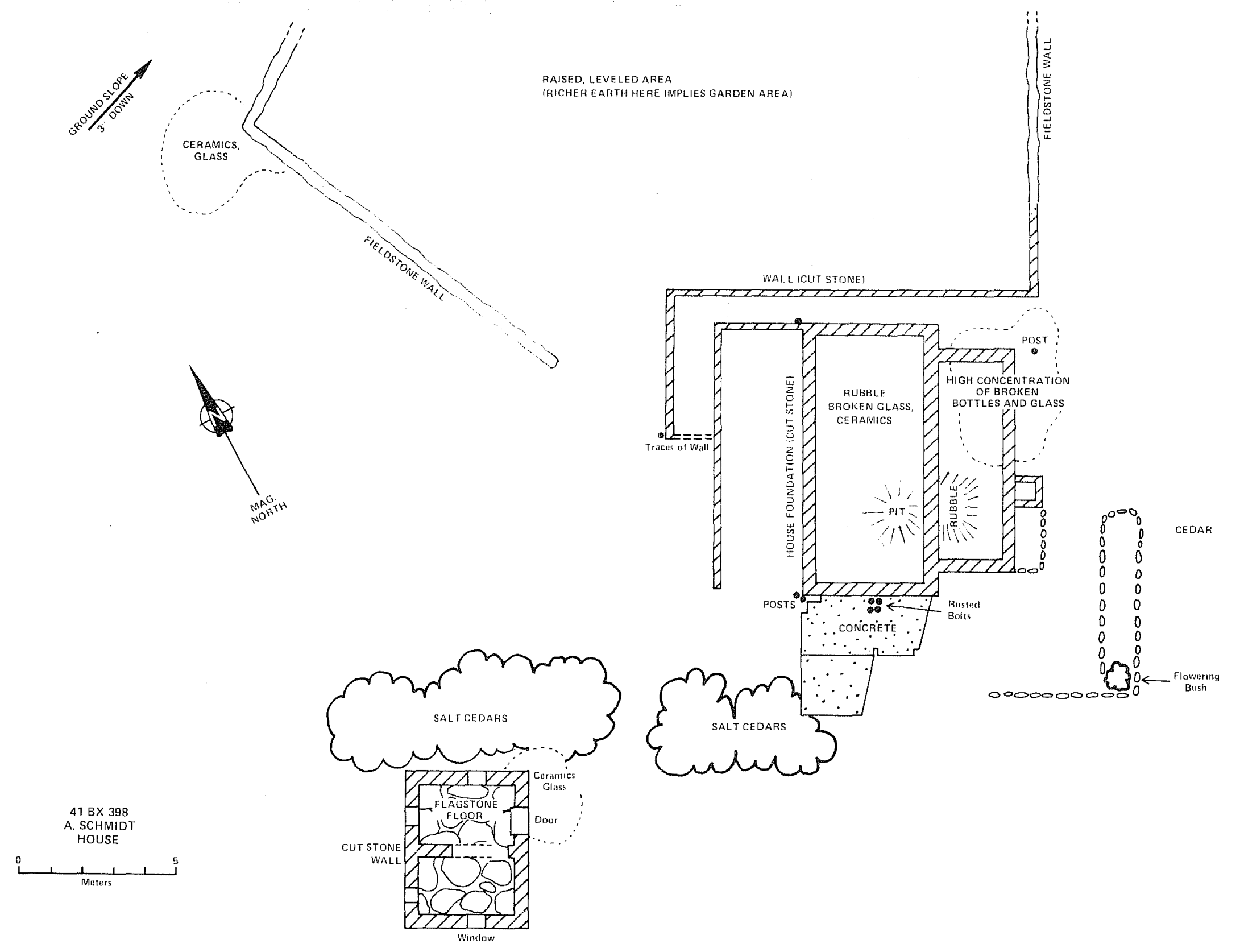

Figure 61. Site 41 BX 398, A. Schmidt House, Camp Bullis. 

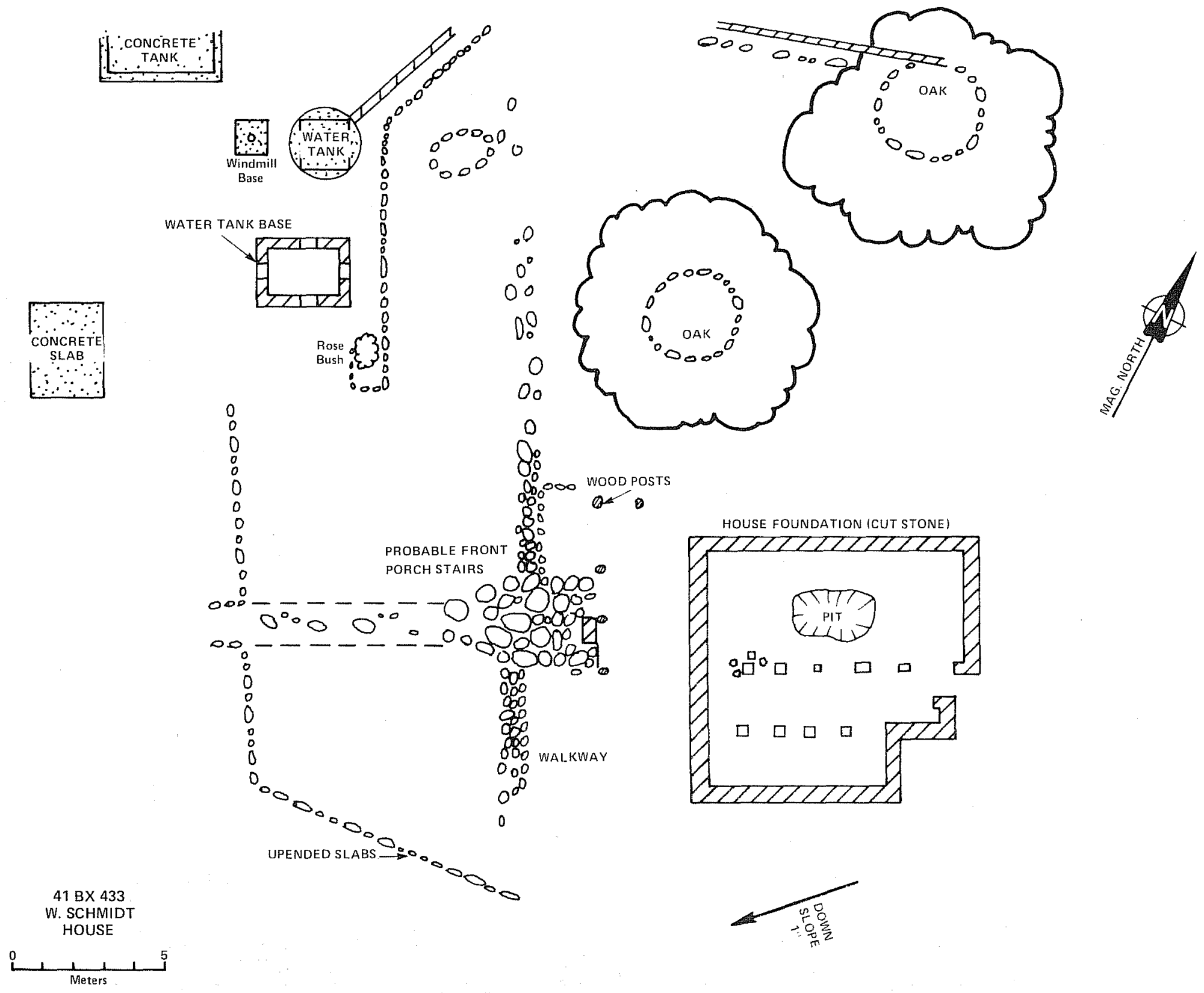

Figure 62. Site $41 B \times 433$, w. Schmidt House, Camp Bullis. 
Artifacts collected on the site indicate an occupation period of about 1880 to 1940. The characteristic 1ate 19th-early 20th century strong predominance of plain white earthenwares is alone enough to indicate such a dating, and the lack of machine-cut square nails supports this. Little trace of the subs istence activities of the inhabitants is seen in the artifact collection; beyond the household activities indicated by the plates, bowls and crockery, and several varieties of wine and medicine bottles, few other artifacts are found. No tools or major metal fragments were collected. It is likely that these are still on the site, entangled in the mounds of bulldozed debris.

Documentary sources dealing with this complex indicate that this was the headquarters of an extensive ranch, the majority of which was outside the limits of Camp Bullis (BCCDR 1847:352, U.S.A. 1947). This site was purchased by Herman Georg in 1905, and the structures were probably built after that date and prior to 1940 (BCCDR 238:590). A long series of exchanges of this property, beginning with the original land grant in 1845 (BCCDR F2:431), makes it quite possible that the structures were built prior to 1905, and the artifacts could support a speculative date of construction as early as ca. 1880.

In general, the site more strongly resembles the later Schmidt houses (see below) than the earlier 19th century sites (41 CM 95 and 41 BX 420).

\section{BX 394 (the "C. Grossner house")}

This site, like the E. Georg house site, has been severely disturbed by bu11dozers, to the point that no major structural remains are left. For this reason, it was considered unnecessary to map the site.

A number of small utility building remains are still visible on the site, consisting of the base of a small shed or animal house, two round stock tanks of cut stone and two rectangular, smaller stock tanks of fieldstone. In addition, many fence lines are still visible in the utility building area, and one rather enigmatic trough-like structure of fieldstone, $2 \times 5 \mathrm{~m}$, which is similar to a concrete livestock-dipping trough still extant on the H. Schmidt site (41 BX 397).

At least three major mounds of cut stone and debris are visible on the site. In association with two of them are fragments of foundation lines of roughcut stone still apparently in place, but insufficient to make any attempt at a plan reconstruction. It is suspected, however, that the plan consisted of a large house on the northeast corner of the site, with a small stone structure directly south. This is the same sort of general pattern followed at the E. Georg (41 CM 97) and Schmidt houses (41 BX 397, 41 BX 398 and 41 BX 433).

Artifacts collected again indicate a period of occupation between 1880 and 1940. Glass and ceramics are typical of the late 19th-early 20 th centuries, and several fragments of license plates with unreadable dates were seen onsite but not collected. Their general characteristics imply a date in the 1920 s and 1930s. 
In the discussion of $41 \mathrm{CM} 95$ (see above), we have outlined the sequence of ownership of the M. de la Luz Guerra League from Enoch Jones to General J.S. Mason. This site is one kilometer south of the Washington-Mason house, on the south side of cibolo Creek, and in the same league of land.

Soon after Mason began the breaking up of his property, Peter Doeppenschmidt began to buy portions of it, including some tracts outside the Guerra League. By 1896 Doeppenschmidt had bought almost all of the original Mason land (BCCDR 126:280, 138:774, 187:7) and owned it until 1911. In that year he sold most or all of the tract to $C$. Grossner (BCCDR 356:327), who eventually sold a portion of it to A. Grossner in 1935 (BCCDR 1511:78). Since J. S. Mason's house is reasonably identified as having been $41 \mathrm{CM} 95$, it is likely that 41 BX 394 is, then, a house built by either Peter Doeppenschmidt or one of the Grossners.

\section{BX 397 (the "H. Schmidt house")}

The major structure on this site is a large and elaborate house foundation $19 \times 15 \mathrm{~m}$ (Fig. 60). The house was T-shaped with two large porches on the east and west sides of the shaft of the $T$, which pointed generally south. The "front" (southern) yard was bounded by a fence of pre-formed reinforced concrete, $1.5 \mathrm{~m} \mathrm{high}$, covered by decorative wire fencing. Several flowerbed areas are still discernible in this front yard. Most of the floor joistsupporting posts for the house and porch are still in place. Within the foundations of the eastern area of the $T$ is a deep square pit, apparently the remains of a cellar. Slumping of the soil and vegetation prevent a detailed examination of this area. North of the house is a large square pit, either a well or the remains of a septic tank. A well and windmi11s are about $100 \mathrm{~m}$ west of the house, but it is not known whether these formed the primary water source for the site.

Several fragments of the superstructure of the house which stood on the extant foundations are still scattered around the area of the site. These consist of eave-structures (probably from the roofing of the porch), a large fragment of decorative shingling, where the exposed end of each shingle was cut to a point so that the overlapping shingles formed a repeating diamond pattern, and one of the turned wooden posts of the porch. A considerable number of the porch flooring boards also remain, many of them still more or less in place, but badly decayed and slumped.

Twenty meters to the north of the house foundation is a we11-preserved cut stone structure, $4 \times 4 \mathrm{~m}$. The wall s still stand to a height of $2 \mathrm{~m}$, with window and door openings. In the wall of the northwest corner of this building is a construction which would have been considered a small chimney, except for the fact that there is no flue, nor any room for one to have been built. The remains of two mill-cut $2 \times 6$-inch beams of pine found in this building, with wire loops attached at intervals along each beam by large metal staples, imply that the structure was used for at least part of its life as a meat-smoking house. No other structural hints of its purpose have been found. 
To the west of the house complex are the foundations of a large number of other structures, most of them sheds, utility buildings, pens, coops, animal houses and stock tanks. Several of these are quite recent, made of reinforced concrete. Immediately southwest of the house and yard is a large, reinforced concrete garage, wide enough for two or perhaps even three cars. On the westernmost edge of the site is a livestock-dipping trough.

The site in general is very recent. Few artifacts were collected but they are consistent with a construction date of post-1900. The site is quite similar to the A. Schmidt (41 BX 398) and W. Schmidt (41 BX 433) houses and seems to be similar to the E. Georg (41 CM 97) and C. Grossner (41 BX 394) sites.

The small stone structure to the north of the main house is similar to the foundation remains of the E. Georg site (41 CM 97) and also to the standing structure of the W. Schmidt site (41 BX 398). Whether it served the same (unknown) purpose cannot be determined.

H. Schmidt seems to have been quite taken by the then-novel construction technique of reinforced concrete and built at least four major constructions of this material. Most of this construction probably took place ca. 1928, based on the date cut into the cement of the yard fencing while it was still wet. The house and outbuildings form a large farming/ranching complex, probably the central complex of a rather large ranch property.

The northwest corner of Camp Bull is was purchased by Henry C. Schmidt from Christoph Pfeuffer of the George Pfeuffer \& Brother Land Company in 1905 and 1906 (BCCDR 239:232, 245:287). Pfeuffer had bought this area from his own company and had called it the Pfeuffer Ranch (BCCDR 32:592). H. C. Schmidt subdivided the tract, selling the southernmost portion to Albert Stahl in 1906 (BCCDR 245:202) and the northernmost, along the southern bank of Cibolo Creek (not including $41 \mathrm{BX} 398$ ), to Herman J. Schmidt in 1917 (BCCDR 853:613). Other divisions were made later, and portions sold to A. Schmidt and W. Schmidt. The deeds recording these actions are not yet located, and the relationship between these Schmidts is not known, although it is reasonable to assume that A. and W. Schmidt are probably sons of Henry C. Schmidt. It is fairly clear, however, that the three Schmidt houses were all built after 1906 and before 1940, and a date around 1910-1920 would accord well with the artifacts collected at these sites.

\section{BX 398 (the "A. Schmidt house")}

The primary structure on this site is a foundation of roughly squared limestone blocks, forming the plan of a house $9 \times 10 \mathrm{~m}$ (Fig. 61). A later concrete porch base was added on the western face, or front, of the house. Yard edging and flowerbeds are still discernible along the southwestern corner, and an area on the northeast, bounded by fieldstone retaining walls and the last traces of a fence line, was apparently a large garden. A smaller stone structure of wellshaped cut stone $4 \times 5 \mathrm{~m}$ is found near the northwest corner of the house, with a possible windmill base and well against its exterior north wal1. 
The house is separated along its eastern end from the "garden" area by a narrow passage, about $1.0 \mathrm{~m}$ wide, which is up to $0.5 \mathrm{~m}$ in depth. The purpose of this narrow passage is unknown, although it may have simply been a means of walking around the house without having to open the garden gates.

In the center of the central room of the house is an oval pit about $0.5 \mathrm{~m}$ deep, containing several large chunks of iron pipe about five inches in diameter. To the south of this pit, across the foundation wall in the next room, is a mound of earth and stones which appears to be the excavated fill from the pit. This could be a large pothole or a "foxhole" dug by the U.S. Army during one of its training exercises.

The smaller structure, whose walls stand to $2.5 \mathrm{~m}$ in most places, has been partially rebuilt by the Army, using dry wall construction and rough stones. The original fabric of the structure is mortared with a now-crumbling sandy lime mortar. The Army has constructed a new wooden roof over this building and apparently uses it and the surrounding area as a tactical position in its maneuvers.

To the west and south of these two primary structures are the remains of a number of other buildings, stone based or wooden, of the utility, shed and coop variety. Several fence lines are traceable, showing the major divisions of the area into small pasturage and pens for animals. Several cut stone stock tanks of rectangular shape are directly west of the smaller stone building.

This site is quite similar to the H. Schmidt site (41 BX 397), without the reinforced concrete additions, and the $W$. Schmidt site (41 BX 433). Artifacts indicate an occupation period of 1900-1930. There is a rather large quantity of bottle-glass in a single concentration on the southern side of the house, perhaps derived from the nearby excavated pit in the center of the house foundation. A second, smaller concentration of the artifacts is found around the door of the smaller stone building, perhaps deposited there as a result of the Army's reconstruction and cleaning-out of the structure.

\section{BX 420 (the "Comanche Spring site")}

The primary site is a large structure $14 \times 13 \mathrm{~m}$, built on two levels up the side of "Schasse Hill." Two flights of stairs, one each at the north and south ends of the site, connect the lower level with the upper. The south flight leads to a third, smaller set of stairs rising to the north which apparently gave access to a wooden structure along the southern edges of the upper level. North of this presumed structure was a further flat area of natural stone, off of which opened a narrow passage on the western edge of the building, between the walls of the upper level and the face of the bluff. The remainder of the upper level consisted of at least two and possibly three rooms or spaces (Fig. 63).

The lower level consists of two recognizable rooms. The southernmost again opened onto a passage along the western edge of the northern rooms. 


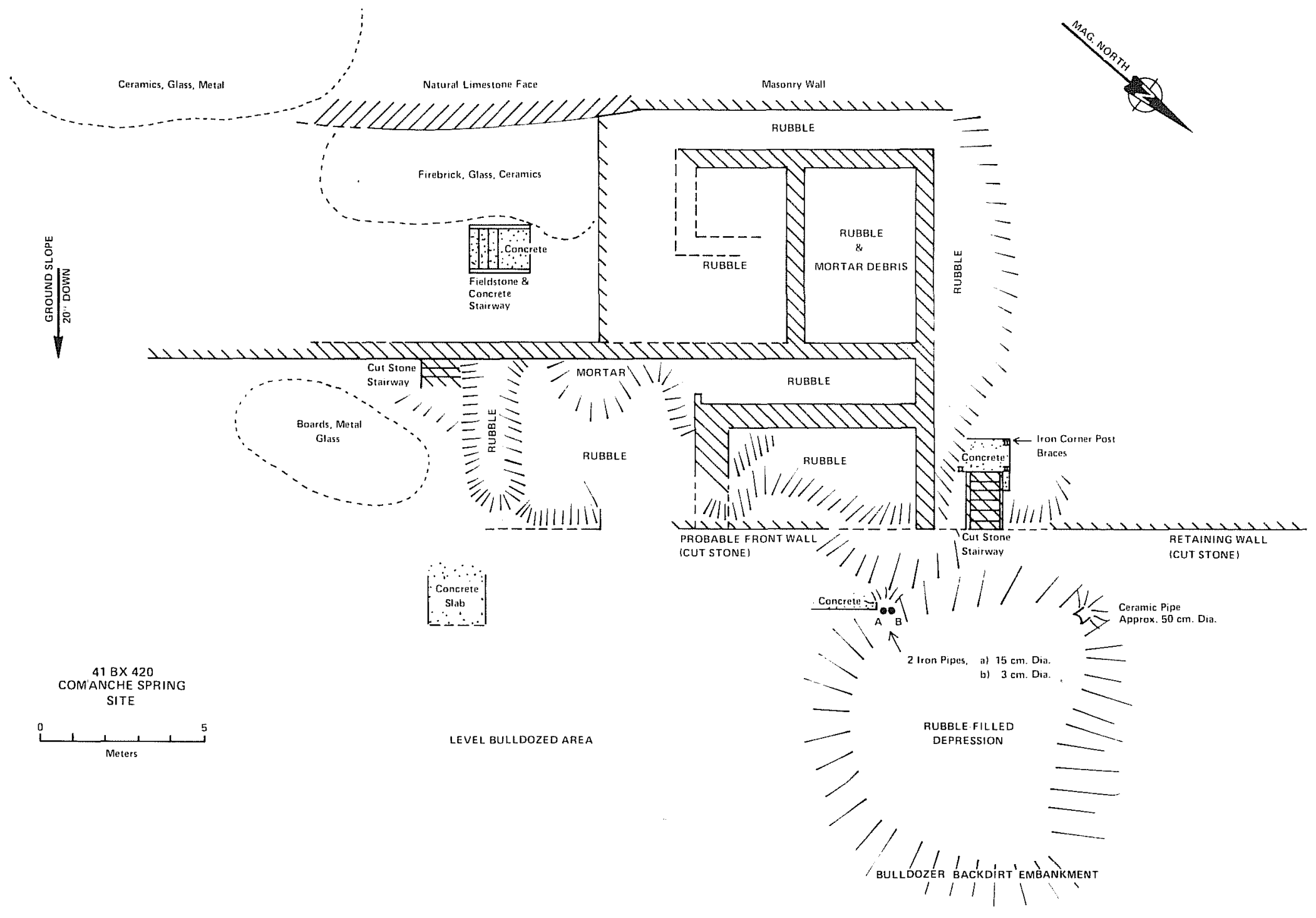

Figure 63. Site 41 BX 420, Comanche Spring, Camp Bullis. 
The northern stairway ends on a concrete platform which has several iron fixtures set into its surface (Fig. 64). These are at each visible corner and appear to be anchor points for square wooden posts, which probably supported a wooden platform somewhat like the one surmised for the south side of the upper level.

A large area of concrete pavement is at the southeastern corner of the structure. A section of concrete retaining wall is visible at the very foot of the structure, largely covered by fallen debris; but two iron pipes, one six inches in diameter, are still protruding horizontally from its face. Two meters away to the north, a collapsed pit has uncovered a section of ceramic pipe which must be about 24 inches in diameter, if not larger, extending under the rubble in a northwesterly direction. These pipes are probably associated with the up-welling point of Comanche Spring.

Most of the structure was apparently of rough-cut stone, cemented with sandy lime-mortar, and most of the upper sections of wall have fallen into neighboring rooms or down to lower levels. Great quantities of rotted mortar and a considerable number of wall fragments are found intermixed with the fallen walls. These rockfalls effectively prevent any detailed examination of the structure, but have probably preserved many structural features and details within the rooms, and would be relatively easy to clean out.

On the level ground at the foot of the hill, east of the primary structure, can be seen the traces of what was probably a house. Only one corner and perhaps four meters of wall line are visible in the earth. Several alignments of trees in the immediate area reveal old fence lines, but the majority of the region has been extensively bulldozed for the construction of an Air Force training area. It is likely, however, that a fair portion of the structure is stili intact in the earth, al though artifacts and stratigraphy probably were disturbed by the scraping of the surface. Historical records indicate that this house had been torn down long before the Air Force construction was begun.

Along the hillside are several lines of retaining walls associated either with the house on the level ground, the primary structure above, or both. Several fence lines still survive on the hillside and the surrounding lowlands.

Artifacts found scattered around the primary structure and other nearby areas quite firmly place the inception date of the site in the mid-19th century. Banded slipware and shell-edged ware fragments, both usually implying a date earlier than 1850, leave little room for doubt. The majority of the artifacts, however, date from the last half of the 19th century.

At least five large fire bricks were found in the debris of the second level of the primary structure, and several others at other locations in the area. These are of a variety which must have been associated with high temperatures and a large furnace: they are about $30 \times 20 \times 8 \mathrm{~cm}$ and flanged so that they form an interlocking surface when set together. Each brick has a heavy coating of high-temperature slag on one surface. The chemical make-up of the slag is unknown, but could probably tell us what material was being produced by the furnace which was once lined by these bricks. 


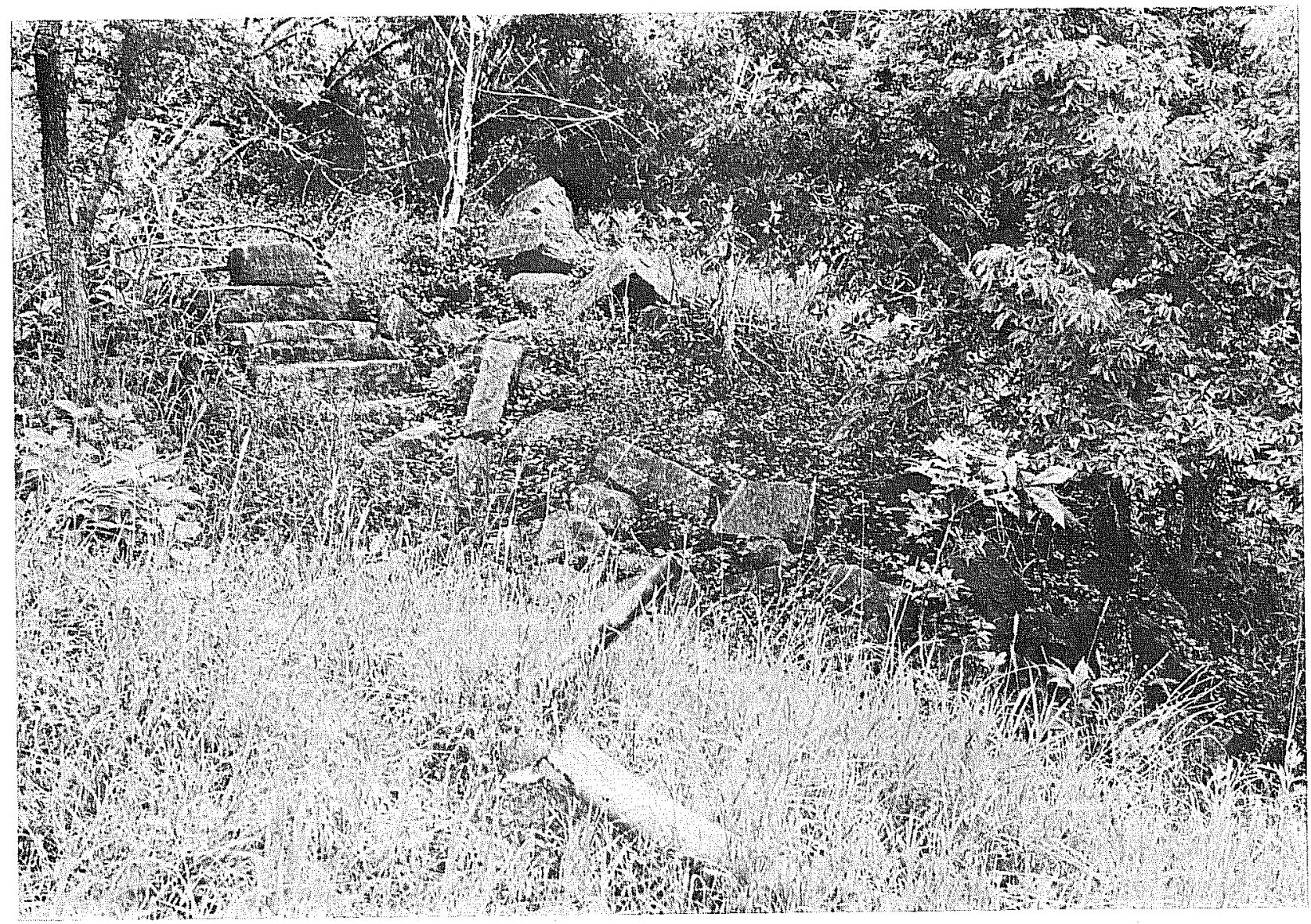

Figure 64. Comanche Spring (41 BX 420), Camp Bullis. Schasse house foundations, looking southwest at staircase at the northern end of the house remains. 
Historical records show that this area was once part of a very extensive tract of land owned by Nathaniel Lewis, a cattle rancher and businessman of San Antonio who had come to Texas in about 1832 (Chabot 1937:328). Lewis sold this land to John 0. Meusebach in November 1847. According to the deed, the Tand consisted of nine grants total1ing 2,577 acres and included most of the upper Salado Creek Valley ". . . in the immediate vicinity of a certain spring commonty known as the comanche Spring. .." (BCCDR F2:382). The onty spring indicated on Salado Creek within the Meusebach land is in the Nathaniel Lewis survey (General Land Office Patent No. 419, Vol. 1, August 28, 1844; GLO map of Bexar County, 1932), immediately north of the Comanche Spring site and across the creek, al though historical records indicate that this spring, or a second one, was located at the house sites.

The presence of the spring and the early artifacts dating prior to 1850 strongly indicate that the house traces on the level ground east of the primary structure are the remains of John Meusebach's house at Comanche Spring. He lived at "Comanche Spring Ranch" after resigning his position as Commissioner-General of the Society for the Protection of German Immigrants in Texas. He moved to the Fredericksburg area when the Civi1 War began (King 1967:139, 157). Identification of this structure as the Meusebach house, if confirmed, will have great significance for those of German descent in central Texas.

Meusebach sold Comanche Spring to Henry Habermann (BCCDR L]:490). The deed is dated 0ctober 20, 1853, but is probably a mortgage since Meusebach continued to live on the ranch until ca. 1862 (King 1967:139, 157). Habermann and his wife Tived on the farm until his death on June 29, 1871 (BC Probate Minutes, \#947). His wife eventually sold the land to Conrad Schasse, a family friend, in 1881 (BCCDR 22:114). Schasse, a druggist in San Antonio, Tived in town but operated the old Comanche Spring Ranch as a cattle ranch (Johnson and Chapman $1891: 277)$. In 1906 he sold most of his land along Salado Creek to the U.S. government (BCCDR 258:152).

The 1947 map of Leon Springs Military Reservation (U.S.A. 1947) shows clearly that the Schasse ranch house was located where the primary foundation of the Comanche Spring site now stands. O1d fence lines on the 1947 map are still traceable and permit a firm identification of this house site. The structure was probabiy built ca. 1887 and fell to ruin or was dismantled by the Army after 1906. The old Meusebach house was probably dismantled by Schasse after 1880 .

\section{BX 432 (the "Oppenheimer house")}

The Oppenheimer house site consists of a square cut limestone foundation, $16 \times 10 \mathrm{~m}$, with two apparent chimney bases, centered in the northeast and southwest halves of the house (see Fig. 65). A walkway of large, trimmed stones was built along the northeast exterior wali of the house, with two apparent doorways opening onto it. A large sunken pit was found near the northernmost corner of the structure, filled with debris. This could be a filled well or a collapsed cistern. An area of the house centered on the northwest side was floored in concrete, with iron pipe fixtures set into the pavement. The southwestern chimney base is about one meter higher than the rest of the site, and both chimney bases show clear signs of heat damage on their upper surfaces. 


$$
\begin{aligned}
& 211 \% \\
& =0 \div 3
\end{aligned}
$$

COLLAPSED WELL OR CISTERN

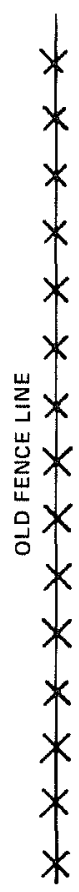

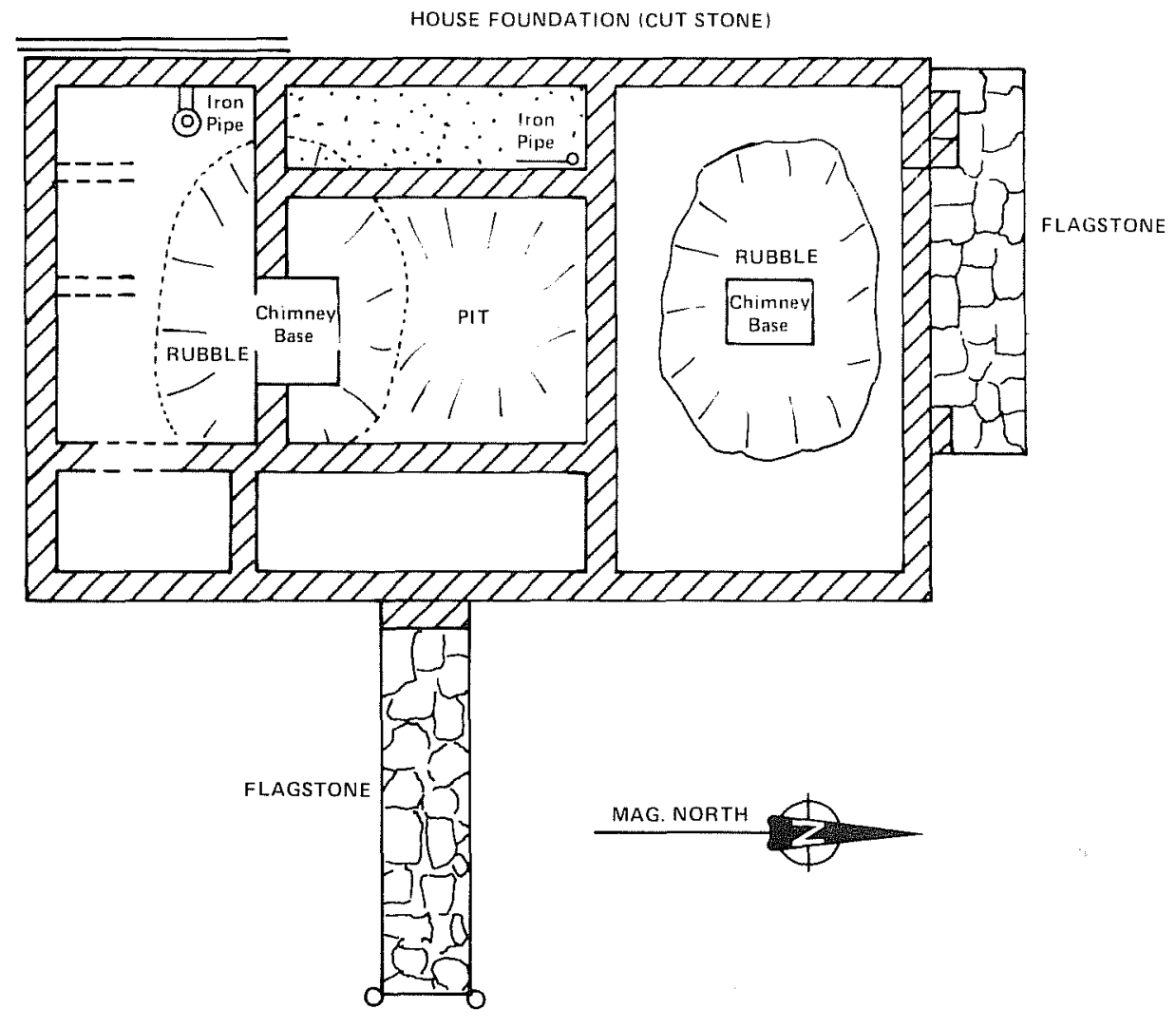

$41 \mathrm{BX} 432$

OPPENHEIMER HOUSE

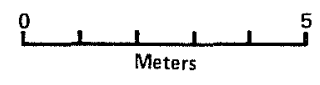

Figure 65. Site 41 BX 432, Oppenheimer House, Camp Bullis.
DOWN SLOPE 
A large pit has been dug into the debris of the central room. Debris, possibly from the fall of the two chimneys, covers the central area of the house outside the pit, which was apparently dug through the fall. A front door step is visible on the southeastern face of the house foundations, and a trimmed fieldstone walk extends to the southeast towards Oppenheimer Road for a distance of nine meters, ending at two flanking fence posts (see Fig. 66,a).

Some traces of outbuildings are visible to the west and north of the house foundations, and several large shed and barn foundations of cut stone have been located $200 \mathrm{~m}$ to the northeast, north of the intersection of Oppenheimer Road and Malabang Traill.

Artifacts indicate an occupation between 1880 and 1940 . The general appearance of the house and associated structural traces implies that the building served as the primary habitation and utility buildings of a large farming and ranching complex. This is proven to be the case by the deed records. As previously mentioned on page 259, the Oppenheimer ranch was the largest single tract acquired by the Army while purchasing land to form Camp Bullis.

As was mentioned in the discussion of the Schasse site, $41 \mathrm{BX} 420$, Nathaniel Lewis had owned most of the Bullis area in the 1840s. After his sale of the Salado Creek land to Meusebach in 1847, he continued to use the remainder of the land for a cattle ranch. Soon after his death in 1872, his property went to his wife and two sons (BCCDR 27:423). The land was finally sold to G. A. Hoerle of New Jersey and Henry Fink of San Antonio in 1883.

Hoerle also bought several thousand acres north of the Lewis property in 1882 (BCCDR 23:405-408) from William D. Parrish. Parrish had purchased the property from the original owner, Joseph Landa (after whom Landa Park in New Braunfels is named), in 1866.

These two tracts, the Lewis Ranch and the Landa Ranch, were both sold by Hoerle and Fink to Daniel and Anton Oppenheimer in 1896. The Oppenheimers used the land as a cattle ranch until 1906, when they sold it to the U.S. government.

The Oppenheimer house is located on the old Landa Ranch and may have been built as early as the 1850s. The artifacts found, however, indicate that the house was built around 1880-1890.

\section{BX 433 (the "W. Schmidt house")}

This site (Fig. 62) is very similar to the A. Schmidt house, 41 BX 398 (Fig. 61). It consists of a foundation of trimmed limestone $9 \times 9 \mathrm{~m}$, with two parallel lines of isolated blocks extending along a north-south line through $i$ ts center, apparently to serve as floor-joist supports. The site has a freestanding stone stairway of two steps on its south face, built of fieldstone and cut limestone blocks, which once provided access to a wooden porch along a portion of the south front of the house. A walkway of fieldstone extended southward $9 \mathrm{~m}$ from the stairs to a gate at the entrance to the front yard. The yard is edged in fieldstone except along its western limits, which are formed by a line of square-cut blocks of limestone, accompanied by a fence. The yard had been well-maintained at one time: several of the large oaks have 
Figure 66. Historic Sites 41 BX 432 and 41 BX 434, Camp Bullis. a, 0ppenheimer house (41 BX 432), looking northwest at area of front walk and doorstep. Meter stick at upper left is on southernmost chimney base. Northernmost chimney base is visible at upper right; b, Doeppenschmidt house (41 BX 434), looking north. Person in center stands at the back wall with chimney base just below to his left. Some stones of the front walk may be seen in the grass at lower right. 


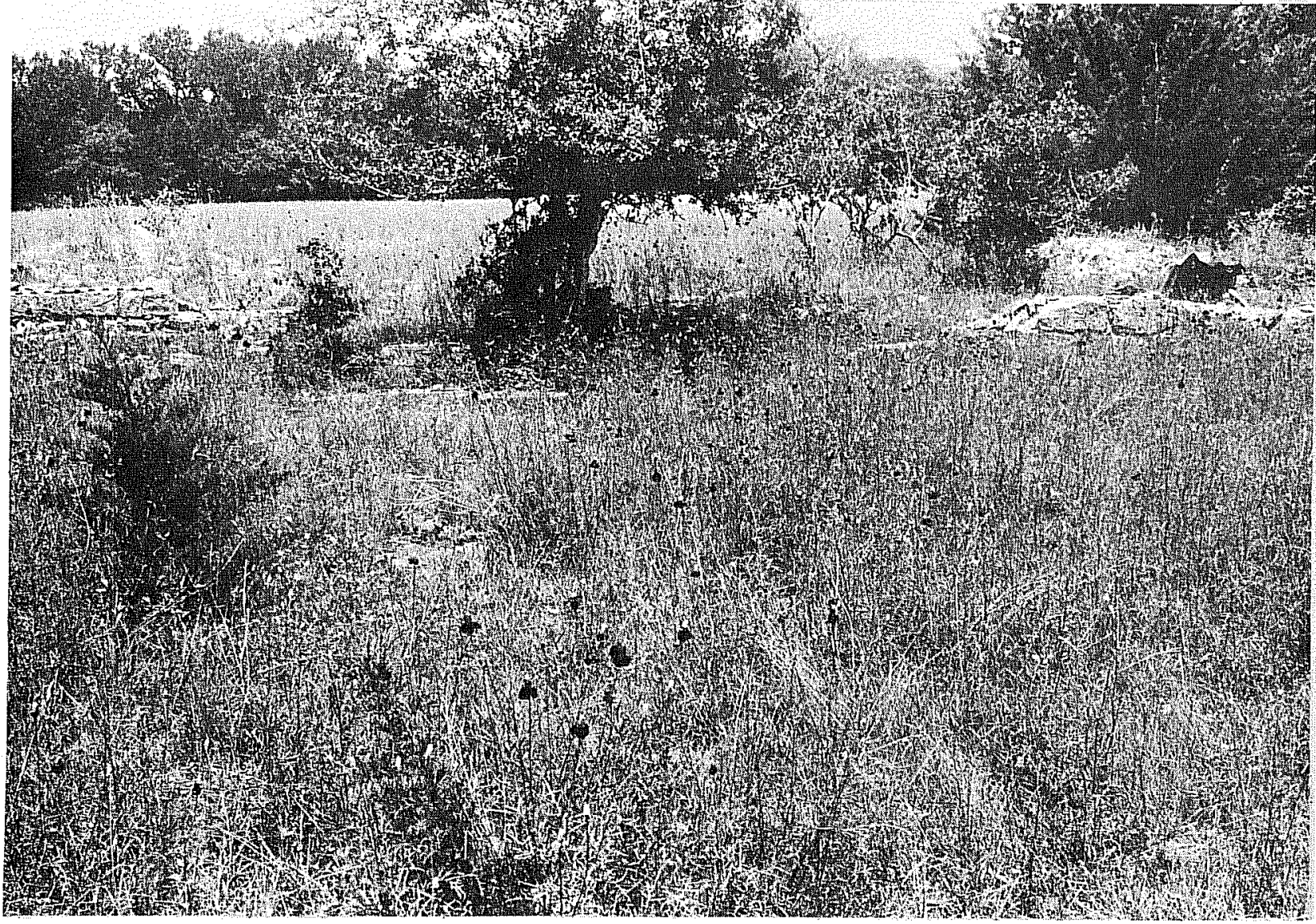

a

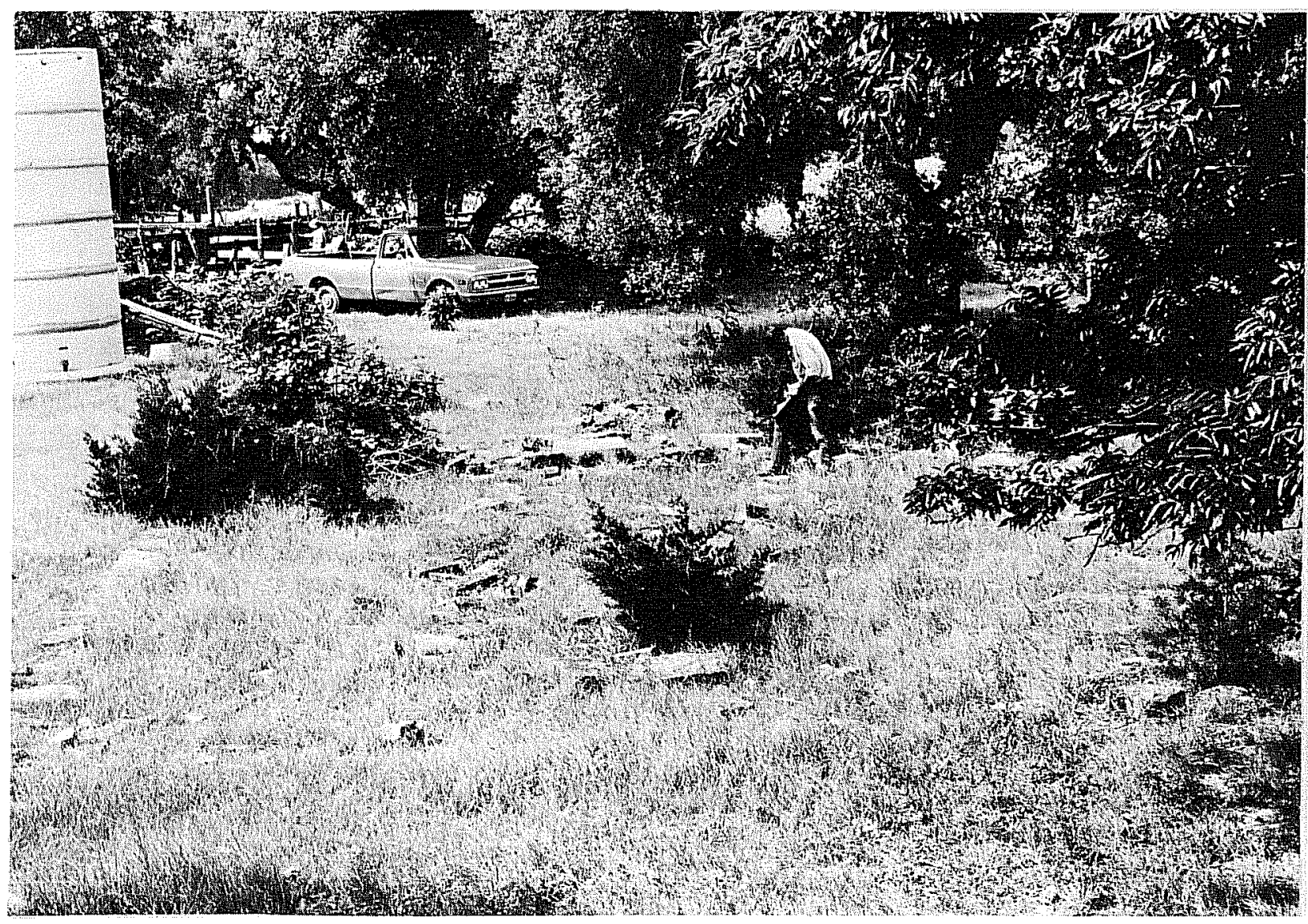


rings of fieldstone on edge around their bases, and other flowerbeds along the western fence, the front porch and in the southwestern corner of the yard are still traceable by the same fieldstone edging. A small stone building $3 \times 12 \mathrm{~m}$, similar to those of the H. Schmidt (41 BX 397) and A. Schmidt (41 BX 398) houses, is still largely standing but of far less substantial stonework. Immediately west of this smaller stone structure stands a concrete water tower, and just south of the tower is a windmill base and well. It is probable that the small stone structure had served as a water tank base before construction of the concrete water tower.

To the south of the primary site structures are the usual complex of utility and farm buildings, most of them of rough fieldstone, al though some have a few squared stone blocks. Several rectangular stock tanks are found on the site.

In artifact collections, time period and site utilization, the $W$. Schmidt house is virtually identical to the A. Schmidt house. The artifact collection is a good deal smaller, however; no massive deposit of glass as found at the A. Schmidt site was located here. A pit was excavated at one time within the foundations of the house, but it is small and there are no associated artifacts.

\section{BX 434 (the "Doeppenschmidt house")}

This is a small square foundation, $9 \times 8 \mathrm{~m}$, with an apparent chimney base in the approximate center of the house (Figs. 66,b; 67). A paved walk of fieldstone extends southward from the southeast corner of the structure some $8 \mathrm{~m}$ to a gate in the still traceable fence line. Two other doors are probably present, one at the southwest corner and one centered on the northern, or back, face of the house. Some traces of fieldstone edging of flowerbeds along the front and west walls of the house are still visible. A large area of fieldstone covers the area immediately to the north of the house, but it is not possible to determine if this is intentional. A windmill base, now equipped with an electric pump, is $13 \mathrm{~m}$ north of the house and is now just north of a recent concrete water tank. 0ther, prior provisions for water storage were not found and may have been obliterated by the recent tank.

Several traces of fieldstone shed foundations and small stock tanks are detectable to the southeast of the house but are not extensive. A one-seat outdoor privy base was found about $60 \mathrm{~m}$ west of the house, made of concrete and therefore fairly recent. This is the only example of sanitation structures found amoung these sites, other than the possible septic tank of the H. Schmidt house (41 BX 397). An extensive complex of corrals was found and may be relatively recent. The most outstanding feature of the site is the huge cleared pasture to its northeast, presently in use as a cattlegrazing area. In fact, some difficulty was encountered while attempting to map the site because of the unwelcome attention of several large bulls of the herd now pastured there. 

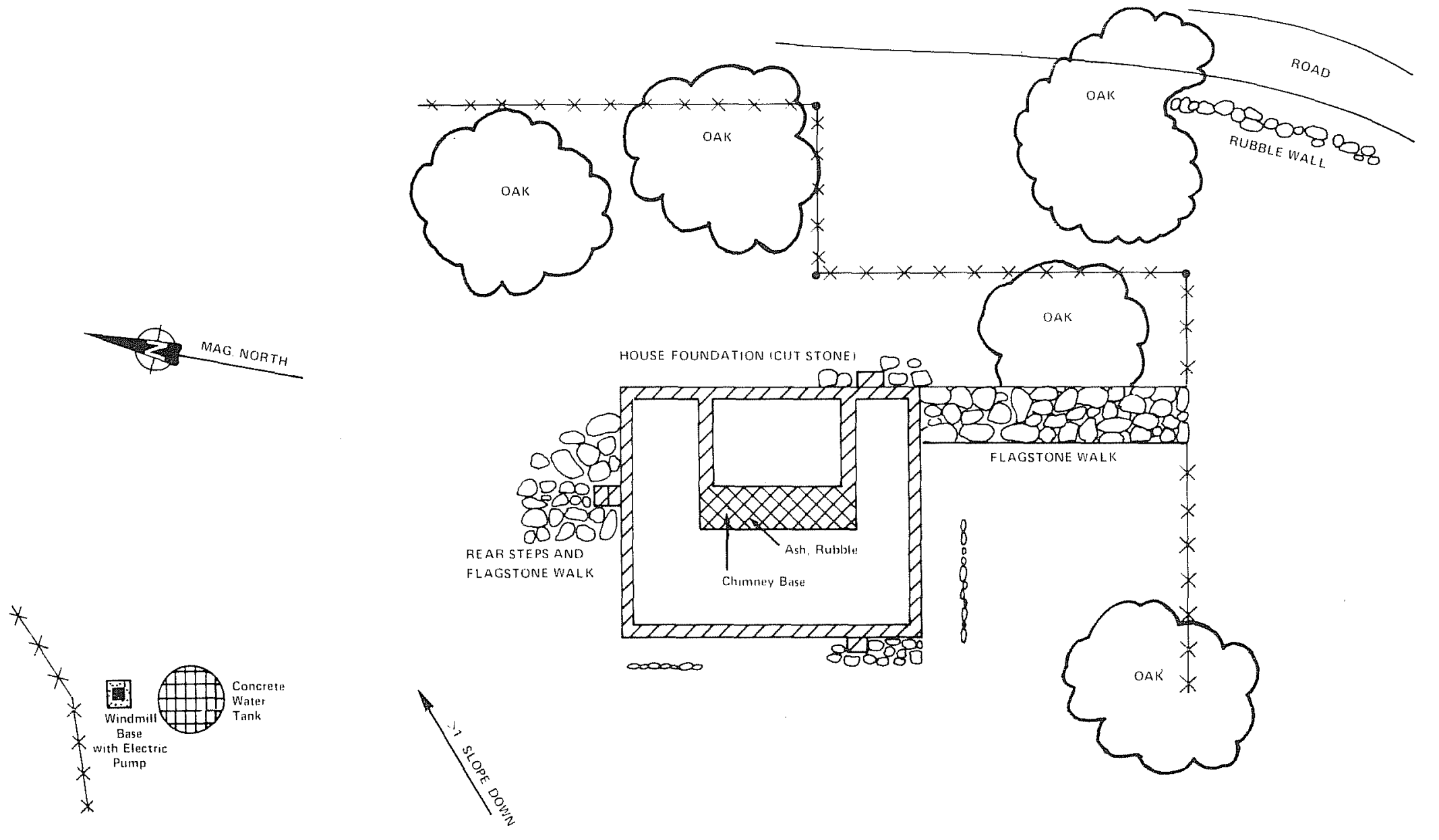

$41 \mathrm{BX} 434$

DOEPPENSCHMIDT

HOUSE

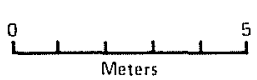

Figure 67. Site 41 BX 434, Doeppenschmidt House, Camp Bullis. 
Few artifacts were found at this site, and those few were predominantly bottleglass. Two fragments of a cast iron stove were also found. In general, the site appears to be late, and an estimate of the occupation period is 18801940.

In the discussion of 41 BX 394, the "C. Grossner house," it was mentioned that Peter Doeppenschmidt had purchased and later sold a large tract of land to the west of this house. That sale took place in 1911; in 1912, Doeppenschmidt purchased this tract of Comal County and owned it until his death in 1931 (BCCDR 401:26, Comal County Courthouse Records, Probate Minutes Vol. 9, p.240).

The house could have been built as early as 1893 by Adam Becker, who purchased the land from J. S. Mason in that year (BCCDR 116:393). There is, however, no doubt that the house was occupied by Peter Doeppenschmidt and his wife from 1912 to 1931. The house was probably dismantled by the Army after its purchase of the land in 1941.

Presented in Table 34 is data pertaining to several characteristics of the historic sites at Camp Bullis. In addition, names of people associated with the sites and the deed record references are provided. 
TABLE 34. HISTORICAL SITE ANALYSIS

Site Characteristics

Distance to nearest stream

Approximate soil depth

at site

Elevation of

site

Water source

on site

Approximate

date of

construction

Approximate date of

abandonment

Type of site

Structural

remains

on

site

Condition

of site

Names

associated

with site

Deed

Record

References

$\underline{S} \underline{I} \underline{E} \underline{S}$

41 CM 95

$2.5 \mathrm{~km}$

(Cibolo

Creek)

$1 \mathrm{~m}$

$1220 \mathrm{ft}$

Cistern

1850-1857

1900

House

Somewhat disturbed

T. A. Wash-

ington,

1860-1867;

J. S. Mason,

1867-1896?

BCCDR

Book S1:389

Book U2:132

Book 138:774
41 CM 97

$1 \mathrm{~km}$

(Cibolo

Creek)

$10 \mathrm{~cm}$

$10 \mathrm{~cm}$

$1335 \mathrm{ft}$

Well and

Well and

windmil1

1880-1890

1895

1930

1930

House and

farming/

ranching

House, numerous

farm/ranch

buildings

molasses \& fencing

cooker

Severely

disturbed

Severely

disturbed

H. Georg,

1905-1941

P. Doeppen-

schmidt, 1896-1911;

C. Grossner, 1911-1935;

A. Grossner

1935-1941

BCCDR
Book 238:590

BCCDR

Book U2:132 Book 239:232

Book 138:774 Book 245:287

Book 1847:352
BCCDR
Slightly Somewhat disturbed disturbed

Henry C. Schmidt, A. Schmidt, after 1905-1941
House and farming/ ranching

House, numerous farm/ranch buildings
Well and windmi11?

1900

1930 
TABLE 34. (continued)

Site Character-

istics

Distance to

nearest stream

Approximate

soil depth

at site

Elevation

of site

Water source

on site

Approximate

date of

construction

Approximate

date of

abandonment

Type of

site

Structural

remains

on

site

Condition

of site

Names

associated

with site
S I I E $\underline{S}$
41 BX 420

$1 \mathrm{~km}$

(Salado

Creek)

$10 \mathrm{~cm}$

$1180 \mathrm{ft}$

Spring?

$1850-1860$

1900

House

House

Two houses

House, some

farm/ranch

buildings;

other struc-

tures within

one mile

One house fair, Somewhat

one house

severely

disturbed
J. 0. Meuse- bach;
D. Oppen-
heimer,
H. Habermann;
C. Schasse

1900

1930

$41 \quad B \times 433$

$6.5 \mathrm{~km}$

(Meusebach

Creek)

$10 \mathrm{~cm}$

$1180 \mathrm{ft}$

Well and

windmi 11

House and

farming/

ranching

House, numerous

farm/ranch

buildings

Slightly

disturbed

Slightly

disturbed

$3 \mathrm{~km}$
(cibolo
Creek)

$50 \mathrm{~cm}$

$1265 \mathrm{ft}$

Well and windmi 11

1880

1930

House

and ranching

Small house, ranch buildings and fencing
W. Schmidt, after 19051941

A. and J.
Becker,
1893-1912;
P. Doeppen-
schmidt,
1912-1931
BCCDR
Book 116:393
Book $401: 26$

BCCDR

Book U2:74

Book 23:405

Book 159:49

Book 258:158 


\author{
III. B.3 \\ MATERIAL CULTURE \\ James E. Ivey and Daniel .E. Fox
}

\title{
INTRODUCTION
}

The nine historical sites encountered during this survey yielded 474 artifacts. These were sorted into three major groups: ceramics, glass and metal. Ceramics were further subdivided into vessel and non-vessel fragments, as was glass. Metal was classified into general functional groups: household items, machinery and related objects, hardware (such as nails, hinges, etc.), tools, personal items (such as harmonicas, lipstick cases, etc.) and firearm and related items. In all three major goups, further subdivisions were set up peculiar to the nature of the material.

Additional discussion of each variety of artifact is presented here followed by a table of the number of artifacts of each variety found at each site.

\section{CERAMICS}

As has been said, ceramics were divided into vessels and non-vessels. Vessels were further divided into white paste earthenware, porcelain and stoneware; non-vessels were grouped according to general functional type.

\section{Ceramic Vessels}

White Paste Earthenware

\section{(1) Decorated Earthenware}

\section{(a) Edgeware (3 specimens)}

A11 three sherds of edgeware are of the type called "shell edged" with fine radical ridges molded into the surface of the paste along the rim of the vessel, and then painted with varying degrees of care in red, green, blue or, occasionally, purple (Fig. 68,a). The three specimens discussed here are all blue edged. Blue edgeware was most common in Texas between 1820 and 1870 (Fox et al. 1974:219).

(b) "Flown Blue" Ware (1 specimen)

This decoration is actually a variation of the transfer print but is distinctive enough to warrant a separate class (Fig. 68,h). The "flown blue" technique was originated in 1825 and was most popular in the mid and late 19th century (McClinton 1951:27-29). 

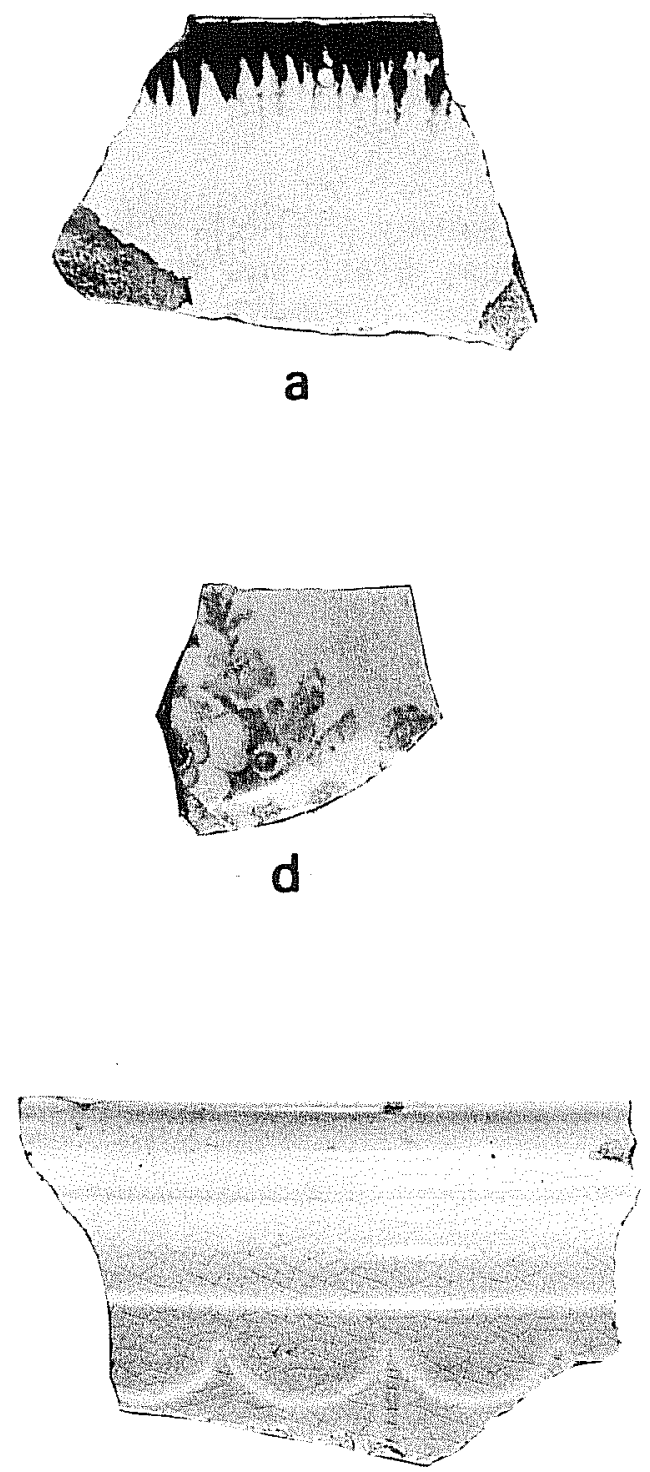

9

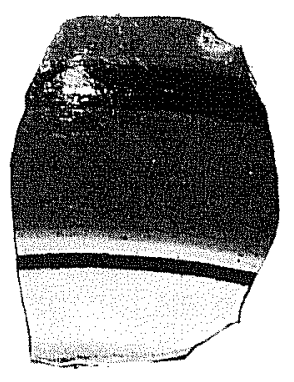

b
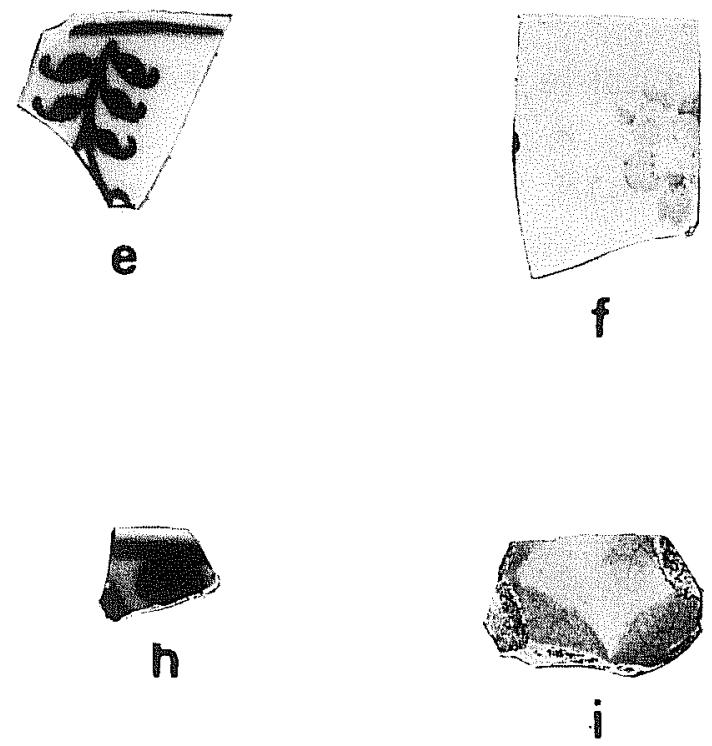

$\left.\left.\left.\left.\mathrm{cm}^{\prime}{ }^{\prime}\right|^{\prime}{ }^{\prime} 2\right|^{\prime} 3\right|^{\prime} 4\right|^{\prime} 5 \mid$

Figure 68. Historic Artifacts from Sites at Camp Bullis: Ceramic Artifacts. a-e, 41 BX 420 ( $a$, blue shell-edged ware; b, banded slipware; $c$, Bennington ware; d, decalcomania; e, porcelain); $f, g, 41$ BX 432 ( $f$, decalcomania; g, undecorated whiteware); $h, i, 41 \mathrm{CM} 95$ ( $h$, flown blue transfer print; $i$, Victorian Majolica). 
(c) Banded S7ipware (7 specimens)

This style of decoration, also known as "mocha," is usually applied to cups and other high-sided vessels (Fig. 68,b). The technique came into use around 1790 but did not appear in any quantity in America until after 1800 (McClinton 1951:2). Its greatest popularity in America was from 1800 to 1850 (Fox et al. 1974:220). The bright-colored articles are considered to be later (McClinton 1951:7).

(d) Victorian Majolica (4 specimens)

This earthenware is essentially a white paste earthenware decorated with colored glazes and has no relationship to the tin-enameled Spanish and Mexican wares also called "Majolica" (Mankowitz and Haggar 1957:138-139). The four specimens here are decorated on the exterior in rounded splotches of brown, blue and a muddy combination of the two on a cream background, and on the interior in a solid, intense pink or violet ( $F i g .68, i)$. The style was produced primarily in the period 1850-1900 (McClinton 1951:31).

(e) Transfer printed (2 specimens)

Transfer-print decoration differs from decal decoration (see below) in that transfer-prints are monochrome and are applied under glaze (Fox et al. 1974:219). The process was first used in 1759 (Schuetz 1969:14) and was popular in America throughout the 19th century and wel1 into the 20th century. The two specimens found are decorated with a brown floral print, and with a green floral print with an added gilt trim over glaze (Fig. 69,a,d,).

(f) Decalcomania (6 specimens)

The decal decoration is applied.over glaze, onto an already fired vessel, and is usually polychrome (Fig. 68,d,f). The technique was known in the 19th century but did not become popular until the 20th century (Fox et al. 1974:220). The six sherds in this collection are all polychrome floral designs applied to cream-colored or pink vessels, which seem to be cups and saucers.

One sherd has a green transfer print maker's mark:

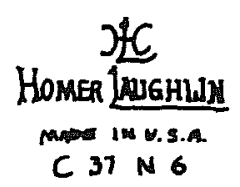

This is the mark of the Homer Laughl in China Company established in 1897. This mark was used only well after 1900 (Barber n.d.:110). 

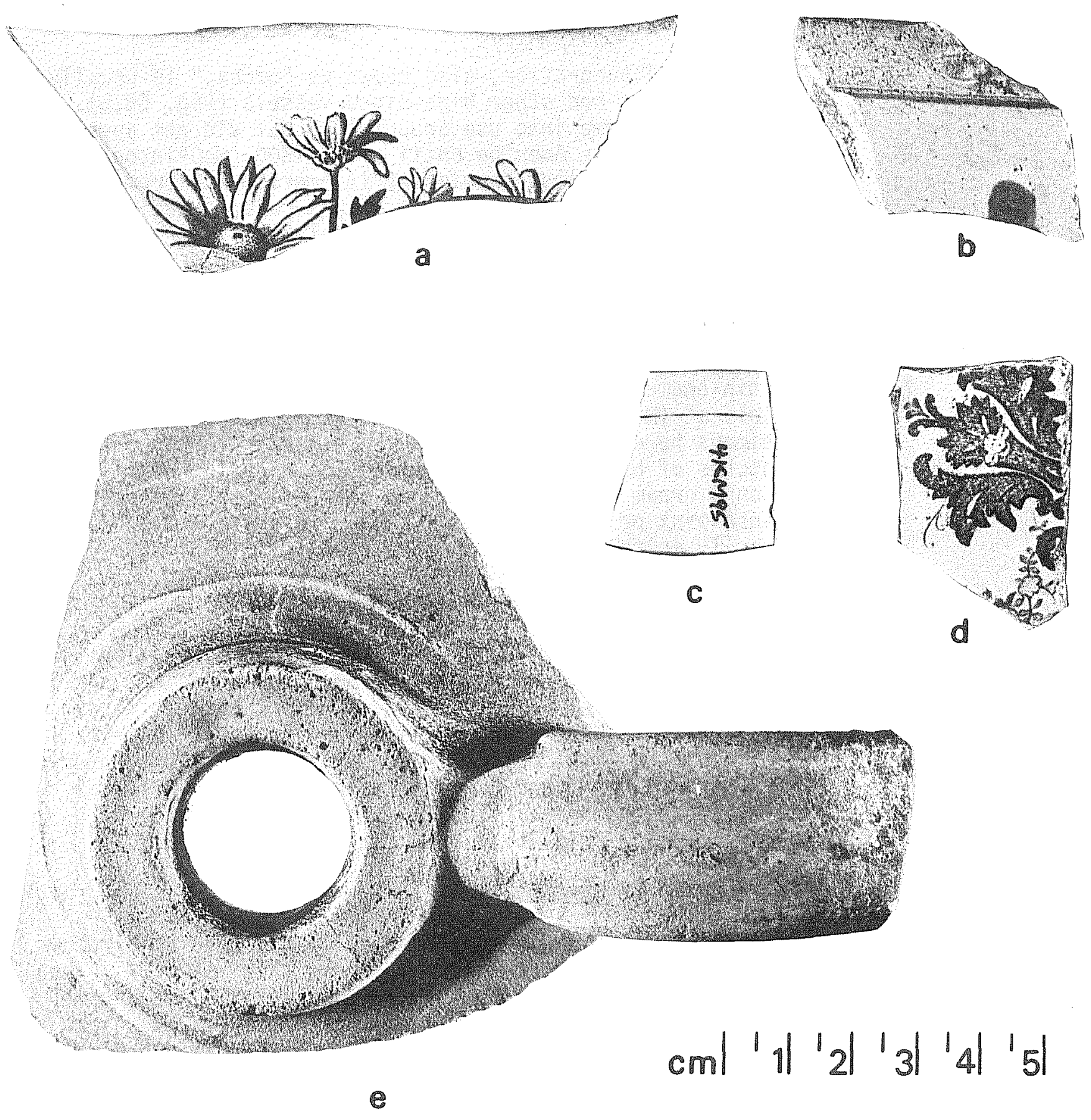

Figure 69. Historic Artifacts from Sites at Camp Bullis: Ceramic Artifacts. $a, c, 41$ CM 95 ( $a$, transfer-printed; $c$, porcelain); b,e, 41 BX 433 (b, Bristolglazed crockery; e, Meyer ware jug); d, 41 BX 397 (transfer print). 
(2) Undecorated Earthenware (78 specimens)

(a) These are grouped in Table 35 by the part of the vessel from which the sherd came. Most are of ironstone, which began to be imported from England in large quantities after 1860 (Fox et al. 1974:221). The fragments seem to be from a variety of bowls, plates and other vessels (Fig. 68,g).

(b) Undecorated white paste, clear glazed sherd with an aquamarine transfer maker's mark:

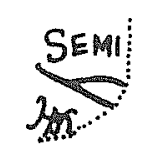

This is the mark of the Harker Pottery Company, East Liverpool, Ohio, and was used on "semi-porcelain" earthenware beginning in 1897 (Barber n.d.:105).

(c) Undecorated white paste, clear glazed sherd with the brown transfer maker's mark "PORC..." and a fragment of a shield, mantling, scroll and sword-hilt coat of arms. Probably the mark of the Prospect Hill Pottery Company, Trenton, N.J., established in 1880 (Kovel and Kovel 1953:24; Barber n.d.:61).

Porcelain

(1) Decorated (5 specimens)

(a) Three sherds decorated in a blue floral design, from two vessels. The single sherd could be of Chinese manufacture (Fig. 68,e).

(b) One sherd from a plate or saucer with a scalloped edge and an unrecognizable molded design, with faint traces of gilding along this edge.

(c) One rim sherd from a saucer with one narrow silver line $0.7 \mathrm{~cm}$ inside edge, and traces of silvering between the line and the edge (Fig. 69, C).

(2) Undecorated (10 specimens)

The fragments seem to be from bowls, cups, a plate or platter and possibly a teapot. 


\section{Stoneware}

\section{(1) Texas-made Crockery}

(a) Meyer Ware (5 specimens)

Meyer crockery is characterized by a smooth semi-gloss to matte Leon glaze, ranging from yellow-green through various shades of pale green, green-and-orange, and orange-brown, to a dark red-brown with green specks. The paste is usually white to tan, and the interior surfaces coated with an Albany slip of semi-gloss to matte brown (Greer and Black 1971:2,4). These specimens are all from jugs (Fig. 69,e).

(b) "Elmendorf" Ware (7 specimens)

These specimens are characteristic of the potters of Elmendorf, Texas (G. Greer, personal communication). Three sherds have an off-white or buff Bristol glaze and a glossy or semigloss very dark brown Albany-slipped interior. Two specimens are of a lid-like object, but with closure surfaces on both sides. The upper surface is coated with a pale brown Albany slip and edged in Bristol glaze, which continues on the underside, more typical of the late 19th and early 20th centuries.

(c) "La Vernia" Ware (5 specimens)

These specimens were probably made by the Suttles pottery of La Vernia, Texas, 13 miles east of Elmendorf. They are glazed in Albany slip on both sides or in Bristol glaze with Albany slip interiors and are typical of late 19th century and early 20th century crockery (G. Greer, personal communication).

(2) Out-of-State Crockery (6 specimens)

Of these six sherds, one is a jug or churn base fragment with a glossy brown Albany-slipped interior and a white Bristol glaze exterior; one is Bristol glazed on both surfaces; one has a Bristol-glazed exterior and a black-glazed interior; one has a grey salt-glazed exterior and an Albany-slipped interior; one has a white Bristol-glazed interior and exterior with cobalt blue decorations on the exterior (Fig. 69,b); and one sherd of a peculiar stoneware vessel has a clear lead-glazed upper surface.

(3) Bennington Ware (2 specimens)

These are flint-enameled sherds of a gold-brown color, typical of the glazing techniques used by $\mathrm{C}$. W. Fenton at Bennington, Vermont, after 1840 and Peoria, Illinois, after 1856 (Fig. 68,C). The glaze is essentially a glossy Albany slip applied in varying densities to make a range of shades of brown (Raycraft and Raycraft 1975:

Plate 11). 
(4) Yellow-Glazed Crockery (9 specimens)

A11 nine sherds are from the same vessel and appear to be the lid to a jar. This is typical "Yellow ware" crockery, popular as mail-order goods in the late 19th and early 20th centuries (Raycraft and Raycraft 1975:Plate 16).

Ceramic Non-Vessels

Glazed Brick (1 specimen)

This is a fragment of red-brown brick coated with gray salt-glaze. Such bricks were used as a decorative construction material on a fireplace (Fig. $70, \mathrm{~b}$ ).

Sewer Pipe (1 specimen)

Fire Brick (2 specimens)

These specimens are from $41 \mathrm{BX} 420$. They are large flat bricks, perhaps $20 \times 30 \times 8 \mathrm{~cm}$ when complete, with flanged edges so that adjoining bricks interlock and reduce heat loss. One surface of one of the fragments is marked "...LLEF...." One side of each of the fragments has a heavy deposit of slag from some sort of hightemperature firing process, for which these bricks must have formed the kiln-lining. They are as yet unidentified as to date or place of manufacture (Fig. 70,a).

Orange Paste Tile (1 specimen)

This fragment is $12 \times 9 \mathrm{~cm}$ and is $2 \mathrm{~cm}$ thick.

Porcelain Insulator (1 specimen)

This is a fragment of an electrical insulator and is $2.5 \times 2.5 \mathrm{~cm}$, cylindrical in shape, with a $0.5 \mathrm{~cm}$ hole through its center.

Porcelain wheel (1 specimen)

A fragment of a sma 11 caster whee $1,3 \mathrm{~cm}$ in diameter and $1.5 \mathrm{~cm}$ thick, possibly used as a furniture caster.

Porcelain Animal (1 specimen)

The animal appears to be an ox or bull with a pad on its back; its dimensions are $5 \times 3.5 \mathrm{~cm}$ (Fig. 70, c). An impressed mark along the base says "Japan." 

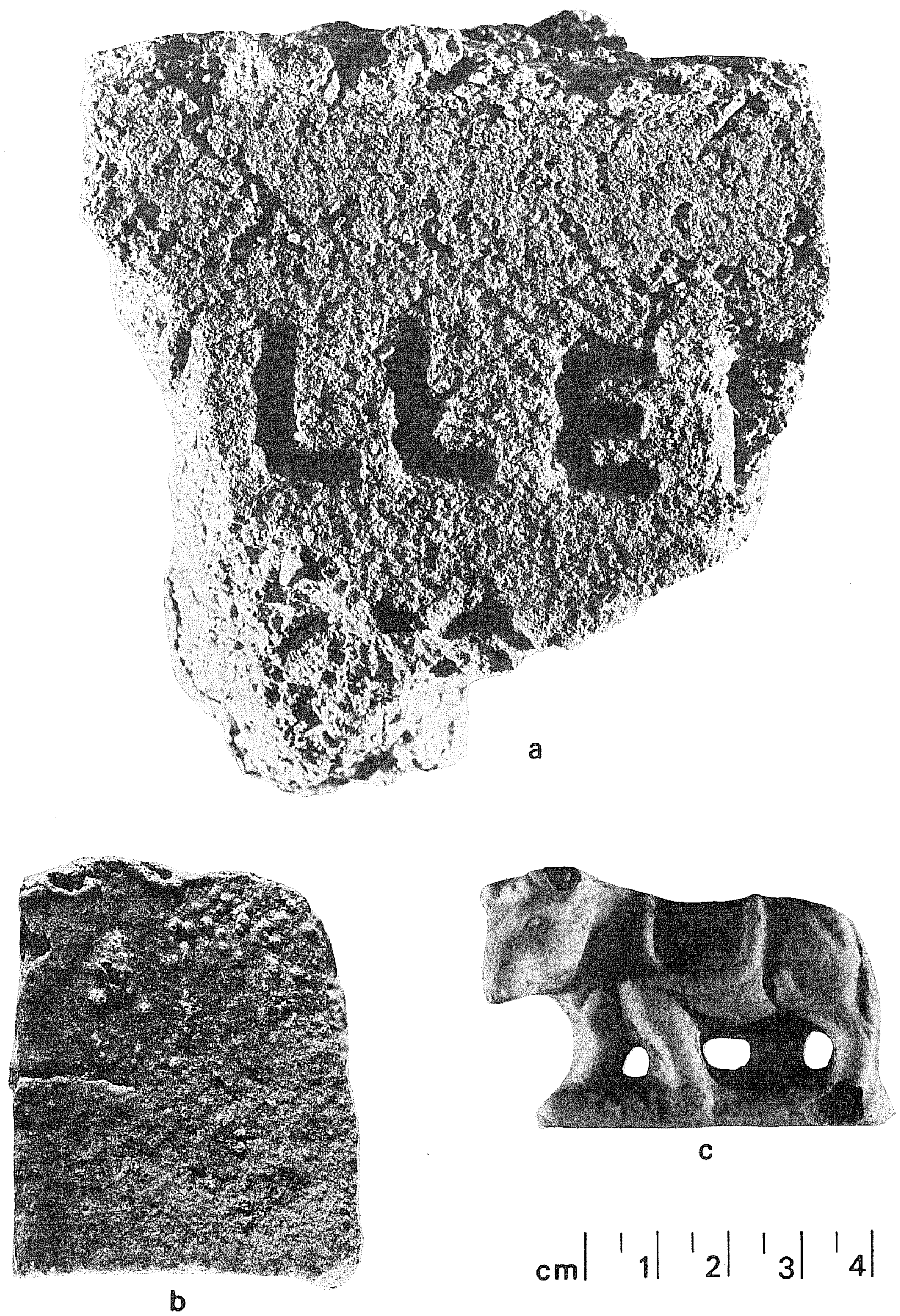

C

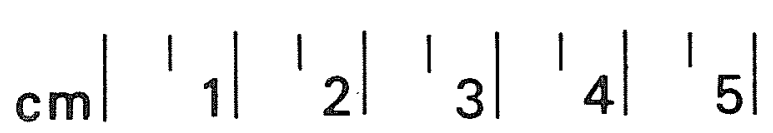

Figure 70. Historic Artifacts from Sites at camp Bullis. a, brick with slag, 41 BX 420; b, glazed brick, 41 CM 95; c, ceramic figurine, 41 BX 394. 
GLASS

Glass Vessels

Bottle Glass

These specimens were divided into groups by color. Colors occur in a very general time sequence, with considerable overlap: dark green glass is earliest, followed by aquamarine, brown, purple and clear. Bottle shapes indicate that whiskey, wine, medicine, fruit, milk and soft drinks were contained in them.

(1) Dark Green (24 specimens)

These are probably all wine bottle fragments. There are four base fragments, 17 body fragments, one neck fragment, one 1 ip fragment and one complete neck and lip (Fig. 71,C).

(2) Light Green (Seven-Up bottle color, 6 specimens)

One fragment is a Seven-Up bottle base, manufactured in San Antonio. A second base is also in this group, but of an unidentified vesse1. There are two body sherds of the same Seven-Up green, and one body sherd of a slightly lighter green. Also included in this group is a mass of glass which has been severely melted.

(3) Aquamarine (27 specimens)

of these, nine fragments are bases, four are neck and lip fragments, 14 are body fragments and one is a complete Fletcher's Castoria bottle. Most of the bottles seem to be medicinal.

(4) Brown (30 specimens)

Eleven of these fragments are bases, one is a neck and lip, and 18 are body fragments (Fig. $71, \mathrm{~b}$ ). Most of them are from whiskey bottles; one, however, is marked "Dr. Harter's wild Cherry," and another appears to be the bottom of a syrup bottle.

(5) Purple (15 specimens)

This group contains one neck and lip fragment, six base fragments and eight body fragments. Some of these vessels are medicinal, but others are of no identifiable type.

(6) Blue (6 specimens)

In this group are one base fragment and five body fragments. Some are medicinal bottle fragments. 

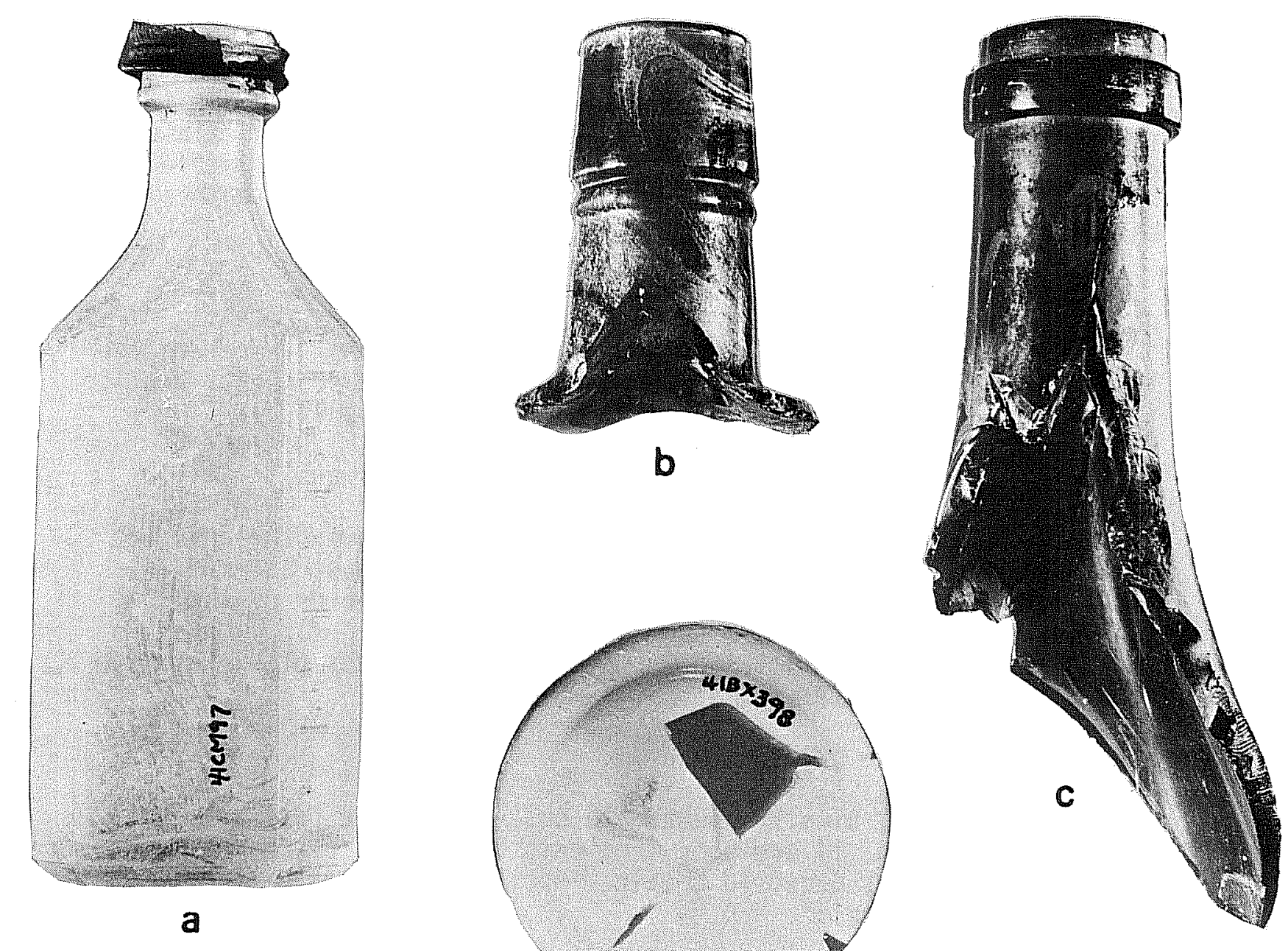

$\left.\left.\left.\left.\mathrm{cm}^{\prime}{ }^{1}\right|^{\prime}{ }^{\prime}\right|^{\prime}{ }^{\prime} 3\right|^{\prime} 4\right|^{\prime}{ }^{\prime}{ }^{\prime} \mid$

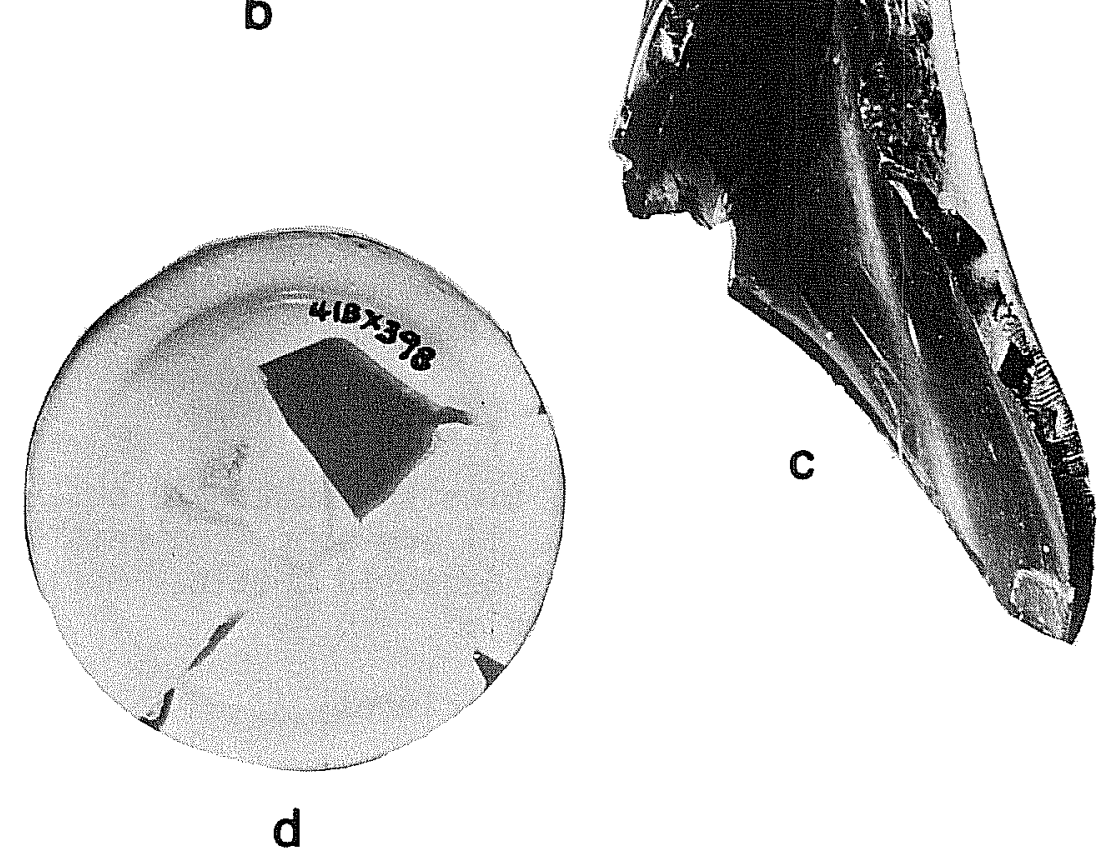

Figure 71. Historic Artifacts from Sites at Camp Bullis: Artifacts of Glass. a, 41 CM 97, clear medicinal bottle; b-d, 41 BX 398 (b, brown whiskey bottle neck; $c$, green wine bottle neck; d, Mason jar lid liner). 
(7) Clear (78 specimens)

Forty-two of these specimens are body fragments, 27 are base fragments, seven are neck and 1 ip fragments, and two are complete bottles (Fig. 71,a). Of these, al1 are of 20th century manufacture; most are soft-drink and medicinal bottles.

Jars

(1) Aquamarine (1 specimen)

This is from a wide-mouthed jar with a screw-on lid and was probably for preserved fruit or vegetables.

(2) Clear (6 specimens)

Five are neck and lip fragments of wide-mouthed jars with screw-on metal tops. The sixth is a complete jar, of the type used for maraschino cherries.

(3) Milk G1ass (16 specimens)

A11 are pieces of several sizes of Pond's Hand Cream jars.

Drinking Glasses

(1) Purple (1 specimen)

This is the base of an eight-sided, thick-walled glass.

(2) Clear (1 specimen)

This is the base of a round glass.

Glass Non-Vesse1s

Kerosene lamp (3 specimens)

These three pieces fit together to make most of the base of a clear glass kerosene lamp.

Insulator ( 1 specimen)

This is a fragment of the base of an aquamarine electrical insulator, of the sort used on utility poles.

Jar Liners (20 specimens)

These are Mason jar lid liners. Five fragments are from three

lids with the words "WHITE CROWN CAP/PAT-11-22-10" on their upper surfaces. Nine fragments are from two lids marked "BOYD'S GENUINE PORCELAIN LINED CAPS" and one fragment has the words "GENUINE BOYD CAP..." (Fig. 71,d). Six fragments are unmarked or unreadable. 
Window Pane (24 specimens)

Thickness ranges from $2 \mathrm{~mm}$ to $3.1 \mathrm{~mm}$.

METAL

\section{Household I tems}

(1) Stove parts (2 specimens)

Cast iron stove with embossed decorations (Fig. 72,b)

(2) Tablespoon (1 specimen)

Iron; the date 1917 is stamped on the back of the handle

(3) Knife handle fragment (1 specimen)

(4) Rectangular lid (1 specimen)

Dimensions are $5 \times 4 \mathrm{~cm}$, sheet metal, with a hole $7 \mathrm{~mm}$ in its center

(5) Crown cap (1 specimen)

Soft drink bottlecap

(6) Key (1 specimen)

Iron

(7) Lion ornament (1 specimen)

Cast iron, $11 \times 10 \mathrm{~cm}$ with a hole in the center of the body, probably for attachment

Machinery and Related Objects

(1) Plow fragment (?) (1 specimen)

This is a flat piece of iron with an angular broken edge and a smoothly curved edge which is much thinner than the rest of the artifact. Dimensions are $20 \times 10 \times 0.5 \mathrm{~cm}$ (at the center) tapering to a thickness of $1 \mathrm{~mm}$ or less at the curved edge.

(2) License plate (1 specimen)

Texas license plate No. 62-993, year: 1933. $32 \times 12 \mathrm{~cm}$. 

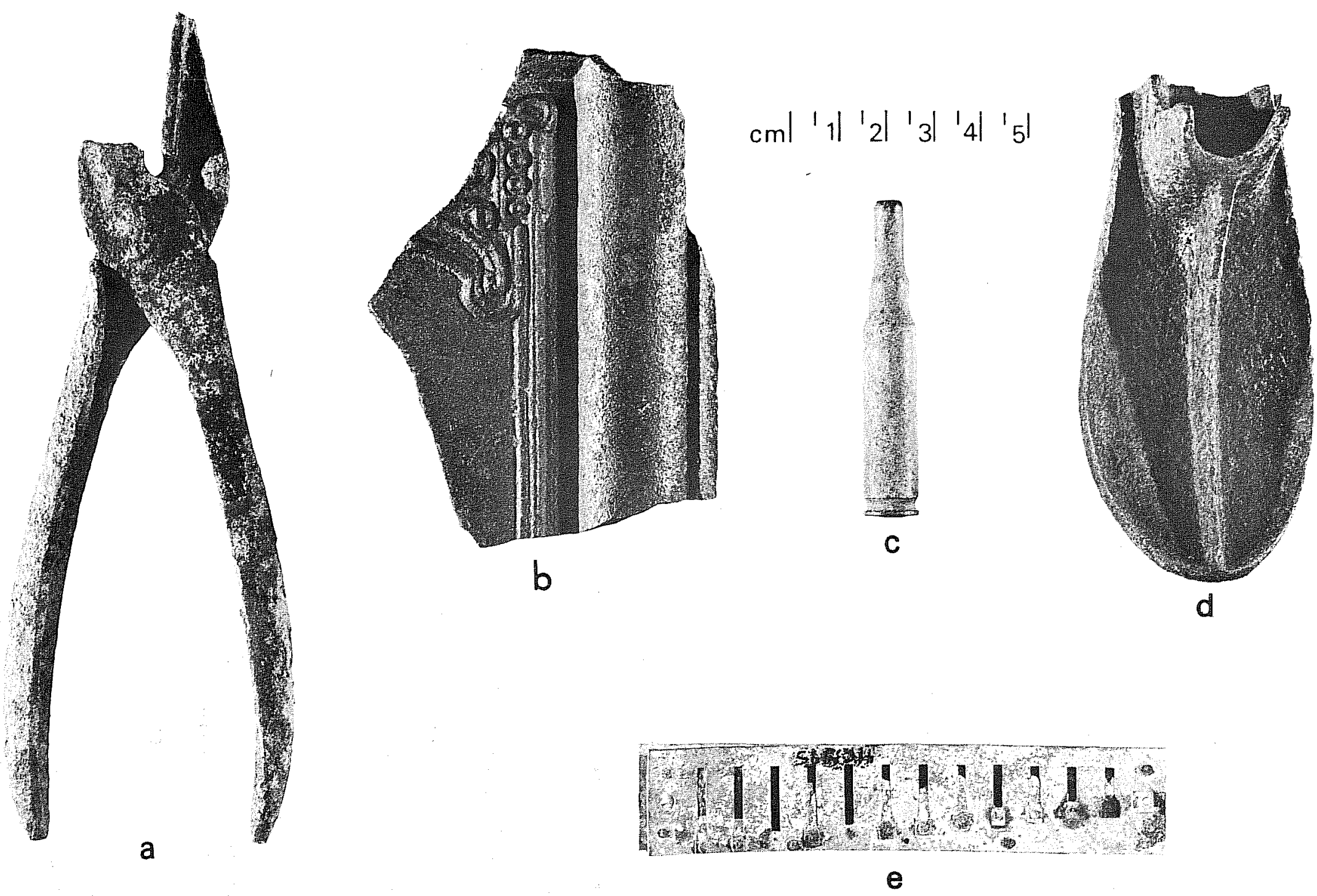

Figure 72. Historic Artifacts from Sites at Camp Bullis: Artifacts of Metal: a, d, 41 BX 433 (a, p7iers; d, shoe anvil); b,c, 41 BX 434 (b, stove fragment; c, $7.62 \mathrm{~mm}$ NATO blank cartridge case); e, 41 CM 95 ,
harmonica reeds. 
(3) Unidentified (2 specimens)

One of these objects is a curved metal strip, $12 \times 0.75 \mathrm{~cm}$, with a small hole $3 \mathrm{~mm}$ from one end and the end of an attached, stiff wire welded through a hole $2.3 \mathrm{~cm}$ from the opposite end.

The second is a flat rectangular chunk of iron, $7.5 \times 3.5 \mathrm{~cm}$ and $1.5 \mathrm{~mm}$ thick.

Hardware

(1) Large butt hinge (1 specimen)

Iron, $13.5 \times 16 \mathrm{~cm}$

(2) Brass grommet (1 specimen)

Probably a U.S. Army tent rope eyelet

(3) Tent rope tightener (1 specimen)

Brass. Used to allow ropes to be tightened and then locked in place.

(4) Machine cut square nails (24 specimens)

Range in length from $9.5 \mathrm{~cm}$ to $4 \mathrm{~cm}$

(5) Wire nails (4 specimens)

Range in size from $9 \mathrm{~cm}$ to $6 \mathrm{~cm}$

(6) Roofing tack (1 specimen)

Iron, $2 \mathrm{~cm}$ in length, about $1.5 \mathrm{~cm}$ head diameter

$\underline{\text { Tools }}$

(1) Shoe anvil (1 specimen)

Fragment of iron, $10.5 \mathrm{~cm}$ long $\times 5 \mathrm{~cm}$ across its widest point (Fig. 72,d).

(2) P1iers (1 specimen) (Fig. 72,a)

Personal Items

(1) Harmonica reeds (2 specimens) (Fig. 72,e)

(2) Lipstick case (1 specimen)

Aluminum 
Firearms and Related Items

(1) $44 \mathrm{cal}$. Winchester center fire cartridge case, WRA Co.

(2) 44 cal. center fire cartridge case, unknown maker

(3) 30-06 cal. Springfield cartridge case, unknown maker

(4) $7.62 \mathrm{~mm}$ NATO blank cartridge, 1969, LC (Fig. 72,c)

(5) $5.56 \mathrm{~mm}$ blank cartridge, 1974, LC.

(6) $38 \mathrm{cal}$. bullet, two grease grooves, concave base

(7) Lead fragment, apparently from a bullet impact (2 specimens)

Quantitative data for these artifacts is given in Table 35. 
TABLE 35. QUANTITATIVE DATA: ARTIFACTS FOUND AT HISTORIC SITES

\section{CERAMICS}

Ceramic Vessels

White Paste Earthenware

\begin{tabular}{|c|c|c|c|c|c|c|c|c|}
\hline Lم & $\hat{\sigma}$ & ন্ల & 旤 & $\stackrel{\infty}{\mathscr{m}}$ & $\underset{\sim}{\sim}$ & $\underset{\varpi}{\sim}$ & $\underset{m}{m}$ & $\underset{\sigma}{+}$ \\
\hline$\sum$ & $\sum$ & শ્ఐ & త্㐅 & ঝ্口 & শ્ద & 지 & 希 & 层 \\
\hline
\end{tabular}

Decorated Earthenware

Edgeware (B1ue)

"Flown Blue" Ware

Banded Slipware (Mocha)

Victorian Majolica

Transfer Printed

Decalcomania

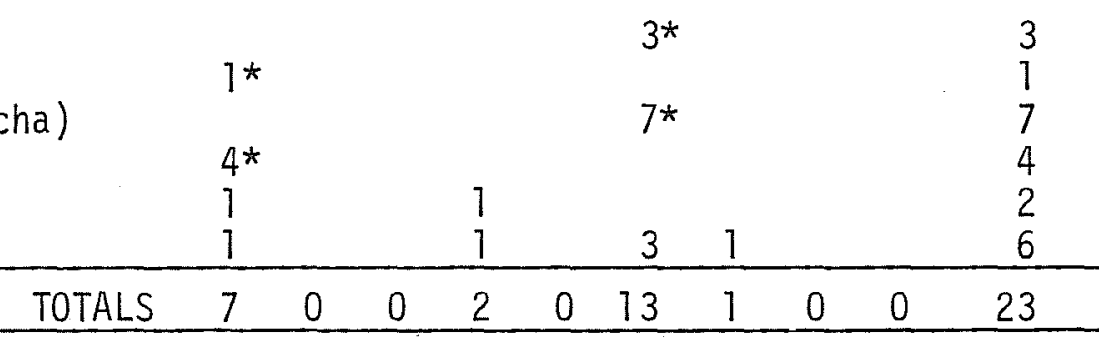

Undecorated Earthenware

Rim Sherds

Handle Fragment

Basal Sherds

Body Sherds

\begin{tabular}{rrrrrrrrrrr} 
& 5 & 6 & 2 & 2 & 4 & 2 & 6 & & & 27 \\
& 2 & 3 & & 1 & 4 & 5 & 9 & & & 1 \\
& 3 & 3 & & & 3 & 7 & 9 & & 1 & 24 \\
\hline TOTALS & 10 & 12 & 2 & 3 & 11 & 14 & 25 & 0 & 1 & 78 \\
\hline
\end{tabular}

Porcelain

Decorated

Undecorated

\begin{tabular}{cccccccccccc}
\hline Decorated & & 1 & & & 1 & 3 & & & 5 \\
Undecorated & 2 & & 2 & & 2 & 4 & & 10 \\
\hline & TOTALS & 3 & 0 & 0 & 2 & 1 & 5 & 4 & 0 & 0 & 15 \\
\hline
\end{tabular}

Stoneware

Crockery (Texas-made and out-of-State)

Bennington Ware

$\begin{array}{llllllll}5 & 3 & 3 & 5 & 2 & 3 & 2 & 23\end{array}$

Yellow-Glazed Crockery $9 *{ }^{2 *} \quad 2$

$\begin{array}{lllllllllll}\text { TOTALS } & 5 & 3 & 0 & 3 & 14 & 4 & 3 & 2 & 0 & 34\end{array}$

TOTALS (VESSELS)

$\begin{array}{lllllllllll}25 & 15 & 2 & 10 & 26 & 36 & 33 & 2 & 1 & 150\end{array}$

Ceramic Non-Vessels

Glazed Brick

Sewer Pipe

Fire Brick

Orange Paste Tile

Porcelain Insulator

Porcelain wheel

Porcelain Animal

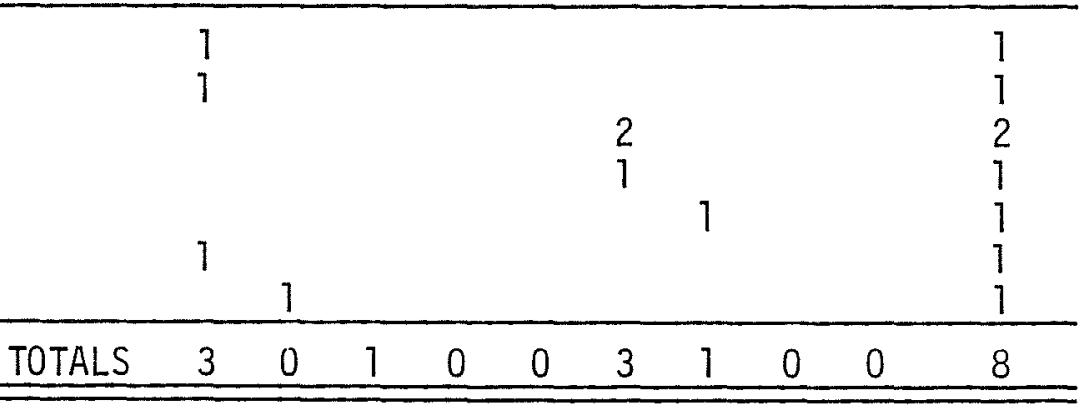

$\begin{array}{llllllllll}28 & 15 & 3 & 10 & 26 & 39 & 34 & 2 & 1 & 158\end{array}$ 
TABLE 35. (continued)

GLASS

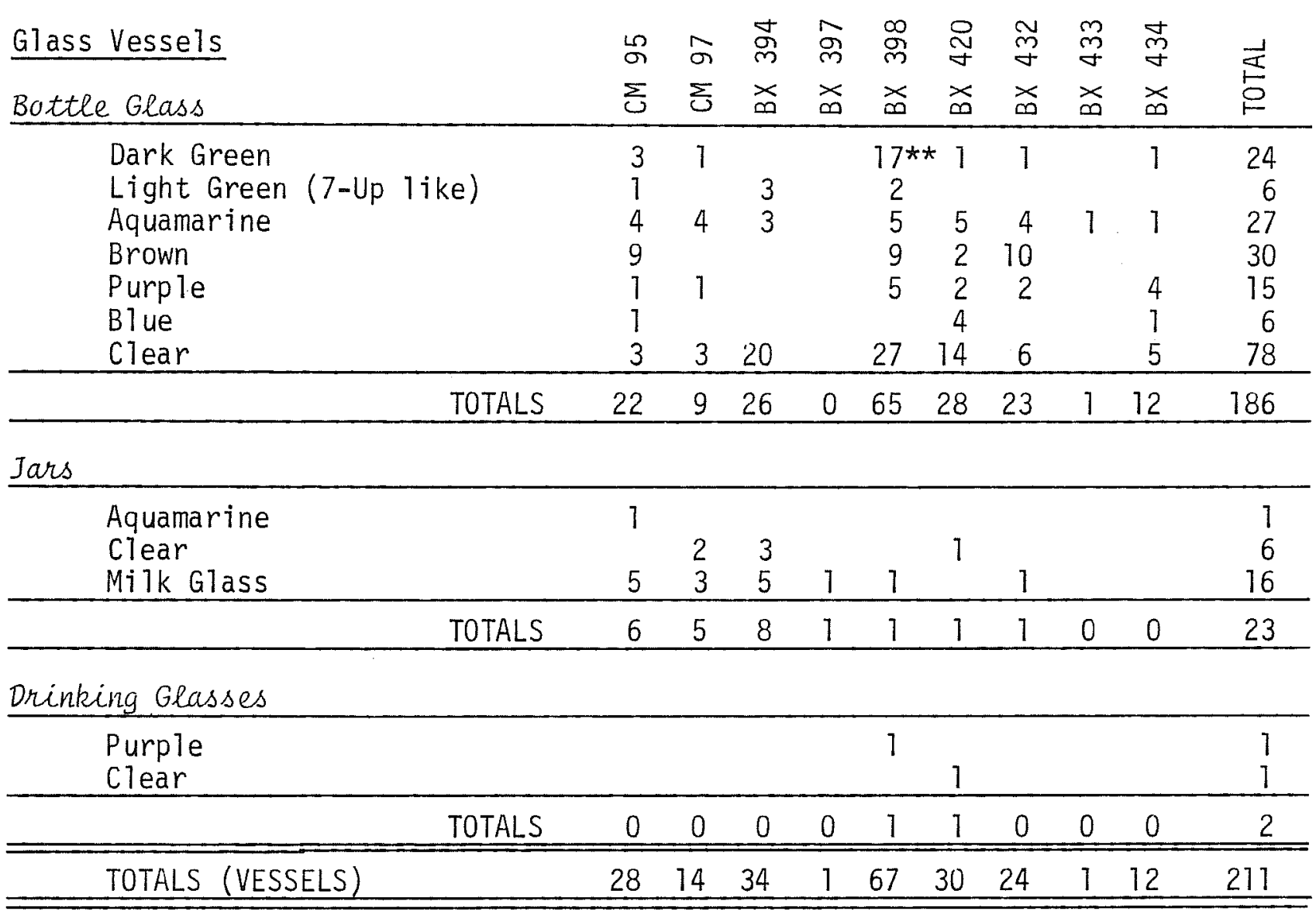

Glass Non-Vessels

\begin{tabular}{|c|c|c|c|c|c|c|c|c|c|c|c|c|}
\hline & $\begin{array}{l}\text { Kerosene Lamp ICe } \\
\text { Insulator IAquama } \\
\text { Jar Liners IMilk } \\
\text { Window Pane IAqua }\end{array}$ & $\begin{array}{l}\text { ear) } \\
\text { rine) } \\
\text { Glass) } \\
\text { and clear) }\end{array}$ & $\begin{array}{l}1 \\
6\end{array}$ & $\begin{array}{l}1 \\
5\end{array}$ & $3^{x}$ & & 12 & $\begin{array}{l}1 \\
9 \\
\end{array}$ & $\begin{array}{l}1 \\
3 \\
\end{array}$ & & 1 & $\begin{array}{r}3 \\
1 \\
20 \\
24 \\
\end{array}$ \\
\hline & & TOTALS & 7 & 6 & 8 & 0 & 12 & 10 & 4 & 0 & 1 & 48 \\
\hline GRAND & TOTALS (GLASS) & & 35 & 20 & 42 & 1 & 79 & 40 & 28 & 1 & 73 & 259 \\
\hline
\end{tabular}


TABLE 35. (continued)

METAL

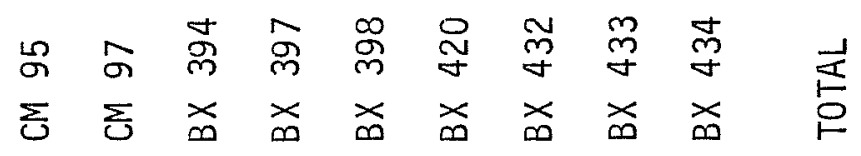

Household I tems

Stove parts

Tablespoon

Knife handle fragment

Rectangular lid

Crown cap

Key

Lion ornament (Cast iron)

Machinery and Related Objects

Plow fragment

License plate (1933)

Unidentified

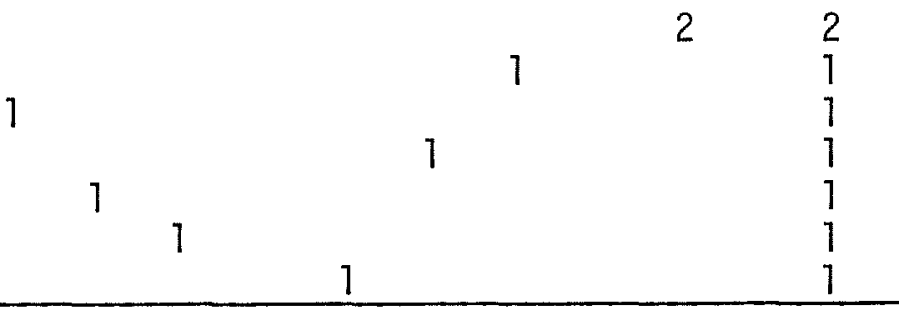

$\frac{1}{1}$

Hardware

Large butt hinge

Brass grommet

Tent rope tightener

Machine cut square nails

Wire nails

Roofing tack

\begin{tabular}{lll}
1 & 1 & 1 \\
1 & 1 & 1 \\
\hline
\end{tabular}

$\underline{\text { Tools }}$

Shoe anvil

Pliers

\begin{tabular}{llrr} 
& 1 & & 1 \\
& & 1 & 1 \\
$3 *$ & 1 & & 1 \\
2 & 1 & & 24 \\
& 1 & & 4 \\
\hline
\end{tabular}

\section{Pliers}

Personal I tems

Harmonica reeds

Lipstick case (Al uminum)

$\begin{array}{llll}13^{*} & 1 * & 3^{*} & 7^{*} \\ 1 & 2 & 1 \\ & & 1 \\ \end{array}$

\begin{tabular}{|c|c|c|c|c|c|c|c|c|c|c|}
\hline $\begin{array}{l}\text { Harmonica reeds } \\
\text { Lipstick case (Aluminum) }\end{array}$ & 1 & & 1 & & & 1 & & & & $\begin{array}{l}2 \\
1\end{array}$ \\
\hline \multicolumn{11}{|l|}{ Firearms and Related Items } \\
\hline $\begin{array}{l}44 \text { cal. Winchester, WRA Co. } \\
44 \text { cal., unknown maker } \\
30-06 \text { cal. Springfield } \\
7.62 \mathrm{~mm} \text { NATO blank, 1969, LC } \\
5.56 \mathrm{~mm} \text { blank, 1974, LC } \\
38 \text { cal. bullet, concave base } \\
\text { Lead bullet splash }\end{array}$ & 1 & 1 & 1 & & & $\begin{array}{l}1 \\
1 \\
\end{array}$ & $\begin{array}{l}1 \\
1\end{array}$ & & 1 & $\begin{array}{l}1 \\
1 \\
1 \\
1 \\
1 \\
1 \\
2\end{array}$ \\
\hline TOTALS (METAL) & 16 & 3 & 6 & 1 & 1 & 8 & 16 & 2 & 4 & 57 \\
\hline
\end{tabular}

$*=19$ th century chronological affiliation

$\star \star=$ all froni same vesse $]$ 


\title{
III. B. 4
}

\section{CONCLUSIONS}

\author{
James E. Ivey
}

When this survey of the historical sites on Camp Bullis was begun, it was expected that the sites would form a fairly uniform group, composed largely of an extended community of German settlers of the period 1850-1890, with quite similar house designs, artifact collections, associated structure design and positioning, and subsistence patterns (Carter and Ragsdale 1976:64-68).

An examination of the preceding pages shows a very different picture. A1though many of the landowners were of German origin, there is little indication of a concerted development of the region by a German community, and indeed little indication of any community at al1. Only those late sites on the eastern side of the survey area show any uniformity of design, subsistence or family/community ties.

The sites seem to form into several groups: (1) the Schmidt houses, all of the period 1900-1940, all similar in design and purpose; (2) the Grossner and Georg houses, both somewhat similar and of a somewhat earlier period, but more confused in their attributes because of their nearly total demolition--it is suspected that in general design they resembled the Schmidt group; (3) the remainder of the sites, similar only in that they are each unlike the other. The Washington-Mason house shows few traces of a solid foundation, has a large cistern, two chimneys and a construction date in the mid-19th century. The Doeppenschmidt house is sma11 and has few associated structures; it is probably a secondary residence associated with a primary central residence elsewhere, most likely the Toepperwein house. The Oppenheimer site is a large foundation with two centralized chimneys and associated outbuildings at some distance. Finally, the Comanche Spring site has a mid-19th century component, probably the house of John Meusebach, and a late 19th century component, the home of Conrad Schasse. Taken altogether, the sites are a very non-homogeneous group.

The Schmidt houses come closest to our original concept of an extended German community, but neither they nor any of the sites show any design characteristics or artifact selection which would imply a central European cultural bias.

The conclusion we must reach, then, is that the inhabitants of these sites were as diverse in outlook and subsistence pattern as the sites they left behind are diverse. The cultural background seems to be that of generally Anglo-American middle-class farmers and ranchers. 

PART III

THE CAMP BULLIS STUDY

SECTION C

HISTORY OF CAMP BULLIS 



\section{C \\ HISTORY OF CAMP BULLIS}

Sara E. Kleine

During the turbulent years between the war for Texas independence (1836), the creation of the State of Texas (1845), the Civil War (1861-1865) and the Spanish-American War (1898), there were continual threats of Indian attack and Mexican invasion. Recognizing the danger to this area, Camp Funston, named for General Frederick Funston who was the commanding general of the Southern Department at the time, was established near Leon Springs in 1906. Camp Funston, described as "the Military Reservation near Leon Springs" on a tactical map dated 1908, was used about three months a year as a temporary maneuver and training area by the Third Brigade, Maneuver Division.

In 1915 conditions with Mexico grew worse, causing an influx of military forces to the area. Upon recommendation of the commanding general, Southern Department, Camp Bu11 is was estab7ished on September 16, 1917, as a maneuver ground and target range. The original authorization for expenditure of $\$ 376,941.00$ to acquire 16,000 acres was reduced to $\$ 95,000.00$ to acquire no more than 5,000 acres.

The land was to be adjacent to Camp Funston and was intended to extend the boundary in a southerly direction to within 10 miles of Fort Sam Houston, thus making it an easy march for infantry troops. Portions of the additional area were intended also to be used for grazing purposes.

At first the commanding general, Southern Department, was authorized to lease this land; outright purchase was deferred until adequate water supplies could be determined. When a successful well was drilled in 1919, the commanding genera1, Southern Department, recommended that certain tracts be purchased. A target range, the only adequate target range in the vicinity, and a 40-foot roadway were constructed to be used during World War I.

With numerous small land purchases since then, the Camp Bullis area now consists of 28,021 acres. The last purchase of 2,200 acres in 1941 extended the reservation north of Cibolo Creek. Various land easements for road improvement and the parks have returned approximately 662 acres of the original 32,700 acres to public use.

Camp Bullis is named for John Lapham Bullis, a New Yorker who joined the Army during the Civil War, served on the Texas border from 1865-1866 and entered the Regular Army in 1867. The rest of his career was spent in Indian warfare where he won state and national recognition and a resolution of thanks. In 1897 Bullis was promoted to major and made paymaster at Fort Sam Houston; in 1905 he was promoted to brigadier general by President Theodore Roosevelt. Bullis retired from service the very next day, at his own request. In addition to Camp Bullis, a town in southern Val Verde County and the Bullis Gap Ridge in eastern Brewster County were named in his honor. 
Although Camp Bullis is on the inactive list of installations, it is a very active sub-post of Fort Sam Houston. It hosts in excess of 458,000 people annually for recreation or training, including such groups as the Boy Scouts, city, county and state police units, the FBI, the Secret Service, the Active Army and Air Force, Army Reserve, National Guard and Marine Reserve.

The mission of Camp Bullis has not changed from the original plan to serve as a maneuver and target ground, although the Army has added the monitoring of a program of conservation and protection of wildlife and control of its harvest on the reservation.

Although its contribution as a military establishment has decreased somewhat in comparison to that of other facilities, Camp Bullis is also serving the four Air Force bases located in and around San Antonio as well as the Academy of Health Sciences.

References consulted for preparation of this section were: Anonymous (n.d.), Anonymous (1971), Doss (n.d.) and Franklin (1939). 
PART IV

THE FORT SAM HOUSTON STUDY

SECTION A

ARCHAEOLOGICAL RESOURCES 

IV. A

ARCHAEOLOGICAL RESOURCES

Cristi Assad

\section{INTRODUCTION}

Fort Sam Houston, located within the city limits of San Antonio, Texas, has 3,287 acres and is 4.25 miles long and 1.50 miles wide. Military activities at Fort Sam Houston are "primarily administrative, medical, educational/ training and residential" (Freese and Nichols, Inc. 1977:9).

\section{ENV IRONMENT}

A brief discussion of the climate, geology, geography, flora and fauna will be presented here. This is covered in more detail in III.A.2, in reference to Camp Bullis.

San Antonio is located at the northern edge of the Coastal Plain Province (Carr 1967). Geologically, Fort Sam Houston is composed of alluvial deposits which have poor drainage characteristics (Freese and Nichols, Inc. 1977). Salado Creek is the major drainage through the Fort. The major source of water at the point that Salado Creek runs through Fort Sam Houston is from runoff. An artesian well on the property adds to the water volume (ibid.).

The climate of the area is "modified subtropical," the same as that described for Camp Bullis. According to Blair (1950), San Antonio is in the northern part of the Tamaulipan Biotic Province and is bounded on the north by the Balconian province at the Balcones Fault Zone. The predominant vegetation of the Tamaulipan province is thorny brush. Table 1 (III.A.2) lists plants typical of Bexar County, and Camp Bullis and Fort Sam Houston in particular, which may have been utilized by the native peoples.

The fauna of the area would have been closely related to that found in the Camp Bullis area (Table 2, III.A.2), al though the majority of the Tamaulipan fauna consists of grassland species. The modern fauna of Fort Sam Houston is covered in detail in the environmental statement by Freese and Nichols, Inc. (1977).

\section{ARCHAEOLOGICAL RESOURCES}

The sites recorded on Fort Sam Houston (41 BX 194, 41 BX 389 and $41 \mathrm{BX} 422$ ) are all fairly close to each other (Fig. 73). They are all located on the flood plain of the Salado Creek or its tributaries.

Site 41 BX 422 is located south of Winans Road on the east side of the MARS Radio Station tower field. It lies approximately $100 \mathrm{~m}$ south of $41 \mathrm{BX} 305$ which is located in John James Park (Frkuska et al. 1977). 41 BX 305 was 


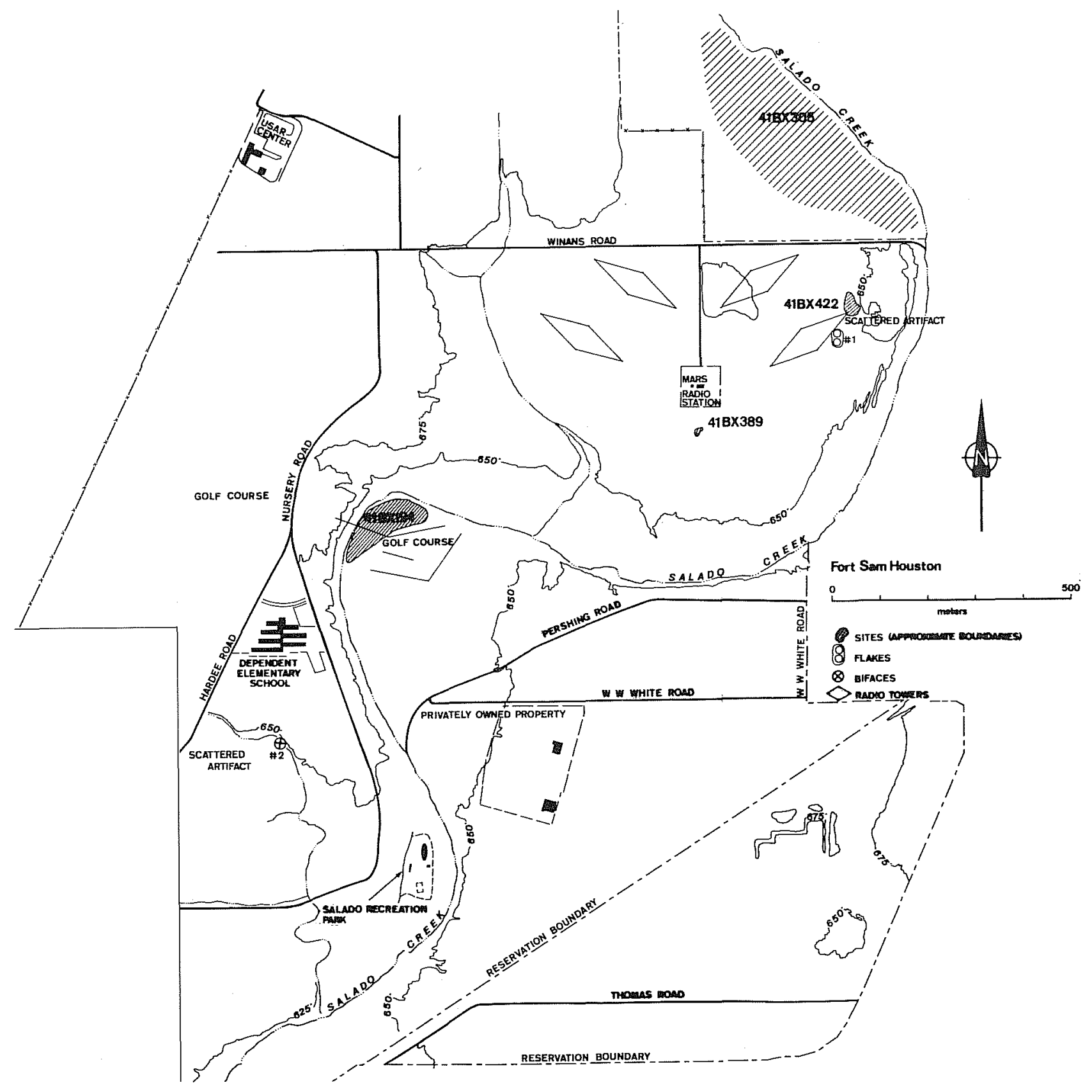

Figure 73. Locations of Archaeological Sites and Scattered Artifacts at Fort Sam Houston. Major contour lines, creeks, roads and other landmarks are also shown. 
reported as extending to Winans Road. The relationship between the two sites is currently unknown. An artifact scatter (\#1) is located $100 \mathrm{~m}$ south of $41 \mathrm{BX} 422$ and is probably related to it.

Site 41 BX 389 , likely a temporary campsite, is located approximately $200 \mathrm{~m}$ southwest of 41 BX 422 and less than $50 \mathrm{~m}$ south of the MARS Radio Station.

Site $41 \mathrm{BX} 194$ is located on a bend of Salado Creek approximately $3.2 \mathrm{~km}$ downstream from 41 BX 305 in John James Park. In 1974, 41 BX 194 was discovered and recorded as a major prehistoric site: (Hester 1974a; Fig. 74,a). Extension of the golf course across the Salado Creek from its planned boundaries caused extensive damage to, and possibly destroyed, the site. No evidence of $41 \mathrm{BX}$ 194 was found during the present survey. The State Archeologist and the National Park Service were notified in 1974 of the destruction of 41 BX 194 and both agencies were genuinely concerned. Steps taken to halt the damage and blatant destruction met with little cooperation or sensitivity on the part of the military authorities at Fort Sam Houston (T. R. Hester, personal communication).

The only other recorded artifact scatter (\#2) on Fort Sam Houston is on a small tributary of Salado Creek. Two quarry blanks were found in the bottom of the stream bed and were probably in secondary deposits.

\section{CONCLUSION}

A $100 \%$ survey for historic and prehistoric sites was conducted on Fort Sam Houston. Three sites (including $41 \mathrm{BX}$ 194, recorded in 1974) and two artifact scatters were documented.

All of the sites recorded are very close to Salado Creek. Extensive use and modification of Fort Sam Houston is a definite factor when considering the scarcity of archaeological resources along this section of Salado Creek. III.A.3 discusses in detail the density and variety of archaeological resources along Salado Creek, including Fort Sam Houston. Salado Creek was unquestionably an area of long and intensive human habitation.

\section{SITE SUMMARY}

\section{BX 194}

Location: Terrace site; Salado Creek at edge of the site. Elevation: 630' Environment: Area of large trees and riparian vegetation. The site is now a golf course.

Description: An extensive terrace site which has been either completely destroyed by military construction activity or has been covered with fill; as a golf course was built upon the site after 1974. In 1974, several in situ 


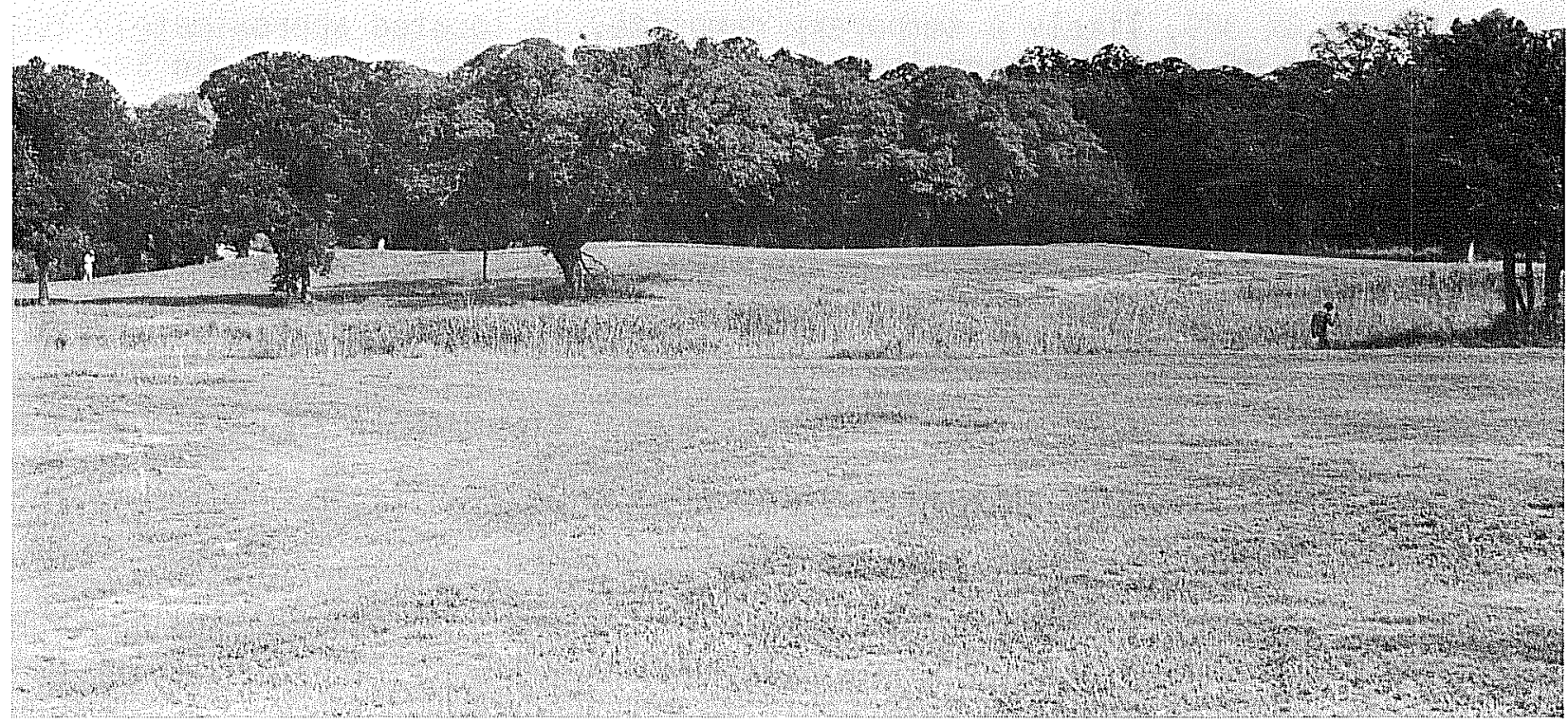

2.

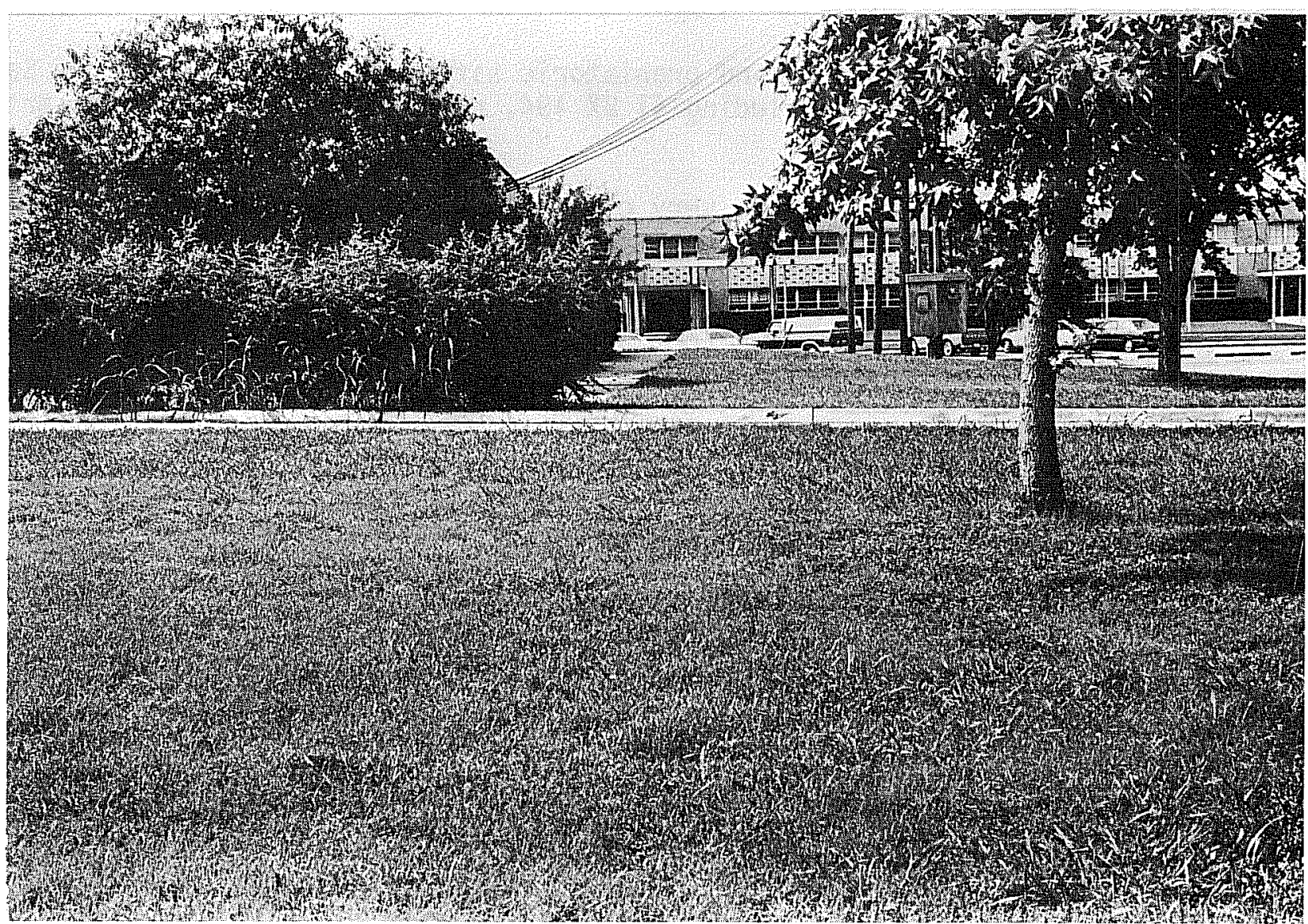

b

Figure 74. V iews of Areas Surveyed, Fort Sam Houston Project. a, view of the area in which site 41 BX 194 was once located, Fort Sam Houston; b, view of the Pasadena, Texas, USAR Center. 
hearths, burned rock scatters, extensive lithic scatters and faunal material were reported. Some of the artifacts collected in 1974 represent the Middle and Late Archaic (Abasolo, Tortugas dart points) and the Late Prehistoric (bone-tempered potsherds and Scallorn and Perdiz arrow points) periods.

Investigation: The area was surveyed but only a few flakes were observed. Site Type: Multi-component habitation site with Middle and Late Archaic and Late Prehistoric occupations.

\section{BX 389}

Location: Flood plain, with water within $1 \mathrm{~km}$. Elevation: 670'

Environment: A reddish clayey soil with some depth. The vegetation consists of woods of live oak, hackberry, huisache, cedar and elm.

Description: Dimensions for the site are $60 \times 40 \mathrm{~m}$. Surface artifacts are widely scattered and include cores, flakes and burned rocks.

Investigation: The area was surveyed. No artifacts were collected.

Site Type: Habitation site of unknown occupation period.

\section{$41 B \times 422$}

Location: Flood plain; Salado Creek is within $1 \mathrm{~km}$. Elevation: 670'

Environment: The soil is a reddish clay and has considerable depth. Vegetation consists of live oak, hackberry, huisache, cedar and elm.

Description: Dimensions of $40 \times 60 \mathrm{~m}$ were determined for this site. The surface is a thin scatter of a few flakes, two core fragments and a unifacial ovoid scraper. There is a heavy grass cover throughout the area. A horse riding trail cuts through the site, with a mowed field on one side and thick grass on the other.

Investigation: The area was surveyed and a map was drawn of the site location. No artifacts were collected.

Site Type: Probably a temporary campsite or plant collecting site of unknown occupation.

\section{Artifact Scatter Summary}

Scattered Artifact \#1

Location: Flood plain, with Salado Creek within $1 \mathrm{~km}$. Elevation: 670' 
Environment: Soil is reddish clay. Vegetation consists of live oak, hackberry, huisache, cedar and elm.

Description: The materials consisted of one biface, one core, one thick, possibly worked flake and one chunk. The area is completely disturbed by military activity.

Investigation: Area surveyed. Nothing was collected. May be part of or related to 41 BX 422 or 41 BX 389.

Scattered Artifact \#2

Location: Flood plain, in a side drainage of Salado Creek. Elevation: 645'

Environment: Black loamy soil with some depth. Vegetation consists of woods of live oak, hackberry, cedar and elm.

Description: Two quarry blanks were found in a drainage bottom within $20 \mathrm{~m}$ of each other.

Investigation: The two artifacts were collected. They are probably from a secondary deposit. 
PART IV

THE FORT SAM HOUSTON STUDY

\section{SECTION B}

HISTORY OF FORT SAM HOUSTON 
IV. B

\section{HISTORY OF FORT SAM HOUSTON}

Sara E. Kleine

Military contingents from Spain, Mexico and the Republic of Texas have occupied the San Antonio area since 1718; the first troops from the United States arrived in 1846. These federal troops occupied various facilities in the rebuilt Alamo and the San Antonio Arsenal. Then, in 1870, Fort Sam Houston was established and today serves as Headquarters, Fifth U.S. Army.

With its inception in 1870, the Post of San Antonio, or Fort Sam Houston as it is known now, has enjoyed a rich history filled with colorful people and exciting events. It has made many cultural, as well as military, contributions to the city, state and country, which is why a large part of it is included in the National Register of Historic Places.

The Post of San Antonio was created as a permanent army post with the original donation of 40 acres in 1870, an additional 43 acres in 1871 and another nine in 1875, all given by the city of San Antonio to the War Department. Construction of the first building, the Quadrangle, began in 1876, and upon its completion in 1879 the troops began moving in. The Post's first mission was that of Quartermaster Depot, but the troops were assigned to patrol and protect the border and settlers from Indian raids. In 1886, Geronimo, the Apache chief, and his small band were captured, moved to the fort, and imprisoned for 30 days in the Quadrangle until they were transferred to Florida.

In 1890 the Post of San Antonio was renamed Post Sam Houston in honor of General Sam Houston who had been the Commander in Chief of the Army of the Republic of Texas. Later that year it was changed from Post to Fort Sam Houston by order of the War Department.

With the outbreak of the Spanish-American War in 1898, the 18th Infantry Regiment and the 5th Cavalry were sent to New Orleans to protect the United States from possible invasion by Spain. This nearly emptied the post until the first contingent of the First Voluntary Cavalry, popularly called the "Rough Riders," arrived from Arizona. Commanded by Colonel Leonard Wood and Lieutenant Colonel Theodore Roosevelt, the group completed its training and readied itself for departure to Cuba. After the end of the Spanish-American War, the quartermaster depot began equipping and supplying U.S. troops who were en route to the Philippines to squelch the insurrection there.

During a review and inspection in 1904, the Department Commander reported: "Military appearance and marching generally good . . . Quarters and other buildings in from fair to good condition. Necessary repairs under way . . The officers and men appear to be efficient and generally well enough drilled and instructed for usual field duties and tactical exercises . . . . The affairs of the post are efficiently administered by the able post commander, Colonel Constant Wi11iams, 26th Infantry" (Lee 1904:30).

Between the Spanish-American War and World War I, Fort Sam Houston grew to be the largest military installation in the United States. The initial building 
program included the Quadrangle and Clock Tower and four groups of buildings, including the Staff Post, Infantry Post, Artillery Post and Cavalry Post. Each group of buildings is visually related to the Quadrangle and reflects an aspect of the post's history and the varying architectural styles of the day. The groups cover approximately 400 acres including 130 major historic structures.

After the turn of the century, additional important buildings were added, such as the hospital and permanent associated hospital buildings. The Post Chapel was funded by the citizens of San Antonio and the garrison of Fort Sam Houston.

In 1910 Lieutenant Benjamin F. Foulois, a Signal Corps officer, made the first military flight in a Wright Brothers plane which had been purchased by the War Department and restored by Foulois. Active years were 1916 and 1917 as there were 13,000 National Guard troops trained on post. At this time General John J. Pershing led the "Punitive Expedition" from Fort Sam Houston, and an additional 1016 acres were bought to accommodate his troops. With America's entry into World War I, still more acreage was acquired and designated as Camp Travis, making Fort Sam Houston one of the largest National Army Cantonments. At the end of the war, Camp Travis was absorbed into Fort Sam Houston and demobilization began.

The public works projects of the Depression stimulated the building of barracks and quarters. Shortly thereafter, the Post Theater was built. By this time the post had grown from the original 40 acres to over 3000 . In 1937 Brooke General Hospital, later changed to Brooke Army Hospital, was built. In 1946 Brooke Army Medical Center was established, and there have been many additions to the medical facilities up to the present.

Of particular importance is the fact that almost half of the troops (5 out of 11) activated or reactivated for the entrance of the United States into World War II in 1941 were organized at Fort Sam Houston. During this confrontation, Fort Sam Houston held a position as one of the major training centers for the Fourth U.S. Army Headquarters, which encompassed an area of over half a million square miles in five states.

In 1971, the Fourth U.S. Army was deactivated and the Fifth Army Headquarters, having a 13-state responsibility, was transferred to Fort Sam Houston. Since then, some major command changes have occurred at Fort Sam Houston as a result of the reorganization of the Army.

In observation of the historical as well as the military value of Fort Sam Houston, about 550 acres of the reservation were declared a National Historic Landmark. This includes some especially interesting buildings such as the Quadrangle and Clock Tower, the Pershing House (Staff Post 6), the Eisenhower House (Quarters 179) and the Memorial Chapel (Building 2200).

The Quadrangle is significant as the first building constructed at Fort Sam Houston. Begun in 1876 and completed in 1879, it was constructed of gray limestone and measures 624 feet along each side. The south side has two stories containing offices, while the east and west sides are single stories 
containing shops, sheds and warehouse space. The north side is formed by a high wal1. The clock Tower is also constructed of gray limestone and measures 15 feet square and approximately 90 feet high. This structure houses a clock with a face on all four sides, a sentry station and a water tank.

Once the quartermaster depot and the Department of Texas headquarters were established at the post, additional facilities were needed. In 1881, 15 sets of quarters were built on Staff Post to accommodate the officers. A11 were designed by the outstanding English-Texan architect Alfred Giles. Quarters 6 (originally Quarters 1) has always housed the post's senior ranking officer. It is often called the Pershing House in reference to its most prominent resident, John J. Pershing, even though Pershing lived there for only three months in 1917. Structurally the Pershing House is unique among Fort Sam Houston buildings and is considered by many to be the most attractive and interesting. It contains 10,830 square feet of basement, floor and porch space in two irregularly shaped stories with a decorated gallery extending across the front and two sides.

Of special significance is the familiar story of Dwight Eisenhower and Mamie Doud's first meeting and subsequent early years of marriage on the post in what is known as the Eisenhower House. This was one of 20 quarters utilizing one of two floor plans. One plan provided 7,355 square feet of floor space for 14 of the family quarters; the other provided 6,329 square feet of floor space for the remaining six quarters. Al1 were similar in appearance and design.

San Antonians dedicated the funds and land for the construction of the Memorial Chapel, which was personally dedicated by President William Howard Taft in 1909. The chapel is an irregularly shaped, white painted brick building containing more than 21,000 square feet. Outstanding features include 22 stained glass windows set in flat-arched openings, a copper dome and bracketsupported entablature and parapet extending completely around the roofline.

Fortunately, all of these buildings remain intact and virtually unchanged, except for some necessary remodeling. Many of the early vintage barracks, officers' quarters and other buildings are still in use.

Today Fort Sam Houston is a vital military installation serving a modern Army. It is an open base and maintains a museum for the public.

References consulted in the preparation of this section were: Adams (1974), Doss (n.d.), Emery (1976), George (1977), Lee (1904) and Meyer (1974). 



\section{PART V}

STUDIES AT FORT SAM HOUSTON PROPERTIES: U.S. ARMY RESERVE CENTERS AND CANYON LAKE RECREATION AREA

SECTION A

ARCHAEOLOGICAL RESOURCES 

V. A

ARCHAEOLOGICAL RESOURCES

Cristi Assad

An intensive survey was made of the 22 USAR Centers and the Fort Sam Houston Recreation Area on Canyon Lake. No previously unrecorded historic or prehistoric sites were found at any of the locations.

There was a thick grass cover (1awn) on the majority of the USAR Center properties. Many of the USAR Center sites also had areas of fields with highgrowing grasses and weeds. This inhibited on-the-ground survey.

The USAR buildings are made of brick and most were built within the last 20 years (Fig. 74,b). Table 36 shows the information recovered from the survey and significant historic sites with which the USAR Centers are associated. See Figure 75 for the locations.

There was one isolated piece of worked chert (scattered artifact), a unifacially flaked side-and-end-scraper, found in a field at the USAR Center on New Callaghan Road in San Antonio. No other artifacts were found, possibly due to extensive disturbance by heavy machinery in the immediate areas.

Despite the fact that no archaeological information was recovered at any of the USAR Centers or the Fort Sam Houston recreation facility at Canyon Lake, there are many archaeological sites throughout southern and coastal Texas. Human occupation has been continuing in the Rio Grande Plain since the PaleoIndian period with sites near cities such as Corpus Christi, Victoria and Falcon Reservoir near Rio Grande City, among others (Hester 1976a). Texas Southmost College, Brownsville, is currently excavating at Fort Brown, where the college is located (Yolanda Gonzalez, personal communication). The Center for Archaeological Research, UTSA, has excavated at Fort McIntosh in Laredo, Texas (Ivey, Medlin and Eaton 1977).

Briggs (1971b) provides data on known archaeological resources by county for the coastal lowlands and littoral. Hester (1976b) and Corbin (1976) provide information on the Archaic period, specifically dealing with the Texas coast and southern Texas respectively.

It is possible that buried sites exist on some of the USAR Center properties. If modification is undertaken and any such sites are located, the appropriate authorities and archaeologists should be notified. 


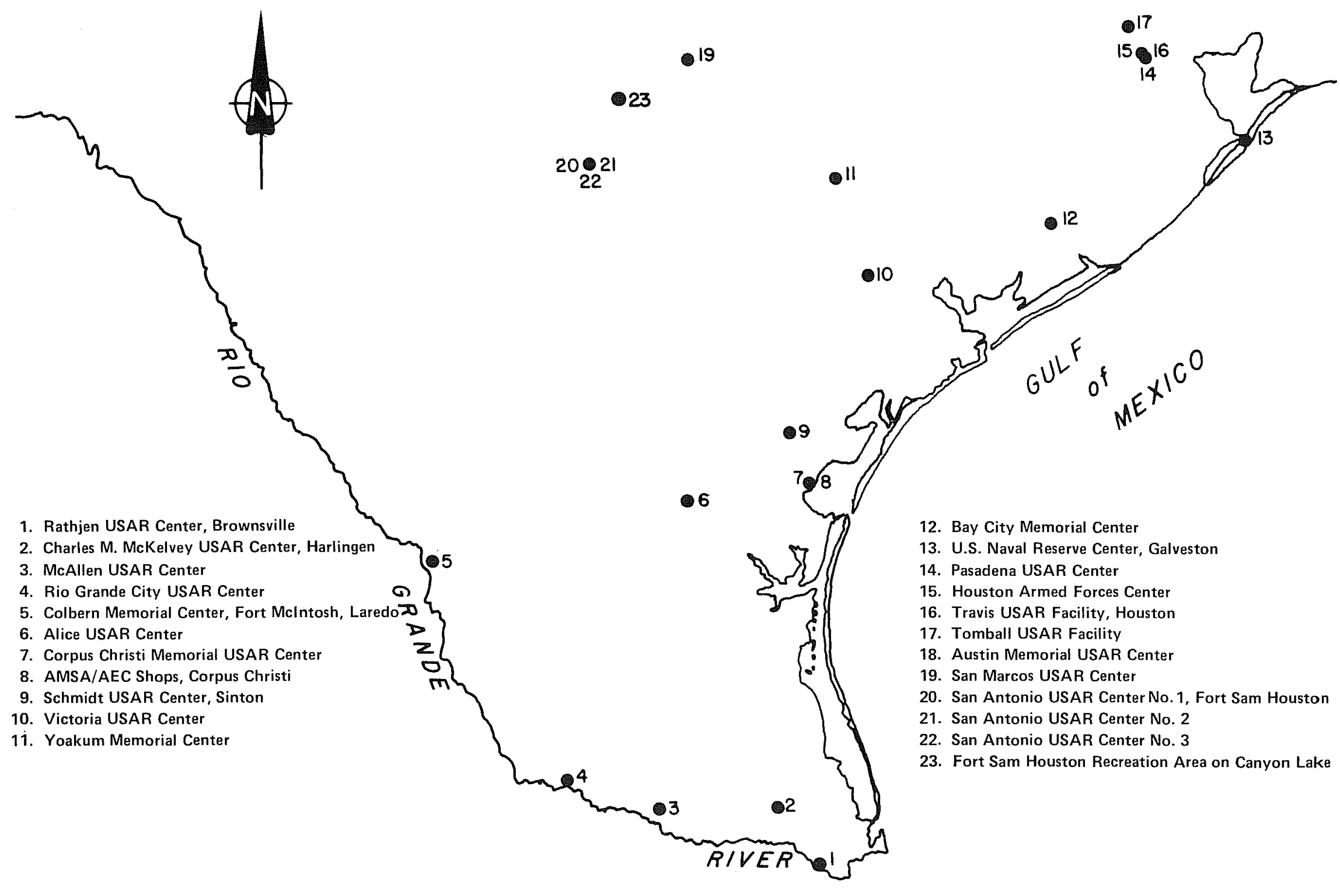

1. Rathjen USAR Center, Brownsville

2. Charles M. McKelvey USAR Center, Harlingen

6. Alice USAR Center

. Corpus Christi Memorial Us

10. Victoria USAR Center
Figure 75. Locations of USAR Centers and the Fort Sam Houston Recreation Area. 
TABLE 36. FORT SAM HOUSTON PROPERTIES: USAR CENTERS AND CANYON LAKE RECREATION AREA

Facility

Alice USAR Center

Austin Memorial USAR Center

Bay City Memorial USAR Center

Rathjen USAR Center

Corpus Christi Memorial USAR Center AMSA/AEC Shops

US Naval Reserve Center

Charles M. McKelvey USAR Center

Houston Armed Forces Center

Travis USAR Facility

Colbern Memorial USAR Center

McAllen USAR Center

Pasadena USAR Center

Rio Grande City USAR Center

San Antonio USAR Center No. 1

San Antonio USAR Center No. 2

San Antonio USAR Center No. 3

San Marcos USAR Center

Schmidt USAR Center

Tomba11 USAR Facility

Victoria USAR Center

Yoakum Memorial Center
Address

100 Stadium Drive

4601 Fairview Drive

1209 Tenth Street

340 Porter Street

4722 McArdle Road

5568 Ayers Street

5301 Avenue S

1920 E. Washington St.

1850 01d Spanish Trail

2800 Travis Street

B7dg.P-50, Fort McIn.

600 South 2nd Street

3705 San Augustine Ave.

2222 East Highway

2010 Harry Wurzbach Rd。

432 Boswell Street

3100 New Callaghan

631 E. Hopkins Street

2000 Highway 77 South

PO Box N Hooks Airport

406 N. Ben Jordan St.

705 Yoakum Street

\begin{tabular}{r} 
\\
Acre \\
\hline \\
4 \\
10 \\
3 \\
4 \\
5 \\
2 \\
1 \\
6 \\
8 \\
7 \\
6 \\
3 \\
5 \\
4 \\
5 \\
5 \\
5 \\
4 \\
5 \\
5 \\
4 \\
4
\end{tabular}

Archaeologica 1

City

Sites

Associated

Historical

Alice

Austin

Bay City

Brownsville

Corpus Christi

Corpus Christi

Galveston

Harlingen

Hous ton

Hous ton

Laredo

McAllen

Pasadena

Rio Grande

San Antonio

San Antonio

San Antonio

San Marcos

Sinton

Tombal1

Victoria

Yoakum 0
Camp Mabry

Fort Brown

Fort McIntosh

Fort Ringgold

Fort Sam Houston

Fort Sam Houston Recreation Area on Canyon Lake

*Scattered Artifact 



\section{PART V}

STUDIES AT FORT SAM HOUSTON PROPERTIES: U.S. ARMY RESERVE CENTERS AND CANYON LAKE RECREATION AREA

SECTION B

HISTORICAL BACKGROUND 



\section{B \\ HISTORICAL BACKGROUND}

Anne A. Fox

\section{INTRODUCTION}

This section includes a brief history of each town in which a USAR center is located, with special reference to the relationship of the center, where pertinent, to historic sites in the area. Numerous more detailed sources for the town histories in question are included in the Historical Bibliography at the end of this report (VII.B). The location of each of the USAR Centers can be found in Table 36.

\section{RATHJEN USAR CENTER, BROWNSVILLE}

Brownsville, on the north bank of the Rio Grande in southern Cameron County, was named in honor of Major Jacob Brown, who died while defending the fort constructed by Zachary Taylor when the Army of 0ccupation reached the Rio Grande in 1846. In 1848 the town became the county seat of the newly created Cameron County.

Soon after Major Brown's death, the original fort was named Fort Brown. The structure had earthen walls more than nine feet high, six bastions and a 15-foot parapet, and was surrounded by a ditch 15 feet deep and 20 feet wide. The battles of Palo Alto and Resaca de la Palma in 1846 were fought when Mexican troops attempted to intercept American supply trains going from Point Isabel to the fort. The Mexicans also bombarded the fort from Matamoros, across the Rio Grande.

In 1848, quarters for officers and enlisted men and a permanent post were constructed a quarter of a mile north of the first fort. The new fort, designated Brownsville Barracks, was in service until the Civil War, when the United States troops were replaced by Confederate Texans. Except for a brief period in 1863-64, the Confederates held the fort until the end of the war.

Permanent buildings, including the post hospital, administration building and chape1, were built in 1869. Many of the buildings were destroyed by a hurricane in the fall of 1876, but barracks and quarters for six companies were erected on the original site in 1888. The new post was named Fort Brown, after the original fort which in later years was used as a backstop for the firing range.

Fort Brown was hit by another destructive hurricane in 1933 which necessitated reconstruction of many of the buildings. The fort was inactivated in 1944, and in 1948 the old post hospital was granted to the Brownsville School District for the use of Texas Southmost College, and the front 162 acres were deeded to the city of Brownsville. 
The Rathjen Center is located in one of the buildings reconstructed in 1940 after the 1933 hurricane. The site is a part of the old fort and probably contains remains of earlier structures beneath the surface (see VI.B).

Sources consulted: Chatfield (1893), Sides (1942), Webb (1952), Branda. (1976) and survey field notes on file at the Center for Archaeological Research, UTSA.

\section{CHARLES M. MCKELVEY USAR CENTER, HARLINGEN}

Harlingen, located in western Cameron County, was begun in 1905 when the Gulf Coast Railroad line reached a townsite which had previously been laid out by Lon C. Hi11. Hill had moved to the area in 1901. However, the town's real growth did not begin until 1927. Situated at the crossing of two main highways and two major railroads, Harlingen today is a major distribution and transportation center for the southern tip of Texas.

Harlingen Army Air Field, located three miles northwest of the town in 1941, was in operation until 1946. It was reopened as Harlingen Air Force Base from 1952 to 1963. The site is now occupied by the Marine Military Academy.

No historical significance has been determined for the site of the Charles M. McKelvey USAR Center.

Sources consulted: Webb (1952), Branda (1976) and survey field notes.

\section{MCALLEN USAR CENTER}

McAllen, in southern Hidalgo County in the lower Rio Grande Valley, was founded in 1904 as a stop on the St. Louis, Brownsville and Mexico Railroad. By 1906, an irrigation system had been laid out and crops were being shipped on the new railroad. It soon became a center for production and processing of fruits and vegetables. With the discovery of oil in the vicinity, it became a center for production of farm chemicals and petroleum products as well.

The MCAllen USAR Center is located on land which was previously an orange grove. No historical significance is known for the site.

Sources consulted: Webb (1952), Branda (1976) and survey field notes.

\section{RIO GRANDE CITY USAR CENTER}

Rio Grande City was a part of José de Escandón's original colony in 1753. In 1847, Henry Clay Davis, an adventurer from the United States, established a town on the site, calling it Ranch Davis. The town became an important stop for river traffic.

In 1848, Zachary Taylor established Fort Ringgold as protection for the local settlers against border bandits and Indian raids. The original fort, built 
of adobe, was located near the bank of the Rio Grande, east of the town. Fort Ringgold was alternately occupied and deactivated until 1946, when it was purchased by the Rio Grande City Consolidated Independent School District. Many of the old fort buildings are now used by the School District as classroom and administration buildings for the elementary, junior high and high schools.

The Rio Grande City USAR Center is located on land which was once part of the cavalry riding school for Fort Ringgold. The Center's building, constructed in the 1950s, has no historical significance.

Sources consulted: Garza and Guerra (1977), Rex and Garcia (1976), Webb (1952), Branda (1976) and field survey notes.

\section{COLBERN MEMORIAL USAR CENTER, LAREDO}

Laredo was established in 1755 when Tomás Sánchez was granted permission by José de Escandón to form a settlement north of the Rio Grande in a bend of the river. A mission was established there in 1762 when the site was named Villa de San Agustin de Laredo, and the town became a major crossing on the trail from Mexico to San Antonio and east Texas. The area was considered a part of Mexico until 1846, when the Texas Rangers raised the U.S. flag over the town, and Mirabeau B. Lamar took command of the town for the duration of the Mexican War. The Treaty of Guadalupe Hidalgo in 1848 established the boundary between the U.S. and Mexico at the Rio Grande, and Laredo officially became the county seat of Webb County the same year.

The Colbern Memorial USAR Center occupies a stone building built by the WPA in 1942 on the northern edge of Fort McIntosh. Fort McIntosh, first called Camp Crawford, was established west of Laredo in 1849, when U.S. troops entered the town at the end of the Mexican War. The name was changed to Fort McIntosh in 1850, at the time of construction of the first fort, a star-shaped earthwork on a bluff overlooking the river. In 1850 the fort was abandoned, and the buildings reverted to the town of Laredo. However, by 1859, the fort was reoccupied by two companies of the First Infantry.

Confederate forces took possession of the fort in 1861, turning it back to United States troops in 1865. At this time a new post was built half a mile to the south, and various changes and improvements were constructed in the late 19 th century.

The site of Fort McIntosh was discontinued as an army post in 1946, and many of the buildings are presently incorporated into the campus of Laredo Junior College and Texas A\&I at Laredo.

The Colbern Memorial Center is located on a part of the fort which was probably not developed until the railroad went through in 1882. Railroad construction and subsequent use have thoroughly disturbed the area. The building in which the center is established was built by the WPA in 1942 and has no historical significance.

Sources consulted: Thompson (1974), Webb (1952), Branda (1976), Wilkinson (1975) and survey field notes. 


\section{ALICE USAR CENTER}

The town of Alice, 42 miles west of Corpus Christi, was founded in 1888 as a depot for the San Antonio and Aransas Pass Railway Company. According to tradition, it was first named Bandana and later changed to Kleberg. Between 1890 and 1895 it was a shipping center for cattle ranchers of the region.

In 1904 the town was incorporated and the name was changed to Alice, in honor of Alice King Kleberg, daughter of Richard King of the King Ranch which is located nearby. Alice became the county seat of Jim Wells County in 1912.

The site of the Alice USAR Center has no known historical significance.

Sources consulted: Webb (1952), Branda (1976) and survey field notes.

\section{CORPUS CHRISTI MEMORIAL USAR CENTER AND AMSA/AEC MAINTENANCE SHOPS}

Corpus Christi is located at the west end of Corpus Christi Bay in northeastern Nueces County. Henry Lawrence Kinney settled at the site in 1832 and established a trading post. General Zachary Taylor landed at Corpus Christi in 1845 with his American Army of Occupation, on their way to the Mexican War. The city continued to be an Army depot until 1855, when headquarters were moved to San Antonio.

In 1846, Corpus Christi became the county seat of Nueces County. The population and prospects of the town were increased rapidly in 1849 when expeditions were formed there to join the gold rush to California. The port was blockaded by Federal troops during the Civil War and was captured in 1864. By the 1880s the town was a center for processing and shipping hides and other cattle byproducts.

Corpus Christi became a deep-water port in 1926, and soon had become one of the largest ports in volume of business on the Texas coast. It is now an industrial-commercial center for a large area of south Texas.

The Corpus Christi Memorial USAR Center and Shops are located in an area away from the old part of the city, and the sites have no known historical significance.

Sources consulted: Pool (1975), Webb (1952), Branda (1976) and survey field notes.

\section{SCHMIDT USAR CENTER, SINTON}

The town of Sinton, in central San Patricio County, was established as a station on the San Antonio and Aransas Pass Rajiroad in 1885. It became the county seat in 1893. The construction of the St. Louis, Brownsville and Mexico Railroad and subdivision of large ranches in the area into small farms helped cause the population to rise from 100 in 1900 to 800 in 1910. Today Sinton is a center for farming, petroleum and petrochemical buildings. 
No historical significance appears to be attached to the site of the USAR Center.

Sources consulted: Webb (1952), Branda (1976) and survey field notes.

\section{VICTORIA USAR CENTER}

Victoria, on the lower Guadalupe River in Victoria County, was established in 1824 by Empresario Martin de Leon and served as the municipal center for the colony. The town was incorporated in 1839, with John J. Linn as mayor. Trade was conducted with Indianola, Galveston and New Orleans, and the town became a market and distribution center for most of the area, and a provisioning station for military traffic.

Before 1900, the city had become an important crossroads settlement with a population exceeding that of other towns in the area. Development of the oil and gas industry and the location of several major industrial plants nearby have contributed to the town's position as a major regional economic center.

Located some distance from the original town site, the Victoria USAR Center has no known historical significance. The present structure was constructed in 1965 .

Sources consulted: Linn (1886), Victoria Sesquicentennial Scrapbook (1974), Webb (1952), Branda (1976) and survey field notes.

\section{YOAKUM MEMORIAL USAR CENTER}

Located in the western part of Lavaca County, on the DeWitt County line, Yoakum was founded on land granted to John May in 1835 by the government of Coahuila and Texas. The area was a collection point for herds going up the Chisholm Trail, and it was not until the San Antonio and Aransas Pass Rai1- road was built in 1887 that the town was laid out, to be incorporated in 1889 .

In the 1940s, Yoakum was known as the tomato capital of south central Texas. It was also a tannery and meat processing center for the area.

No known historical significance is attached to the Yoakum Memorial Center site. The area was previously used by a paving company.

Sources consulted: Webb (1952), Branda (1976) and survey field notes.

\section{BAY CITY MEMORIAL USAR CENTER}

Bay City was established in northeast Matagorda County in 1894 to replace Matagorda as county seat. The move inland was considered necessary to avoid the storms which battered Matagorda. It is presently a commercial center for nearby petrochemical and petroleum plants as well as for farmers and ranchers in the area. 
The Bay City USAR Center was built in 1960, and the site has no known historical importance.

Sources consulted: Webb (1952), Branda (1976) and survey field notes.

\section{U.S. NAVAL RESERVE CENTER, GALVESTON}

When the first European explorers arrived in the area, Galveston Island was the site of a Karankawa Indian camp. The first European settlement on the is land was the fort of the pirate Jean Laffite in 1817. In 1830, a garrison of Mexican soldiers guarded a customhouse on the island, and by 1832 the community had grown to 300 persons.

In 1836 Galveston became the temporary capital of Texas, when officials of the provisional government attempted to escape the approaching army of Santa Anna. The site of the present city was purchased for development from the First Congress of the Republic in 1836 by Michel B. Menard. Menard set up a post office and customhouse, and the town became an official port of entry in 1837. The city was an important shipping port and metropolis throughout the Republic and early statehood periods.

Continually swept by storms, in 1900 Galveston was badly damaged by a flood and tidal wave in which thousands of lives were 1ost. A seven-mile seawal1, built after this storm, now protects the city.

The former USAR Center has now become the U.S. Naval Reserve Center. It is located well outside of the early part of Galveston, and apparently the site has no historical significance.

Sources consulted: Webb (1952), Branda (1976), Zweiner and Darst (1966) and survey field notes.

\section{PASADENA USAR CENTER}

Located 10 miles southeast of the City of Houston in Harris County, Pasadena was named by surveyors for the Galveston, Harrisburg and San Antonio Railroad which was built through the area in the 1850s. It was a rural post office by 1900 and became a residential suburb of Houston as that city grew into an important industrial center. The town was incorporated in 1943.

No historical importance appears to be associated with the site of the Pasadena USAR Center. The building presently in use was built in 1963 in an old farming area which had recently been used for landfill.

Sources consulted: Webb (1952), Branda (1976) and survey field notes.

HOUSTON ARMED FORCES CENTER AND TRAVIS USAR FACILITY

The settlement of Houston was begun in 1836 as a replacement for the town of Harrisburg, burned by Santa Anna just before the battle of San Jacinto. John 
and Augustus Allen bought the land and laid out the town, naming it for Sam Houston. In 1837 the town was incorporated, and it served as the capital of the Republic until the government was moved to Austin in 1839.

Development of the ship channel began in the 1840s, and by the 1860s Houston had become a major port, served by numerous railroad lines. It became a manufacturing center and, with the development of the oil industry, a major refining and oil field equipment center as we11.

As far as could be determined, neither Reserve facility site in Houston has any particular historical importance. The land upon which the Armed Forces Center was built in 1957 once belonged to George Henry Hermann, a wealthy eccentric who donated Hermann Park to the City of Houston. The Center site lies on the edge of the Pierce salt dome.

The site of the facility on Travis Street was previously a grocery store and, prior to that, an employment office. The Reserve Center took over the site in 1974 .

Sources consulted: Koch (1873), Webb (1952), Branda (1976) and survey field notes.

\section{TOMBALL USAR CENTER}

Located in northern Harris County, Tomball is a retail center for an agricultural and lumbering community on Spring Creek. $0 i 1$ was discovered nearby in 1933. The population has risen from 668 in 1940 to 2734 in 1970.

The Tombal1 USAR Center is located on Hooks Airport. The land is leased from Charles Hooks, owner of the airport which was built in 1965. The site has no known historical importance.

Sources consulted: Webb (1952), Branda (1976) and survey field notes.

\section{AUSTIN MEMORIAL USAR CENTER}

Austin, the county seat of Travis County and the capital of Texas, is located on a bend of the Colorado River in central Travis County. The townsite lies within an eight league grant made to Thomas Jefferson Chambers in 1834. In 1838 Jacob M. Harrel1 moved from the Reuben Hornsby settlement to the south to live in a tent on the north bank of the Colorado, near present Congress Avenue: and became the first settler at the site. As other settlers came, the settlement was named Waterloo.

On the recommendation of Mirabeau B. Lamar, who had visited the site, it was selected to be the permanent capital of the Republic, and construction was begun on government buildings in 1839. After the Mexican invasion of 1842, the capital was moved to Houston, then to Washington-on-the Brazos. In 1845, it was returned to Austin, and in 1850 Austin was made the permanent capital at which time the population was 629 . 
During the Civil War, Austin was the site of Confederate military posts, and citizens served in the Confederate Army and in Terry's Texas Rangers. The first railroad reached Austin in 1871, and a period of industrialization from 1880 to 1900 increased the population to 20,000. World War II saw the construction of Bergstrom Air Force Base at Austin and Camp Swift and Fort Hood nearby.

Camp Mabry, within which the USAR Center is 1ocated, was established in 1890 by the Texas Volunteer Guard, later to become the National Guard. During the First World War it became a federal post. It was reactivated during World War II and served as an induction center and supply depot. The building in which the USAR Center is housed was constructed in 1963, and the site does not appear to have historical significance.

Sources consulted: Pool (1975), Webb (1952), Branda (1976) and survey field notes.

\section{SAN MARCOS USAR CENTER}

Located in Hays County on the old Spanish road to East Texas, San Marcos was named for the river upon which it is 10cated. In 1755, the spot was the temporary location of the San Xavier missions and presidio. The Spanish attempted to start a settlement there in 1808, called San Marcos de Neve. However, floods and Indian attacks forced its abandonment by 1812 .

The land was granted to Juan Martin Veramendi in 1831, who sold it to William Lindsey, Edward Burleson and Eli T. Merriman in 1851 to start a town for the service of settlers who had begun moving into the area. Incorporated in 1877, San Marcos is the county seat for Hays County.

No historical significance is apparently associated with the site of the USAR Center in San Marcos.

Sources consulted: Webb (1952), Branda (1976) and survey field notes.

SAN ANTONIO USAR CENTERS

San Antonio, in Bexar County, originated as the Spanish villa San Fernando de Béxar, the first civil settlement in Texas. The villa was established on the San Antonio River in 1731 at the site of Presidio de Béxar and Mission San Antonio de Valero, established in 1718, and Mission San José y San Miguel de Aguayo, established in 1720. The colonists who made up the settlement were brought from the Canary Islands. Later the same year, three additional missions were moved to the same general area on the San Antonio River.

Constant raiding by Lipan Apache and Comanche Indians throughout the 18th and 19th centuries made life difficult for the city's residents for over a hundred years. Before the early 1800s the population consisted entirely of Mexicans, but after the secularization of the missions, and as Mexico gained independence from Spain in the early 19th century, Texas was opened to colonization from 
the United States and Europe through empresario contracts. At this time, Anglo-Americans gradually began to settle in the town. San Antonio de Bexar changed hands numerous times during the Texas Revolution. Following the defeat of Santa Anna at San Jacinto in 1836, the town was nearly deserted as most of the inhabitants retreated into Mexico.

After Texas achieved statehood, San Antonio became the county seat of Bexar County and began its rapid growth as an Anglo-American town. With the arrival of the railroads, San Antonio quickly became a major shipping point for farm products and cattle. Its location on the cattle trail to Kansas brought a rough era of saloons and bawdy houses in the late 19th century. The energy of the river was harnessed to run numerous mills, and industry slowly began to grow.

Today, San Antonio is a major historical, cultural and international center for the southwest Texas area.

Dodd Field, at Fort Sam Houston, is the location of two USAR facilities in San Antonio. The site began as a camping area for National Guard troops concentrating on the border. Later it was a garrison for units of the Regular Army. In 1916 it contained headquarters of the First Aero Squadron, part of the U.S. Army Signal Corps. In the First World War planes from Dodd Field flew for Pershing in Mexico. During World War II it became a center for draftees and a German prisoner of war camp.

None of the San Antonio USAR Center sites appear to have any particular historical importance in their own right.

Sources consulted: Corner (1890), Ramsdel1 (1959) and Woolford (1963).

FORT SAM HOUSTON RECREATIONAL FACILITY AT CANYON LAKE

The Facility is located on Canyon Lake, a man-made reservoir on the Guadalupe River in northern Comal County. An archaeological survey of the proposed reservoir in 1949 found no historic sites in the area where the Facility is located. The only known historical reference to that portion of Comal County relates to its use as a camping site by Comanche Indians massing for raids on San Antonio in the late 18th century.

No historic sites are known to exist within the Facility.

Sources consulted: John (1975) and Stephenson (1951). 

PART VI

RECOMMENDATIONS

SECTION A

CAMP BULLIS 

VI. A

CAMP BULLIS

Thomas C. KelTy, James E. Ivey and Thomas R. Hester

\section{INTRODUCTION}

The largest site survey units in Bexar County until now have been restricted to the flood pool limits of floodwater retarding structures along the Salado Creek drainage. None of these areas have been larger than 200 acres, thus severely limiting any comprehensive intersite studies. The Fort Sam Houston project has indicated that Camp Bu11is, with 28,021 acres and abundant archaeological resources, is perhaps the last remaining area in the county suitable for studying intersite relationships, settlement and subs is tence systems, distribution of lithic resources and other archaeological problems over a time span from Late Paleo-Indian to Historic times.

In this section of the report, we present our recommendations regarding the cultural resources documented during the Fort Sam Houston project. First of all, we shall present specific recommendations on a site-by-site basis, first for Camp Bullis, and then for Fort Sam Houston and its affiliated Reserve Centers. Finally, we shall offer some thoughts and general recommendations for the long-range protection of prehistoric and historic sites documented during our investigations.

\section{$41 \mathrm{BX} 36$}

The site is the only known major base camp located on Camp Bullis. Despite the damage already done to the site, it contains artifacts of Paleo-Indian through Late Prehistoric times. It could contribute to solving certain problems of inter- and intra-site relationships for not only the Camp But1is area, but also similar sites in south-central Texas.

Recommendation: Nomination to the National Register of Historic Places (hereafter abbreviated National Register), and protection from further disturbance related to military activities. Open area, or block, excavations at the site are recommended. These would serve to mitigate the previous adverse impact caused by illegal relic-hunting and the construction, several years ago, of sewage settling tanks.

\section{BX 372}

This major lithic quarry area and campsite overlooking Georgs Hole was probably the largest and most used aboriginal campsite on Cibolo Creek. The same factors that made it popular with prehistoric peoples have unfortunately made it too popular with civilians and military personnel alike for many decades. Its archaeological value has been destroyed on the surface, and subsurface testing for such a large area is impractical. 
Recommendation: Archaeological area subsurface testing using a powered auger and followed by controlled hand excavations should be done to determine the extent of remaining resources. Collectors, troop maneuvering and any heavy equipment operations should be prohibited in the area until this is accomplished. Nomination to the National Register is recommended.

\section{BX 374}

The site is a lithic scatter in a cultivated field. Plowing and collecting have damaged the site to such an extent that the site type could not be identified. Present utilization of the field will do little further harm to the site.

Recommendation: No action required unless utilization of the field should change. Mitigation would be limited to testing below the plow zone.

\section{BX 375}

This extensive quarry site saw heavy utilization in Pre-Archaic and Late Archaic periods and probably also at other times. Present utilization of the area is not a threat.

Recommendation: Should utilization change, an intensive area survey with mapping of artifact concentration should be carried out. Nomination to the National Register is recommended.

\section{BX 376}

The site is situated on a high overlook. It is a Late Paleo-Indian and PreArchaic campsite buried in a thin soil.

Recommendation: This is a National Register quality site and should be protected (by fencing if necessary).

\section{BX 377}

The site is a buried flood plain Pre- and Late Archaic-Late Prehistoric period campsite with a considerable potential for problem-oriented archaeological research. It is the only deep site located on Cibolo Creek in the survey. The site has already been severely damaged by a deep road cut and must be either protected or mitigated. Erosion and heavy truck traffic will eventually destroy the entire site. Mitigation would involve area excavation of approximately $25 \mathrm{~m}^{2}$.

Recommendation: Nomination to the National Register and a program of preservation or mitigation as soon as possible. 


\section{BX 378 AND 41 BX 379}

These two sites may be treated as a unit. Limited testing revealed the two to be smal1 knapping areas of Late Archaic and Late Prehistoric age. The sites are fragile and would easily be destroyed by military activities. Mitigation would require an intensive surface survey and mapping, with the clearing of the covering vegetation and very shallow soil mantle over an area of approximately $25 \times 50$ meters $\left(1250 \mathrm{~m}^{2}\right)$.

Recommendation: Put area off limits or perform mitigation.

\section{BX 383}

This is an excellent sample of a south-central Texas Late Prehistoric campsite. The sampling (105 one-meter squares) is considered by us to be adequate for the present. This site should be preserved for future archaeological investigation.

Recommendation: Nomination to National Register and immediate protection from alT military activities.

\section{BX 384}

This was an important quarry site area. Further survey and testing could provide more information on the distribution and use of a resource (chert) that is scarce along this portion of Cibolo Creek.

Recommendation: This site should be protected from military activities. If modification of the area is planned, intensive survey and testing should be done.

\section{$41 \mathrm{BX} 385$}

The site is a pure Late Prehistoric, Austin phase site. Depth is only $5 \mathrm{~cm}$ in humus zone. Five $1-\mathrm{m}^{2}$ units were excavated, producing a large but, to us, still inadequate sample. Because of its fragility (much military activity has taken place in the immediate area), mitigation would probably be better than trying to protect the site. Testing and mapping would be preferable to fencing and posting. The area involved is approximately $10 \mathrm{~m}^{2}$.

Recommendation: Further testing and mapping are recommended; possible future disturbance from military activities. Nomination to the National Register is recommended.

\section{BX 395 AND 41 BX 399}

Both are quarry sites and probably located at the major source of large chert nodules in the area. 
Recommendation: Intensive surface survey and mapping of both sites are recommended as this area is continually affected by heavy machinery.

41 BX 404

This large quarry site possesses considerable potential for future studies of 1ithic technology and artifact distribution.

Recommendation: Site is not threatened unless present military use of the area changes.

41 BX 406

Site would be valuable in studies of lithic technology and chert distribution. Site is not currently threatened by military activities.

Recommendation: No further action is recommended unless utilization of this area changes.

41 BX 407

This site is similar to $41 \mathrm{BX} 404$ and $41 \mathrm{BX}$ 406, and can provide valuable information on stone-working techniques.

Recommendation: Site is currently not threatened but should be mitigated if utilization of the area changes.

41 BX 409

This is a campsite with Pre-Archaic and Transitional Late Archaic components associated with the southern Camp Bullis lithic quarry areas. This is also a Boy Scout camping area, and the before-and-after comparison from one of their campouts was appalling in terms of site disturbance. Area has also been heavily utilized by troops, and the site will surely be destroyed unless put off limits. Adequate mitigation would require shallow $(10 \mathrm{~cm})$ test pits covering approximately $100 \mathrm{~m}^{2}$.

Recommendation: Site should either be fenced and placed off limits, or excavations conducted to mitigate continuing adverse impacts. Nomination to the National Register.

41 BX 410, 41 BX 411, 41 BX 412 AND 41 BX 413

These are all discrete quarry areas and are certainly threatened by activities at Camp Bullis. 41. BX 411 is the most important of the four. 
Recommendation: $41 \mathrm{BX} 411$ should be either fenced and placed off limits or mitigated by controlled surface collection. It is of National Register quality. We also urge the protection of $41 \mathrm{BX} 410,41 \mathrm{BX} 412$ and $41 \mathrm{BX} 413$.

\section{BX 414}

This is a quarry site. It is not threatened by current military activities. Recommendation: No further action is recommended unless use of area changes.

\section{BX 415, 41 BX 416, 41 BX 417, 41 BX 418, 41 BX 419 AND 41 BX 421}

A11 are quarry sites in the southeastern portion of Camp Bullis. None are threatened by present activities.

Recommendation: No further action unless use of area changes.

\section{BX 420}

The site has the remains of two houses and associated structures. One of the houses was in all likelihood the home of John 0. Meusebach, a person of importance in the German colonization of Texas. This site is of historical significance and has already been damaged by building construction. The site is within a heavily used training complex, partially beneath a gravel road, and is constantly being exposed to further disturbance.

Recommendation: The site should be recommended to the National Register, and protection or mitigation begun.

\section{$41 \mathrm{BX} 423$}

This is an upland camp and special activity site on a saddle on Davis Ridge in Zone 9 , the impact area. Its time period and exact functions were not identified. There is some depth to it, and it would be highly desirable to know just where it fits into the Camp Bullis archaeological pattern. It is not threatened by present Camp Bullis activity but is being damaged by erosion.

Recommendation: Protect; or, if threatened by destruction, further testing is recommended.

\section{$41 \mathrm{BX} 424$}

This Late Paleo-Indian site at Panther Springs may be completely deflated, but it covered an area too large to test in the present survey. Three Angostura projectile points were found at the site. There may be other Paleo-Indian sites around the Panther Springs vicinity.

Recommendation: Limited testing of the site, and an intensive surface survey in the vicinity. Nomination to National Register. 
41 BX 425

This enigmatic alluvial terrace site is only $40 \mathrm{~m}$ across a ravine from $41 \mathrm{BX}$ 377 , yet based on data from minimal testing, has a much longer archaeological history. Its functions and relationships with other sites in the near vicinity (41 BX 377, $41 \mathrm{BX} 378,41 \mathrm{BX} 379$ ) present a real opportunity to help unravel the complicated archaeological picture of northern Bexar County. Vitally needed radiocarbon samples might be obtained from this site. The site is cut by a jeep road on the west side and by a steep ravine on the east and will inevitably be destroyed by erosion and/or military activities.

Recommendation: Protection or mitigation which would involve excavation of approximately $25 \mathrm{~m}^{2}$ to a depth of one meter. Nomination to National Register is recommended.

41 BX 426

This food procurement and knapping site is possibly associated with the complex of sites $41 \mathrm{BX} 377,41 \mathrm{BX} 378,41 \mathrm{BX} 379$ and $41 \mathrm{BX} 425$. Erosion is damaging the site.

Recommendation: Site should be tested because of erosion. Approximately $25 \mathrm{~m}^{2}$ excavated to a depth of $\mathrm{ca} .25 \mathrm{~cm}$ should be adequate.

\section{$41 \mathrm{BX} 428$}

This is a deep circular burned rock midden found on Camp Bullis, and knowledge of its functions and relationships with 41 BX 36 would be invaluable. The site is in a protected portion of the impact zone (9) and not much threatened by present Camp Bullis activities.

Recommendation: Nomination to National Register and protection from military activities.

\section{BX 429}

This is a quarry site on the Balcones Fault Zone and closest known chert source to $41 \mathrm{BX} 36$. Its relationship with $41 \mathrm{BX} 36$ and other sites needs to be established. The survey area was so high in grass and weeds that it was impossible to evaluate the extent or time period of the site. The site is behind firing ranges (Field Fire \#2) and will be damaged by both impact and erosion.

Recommendation: An intensive survey and limited testing would be the minimal course of action in order to evaluate its National Register potential.

\section{BX 430}

This is a small circular burned rock midden and is as enigmatic as its neighboring site $41 \mathrm{BX} 428$, only a valley to the west. The midden is shallow 
(approximately $30 \mathrm{~cm}$ deep) and no adjacent camp area was found. It may be a completely different type of burned rock midden than 47 BX 428 and should be tested. The site is not threatened by present Camp Bullis activities. However, it is in a more exposed area of the impact zone (Zone 9).

Recommendation: Nomination to the National Register is recommended, as is a testing program.

\section{BX 431}

This is a colluvial terrace site and the only large campsite found along the eastern side of Camp Bullis. It is adjacent to a main road to the Air Force Field Fire and M79 Launcher ranges along Blanco Road and has probably been extensively collected in the past. It is still productive in terms of lithic material and has enough soil depth (approximately $25 \mathrm{~cm}$ ) that significant data recovery could be expected from subsurface testing. It is endangered by collectors and slope erosion.

Recommendation: The site should either be protected and preserved or subjected to a program of limited excavations, mapping and controlled surface collecting.

\section{CM 95}

This site was a house constructed in the 19th century, and occupied or owned by military personnel for most of its existence. It is in a relatively unused part of Camp Bullis.

Recommendation: The site should be nominated to the National Register and further historical research done. If utilization changes, the site should be protected or further mitigation carried out.

\section{CM 96}

The site consisted of patinated debitage and a single projectile point, morphologically similar to the Big Sandy type point. Site is in area flooded by Cibolo Creek and will be either buried or eroded.

Recommendation: Limited subsurface testing.

\section{CM 99}

This discrete small Late Prehistoric site was partially excavated, but the larger surrounding Archaic period component should also be tested. Erosion is the only presently known threat to the site.

Recommendation: Complete excavation of the Late Prehistoric component (approximately $25 \mathrm{~m}^{2}$ to $15 \mathrm{~cm}$ depth) and testing and mapping of the Archaic site. Nomination to the National Register is recommended. 
$41 \mathrm{CM} 101$

Site is a lithic concentration. Flooding of Cibolo Creek during the time of the survey prevented adequate attention to the site.

Recommendation: Site should be re-checked in any future archaeological work at Camp Bul7is.

A number of additional sites listed in Table 37 are judged to be of such a condition that no further work is recommended.

Many of the sites recommended above for protection or mitigation cluster are in a small area along Cibolo Creek. The area is approximately $1 \times 1.8 \mathrm{~km}$ and includes $41 \mathrm{CM} 99,41 \mathrm{CM} 100,41 \mathrm{CM} 101,41 \mathrm{BX} 375,41 \mathrm{BX} 377,41 \mathrm{BX} 378$, 41 BX 379, 41 BX 380, 41 BX 381, 41 BX 382, 41 BX 425 and 41 BX 426 . While a number warrant individual nomination to the National Register, it might be better if a National Register District were created in this area, encompassing all of these sites.

It is also advisable that work begin immediately to protect the archaeological and historical resources identified by this study, both physically (such as fencing and posting of off limits signs) and through new regulations at Camp Bullis. Special efforts must be made to inform all people who handle roadbuilding and heavy equipment to preserve and protect archaeological resources. Borrow pits should never be opened without an archaeological survey of the area, and any future roadbuilding, laying of pipelines, land clearing projects or other modifications of the terrain should be preceded by archaeological investigations. 
TABLE 37. SITES AT CAMP BULLIS AT WHICH NO FURTHER ACTION IS RECOMMENDED*

$\begin{array}{llll}\text { Eroded/ } & \begin{array}{l}\text { Thin, } \\ \text { Severely }\end{array} & \begin{array}{c}\text { Scattered } \\ \text { Deposits }\end{array} & \begin{array}{c}\text { Sufficient } \\ \text { Work Done }\end{array} \\ \text { Site } & \text { Deflated } & \text { Damaged } & \text { Seposits }\end{array}$

41 BX 371

41 BX 373

41 BX 380

41 BX 381

41 BX 382

41 BX 386

41 BX 387

41 BX 388

41 BX 390

41 BX 391

41 BX 392

41 BX 393

41 BX 394

41 BX 396

41 BX 397

41 BX 398

41 BX 400

41 BX 402

41 BX 403

41 BX 405

41 BX 408

41 BX 432

41 BX 433

41 BX 434

$41 \mathrm{CM} 70$

$41 \mathrm{CM} 94$

$41 \mathrm{CM} 97$

$41 \mathrm{CM} 98$

$41 \mathrm{CM} 100$

$41 \mathrm{CM} 102$ $x$
$x$

X

$x$

$x$

$x$

$x$

$x$

$x$

$x$

$\mathrm{X}$

$x$

$x$

$x$

$x$

X

$x$

$x$ $x$

$X$

$x$

$X$

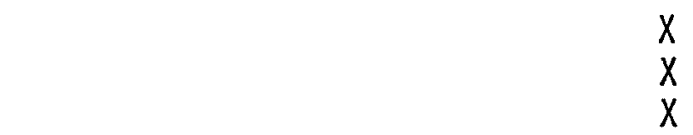

$x$

$X$
$X$
$X$

$x$

X

$x$

$x$

* Reasons for this recommendation are summarized in the column headings.

"Eroded/Deflated" refers to natural processes. "Severely Damaged" refers to recent man-caused destruction, usually the result of military activities. "Thin, Scattered Deposits" refers to the amount of cultural material on the site. 

PART VI

RECOMMENDATIONS

SECTION B

FORT SAM HOUSTON AND

FORT SAM HOUSTON PROPERTIES 



\author{
VI. B \\ FORT SAM HOUSTON AND FORT SAM HOUSTON PROPERTIES \\ Thomas C. Kelly and Thomas R. Hester
}

FORT SAM HOUSTON

No recommendations are offered for prehistoric and historic sites at Fort Sam Houston. The history of the fort is well known and preservation measures of historic buildings have already been taken. The prehistoric sites have already been disturbed to such a degree that only minimal information is preserved.

If any land modification is planned, it is advised that appropriate authorities and a professional archaeologist be notified in the event that a site is uncovered. The probability of such an occurrence is good, considering the intensity of prehistoric and historic land use along Salado Creek. The sad history of the destruction of site 41 BX 194 since 1974 is a case in point.

FORT SAM HOUSTON PROPERTIES: USAR CENTERS AND CANYON LAKE RECREATION AREA

The following centers are located in areas which have historical significance and might possibly contain historic deposits beneath the surface:

Rathjen Center: Fort Brown

Rio Grande City Center: Fort Ringgold

Colbern Memorial Center: Fort McIntosh

Fort Brown and Fort McIntosh are already on the National Register of Historic Places. We recommend that Fort Ringgold also be placed on the National Register. If any subsurface modifications for these above sites are planned, it is advised that they be preceded by historical research and archaeological investigations to insure that any existing remains be properly recovered and preserved. 
PART VI

RECOMMENDATIONS

SECTION C

SOME FINAL THOUGHTS ON PROTECTION

OF CULTURAL RESOURCES 



\section{C \\ SOME FINAL THOUGHTS ON PROTECTION OF CULTURAL RESOURCES}

Thomas C. Kelly and Thomas R. Hester

In various parts of this report, we have noted the effects of military activities on archaeological and historical sites. Particularly disturbing have been the destruction of 41 BX 194 at Fort Sam Houston and the extensive damage caused to 41 BX 36 at Camp Bul1is. At 41 BX 194, the destruction was noted while in progress, but the National Park Service, which sent a representative to meet with military officials at the fort, was unable to stop the bulldozing of this site for use as golf course fill. Site 41 BX 36 was seriously damaged by the construction of sewage settling basins some years ago. However, because it is located close to the Bullis headquarters and was known to be an archaeological site, it has suffered almost as badly from collecting and uncontrolled digging by military personnel.

As we noted earlier, any significant sites once present at Fort Sam Houston (such as 41 BX 194) are now gone. At Camp Bullis, however, sites are numerous and, in general, they are in remarkably good shape and should be protected. The kinds of military activities which have been particularly damaging to some sites include road construction, off-road use of tracked vehicles and vehicular use of trails which has caused increased erosion. At 41 BX 377 , over half of the site was destroyed by a road cut (see Fig. 37). The shallow deposits at some occupation sites, and particularly at quarry sites, have been affected by roads and tracked vehicles (e.g., at sites 41 BX 385). A jeep trail at 41 BX 425 has lead to significant erosion of site deposits. At quarry site 41 BX 429, artillery impact has caused considerable surface damage. In this regard, we must reiterate the fact that we could not, for obvious reasons, survey areas of present-day arti1lery impact. We suspect that numerous sites are still to be found in these areas, and some may possibly be damaged by shelling. Historic sites at Camp Bullis have also suffered (e.g., 41 BX 394, 41 BX 420, 41 BX 432, 41 CM 97). The construction of a training complex and roads has caused particular damage at site 41 BX 420. The use of a part of the base for Boy Scout campouts (in the vicinity of $41 \mathrm{BX} 409$ ) has led to site damage. And, for many years, sites on the base have been extensively surface collected by both military personnel and civilians.

Except for the work reported in this monograph, there is presently no provision for the recording, protection or, where necessary, mitigation of most of the known cultural resources under the control of Fort Sam Houston. Some military bases with large numbers of archaeological sites such as Fort Bliss, Texas, and Fort Hood, Texas, have hired qualified archaeologists to protect these resources. A similar arrangement for the Fort Sam Houston properties would be ideal. However, we feel that it would be satisfactory if a professional archaeologist were to be contracted to provide these services on an as-needed basis, rather than creating a permanent position. This person could provide services when required, such as following up on recommendations stemming from the present project. We believe it would be desirable for a position of "Fort Sam Houston archaeologist" to be established either by creation of a permanent civil service position or on a contract basis. Furthermore, we hope that funds can be provided to implement the recommendations presented here--to identify, preserve and, when necessary, mitigate adverse effects on the cultural resources found within Fort Sam Houston properties. 



\section{PART VII}

\section{BIBLIOGRAPHY}

\section{SECTION A}

ETHNOHISTORY 

VII. A

BIBL IOGRAPHY

ETHNOHISTORY

Berlandier, J. L.

1969. The Indians of Texas in 1830. Edited and introduced by John c. Ewers. Smithsonian Institution Press, Washington.

Campbe11, T. N.

1972 Systematized Ethnohistory and Prehistoric Culture Sequences in Texas. Bulletin of the Texas Archeological Society 43:1-11.

1975 The Payaya Indians of Southern Texas. Southern Texas Archaeological Association, Special Publication 1, San Antonio.

1977 Ethnic Identities of Extinct Coahuiltecan Populations: Case of the Juanca Indians. The Pearce-Sellard Series 26. Texas Memorial Museum, Austin.

Fehrenbach, T. R.

1968 Lone Star: A History of Texas and the Texans. Macmillan Company, Toronto.

1974 Comanches: The Destruction of a People. A. A. Knopf, New York.

Flach, $V$.

1974 A Yankee in German America: Texas Hill Country. Naylor, San Antonio.

Gatschet, A. S.

1891 The Karankawa Indians, The Coast People of Texas. Archaeological and Ethnological Papers of the Peabody Museum. Harvard university 1(2).

Hasskarl, R. A., Jr.

1962 The Culture and History of the Tonkawa Indians. Plains Anthropologist 7(18):217-231.

Hogan, W. R.

1969 The Texas Republic: A Social and Economic History. University of Oklahoma Press, Norman.

Institute of Texan Cultures

1975 The Afro-American Texans. A pamphlet in the series The Texians and Texans. The University of Texas at San Antonio. 
Jones, W. K.

1969 Notes on the History and Material Culture of the Tonkawa Indians. Smithsonian Contributions to Anthropology 2(5).

Jordan, T. G.

1975 German Seed in Texas Soil: Immigrant Farmers in NineteenthCentury Texas. The University of Texas Press, Austin.

Leutenegger, B. and C. Perry

1976 The Spanish Missions, Part I: The Establishment of the Missions and the Work of the Missionary Fathers. In San Antonio in the Eighteenth Century:73-83. Clarke Printing Company, San Antonio.

Lowrie, S. H.

1967 Culture conflict in Texas, 1821-1835. AMS Press, Inc., New York.

Meinig, D. W.

1969 Imperial Texas: An Interpretive Essay in Cultural Geography. The University of Texas Press, Austin.

Newcomb, W. W., Jr.

1956 A Reappraisal of the "Cultural Sink" of Texas. Southwestern Journal of Anthropology 12(2):145-153.

1960 Indian Tribes of Texas. Bulletin of the Texas Archeological Society 29:1-34.

1961 The Indians of Texas. The University of Texas Press, Austin. Nunley, J. P.

1971 Archaeological Interpretation and the Particularistic Model: The Coahui1tecan Case. Plains Anthropologist 16(59), Part 1: 302-310.

Ruecking, F. H., Jr.

1955 The Coahuiltecan Indians of South Texas and Northeast Mexico. M.A. thesis, The University of Texas, Austin.

Schuetz, M. K.

1969 The History and Archeology of Mission San Juan Capistrano, San Antonio, Texas, Vol. II (of 2 volumes). State Building Commission Archeological Program Report 11, Austin. 
1976 The People of San Antonio, Part I: In the Period 1718-1731. In San Antonio in the Eighteenth Century:73-83. Clarke Printing Company, San Antonio.

Sjoberg, A. F.

1953a The Culture of the Tonkawa, A Texas Indian Tribe. Texas Journal of Science 5(3):280-304.

1953b Lipan Apache Culture in Historical Perspective. Southwestern Journal of Anthropology 9(1):76-98.

Tunne 11, C. and W. W. Newcomb, Jr.

1969 A Lipan Apache Mission, San Lorenzo de 1a Santa Cruz, 1762-1771. Bulletin of the Texas Memorial Museum 14. 

PART VII

BIBL IOGRAPHY

SECTION B

HISTORY 

VII. B

BIBLIOGRAPHY

HISTORY

Adair, A. G.

1946 Austin, Its Place Under Texas Skies. Austin.

*Adams, G. R.

1974 Fort Sam Houston Inventory-Nomination Form, National Register of Historic Places, December 1. San Antonio.

Anonymous

n.d. Camp Bullis--Little Known But Much Used. Article from files at Fort Sam Houston. San Antonio.

1904 Journal of Stephen F. Austin on His First Trip to Texas, 1821. Texas Historical Association Quarterly 7:286-307.

1971 San Antonio Express, "Action Express" Column, December 22.

Bancroft, H. H.

1886 History of the North Mexican States and Texas, 1531-1800.

Two volumes. A. L. Bancroft \& Company, San Francisco.

Barkley, M. S.

1963 History of Travis County and Austin, 1839-1899. Texian Press, Waco.

Barnstone, $\mathrm{H}$.

1966 The Galveston That Was. Macmillan, New York, and Museum of Fine Arts, Houston.

Bartholomew, E.

1951 The Houston Story, A Chronicle of the City of Houston and the

Texas Frontier from the Battle of San Jacinto to the War

Between the States, 1836-1865. The Frontier Press, Houston.

Bedichek, R.

1950 Karankaway Country. Doubleday and Company, Garden City, New York. BCCDR

Bexar County Courthouse Deed Records. San Antonio. 
Boethel, P. C.

1936 The History of Lavaca County. Naylor, San Antonio.

Bolton, H. E。

1970 Texas in the Middle Eighteenth Century. The University of

Texas Press, Austin.

Branda, E. S., Editor

1976 The Handbook of Texas, A Supplement. Volume III. State Historical Association, Austin.

Brashar, E. A.

1941 Galveston, Past, Present and Future. M.A。 thesis, Sam Houston State Teachers College. Huntsville.

Castaneda, C.

1936- Our Catholic Heritage in Texas. Seven volumes. Von Boeckmann1950 Jones, Austin.

Chabot, F. C.

1937 With the Makers of San Antonio. Artes graficas, San Antonio.

*Chatfield, W. H. (Compiler)

1893 The Twin Cities of the Border and the Country of the Lower

Rio Grande. E. P. Brandao, New Orleans.

Clark, J. L.

1955 The Texas Gulf Coast: Its History and Development. Four volumes. Lewis Historical Publishing Company, New York.

*Corner, $w$.

1890 San Antonio de Bexar: A Guide and History. Bzinbridge \& Corner, San Antonio。

Crawford, P. P.

1925 The Beginnings of Spanish Settlement in the Lower Rio Grande Valley. MoA. thesis, The University of Texas, Austin.

DeCamara, $K$.

1949 Laredo on the Rio Grande. Naylor, San Antonio.

Deviney, MoL。

1933 The History of Nueces County to 1850。 M.A. thesis, The University of Texas, Austin. 
Dobie, D。R.

1948 A Brief History of Hays County and San Marcos, Texas. Privately printed, San Marcos。

Doss, E.

$*_{n}$.d. History of Camp Bullis, compiled from files, notes and records at Fort Sam Houston.

${ }^{*}$ n.d. History of Fort Sam Houston, compiled from files, notes and records at Fort Sam Houston.

Dyer, J。0。

1916 The Early History of Galveston. Privately printed, Galveston.

*Emery, G. F.

1976 Letter to Lieutenant Colonel Martin B. Carson, Director, Facilities Engineering, Fort Sam Houston. October 26.

*Fehrenbach, T. R.

1968 Lone Star: A History of Texas and the Texans. Macmillan, Toronto.

Ferguson, H. N。

1976 The Port of Brownsville, A Maritime History of the Rio Grande valley. Springman-King Press, Brownsville.

*Flanagan, S。

1974 Trailing the Longhorns a Century Later. Madrona Press, Austin.

${ }^{\star}$ Frank 1 in

1939 Camp Bullis. MS, Historic Section, Army War College.

Freund, M., Translator and Editor

1954 Gustav Dresel's Houston Journal. Austin.

Fuller, H. C。

1951 The Story of Fort Brown. Frontier Times, May.

Galveston Chamber of Commerce

1948 Port of Galveston on the Gulf of Mexico, America's Port of Quickest Dispatch. Traffic Department, Galveston. 
*Garza, E。 and M. A. Guerra

1977 ESAA IV Bilingual-Bicultural Program, 1976-77. Rio Grande City. *George, M。

1977 Alamo City's Historic Military Homes. San Antonio Magazine, June.

Green, R. M。

1921 Memoirs of Mary A. Maverick, San Antonio's First American Woman. Alamo Printing Company, San Antonio.

Grimes, R.

1968300 Years in Victoria County. Advocate Publishing Company, Victoria.

Habig, M. A。

1968 The Alamo Chain of Missions. Franciscan Herald Press, Chicago. Handy, Mo 0.

1951 History of Fort Sam Houston. Naylor, San Antonio.

Hayes, Co $W$ 。

1974 Galveston, History of the Island and the City. Two volumes. Jenkins Garrett Press, Austin.

Hildebrand, $W . W$ 。

1950 History of Cameron County, Texas. M.S. thesis, North Texas State College, Denton.

Hi11, L. F。

1926 Jose de Escandón and the Founding of Nuevo Santander. Ohio State University Press, Columbus.

Hol comb, G. B。

1948 Early Transportation in the Brownsville, Texas, Area with Historical Background. MoA。 thesis, Texas A \& I University, Kingsville.

Horgan, $P$.

1954 Great River, The Rio Grande in North American History. Two volumes. Rînehart, New York. 
Hunter, J。M。

1930 Indian Stories Told by Hays County Women. Frontier Times, January.

James, V。L。

1938 Frontier and Pioneer Recollections of Early Days in San Antonio and West Texas. Artes graficas, San Antonio.

*John, E。 A。

1975 Storms Brewed in Other Men's worlds: The Confrontation of

Indians, Spanish, and French in the Southwest, 1540-1795. Texas

A \& M University Press, College Station。

Jones, $C$. $A$ 。

1897 Early History of Harris County, Texas. Burke's Texas Almanac for 1897. Reprinted by the Union National Bank, Houston, 1928.

Kilgore, $D$ 。 $E$ 。

1975 Nueces County, Texas, 1750-1800, A Bicentennial Memoir. The Friends of the Corpus Christi Museum Occasional Papers I.

*Koch, A.

1873 Houston, Texas。 Lithograph. Copy in Daughters of the Republic of Texas Library, San Antonio.

*Lee, J. M.

1904 Annual Report. Headquarters Department of Texas, San Antonio.

*Linn, J。 J。

1886 Reminiscences of Fifty Years in Texas. D. \& J. Sadlier \& Company, New York.

McCampbe11, C。

1952 Texas Seaport: The Story of the Growth of Corpus Christi and the Coastal Bend Area. Exposition Press, Jericho, New York.

McComb, D. G.

1969 Houston the Bayou City. The University of Texas Press, Austin. *Meyer, G. H.

1974 Letter to Commander, U.S. Army Forces Command, Fort McPherson, Georgia. November 1 . 
Military Division of the Missouri

1876 Outline Description of the Posts in the Military Division of the Missouri, Commanded by Lieutenant General P. H. Sheridan. Chicago。

Morfí, J。A。

1935 History of Texas. Translated and annotated by Carlos Castaneda. The Quivira Society, Albuquerque.

Oberste, W. H.

1953 Texas Irish Empresarios and Their Colonies, Power \& Hewetson, Mullen \& McGloin. Von Boeckmann-Jones, Austin.

Orchard, E.

1937 The History of the Development of Fort Sam Houston. M.A. thesis, The University of Texas, Austin.

Pierce, $F$ 。

1917 Brief History of the Lower Rio Grande. Menosha, Wisconsin.

Pierce, G. S.

1969 Texas Under Arms. The Camps, Posts, Forts, \& Military Towns of the Republic of Texas, 1836-1846。 Encino Press, Austin.

*Pool, W. C。

1975 A Historical Atlas of Texas. Encino Press, Austin.

*Ramsde11, C。

1959 San Antonio, A Historical and Pictorial Guide. The University of Texas Press, Austin. Revised edition by Carmen Perry, 1976.

*Rex, Y. and B。 Garcia

1976 ESAA III Curriculum Development Project, 1975-1976. Rio Grande City.

Rose, V. M.

1883 Some Historical Facts in Regard to the Settlement of Victoria, Texas. Daily Times Print, Victoria. 
Scott, F. J.

1937 Historical Heritage of the Lower Rio Grande Valley. Naylor, San Antonio.

*Sides, J. C.

1942 History of Fort Brown, Texas: Border Post of the Rio Grande. Naylor, San Antonio.

Steighorst, J. J.

1965 Bay City and Matagorda County: A History. Pemberton, Austin.

*Stephenson, R. L.

1951 A Preliminary Survey of Canyon Reservoir, Comal County, Texas. Mimeographed report of the River Basin Surveys, Smithsonian Institution, Austin Office.

Terre11, A. W.

1910 The City of Austin from 1839 to 1865. Quarterly of the Texas State Historical Association 14:113-128.

*Thompson, J.

1974 Sabers on the'Rio Grande. Presidial Press, Austin.

*The Victoria Sesquiscentennial, Inc.

1974 The Victoria Sesquiscentennial Scrapbook, 1824-1974.

Vigness, D. M.

1955 Indian Raids on the Lower Rio Grande, 1836-1837. Southwestern Historical Quarterly 59:14-23.

*Webb, W. P., Editor-in-Chief

1952 The Handbook of Texas. Two volumes. State Historical Association, Austin.

*Weddle, R. S. and R. H. Thonhoff

1976 Drama and Conflict, the Texas Saga of 1776. Madrona Press, Austin. 
Wilcox, S. S.

1938 Laredo During the Texas Republic. Southwestern Historical Quarterly 42:83-107.

*Wilkinson, J. B.

1975 Laredo and the Rio Grande Frontier. Jenkins Publishing Company, Austin.

Wolffarth, L.

1939 The Transportation Problem of Corpus Christi, Texas. M.A. thesis, Texas Technical College, Lubbock.

*Wood, A. K.

1971 Texas Coastal Bend: People and Places. Naylor, San Antonio.

*Woolford, S., Editor

1963 San Antonio...A History for Tomorrow. Naylor, San Antonio. Wortham, L. J.

1924 A History of Texas. Five volumes. Fort Worth.

Wright, S. J.

1916 San Antonio de Bexar. Austin.

Writers Program of the W.P.A.

1942 Houston, A History \& Guide. Anson Jones Press, Houston.

Young, S. 0.

1912 A Thumb-Nail History of the City of Houston, Texas from its Founding in 1836 to the Year 1912. Rein \& Sons, Houston.

*Zweiner, D. R. and E. Darst

1966 A Guide of Historic Galveston. Privately printed map.

*References directly referred to in the text. Others are supplied for use in future research. 


\section{PART VII}

\section{BIBLIOGRAPHY}

SECTION C

ARCHAEOLOGY 

VII. C

BIBLIOGRAPHY

ARCHAEOLOGY

Allen, D. C. and E. P. Cheatum

1961 Ecological Implications of Fresh-Water and Land Gastropods in Texas Archeological Studies. Bulletin of the Texas Archeological Society 31:291-316.

Anonymous

n.d. The Edwards Underground Water District and Edwards Underground Reservoir. Edwards Underground Water District, San Antonio.

1970 Environmental Analys is for the Alamo Area Council of Governments. Alamo Area Council of Governments, San Antonio.

Barber, E. A.

n.d. Marks of American Potters. Cracker Barrel Press, Southhampton, New York.

Barnes, V. E.

1974 Geologic Atlas of Texas, San Antonio Sheet. Bureau of Economic Geology, The University of Texas at Austin.

Bass, F. A., Jr. and T. R. Hester

1975 An Archaeological Survey of the Upper Cibolo Creek Watershed, Central Texas. Center for Archaeological Research. The University of Texas at San Antonio, Archaeological Survey Report 8.

BCCDR

Bexar County Courthouse Deed Records, San Antonio.

$B C$ Probate Minutes

Bexar County Courthouse Probate Minutes, San Antonio.

Blair, W. F.

1950 The Biotic Provinces of Texas. Texas Journal of Science 2(1): 93-117.

Bogusch, E. R.

1952 Brush Invasion in the Rio Grande Plain of Texas. Texas Journal of Science $4(1): 85-91$. 
Briggs, A. K.

1971a An Archeological Survey of Ingram Reservoir. Texas Historical Survey Committee and Texas Water Development Board, Archeological Survey Report 9.

1971b Archaeological Resources in the Texas Coastal Lowlands and Littoral. Texas Historical Survey Committee, Texas Water Development Board, Austin.

Bryant, V., Jr.

1969 Late Full-Glacial and Post-Glacial Pollen Analysis of Texas Sediments. Ph.D. dissertation on file at the University of Texas Library, Austin.

Buckman, H. O. and N. C. Brady

1969 The Nature and Properties of Soils, Seventh Edition. Macmillan Company, New York.

Burt, W. H. and R. P. Grossenheider

1964 A Field Guide to the Mammals. Houghton Mifflin Company, Boston. Campbe11, T. N.

1960 Archeology of the Central and Southern Sections of the Texas Coast. Bulletin of the Texas Archeological Society 29:145-176.

1975 The Payaya Indians of Southern Texas. Southern Texas Archaeological Association, Special Publication 1, San Antonio.

Cantu, E. G., R. P. Lauderdale and D. Stoner

ms. The Perry Haass Collection, St. Mary's Hall Site, 41 BX 229. Manuscript on file, Center for Archaeological Research, The University of Texas at San Antonio.

Carr, J. T., Jr.

1967 The Climate and Physiography of Texas. Texas Water Development Board Report 53, Austin.

Carter, E. S. and C. S. Ragsdale

1976 Biegel Settlement: Historic Sites Research, Fayette Power Project, Fayette County, Texas. Texas Archeological Survey

Research Report 59, The University of Texas at Austin.

Chabot, F. C.

1937 With the Makers of San Antonio. Artes graficas, San Antonio. 
Chapt in, R. E.

1971 The Study of Animal Bones from Archeological Sites. Seminar Press, New York.

Clark, J. W., Jr.

1969 Implications of Land and Fresh-Water Gastropods in Archeological Sites. Arkansas Academy of Science Proceedings 23.

1976 The Sugar Industry at Mission San Jose y San Migue1 de Aguayo. Bulletin of the Texas Archeological Society 47:245-259.

Corbin, J. E.

1976 The Archaic of the Texas Coast. In: The Texas Archaic: A Symposium (T. R. Hester, Editor). Center for Archaeological Research, The University of Texas at San Antonio, Special Report 2:91-97.

Cornwa11, I. W.

1958 Soils for the Archaeologist. Macmillan Company, New York.

Crawford, D. D.

1965 The Granite Beach Site, Llano County, Texas. Bulletin of the Texas Archeological Society 36:71-97.

Davis, W. B.

1974 The Mamma7s of Texas. Texas Parks and Wildlife Bulletin 41, Austin.

Dillehay, T.

1974 Late Quaternary Bison Population Changes on the Southern

Plains. Plains Anthropologist 19(64):180-196.

Dimbleby, G.

1957 Pollen Analysis of Terrestrial Soils. New Phytologist 65:12-28.

Dixon, W. J., Editor

1975 BMDP: Biomedical Computer Programs. University of California Press, Berkeley and Los Angeles.

Elsik, W. C.

1971 Microbiological Degradation of Sporopollenin. In: Sporopollenin, G. Brooks, Editor. Academic Press, New York. 
Fawcett, W. B., Jr.

1972 The Prehistory of Bexar County: A Study of Previous Work in South Central Texas. Bulletin of the Lower Plains Archeological Society 2.

Fox, A. A. and D. E. Fox

1967 The Classen Rockshelter (41 BX 23). Unpublished manuscript on file, Center for Archaeological Research, The University of Texas at San Antonio.

Fox, D. E.

1965 The Rogers site (41 BX 22). Unpublished manuscript on file, Center for Archaeological Research, The University of Texas at San Antonio.

Fox, D. E., R. T. Mallouf, N. O'Malley and W. M. Sorrow

1974 Archeological Resources of the Proposed Cuero I Reservoir, DeWitt and Gonzales Counties, Texas. Texas Historical Commission and Texas Water Development Board, Archeological Survey Report 12.

Freese and Nichols, Inc.

1977 Environmental Statement, Overall Mission, Fort Sam Houston, Texas. Department of the Army Headquarters, Forces Command.

Frkuska, E. C., A. Frkuska, F. Va1dez, Jr. and T. R. Hester

1977 An Initial Archaeological Assessment of John James Park, City of San Antonio, Texas. Center for Archaeological Research, The University of Texas at San Antonio, Archaeological Survey Report 25.

Garretson, M. S.

1934 A Short History of the American Bison. The American Bison Society, New York.

Goldstein, S.

1960 Degradation of Pollen by Phycomycetes. Ecology 41:543-545.

Graves, C. and L. Highléy

197841 ME 7: A Cave Site in Medina County, Texas. La Tierra 5:2. 
Green, L. M. and T. R. Hester

1973 The Finis Frost Site: A Toyah Phase Occupation in San Saba County, Central Texas. Bulletin of the Texas Archeological Society 43:69-88.

Greer, G. H. and H. Black

1971 The Meyer Family: Master Potters of Texas. Trinity Universtiy Press, San Antonio.

Greer, J.W.

1965 A Typology of Midden Circles and Mescal Pits. Southwestern Lore 31:47-55.

1967 Midden Circles Versus Mescal Pits. American Antiquity 32(1): 108-109.

Haines, F.

1970 The Buffalo. Crowe11, New York.

Havinga, A. J.

1971 An Experimental Investigation into the Decay of Pollen and Spores in Various Soil Types. In: Sporopollenin, G. Brooks, Editor. Academic Press, New York.

Hester, T. R.

1970a An Interim Statement on Archaeological Research at Chaparrosa Ranch, Texas. Unpublished manuscript submitted to the Texas State Historical Survey Committee.

1970b Burned Rock Midden Sites on the Southwestern Edge of the Edwards Plateau, Texas. Plains Anthropologist 15(50), Part 1 237-250.

1971 Archaeological Investigations at the La Jita Site, Uvalde County, Texas. Bulletin of the Texas Archeological Society 42:41-148.

1973 The Formation of a "Burned Rock Midden": A California Example. The Record, Dallas Archeological Society 29(3):4.

1974a 41 BX 194: A Terrace Site, Fort Sam Houston, Texas. Report on file, Center for Archaeological Research, The University of Texas at San Antonio

1974b Bibliographic Guide to the Archaeology of Southern Texas. Journal of South Texas 1. 
1975a Archaeological and Historical Resources in the San AntonioGuadalupe River Basins: A Preliminary Statement. T. R. Hester, Assembler. Center for Archaeological Research, The University of Texas at San Antonio, Regional Studies 1.

1975b Late Prehistoric Cultural Patterns Along the Lower Rio Grande of Texas. Bulletin of the Texas Archeological Society 46:107-125.

1975c Chipped Stone Industries on the Rio Grande Plain, Texas: Some Preliminary Observations. The Texas Journal of Science 26(1-2): 213-222.

1976a Hunters and Gatherers of the Rio Grande Plain and the Lower Coast of Texas. Center for Archaeological Research, The University of Texas at San Antonio.

1976b The Archaic of Southern Texas. In: The Texas Archaic: A Symposium. T. R. Hester, Editor. Center for Archaeological Research, The University of Texas at San Antonio, Special Report 2:83-90.

1977 The Current Status of Paleo-Indian Studies in Southern Texas and Northeastern Mexico. In: "Paleoindian Lifeways," Eileen Johnson, Editor. The Museum Journal, XVII, West Texas Museum Association, Texas Tech University, Lubbock.

1978 Early Human Occupations in South Central and Southwestern Texas: Preliminary Papers on the Baker Cave and St. Mary's Hall Sites. Center for Archaeological Research, The University of Texas at San Antonio.

Hester, T. R., with the collaboration of F. A. Bass, Jr., A. A. Fox, T. C. Kelly, M. F. Chadderdon and E. S. Harris

1974 Archaeological Survey of Areas Proposed for Modification in the Salado Creek Watershed, Bexar County; Texas. Center for Archaeological Research, The University of Texas at San Antonio, Archaeological Survey Report 3.

Hester, T. R., F. A. Bass, Jr. and T. C. Kelly

1975 Archaeological Investigations of Portions of the Comal River Watershed, Coma 1 County, Texas. Center for Archaeological Research. The University of Texas at San Antonio, Archaeological Survey Report 6.

Hester, T. R., D. Gilbow and A. D. Albee

1973 A Functional Analysis of "Clear Fork" Artifacts from the Rio Grande Plain, Texas. American Antiquity 38(1):90-96. 
Hester, T. R. and T. C. Hi11, Jr.

1975 Some Aspects of Late Prehistoric and Protohistoric Archaeology in Southern Texas. Center for Archaeological Research, The University of Texas at San Antonio, Special Report 1.

Hester, T. R. and T. C. Kelly

1976 Archaeological Investigations at Sites Near Natalia, Medina County, Texas. Center for Archaeological Research, The University of Texas at San Antonio, Archaeological Survey Report 20.

Hester, T. R. and H. Kohnitz

1975 The Chronological Placement of "Guadalupe" Tools. La Tierra 2(2):22-25.

Hester, T. R. and H. J. Shafer

1975 An Initial Study of Blade Technology on the Central and Southern Texas Coast. Plains Anthropologist 20(69):175-185.

Honea, K. H.

1961 The Rammadyat of Northwest Africa and the Burned Rock Middens of Texas. Bulletin of the Texas Archeological Society 32 .

Hornaday, W. T.

1887 The Extermination of the American Bison. Annual Report of the Board of Regents of the Smithsonian Institution, Part II. Government Printing Office, Washington.

House, J.W. and T. R. Hester

1967 The Carrizo Type. Texas Archeology, The Newsletter of the Texas Archeological Society 11(3):8-9.

Hsu, D. P. and R. W. Ralph

1968 An Appraisal of the Archeological Resources of Cibolo Reservoir, Wilson County, Texas. Texas State Building Commission and Texas State Water Development Board, Archeological Survey Report 1.

Hudson, W. R., Jr., W. M. Lynn and D. Scurlock

1974 Walker Ranch: An Archeological Reconnaissance and Excavations in Northern Bexar County, Texas. Texas Historical Commission, office of the State Archeologist, Report 26.

Ivey, J. E., T. Medlin and J. D. Eaton

1977 An Initial Archaeological Assessment of Areas Proposed for Modification at Fort McIntosh, Webb County, Texas. Center for Archaeological Research, The University of Texas at San Antonio, Archaeological Survey Report 32. 
Jaquier, J. A.

1976 Flotation Recovery Techniques During Archaeological Excavation. La Tierra 3(4):9-15.

Jaquier, J. A., T. R. Hester, F. Valdez, Jr., A. J. McGraw and I. W. Cox

1978 Archaeological Test Excavations at Site 41 BX 228, Walker Ranch, Bexar County, Texas. Center for Archaeological Research. The university of Texas at San Antonio, Archaeological Survey Report 46.

Jelks, E. B.

1962 The Kyle Site, A Stratified Central Texas Aspect Site in Hill County, Texas. Department of Anthropology. The University of Texas at Austin. Archaeology Series 5.

Johnson and Chapman

1891 General Directory of the City of San Antonio. Johnson Brothers. San Antonio. Copy in the San Antonio Conservation Society Library.

Johnson, L., Jr.

1967 Toward a Statistical Overview of the Archaic Cultures of Central and Southwestern Texas. Texas Memorial Museum Bulletin 12.

Johnson, L., Jr., D. A. Suhm and C. D. Tunnel1

1962 Salvage Archeology of Canyon Reservoir: The Wunderlich, Footbridge and 0blate Sites. Texas Memorial Museum Bulletin 5.

Jones, J. K., Jr., D. Carter and H. Genoways

1973 Checklist of North American Mammals North of Mexico. Occasional Papers, The Museum, Texas Tech University 12:1-14.

Judge, W. J.

1973 Paleoindian Occupation of the Central Rio Grande Valley in New Mexico. University of New Mexico Press, Albuquerque.

Judge, W. J., J. I. Ebert and R. K. Hitchcock

1975 Sampling in Regional Archaeological Survey. In: Sampling in Archaeology, J. W. Mueller, Editor. University of Arizona Press, Tucson.

Katz, P.

197841 BX 300 Mitigation. Report in preparation. 
Katz, S. R.

1977 An Archaeological Test Excavation at John James Park, City of San Antonio, Texas. Center for Archaeological Research. The University of Texas at San Antonio, Archaeological Survey Report 38.

Kelley, J. C. and T. N. Campbell

1942 What are the Burnt Rock Mounds of Texas? American Antiquity $7(3): 319-322$.

Kel1y, T. C.

1961 The Crumley Site: A Stratified Burnt Rock Midden, Travis County, Texas. Bulletin of the Texas Archeological Society 27(3).

1974 Appendix II: Notes on Test Excavations at Site 41 BX 228 (Panther Springs Site). In: Archaeological Survey of Areas Proposed for Modification in the Salado Creek Watershed, Bexar County, Texas. Center for Archaeological Research. The University of Texas at San Antonio, Archaeological Survey Report 3.

1976a An Archaeological Survey of Floodwater Retarding Structure No. 13A in the Salado Creek Drainage. Letter report to the United States Department of Agriculture Soil Conservation Service, Temple, Texas, on file, Center for Archaeological Research, The Universtiy of Texas at San Antonio.

1976b Typological Studies of Plainview and Golondrina Points in Southern Texas. Paper presented at the Second Quarterly Meeting of the Southern Texas Archaeological Association, San Antonio.

n.d. The Elm Waterhole Creek Site (41 BX 300): 1976 Investigations. Notes on file, Center for Archaeological Research, The University of Texas at San Antonio.

Kelly, T. C. and T. R. Hester

1975a Archaeological Investigations at Four Sites in the Dry Coma 1 Watershed, Comal County, South Central Texas. Center for Archaeological Research. The University of Texas at San Antonio, Archaeological Survey Report 15.

1975b Additional Archaeological Survey in the Dry Comal Watershed, Coma 1 County, South Centra1 Texas. Center for Archaeological Research, The University of Texas at San Antonio, Archaeological Survey Report 10.

1976 Archaeological Investigations at Sites in the Upper Cibolo Watershed, Central Texas. Center for Archaeological Research, The University of Texas at San Antonio, Archaeological Survey Report 17. 
King, I. M.

1967 John 0. Meusebach, German Colonizer in Texas. The University of Texas Press, Austin.

Kneberg, $M$.

1956 Some Important Projectile Point Types Found in the Tennessee Area. Tennessee Archaeologist 12(1):17-28.

Knudson, R.

1973 Organizational Variability in Late Paleo-Indian Assemblages. UnpubTished Ph.D. Dissertation, Washington State University, Pullman.

Kove1, R. M. and T. H. Kovel

1953 Dictionary of Marks--Pottery and Porcelain. Crown Publisher, Inc., New York.

Krieger, A. D.

1956 Food Habits of the Texas Coastal Indians in the Early Sixteenth Century. Bulletin of the Texas Archeological Society 27:47-58.

Levy, J. E.

1961 Ecology of the South Plains: The Ecohistory of the Kiowa, Comanche, Cheyenne, and Arapaho, 1830-1870. Viola Garfield, Editor. Proceedings of the 1961 Annual Spring Meeting of the American Ethnological Society.

Lewis, T. N. and M. N. Lewis

1961 Eva, An Archaic Site. The University of Tennessee Press, Knoxville. Lundelius, E. L., Jr.

1967 Late Pleistocene and Holocene Faunal History of Central Texas. In: Pleistocene Extinctions: The Search for a Cause. P. S. Martin and H. E. Wright, Jr., Editors. Yale University Press, New Haven.

Mallouf, T., D. E. Fox and A. K. Briggs

1973 An Assessment of the Cultural Resources of Palmetto Bend Reservoir, Jackson County, Texas. Texas Historical Commission and Texas Water Development Board, Archeological Survey Report 11.

Mankowitz, W. and R. H. Haggar

1957 The Concise Encyclopedia of English Pottery and Porcelain. Hawthorn Books, Inc., New York. 
Martin, P. S.

1963 The Last 10,000 Years: A Fossil Pollen Record of the American Southwest. University of Arizona Press, Tucson.

McClinton, K. M.

1951 Antique Collecting for Everyone. Bonanza Books, New York.

Newcomb, W. W., Jr.

1960 Indian Tribes of Texas. Bulletin of the Texas Archeological Society 29 (for 1958): 1-34.

Patterson, L. W. and T. H. Adams

1977 An Archeological Complex in Kenda11 County, Texas. La Tierra $4(2): 6-16$.

Peterson, R. T.

1947 A Field Guide to the Birds. Houghton Mifflin Company, Boston.

Ralph, E. K., H. N. Michael and M. C. Han

1973 Radiocarbon Dates and Reality. Applied Science Center for Archaeology, MASCA Newsletter 9(1):1-20.

Raycraft, D. and C. Raycraft

.1975 American Country Pottery. Wallace-Homestead Book Company, Des Moines.

Roe, F. G.

1951 The North American Buffalo. Toronto.

Sangster, A. and H. Dale

1961 A Preliminary Study of Differential Pollen Grain Preservation. Canadian Journal of Botany 39:35-43.

1964 Pollen Grain Preservation of Underrepresented Species in Fossil Spectra. Canadian Journal of Botany 42:437-449.

Schuetz, M. K.

1956 An Analysis of Val Verde County Cave Material. Bulletin of the Texas Archeological Society 27:129-160. 
1966 The Granberg Site: An Archaic Habitation in Bexar County, Texas. witte Museum Studies 1.

1969 The History and Archeology of Mission San Juan Capistrano, San Antonio, Texas, Vol. II (of two volumes). State Building Commission Archeological Program Repart 11, Austin.

Scurlock, D., A. Benavides, Jr., D. Isham and J. W. Clark, Jr.

1976 An Archeological and Historical Survey of the Proposed Mission Parkway, San Antonio, Texas. Texas Historical Commission, Austin.

Shackley, M. L.

1975 Archaeological Sediments. Halsted Press, New York.

Shafer, H. J.

1963 Test Excavations at the Youngsport Site: A Stratified Terrace Site in Bell County, Texas. Bulletin of the Texas Archeological Society $34: 57-81$.

1969 Archeological Investigations in the Robert Lee Reservoir Basin, West Central Texas. Papers of the Texas Archeological Salvage Project 17.

1971 Late Prehistory of Central Texas 500 B.C.-A.D. 1700. Paper presented at 74th Annual Meeting of the Texas Academy of Science, Nacogdoches.

Shafer, H. J. and E. P. Baxter

1975 An Archeological Survey of the Lignite Project, Atascosa and McMullen Counties, Texas. Texas A\&M University. Anthropology Laboratory Report 7.

Sjoberg, A. F.

1953 The Culture of the Tonkawa, A Texas Indian Tribe. Texas Journal of Science $5(3): 280-304$.

Skinner, S. A.

1971 Prehistoric Settlement of the DeCordova Bend Reservoir, Central Texas. Bulletin of the Texas Archeological Society 42:149-269.

Skinner, S. A. and T. Gallagher

1974 An Evaluation of the Archeological Resources at Lake Whitney, Texas. Southern Methodist University, contributions in Anthropology 14. 
Smith, B. D.

1975 Middle Mississippi Exploitation of Animal Populations. Museum of Anthropology, University of Michigan, Ann Arbor.

Sollberger, J.B.

1967 A New Type of Arrow Point With Speculations as to its Origin. The Record 23(3): 16-22.

1971 Technological Study of Beveled Knives. Plains Anthropologist $16(53): 203-218$.

Sollberger, J. B. and T. R. Hester

1972 The Strohacker Site: A Review of Pre-Archaic Manifestations in Texas. Plains Anthropologist 17(58):326-344.

Sorrow, W. M.

1968 The Devil's Mouth Site: The Third Season--1967. Papers of the Texas Archeological Salvage Project 14.

Sorrow, W. M., H. J. Shafer and R. E. Ross

1967 Excavations at Stillhouse Hollow Reservoir. Papers of the Texas Archeological Salvage Project 11.

Stebbins, R. C.

1966 A Field Guide to Western Reptiles and Amphibians. Houghton Mifflin Company, Boston.

Suhm, D. A.

1957 Excavations at the Smith Rockshelter, Travis County, Texas.

Texas Journal of Science $9(1): 26-58$.

1959 The Williams Site and Central Texas Archeology. Texas Journal of Science $11(2): 218-250$.

1960 A Review of Central Texas Archeology. Bulletin of the Texas Archeological Society 29:63-108.

Suhm, D. A. and E. B. Jelks

1962 Handbook of Texas Archeology: Type Descriptions. Texas Archeological Society, Special Publication 1, and Texas Memorial Museum, Bulletin 4.

Suhm, D. A., A. D. Krieger and E. B. Jelks

1954 An Introductory Handbook of Texas Archeology. Bulletin of the Texas Archeological Society 25. 
Taylor, F. B., R. B. Hailey and D. L. Richmond

1966 Soil Survey of Bexar County, Texas. U.S. Department of Agriculture, in cooperation with the Texas Agricultural Experiment Station.

Townsend, J. C.

1975 Report on Site 41 BX 36. Manuscript on file, Center for Archaeological Research, The University of Texas at San Antonio.

Tschudy, R. H.

1969 Applied Parynology. In: Aspects of Palynology, Tschudy and Scott, Editors. John Wiley and Sons, Inc., New York.

U.S.A.

1947 Map of Leon Springs Military Reservation, United States Army.

Valdez, F., Jr. and A. J. McGraw

1977 An. Archaeological Evaluation of Three Prehistoric Sites, Upper Cibolo Creek Watershed, Kenda 11 County, South Central Texas. Center for Archaeological Research. The University of Texas at San Antonio, Archaeological Survey Report 44.

Weir, F. A.

1976 The Central Texas Archaic. Unpublished Ph.D. Dissertation, Washington State University, Department of Anthropology, Pullman.

Woolford, S. W.

1935 Types of Archaeological Sites in Bexar County, Texas. Witte Museum, Archaeological Bulletin 4. 